\author{
Universidade de São Paulo \\ Faculdade de Medicina de Ribeirão Preto \\ Programa de Pós-Graduação em Imunologia Básica e Aplicada
}

\title{
O Papel dos microRNAs de Células T na Susceptibilidade/Resistência a Artrite Reumatóide Experimental
}

Paula Barbim Donate Yabuta

Ribeirão Preto 


\author{
Universidade de São Paulo \\ Faculdade de Medicina de Ribeirão Preto \\ Programa de Pós-Graduação em Imunologia Básica e Aplicada
}

\title{
O Papel dos microRNAs de Células $T$ na Susceptibilidade/Resistência a Artrite Reumatóide Experimental
}

Paula Barbim Donate Yabuta

Tese apresentada ao Programa de Pósgraduação em Imunologia Básica e Aplicada da Faculdade de Medicina de Ribeirão Preto da Universidade de São Paulo para obtenção do Título de Doutor em Ciências, Área de concentração: Imunologia

Orientador: Prof. Dr. Geraldo A. S. Passos

Co-orientador: Prof. Dr. Fernando Q. Cunha

Ribeirão Preto 
DONATE-YABUTA, PAULA B.

O PAPEL DOS MICRORNAS DE CÉLULAS T NA SUSCEPTIBILIDADE/RESISTÊNCIA A ARTRITE REUMATÓIDE EXPERIMENTAL. RIBEIRÃO PRETO, 2012

228 p. il. $30 \mathrm{~cm}$

TESE DE DOUTORADO APRESENTADA À FACULDADE DE MEDICINA DE RIBEIRÃO PRETO, USP, ÁREA DE CONCENTRAÇÃO: IMUNOLOGIA.

ORIENTADOR: PASSOS, GERALDO ALEIXO DA SILVA 


\section{Apoio e suporte financeiro}

Este trabalho foi realizado no Laboratório de Imunogenética Molecular, localizado no Departamento de Genética da Faculdade de Medicina de Ribeirão Preto (FMRP) - USP com o apoio financeiro das seguintes entidades e instituições:

Coordenação de Aperfeiçoamento de Pessoal de Nível Superior (CAPES) por meio da bolsa de Doutorado CAPES/PROEX.

Fundação de Amparo à Pesquisa de Estado de São Paulo (FAPESP) por meio do Projeto Temático Processo 08/56594-8.

Faculdade de Medicina de Ribeirão Preto - FMRP - USP.

Conselho Nacional de Desenvolvimento Científico e Tecnológico (CNPq) por meio da bolsa de Doutorado Sandwich em Glasgow, Escócia Processo 201937/2010-7.

Center for Rheumatic Diseases in the Institute of Infection, Immunity and Inflammation, University of Glasgow, Glasgow, Scotland, UK. 


\section{DEDICO ESTE TRABALHO...}

Às pessoas que mais amo na minha vida:

Meu marido, amigo e companheiro, Anderson por todo amor, carinho e compreensão. Obrigada por estar sempre ao meu lado e fazer parte da minha vida.

Minha mãe, Marina, minha melhor amiga e confidente, por sempre confiar e acreditar em mim, e me apoiar incondicionalmente em minhas conquistas. Obrigada por toda a força.

As minhas irmãs, Michele e Bruna, pela compreensão e apoio. Espero ser sempre um exemplo para vocês.

Não há palavras para descrever o quanto vocês são importantes em minha vida, e o quanto sou grata a Deus por vocês existirem.

OBRIGADA POR TUDO!!! 


\section{Agradecimentos}

Meus sinceros agradecimentos a todos que colaboraram e participaram, direta ou indiretamente, da realização deste trabalho e da minha formação profissional.

Ao meu orientador, Prof. Dr. Geraldo Aleixo da Silva Passos, pela orientação e dedicação durante o desenvolvimento deste trabalho, e por seu exemplo de profissionalismo e seriedade que contribuíram e continuam a contribuir para meu crescimento profissional. Muito Obrigada!!!

Ao Prof. Dr. Fernando de Queiróz Cunha, que me acompanha desde a iniciação científica, pela confiança, pelos ensinamentos e apoio durante estes anos, e por disponibilizar o laboratório para que este trabalho pudesse ser desenvolvido. Quero agradecer também a todo laboratório de inflamação e dor, por toda ajuda, disponibilidade e amizade.

Ao departamento de Imunologia Básica e Aplicada da Faculdade de Medicina de Ribeirão Preto (FMRP) pela dedicação, destacando o laboratório do Prof. Dr. João Santana pelo auxílio na utilização do FACs, e especialmente a Ana por todo carinho e paciência, sem ela o departamento não seria o mesmo!

Aos Professores Dr. Eduardo Antonio Donadi e Dra. Elza Tieme Sakamoto-Hojo pela colaboração e amizade que auxiliaram no desenvolvimento deste estudo.

A CAPES pelo auxílio concedido por meio da bolsa de doutorado; a FAPESP pelo apoio financeiro de suma importância para o desenvolvimento deste projeto; e ao CNPq pelo auxílio concedido por meio da bolsa de doutorado sandwich pelo período de seis meses na Divisão de Imunologia,Infecção e Inflamação da Universidade de Glasgow, na Escócia, Reino Unido.

As minhas grandes amigas do grupo de Imunogenética Molecular, pela convivência extremamente agradável, pelos ensinamentos, colaborações e pelas alegrias que marcaram estes anos. A amizade de vocês é muito importante para mim. Vocês são muito especiais!!!

Thanks to Dra. Mariola Kurowska-Stolarska and Dr. Ian B. McInnes for the opportunity to learn more and for all the support during the six months in the Center for Rheumatic Diseases in the Institute of Infection, Immunity and Inflammation, University of Glasgow. It was amazing six months! 


\section{Resumo}

Os microRNAs são pequenos RNAs, não-codificantes que funcionam como reguladores a nível pós-transcricional da expressão gênica. Nos últimos anos, novas evidências demonstram o papel importante dos microRNAs na regulação $\mathrm{e}$ desenvolvimento do sistema imune. Apesar da função de poucos microRNAs ser conhecida, a sua expressão alterada vêm sendo associada a patogênese de diversas doenças autoimunes, incluindo a artrite reumatóide (AR). Recentemente a expressão desregulada de uma série de microRNAs está sendo descrita em pacientes com $A R$, e o papel patogênico de apenas uma parte deles foi investigada em modelos animais. A artrite reumatóide é uma doença autoimune sistêmica caracterizada por um intenso processo inflamatório na sinóvia, podendo causar destruição óssea e articular. Os linfócitos $\mathrm{T}$ apresentam papel importante na indução, manutenção e progressão da doença. A artrite induzida por colágeno é um modelo animal amplamente utilizado por suas características fisiopatológicas muito similares à doença em humanos. A linhagem de camundongos DBA-1/J desenvolve a doença após imunização e booster com colágeno do tipo II, enquanto que a linhagem DBA-2/J se mostra refratária. Isso confere um sistema modelo de susceptibilidade/resistência à artrite, que pode ser estudado em diferentes abordagens. $\mathrm{O}$ objetivo do nosso estudo foi identificar o perfil transcricional e as redes de interação entre um grupo de microRNAs e seus respectivos alvos nos timócitos e linfócitos T CD3+ periféricos nos camundongos da linhagem DBA-1/J e DBA-2/J. Para a avaliação da expressão gênica, utilizou-se a tecnologia de microarrays. O uso de programas de análise e para a construção das redes foi imprescindível. Os resultados encontrados evidenciam uma expressão diferenciada de mRNAs e microRNAs em timócitos e linfócitos $\mathrm{T} \mathrm{CD}^{+}$ periféricos entre as duas linhagens utilizadas. Novos microRNAs foram encontrados nos diferentes estágios de desenvolvimento do linfócito T. Nas redes de interação microRNARNAm obtidas, genes importantes associados aos processos de sistema imune, adesão e diferenciação celular, apoptose, recombinação, ativação de linfócitos $\mathrm{T}$ e resposta inflamatória, foram encontrados como potenciais alvos. Além disso, em uma perspectiva clínica, baseados nos resultados obtidos em camundongo, nos encontramos a expressão do miR-505 nos linfócitos $\mathrm{T}$ de pacientes com AR. Nossos resultados contribuem para a melhor compreensão dos mecanismos molecular envolvidos na resistência/susceptibilidade a CIA. 


\section{Abstract \\ The role of T lymphocytes microRNAs in the resistance/susceptibility to the experimental arthritis}

MicroRNAs (miRNAs) are small non-coding RNA molecules that modulate the expression of multiple protein-encoding genes at the post-transcriptional level. During the last several years, evidence has emerged to show their critical role for the regulation and development of immune system. Although the function of most mammalian miRNAs has yet to be determined, their aberrant expression has been associated with several autoimmune conditions, including rheumatoid arthritis (RA). Recently, the deregulated expression of a dozen miRNAs has been reported in patients with RA, and the pathogenic role of only a few of these has been investigated in experimental mouse models. RA is a systemic autoimmune disorder mainly characterized by the inflammation of synovial tissue that can lead to destruction of bone and cartilage. The role of effectors $\mathrm{T}$ cells in induction, maintenance and progression of the disease is now becoming better understood. Collageninduced arthritis is an animal model widely studied due to its similarities to human disease. The DBA-1/J mouse strain develops arthritis after immunization process and booster with Type II collagen, and the DBA-2/J strain is refractory to the disease induction. This offers an useful susceptibility/resistance model-system to study RA. The aim of this study was to identify the expression profiles and interaction networks between a set of microRNAs and their mRNA targets in thymocytes and peripheral $\mathrm{CD}^{+} \mathrm{T}$ lymphocytes in DBA-1/J and DBA-2/J mice strain. For this purpose we used the microarray technology to evaluate the expression of the miRNAs and mRNAs as possible targets involved in this process. The use of bioinformatics software to reconstruct the networks was essential. The results show differential expression of mRNAs and miRNAs in thymocytes and peripheral CD3 $+\mathrm{T}$ lymphocytes between both strains. New miRNAs were found during all the stages of $\mathrm{T}$ cells development. The microRNA-mRNA interaction networks obtained in this study showed that important genes related to apoptose, immune system, recombination, cell adhesion and differentiation, inflammatory process and $\mathrm{T}$ cell activation were found as potential targets. In addition, in a clinical prospects, based on the results obtained in mice, we found the expression of the miRNA miR-505 in T cells of RA patients. Our results contribute to a better understand of the molecular mechanisms evolved in the resistance/susceptibility to CIA. 


\section{Lista de Figuras}

Figura 1. Modelo esquemático da via imunológica na articulação durante a artrite reumatóide

Figura 2. Diagrama esquemático do processo inflamatório e erosão óssea na

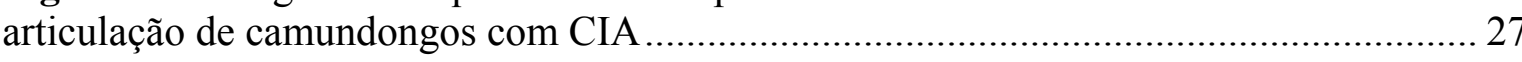

Figura 3. Migração dos tímocitos para desenvolvimento e seleção dos linfócitos T ......... 31

Figura 4. Biogênese e ação dos microRNAs em células animais...................................... 42

Figura 5. MicroRNAs na regulação da imunidade inata ............................................... 45

Figura 6. MicroRNAs na regulação da imunidade adaptativa ......................................... 47

Figura 7. Aparelho Bioanalyzer 2100 Agilent e RNA 6000 Nano Chips utilizados na eletroforese microfluídica

Figura 8. Agilent microarrays genoma completo no formato $4 \times 44 \mathrm{k}$ contendo oligonucleotídeos sintetizados com base nas sequências de RNAs mensageiros

Figura 9. Agilent microarrays de miRNAs no formato $8 \times 15 \mathrm{k}$ contendo oligonucleotídeos sintetizados a com base nas sequências de microRNAs

Figura 10. Eletroforese microfluídica das amostras de RNA estudadas 83

Figura 11. Densitometria das amostras de RNA estudadas. 84

Figura 12. Análise da pureza de células $\mathrm{T}$ por citometria de fluxo 85

Figura 13. Caracterização da população de células $T$ em camundongos DBA-1/J e DBA-2/J por citometria de fluxo

Figura 14. Matriz de expressão de 14.230 RNAm de timócitos e linfócitos $\mathrm{T} \mathrm{CD}^{+}$ periféricos em camundongos das linhagens DBA-1/J e DBA-2/J.

Figura 15. Matriz de expressão de 3.155 RNAms de linfócitos $\mathrm{T} \mathrm{CD}^{+}$periféricos em camundongos das linhagens DBA-1/J e DBA-2/J durante processo de imunização.

Figura 16. Matriz de expressão de 91 microRNAs de timócitos e linfócitos T $\mathrm{CD} 3^{+}$ periféricos em camundongos das linhagens DBA-1/J e DBA-2/J.....

Figura 17. Matriz de expressão de 63 microRNAs de linfócitos $\mathrm{T} \mathrm{CD} 3^{+}$periféricos em camundongos das linhagens DBA-1/J e DBA-2/J durante processo de imunização

Figura 18. Rede mostrando a interação dos microRNAs induzidos em timócitos das linhagens DBA-1/J e DBA-2/J com seus respectivos alvos relacionados aos processos biológicos de apoptose e adesão celular. 
Figura 19. Rede mostrando a interação dos microRNAs induzidos em timócitos das linhagens DBA-1/J e DBA-2/J com seus respectivos alvos relacionados aos processos biológicos de diferenciação celular e recombinação ...

Figura 20. Rede mostrando a interação dos microRNAs induzidos em timócitos das linhagens DBA-1/J e DBA-2/J com seus respectivos alvos relacionados ao sistema imune

Figura 21. Rede mostrando a interação dos microRNAs induzidos em linfócitos $T$ $\mathrm{CD}^{+}$provenientes de baço e linfonodos inguinais das linhagens DBA-1/J e DBA-2/J, não imunizados, com seus respectivos alvos relacionados aos processos de apoptose $\mathrm{e}$ adesão celular

Figura 22. Rede mostrando a interação dos microRNAs induzidos em linfócitos $T$ $\mathrm{CD}^{+}$provenientes de baço e linfonodos inguinais das linhagens DBA-1/J e DBA-2/J, não imunizados, com seus respectivos alvos relacionados aos processos de diferenciação celular e recombinação.

Figura 23. Rede mostrando a interação dos microRNAs induzidos em linfócitos $T$ $\mathrm{CD}^{+}$provenientes de baço e linfonodos inguinais das linhagens DBA-1/J e DBA-2/J, não imunizados, com seus respectivos alvos relacionados ao sistema imune.

Figura 24. Rede mostrando a interação dos microRNAs induzidos em linfócitos $T$ $\mathrm{CD}^{+}$provenientes de baço e linfonodos inguinais das linhagens DBA-1/J e DBA-2/J durante a indução de CIA, com seus respectivos alvos relacionados ao processo de morte celular

Figura 25 Rede mostrando a interação dos microRNAs induzidos em linfócitos $\mathrm{T}$ $\mathrm{CD}^{+}$provenientes de baço e linfonodos inguinais das linhagens DBA-1/J e DBA-2/J durante a indução de CIA, com seus respectivos alvos relacionados ao sistema imune... 105

Figura 26. Rede mostrando a interação dos microRNAs induzidos em linfócitos $T$ $\mathrm{CD}^{+}$provenientes de baço e linfonodos inguinais das linhagens DBA-1/J e DBA-2/J durante a indução de CIA, com seus respectivos alvos relacionados aos processos inflamatórios, diferenciação e proliferação de linfócitos $\mathrm{T}$

Figura 27. Rede mostrando a interação do microRNA miR-29a* reprimido em linfócitos $\mathrm{T} \mathrm{CD}^{+}$provenientes de baço e linfonodos inguinais da linhagem DBA-1/J durante a indução de CIA e seus respectivos alvos

Figura 28. Rede mostrando a interação do microRNA miR-135a* reprimido em linfócitos $\mathrm{T} \mathrm{CD}^{+}$provenientes de baço e linfonodos inguinais da linhagem DBA-1/J durante a indução de CIA e seus respectivos alvos

Figura 29. Matriz de expressão de 75 microRNAs de linfócitos $\mathrm{T} C D 3^{+}$periféricos em camundongos da linhagem DBA-1/J, durante a indução de CIA

Figura 30. PCR quantitativa dos microRNAs miR-29b*, miR-30b*, miR-500 e miR505 em linfócitos $\mathrm{T} \mathrm{CD}^{+}$isolados de PBMCs de indivíduos saudáveis (controles) e pacientes com artrite reumatóide 
Figura 31. PCR quantitativa dos microRNAs miR-29a*, miR-let-7d, miR-15b* e miR135a* em linfócitos T CD4 ${ }^{+}$isolados de PBMCs de indivíduos saudáveis (controles) e pacientes com artrite reumatóide

Figura 32. Rede de interação entre o miR-505 e seus alvos preditos pelo banco de dados targetscan

Figura 33. Análise da pureza de células T CD4+ provenientes de doadores saudáveis por citometria de fluxo

Figura 34. PCR quantitativa do microRNA miR-505 em linfócitos TCD4 ${ }^{+}$estimulados com anti-CD3 e anti-CD3 ${ }^{+} /$anti-CD28 nos períodos de 4, 8, 12, 24, 48, e 72 horas....

Figura 35. PCR quantitativa do microRNA miR-505, em linfócitos TCD $4^{+}$estimulados com TNF, Il-2, e IL-6 recombinantes na concentração final de $25 \mathrm{ng} / \mathrm{ml}$ (TNF e IL-2), e 100ng/ml (IL-6), nos períodos de 3, 5, e 7 dias.

Figura 36. Análise da pureza de células $\mathrm{T} \mathrm{CD} 4^{+} \mathrm{CD} 25^{+}$Foxp $^{+}$(Tregs) provenientes de doadores saudáveis por citometria de fluxo.

Figura 37. PCR quantitativa do microRNA miR-505, em linfócitos TCD4 ${ }^{+}$ diferenciados.

Figura 38. Matriz de expressão de 13.332 RNAms de linfócitos $\mathrm{T} \mathrm{CD}^{+}$periféricos em camundongos da linhagem DBA-1/J durante a indução de CIA....

Figura 39. Rede mostrando a interação do microRNA miR-505 e seus respectivos alvos preditos pelo $\mathrm{GenMiR}^{++}$

Figura 40. Ensaio de luciferase em células da linhagem HEK292 transfectadas com vetores contendo a região de ligação do miR-505 no gene IKZF2 


\section{Lista de tabelas}

Tabela I. Dados demográficos e clínicos da população estudada

Tabela II. Primers utilizados nas reações de qPCR e suas respectivas seqüências sense e antisense.

Tabela III. MicroRNAs selecionados com base no perfil de expressão das diferentes fases do desenvolvimento das células $\mathrm{T}$.....

Tabela IV. MicroRNAs selecionados com base no perfil de expressão de timócitos e de linfócitos $\mathrm{T} \mathrm{CD}^{+}$de camundongos não imunizados, DBA-1/J e DBA-2/J, e seus alvos definidos pelo uso do algoritmo $\mathrm{GenMiR}^{++}$

Tabela V. MicroRNAs selecionados pelo perfil de expressão nos linfócitos $\mathrm{T} \mathrm{CD}^{+}$de camundongos DBA-1/J e DBA-2/J, durante a indução de CIA e seus respectivos alvos definidos pelo uso do modelo GenMiR ${ }^{++}$

Tabela VI. Estrutura molecular de interações microRNA-RNAm selecionadas, e suas respectivas energias livres de interação obtidas pelo programa RNAhybrid

Tabela VII. MicroRNAs diferencialmente expressos nos linfócitos $\mathrm{T} \mathrm{CD}^{+}$durante a indução de CIA comparado ao controle

Tabela VIII. Alvos preditos do microRNA miR-505 pelo banco de dados targetscan em humanos

Tabela IX. Alvos preditos do microRNA miR-505 utilizando o modelo GenMiR ${ }^{++}$em camundongos 


\section{Lista de abreviaturas}

Aire: autoimmune regulator

AR: artrite reumatóide

ATOC : Adult Thymus Organ Culture

CCL: CC-chemokine ligant

CCP: cyclic citrullinated peptide (peptídeo citrulinado cíclico)

CD: cluster differentiation

cDNA: DNA complementar

CFA: complete Freund Adjuvant (adjuvante completo de Freund

CIA: collagen-induced arthritis (artrite induzida por colágeno)

CII: colágeno do tipo II

cTEC: Células epiteliais corticais tímicas

CTLA4: citotoxic T-lymphocyte antigen 4)

Cy3: cianina 3

DAS: disease activity score

DEPC: Dietil pirocarbonato

DMARDs: drogas anti-reumáticas modificadoras da doença (anti-reumáticos modificadores da doença)

DMSO: dimetilsulfóxido

DN: duplo negativo

DP: duplo positivo

FR: fator reumatóide

FTOC: fetal thymus organ culture

GO: gene ontology

HLA: human leukocyte antigen (antígenos leucocitários humanos)

IFN: interferon

Ig: imunoglobulina

Il: interleucina 
MFE: minimum free energy

MHC: major histocompatibility complex (complexo principal de histocompatibilidade)

MIP-1: macrophage inflammatory protein 1

MMP: metaloproteinases

MP: micro partículas de plaquetas

mTEC: Células epiteliais medulares tímicas

NK :natural killer

pb: pares de base

PBMCs: peripheral blood mononuclear cell (células mononucleares do sangue periférico)

PBS: phosphate buffered saline (tampão fosfato-salino)

PCR: Polymerase chain reaction

PGE: Promiscuous gene expression (Expressão gênica promíscua)

RISC: complexo de indução de silenciamento do RNA

RNA: ácido ribonucléico

RNAi: RNA interferente

MRNA: RNA mensageiro

NT: nucleotídeos

$\mathrm{S}_{1} \mathrm{P}_{1}$ : receptor 1 de esfingosina-1-fosfato

STAT: signal trabsducer and activator

TCR: Receptor de células T

TECs: células epiteliais tímicas

Th: T helper

TNF: fator de necrose tumoral

TRAs: Antígenos relacionados a tecido

Tregs: linfócitos T reguladores

UTR: untranslated regions

UV: Ultra violeta 


\section{Sumário}

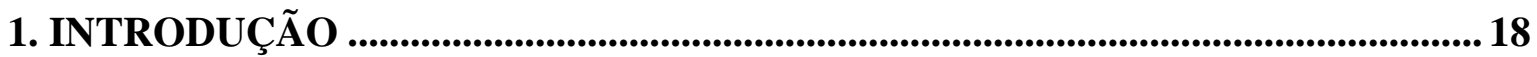

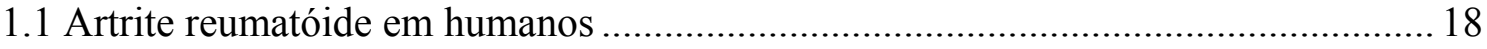

1.1.1 Fatores genéticos envolvidos na artrite reumatóide .......................................... 19

1.1.2 Fatores ambientais envolvidos na artrite reumatóide........................................ 20

1.1.3 Fatores imunológicos envolvidos na artrite reumatóide .................................. 21

1.1.4 Estratégia de tratamento para a artrite reumatóide.............................................23

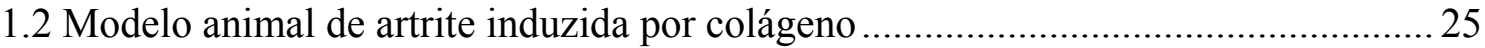

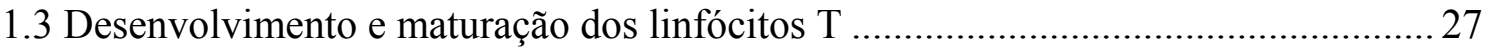

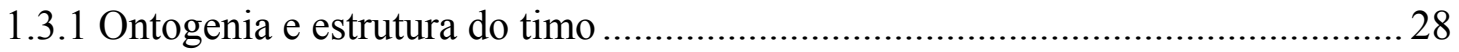

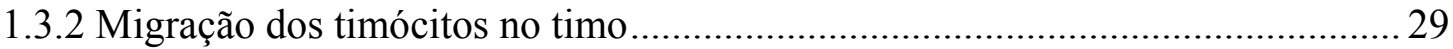

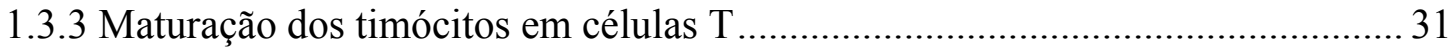

1.3.4 Indução da Tolerância Imunológica .................................................................. 33

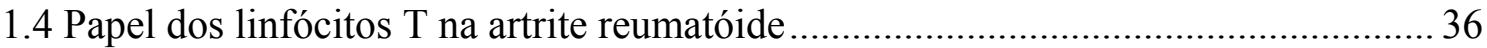

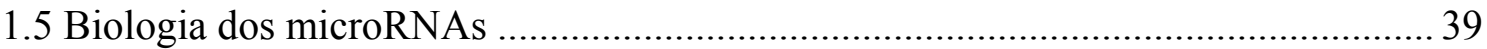

1.5.1 Descoberta, conceito e características dos microRNAs .................................... 39

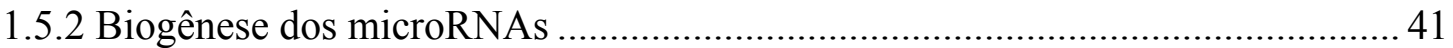

1.5.3 Interação microRNA-RNA mensageiro ........................................................... 43

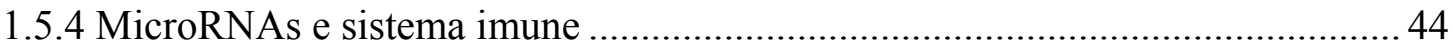

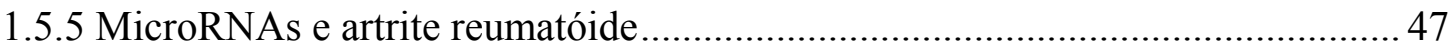

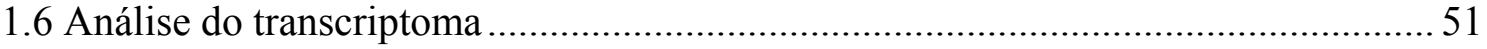

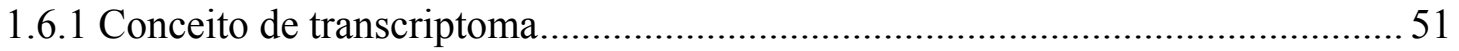

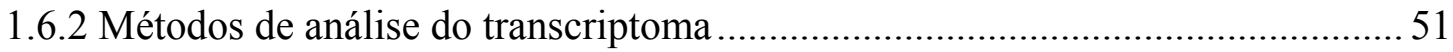

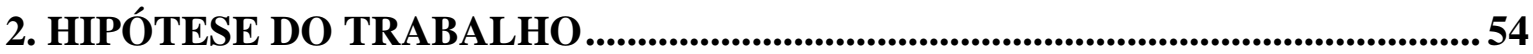

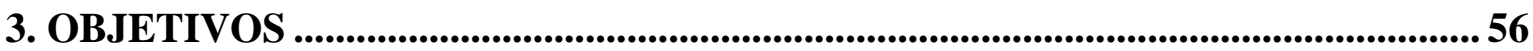

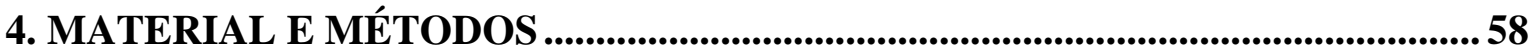

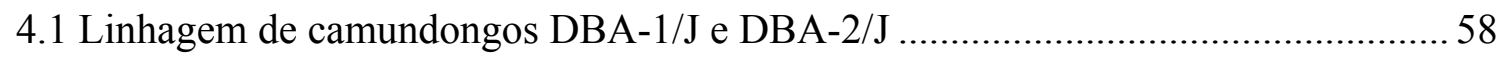

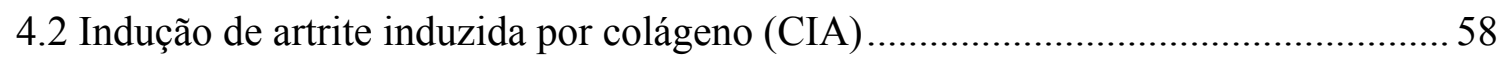

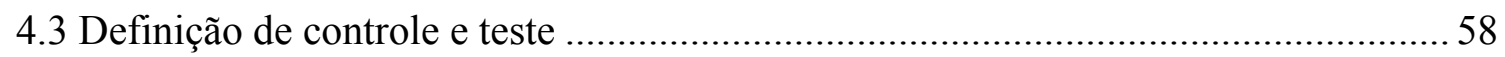

4.4 Separação dos timócitos e isolamento de linfócitos $\mathrm{T} \mathrm{CD}^{+}$periféricos ....................59 
4.5 Quantificação das populações celulares de camundongo por citometria de fluxo .... 60

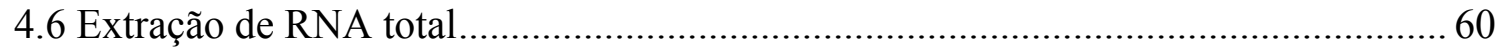

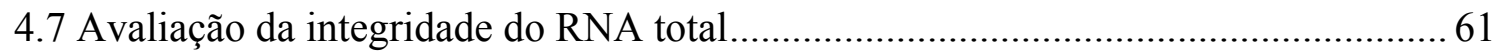

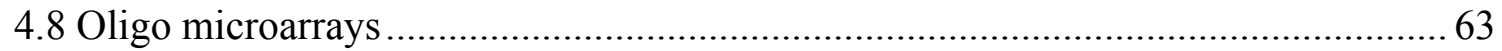

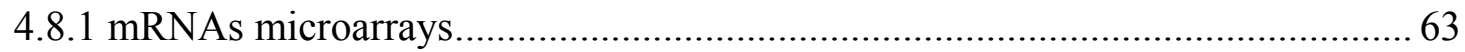

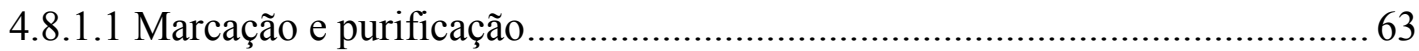

4.8.1.2 Hibridação das amostras e lavagem das lâminas........................................... 65

4.8.1.3 Leitura das lâminas e extração dos dados brutos............................................ 66

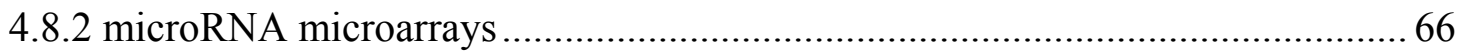

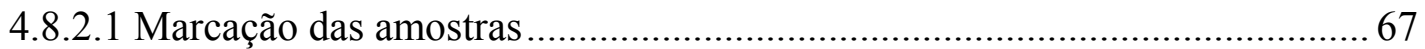

4.8.2.2 Hibridação das amostras e lavagem das lâminas ......................................... 68

4.8.2.3 Leitura das lâminas e extração dos dados brutos............................................ 69

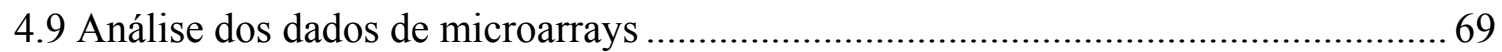

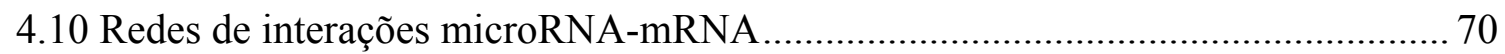

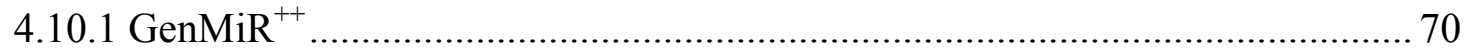

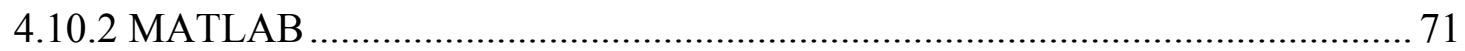

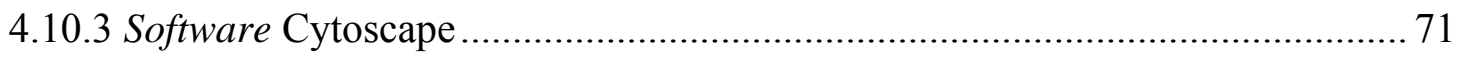

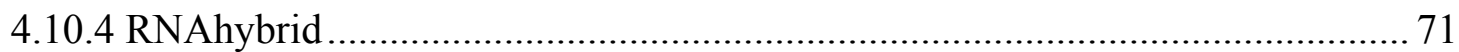

4.11 Amostras de linfócitos $\mathrm{T} \mathrm{CD}^{+}$provenientes de pacientes com artrite

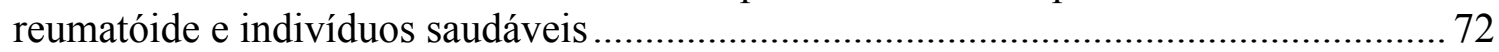

4.12 Separação dos linfócitos $\mathrm{T} \mathrm{CD}^{+}{ }^{+}$e $\mathrm{T} \mathrm{CD} 25^{+} \mathrm{Foxp}^{+}$reguladores de PBMCs de

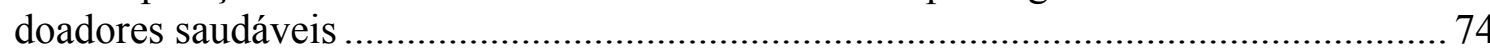

4.13 Quantificação das populações celulares das amostras de doadores saudáveis por

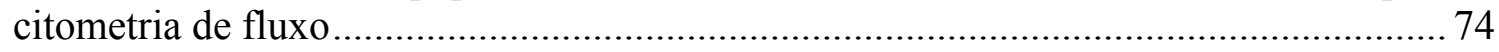

4.14 Extração de RNA total de amostras de pacientes e doadores saudáveis ................. 75

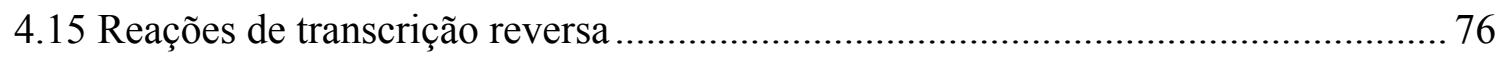

4.16 Reação de polimerização em cadeia em tempo real (qPCR) .................................. 76

4.17 Ensaio de proliferação e diferenciação celular ....................................................... 77

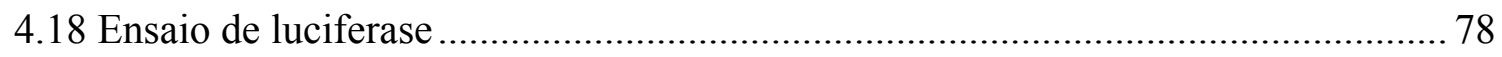

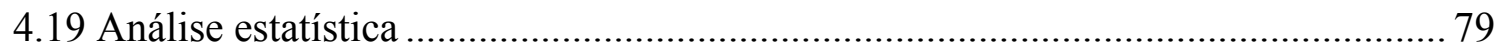

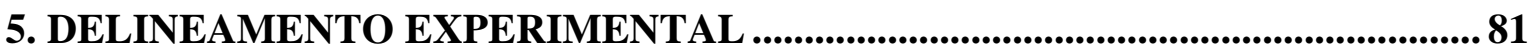

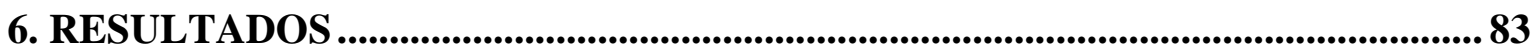

6.1 Avaliação da integridade das amostras de RNA …................................................ 83 
6.2 Quantificação das populações celulares por citometria de fluxo 84

6.3 Análise dos RNAs mensageiros diferencialmente expressos......

6.4 Análise dos microRNAs diferencialmente expressos.............................................. 90

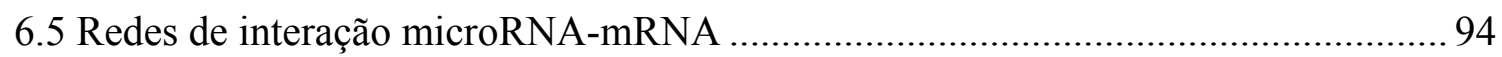

6.6 Identificação de novos microRNAs em pacientes com artrite reumatóide .............. 116

6.6.1 Análise dos microRNAs diferencialmente expressos

6.6.2 Análise da expressão dos microRNAs por PCR quantitativa em tempo real (qPCR).

6.6.3 Avaliação dos alvos do miR-505 em humanos

6.6.4 Ensaios de proliferação e diferenciação celular in vitro e avaliação da

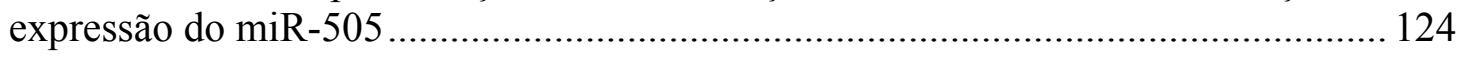

6.6.5 Análise dos mRNAs diferencialmente expressos .......................................... 129

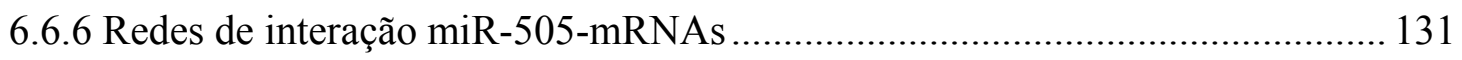

6.6.7 Ensaio de luciferase para verificação do gene IKZF2 como alvo do miR-505. 133

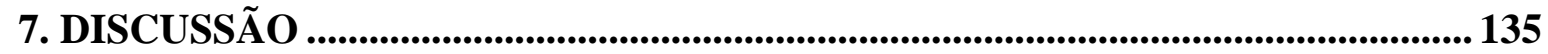

7.1 Caracterização da população de linfócitos T CD3 ${ }^{+}$total.......................................... 136

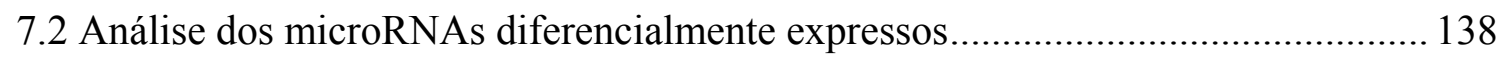

7.3 Análise das redes de interação microRNA-mRNA ................................................ 141

7.4 Papel do miR-505 nos linfócitos T na artrite reumatóide........................................ 146

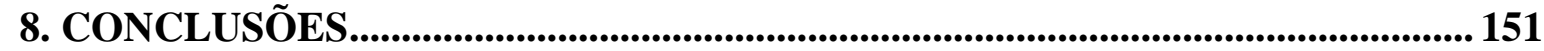

9. REFERÊNCIAS BIBLIOGRÁFICAS ................................................................... 153

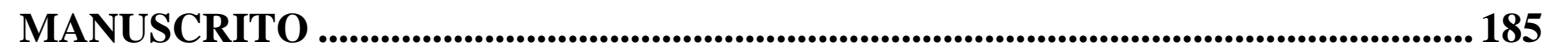

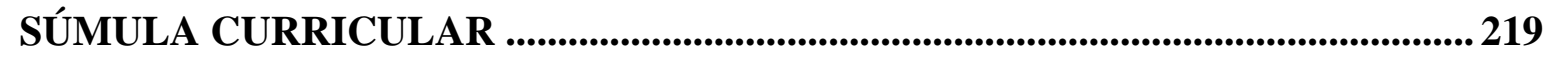

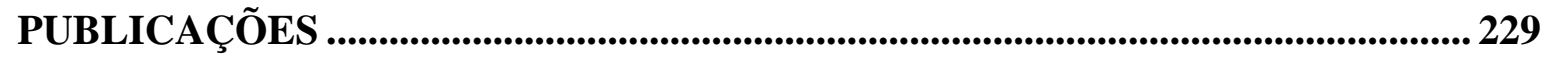


INTRODUÇÃO 


\section{INTRODUÇÃO}

\subsection{Artrite reumatóide em humanos}

A artrite reumatóide (AR) é uma artropatia autoimune, inflamatória sistêmica, de etiologia ainda desconhecida, com prevalência em torno de $1 \%$ em populações caucasóides (FELDMANN et al., 1996a, ACR GUIDELINE, 1996) e entre 0,2-1\% na população brasileira (MARQUES-NETO et al., 1993). Estudos epidemiológicos mostram que a incidência da doença ocorre entre 35-65 anos e afeta três vezes mais mulheres do que homens (SYMMONS et al., 1994). Em coorte retrospectivo realizado em quatro hospitais universitários do Estado de São Paulo, a maioria dos pacientes em tratamento encontravase entre 30 e 60 anos, sendo a relação entre mulher e homem de 5 para 1 (LOUZADAJUNIOR et al., 2007). Caracterizada por um intenso processo inflamatório na sinóvia, deposição de fibrina, hiperplasia de células sinoviais, infiltrados mononucleares, formação de pannus e eventual anquilose em uma ou mais articulações, as pequenas articulações de mãos e pés são preferencialmente afetadas (KOOPMAN et al., 2001). A produção exacerbada de citocinas e mediadores inflamatórios, entre eles interleucinas 1, 6 e 17 (IL-1, IL-6, IL-17), fator de necrose tumoral $\alpha$ (TNF- $\alpha$ ), metaloproteinases (MMP) relacionadas à manutenção da matriz extracelular, resultam em destruição de cartilagem e ossos (AREND et al., 2001; KOTZIN et al., 1998; YAMAMURA et al., 2001; FELDMANN et al., 1996b). Tipicamente, pacientes com AR exibem manifestações sistêmicas, como produção de auto-anticorpos; nódulos reumatóides, a lesão cutânea mais comum; vasculite, uma complicação que pode afetar muitos órgãos vitais causada por uma endoartrite obliterativa, doenças cardiovasculares; entre outros (MUSTILA et al., 2000; GORONZY et al., 1995).

A AR está sendo subdividida baseado no perfil específico de auto-anticorpos (BUKHARI et al., 2002; ZENDMAN et al., 2006). O fator reumatóide (FR) é o autoanticorpo clássico da artrite reumatóide, direcionado contra a porção $\mathrm{Fc}$ de uma imunoglobulina (Ig), sendo os subtipos IgM e IgA os principais marcadores patogênicos. O ensaio do fator reumatóide apresenta uma sensibilidade de 60 a 80\%, apesar de baixa especificidade, estando presente em outras doenças autoimunes, doenças infecciosas e em indivíduos idosos, sem evidência clínica de AR. Outro auto-anticorpo importante é o direcionado contra peptídeos citrulinados cíclico (anti-CCP). Embora a maioria dos pacientes anti-CCP positivos também apresentem fator reumatóide positivo, os anticorpos 
anti-CCP são mais específicos para o diagnóstico e parecem ser melhores preditores de pior prognóstico.

Os mecanismos envolvidos na origem e progressão da doença ainda não são totalmente compreendidos. Sabe-se que a persistente ativação do sistema imune resulta em autoimunidade, entretanto o gatilho que provoca essa ativação ainda é desconhecido.

A autoimunidade é um fenômeno caracterizado pelo estado de sensibilidade do sistema imunológico a antígenos autólogos, podendo acarretar uma doença autoimune quando o mesmo responde causando lesão celular e tecidual (KAMRADT \& MITCHISON, 2001; TARNER \& FATHMAN, 2001). A complexidade das doenças autoimunes, se deve a interação de três componentes: genético, ambiental e regulação imunológica, que resultam na falha de auto-tolerância (FATHMAN et al., 2005; JIANG et al., 2005).

\subsubsection{Fatores genéticos envolvidos na artrite reumatóide}

Desde 1970, o conhecimento da associação entre os fatores genéticos e a susceptibilidade a AR vem contribuindo para dissecação dos mecanismos moleculares envolvidos na patogênese da doença. Em estudos com gêmeos, estimou-se que a contribuição relativa dos fatores genéticos é em torno de 50\% (MACGREGOR et al., 2000), enquanto que o restante estaria associado a fatores ambientais.

Fatores importantes e bem conhecidos são os produtos gênicos provenientes de certas classes de MHC de classe II, mais precisamente, a molécula HLA-DR situado no cromossomo humano 6p21. A mais importante associação genética da AR humano é com o locus HLA-DRB1, que codifica a cadeia beta das moléculas de MHC de classe II. A maioria dos alelos HLA-DRB1 possuem um motivo (sequência) comum de aminoácidos conservados na fenda de ligação ao antígeno, conhecido como epítopo compartilhado (GREGERSEN et al., 1987), que está envolvido com a apresentação de peptídeos autoantigênicos específicos.

Um estudo recente demonstrou que o epítopo compartilhado encontrado na molécula HLA-DRB1*1001 pode ligar certos peptídeos citrulinados provenientes de autoantígenos, e especificamente a citrulina, mas não a arginina, poderia se ligar as fendas da região de ligação e estimular a resposta específica de linfócitos T (JAMES et al., 2010). 
Esta associação de alelos de um complexo de apresentação de antígenos (HLA) com a doença teve um grande impacto sobre as teorias de patogênese molecular da AR, reforçando a idéia do papel central da ativação de linfócitos T e B dependente de MHC nesta doença.

Em 2004, identificou-se a associação entre o gene PTPN22 (proteína tirosina fosfatase, não receptor, tipo 22) e a susceptibilidade a AR (BEGOVICH et al., 2004). Esse gene codifica uma tirosina fosfatase citoplasmática que regula negativamente o limiar de ativação de linfócitos $\mathrm{T}$ via $\mathrm{TCR}$, e atualmente representa o segundo maior fator de risco à AR.

Outros alelos de risco para o desenvolvimento de AR, em genes cujos produtos protéicos estão associados com o desenvolvimento da resposta imune foram identificados. Polimorfismos importantes são o do fator associado ao receptor de TNF (TRAF1), envolvido na transdução de sinal e ativação de vias MAP quinases; e do fator de transcrição STAT4 (Signal Transducer and Activator of Transcription 4) (PLENGE RM et al., 2007; KURREEMAN FA et al., 2007; REMMERS EF et al., 2007). Esses estudos são de grande importância no sentido de identificar potenciais e distintas vias moleculares, nas quais muitos genes trabalham em conjunto no desenvolvimento da AR.

\subsubsection{Fatores ambientais envolvidos na artrite reumatóide}

A prevalência da artrite reumatóide é aumentada por fatores ambientais que interagem com determinantes genéticos. Entre esses fatores estão as doenças infecciosas, a fumaça de cigarro, poeira de sílica, óleos minerais e aerossóis poluentes (KLOCKARS et al., 1987; OLSSON et al., 2004; SVERDRUP et al., 2005).

Fatores como a reposição hormonal pós-menopausa em muitos estudos, porém não em todos, têm sido associado com a proteção da doença (OLIVER \& SILMAN, 2006). O consumo moderado de bebidas alcoólicas parece também estar associado à redução dos riscos a AR (AHO \& HELIOVAARA, 1993; KALLBERG et al., 2008), como visto na artrite experimental em roedores, no qual os riscos e a severidade da doença foram reduzidos (JONSSON et al., 2007).

A fumaça de cigarro é o fator de risco com associação melhor descrita para o desenvolvimento de artrite reumatóide, fator reumatóide e anti-CCP positivos (VESSEY et al., 1987; SYMMONS et al., 1997; KARLSON et al., 1999). A principal interação 
genótipo-ambiente é observada justamente para este tipo de $\mathrm{AR}$ entre os alelos de risco do HLA-DR e o habito de fumar. A combinação entre o histórico de fumo e a presença de duas cópias do HLA-DR com epítopo compartilhado aumenta 21 vezes o risco de desenvolver $\mathrm{AR}$ comparado com o risco entre não fumantes portadores do epítopo compartilhado (PADYUKOV et al., 2004). Estes estudos demonstram que uma exposição a compostos presentes na fumaça do cigarro pode mudar a magnitude da associação genética em uma doença complexa.

\subsubsection{Fatores imunológicos envolvidos na artrite reumatóide}

A inflamação sinovial é caracterizada pela presença e interação de diferentes tipos celulares do sistema imune. As células apresentadoras de antígeno se comunicam com os linfócitos T através da interação do receptor de células T (TCR) e as moléculas do MHC, e a ativação destas últimas ocorre apenas na presença de sinais co-estimuladores mediados pela família de receptores CD28-B7 (CD80/86). Os linfócitos B apresentam função tanto de células apresentadoras de antígeno, como produtoras de anticorpos, sendo a liberação desses anticorpos envolvida na formação de imunocomplexos. Análises por citometria de fluxo, demonstraram que os linfócitos $\mathrm{B}$ periféricos de pacientes apresentam expressão alterada de moléculas importantes, com altos níveis da molécula co-estimuladora CD86, e baixos níveis do receptor inibitório de imunocomplexos IgG (FcrRIIb) (CATALAN et al., 2010). Os macrófagos, ativados pelos linfócitos $\mathrm{T}$ e os imunocomplexos, produzem grandes quantidades de citocinas pró-inflamatórias, como o TNF, IL-1 e IL-6, que podem provocar o aumento na expressão de moléculas de adesão celular e a contínua produção de citocinas.

$\mathrm{Na} A \mathrm{R}$ a expressão do receptor de quimiocina CCR9, essencial para a migração e retenção dos leucócitos para as articulações, é aumentada na população de monócitos e macrófagos periféricos (SCHMUTZ et al., 2010). Dependendo das citocinas liberadas no ambiente inflamatório, os linfócitos $\mathrm{T}$ ativados podem apresentar fenótipos distintos, como os linfócitos Th17 (T helper 17), que são dependentes da estimulação por IL-6 e produzem IL-17. Essa molécula aumenta a liberação de citocinas, produção de enzimas que promovem a destruição articular, e moléculas relacionadas à destruição óssea, como é o caso do RANKL (CHOY \& PANAYI, 2001; MCINNES \& SCHETT, 2007). 
A figura 1 esquematiza o conhecimento recente acerca do processo inflamatório nas articulações durante a AR.

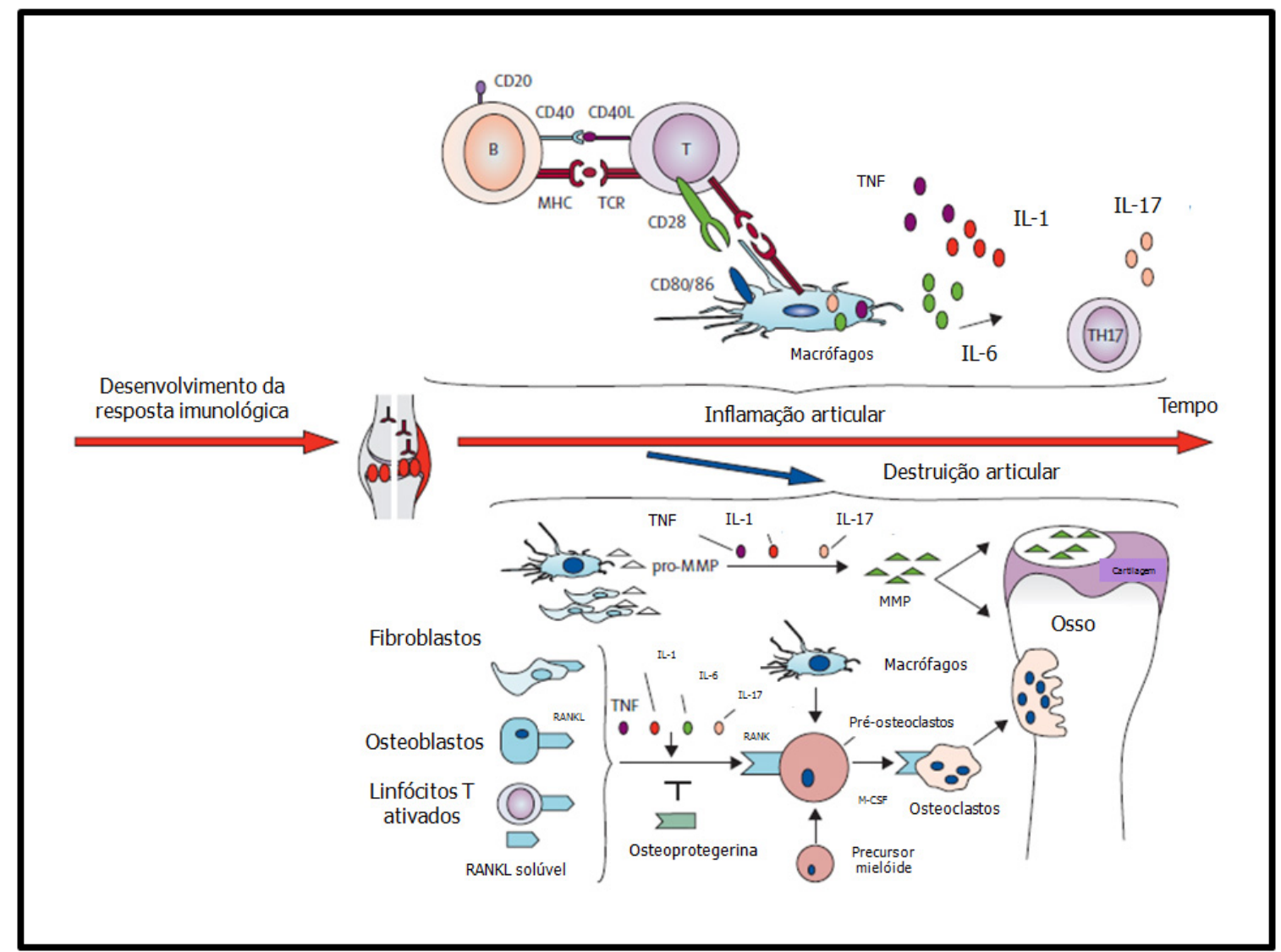

Figura 1. Modelo esquemático da via imunológica na articulação durante a artrite reumatóide. A parte de cima representa a inflamação articular, e a parte de baixo a destruição articular. [Extraído e modificado de KLARESKOG et al., 2009].

A relação de outros componentes do sistema imune com a patogênese da AR está sendo identificado. Entre eles estão as micro partículas de plaquetas (MP), que são encontradas no líquido sinovial das articulações inflamadas. Uma série de estudos consecutivos sugere que a glicoproteína VI, um receptor de colágeno expresso pelas plaquetas é o mecanismo utilizado pelos fibroblastos sinoviais para gerar essas micropartículas. As MPs expressas são capazes de se ligar a IL-1 $\alpha$ e IL-1 $\beta$, estimulando os fibroblastos a liberarem IL-6 e IL-8 (BOILARD et al., 2010). Além das funções descritas, as MPs são também ativadoras do sistema complemento. Uma disfunção da via do complemento está associada a doenças inflamatórias, e a sua ativação por manose ou $\beta$ glucana provoca artrite autoimune em camundongos SKG (KIMURA et al., 2010). 
Experimentos utilizando microarrays identificaram níveis elevados de expressão do RNA mensageiro que codifica a proteína FOXO3a (Forkhead Box O3), nas células polimorfonucleares do sangue de pacientes com AR. Essa proteína é um fator de transcrição envolvido na regulação e sobrevivência celular, e sua alta expressão sugere que o FOXO3a estaria prolongando a sobrevivência de células durante a doença, contribuindo para a inflamação crônica característica (TURREL-DAVIN et al., 2010). Outra molécula identificada, encontrada em altos níveis no soro de pacientes é a B7-H4, responsável pela inibição da via de sinalização B7-CD28. Estudo utilizando modelos animais demonstrou que a H4 solúvel estaria exacerbando a artrite por estar competindo com as moléculas de superfície celular (AZUMA et al., 2009).

O poder destrutivo do sistema imunológico, implicado nos danos característicos relacionados ao desenvolvimento da AR, é resultado do seu fenótipo alterado e ausência dos mecanismos de regulação apropriados. Os linfócitos $\mathrm{T}$ apresentam papel central na indução e progressão da doença, e os diversos subtipos de linfócitos $\mathrm{T}$ estão associados à manutenção local e sistêmica do processo inflamatório e subseqüente dano tecidual.

A importância dessas células foi o que motivou o desenvolvimento desse estudo, que visa contribuir para o melhor entendimento dos mecanismos moleculares envolvidos na AR.

\subsubsection{Estratégia de tratamento para a artrite reumatóide}

As estratégias no tratamento da AR têm sofrido grandes alterações durante a última década, e essas alterações são o resultado de três principais metas: 1) redução consistente do processo inflamatório e em estágios iniciais da doença; 2) os alvos devem ser mecanismos moleculares específicos implicados na patogênese; e 3) a AR é uma doença dinâmica, na qual os diferentes tratamentos funcionam de maneira individual e independente da fase dos pacientes (KLARESKOG et al., 2009).

O tratamento mais agressivo e nos estágios iniciais da doença com os medicamentos anti-reumáticos modificadores da doença (DMARDs do inglês Diseasemodifying antirheumatic drugs), como o metotrexato, sulfasalazina, hidroxicloroquina e glicocorticóides, podem ser benéficos para o controle da atividade inflamatória e o desenvolvimento de erosões em muitos pacientes (O'DELL et al., 1996; BOERS et al., 1997; MOTTONEN et al., 1999; SVENSSON et al., 2005). 
Entretanto, o desenvolvimento de estratégias que apresentam como alvo moléculas e vias específicas da patogênese da AR, significou um importante passo a frente. Esses tratamentos estão mudando a face da doença, o destino dos pacientes, a prática e a ciência na reumatologia (KLARESKOG et al., 2009).

O primeiro passo no desenvolvimento dos tratamentos com alvos específicos foi realizado com base nos estudos de clonagem e caracterização biológica do TNF, e pesquisas sobre a biologia das citocinas nas articulações (BRENNAN et al., 1989). A contribuição clínica chave veio quando pesquisadores do Instituto Kennedy em Londres definiram o papel importante do TNF na AR com um pequeno ensaio clínico bloqueando o TNF nos pacientes (ELLIOTT et al., 1993), que posteriormente foram confirmados (ELLIOTT et al., 1994; MAINI et al., 1998).

Os agentes bloqueadores de TNF circulante e da sinóvia (anticorpos monoclonais ou outras moléculas incluindo as recombinantes) aprovados para uso clínico são o infliximab (anticorpo anti-TNF quimérico), etanercept (receptor de TNF solúvel), e adalimumab (anticorpo anti-TNF humanizado).

Com o sucesso dos bloqueadores de TNF, rapidamente novas drogas biológicas foram surgindo, apresentando como alvos diferentes moléculas relacionadas às vias inflamatórias da doença. Em particular, anticorpos anti-IL1 (anakinra), anti-IL6 (tocilizumab), anti-CD20 (rituximab), e anti-CTLA4 (abatacept) têm se mostrado efetivas (BRESNIHAN et al., 199; KREMER et al., 2003; EDWARDS et al., 2004; SMOLEN et al., 2008). Muitos outros componentes imunológicos têm sido utilizados com alvos, e estão em estágio clínico ou aguardando aprovação.

Apesar do visível sucesso e do grande avanço em termos de estratégias terapêuticas na $\mathrm{AR}$, a resposta a essas drogas é variável entre os pacientes, e nem sempre as condições associadas à inflamação desaparecem por completo. A explicação biológica para isso ainda é desconhecida, porém, tem motivado diversas pesquisas a encontrar novos fatores envolvidos na patogênese da doença, no intuito de auxiliar no desenvolvimento de novos tratamentos, e ou prevenção.

Uma área promissora de pesquisa nesta direção foi a descoberta dos microRNAs, que regulam a expressão gênica, influenciando vários processos fisiológicos e patológicos. A expressão anormal dos microRNAs têm sido descrita em doenças autoimunes, e sua expressão alterada em diversos estágios da progressão de uma doença, pode auxiliar na sua 
identificação como potenciais biomarcadores, no melhor entendimento da patogênese de doenças, e monitoração da atividade e efeitos dos tratamentos administrados.

\subsection{Modelo animal de artrite induzida por colágeno}

Como aconteceu com grande parte das doenças auto-imunes nas quais muitas das evidências foram encontradas utilizando modelos animais, a artrite induzida por colágeno em camundongos (collagen-induced arthritis ou CIA) representou um grande avanço experimental. O sistema-modelo foi relatado pela primeira vez por Trentham e colaboradores, que observaram a doença em ratos após injeção intradérmica de colágeno do tipo II (CII) somado a adjuvante completo de Freund (CFA - Complete Freund Adjuvant) (TRENTHAM et al., 1977). Estudos posteriores demonstraram que uma patologia similar poderia ser induzida em primatas e em certas linhagens de camundongos geneticamente susceptíveis.

Esse modelo tem sido amplamente utilizado por apresentar características similares a AR, como deposição de fibrina, hiperplasia de células sinoviais, infiltração mononuclear, formação de pannus, destruição óssea e cartilaginosa, presença de fatores reumatóides e manifestações sistêmicas (HOLMDAHL et al., 1989; BURKHARDT et al., 1991; TERATO et al., 1992; SVENSSON et al.,1998).

Como em muitas das doenças autoimunes, a susceptibilidade associada à expressão de genes específicos de MHC de classe II, também é uma característica na CIA. Dependendo da linhagem e da origem das proteínas de colágeno do Tipo II, a susceptibilidade a CIA difere. Camundongos, como o DBA-1/J e o B10.Q, que apresentam respectivamente os haplótipos $\mathrm{H}-2^{\mathrm{q}}$ e $\mathrm{H}-2^{\mathrm{r}}$ são susceptíveis a doença (WOOLEY et al., 1981; BRUNSBERG et al., 1994), o que já não ocorre com outras linhagens, entre elas a DBA-2/J, que se mostra resistente mesmo quando exposta ao mesmo tratamento, e possui o haplótipo $\mathrm{H}-2^{\mathrm{d}}$.

Após o processo de imunização, a resposta proliferativa de linfócitos $\mathrm{T} \mathrm{CD}^{+}$ específicos ao CII pode ser observada no baço e linfonodos a partir da terceira semana após a primeira imunização. A inflamação do tecido articular se inicia cinco semanas após a primeira imunização, e a artrite persiste por pelo menos nove semanas (LOROSS \& WILLIANS, 2001). 
O modelo de CIA representa uma doença imunológica multifacetada que envolve células $\mathrm{T}, \mathrm{B}$, além das células inflamatórias que infiltram as articulações. Os anticorpos anti-CII são principalmente da subclasse IgG2, e ambos IgG2a e IgG2b estão envolvidos. Altos níveis desses anticorpos são detectados no pico do desenvolvimento da doença (WOOLEY et al., 1984; NANDAKUMAR \& HOLMDAHL, 2005). A ativação da cascata do sistema completo, principalmente a molécula C5a (resultante da quebra de C5), recruta neutrófilos e macrófagos. A ativação dessas células se dá através da ligação do receptor FcgR, e promove a secreção de quimiocinas, citocinas pró-inflamatórias, como a IL-1, TNF, IL-8, IL-6, MIP-1 $\alpha$, óxido nítrico e prostaglandinas. Esses fatores recrutam e ativam diversos tipos celulares, como células NK, células dendríticas, linfócitos $\mathrm{T}$ e $\mathrm{B}$, bem como macrófagos e fibroblastos sinoviais. A produção de citocinas pelas células sinoviais induzem a produção de outras citocinas, como a IL-23 e a IL-17, além de enzimas de degradação da matriz extracelular. O CII quebrado por essas enzimas é processado e apresentado por células apresentadoras de antígeno aos linfócitos $\mathrm{T}$, o que resulta no aumento da resposta imune específica, exacerbação do processo inflamatório e destruição da articulação (CHO et al., 2007). A progressão do processo inflamatório e a erosão óssea na articulação de camundongos durante o desenvolvimento da CIA podem ser visualizadas na figura 2.

O modelo de CIA representa um excelente modelo para dissecar os mecanismos moleculares envolvidos na patogênese da $A R$, e seu uso contribuiu para elucidação do papel dos linfócitos $\mathrm{T}$ na indução, manutenção e controle da doença através de diversos mecanismos. Apesar da existência de inúmeros outros modelos animais frequentemente utilizados para o estudo da AR, e igualmente importantes em relação a sua contribuição, no presente trabalho nós optamos por utilizar o modelo de CIA, modelo este amplamente conhecido e aceito, para o estudo do controle pós-transcricional dos microRNAs nos linfócitos $\mathrm{T}$. 


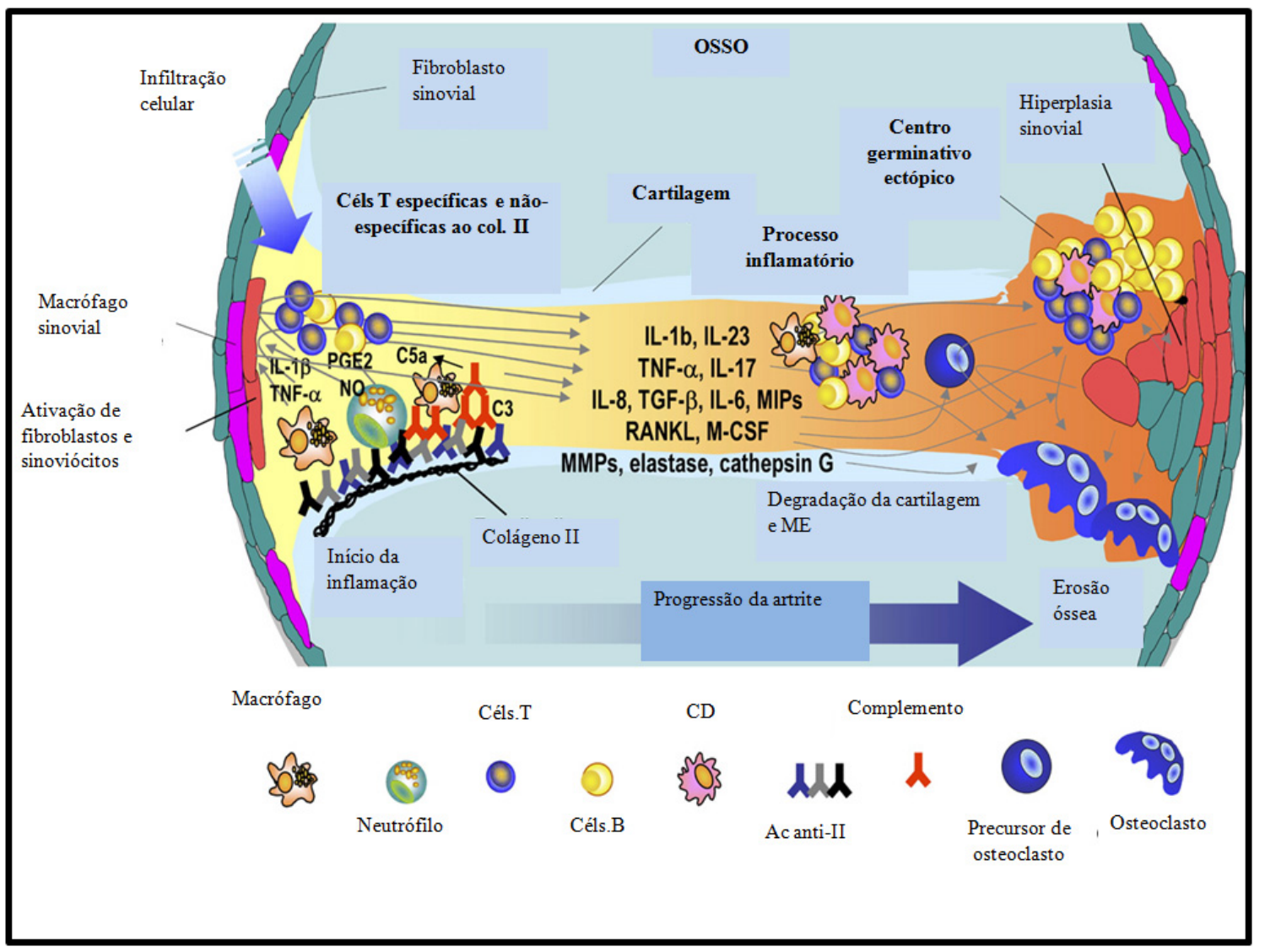

Figura 2. Diagrama esquemático do processo inflamatório e erosão óssea na articulação de camundongos com CIA. Os anticorpos anti-CII produzidos pela imunização com CII e CFA se liga ao CII da cartilagem, e o sistema complemento é ativado. C5a, produto da quebra do componente 5 do complemento, é um potente quimiatraente de neutrófilos e macrófagos e modula a expressão do receptor FcgR. Seguida da ligação deste receptor, os leucócitos ativados secretam quimiocinas, citocinas pró-inflamatórias, óxido nítrico e prostaglandinas, que ativa macrófagos sinoviais e o infiltrado de células mononucleares. Durante o processo inflamatório, linfócitos $\mathrm{T}, \mathrm{B}$, células dendriticas e macrófagos sinoviais proliferam e atuam em conjunto para secretar citocinas, enquanto interagem umas com as outras. Metaloproteinases, elastase e catepsina G degradam a matrix extracelular e a cartilagem. Os macrófagos e fibroblastos sinoviais progridem para a hiperplasia. Sob condições restritas, baixos níveis de IFN- $\gamma$ e IL-4, e altos níveis de TGF- $\beta$ e IL-6 induzem o fenótipo TH17 e a osteoclastogênese ocorre. A geração de osteoclastos resulta em erosão óssea. [Extraído e modificado de CHO et al., 2007].

\subsection{Desenvolvimento e maturação dos linfócitos T}

O timo é o órgão que dá suporte a diferenciação e seleção dos linfócitos $\mathrm{T}$ (MILLER et al.,1961; ZINKERNAGEL et al.,1978, TAKAHAMA, 2006, ANDERSON et al., 2006). Esse processo envolve várias etapas: 1) a entrada do progenitor linfóide no timo; 2) a geração de timócitos duplo positivos $\left(\mathrm{CD}^{+} \mathrm{CD}^{+}\right)$; 3$)$ a seleção positiva desses timócitos na região cortical, 4) a interação das células selecionadas positivamente com as células epiteliais medulares, para completar o desenvolvimento dos timócitos e assegurar a tolerância central (seleção negativa); e 5) a saída dos linfócitos T maduros para a periferia. 
Para que o desenvolvimento seja bem sucedido, as etapas devem ocorrer nos locais certos, e na sequência correta, proporcionando um contato íntimo dos timócitos com as células estromais tímicas. Ao contrário, clones de linfócitos auto-reativos que normalmente são selecionados (excluídos) no ambiente tímico, migram para a periferia e futuramente poderão reagir contra componentes próprios do corpo (SAINTE-MARIE \& LEBLOND, 1964; CANTOR \& WEISSMAN, 1976; STUTMAN et al., 1978; BHAN et al., 1980; PETRIE et al., 2003; GRAY et al., 2005).

\subsubsection{Ontogenia e estrutura do timo}

O timo é um órgão linfóide primário representado por células não linfóides e linfóides e por componentes da matriz extracelular. É um órgão altamente especializado cujo microambiente peculiar favorece a proliferação, a sobrevivência, a maturação e a migração de timócitos imaturos (TAKAHAMA, 2006).

No camundongo o timo inicialmente se desenvolve a partir da terceira bolsa faringeal, por volta dos dias 10-11 do período embrionário, período que possibilita a detecção morfológica de um epitélio rudimentar (MANLEY et al., 2000), e são colonizados por progenitores hematopoéticos por volta do 11,5 dia do desenvolvimento embrionário no camundongo, e na oitava semana de gestação em humanos (OWEN \& RITTE, 1969; HAYNES \& HEINLY, 1995). É bem estabelecido que o fator transcricional FoxN1 tem um papel essencial no desenvolvimento tímico, bem como na formação de um microambiente epitelial funcional (NEHLS et al., 1996; BOEHM et al., 2003).

Até 2001, a organogênese do timo foi, pelo menos em parte, baseada em estudos morfológicos. Ao longo dos anos, a contribuição de células mesenquimais de origem neuroectodérmica (crista neural) (LE DOUARIN \& JOTEREAU, 1975; BOCKMAN \& KIRBY, 1984; RODEWALD, 2008) para o desenvolvimento do timo foi confirmada, porém a origem das células epiteliais ainda era incerta (MANLEY et al., 2003).

Estudos com análises clonais, utilizando embriões com 12 dias de desenvolvimento (ROSSI et al., 2006), e experimentos com mapeamentos indicando um progenitor comum para as células corticais e medulares (BLEUL et al., 2006), tem conclusivamente mostrado que somente um folheto germinativo contribui para o desenvolvimento do compartimento epitelial tímico e esse folheto seria a endoderme. Contudo, não se podem excluir sinais de 
indução e/ou sobrevivência de outro folheto germinativo (MANLEY et al., 2003; GORDON et al., 2004; BOEHM \& BLEUL, 2006).

O estroma tímico pode ser visto como todos os componentes não hematopoiéticos do timo, que são funcionalmente definidos como aqueles elementos, independentemente da sua origem e linhagem, que constituem a estrutura do timo e, portanto, fornecem a matriz sobre a qual os timócitos se desenvolvem. Uma simples e usual classificação para o estroma está baseada não só no marcador hematopoiético CD45, mas também quanto a expressão de queratina. As células do epitélio tímico (TECs) são queratina ${ }^{+}$enquanto que as células mesenquimais são queratina' (RODEWALD, 2008).

O córtex proporciona um microambiente necessário para a seleção positiva dos timócitos imaturos enquanto que a medula é responsável pela seleção negativa das células $\mathrm{T}$ autorreativas. Cada um destes compartimentos forma um microambiente estromal especializado que é crucial para controlar a maturação das células T. O timo tem um suprimento vascular abundante e vasos linfáticos eferentes que drenam para os linfonodos do mediastino (VAN EWIJK, 1991; GRAY et al., 2002).

A manutenção do microambiente tímico, e o processo de desenvolvimento dos timócitos, requerem interações recíprocas entre timócitos e células estromais, denominadas de crosstalk tímico (VAN EWIJK et al., 1994; VAN EWIJK et al., 2000; GERMERAARD et al., 2003; GRAY et al., 2006). O desenvolvimento tímico envolve um processo de seleção estringente, do qual apenas 1-3\% dos timócitos sobrevivem e são exportados para a periferia (SCOLLAY et al., 1980; EGERTON et al., 1990). Em contrapartida, as células estromais precisam do contato íntimo com os timócitos para propiciar o microambiente apropriado que promove e regula esse desenvolvimento.

A interação dos precursores de timócitos com o microambiente estromal permite o comprometimento desses com as linhagens celulares $\mathrm{T}$ e essencialmente elimina ou permite a supressão de células autorreativas (BOEHM \& BLEUL, 2006; ANDERSON et al., 2007).

\subsubsection{Migração dos timócitos no timo}

A entrada dos precursores de linfócitos $\mathrm{T}$, ou células imaturas da linhagem de células $\mathrm{T}$ derivados da medula óssea, no timo, se inicia no período embrionário, antes mesmo da vascularização do órgão. A colonização do timo fetal é regulada por atração 
quimiotática, e a função parcial, porém significante de duas quimiocinas, da subfamília CC, CCL21 (CC-chemokine ligant 21) e CCL25 (CC-chemokine ligant 21) foram identificadas (BLEU \& BOEHM, 2000; WURBEL et al., 2001; LIU et al., 2005). Após o nascimento, os progenitores linfóides entram no timo adulto pela junção córtico-medular e então migram para a região subcapsular antes, porém, retornando pelo córtex em direção a medula (ANDERSON \& JENKINSON, 2001). Essa entrada é regulada pela interação do receptor 1 de esfingosina-1-fosfato $\left(\mathrm{S}_{1} \mathrm{P}_{1}\right)$, expressa pelos progenitores, e a P-selectina expressa no endotélio tímico (ROSSI et al., 2005).

Uma vez que os timócitos entram no timo, seu contato com o estroma tímico; composto essencialmente de células epiteliais (TECs), fibroblastos reticulares, células dendríticas e macrófagos derivados da medula óssea, além de estruturas conhecidas como corpúsculos de Hassal, localizados especificamente na medula tímica e composto de espirais compactas de células epiteliais remanescentes de células em degeneração (VAN EWIJK et al., 1991; GRAY et al., 2002); guia sua maturação. Isso ocorre mesmo durante os estágios de desenvolvimento tímico mostrando que o microambiente é capaz de promover a maturação de timócitos e simultaneamente dar continuidade ao seu próprio programa de desenvolvimento. Esse processo ocorre devido à presença de mediadores importantes como a interleucina 7 (IL-7) e os ligantes Notch (ZAMISCH et al., 2005; HARMAN et al., 2005).

Entre os sinais requeridos para o processo de migração, quimiocinas produzidas pelas células estromais nos microambientes individuais apresentam papel central em guiar a migração dos tímocitos. Os timócitos por sua vez, durante seu desenvolvimento encontram seu caminho através da expressão seqüencial de diferentes receptores dessas quimiocinas. (NITTA et al., 2011). Além disso, proteínas da matriz extracelular também auxiliam nesse processo, e uma função combinada para estas moléculas parece contribuir para os padrões de migração resultantes dos timócitos em seus vários estágios de diferenciação (SAVINO et al., 2003; SAVINO et al., 2006) (figura 3). 


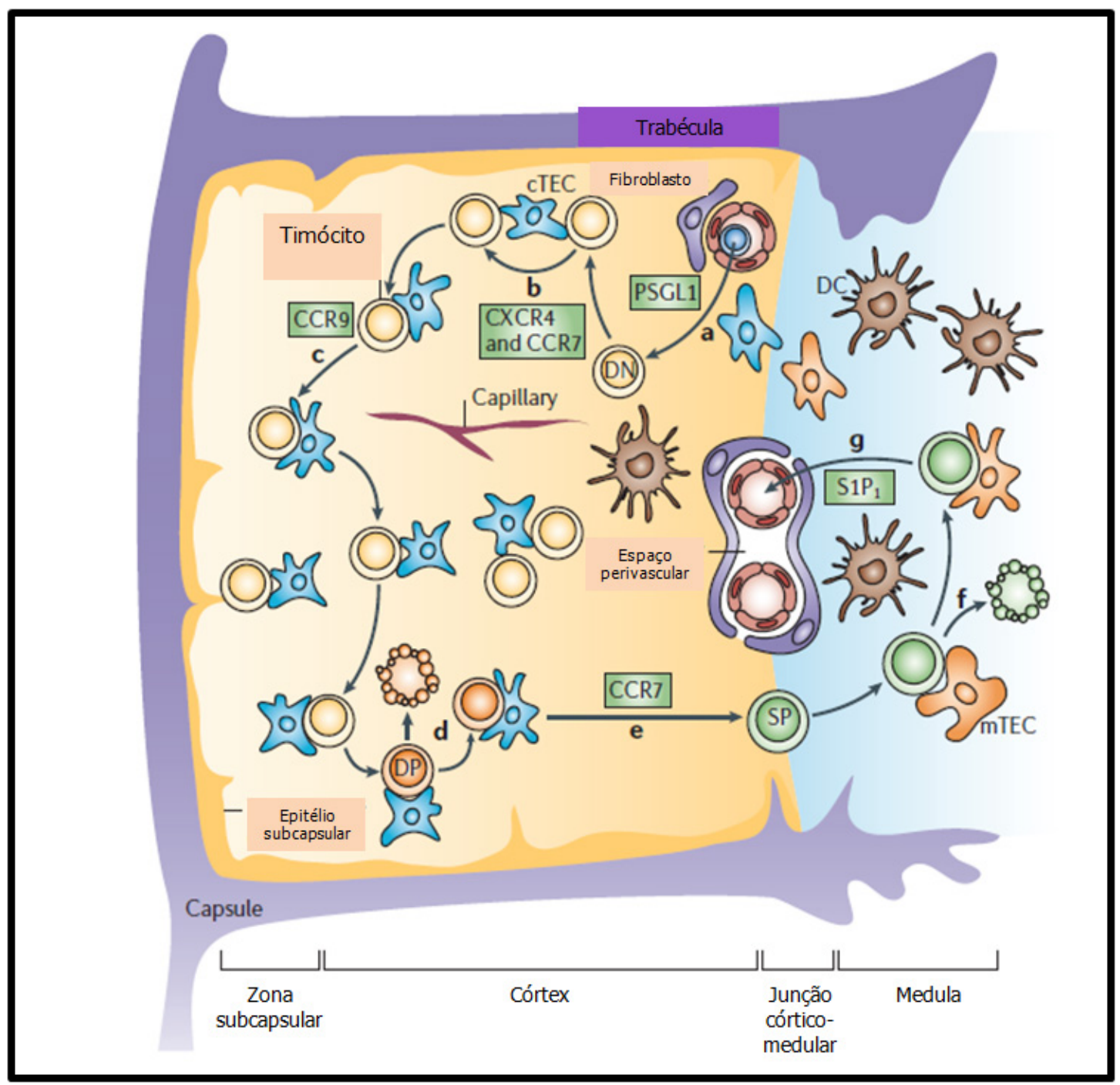

Figura 3. Migração dos tímocitos para desenvolvimento e seleção dos linfócitos T. a) Os progenitores linfóides $\mathrm{T}$ entram no timo através dos vasos na região córtico-medular. b) A migração dos timócitos duplonegativos (CD4- CD8-) pela cápsula é regulada por sinais quimiotáticos através dos receptores CXCR4 e CCR7. c) A posterior migração dos timócitos pela região subcapsular é mediada pela sinalização de CCR9. d) Os timócitos duplo-positivos (CD4+ CD8+) gerados interagem com células estromais do córtex para seleção positiva. e) Os timócitos selecionados positivamente se diferenciam em simples-positivo (CD4+ ou CD8+) e aumentam a expressão de CCR7 e se direcionam para a medula. f) Na medula a seleção negativa deleta as células com potencial auto-reativo e promove a geração de células T reguladoras (Tregs). g) Os timócitos simples-positivos maduros expressam S1P1 e são atraidos de volta para a circulação, que contém altas concentrações de esfingosina 1 fosfato. [Extraído e modificado de TAKAHAMA, 2006].

\subsubsection{Maturação dos timócitos em células T}

O processo de maturação dos linfócitos consiste numa complexa seqüência de eventos biológicos, compreendendo a proliferação das linhagens celulares precursoras, a expressão diferencial de proteínas de membrana, rearranjos gênicos do receptor de antígeno, a seleção do repertório de linfócitos maduros, e conseqüente morte celular programada dos linfócitos não selecionados e finalmente a migração celular. 
Os timócitos imaturos corticais recém-chegados ao timo contêm os genes de receptores na configuração germinativa e, portanto, ainda não expressam o TCR ( $T$ cell receptor), $\mathrm{CD} 3$, as cadeias $\zeta$ e os co-receptores CD4 e CD8. Essas células são chamadas de timócitos duplo-negativos (DN) e se submetem a múltiplos ciclos de proliferação e de progresso ao estágio duplo-negativo $\mathrm{CD}^{-} \mathrm{CD}^{-}(\mathrm{DN})$, aproximadamente $5 \%$ do total de timócitos, com discretos passos de maturação distinguidos pela expressão de marcadores de superfície celular CD44 ${ }^{\text {high }} \mathrm{CD} 25^{-}$(DN1), CD $44{ }^{\text {high }} \mathrm{CD} 25^{+}$(DN2), CD $44{ }^{\text {low }} \mathrm{CD} 25^{+}$(DN3), e CD44 ${ }^{\text {low }} \mathrm{CD} 25^{-}$(DN4). As proteínas do complexo recombinase (Rag-1 e Rag-2) são expressas pela primeira vez nesse estágio, e os rearranjos V(D)J se iniciam. Durante a transição da fase DN para duplo-positiva $\mathrm{CD}^{+} \mathrm{CD}^{+}$(DP), aproximadamente $85 \%$ dos timócitos se redistribuem à região cortical (RAMIALISON et al., 2002). O rearranjo dos genes da cadeia $\alpha$ e a expressão do heterodímero TCR $\alpha \beta$ ocorrem na população $\mathrm{CD} 4^{+} \mathrm{CD} 8^{+}$, exatamente antes ou durante a migração dos timócitos do córtex para a medula.

A recombinação $\mathrm{V}(\mathrm{D}) \mathrm{J}$ dos receptores de células $\mathrm{T}$ é um evento genético molecular essencial na maturação destas células. É um processo de recombinação sítio específico da molécula de DNA que só ocorre nos estágios iniciais de desenvolvimento dos linfócitos T e B.

A geração de grande diversidade nas regiões variáveis do receptor de antígeno de linfócitos $\mathrm{T}$ é crucial para que os organismos possam reconhecer e responder virtualmente contra todo e qualquer antígeno estranho. As primeiras células que expressam os TCRs estão no córtex tímico, e essa expressão é baixa em comparação com a célula T madura. Em virtude da expressão de seus complexos TCR completos, as células duplo-positivas podem responder ao antígeno e ficam sujeitas à seleção positiva e negativa. A maioria das células DP, as quais constituem cerca de $80 \%$ daquela população, morre por negligência porque não reconhecem moléculas disponíveis de MHC expressas por células estromais tímicas (SAVINO, 2006).

As células que passam com sucesso pelos processos de seleção amadurecem em células $\mathrm{T} \mathrm{CD}^{+}$ou $\mathrm{CD}^{+}$e são chamadas de timócitos simples positivos (SP), e compreendem aproximadamente $10 \%$ dos timócitos no timo (RAMIALISON et al., 2002). Assim, os estágios de maturação das células $\mathrm{T}$ podem ser rapidamente distinguidos pela análise da expressão das moléculas CD4 e CD8. Essa maturação fenotípica é acompanhada da maturação funcional.

Finalmente, os timócitos maduros com positividade única (células T CD4 e CD8 restritas ao $\mathrm{MHC}$ ) entram na medula do timo e deixam esse órgão pelos vasos sanguíneos para colonizar os tecidos linfóides periféricos (HAKS et al., 1998). Apenas os timócitos que vivem no timo nesta fase vão formar a maioria do repertório de células $\mathrm{T}$ periféricas (SAVINO, 2006; CIOFANI \& ZÚÑIGA-PFLÜCKER, 2007). 


\subsubsection{Indução da Tolerância Imunológica}

A tolerância imunológica aos antígenos próprios envolve processos de seleção negativa e positiva de linfócitos $\mathrm{T}$ que se desenvolvem no timo. A seleção positiva é o processo na qual os timócitos DP (no córtex) que apresentam TCR completo na superfície, se ligam com baixa avidez (fracamente) ao complexo peptídeo MHC próprio e são estimulados a sobreviver. Os timócitos cujos receptores não reconhecem as moléculas de MHC próprias morrem por apoptose. Isso assegura que as células $\mathrm{T}$ maduras sejam restritas ao MHC próprio. Na seleção positiva também há restrição de moléculas de classe I ou de classe II do $\mathrm{MHC}$ com os subtipos de linfócitos $\mathrm{T}$, assegurando que as células $\mathrm{T} \mathrm{CD} 8^{+}$citotóxicas sejam específicas a peptídeos expostos pelas moléculas de MHC de classe I, enquanto que as células $\mathrm{T} \mathrm{CD}^{+}$auxiliares ligam-se às moléculas de MHC de classe II associadas ao peptídeo (ANDERSON et al., 2006; KLEIN et al., 2009). Após a seleção positiva e o comprometimento em linhagem CD4 ou CD8, os timócitos se deslocam para a medula onde residem de 4 a 5 dias (MCCAUGHTRY et al., 2007).

Em contraste, a seleção negativa é a eliminação por apoptose dos timócitos cujos TCRs ligam-se com avidez (fortemente) ao antígeno próprio apresentado pela molécula de MHC própria de células dendríticas ou de células epiteliais tímicas medulares (mTECs). A avidez do reconhecimento do antígeno depende da afinidade do TCR e da concentração do peptídeo que a célula T reconhece (SPRENT, 1995; JAMESON \& BEVAN; 1998; Klein et al., 2009). Este processo elimina células $\mathrm{T}$ em desenvolvimento que são fortemente autorreativas contra antígenos próprios ubíquos, que são os antígenos próprios expressos pelas mTECs, e relacionados a tecidos (TRAs).

A seleção negativa envolve moléculas de superfície como CD28, CD5, CD43 e Fas que agindo conjuntamente levam a eficiência do processo (KISHIMOTO \& SPRENT, 1999). Em adição ao mecanismo de deleção, que ocorre na medula e assegura a tolerância ao próprio, é importante ressaltar que é neste mesmo local que são geradas as células reguladoras (Tregs) Foxp3 ${ }^{+}$(FONTENOT et al., 2005). Estudos demonstraram a importância do corpúsculo de Hassall em produzir a citocina linfopoetina tímica estromal (TLSP), que ativa as células dendríticas tímicas e favorece a geração de Tregs (WATANABE et al., 2005).

De fato, todos os grupos de células apresentadoras de antígenos (APCs), assim como as corticais tímicas (cTECs), medulares tímicas (mTECs), células dendríticas e macrófagos tem suas funções na apresentação de grupos de peptídeos próprios, e 
especialização nas suas habilidades para suportar as seleções positiva e negativa, contribuindo para a diversidade do quadro de antígenos próprios no timo (KLEIN \& KYEWSKI, 2000a; KYEWSKI \& DERBINSKI, 2004; ANDERSON et al., 2006; KLEIN et al., 2009). A aquisição dessa tolerância é dependente da interação entre receptor de célula T (TCR - Tcell receptor) e ligantes peptídeos-MHC próprios. Logo a diversidade de antígenos próprios acessível a esse repertório no timo é quem vai determinar a extensão e especificidade dessas células (KLEIN \& KYEWSKI, 2000b).

A discriminação do próprio/não-próprio é uma propriedade essencial do sistema imune que dirige uma variedade de mecanismos efetores contra agentes patogênicos enquanto ignora os constituintes próprios do organismo. Somente quando a tolerância ao próprio está balanceada é que a integridade do corpo é garantida (KYEWSKI \& DERBINSKI, 2004). O timo é visto como o principal órgão envolvido com a indução de tolerância aos antígenos próprios que são expressos pelas células tímicas (tolerância central).

A evidência da expressão de antígenos relacionados a tecidos (TRAs), de órgãos e tecidos parenquimais, no timo de camundongos e de humanos foi referida como "expressão gênica promíscua" (PGE) e seu entendimento tem sido alvo de muitas pesquisas, cujos resultados reforçam a concepção de tolerância central de antígenos tecidos específicos (JOLICOEUR et al., 1994; SOSPEDRA et al.,1998; DERBINSKI et al., 2001; GOTTER et al., 2004; KYEWSKI \& DERBINSKI, 2004; DONATE et al., 2010).

A descrição do fenômeno da expressão promíscua de genes de TRAs pelas mTECs iniciou uma nova fase na pesquisa em imunogenética que se ocupa da reavaliação das bases moleculares da tolerância central das células $\mathrm{T}$ na prevenção da autoimunidade (KYEWSKI \& DERBINSKI, 2004; MAGALHÃES et al., 2006).

O controle molecular da expressão gênica promíscua no timo tem sido investigado. O gene Aire (Autoimmune regulator), codifica uma proteína de 552 aminoácidos expressa principalmente no timo, e em menor extensão nos linfonodos, e em alguns outros tecidos (ZUKLYS et al., 2000; HALONEN et al., 2001; ADAMSON et al., 2004). Essa proteína é um regulador transcricional, que contém domínios de ligação com DNA (KUMAR et al., 2001), e controla a expressão de um conjunto de genes de TRAs em mTECs, mas de maneira independente da posição de promotores (PITKÄNEN et al., 2003). Os genes controlados por Aire são altamente diversos com relação à estrutura e função, o que dificultam as conclusões sobre seu modo de ação detalhado. Um estudo recente mostrou que a expressão do gene Aire não é restrita ao estroma tímico (células mTEC), mas é 
também expresso pelos timócitos e linfócitos periféricos. Demonstraram que o gene é pouco expresso pelos timócitos $\mathrm{CD} 4^{+} \mathrm{CD} 8^{+}$duplo positivos enquanto que no sangue periférico ele é mais expresso nas células $\mathrm{B}$ quando comparados com as células $\mathrm{T}$, sendo também altamente expresso em células dendríticas/macrófagos $\mathrm{CD}_{14}{ }^{+}$e em granulócitos (SUZUKI et al., 2008). Entretanto, nada se sabe sobre o papel do Aire nos timócitos.

Uma parte dos transcritos de TRAs, porém parecem ser independentes da expressão de Aire (DeRBINSKI et al., 2005; KURODA et al., 2005), que também regula positiva e negativamente a transcrição de uma gama de genes nas células epiteliais, que não codificam para TRAs. O significado deste controle no timo foi observado em estudos com animais Aire-knockout, onde a ausência desse gene promove o aparecimento de autoanticorpos, especialmente para o olho e o estômago (DEVOSS et al., 2006; GAVANESCU et al., 2007), sendo suficiente para causar autoimunidade. Em outro estudo, análises de camundongos Aire ${ }^{-}$mostram que a expressão de algumas TRAs é reduzida ou ausente em células mTECS deficientes de Aire e a seleção negativa dos timócitos é prejudicada (LISTON et al., 2004).

Nosso grupo de pesquisa (Grupo de Imunogenética Molecular, USP, Ribeirão Preto) vem trabalhando e procurando compreender melhor a ação do gene Aire in vitro em culturas de timo fetal (FTOC, Fetal Thymus Organ Culture) e adulto (ATOC, Adult Thymus Organ Culture). Aliando este recurso com a tecnologia dos cDNA microarrays demonstrou-se a maturação de células T por meio da detecção da recombinação $V(D) J$ de receptores de células T (TRVB8.1) e a modulação da expressão gênica em FTOCs numa escala de transcriptoma evidenciando a participação de genes essenciais implicados no desenvolvimento do timo (CARDOSO et al., 2006). Em outro estudo, mostrou-se o controle do Aire sobre a PGE após o seu silenciamento in vitro por meio de RNA interferente (RNAi) em cultura de células mTECs murinas. Tal silenciamento levou a modulação diferencial de muitos genes e com a reconstrução de redes de interações transcricionais foi possível identificar nós gênicos como o caso do gene Gucy2d que apresentou interação com genes “down-stream” de TRAs (MACEDO et al., 2009).

Durante nosso trabalho de mestrado (DONATE et al., 2011) demonstramos que a expressão do gene Aire e de genes de TRAs decrescem no estroma tímico de DBA-1/J, o que dentro do contexto de CIA pode sinalizar uma redução na seleção negativa dos respectivos clones de timócitos autorreativos e, consequentemente, contribuir com a reação autoimune (DONATE et al., 2011). Em outro estudo sobre genes de TRAs e a 
desregulação cronológica da tolerância imunológica (associada à idade), ficou evidente que durante a transição do estado pré-autoimune (pré-diabético) para autoimune (diabético), os camundongos Non Obese Diabetic (NOD) apresentam alteração da PGE no estroma tímico envolvendo inclusive genes que codificam antígenos importantes relacionados ao diabetes tipo I (DM-1) durante o desenvolvimento da doença (FORNARI et al., 2010).

No presente trabalho, continuamos com interesse nos fenômenos genéticomoleculares do controle da tolerância imunológica e no surgimento das doenças autoimunes. Na tentativa de dar um sentido complementar ao fenômeno da PGE que ocorre no estroma tímico, voltou-se dessa vez a atenção para os timócitos e para os linfócitos $\mathrm{T}$ $\mathrm{CD} 3^{+}$periféricos.

\subsection{Papel dos linfócitos $T$ na artrite reumatóide}

Os linfócitos T foram identificados nas articulações de pacientes com AR em 1975 (VAN BOXEL et al., 1975). Estudos posteriores, utilizando testes mais específicos, identificaram que diferentes subtipos de linfócitos $\mathrm{T}$ estavam envolvidos na doença, e que tanto as células $\mathrm{CD}^{+}$quanto as $\mathrm{CD}^{+}$estavam presentes nas articulações (ABDEL-NOUR et al., 1986). A associação da AR com os alelos HLA-DR1, evidencia o papel central dessas células na patogênese da doença, e a função efetora destas, na manutenção local ou sistêmica da inflamação e subsequente dano articular, vêm sendo recentemente melhor compreendido através da utilização de modelos animais. As citocinas pró e antiinflamatórias, as quimiocinas e seus receptores são componentes chave da função efetora dos linfócitos T (RAZA et al., 2005).

Os linfócitos T na AR apresentam um fenótipo não usual. Essas células apresentam um fenótipo claro de ativação, indicado pela elevada expressão de CD69 e HLA-DR, mas não respondem a estímulos mitogênicos, na presença de IL-2, sugerindo que os linfócitos T $\mathrm{CD}^{+}$encontrados na articulação se encontram em estado de exaustão devido a um excesso prévio de ativação (HOVDENES et al., 1989).

Nos últimos anos, um grande número de evidências apontam para o papel central da citocina IL-17 na imunopatologia da AR. O papel da IL-17 na artrite foi primeiro confirmado no modelo animal (camundongo) de indução de artrite pelo colágeno (CIA do inglês collagen induced arthritis). Os níveis de IL-17 nas articulações de animais imunizados aumentavam com a progressão da doença. Seu bloqueio suprimia a doença de maneira dose-dependente, 
enquanto que sua transferência local ou sistêmica por adenovirus era responsável pela exacerbação do processo inflamatório, progressão da doença, e dano tecidual (LUBBERTS et al., 2001). A IL-17 é produzida pelo subtipo de células T helper $\mathrm{CD}^{+}$, denominado Th17 (INFANTE-DUARTE et al.,2000). Sendo pró-inflamatória, esta célula pode estimular fibroblastos, células endoteliais, células epiteliais e macrófagos a produzir quimiocinas, GMCSF, IL-1, IL-6, ICAM-1, PGE2, RANTES, metaloproteinases, NOS-2, RANKL, dentre outros mediadores envolvidos com a migração neutrofílica, reabsorção óssea e destruição tecidual (WITOWSKI et al., 2004). A expressão dessa citocina é aumentada nas células presentes na sinóvia e na circulação em pacientes com AR (KOTAKE et al., 1999; CHABAUD et al., 1999), e os elevados níveis de RNA mensageiro na membrana sinóvial é um preditivo da progressão do dano na articulação na doença.

Demonstrou-se também, que as células Th17 estão envolvidas na indução da destruição óssea na artrite autoimune por seu papel osteoclastogênico via IL-17 - RANKL (SATO, 2006).

Os linfócitos $\mathrm{T}$ reguladores (Treg) modulam a resposta autoimune mediada por linfócitos $\mathrm{T}$, mantendo a tolerância periférica e prevenindo o desenvolvimento da doença autoimune. (VIGNALI et al., 2008; SAKAGUCHI et al., 1995; 2005). As Tregs são fenotipicamente determinadas como linfócitos $\mathrm{CD} 4{ }^{+} \mathrm{CD} 25^{+}$que possuem o fator de transcrição intracelular FOXP3, essencial para diferenciação e regulação do fenótipo supressor desta célula (HORI et al., 2003; FONTENOT et al., 2003). A deficiência ou ausência de células Tregs, e a reduzida expressão de FOXP3 em humanos e camundongos, está relacionada com o desenvolvimento de doenças autoimunes (BUCKNER et al.,2010). Na CIA as Tregs podem ser encontradas nas articulações, líquido sinóvial e linfonodos drenantes. Entretanto, enquanto as Tregs de camundongos saudáveis são efetivas em suprimir a resposta de linfócitos $\mathrm{T}$ efetores, o mesmo não ocorre com as Tregs provenientes de animais com artrite (MORGAN et al., 2005; GONZALEZ-REY et al., 2007).

O mesmo perfil é visto em humanos. Apesar da alta frequência dessas células no líquido sinovial e no sangue periférico de pacientes com $A R$, a inflamação articular persiste (CAO et al., 2003; VAN AMELSFORT et al., 2004; LIU et al., 2005; MOTTONEN et al., 2005), sugerindo que a função supressora dessas células é deficiente. As Tregs isoladas de pacientes com a doença ativa apresentam níveis reduzidos do fator de transcrição FOXP3, e não são capazes de suprimir linfócitos efetores $\left(\mathrm{CD} 4^{+} \mathrm{CD} 25^{-}\right)$ (FONTENOT et al., 2003; ALLAN et al., 2005). Sugere-se que o TNF- $\alpha$ produzido na 
sinóvia durante a progressão da doença esteja inibindo a função dessas células, já que têm se demonstrado que o tratamento com anti-TNF aumenta a expressão de Foxp3, e restaura seu perfil supressor (EHRENSTEIN et al., 2004; VALENCIA et al., 2006).

Já é bem conhecido a predominância de citocinas do padrão Th2 nos estágios iniciais do desenvolvimento da AR (RAZA et al., 2005). O seu papel indutor ou protetor da doença ainda é controverso. Alguns estudos utilizando modelos animais demonstraram a propriedade das células com perfil Th2 em estabelecer a artrite (DONCARLI et al., 1997; OKAMOTO et al., 2000). Por outro lado, muitos estudos utilizando o modelo de CIA descreveram o papel protetor de IL-4 (CHU et al., 1996, JOOSTEN et al., 1999; LUBBERTS et al., 2000; SARKAR et al., 2009), uma citocina produzida por linfócitos do padrão Th2. Análises do nível de IFN- $\gamma$ e IL-4 no líquido sinovial e soro dos pacientes com AR, indicam uma clara predominância do perfil inflamatório sobre o perfil Th2, quando comparados a indivíduos saudáveis. Além disso, durante condições que favorecem o perfil Th2, como por exemplo, durante a gravidez, os sintomas da AR são amenizados (VERHOEF et al., 1998; VAN ROON et., al 2002). As evidências mostram que o aumento de estrógeno durante a gravidez, resulta em polarização dos linfócitos para o perfil Th2 e aumenta a produção sistêmica de IL-4. Assim, a prevalência de AR em mulheres que passaram pela menopausa, pode ser em parte devido à perda da proteção promovida pela resposta Th2 (DORIA et al., 2006). Muitos estudos em modelo animal dão suporte ao papel protetor e a função reguladora desse perfil na doença.

O papel crucial dos linfócitos $\mathrm{T} \mathrm{CD}^{+}$na indução de muitos modelos experimentais de doença autoimune, como o diabetes e a esclerose múltipla têm sido demonstrado (WANG et al., 1996; ZHANG et al., 1996; SUN et al., 2001). Entretanto, a importância e o papel dessas células na $\mathrm{AR}$ ainda é controverso. Alguns estudos indicam que os linfócitos $\mathrm{T} \mathrm{CD}^{+}$são importantes na fase efetora da doença, sendo dispensáveis na sua indução (VAN DEN BROEK et al., 1992). Sugere-se ainda, que a capacidade de camundongos da linhagem DBA1/J em desenvolver artrite na ausência de linfócitos $\mathrm{T} C D 4^{+}$, deve-se a presença de células $\mathrm{CD}^{+}$(TADA et al., 1996). Sabe-se muito pouco a respeito do papel desses linfócitos em pacientes com AR, entretanto sugere-se que ela tenha um papel supressor (SUZUKI et al., 2008). Essas informações são baseadas em estudos com modelos animais, no qual a habilidade desses linfócitos em produzir IFN- $\gamma$ poderia explicar alguns dos mecanismos reguladores propostos, já que essa citocina é capaz de induzir IDO (indolamina 2,3-dioxigenase). A IDO cataboliza o triptofano, e seus derivados apresentam efeitos imunossupressores, por serem 
capazes de suprimir a resposta efetora, induzir apoptose de linfócitos $\mathrm{T}$, e aumentar as funções das Tregs (MUNN \& MELLOR, 2007). Esses dados corroboram com achados de que camundongos deficientes para IDO apresentam maior incidência de CIA e exacerbação da doença (CRIADO et al., 2009).

Estudos recentes têm demonstrado a participação de microRNAs no controle póstranscricional durante a diferenciação dos linfócitos bem como de outros processos relacionados ao sistema imune.

No presente trabalho, tivemos interesse em tentar revelar novas interações entre microRNAs e mRNAs associados a diferentes fases da diferenciação das células $\mathrm{T}$ em camundongos susceptíveis (DBA-1/J) e refratários a CIA (DBA-2/J).

\subsection{Biologia dos microRNAs}

\subsubsection{Descoberta, conceito e características dos microRNAs}

O primeiro microRNA, lin-4, foi descrito em 1993. Os pesquisadores descobriram que o gene lin-4 não codificava nenhuma proteína, mas sim um par de pequenos RNAs (LEE et al., 1993). Um dos RNAs tinha apenas 22 nucleotídeos de comprimento, enquanto o segundo, de aproximadamente 61 nucleotídeos de comprimento, formava uma estrutura em forma de grampo, e foi proposto ser o precursor do primeiro. Além disso, foi observado que esses RNAs apresentavam complementaridade a múltiplos sítios da região 3' UTR do RNA mensageiro lin-14, regulando sua tradução, e influenciando o desenvolvimento em $C$. elegans, promovendo a progressão do primeiro estágio larval para o segundo (LEE et al., 2003; WIGHTMAN et al., 1993).

Durante sete anos nenhum homólogo do lin-4 foi identificado. Isso mudou quando outro gene heterocrônico, o let-7, foi descoberto por codificar um RNA com 21 nucleotídeos e função regulatória, atuando na transição do último estágio larval do verme para sua forma adulta (REINHART et al., 2000). Devido à função comum, associada ao processo de desenvolvimento, desses dois RNAs, o lin-4 e o let-7 ficaram conhecidos como pequenos RNAs temporais (stRNAs - small temporal RNAs) (PASQUINELLI et al., 2000).

Um ano após a descoberta do let-7, homólogos desses RNAs foram encontrados em humanos e outras espécies. Entretanto, esses novos RNAs não eram expressos nos diferentes estágios de desenvolvimento, mas sim encontrados em tipos celulares 
específicos. Assim, o termo microRNA (miRNA) foi introduzido para se referir aos stRNAs e todos os outros pequenos RNAs com características semelhantes, mas funções desconhecidas (LAGOS-QUINTANA et al., 2001; LAU et al., 2001; LEE \& AMBROS, 2001; BARTEL et al., 2004).

Desde então, os microRNAs já foram relatados em uma grande variedade de organismos que vão desde algas unicelulares aos seres humanos, sugerindo que os microRNAs sejam um elemento regulatório antigo e essencial (BARTEL \& CHEN, 2004; ZHAO et al., 2007).

Hoje, os microRNAs são definidos como pequenos RNAs, não-codificantes de aproximadamente 21 nucleotídeos de comprimento, que funcionam como reguladores póstranscricionais da expressão gênica (KROL et al., 2010). Com relação à nomenclatura, novos microRNAs são nomeados após confirmação experimental (AMBROS et al., 2003). A abreviação "miR" se refere aos microRNAs maduros, e esse prefixo é acompanhado por um número que segue a ordem de descoberta do microRNA. MicroRNAs que diferem em apenas 1 ou 2 nucleotídeos em uma sequência específica, denominada seed, recebem o mesmo número, mas é adicionado uma letra minúscula ao nome. A região seed corresponde a uma sequência localizada na região 5' do microRNA, que compreende os nucleotídeos da posição 2 a 7, e é de extrema importância para o reconhecimento do RNAm alvo, e sua posterior ação regulatória.

O banco de dados de microRNAs conhecido como miRBase (http://www.mirbase. org/) traz um registro de 1.527 microRNAs humanos e 741 murinos (pesquisa realizada em 10/02/2012). Porém, novos microRNAs estão sendo validados com a ajuda de algorítimos de predição em programas disponíveis em sites da internet como TargetScan (http://www.targetscan.org/) (LEWIS et al., 2005), PicTar (http://pictar.mdc-berlin.de/) (KREK et al., 2005) e MiRanda (http://www.microrna.org/microrna/home.do) (BETEL et al., 2008), entre outros (HUANG et al., 2010).

Um único microRNA pode regular de centenas de alvos. Eles podem influenciar aproximadamente 50\% ou mais dos genes codificadores de proteína (KROL et al., 2010), e 30-92\% dos genes humanos seriam regulados (ENGELS et al., 2006; LEWIS et al., 2005; GRIFFITHS-JONES, 2004).

Assim, como nova e importante peça do processo de regulação gênica, os microRNAs apresentam diversas e cruciais funções biológicas nas células animais e tem sido alvo de muito interesse para estudo nos últimos anos. 


\subsubsection{Biogênese dos microRNAs}

A biogênese dos microRNAs é um processo complexo que envolve muitos passos, começando no núcleo e terminando no citoplasma. No primeiro passo do processo, a RNA polimerase II transcreve genes miR gerando transcritos primários (pri-mRNAs) que tem normalmente muitos nucleotídeos e contém uma ou muitas estruturas na forma de grampo (hairpin) possuindo ainda um cap na região 5' e uma cauda poli A. Na via canônica da biogênese, os pri-miRNAs são clivados no núcleo por um complexo que compreende a enzima RNase III, uma ribonuclease RNA-específica chamada de Drosha e a proteína DGCR8 (DiGeorge sybdrome critical region protein 8) produzindo os precursores dos microRNAs, os pre-miRNAs de 70 nucleotídeos de tamanho (PAULEY et al., 2009, HAN et al., 2004).

Uma via alternativa, não canônica, da biogênese de um pequeno grupo de miRNAs, conhecidos como mirtrons foi descrita. Os mirtrons são gerados a partir de regiões intrônicas nos spliceossomos. Esses microRNAs são também transcritos em estruturas na forma de grampo, e processados em pre-miRNAs utilizando a maquinaria de splicing de RNAs mensageiros, pulando o passo de processamento pela Drosha (BEREZIHOV et al., 2007).

O pre-miRNA é exportado para o citoplasma pela exportina 5, e lá é processado por outra enzima, Dicer, o segundo membro da família de RNAses do tipo III. Neste estágio o pre-miRNA perde sua estrutura em forma de grampo e da origem a um RNA de dupla fita imperfeito de aproximadamente 22 nucleotídeos, composto de uma fita "guia" e uma fita de passagem (indicado por um *). O microRNA agora está pronto para ser acoplado a proteína argonauta (Ago), um dos componentes chave do complexo de indução de silenciamento do RNA (RISC). O complexo é formado por 4 proteínas argonautas em mamífero (Ago1-ago4), e a proteína TRBP (Trans-activator RNA Binding Protein) (LIU et al., 2004; EYSTATHIOY et al., 2002). O recrutamento e retenção de umas fitas a bolsa de ligação na Ago2 é baseado em termodinâmica. Assim, a proteína Ago2 protege e mantém a estabilidade da fita madura para reconhecimento do seu mensageiro alvo, resultando em repressão e ou degradação (Figura 4).

A fita que não se liga ao complexo, denominada fita de passagem, é descartada e frenquentemente degradada (FILIPOWICZ et al., 2008). Entretanto, estudos recentes demonstraram que esta fita também é estável e está implicada a funções biológicas de importância (FABIAN et al., 2010). Zhou e colaboradores, demonstraram que a expressão 
do miR-155 e sua fita complementar miR-155* em células dendríticas plasmocitóides coordenam a função de estimular a produção de IFN do tipo I (ZHOU et al., 2010).

Avanços nos sequenciamentos vêm permitindo a identificação de certos microRNAs que não são processados pela Dicer (CIFUENTES et al., 2010). O significado desses pequenos RNAs independentes de Drosha e Dicer em células somáticas de mamíferos ainda precisa ser estudada.

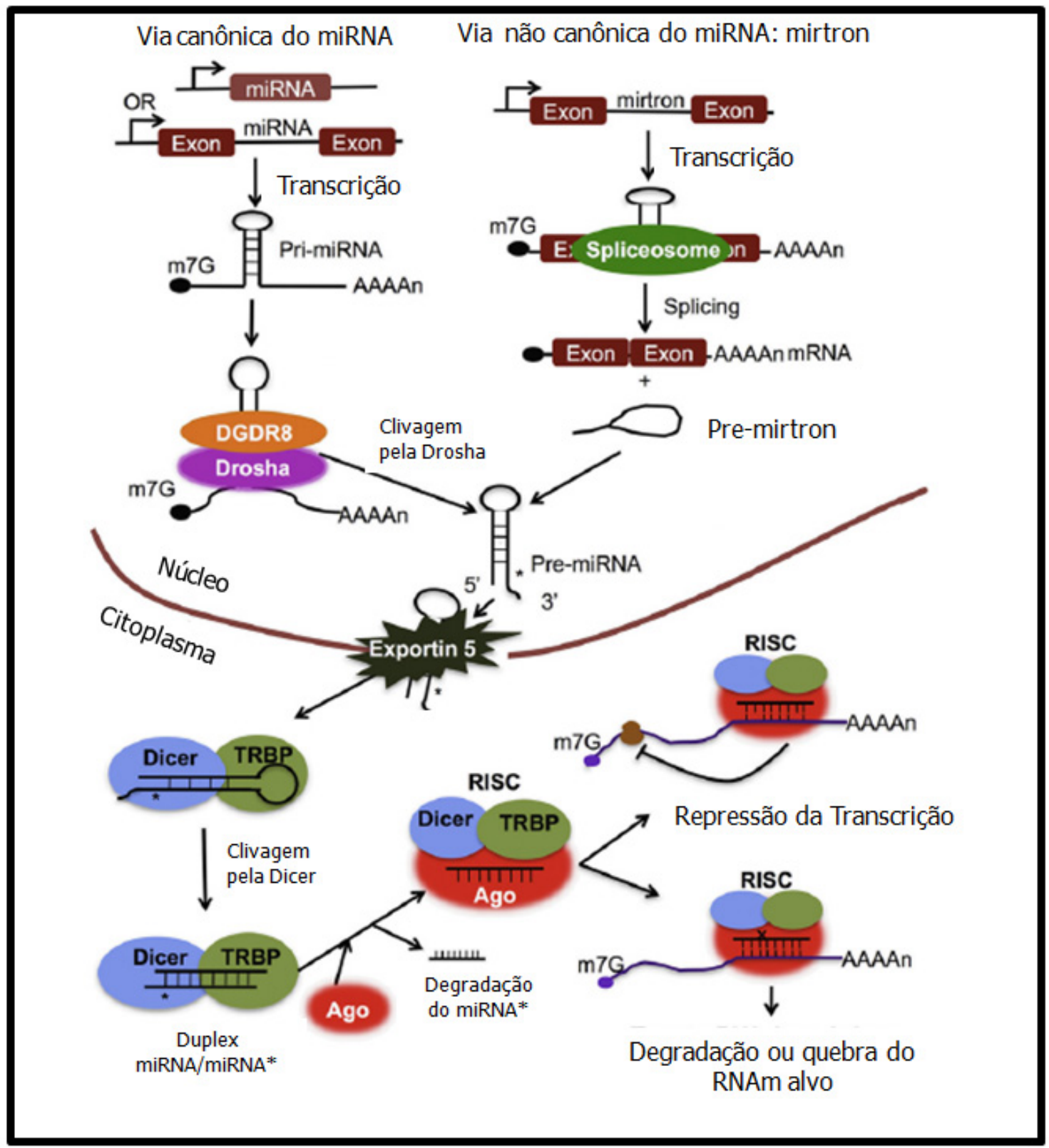

Figura 4. Biogênese e ação dos microRNAs em células animais. Na via da biogênese o pri-miRNA é processado pela DGCR8/Drosha gerando o pre-miRNA. A Exportin 5 transporta o pre-miRNA do núcleo para o citoplasma que sera processado pela Dicer generando o duplex miRNA/miRNA*. Somente a fita madura (miRNA) se mantém no complex RISC juntamente com a Dicer e a proteína Ago. A perfeita complementariedade entre o miRNA e seu mRNA alvo resulta na repressão dos genes alvos e na diminuição da expressão ou clivagem do mRNA. [Extraído e modificado de Dai \& Ahmed, 2011]. 
A principal proteína responsável pela repressão da tradução é a GW182, uma proteína de $183 \mathrm{kDa}$ rica em domínios glicina-triptofanos (JAKYMIW et al., 2007). Dados recentes demonstraram que essa proteína apresenta vários sítios de ligação a Ago2 (LIAN et al., 2009). Ambas as proteínas são alvos de autoanticorpos, e estão localizadas no citoplasma em estruturas chamadas corpos GWBs. O tamanho e o número dessas estruturas está relaciona a atividade de microRNAs na células (JAKYMIW et al., 2006; PAULEY et al., 2006; BHANJI et al., 2007). Essas estruturas também são chamadas de corpos processadores ou corpos $\mathrm{P}$, e sua formação parece ser uma conseqüência ao invés da causa da atividade dos miRNA.

\subsubsection{Interação microRNA-RNA mensageiro}

Desde que os primeiros microRNAs foram descobertos, foi demonstrado sua ligação na região 3' UTR de seu mensageiro alvo e sua função exercida através do pareamento perfeito ou imperfeito com sequências apenas desta região. $\mathrm{O}$ pareamento imperfeito, ainda sim requer o pareamento de uma região que começa no nucleotídeo 2 e vai até o nucleotídeo 7, do final 5' do microRNA. Essa região, denominada região seed, e um aspecto importante é o pareamento contínuo e perfeito dessa com seu mensageiro alvo (BARTEL et al., 2009). Já foram descritos casos de interação na região 5'-UTR, ou em regiões codificantes do gene, o que resulta em aumento da tradução e fraca repressão (OROM et al., 2008). Isso implica em algumas conseqüências relacionadas à investigação dos alvos, já que grande parte dos algoritmos e programas computacionais se baseiam na região 3' UTR.

Outra descoberta recente identificou os chamados "sítios centrais", que corresponde a uma classe específica de sítios de ligação dos microRNAs aos seus alvos, que vem ampliar o mecanismo de ação dos microRNAs, fora da região seed convencional. Esse mecanismo envolve o pareamento de pelo menos 11 nucleotídeos contínuos do RNA alvo com os nucleotídeos da posição 4-14 ou 5-15 do microRNA (SHIN et al., 2010). Essa descoberta mostra a versatilidade da regulação dos microRNAs em seus alvos específicos, e é importante ressaltar a ausência de programas computacionais convencionais, delineados para detectar esse tipo de interação. Esses estudos reforçam que nosso conhecimento a respeito da função dos microRNAs ainda é incompleto. 
Outro aspecto que deve ser levado em consideração são os fatores envolvidos ao contexto celular, como a associação de proteínas de interação ao RNA, e a possível estrutura 3D do RNA. A grande maioria dos programas computacionais de predição não leva em consideração esses fatores, que podem influenciar na ligação dos microRNAs preditos. A identificação de interações microRNA-mRNA bem definidas é de grande importância para a compreensão do controle de expressão gênica.

Os microRNAs são capazes de induzir repressão transducional ou degradação do seu alvo, e desta maneira acredita-se que eles controlem mais de $50 \%$ de todos os genes codificadores de proteína em mamíferos (KROL et al., 2010). Estudo recente descreve como a maior parte das regulações mediadas por microRNAs resultam em degradação do RNA mensageiro alvo (GUO et al., 2010). Muito tem se aprendido a respeito dos microRNAs, desde a sua descoberta.

Funções conhecidas dessa classe de moléculas em animais incluem desenvolvimento, regulação da proliferação e diferenciação celular, balanço do metabolismo de gorduras e lipídios, e secreção de insulina. Assim, não é surpresa que os microRNAs tenham um papel importante em muitas condições patológicas, das quais o câncer é uma das mais bem estudadas (MEDINA \& SLACK, 2008; PALMERO et al., 2011). É muito claro, que a regulação apropriada exercida pelos microRNAs é crítica para as funções normais do sistema imune, evitando o desenvolvimento de autoimunidade.

\subsubsection{MicroRNAs e sistema imune}

Durante os últimos anos, inúmeras evidências apontam para o papel importante dos microRNAs, não só para o desenvolvimento do sistema imune, bem como para as funções da imunidade inata e adaptativa (BALTIMORE et al., 2008; SONKOLY et al., 2008; XIAO et al., 2009; O'CONNELL et al., 2010). Os microRNAs podem controlar muitos processos imunológicos, incluindo a granulopoiese, desenvolvimento e maturação dos linfócitos T e B, apresentação de antígeno, cascata de sinalização de receptores do tipo Toll e produção de citocinas, recombinação e troca de isotipos nos linfócitos B, e sinalização dos receptores de células $\mathrm{T}$.

Estudos recentes revelaram o papel dos microRNAs associados não só ao desenvolvimento de células envolvidas na resposta imune inata, mas também ao seu papel regulador da resposta, principalmente como feedback negativo na via de sinalização pelos 
receptores do tipo Toll (TAGANOV et al., 2007; GRANTIER et al., 2007; O'CONNELL, 2010). Além disso, têm se demonstrado a alteração de vários microRNAs após estimulação dos PAMPs, e por citocinas inflamatória (TAGANOV et al., 2006; TILI et al., 2007; CHEN et al., 2007) (figura 5).

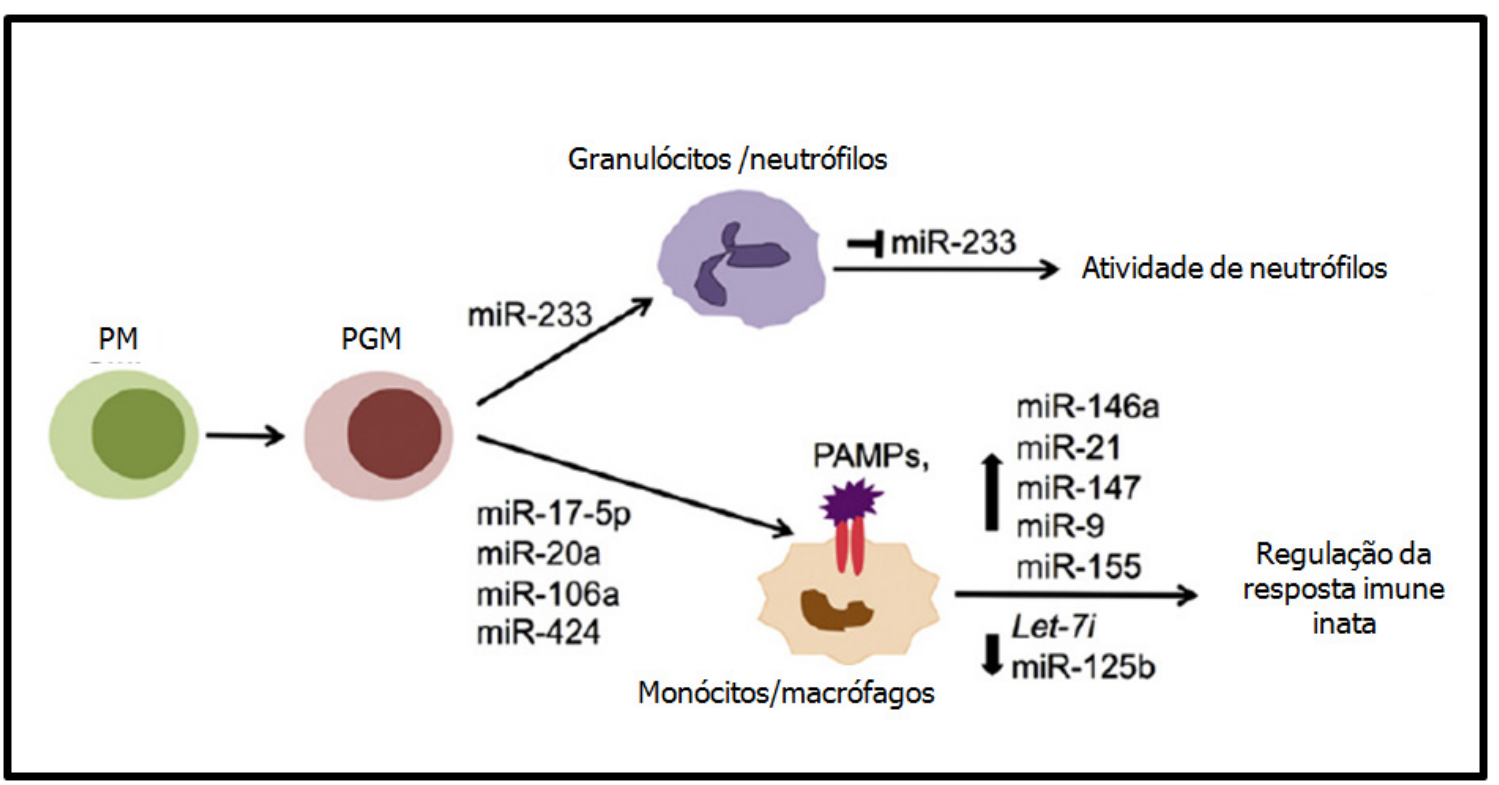

Figura 5. MicroRNAs na regulação da imunidade inata. Essa figura mostra o potencial envolvimento de diversos microRNAs descritos, e seu envolvimento no desenvolvimento e função de neutrófilos, e monócitos/macrófagos. PM, progenitor mielóide; PGM, progenitor granulócito-monócito. [Extraído e modificado de DAI et al 2011].

No sistema imune adaptativo, é clara a importância dos microRNAs na sua regulação, já que uma falha na biogênese do microRNA em progenitores linfóides, prejudica o desenvolvimento de células T e B. Foi demonstrado que a interrupção da síntese de microRNAs por deleção condicional da enzima Dicer nos estágios iniciais do desenvolvimento de linfócitos $\mathrm{T}$, prejudica esse processo, e números reduzidos dessas células são encontradas no timo e nos órgãos linfóides periféricos. Alterações na produção de citocinas e na diferenciação do perfil dos linfócitos T helper (Th), também são causas dessa deleção (COBB et al., 2005). O papel individual de microRNAs específicos na função dos linfócitos foi descrito recentemente (figura 6).

O miR-181a está relacionado ao desenvolvimento de linfócitos B e T, e é bem conhecido seu papel na maturação de timócitos, regulando a intensidade de sinalização do receptor de células T (TCR), durante a seleção positiva e negativa no timo (LI et al., 2007). 
O miR-150 por sua vez, é expresso em linfócitos maduros, mas não nos seus progenitores linfóides. A expressão deste microRNA de forma prematura afeta o desenvolvimento de células $B$ do estágio pro-B para o pré-B, mas não afeta a maturação de linfócitos T, granulócitos e macrófagos (ZHOU et al., 2007).

O miR-155 é um dos microRNAs melhor estudado. Ele é expresso em linfócitos T e B durante sua ativação, e está relacionado ao processo de diferenciação (THAI et al., 2007, VIGORITO et al., 2007). Nos linfócitos T CD4 ${ }^{+}$este microRNA influencia sua diferenciação para o subtipo Th1, e está associado a diversos processos inflamatórios (O’CONNELL et al., 2010). Com relação à regulação do desenvolvimento e função das Tregs, o miR-155 é crítico para o seu desenvolvimento, entretanto não é essencial para sua função supressora (KOHLHAAS et al., 2009). A inibição deste microRNA em linfócitos Th $\mathrm{CD} 4^{+}$resulta em aumento da atividade supressora mediada por Tregs (STAHL et al., 2009).

Este microRNA foi também recentemente associado com a diferenciação de um outro subtipo de linfócito T CD4 ${ }^{+}$, o Th17, e com sua produção de IL-17. Além dele, o miR-326 foi descrito nesse subtipo celular e apresenta como alvo, o RNA mensageiro do gene Ets, um fator de transcrição que regula negativamente a diferenciação dessas células (DU et al., 2009).

O miR-146a, assim como o miR-150 e miR-155 é altamente expresso em linfócitos T CD4 ${ }^{+}$diferenciados para subtipo Th1, impedindo sua diferenciação para o subtipo Th2 (MONTICELLI et al., 2005). Nas Tregs ele controla sua função supressora em resposta de células T mediadas por IFN- $\gamma$, tendo como alvo o fator de transcrição STAT1 (Signal transducer and activator of transcription) (LU et al., 2010). Nas Tregs, além dos microRNAs citados, foi demonstrado o envolvimento dos microRNAs miR-31 e miR-21 na regulação de FOXP3 (ROUAS et al., 2009).

Em conjunto, um número crescente de evidências tem mostrado que a expressão e função dos microRNAs são essenciais para o desenvolvimento, função e diferenciação de vários tipos celulares do sistema imune. É importante ressaltar que a expressão dos microRNA deve ser regulada apropriadamente para manter a homeostase imunológica. Uma desregulação da expressão de microRNAs está envolvida em uma diversidade de doenças, e pode promover a indução de autoimunidade. 


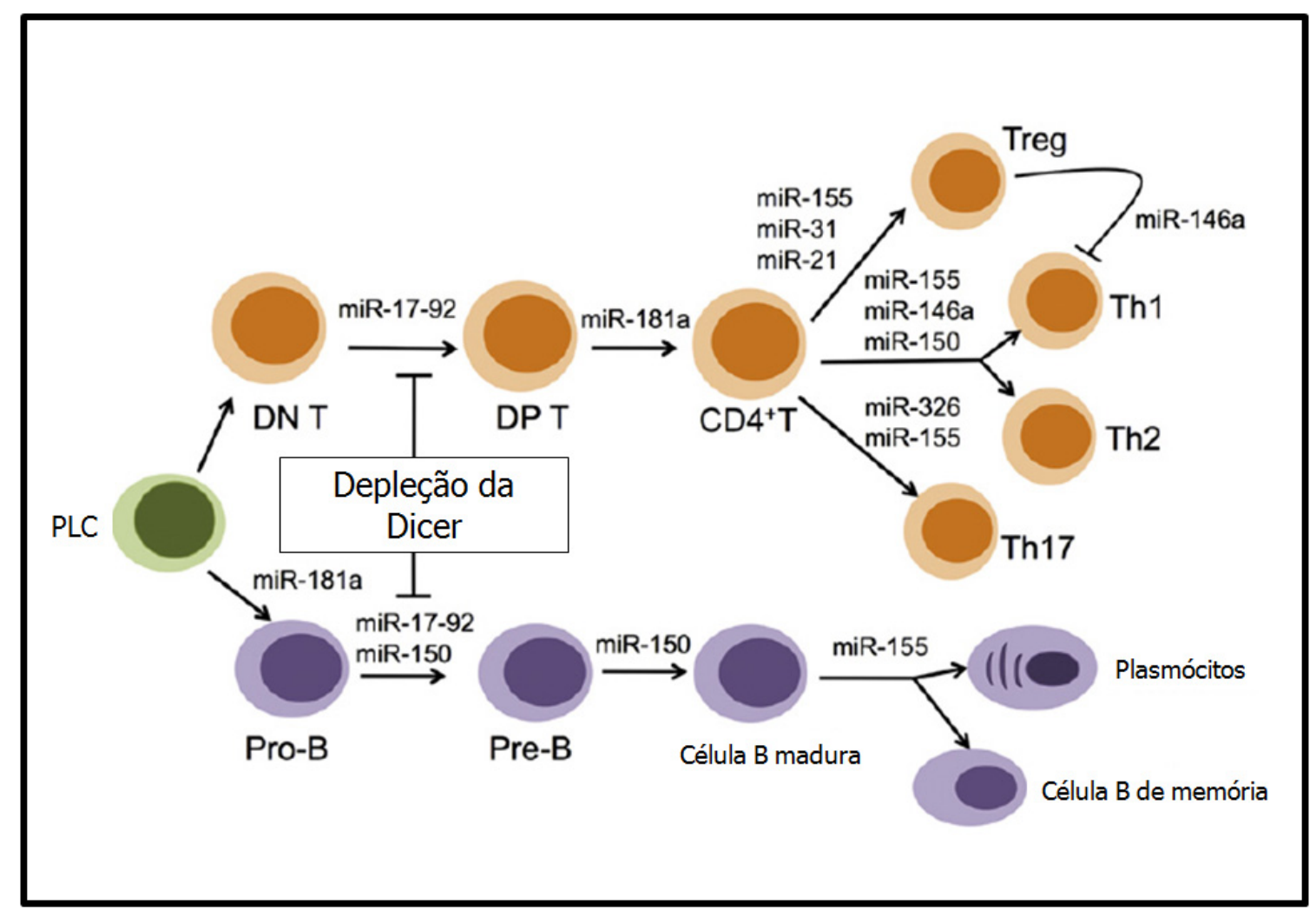

Figura 6. MicroRNAs na regulação da imunidade adaptativa. Essa figura mostra os diversos microRNAs descritos e relacionados ao desenvolvimento e diferenciação dos linfócitos $\mathrm{T}$ (parte superior da figura), e linfócitos B (parte inferior da figura). PLC, progenitor linfóide comum; DN T, timócito duplo positivo (CD4CD8-); DP T, timócito duplo positivo (CD4+ CD8+); Tregs (células T reguladoras). [Extraído e modificado de DAI et al., 2011].

\subsubsection{MicroRNAs e artrite reumatóide}

Como os microRNAs desempenham um papel importante em muitos processos biológicos, eles têm sido considerados reguladores chaves da expressão gênica, no qual um único microRNA pode regular uma via inteira, ou até múltiplas vias (AMBROS et al., 2004). A regulação apropriada do sistema imune é vital para prevenir doenças causadas por patôgenos, e os mamíferos desenvolveram um sistema complexo de monitoramento e balanço do sistema imune, para manter a tolerância própria, enquanto mantém uma resposta eficiente aos patôgenos (PAULEY et al., 2009).

O papel central dos microRNAs em respostas imunológicas anormais, e nas doenças reumáticas, foi descoberto nos últimos anos. De fato, o potencial dos microRNAs como biomarcadores em doenças é uma área nova e promissora (ALEVIZOS \& ILLEI, 2010; PAYLEY et al., 2009). 
A identificação de microRNAs candidatos, cujos alvos são genes importantes nas doenças reumáticas e a avaliação da conseqüência de mutações em regiões de interação, associados a estudos fenotípicos e de expressão gênica, pode contribuir para melhorar nossa compreensão dos mecanismos moleculares envolvidos nessas doenças (TILI et al., 2008).

O aumento do conhecimento dos microRNAs tem aprimorado o desenvolvimento de modelos animais para o estudo in vivo do uso de microRNAs específicos como forma terapêutica. Um exemplo disso, foi um estudo que demonstrou que a injeção da fita dupla do miR-15a na sinóvia do camundongo com artrite mediada por anticorpos, foi capaz de entrar na células e induzir apoptose, atingindo o gene anti-apoptótico Bcl2 (B-cell lymphoma 2) (NAGATA et al., 2009).

Recentemente, muitos estudos têm voltado sua atenção à identificação da expressão alterada de microRNAs em pacientes com AR, quando comparados aos indivíduos saudáveis ou com osteoartrite. Alguns estudos visam a expressão dos microRNAs no plasma e soro, enquanto outros estudam e analisam os tecidos (MURATA et al., 2010). A expressão aberrante de muitos microRNAs foram detectados na $\mathrm{AR}$, em diferentes tipos celulares, e esses microRNAs podem regular vias específicas, resultando no ambiente inflamatório característico da doença (WITTMANN \& JACK, 2001).

Nas células sinoviais de pacientes com AR foi encontrada a expressão dos microRNAs miR-155 e miR-146a quando comparados a pacientes com osteoartrite (STANCUZYK et al., 2008). Os altos níveis do miR-155 foram associados a produção de metaloproteinases, ocasionando inflamação articular. Este mesmo grupo identificou o miR203. A expressão deste microRNA em fibroblastos sinoviais é responsável pelo aumento da produção de metaloproteinases e Il-6, indicando que o miR-203 tem papel fundamental como fator pró-inflamatório e destrutivo das articulações na AR. Além disso, a regulação de sua expressão é dependente de metilação.

Em mononucleares do sangue periférico a expressão aumentada de alguns microRNAs, como o miR-155, miR-146a, miR-132, miR-16, foi demonstrada. Os níveis de expressão de TRAF6 (TNF receptor associated factor protein family 6) e IRAK1 (interleukine-1 receptor-associated kinase 1), dois alvos do microRNA miR-146a, não estavam aumentados nos pacientes quando comparados aos indivíduos controle. Em estudo com a linhagem monocítica humana THP-1, a repressão desses alvos resulta em $86 \%$ de redução na produção de TNF- $\alpha$, sugerindo que a expressão normal do miR-146 é 
importante para a regulação da produção de TNF (PAULEY et al., 2008). Como a expressão do miR-146a pode estar relacionado a produção persistente de TNF na AR ainda não se sabe. A hipótese é a de que o miR-146 é expresso, entretanto, incapaz de regular seus alvos TRAF6/IRAK1, resultando na produção prolongada de TNF.

Outro grupo estudou a expressão do miR-146a no tecido sinovial de pacientes, no qual o microRNA maduro miR-146a e os primários miR-146a/b foram detectados no tecido. As células positivas para o miR-146 eram principalmente macrófagos CD $68^{+}$, mas

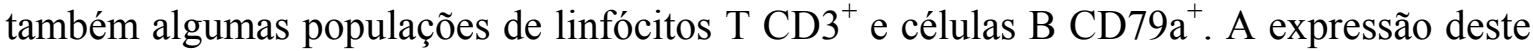
microRNA era aumentada após estimulação com TNF e IL-1 (NAKASA et al., 2008). O miR-146 foi também relacionado a altos níveis de expressão da citocina pró-inflamatória Il-17. A expressão aumentada deste microRNA em linfócitos $\mathrm{T} \mathrm{CD}^{+}$nos pacientes já havia sido previamente identificada, e ele estaria relacionado a expressão de TNF e regulação da apoptose nessas células, mantendo o ambiente inflamatório (LI et al., 2010). Recentemente demonstrou-se que o miR-146a pode inibir a osteoclastogênese, e a administração da dupla fita pode prevenir a destruição da cartilagem no modelo de artrite induzida por colágeno (NAKASA et al., 2011).

A maior vantagem da detecção deste microRNA em células da circulação, é a possibilidade de se encontrar potenciais biomarcadores para monitorar o andamento da doença, sem a necessidade de procedimento cirúrgico evasivo para obtenção de tecidos da articulação e células para análise dos microRNAs.

Como mencionado previamente, a predisposição genética é um dos fatores envolvidos na patogênese da AR. Trabalho recente demonstrou que o polimorfismo na região 3'-UTR do gene IRAK1, um dos alvos do microRNA miR-146a, ocasiona o aumento da predisposição ao desenvolvimento da doença (CHATZIKYRIAKIDOU et al., 2010). Esta observação abre a possibilidade de novos estudos relacionados em como os microRNAs e o polimorfismo do seus alvos, pode levar ao desenvolvimento de AR em grupos étnicos específicos, e em associação com os fatores ambientais.

Nos últimos anos, novos microRNAs, com perfis de expressão específicos e associados as vias inflamatórias foram identificados. A expressão de miR-124a foi identificada em sinoviócitos (NAKAMACHI et al., 2009). Este microRNA está relacionado a proliferação celular, e a tranfecção do precursor leva a inibição do ciclo celular, na fase G1. Além disso, dois alvos deste microRNA, CDK2 (cyclin-dependent kinase 2) e MCP-1 (monocyte chemotactic protein-1), envolvidas no processo inflamatório, 
são controlados por esse microRNA. Logo após a identificação do miR-124a, outro grupo identificou um novo microRNA expresso em fibroblastos da sinóvia, o miR-346 (ALSALEH et al., 2009). Este microRNA é capaz de regular indiretamente a liberação da citocina pró-inflamatória Il-18.

$\mathrm{Yu}$ e colaboradores contribuíram para esclarecer a via pós-transcricional em linfócitos $\mathrm{T}$, que regula sua proliferação associada ao processo de autoimunidade. Camundongos deficientes para o co-estimulador induzido de células $T$ (ICOS) são resistentes a CIA, e não desenvolvem inflamação no tecido articular. De maneira interessante o microRNA miR-101 foi identificado como regulador do ICOS, o que destaca o potencial terapêutico de inibir parcialmente a via do ICOS, e prevenir a autoimunidade limitando os níveis de linfócitos T, pelo uso de microRNAs (YU et al., 2007).

Um trabalho recente de Li e colaboradores, investigou o perfil de expressão e

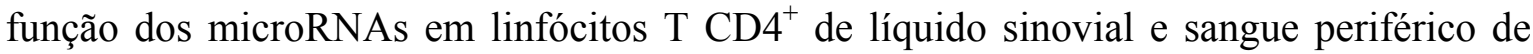
pacientes com AR (LI et al., 2010). Esse estudo identificou a expressão de miR-146a, enquanto que o miR-363 e o miR-498 se encontravam reprimidos nessas células. A abundância do miR-146a apresentava correlação positiva com os níveis de TNF- $\alpha$, e experimentos in vitro mostraram que o TNF era capaz de induzir a expressão desse microRNA. Além disso, esse o miR-146a estaria envolvido na supressão da apoptose regulando o fator 1 associado a Fas.

Um novo microRNA foi identificado recentemente em linfócitos $\mathrm{T}$ de sangue periférico de pacientes comparados aos indivíduos saudáveis, o miR-223. A expressão deste microRNA foi detectada em células $T$ não diferenciadas, mas não nos linfócitos do subtipo Th17. Como as células dos doadores saudáveis não expressavam o miR-223, mesmo após estimulação do seu receptor, a expressão alterada desse microRNA parece estar diretamente relacionada a patogênese da doença, mas sua função ainda é desconhecida (FULCI et al., 2010).

Os resultados obtidos até o momento esclarecem vários aspectos da estrutura e funcionamento dos microRNAs em uma doença complexa como a AR. Entretanto novos estudos ainda são necessários, já que há muitas limitações em se determinar a função completa de muitos microRNAs. Um problema são as diferenças nos delineamentos experimentais que pode favorecer um tipo de repressão em detrimento de outra. Para auxiliar na compreensão do papel dos microRNAs nas doenças, os estudos in vivo utilizando-se modelos animais são de extrema importância. 


\subsection{Análise do transcriptoma}

\subsubsection{Conceito de transcriptoma}

Em analogia ao termo genoma o qual se refere ao conjunto de genes de uma determinada espécie, criou-se o termo transcriptoma para se referir ao conjunto de RNAs, ou seja, os transcritos de uma célula num dado momento de seu ciclo. Como são os RNAs mensageiros (RNAm) os responsáveis pela codificação da síntese de proteínas e, portanto, os mais importantes no estudo da expressão do genoma, geralmente entende-se que o transcriptoma é o conjunto destes RNAs. Mas é oportuno lembrar que tanto os RNAs transportadores (tRNAs) e os RNAs ribossômicos (rRNAs) devem ser incluídos no conceito do transcriptoma apesar de não serem codificadores de proteínas.

Para a inclusão dos microRNAs no transcriptoma, criou-se o termo miRNoma seguindo a mesma analogia.

Durante todo o processo de diferenciação celular e tecidual, um conjunto diversificado de proteínas é mobilizado como resultado da expressão diferencial dos respectivos genes. Portanto, pode-se dizer que durante o desenvolvimento o primeiro ponto de controle molecular é a expressão gênica ao nível do conjunto de RNAm. Hoje, sabe-se que o transcriptoma das células e tecidos é reflexo da razão entre a biossíntese de RNAm (transcrição) e sua degradação, muitas vezes causada pelos microRNAs (SEVIGNANI et al., 2006). Além disso, o transcriptoma é variável entre os diferentes tipos de células, tecidos e órgãos de um dado indivíduo, sendo que as próprias condições fisiológicas normais, como as diferentes fases do ciclo celular, ou patológica, como por exemplo, infecções ou neoplasias, influenciam no chamado perfil do transcriptoma (PASSOS et al., 2000).

\subsubsection{Métodos de análise do transcriptoma}

Um grande progresso tem ocorrido nos últimos anos para a técnica de arranjos de alta densidade (microarrays) para a análise de expressão gênica em grande escala. Há alguns anos atrás iniciou-se a caracterização por meio de clones de cópias de RNAm na forma de DNA (DNA complementar ou simplesmente cDNA) de humanos, camundongos e outros organismos-modelo (DUGGAN et al., 1999; LIPSHUTZ et al., 1999).

Várias técnicas para a análise do transcriptoma estão disponíveis, como por exemplo, o SAGE (análise em série da expressão gênica, do inglês Serial Analysis of Gene 
Expression) (YE et al., 2002). Entretanto, esses métodos possuem desvantagens, quando o objetivo é analisar expressão em grande escala, o que pode ser solucionado por meio da tecnologia de microarrays (JORDAN, 1998; PASSOS et al., 2000; VAN HAL et al., 2000; SAKAMOTO-HOJO et al., 2003). Essa tecnologia mostrou ser uma ferramenta poderosa e muito difundida nos estudos de expressão gênica com aplicações no estudo de vários organismos tanto em situações normais como patológicas (WHITNEY \& BECKER, 2001). Além disso, tal tecnologia permite a expressão de centenas de genes simultaneamente e fornece assinaturas moleculares das atividades celulares nos estudos de doenças complexas e multigênicas como é o caso das doenças autoimunes (FATHMAN et al., 2005).

Atualmente, o estudo de microarrays pode ser realizado através da utilização de plataformas diferentes por meio de chips que contém todo o genoma da espécie de interesse (humano, camundongo, rato e muitas outras espécies) ou ainda todos os microRNAs relatados até o presente momento. Em microarrays padrão, as sondas são sintetizadas e depositadas a uma superfície sólida por meio de ligação covalente a uma matriz química (via epóxi -silano, amino -silano, lisina , poliacrilamida ou outros). A superfície sólida pode ser de vidro ou um chip de silício, caso em que eles são coloquialmente conhecidos como um AFFY chips quando um chip Affymetrix é usado. Plataformas de microarrays como Illumina, usam micro esferas de sílica cobertas com centenas de cópias de um oligonucleotídeo específico, que agem como sequências de capturas em um dos ensaios. Essas micro esferas são depositadas em microcavidades em substratos de fibra óptica ou lâminas de sílica. Alternativamente, os microarrays da Agilent podem ser construídos pela síntese direta de sondas de oligonucleotídeos em lâminas de vidro previamente preparadas por um sistema de impressão, processo conhecido como SurePrint. Este processo de síntese in situ possibilita a deposição de oligonucleotídeos, base a base, com extrema precisão utilizando arquivos de RNAm ou de microRNAs provenientes de bancos de dados.

Pelo conhecimento do perfil de expressão gênica, é possível responder importantes questões, tais como, quantos genes estão envolvidos num determinado processo biológico, e quais suas intensidades de expressão. Além disso, reflete o perfil transcricional de milhares de genes em resposta, por exemplo, a um estímulo farmacológico ou em uma resposta imune específica, entre outros (KURELLA et al., 2001).

O presente trabalho representa um esforço no sentido de identificar as prováveis modificações ocorridas, na expressão gênica e no controle pós transcricional exercido pelos microRNAs, ao longo do processo de desenvolvimento dos linfócitos $\mathrm{T}$ de camundongos DBA-1/J e DBA-2/J, e seu papel na suceptibilidade/resistência a CIA. 


\section{HIPÓTESE DO TRABALHO}

Considerando que os linfócitos $\mathrm{T}$ desempenham papel importante no processo inflamatório na AR os quais estão envolvidos com a indução, manutenção e progressão da doença, formulamos a primeira hipótese de que estas células podem ser utilizadas como "repórteres" indicando os perfis de expressão transcricional (mRNAs e microRNAs) associados com a doença.

Considerando o papel desempenhado pelos microRNAs na modulação da expressão gênica do sistema imune, formulamos a segunda hipótese de que a desregulação na expressão dos mesmos e na sua associação com alvos (mRNAs) específicos de linfócitos $\mathrm{T}$, pode interferir na susceptibilidade a doenças autoimunes, incluindo artrite reumatoide $(\mathrm{AR})$. 
OBJETIVOS 


\section{OBJETIVOS}

\section{Objetivo amplo:}

Identificar os perfis de expressão e as redes de interação entre um conjunto de microRNAs e seus respectivos alvos de RNAm nos timócitos e nas células T $\mathrm{CD}^{+}$ periféricas durante o processo de indução de artrite pelo colágeno (CIA) em camundongos da linhagem DBA-1/J (susceptíveis) e da linhagem DBA-2/J (refratários a CIA).

\section{Objetivos específicos:}

1) Identificar perfis específicos de expressão de RNAs mensageiros (transcriptoma dos mRNAs) nos timócitos de camundongos DBA-1/J e DBA-2/J, utilizando a tecnologia de microarrays genoma completo.

2) Identificar perfis específicos de expressão de RNAs mensageiros (transcriptoma dos mRNAs) nos linfócitos $\mathrm{T} \mathrm{CD}^{+}$periféricos naives (animais não imunizados) e desse mesmo tipo de células de animais imunizados com colágeno, de camundongos DBA-1/J e DBA-2/J, utilizando a tecnologia de microarrays genoma completo.

3) Identificar perfis específicos de expressão de microRNAs (transcriptoma dos microRNAs ou miRNoma) nos timócitos de camundongos DBA-1/J e DBA-2/J, utilizando a tecnologia de miRNAs microarrays.

4) Identificar perfis específicos de expressão de microRNAs (transcriptoma dos microRNAs ou miRNoma) nos linfócitos $\mathrm{T}_{\mathrm{CD}} 3^{+}$periféricos naives (animais não imunizados) e desse mesmo tipo de células de animais imunizados com colágeno, de linfonodos e baço de camundongos DBA-1/J e DBA-2/J, utilizando a tecnologia de miRNAs microarrays.

5) Reconstruir redes de interação entre microRNAs e potenciais mRNA alvos, tentando identificar o controle pós-transcricional exercido pelos microRNAs na susceptibilidade/resistência a CIA.

6) Com base nos dados de camundongo, selecionar e investigar a expressão de novos microRNAs em linfócitos $\mathrm{T}$ de pacientes com AR. 


\section{MATERIAL E MÉTODOS}




\section{MATERIAL E MÉTODOS}

\subsection{Linhagem de camundongos DBA-1/J e DBA-2/J}

A linhagem DBA-1/J, que representa a linhagem susceptível a indução de artrite reumatóide, foi adquirida junto ao biotério de camundongos isogênicos da Faculdade de Medicina de Ribeirão Preto, enquanto a DBA-2/J, linhagem que por sua vez se mostra resistente a indução da doença, é proveniente do biotério da Universidade Estadual de Campinas (UNICAMP). Os animais foram transferidos para o Laboratório de Imunogenética, no Departamento de Genética da Faculdade de Medicina de Ribeirão Preto, USP, e mantidos e câmara isoladora "Alesco", com entrada de ar filtrado (filtro de $0,45 \mu$ ), temperatura constante de $25^{\circ} \mathrm{C}$, ciclo de iluminação de 12 horas, água e ração ad libitum.

\subsection{Indução de artrite induzida por colágeno (CIA)}

Animais machos das linhagens DBA-1/J e DBA-2/J receberam uma injeção intradérmica na base da cauda de $200 \mu \mathrm{g}$ de colágeno do tipo II bovino (CII Sigma) emulsificados em 0,1ml de adjuvante completo de Freund (1:1 CFA) (Difco, NJ, USA). Após 21 dias os animais são desafiados (injeção intradérmica) novamente com a mesma solução de colágeno. Os camundongos controle falso-imunizados receberam o mesmo tratamento, porém sem administração de colágeno. Os sinais de artrite foram monitorados diariamente, para os quais seguem os scores conferidos para classificação da severidade: $0=$ normal, $1=$ eritema, $2=$ eritema + inchaço, $3=$ perda de função e total=soma das quatro patas. O início da doença é caracterizado pelo aparecimento de inchaço e eritema das patas, entre os dias 25 e 35 .

Este projeto foi realizado com a aprovação da comissão de ética na pesquisa com animais, CEUA, campus USP, Ribeirão Preto (Protocolo nº 119/2008).

\subsection{Definição de controle e teste}

Para as análises envolvendo a indução de CIA, foram considerados como teste os animais que receberam o protocolo de imunização descrito anteriormente, e como controle aqueles animais que receberam a imunização, entretanto sem a administração de colágeno. 
Além disso, os camundongos da linhagem DBA-2/J também representam um controle, já que os mesmos após imunização, não apresentaram nenhuma manifestação visível da doença.

\subsection{Separação dos timócitos e isolamento de linfócitos $\mathrm{T} \mathrm{CD}^{+}$periféricos}

Os procedimentos de separação de células foram realizados em triplicatas, e um total de cinco animais foi utilizado para cada grupo experimental. As amostras provenientes dos cinco animais foram processadas em conjunto, formando pool. Os animais foram sacrificados em câmara de $\mathrm{CO}_{2}$ segundo aprovação da comissão de ética CEUA, campus USP, Ribeirão Preto. Os timos de animais com quatro semanas de idade, de ambas as linhagens (DBA-1/J e DBA-2/J), foram coletados e pinçados em placa de Petri contendo meio de cultura DMEM + F10 para liberação dos timócitos. Uma membrana de nylon de $10 \mu \mathrm{m}$ (Sefar Inc. Depew, NY, USA) foi utilizada para separação dos timócitos de possíveis contaminações com outros tipos celulares. A suspensão de células recuperada foi centrifugada por 8 minutos a $500 \mathrm{x}$ g para formação do botão celular, o qual foi submetido à lavagem em PBS $1 X$. Uma nova centrifugação foi realizada para a formação do botão celular.

Para a separação dos linfócitos $\mathrm{T} \mathrm{CD}^{+}$periféricos, baços e linfonodos inguinais foram macerados em meio de cultura DMEM + F10. Foram utilizados animais com quatro semanas de idade, de ambas as linhagens que não receberam nenhum tipo de imunização; e animais com 12 semanas de idade, também de ambas as linhagens (DBA-1/J e DBA-2/J), que foram submetidos ao protocolo de imunização já descrito anteriormente. Um total de cinco animais foi utilizado para cada um dos seis grupos experimentais (sem imunização, e imunização com ou sem colágeno de ambas as linhagens DBA-1/J e DBA-2/J). Posteriormente, a separação de linfócitos $\mathrm{T}_{\mathrm{CD}}{ }^{+}$totais foi realizada pelo uso de esferas magnéticas através de seleção negativa (Pan T cell isolation Kit, mouse, Miltenyi Biotec, Bergisch Gladbach, Germany) segundo as instruções do fabricante.

As células obtidas em ambos os processos (separação de timócitos e isolamento de linfócitos $\mathrm{T} \mathrm{CD}^{+}$periféricos) foram utilizadas para os experimentos de citometria de fluxo e extração de RNA total. 


\subsection{Quantificação das populações celulares de camundongo por citometria de fluxo}

Os timócitos e os linfócitos $\mathrm{T} \mathrm{CD} 3^{+}$periféricos $\left(1 \times 10^{6}\right.$ células / tubo) foram lavados em $3 \mathrm{ml}$ de PBS $1 \mathrm{X}$ e os botões de células foram obtidos por centrifugação a $400 \mathrm{x}$ g por 10 minutos. O sobrenadante foi descartado e os botões foram ressuspensos em $100 \mu 1 \mathrm{de}$ tampão de FACs com $40 \mu 1$ de FcBlock (soro de coelho). Incubou-se por 30 minutos a $4^{\circ} \mathrm{C}$ e depois, foi adicionado $1 \mu 1$ de cada anticorpo monoclonal marcado: CD3 (PE), CD4 (PerCP) e CD8 (FITC) (eBioscience, CA, USA). Em seguida, as amostras foram incubadas por 45 minutos a $4^{\circ} \mathrm{C}$, e posteriormente foram submetidas aos procedimentos de lavagem, nas quais foram utilizadas $2 \mathrm{ml}$ de tampão de FACs. Após a última lavagem foram adicionados $150 \mu \mathrm{l}$ de PBS com 1\% de formol antes da leitura.

Para a detecção dos fatores de transcrição Foxp3 e Roryt as células foram fixadas e permeabilizadas utilizando-se o Kit Cytofix/Cytoperm (Becton Dickinson, NJ, USA), seguindo as instruções do fabricante. Para a marcação intracelular foram utilizados os respectivos anticorpos: Foxp3 (FITC) e Roryt (PE) (eBioscience, CA, USA).

A leitura das marcações foi feita no citômetro de fluxo Calibur ${ }^{\mathrm{TM}}$ (Becton Dickinson, NJ, USA). Os anticorpos controles apropriados foram utilizados e o ensaio foi realizado em triplicata.

Os dados de citometria de fluxo foram analisados pelo software estatístico GraphPad Prism 5.0 (http://www.graphpad.com/prism/Prism.htm). Para análise estatística dos dados, foram utilizados testes t-student ou One-way ANOVA com a correção de Bonferroni, sendo $\mathrm{p}<0,05(*)$.

\subsection{Extração de RNA total}

A fim de prevenir a contaminação por ribonucleases durante a extração e manuseio dos RNAs, toda a vidraria, tubos plásticos, espátulas e pinças utilizadas foram previamente autoclavados. Todo o procedimento foi realizado usando luvas de látex sem talco e descartáveis.

Para a extração de RNA total dos timócitos e linfócitos $\mathrm{T} \mathrm{CD}^{+}$periféricos utilizamos o kit mirVana PARIS ${ }^{\circledR}$ (Ambion, Austin, TX, USA) que permite a separação simultânea de RNAs de alto peso molecular ( $\leq 200 \mathrm{nt}$ incluindo os RNAs mensageiros) e 
de RNAs de baixo pelo molecular ( $\geq 200$ nucleotídeos, nt, incluindo os microRNAs de $23 \mathrm{nt})$.

Em cada amostra foram adicionados $1.000 \mu \mathrm{l}$ de solução de lise agitando-se vigorosamente com a ajuda de um aparelho tipo vórtex para a lise completa das células (lisado celular). Em seguida, adicionou-se $100 \mu l$ de miRNA Homogenate Additive, e após agitação por 15 segundos, as amostras ficaram em gelo picado por 10 minutos.

O passo seguinte incluiu a adição de $1 \mathrm{ml}$ de fenol:clorofórmio ácido e agitação vigorosa no vórtex por 60 segundos. O lisado foi então centrifugado a 10.000 x g por 5 minutos à temperatura ambiente para a formação de uma fase aquosa contendo os RNAs em solução. A fase aquosa foi cuidadosamente transferida para um novo tubo ao qual foram adicionados $1,25 \mathrm{x}$ do volume recuperado, de etanol $100 \%$ a temperatura ambiente.

Para cada amostra foi utilizada uma coluna em um tubo coletor no qual $700 \mu 1$ da mistura lisado/etanol foram pipetados na coluna e centrifugados por 15 segundos a 10.000 x g. O líquido foi descartado e o procedimento repetido até que toda a mistura fosse filtrada. Em seguida, aplicou-se $700 \mu 1$ de miRNA Wash Solution 1 a coluna e centrifugouse por 10 segundos a $10.000 \mathrm{x}$ g. O líquido foi descartado e $500 \mu 1$ de miRNA Wash Solution 2/3 foram aplicados a coluna e centrifugados por 10 segundos a $10.000 \mathrm{x}$ g. Repetiu-se o último passo, e após descartar o líquido, centrifugou-se 1 minuto para remover resíduos líquidos no filtro. A coluna foi transferida para um tubo novo coletor, e a ela foram adicionados $100 \mu \mathrm{l}$ de água DEPC pré-aquecida $\left(95^{\circ} \mathrm{C}\right)$. Centrifugou-se 30 segundos para eluição do RNA o qual foi então conservado a $-80^{\circ} \mathrm{C}$.

As quantificações das amostras de RNA total foram feitas utilizando o aparelho NanoDrop ND-1000 UV-VIS espectrofotômetro (NanoDrop Technologies) sendo que $1 \mathrm{U}$ $\mathrm{A}_{260}$ corresponde a $40 \mu \mathrm{g}$ de $\mathrm{RNA} / \mathrm{ml}$.

\subsection{Avaliação da integridade do RNA total}

A qualidade das amostras de RNA total foi determinada por meio de eletroforese microfluídica (On-Chip electrophoresis) utilizando o aparelho Bioanalyzer 2100 Agilent e com os RNA 6000 Nano Chips (Agilent Technologies, Santa Clara, CA, USA) (Figura 7). 


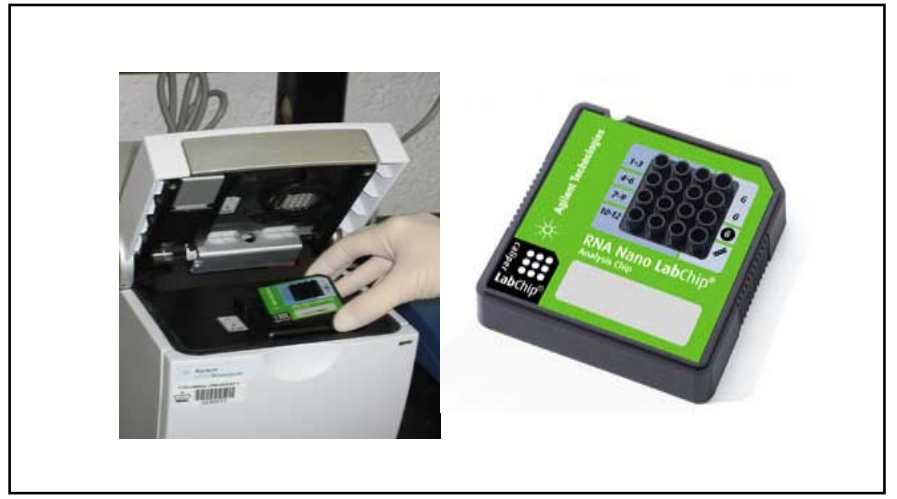

Figura 7. Aparelho Bioanalyzer 2100 Agilent e RNA 6000 Nano Chips utilizados na eletroforese microfluídica.

Antes de iniciar o preparo do gel para a eletroforese, todos os reagentes, que até o momento estavam a $4^{\circ} \mathrm{C}$, foram mantidos por 30 minutos a temperatura ambiente. Decorrido o tempo, iniciou-se o procedimento com o preparo do gel, pipetando $550 \mu 1$ do RNA 6000 Nano gel em uma coluna com filtro e centrifugou-se por $1.500 \mathrm{x}$ g durante 10 minutos a temperatura ambiente. Uma alíquota de $65 \mu 1$ foi colocada num tubo $0,5 \mathrm{ml}$ livre de nuclease, na qual foi adicionado $1 \mu \mathrm{l}$ de RNA 6000 Nano dye. Após agitação por 10 segundos centrifugou-se a $13.000 \mathrm{x}$ g por 10 minutos a temperatura ambiente.

Em seguida, iniciou-se o preparo do RNA 6000 Nano chip que foi colocado no priming station com os ajustes corretos. Primeiramente pipetou-se $9 \mu 1$ da mistura gel/dye na região $\mathrm{G}$ indicada no chip e com o auxílio de uma seringa acoplada ao priming station distribuiu-se o gel por todo o chip. Em seguida, pipetou-se outros $9 \mu \mathrm{l}$ da mistura nos demais pontos indicados com a letra G. Pipetou-se ainda $1 \mu 1$ do marcador na posição indicada e $5 \mu$ do RNA 6000 Nano marker em cada uma das 12 amostras bem como na posição do marcador. Por último, $1 \mu \mathrm{l}$ de cada amostra foi adicionado nos respectivos poços marcados de 1 a 12 e com a ajuda de um aparelho tipo vórtex IKA MS 3 (Manca, Hong Kong, CHN), agitou-se o chip horizontalmente a 2.200 rpm por 1 minuto antes da leitura. Com a ajuda do Agilent 2100 Expert Software obteve-se o resultado (eletroforograma e densitometria dos géis) em 30 minutos de corrida eletroforética. Somente as amostras que apresentaram picos correspondentes aos padrões de bandas de RNAr 28S, RNAr 18S, RNAr 5S e RNAt 4S e com RNA Integrity Number (RIN) $\geq 8.5$ foram utilizadas. 


\subsection{Oligo microarrays}

\subsection{1 mRNAs microarrays}

Os microarrays genoma completo da Agilent formato 4 x 44k (Figura 8) são preparados pelo processo SurePrint (sistema de impressão), no qual 44.000 oligos de 60 mer são sintetizados in situ em lâminas de vidro $(2,5$ x 7,5 cm) especialmente preparadas. Este processo de síntese in situ possibilita a fixação de oligonucleotídeos, sintetizando-os base a base com extrema precisão utilizando arquivos de sequências de RNA mensageiros (mRNA) provenientes de bancos de dados.

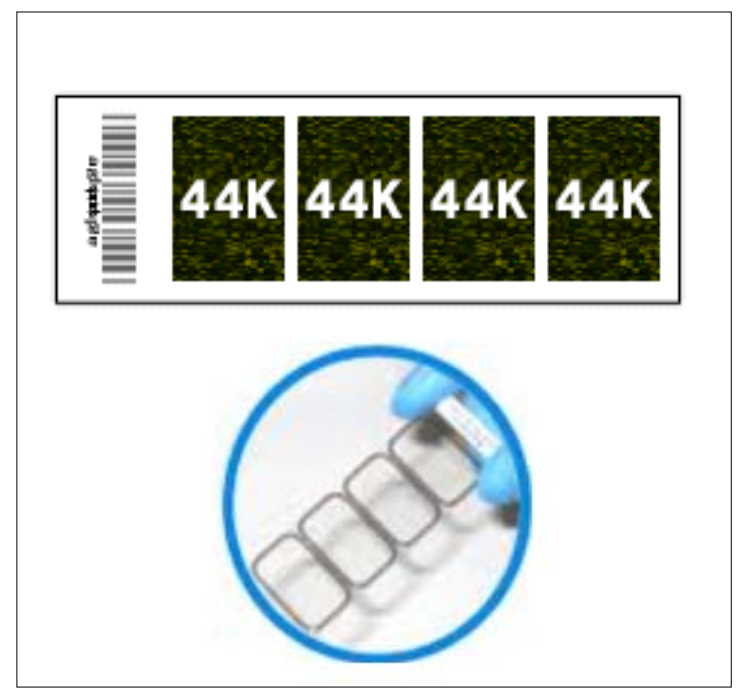

Figura 8. Agilent microarrays genoma completo no formato 4 x 44k contendo oligonucleotídeos sintetizados com base nas sequências de RNAs mensageiros.

\subsubsection{Marcação e purificação}

A amplificação e a marcação das amostras com o fluorocromo foram feitas com o Quick Amp Labeling Kit One-Color (cianina 3, Cy3, verde) (Agilent Technologies, Santa Clara, CA, USA). O primeiro passo envolveu a diluição do Agilent One-Color Spike-Mix. A solução foi aquecida a $37^{\circ} \mathrm{C}$ em banho-maria por 5 minutos, homogeneizada por meio de agitação em vórtex e depois brevemente centrifugada antes do uso. Em seguida, foram feitas diluições seriadas segundo recomendação do fabricante levando em consideração a 
quantidade inicial de RNA total. Para as nossas amostras optamos por utilizar $500 \mathrm{ng}$ de RNA total num volume final de 5,3 $\mu 1$.

A primeira diluição (1:20) foi feita utilizando-se $2 \mu 1$ do Agilent One-Color SpikeMix, e adicionados $38 \mu \mathrm{l}$ do Dilution Buffer proveniente do kit. Após homogeneização em vórtex, retirou-se $2 \mu \mathrm{l}$ da primeira diluição e adicionou-se $48 \mu \mathrm{l}$ do Dilution Buffer obtendo-se assim a segunda diluição (1:25). Para a terceira diluição (1:10) foram utilizados $4 \mu \mathrm{l}$ da segunda diluição, e adicionados $36 \mu 1$ do Dilution Buffer.

Feitas as diluições, iniciou-se o protocolo de amplificação e marcação das amostras adicionando $500 \mathrm{ng}$ de RNA total a um tubo de $1,5 \mathrm{ml}$ e depois $1,2 \mu \mathrm{l}$ de T7 Promoter Primer. Em seguida, adicionou-se água livre de nucleases a $5 \mu 1$ da terceira diluição do Agilent One-Color Spike-Mix obtendo um volume final de 11,5 $\mu$ l. As amostras foram então incubadas em banho-maria a $65^{\circ} \mathrm{C}$ por 10 minutos e posteriormente em gelo por 5 minutos. Durante o período de incubação, o cDNA Master Mix (por lâmina) foi preparado com $18 \mu \mathrm{l}$ do $5 x$ First Strand Buffer (pré-aquecido a $80^{\circ} \mathrm{C}$ por 4 minutos), $9 \mu 1$ de $0,1 \mathrm{M}$ DTT; 4,5 $\mu \mathrm{l}$ de 10mM dNTP mix; 4,5 $\mu$ l MMLV-RT e 2,3 $\mu 1$ de RNaseOut sendo distribuído um volume de $8,5 \mu \mathrm{l}$ do mix em cada tubo de amostra. Após homogeneização as amostras foram incubadas a $40^{\circ} \mathrm{C}$ em um banho-maria por 2 horas. Ao final deste período de incubação, as amostras foram transferidas para banho-maria a $65^{\circ} \mathrm{C}$, incubadas por 15 minutos e posteriormente colocadas em gelo picado permanecendo assim por mais 5 minutos.

Imediatamente antes do uso foi preparado o Transcription Master Mix contendo 68,9 $\mu 1$ de água livre de nucleases; $90 \mu 1$ de $4 x$ Transcription Buffer; $27 \mu 1$ de 0,1M DTT; $36 \mu \mathrm{l}$ de NTP mix; $28,8 \mu \mathrm{l}$ de 50\% PEG (pré-aquecido a $40^{\circ} \mathrm{C}$ por 1 minuto); 2,3 $\mu 1$ de RNaseOut; 2,7 $\mu \mathrm{l}$ de Inorganic pyrophosphatase; 3,6 $\mu 1$ de T7 RNA Polymerase e 10,8 $\mu 1$ de Cyanine 3-CTP (por lâmina). Cada tubo de amostra recebeu $60 \mu 1$ Transcription Master Mix e após homogeneização foram incubados a $40^{\circ} \mathrm{C}$ em um banho-maria por 2 horas.

O passo que sucede a incubação envolve a purificação do RNA amplificado e marcado. Para tal procedimento foi utilizado o Illustra RNAspin Mini RNA Isolation Kit (GE Healthcare, Little Chalfont, Buckinghamshire, UK). Um passo inicial de limpeza do RNA foi realizado adicionando 3,5x o volume da reação $(280 \mu \mathrm{l})$ do tampão RA1 em cada amostra. Em seguida em cada tubo foram adicionados $280 \mu \mathrm{l}$ de etanol 100\% (equivalente também a 3,5x o volume da reação) com posterior homogeneização. 
A purificação do RNA foi realizada através de mini colunas RNAspin aplicando o volume total $(640 \mu \mathrm{l})$ de cada amostra na coluna seguida de centrifugação de 30 segundos a 8.000 x g. Cada coluna foi então transferida para um tubo coletor. Os passos de dessalinização da membrana sílica, digestão do DNA, lavagem e secagem da membrana sílica recomendados pelo kit não foram utilizados. A purificação foi retomada a partir da segunda lavagem aplicando-se $600 \mu \mathrm{l}$ do tampão RA3 em cada coluna seguida de uma centrifugação de 1 minuto a 11.000 x g. O líquido foi descartado e para a terceira lavagem foram utilizados $250 \mu 1$ do tampão RA3, seguida de centrifugação por 2 minutos a $11.000 \mathrm{x}$ g. O último passo do kit envolveu a eluição do RNA em alta concentração adicionando-se $40 \mu \mathrm{l}$ de água livre de nucleases seguido de centrifugação por 1 minuto a $11.000 \mathrm{x}$ g.

Em seguida o RNA foi quantificado em um espectrofotômetro NanoDrop ND-1000 UV-VIS (NanoDrop Technologies) calculando-se a massa de RNA. Além disso, foi determinada a incorporação do fluorocromo cianina (Cy3) nas amostras (pmol Cy3 / $\mu$ l). O valor da incorporação total dividido pela massa total fornece um valor que serve como referência para o prosseguimento do passo de hibridação com os microarrays. Somente as amostras que obtiveram os valores acima de 9 foram utilizadas.

Anterior ao passo de hibridação, as amostras passaram por um processo de fragmentação utilizando o Fragmentation mix para microarrays Agilent 4 x 44K. Cada amostra contendo $1,65 \mu \mathrm{g}$ de RNA marcado e amplificado (cRNA) recebeu $11 \mu \mathrm{l}$ de $10 \mathrm{X}$ Blocking Agent (preparado com a adição de $500 \mu \mathrm{l}$ de água livre de nucleases e aquecido a $37^{\circ} \mathrm{C}$ por 4 minutos). Nesse momento o volume da reação não deve ser superior a $52,8 \mu 1$ sendo necessário completar cada amostra com o volume de água livre de nucleases correspondente. Por último adicionou-se 2,2 $\mu \mathrm{l}$ de 25x Fragmentation Buffer em cada tubo sendo o volume final da reação de $55 \mu \mathrm{l}$. Em seguida as amostras foram incubadas em banho-maria a $60^{\circ} \mathrm{C}$ por 30 minutos. Enquanto ocorria a incubação, as câmaras de hibridação contendo as lâminas da Agilent foram preparadas para receber as amostras.

\subsubsection{Hibridação das amostras e lavagem das lâminas}

Após a incubação, seguindo a recomendação do kit para lâminas de microarrays Agilent 4 x 44K, adicionou-se $55 \mu \mathrm{l}$ do $2 x$ GEx Hybridization Buffer HI-RPM em cada tubo e após homogeneização as amostras foram centrifugadas por 1 minuto a $13.000 \mathrm{x}$. 
Um volume de $100 \mu \mathrm{l}$ de cada amostra foi utilizada imediatamente para o processo de hibridação em forno a $65^{\circ} \mathrm{C}$ com rotação durante 17 horas.

Em cada lâmina Agilent $4 \times 44 k$, estão 4 arrays contendo todo o genoma do camundongo. As marcações dos oito grupos experimentais (timócitos e linfócitos T CD3 ${ }^{+}$ de animais não imunizados, imunizados com colágeno e controles, de ambas as linhagens DBA-1/J e DBA-2/J) foram realizadas em triplicata. Portanto, um total de seis lâminas foram utilizadas neste trabalho.

Após a hibridação, as lâminas passaram por um processo de lavagem na seguinte ordem: tampão 1 (GE Wash Buffer 1 - 0,005\% Triton X-102) por 1 minuto à temperatura ambiente, tampão 2 (GE Wash Buffer 2 - 0,005\% Triton X-102) por 1 minuto a $37^{\circ} \mathrm{C}$. Ambas as lavagens foram feitas em um agitador com o uso de barras magnéticas. Em seguida as lâminas foram colocadas em solução de acetonitrila por 10 segundos à temperatura ambiente e por último na solução Stabilization and Drying por 30 segundos a temperatura ambiente para prevenir a degradação da cianina $3(\mathrm{Cy} 3)$ pelo ozônio do ar ambiente.

\subsubsection{Leitura das lâminas e extração dos dados brutos}

Após serem retiradas da solução, as lâminas foram imediatamente levadas para leitura (scanning) evitando o impacto dos oxidantes ambientais na intensidade dos sinais Para isto, foi utilizado o DNA Microarray Scanner (Agilent Technologies) e os dados foram extraídos com o Agilent Feature Extraction Software.

\subsection{2 microRNA microarrays}

Os microarrays de miRNAs Agilent 8 x 15k (Figura 9) utilizados nesse trabalho (G4471A, Agilent Technologies, Santa Clara, CA, USA) também são preparados pelo processo SurePrint (sistema de impressão), no qual aproximadamente 15.000 oligos são depositados uniformemente em lâminas de vidro previamente preparadas. Este processo de síntese in situ possibilita a deposição de oligonucleotídeos, base a base, de 40-60-mer de comprimento (o que inclui a sequência de microRNA e uma cauda extra), com extrema precisão resultando em alta pureza e alta fidelidade das sondas de microRNAs. 


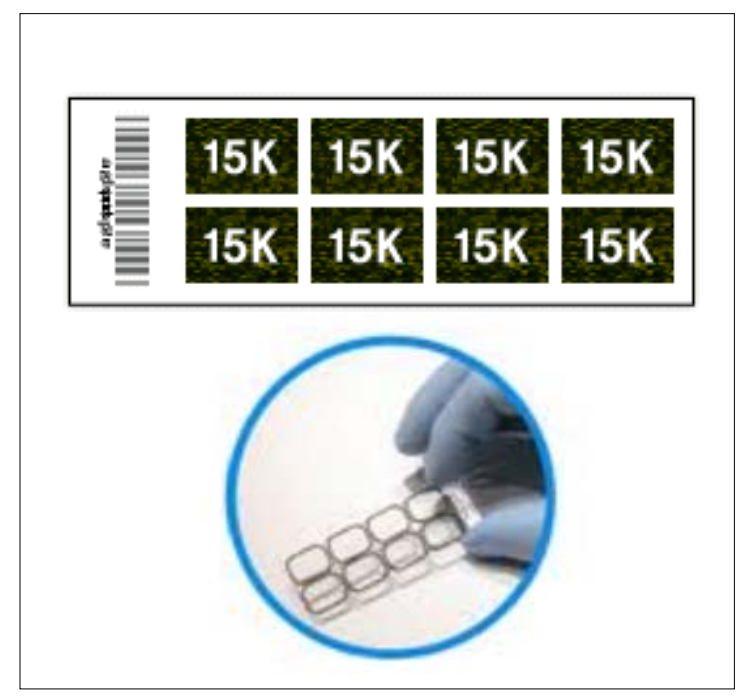

Figura 9. Agilent microarrays de miRNAs no formato $8 \times 15 \mathrm{k}$ contendo oligonucleotídeos sintetizados a com base nas sequências de microRNAs.

\subsubsection{Marcação das amostras}

O processo de foi feito com o miRNA Complete Labeling and Hyb Kit (Agilent Technologies, Santa Clara, CA, USA) no qual foram utilizados $100 \mathrm{ng}$ de RNA total. O primeiro passo envolveu a diluição do RNA total para $50 \mathrm{ng} / \mu \mathrm{l} \mathrm{em}$ água livre de nucleases. Posteriormente adicionou-se $2 \mu \mathrm{l}(100 \mathrm{ng})$ dessa diluição em um tubo de 0,5 $\mathrm{ml}$ e conservou-se no gelo enquanto foi preparado o CIP (Calf Intestinal Alkaline Phosphatase) Master Mix, que foi feito sem a marcação do Spike-In. A reação por amostra do CIP Master Mix continha: 0,4 $\mu 1$ de 10x Calf Intestinal Phosphatase Buffer; 1,1 $\mu 1$ de água livre de nucleases e 0,5 $\mu \mathrm{l}$ de Calf Intestinal Phosphatase, sendo o volume final em cada amostra de $4 \mu l$.

O passo seguinte envolveu a defosforilação das amostras. Todos os tubos foram colocados a $37^{\circ} \mathrm{C}$ em um banho-maria por 30 minutos. Em seguida, para a desnaturação das amostras, foram adicionados $2,8 \mu \mathrm{l}$ de DMSO $100 \%$ deixando a $100^{\circ} \mathrm{C}$ em um banhomaria por 8 minutos. Após esse tempo, os tubos foram colocados imediatamente em um banho frio feito de uma mistura de água e gelo.

Após esse processo de desnaturação, o Ligation Master Mix foi preparado. Nesse mix utilizou-se por amostra: $1 \mu \mathrm{l}$ de 10x T4 RNA Ligase Buffer (aquecido previamente a $37^{\circ} \mathrm{C}$ para dissolução de precipitado); $3 \mu \mathrm{l}$ de Cyanine3-pCp e $0,5 \mu \mathrm{l}$ de T4 RNA Ligase 
(mantida a temperatura ambiente durante o preparo da reação). Após a adição do mix, os tubos contendo um volume final de $11,3 \mu \mathrm{l}$ passaram por rápida centrifugação, e foram levados para incubação a $16^{\circ} \mathrm{C}$ em termociclador por 2 horas.

Decorrido o tempo da incubação, as amostras foram submetidas à secagem a vácuo a uma temperatura entre $45^{\circ} \mathrm{C}$ e $55^{\circ} \mathrm{C}$, no aparelho $\mathrm{SC} 110 \mathrm{~A}$ SpeedVac ${ }^{\circledR}$ Plus Concentrator (Savant Instruments, Holbrook, NY, USA) por aproximadamente 30 minutos, sendo fundamental que estivessem totalmente secas e sem resíduos de DMSO.

$\mathrm{Na}$ etapa que antecede a hibridação, as amostras foram ressuspensas em $18 \mu \mathrm{l}$ de água livre de nucleases e em seguida, pipetou-se 4,5 $\mu 1$ de 10x Blocking Agent (preparado com a adição de $125 \mu \mathrm{l}$ de água livre de nucleases e aquecido a $37^{\circ} \mathrm{C}$ por 4 minutos) e 22,5 $\mu \mathrm{l}$ de $2 x$ Hi-RPM Hybridization Buffer, resultando num volume de $45 \mu$ l. Após serem misturadas gentilmente, as amostras foram incubadas a $100^{\circ} \mathrm{C}$ por 5 minutos $\mathrm{e}$ imediatamente transferidas para o gelo por 5 minutos.

\subsubsection{Hibridação das amostras e lavagem das lâminas}

Enquanto ocorria a incubação, as câmaras de hibridação contendo as lâminas da Agilent foram preparadas para receber as amostras. Tudo deve ocorrer num período máximo de 15 minutos. Para o processo de hibridação foram adicionados $50 \mu 1$ de cada amostra para a hibridação em forno a $55^{\circ} \mathrm{C}$, a uma rotação de $20 \mathrm{rpm}$ durante 20 horas.

Em cada lâmina Agilent 8x15k de microRNA microarray estão 8 arrays, contendo todas as sequências conhecidas de microRNAs de camundongo. As marcações dos oito grupos experimentais (timócitos e linfócitos $\mathrm{T} \mathrm{CD}^{+}$de animais não imunizados, imunizados com colágeno e controles, de ambas as linhagens DBA-1/J e DBA-2/J) foram realizadas em duplicata. Portanto, para o presente trabalho foram utilizadas duas lâminas.

Após a hibridação, as lâminas foram submetidas à imersão em GE Wash Buffer 1 (com $0,005 \%$ Triton X-102), a temperatura ambiente, para a liberação da lâmina em meio líquido, evitando o ressecamento e exposição ao ozônio do ar capaz de degradar a cianina (Cyanine3-pCp).

Em seguida, foram realizadas duas lavagens: a primeira no tampão 1 (GE Wash Buffer 1 - 0,005\% Triton X-102) a temperatura ambiente por 5 minutos e a segunda no tampão 2 (GE Wash Buffer 2 - 0,005\% Triton X-102) por 5 minutos a $37^{\circ} \mathrm{C}$. A adição do Triton reduz a possibilidade de artefatos nos arrays. 


\subsubsection{Leitura das lâminas e extração dos dados brutos}

Após serem retiradas da solução, as lâminas foram imediatamente levadas para leitura (scanning) evitando o impacto dos oxidantes ambientais na intensidade dos sinais Para isto, foi utilizado o DNA Microarray Scanner (Agilent Technologies) e os dados foram extraídos com o Agilent Feature Extraction Software.

\subsection{Análise dos dados de microarrays}

Após o escaneamento das lâminas, os dados foram extraídos com o uso do Agilent Feature Extraction Software e os arquivos gerados no programa foram analisados na plataforma de bioinformática Agilent GeneSpring GX 11.0.

Para a normalização dos dados de mRNA, utilizamos o 75 percentil segundo recomendações da Agilent que informa que os valores dos sinais de expressão nessa situação, em comparação com os sinais da mediana ou do 50 percentil, são mais robustos e representativos quando se usa o one-color microarray.

A distribuição dos valores de intensidade dos dados normalizados para cada amostra foram plotados num gráfico Box-whisker. As amostras dos grupos estudados foram ainda comparadas aos pares, entre os animais de ambas as linhagens (DBA- $1 / \mathrm{J}$ e DBA-2/J).

O software GeneSpring nos permite ainda uma análise de Gene Ontology (GO) com a distribuição dos genes em categorias como: processos biológicos, função molecular e componente celular. Para determinar se há uma representação significante dos dados analisados em relação a essas categorias, um teste estatístico é requerido e um p-value é dado para cada categoria.

Para a normalização dos dados de microRNAs, utilizamos o quantil. A distribuição dos valores de intensidade dos dados normalizados para cada amostra foram plotados num gráfico Box-whisker. As amostras dos grupos estudados foram novamente comparadas aos pares, entre os animais de ambas as linhagens (DBA-1/J e DBA-2/J).

Além disso, fizemos uso dos bancos de dados targetscan (http://www.targetscan. org/), para checar as interações microRNA-mRNAs descritas.

Um estudo em separado nos camundongos da linhagem susceptível a CIA, DBA$1 / \mathrm{J}$, (teste e controle) foi realizado para posterior validação e estudo de novos microRNAs 
em amostras de pacientes com artrite reumatóide. Esses resultados foram obtidos durante estágio na Universidade de Glasgow -Escócia - Reino Unido, por um período de seis meses, sob a supervisão da Dra. Mariola Kurowska-Stolarska.

É importante ressaltar que durante a análise foi realizado a média das replicatas, e sendo assim, nos heat-maps cada grupo é representado por apenas uma coluna.

\subsection{Redes de interações microRNA-mRNA}

Uma grande variedade de metodologias tem sido utilizada para inferir redes gênicas regulatórias a partir de dados temporais. Entre esses métodos estão modelos discretos, como as redes Booleanas e Bayesianas, modelos contínuos, como as redes neurais e equações diferenciais. Todos esses modelos levam em consideração que o nível de expressão de um gene, num determinado intervalo de tempo, é dado em função do nível de expressão dos outros genes nos tempos anteriores (WANG et al., 2006).

A inferência da arquitetura de redes gênicas utilizando dados temporais obtidos de tecnologias experimentais, como por exemplo, os microarrays, ajuda a entender e esclarecer o comportamento do sistema em relação à expressão gênica e a regulação envolvida nessa expressão, tanto durante a transcrição como também de caráter regulatório pós-transcricional, como resultado da ação dos microRNAs.

No presente trabalho, procurou-se estudar o controle pós-transcricional que os microRNAs de timócitos e linfócitos $\mathrm{T} \mathrm{CD}^{+}$periféricos exercem sobre mRNA das mesmas células por meio da reconstrução de redes de interações microRNAs-mRNA na resistência/susceptibilidade a CIA em camundongos DBA-1/J e DBA-2/J.

\subsection{1 $\mathrm{GenMiR}^{++}$}

Para o estudo de interações gênicas utilizou-se o algorítimo de estatística bayesiana GenMiR $^{++}$(Generative model for miRNA regulation) com o intuito de reconstruirmos redes de interações gerando figuras do tipo pathways pelo pareamento dos perfis de expressão de microRNAs e mRNA (HUANG et al., 2007) que calcula, com alta sensibilidade, microRNAs reguladores de MRNA equilibrando as diferentes fontes de incerteza no cálculo. 


\subsubsection{MATLAB}

O MATLAB (MATrix LABoratory) é um programa interativo de alta performance voltado para o cálculo numérico que contém o algorítimo GenMiR ${ }^{++}$.

O MATLAB integra análise numérica, cálculo com matrizes, processamento de sinais e construção de gráficos em ambiente fácil de usar onde problemas e soluções são expressos somente como eles são escritos matematicamente, ao contrário da programação tradicional em linguagem Fortran, Basic ou C.

\subsubsection{Software Cytoscape}

A partir da matriz de dados gerados no $\mathrm{GenMiR}^{++}$dentro do programa MATLAB arquivos no formato texto foram utilizandos para input no programa Cytoscape v.2.8.0 (http://www.cytoscape.org) que tornou possível a visualização gráfica das interações microRNA-mRNA calculadas. Tal programa oferece funcionalidades para integração de dados arbitrários no gráfico, uma representação visual e dados integrados, ferramentas de seleção e filtragem, e uma interface para métodos externos aplicados como plugins (SHANNON et al., 2003).

O programa Cytoscape foi desenvolvido baseando-se na biologia de sistemas e, embora, aplicável a qualquer sistema de componentes e interações moleculares, o programa torna-se mais eficiente quando usado em conjunto com grandes bases de dados de expressão gênica (por exemplo, dados de expressão de RNAs obtidos por microarrays), dados de expressão proteína-proteína ou ainda proteína-DNA.

A organização central do Cytoscape é uma rede gráfica, com genes, proteínas ou outras moléculas representadas como "nós" e as interações como ligações entre os mesmos. Sendo assim, é possível analisar de maneira comparativa, as variações nos perfis de expressão de microRNAs e de seus mRNA alvos.

\subsubsection{RNAhybrid}

O RNAhybrid é uma ferramenta de bioinformática que analisa a estrutura secundária, e determina o sítio de hibridação mais favorável entre um determinado microRNA e seu mRNA alvo (REHMSMEIER et al., 2004; KRÜGER \& REHMSMEIER, 
2006). A metodologia envolve um algoritmo de programação dinâmica que calcula o local para a hibridação mais favorável em termos de energia. Essa metodologia é baseada no princípio da propriedade termodinâmica de interação microRNA-mRNA, na qual uma fita dupla de RNA é mais estável, ou seja, a ligação entre o microRNA e mRNA é mais forte, quando a energia livre é menor (LEWIS et al., 2005). A significância estatística da interação é determinada pela mínima energia livre, ou mfe (do inglês minimum free energy), normalizada pelo comprimento do mRNA alvo. Além disso, o programa oferece ao usuário uma série de opções, como por exemplo, determinar a região do microRNA que deve apresentar complementaridade perfeita com seu alvo, filtrar as interações com menor mfe, e escolher a inclusão ou não de regiões de despareamentos (http://bibiserv.techfak. uni-bielefeld.de/rnahybrid/submission.html).

No presente trabalho, nós fizemos uso dessa ferramenta para confirmação in silico, e obtenção da estrutura molecular de interações microRNA-mRNA selecionadas, previamente definidas pelo uso do modelo bayesiano GenMiR ${ }^{++}$descrito anteriormente.

\subsection{Amostras de linfócitos $\mathrm{T} \mathrm{CD}^{+}{ }^{+}$provenientes de pacientes com artrite reumatóide e indivíduos saudáveis}

Os linfócitos $\mathrm{T} \mathrm{CD}^{+}$, na quantidade de $2 \times 10^{6}$ células, provenientes do banco de amostras do departamento de Imunologia, Infecção e Inflamação da Universidade de Glasgow (Reino Unido), foram utilizados para a identificação de novos microRNAs associados a doença. Essas células foram previamente isoladas de indivíduos saudáveis e pacientes diagnosticados com artrite reumatóide (AR), que apresentavam a doença ativa. Uma amostragem de 10 indivíduos saudáveis, 10 pacientes tratados com DMARDs (disease-mediated anti-rheumatic drugs), entretanto não responsivos ao tratamento, e 10 pacientes tratados com DMARDs e infliximab (anti-TNF), porém também não responsivo a este último foram utilizados para o estudo. Foi feita a extração de RNA total dos linfócitos provenientes dos grupos supracitados. Todos os pacientes preenchem os critérios estabelecidos em 1987 pelo Colégio Americano de Reumatologia (ARNET et al., 1988) e as informações clínicas dos pacientes estão presentes na tabela I. 
Tabela I. Dados demográficos e clínicos da população estudada.

\begin{tabular}{|c|c|c|c|}
\hline & \multirow[t]{2}{*}{ Controle } & \multicolumn{2}{|c|}{ Artrite Reumatóide } \\
\hline & & $\begin{array}{c}\text { Resistentes a } \\
\text { DMARDs }\end{array}$ & $\begin{array}{c}\text { Resistentes a } \\
\text { anti-TNF }\end{array}$ \\
\hline TOTAL (n) & $(n=10)$ & $(n=10)$ & $(n=10)$ \\
\hline Sexo (feminino) \% (n) & $100(10)$ & $60(6)$ & $100(10)$ \\
\hline Idade (Anos - M) & 46.9 & 56.9 & 57.8 \\
\hline Duração da doença (Meses - M) & $N A$ & 116.7 & 198 \\
\hline Fator Reumatóide positivo \% (n) & $N A$ & $80(8)$ & $80(8)$ \\
\hline Anti-CCP positive \% (n) & $N A$ & $80(8)$ & $50(5)$ \\
\hline DAS (M (DP)) & $N A$ & $5.4(1.4)$ & $5.6(1.3)$ \\
\hline Proteína C-reativa (M (DP)) & $N A$ & $24.5(44.1)$ & $19.3(22.3)$ \\
\hline $\begin{array}{l}\text { Sedimentação de eritrócitos } \\
(\mathrm{M}(\mathrm{DP}))\end{array}$ & $N A$ & $22.4(28.8)$ & $36.4(27.5)$ \\
\hline
\end{tabular}

Para todos os pacientes foram obtidos os seguintes parâmetros clínicos: idade, sexo, tempo de doença, medicamentos em uso, atividade da doença estabelecida pelo Índice de Atividade da Doença (Disease Activity Score - DAS 28), estado funcional articular, presença de autoanticorpos (fator reumatóide e anticorpos antipeptídeo citrulinado cíclico), além dos fatores associados à inflamação, como proteína C-reativa e sedimentação de eritrócitos. Para os ensaios in vitro foram utilizados os linfócitos $\mathrm{T} \mathrm{CD}^{+}$isolados de células mononucleares do sangue periférico (PBMCs) doadores saudáveis coletados no hospital Royal Infirmary, (Glasgow UK). Os PBMCs dos doadores foram separados por gradiente de densidade, Ficoll-Hypaque (Sigma, St Louis, MO).

Em detalhes, o sangue dos doadores saudáveis foi diluído na concentração 1:1 em meio de cultura RPMI (Gibco, CA, USA), contendo antibióticos (100U/ml de penicilina, e $100 \mathrm{ug} / \mathrm{ml}$ de estreptomicina). Para a separação dos PBMCs $10 \mathrm{ml}$ de sangue diluído foram 
gentilmente adicionados a um tubo contendo $4 \mathrm{ml}$ de ficoll, tomando cuidado para que o sangue e o ficoll não se misturassem. Esses tubos passaram por centrifugação a $2100 \mathrm{rpm}$ por 20 minutos à temperatura ambiente. Após a centrifugação o anel contendo os PBMCs foi coletado e dispensado em um novo tubo com o auxílio de uma pipeta Pasteur. Foi adicionado um volume de RPMI igual ao obtido da coleta das células seguido de centrifugação a $1800 \mathrm{rpm}$ por 10 minutos também a temperatura ambiente. O sobrenadante foi então descartado e foram adicionados $20 \mathrm{ml}$ de tampão (PBS, 2\% de soro fetal, 100U/ML penicilina, $100 \mathrm{ug} / \mathrm{ml}$ de estreptomicina). Após contagem, uma quantidade de $20 \times 10^{7}$ células foi utilizada para a separação por esferas magnéticas. Os protocolos utilizados foram aprovados pelo comitê de ética local (11/S0704/7) e as cartas de consentimento devidamente assinadas pelos pacientes e doadores.

\subsection{Separação dos linfócitos $\mathrm{T} \mathrm{CD}^{+}$e $\mathrm{T} \mathrm{CD}^{+} 5^{+} \mathrm{Foxp}^{+}$reguladores de PBMCs de doadores saudáveis}

Os linfócitos $\mathrm{T} \mathrm{CD}^{+}$e os linfócitos $\mathrm{T}_{\mathrm{CD}} 4^{+} \mathrm{CD} 25^{+}$reguladores (Tregs) foram isolados utilizando-se esferas magnéticas (CD4_T cell isolation Kit, e CD4 ${ }^{+}$CD25 $5^{+}$ regulatory T cell isolation kit - Miltenyi Biotec, Bergisch Gladbach, Germany), segundo as instruções do fabricante. A separação dos linfócitos $\mathrm{T} \mathrm{CD}^{+}$convencionais é feita por marcação direta, ou seja, as células que apresentam esse marcador ficam retidas na coluna magnética. Para a separação dos linfócitos reguladores a primeira separação é indireta, no qual um mix de anticorpos marca e depleta as células não-T $\mathrm{CD}^{+}$, que ficam retidas na coluna magnética. Posteriormente a população celular não marcada, contendo as células TCD $4^{+}$, passa por um novo processo de separação, e desta vez as células CD $25^{+}$ficam retidas na coluna magnética. Essas células representam as Tregs. A separação foi realizada em aparelho automatizado, autoMacs Pro Separator (Miltenyi Biotec, Bergisch Gladbach, Germany) e posteriormente utilizadas para os ensaios in vitro.

\subsection{Quantificação das populações celulares das amostras de doadores saudáveis por citometria de fluxo}

Com o objetivo de analisar a pureza das células obtidas após a separação por esferas magnéticas, $1 \times 10^{5}$ células/tubo foram utilizadas para o ensaio. Após lavagem em 
$3 \mathrm{ml}$ de PBS 1X, o botão de células foi obtido após centrifugação de 400g, por 10 minutos a $4^{\circ} \mathrm{C}$. O sobrenadante foi descartado, e foram adicionados $100 \mu 1 /$ tubo de tampão (PBS, $2 \%$ de soro fetal, 100U/ML penicilina, $100 \mathrm{ug} / \mathrm{ml}$ de estreptomicina) e $10 \mu \mathrm{l}$ de cada anticorpo monoclonal marcado, anti-CD4 (APC) e anti-CD25 (PE) (eBioscience, CA, USA). As amostras foram incubadas por 35 minutos a $4^{\circ} \mathrm{C}$, e posteriormente lavadas em tampão. $\mathrm{O}$ sobrenadante foi descartado e foram adicionados $250 \mu 1$ de tampão e $250 \mu 1$ de PBS+Formol 1\%. Em seguida foi realizada a leitura no citômetro de fluxo Calibur ${ }^{\mathrm{TM}}$ (Becton Dickinson, NJ, USA). Para a análise da pureza das Tregs as células foram marcadas intracelularmente para a detecção de Foxp3 segundo recomendações do fabricante (Anti-FoxP3 antibodies kit - Miltenyi Biotec, Bergisch Gladbach, Germany). Em detalhes, após a marcação com os anticorpos anti-CD4 e anti-CD25 foi adicionado $1 \mathrm{ml}$ de solução permeabilizante. As células foram incubadas por 30 minutos no escuro a $4^{\circ} \mathrm{C}$. Após lavagem em $2 \mathrm{ml}$ de tampão seguida de centrifugação a $300 \mathrm{~g}$ por 5 minutos a $4^{\circ} \mathrm{C}$, o sobrenadante foi descartado, e foram adicionados $2 \mathrm{ml}$ de tampão de permeabilização seguido de nova centrifugação a $300 \mathrm{~g}$ por 5 minutos a $4^{\circ} \mathrm{C}$. Novamente o sobrenadante foi descartado e foram adicionados $80 \mu 1$ do mesmo tampão de permeabilização e $20 \mu 1$ de FcR Blocking reagent para evitar possíveis marcações inespecíficas. Após incubação de 5 minutos a $4^{\circ} \mathrm{C}$ foram adicionados $10 \mu 1$ de anticorpo anti-FoxP3 seguido de incubação por 30 minutos no escuro a $4^{\circ} \mathrm{C}$. As células foram então lavadas com $2 \mathrm{ml}$ de tampão, centrifugadas a $300 \mathrm{~g}$ por 5 minutos a $4^{\circ} \mathrm{C}$, o sobrenadante descartado e posteriormente adicionados $250 \mu 1$ de tampão e $250 \mu 1$ de PBS+Formol 1\% para leitura no citômetro. Os anticorpos controles apropriados foram utilizados e o ensaio foi realizado em triplicata.

\subsection{Extração de RNA total de amostras de pacientes e doadores saudáveis}

Para a extração de RNA total foi utilizado o kit miRNeasy Mini ${ }^{\circledR}$ (Qiagen, UK) que também permite a separação simultânea de RNAs de alto peso molecular $(\leq 200 \mathrm{nt}$ incluindo os RNAs mensageiros) e de RNAs de baixo pelo molecular ( $\geq 200 \mathrm{nt}$ incluindo os microRNAs de $\sim 23 \mathrm{nt}$ ).

Foram utilizados $700 \mu 1$ de quiazol para lise celular. Após 5 minutos a temperatura ambiente foram adicionados $140 \mu 1$ de clorofórmio aos tubos e o conteúdo misturado vigorosamente, seguido de centrifugação de $12000 \mathrm{~g}$ por 15 minutos a $4^{\circ} \mathrm{C}$. A fase aquosa contendo o RNA foi transferida cuidadosamente para um novo tubo e foram adicionados 
$525 \mu 1$ de etanol 100\%. O volume foi transferido para colunas de sílica e retenção do RNA. Após processo de lavagem, $2 \mathrm{X}$ com $500 \mu 1$ de tampão seguido de centrifugação a $8000 \mathrm{~g}$ por 15 segundos a temperatura ambiente, o RNA foi eluído em $40 \mu 1$ de água livre de nucleases. Os RNAs foram quantificados no nandrop ${ }^{\circledR} 2000$ espectrofotômetro (Thermo Scientific), e utilizados para PCR quantitativa em tempo real.

\subsection{Reações de transcrição reversa}

Para confecção do cDNA foi utilizado o miScript Reverse Transcription Kit (Qiagen, UK), segundo instrução do fabricante. As reações foram realizadas com 40ng de RNA total eluídos em $15 \mu 1$ de água livre de nucleases e foram adicionados $4 \mu 1$ do miScript RT Buffer 5x e $1 \mu$ miScript Reverse Transcriptase Mix. As amostras foram levadas ao termociclador e incubadas a $37^{\circ} \mathrm{C}$ por 60 minutos, 5 minutos a $95^{\circ} \mathrm{C}$, e posteriormente colocadas no gelo.

\subsection{Reação de polimerização em cadeia em tempo real (qPCR)}

Para os ensaios de PCR quantitativa em tempo real, e determinação dos níveis de expressão dos microRNAs: miR-505, miR-500, miR-29b*, miR-30b*, miR-15b, miR135a*, miR-29a*, e miR-let-7b (tabela II), foi utilizado o miScript SYBER ${ }^{\circledR}$ Green PCR kit (Qiagen, UK) de acordo com as recomendações do fabricante. O RNA nuclear RUN6B foi utilizado como controle para normalização dos níveis de expressão.

Na reação foram adicionados $10 \mu 1$ de QuantiTect SYBER Green PCR master mix, $2 \mu 1$ do 10x miScript Universal primer, $2 \mu 1$ do miScript Primer assay, $2 \mu 1$ do cDNA completando a reação com água livre de nucleases para um volume final de $20 \mu 1$. As condições de ciclagem utilizadas foram: 15 minutos a $95^{\circ} \mathrm{C}$, e 40 ciclos de 15 segundos a $94^{\circ} \mathrm{C}, 30$ segundos a $55^{\circ} \mathrm{C}$ e 30 segundos a $70^{\circ} \mathrm{C}$. As reações foram feitas em triplicata, e foi utilizado o aparelho FAST-7500 (Applied Biosystems, CA, USA).

Os primers foram desenhados pela Qiagen, baseados na sequência de cada microRNA encontrada no banco de dados do mirbase (http://www.mirbase.org/). 
Tabela II. Primers utilizados nas reações de qPCR e suas respectivas seqüências sense e antisense.

\begin{tabular}{ccc}
\hline MicroRNA & Número de acesso & Sequência \\
\hline miR-505 & MIMAT0004776 & CGUCAACACUUGCUGGUUUCCU \\
miR-500 & MIMAT0004773 & UAAUCCUUGCUACCUGGGUGAGA \\
miR-29b* & MIMAT0004514 & UAGCACCAUUUGAAAUCAGUGUU \\
miR-30b* & MIMAT0000420 & CUGGGAGGUGGAUGUUUACUUC \\
miR-15b & MIMAT0004586 & UAGCAGCACAUCAUGGUUUACA \\
miR-135a* & MIMAT0004595 & UAUGGCUUUUUAUUCCUAUGUGA \\
miR-29a* & MIMAT0000086 & ACUGAUUUCUUUUGGUGUU \\
miR-let-7d & MIMAT0004484 & AGAGGUAGUAGGUUGCAUAGUU \\
\hline
\end{tabular}

\subsection{Ensaio de proliferação e diferenciação celular}

Os linfócitos $\mathrm{T} \mathrm{CD}^{+}$separados por esferas magnéticas dos PBMCs de doadores saudáveis foram utilizados para os ensaios in vitro de proliferação e diferenciação celular. Para isso uma placa de cultura de 24 wells foi coberta com $500 \mu 1 /$ poço contendo anti-CD3 humano purificado, na concentração de $1 \mathrm{mg} / \mathrm{ml}$ (BD Pharmagen ${ }^{\mathrm{TM}}$ - Biosciences, CA, USA), em PBS $1 \mathrm{X}$ e incubada na estufa por 1 hora. Após o período de incubação a placa foi lavada com $500 \mu 1$ de PBS 1x e então um volume de $250 \mu 1$ de meio RPMI (Gibco, CA, USA) completo (10\% soro fetal, $1 \%$ penincilina, 0,01\% 2-ME, $1 \%$ L-Glutamina) contendo $2 \times 10^{6}$ células/poço foi adicionado. Posteriormente foram adicionados $250 \mu$ l contendo antiCD28 humano purificado, também na concentração de $1 \mathrm{mg} / \mathrm{ml}$ (BD Pharmagen ${ }^{\mathrm{TM}}$ Biosciences, CA, USA) em RPMI completo. Após os períodos de 4, 8, 12, 24, 48 e 72 horas de incubação em estufa $5 \% \mathrm{CO}_{2}$ a $37^{\circ} \mathrm{C}$, as células foram coletadas para extração de RNA total.

Para os ensaios de proliferação celular por citocinas, um volume final de $6,5 \mathrm{ml}$ contendo um total de $13 \times 10^{6}$ células, TNF- $\alpha$ humano recombinante, na concentração final 
de 25ng/ml (Biosource, MD, USA), IL-6 humano recombinante, na concentração de 100ng/ml (Biosource, MD, USA) e IL-2 humano recombinante, na concentração de 25ng/ml (Biosource, MD, USA), foram adicionados a garrafas de cultura, que foram incubadas por 3,5 e 7 dias em estufa $5 \% \mathrm{CO}_{2}$ a $37^{\circ} \mathrm{C}$ para posterior extração de RNA total. Como controle de ambos os experimentos, foi utilizado o RNA total das células recém isoladas e que não colocadas em cultura (0 hora).

Para o ensaio de diferenciação celular foram utilizadas placas de cultura de 24 wells, e $2 \times 10^{6}$ células/poço foram previamente estimulada com anti-CD3 ou anti-CD3 mais anti-CD28, e posteriormente foram adicionados $10 \mathrm{ng} / \mathrm{ml}$ de IL-4 para diferenciação das células no perfil Th2, 10ng/ml de IL-12 para diferenciação no perfil Th1, e as citocinas IL$23(2 \mathrm{ug} / \mathrm{ml})$, IL-1 $\beta(10 \mathrm{ug} / \mathrm{ml})$ e IL-6 $(100 \mathrm{ug} / \mathrm{ml})$ para diferenciação de células no perfil Th17. Após incubação em estufa $5 \% \mathrm{CO}_{2}$ a $37^{\circ} \mathrm{C}$ durante três dias, as células foram coletadas para extração de RNA total. Como controle foi utilizado o RNA de células estimuladas com anti-CD3 e anti-CD28, porém sem estimulo para diferenciação (Th0).

\subsection{Ensaio de luciferase}

Para os ensaios de luciferase, o sítio de ligação do microRNA miR-505 no gene humano IKZF2 (Helios) foi amplificado utilizando-se o par de oligos a seguir: 3'UTR sense GCCTTTTCATTCCAAAGGGGACCCC e 3'UTR antisense: TCCCGCCCCTTCTCTCTTCCTGT, e clonado em ambas as direções no vetor contendo o gene da luciferase (pMIR-REPORT luciferase vector - Ambion, CA, USA). As construções, denominadas "pMIR-HELIOS-miR505" e “pMIR-(A/S)-HELIOS-miR505" foram seqüenciadas para confirmação da presença do inserto, e foram utilizados para transfecção em células da linhagem HEK292. Essas células foram cultivadas em placa de cultura de 96 wells e transfectadas com 0.1ug de pMIR-HELIOS-miR505, pMIR-(A/S)-HELIOS-miR505, 0.01ug do vetor pRL-TK (Promega, WI, USA) contendo Renila luciferase e 40nM do miR-505 mimic ou o microRNA controle 547 de sequência irrelevante (miRIDIAN microRNA mimics and negative controls kit - Thermo Scientific Dharmacon, USA). As transfecções foram realizadas utilizando o Effectene (Qiagen, UK) de acordo com as instruções do fabricante. Para o ensaio de luciferase foi utilizado o kit Dual-Luciferase Reporter Assay (Promega, WI, USA) 24 horas após a transfecção, e sua atividade quantificada em um luminômetro (Luminoskan Ascent, Thermo Scientific, USA). 


\subsection{Análise estatística}

As análises estatísticas foram realizadas utilizando o teste de Mann-Whitney ou ANOVA seguido do teste de Tukey's ou Test T no programa PRISMA. Todos os dados foram realizados em triplicata e $\mathrm{p}<0.05$ foi considerado significante. 
DELINEAMENTO EXPERIMENTAL 


\section{DELINEAMENTO EXPERIMENTAL}

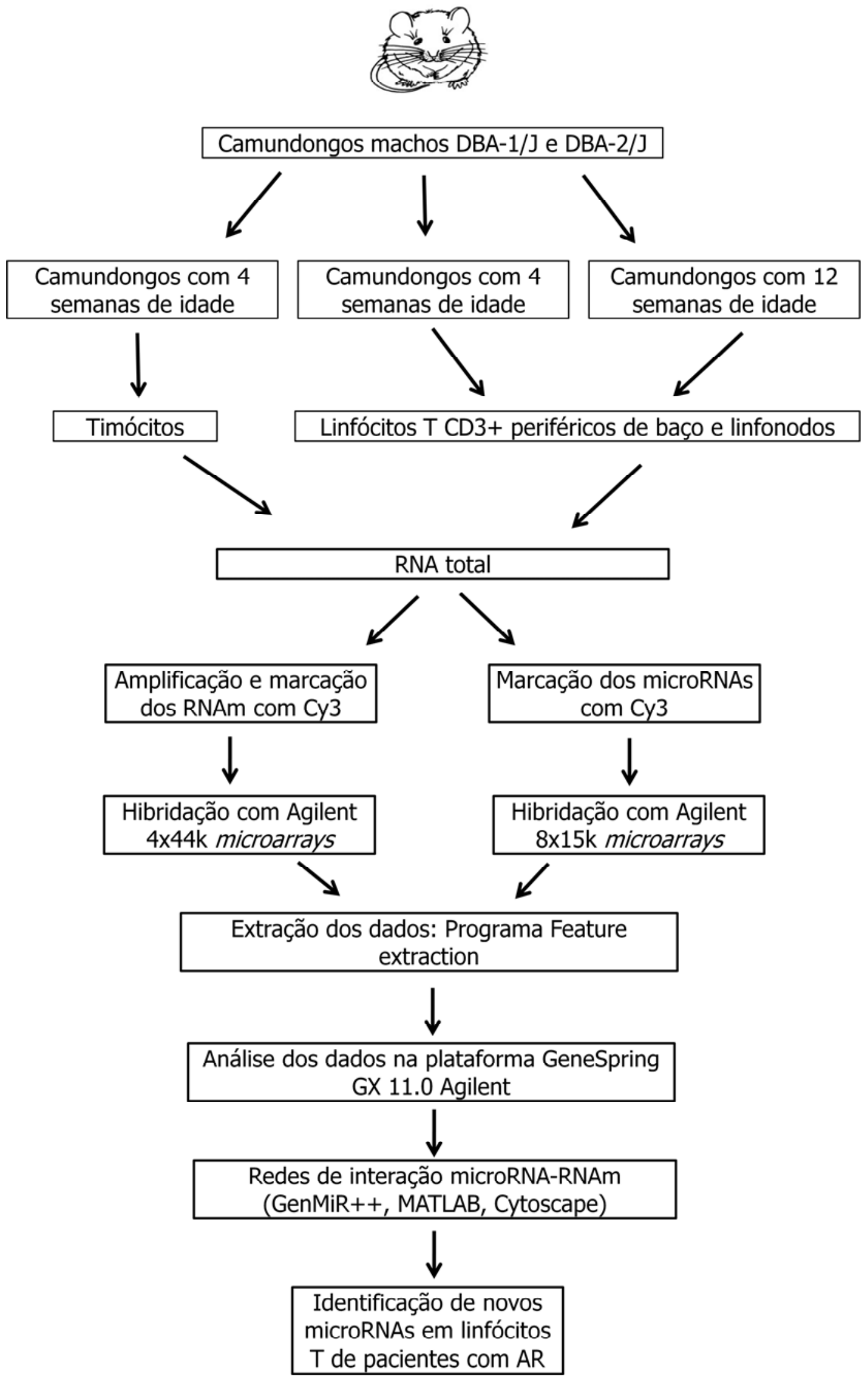


RESULTADOS 


\section{RESULTADOS}

\subsection{Avaliação da integridade das amostras de RNA}

As amostras de RNA total provenientes dos timócitos e linfócitos $\mathrm{T}^{\mathrm{CD}}{ }^{+}$ periféricos de baço, e linfonodos inguinais, dos camundongos das linhagens DBA-1/J e DBA-2/J foram analisadas por eletroforese microfluídica utilizando o aparelho Agilent 2100 Bioanalyzer. A integridade das amostras pode ser observada pela imagem do gel virtual (Figura 10) e da densitometria, nas quais podem ser vistas as frações de RNAr 28S, RNAr 18S, RNAs 4-5S e também de RNAs de baixo peso molecular exibindo perfil de excelente integridade (Figura 11).

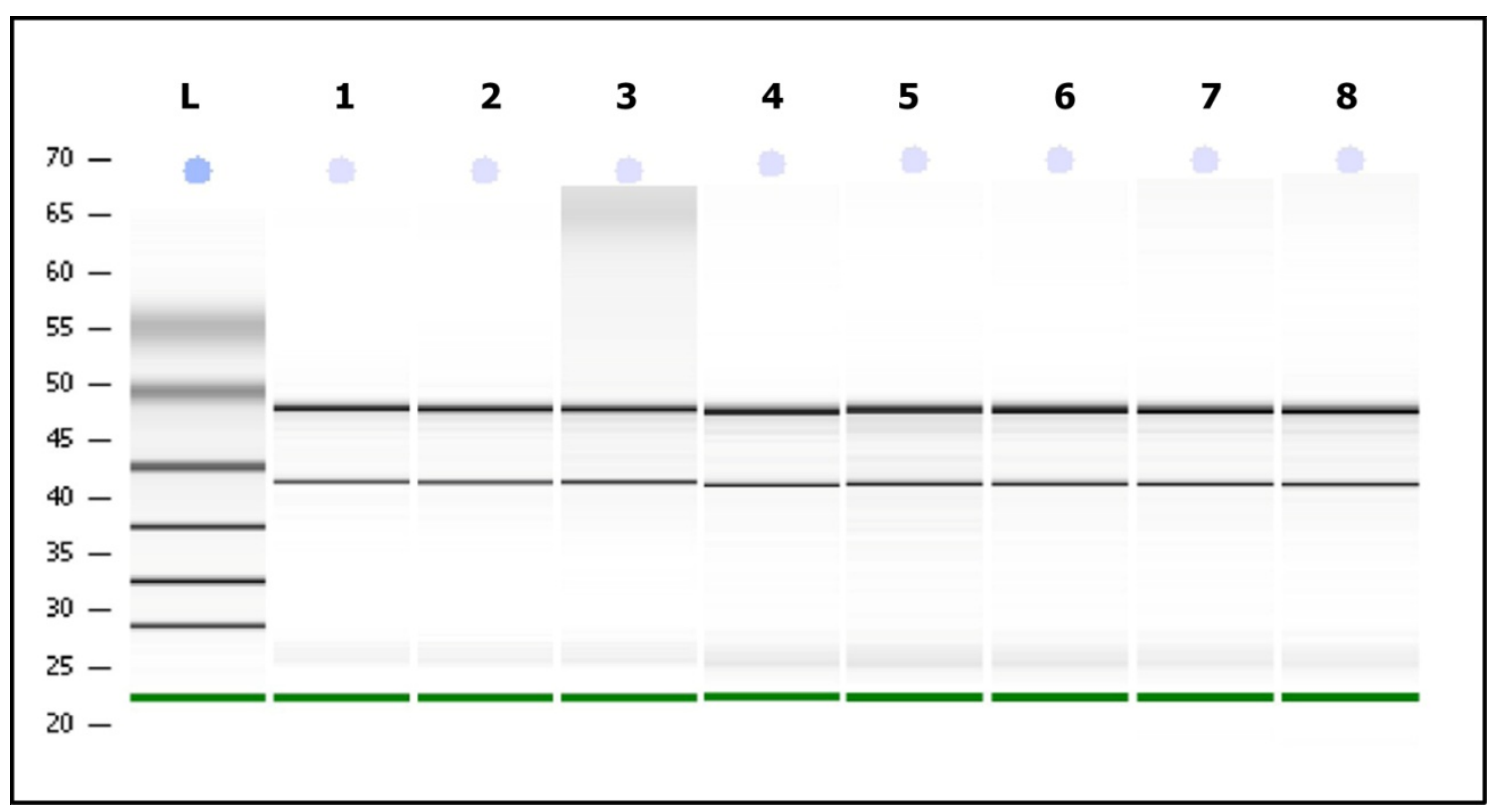

Figura 10. Eletroforese microfluídica (Agilent RNA Nano Chips 6000) das amostras de RNA estudadas mostrando as bandas de RNAr 28S, RNAr 18S e RNAs 4-5S. L = Ladder (de cima para baixo em cada raia) 1) timócitos DBA-1/J 28 dias de idade; 2) timócitos DBA-2/J 28 dias de idade; 3) linfócitos T CD3 ${ }^{+}$DBA-1/J 4 semanas de idade; 4) linfócitos $\mathrm{T} \mathrm{CD}^{+} \mathrm{DBA}-2 / \mathrm{J} 4$ semanas de idade; 5) linfócitos $\mathrm{T}$ CD3 ${ }^{+} \mathrm{DBA}-1 / \mathrm{J} 12$ semanas de idade, imunizados controle; 6) linfócitos T CD3 ${ }^{+} \mathrm{DBA}-1 / \mathrm{J} 12$ semanas de idade, imunizados com colágeno (CIA); 7) linfócitos $\mathrm{CD}^{+}$DBA-2/J 12 semanas de idade, imunizados controle; 8) linfócitos $\mathrm{CD}^{+}$ DBA-1/J 12 semanas de idade, imunizados com colágeno. 


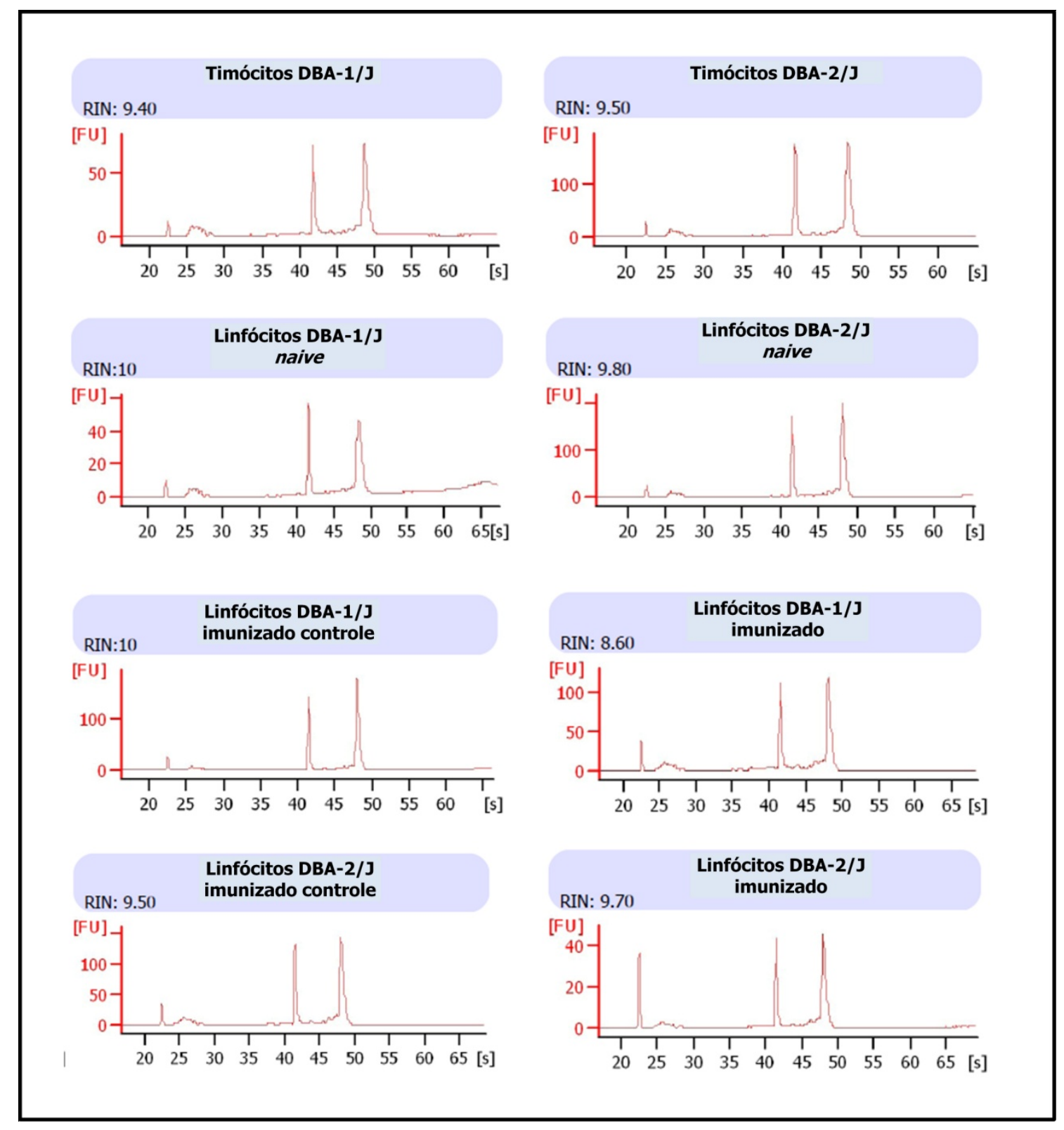

Figura 11. Densitometria da eletroforese microfluídica (Agilent RNA Nano Chips 6000) das amostras de RNA estudadas mostrando os respectivos picos das frações de RNAr 28S, RNAr 18S e RNAs 4-5S. (da direita para a esquerda de cada densitometria). Amostras de timócitos e linfócitos $\mathrm{T} \mathrm{CD} 3^{+}$periféricos com os respectivos "RIN" (RNA integrity number) $>8,5$.

\subsection{Quantificação das populações celulares por citometria de fluxo}

Para avaliar a pureza das células obtidas após a separação de timócitos por

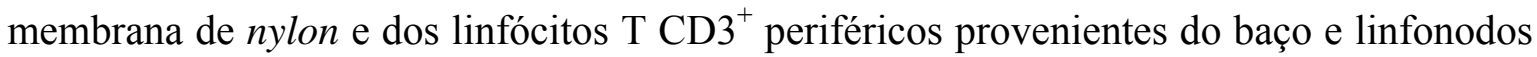
inguinais por meio de esferas magnéticas, foram realizados ensaios de citometria de fluxo e marcação das amostras com o uso de anticorpos anti-CD3. A figura 12A mostra que 
92.98\% das células obtidas pela separação em membrana de nylon correspondem a timócitos positivos para CD3. A figura 12B, por sua vez, mostra uma pureza de $88.3 \%$ de células obtidas por seleção negativa e que correspondem aos linfócitos T CD3 ${ }^{+}$.

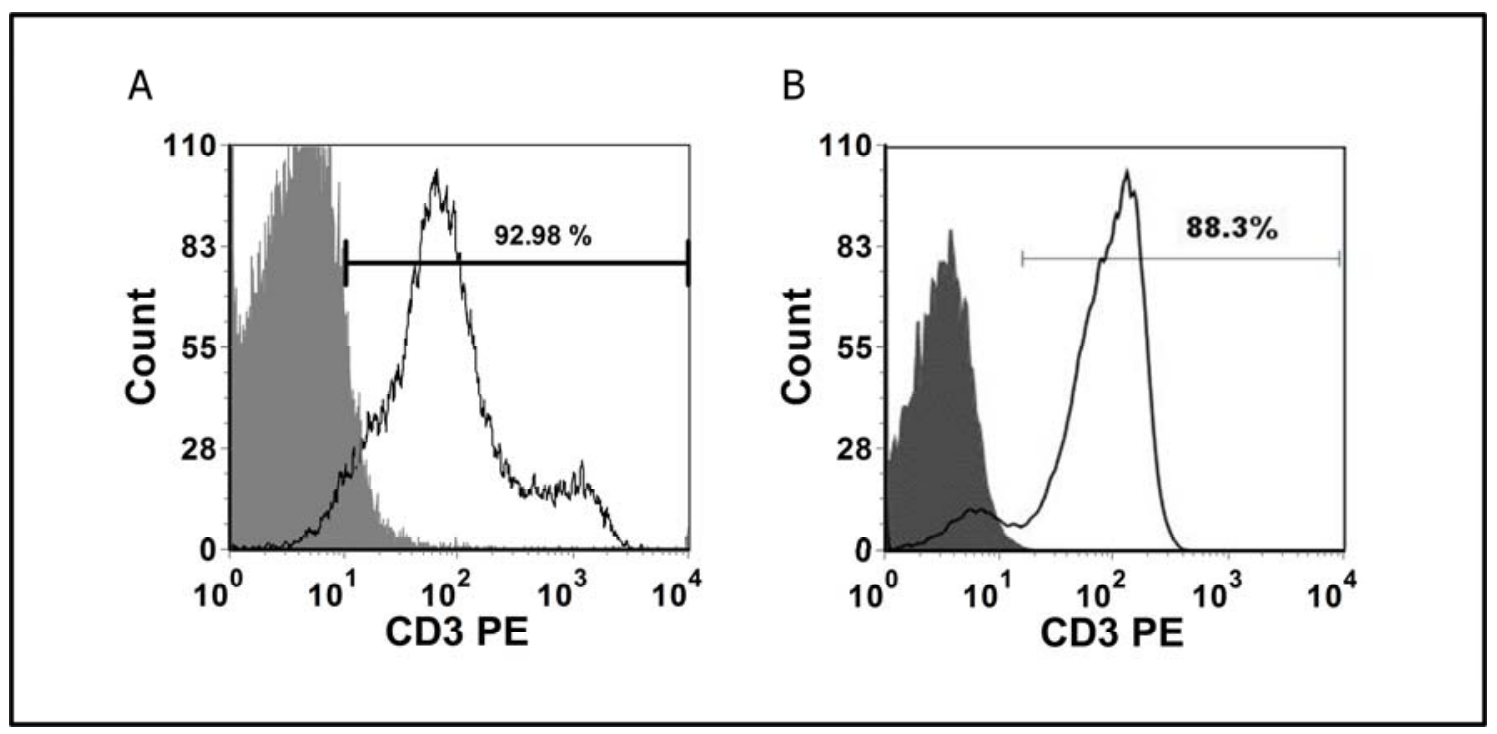

Figura 12. Análise da pureza de células $T$ por citometria de fluxo. A) Timócitos e B) Linfócitos $T$ CD $3^{+}$ periféricos.

Como as populações obtidas representam as células $\mathrm{T} \mathrm{CD}^{+}$totais, procurou-se caracterizar essas células quanto à porcentagem de $\mathrm{CD}^{+}, \mathrm{CD}^{+}$, Tregs $\left(\mathrm{Foxp} 3^{+}\right)$, e Th17 $\left(\right.$ Ror $\gamma \mathrm{t}^{+}$), além de compará-los entre as duas linhagens de camundongo em estudo (DBA1/J e DBA-2/J). Após a incubação com anticorpos específicos para os marcadores de superfície CD3, CD4, CD8 e CD25, e marcação intracelular de Foxp3 e Roryt, seguida de citometria, os dados foram analisados e os resultados podem ser visualizados na figura 13 .

Como podemos observar em relação à porcentagem de linfócitos $\mathrm{T} \mathrm{CD}^{+}$não houve diferença entre as linhagens, bem como nos quatro diferentes grupos estudados (timócitos, camundongo não imunizados, controle e imunizado com colágeno tipo II CIA) (Figura 13 a). Já na população celular positiva para o marcador CD8, a linhagem de camundongos DBA-2/J, resistente a indução de CIA, apresenta uma porcentagem maior dessas células na periferia. Entretanto, o oposto acontece durante a maturação tímica, onde a porcentagem dessas células é maior na linhagem susceptível DBA-1/J (Figura 13b).

Os linfócitos T CD25 ${ }^{+}$Foxp3 $^{+}$, são conhecidos como linfócitos reguladores (Tregs). Apesar de não haver diferença na porcentagem dessas células no timo, na periferia é possível observar um aumento significativo novamente nos camundongos da linhagem 
DBA-2/J, bem como quando comparamos os camundongos DBA-1/J imunizados com colágeno ao seu respectivo controle (Figura 13c).
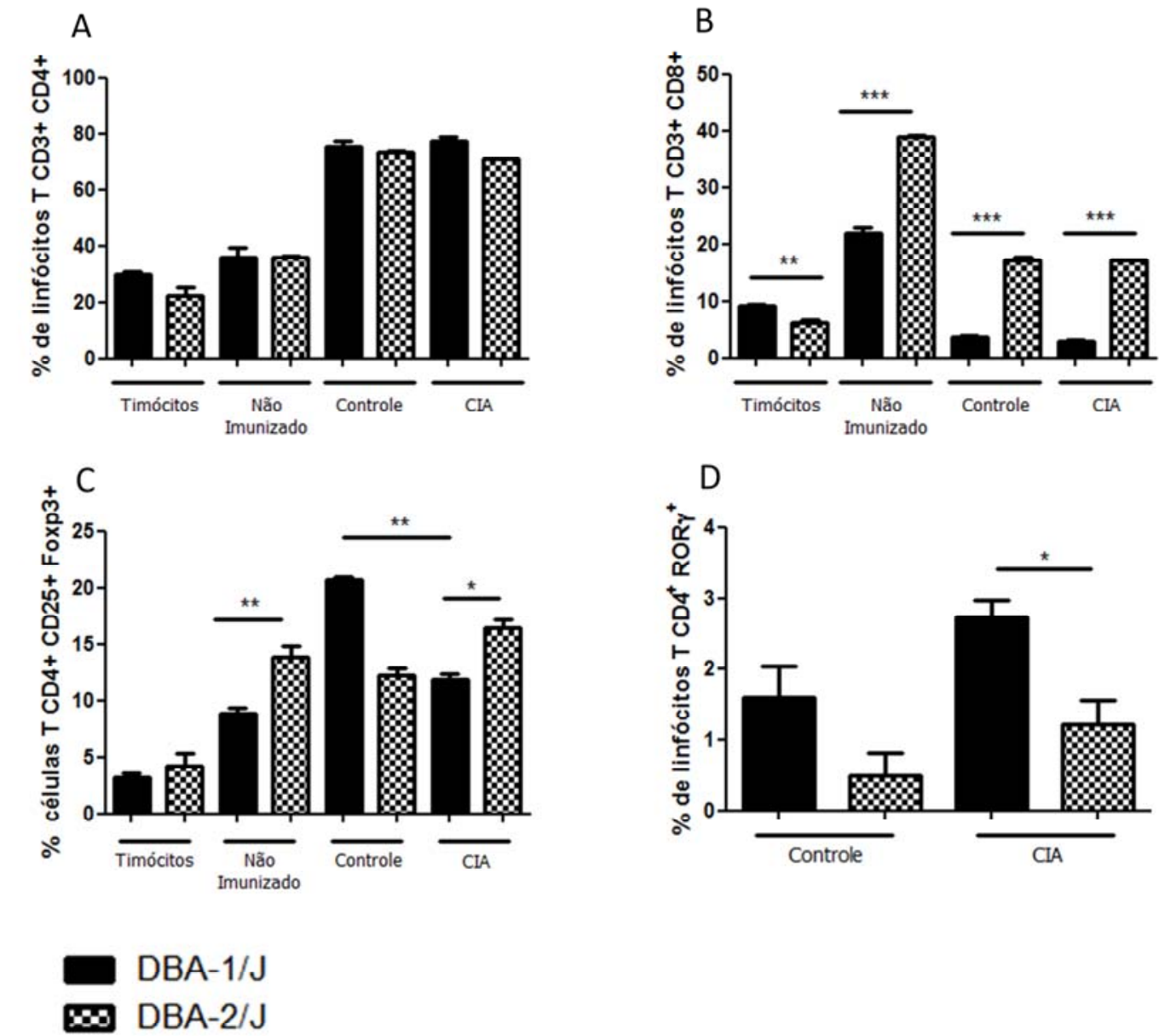

Figura 13. Caracterização da população de células $T$ em camundongos DBA-1/J e DBA-2/J por citometria de fluxo: a) timócitos e linfócitos $\mathrm{T} \mathrm{CD}^{+} \mathrm{CD}^{+}$periféricos; b) timócitos e linfócitos $\mathrm{T} \mathrm{CD}^{+} \mathrm{CD}^{+}$ periféricos; c) timócitos e linfócitos $\mathrm{T} \mathrm{CD} 4^{+} \mathrm{CD}_{2} 5^{+}$Foxp $3^{+}$periféricos (Tregs); e d) linfócitos $\mathrm{T}$ CD4+ Roryt $^{+}$(Th17) periféricos. Os linfócitos periféricos são provenientes de baço e linfonodos inguinais. O grupo identificado como controle se refere aos camundongos imunizados sem o colágeno, e o grupo CIA aos camundongos que receberam imunização contendo colágeno do tipo II.

Os linfócitos $\mathrm{T} \mathrm{CD} 4^{+}$Roryt $^{+}$por sua vez, caracterizam o subtipo Th17 dos linfócitos $\mathrm{T} \mathrm{CD}^{+}$helper. Essas células estão relacionadas a diversas doenças autoimunes, entre elas a artrite reumatóide, e é possível observar, como esperado, uma maior porcentagem dessas células na linhagem DBA-1/J, que é susceptível a indução de CIA, quando comprada a linhagem resistente DBA-2/J (Figura 13d). 


\subsection{Análise dos RNAs mensageiros diferencialmente expressos}

Após o escaneamento das lâminas de microarrays, os dados foram extraídos com auxílio do Agilent Feature Extraction Software e os arquivos gerados foram analisados com o uso do programa GeneSpring $G X 11.0$ da Agilent.

Os dados de RNA mensageiro (mRNA) foram normalizados utilizando o 75 percentil e a distribuição dos valores de intensidade dos dados normalizados para cada amostra foram plotados num gráfico Box-whisker.

Visando um maior entendimento das etapas que envolvem o desenvolvimento, maturação e ativação das células $\mathrm{T}$, nossa análise foi dividida em duas etapas. Primeiro foram analisados os genes diferencialmente expressos entre timócitos e linfócitos periféricos de camundongos que não passaram pelo processo de imunização, de ambas as linhagens (DBA-1/J e DBA-2/J). Após a análise estatística por meio de One-way ANOVA com $p$-value $\leq 0,05$, e posterior fold-change $\geq 2.0$, foram evidenciados $14.230 \mathrm{mRNA}$ diferencialmente expressos (Figura 14). Utilizando-se o banco de dados do Gene Ontology (GO) como ferramenta, e após a escolha de um p-value cut-off $<0,1$ foram selecionados somente os processos biológicos de interesse para o estudo. Entre eles estão os grupos de genes pertencentes aos processos biológicos de adesão e diferenciação celular, recombinação, regulação da apoptose e genes associados ao sistema imune. Somente os genes relacionados aos processos citados acima foram utilizados para os estudos posteriores de interação como os microRNAs.

$\mathrm{Na}$ segunda etapa foram analisados os genes diferencialmente expressos em linfócitos $\mathrm{T}$ periféricos de camundongos imunizados com colágeno, ou seja, durante a emergência da CIA, e seus respectivos controles, de ambas as linhagens DBA-1/J e DBA$2 / \mathrm{J}$. Após a análise estatística (One-way ANOVA com p-value $\leq 0,05$, e fold-change $\geq$ 2.0), foram evidenciados 3.155 MRNA diferencialmente expressos (Figura 15). 


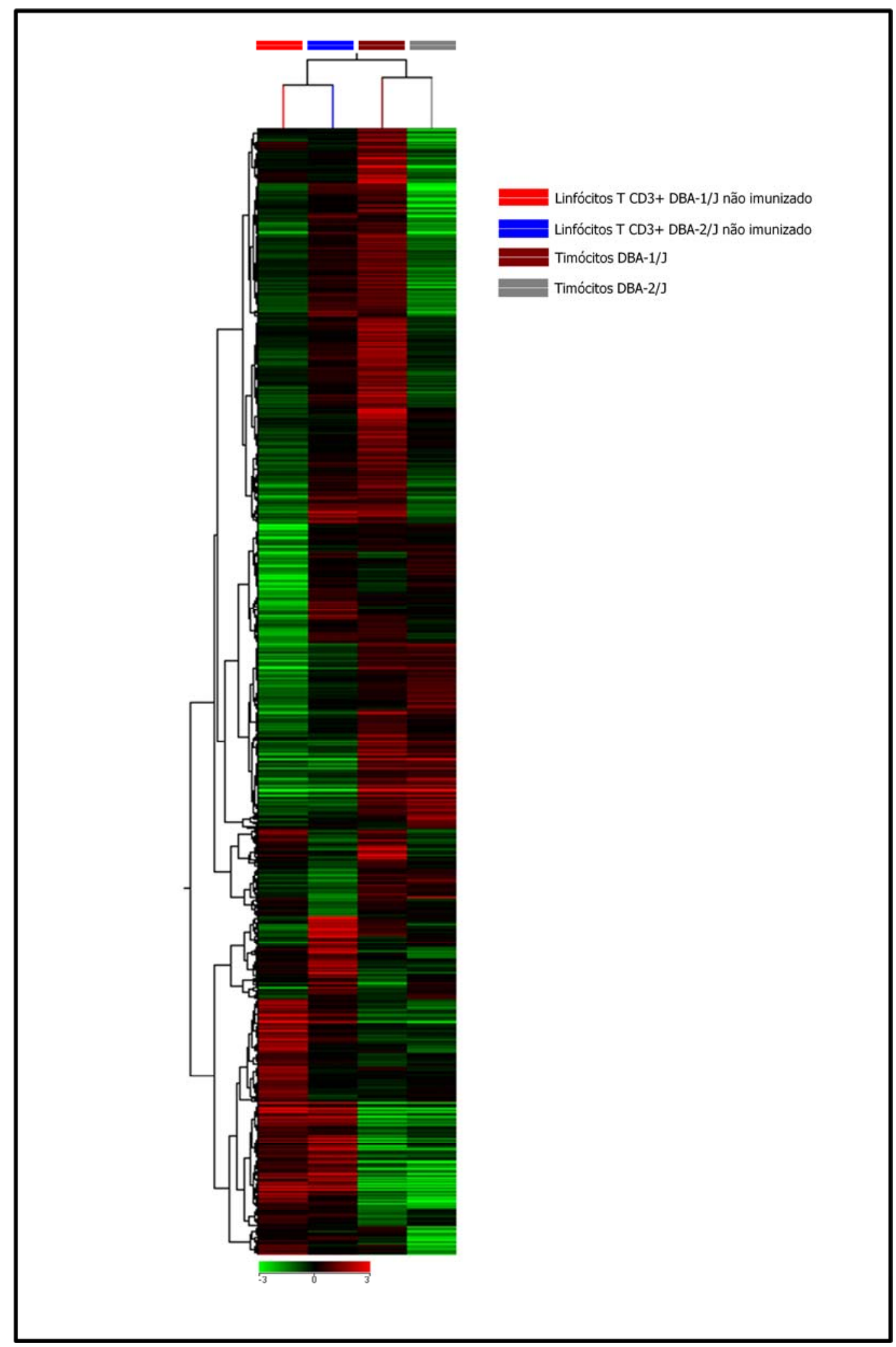

Figura 14. Comparação dos perfis de expressão gênica entre os camundongos das linhagens DBA-1/J e DBA-2/J. Matriz de expressão de 14.230 MRNA de timócitos e linfócitos T CD3 ${ }^{+}$periféricos do baço e linfonodo inguinal de camundongos com 28 dias de idade, e 4 semamas de idade respectivamente. A correlação de Pearson foi utilizada como medida de similaridade. O vermelho representa ativação, o verde repressão, e o preto não modulação. 


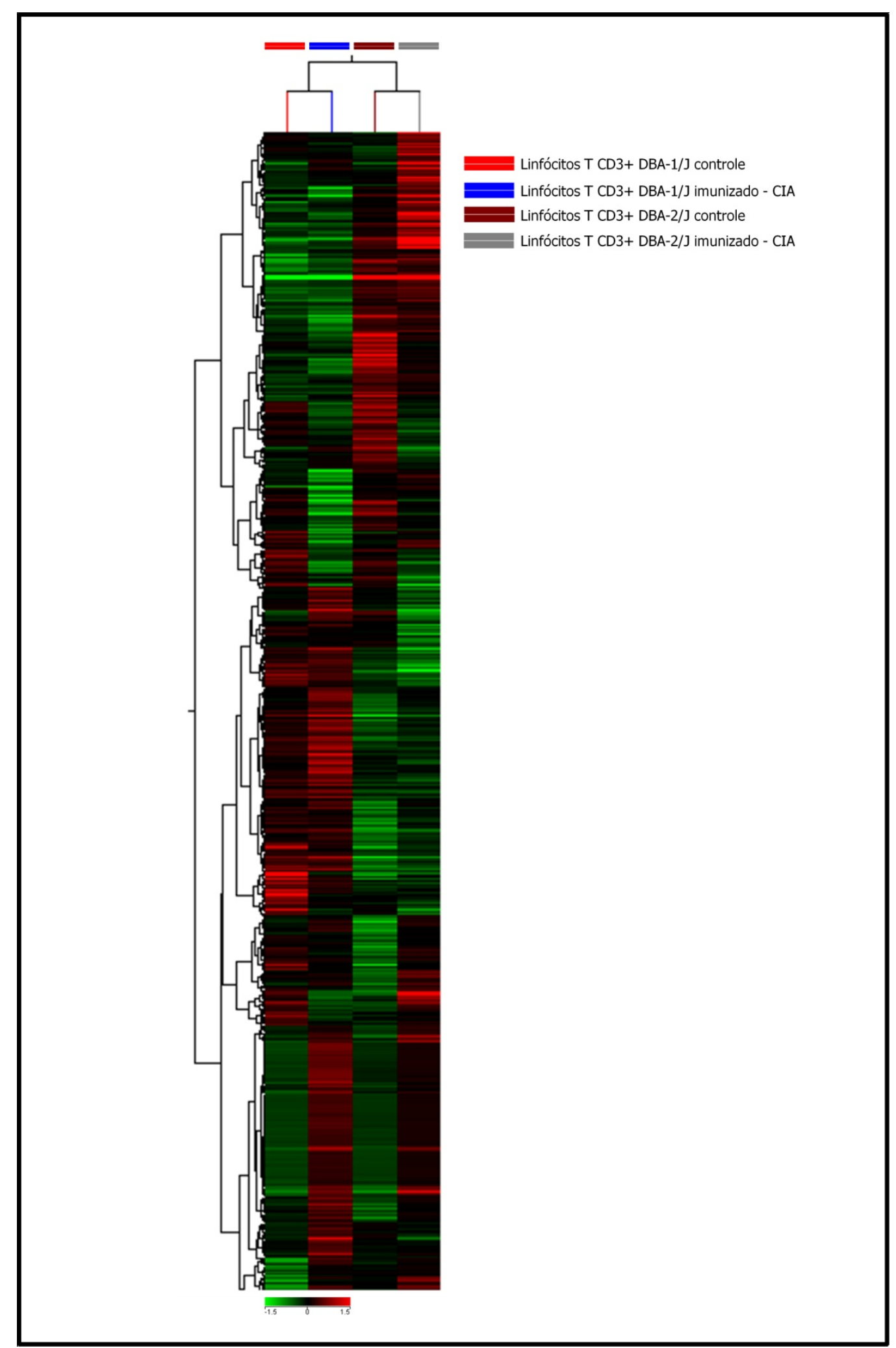

Figura 15. Comparação dos perfis de expressão gênica entre os camundongos das linhagens DBA-1/J e DBA-2/J. Matriz de expressão de 3.155 mRNA de linfócitos T CD3 ${ }^{+}$periféricos do baço e linfonodo inguinal de camundongos com 12 semanas de idade, imunizados com ou sem o colágeno tipo II. A correlação de Pearson foi utilizada como medida de similaridade. $\mathrm{O}$ vermelho representa ativação, o verde repressão, e o preto não modulação. 
Com base no GO ( $p$-value cut-off $<0,1)$, os genes relacionados aos seguintes processos biológicos: resposta imunológica, resposta inflamatória, morte celular e ativação e proliferação de células $\mathrm{T}$, foram selecionados para os estudos posteriores de interação.

\subsection{Análise dos microRNAs diferencialmente expressos}

Da mesma maneira como descrita para os mRNA, os dados de microRNAs foram também extraídos com o uso do programa Agilent Feature Extraction e os arquivos analisados com o uso do programa GeneSpring GX 11.0 da Agilent.

Os dados de microRNAs foram normalizados utilizando o quantil e a distribuição dos valores de intensidade dos dados normalizados para cada amostra foram plotados num gráfico Box-whisker, e novamente as análises foram feitas em duas etapas. Após a análise estatística por meio de One-way ANOVA com $p$-value $\leq 0,05$, e fold-change $\geq 2.0$, foram evidenciados 91 microRNAs diferencialmente expressos em timócitos e linfócitos $\mathrm{T}$ periféricos de camundongos não imunizados (Figura 16), e 62 microRNAs diferencialmente expressos em linfócitos $\mathrm{T}$ periféricos de camundongos imunizados com colágeno, e seus respectivos controles, de ambas as linhagens DBA-1/J e DBA-2/J (Figura 17).

Somente os microRNAs induzidos exclusivos de cada etapa de diferenciação dos linfócitos $\mathrm{T}$, e em cada linhagem, foram utilizados para a construção das redes de interação. A tabela III mostra os microRNAs selecionados para análise. 


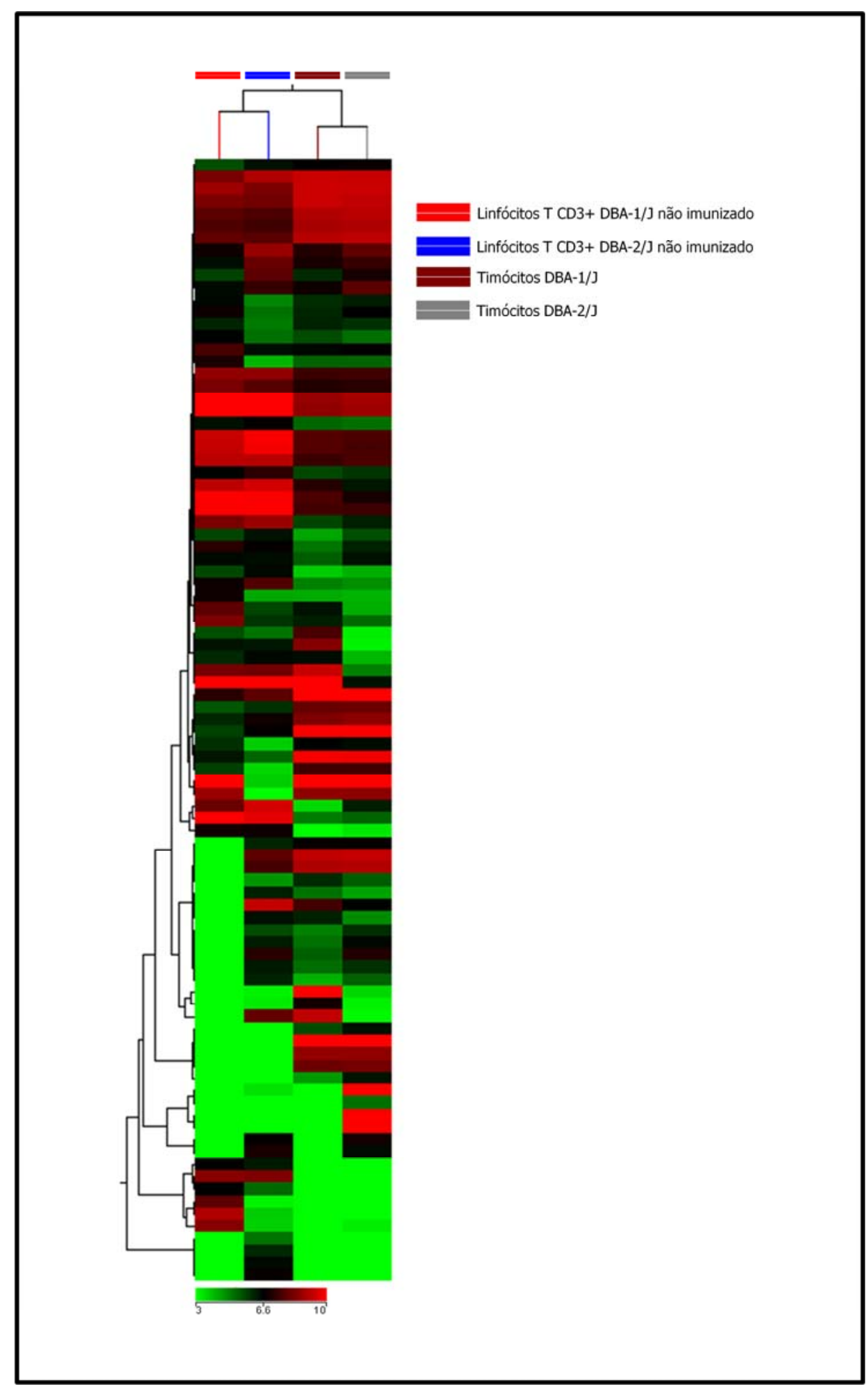

Figura 16. Comparação dos perfis de expressão dos 91 microRNAs diferencialmente expressos entre os camundongos da linhagem DBA-1/J e DBA-2/J. Matriz de expressão de microRNAs de timócitos e linfócitos $\mathrm{T} \mathrm{CD}^{+}$periféricos do baço e linfonodo inguinal de camundongos 4 semamas de idade respectivamente. A correlação de Pearson foi utilizada como medida de similaridade. O vermelho representa microRNA com expressão induzida, o verde representa microRNA com expressão reprimida e o preto representa que a expressão do microRNA não variou entre as amostras. 


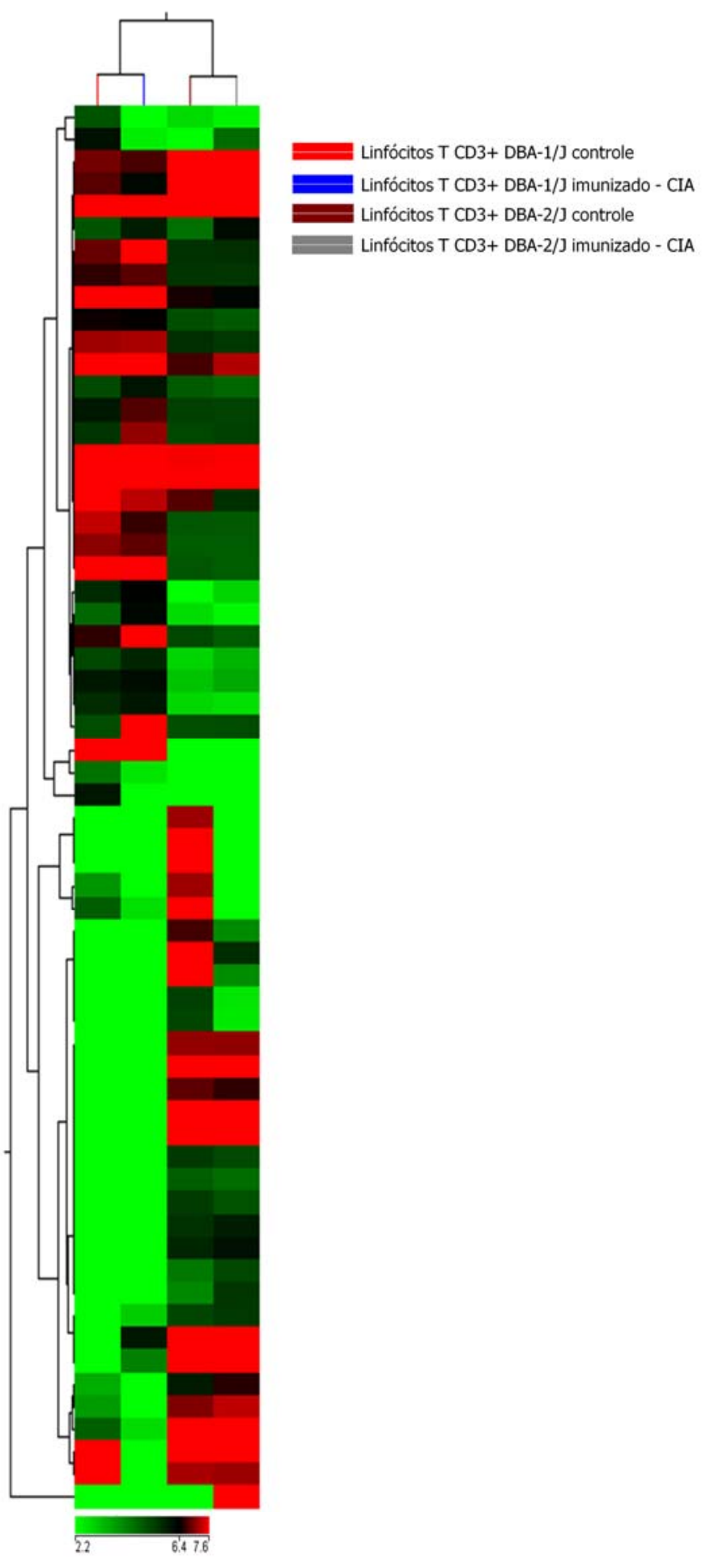

Figura 17. Comparação dos perfis de expressão dos 62 microRNAs diferencialmente expressos entre os camundongos da linhagem DBA-1/J e DBA-2/J. Matriz de expressão de microRNAs de linfócitos T CD3+ periféricos do baço e linfonodo inguinal de camundongos com 12 semanas de idade, imunizados com ou sem o colágeno tipo II. A correlação de Pearson foi utilizada como medida de similaridade. O vermelho representa microRNA com expressão induzida, o verde representa microRNA com expressão reprimida e o preto representa que a expressão do microRNA não variou entre as amostras. 
Tabela III. MicroRNAs selecionados com base no perfil de expressão das diferentes fases do desenvolvimento das células T.

\begin{tabular}{|c|c|}
\hline Grupos (perfil de expressão) & microRNAs \\
\hline Timócitos DBA-1/J (induzidos) & $\begin{array}{l}\operatorname{miR}-126-3 p \\
\operatorname{miR}-221 \\
\operatorname{miR}-200 c\end{array}$ \\
\hline Timócitos DBA-2/J (induzidos) & $\begin{array}{l}\text { miR-let-7e } \\
\text { miR-100 } \\
\text { miR-19a* }\end{array}$ \\
\hline Linfócitos $\mathrm{T} \mathrm{CD}^{+}{ }^{+} \mathrm{DBA}-1 / \mathrm{J}$ não imunizado (induzidos) & $\begin{array}{l}\operatorname{miR}-195 \\
\operatorname{miR}-689 \\
\operatorname{miR}-500 \\
\operatorname{miR}-196 \mathrm{~b} \\
\operatorname{miR}-10 \mathrm{a} \\
\operatorname{miR}-805\end{array}$ \\
\hline Linfócitos $\mathrm{T} \mathrm{CD}^{+}{ }^{+} \mathrm{DBA}-2 / \mathrm{J}$ não imunizados (induzidos) & $\begin{array}{l}\operatorname{miR}-467 \mathrm{e} \\
\operatorname{miR}-101 \mathrm{a} \\
\operatorname{miR}-125-5 \mathrm{p} \\
\operatorname{miR}-669^{\mathrm{a}}\end{array}$ \\
\hline Linfócitos $\mathrm{T} \mathrm{CD}^{+}$ativados (CIA) DBA-1/J (induzidos) & $\begin{array}{l}\operatorname{miR}-181 \mathrm{a} \\
\mathrm{miR}-144 \\
\mathrm{miR}-17 * \\
\mathrm{miR}-202-3 \mathrm{p} \\
\mathrm{miR}-467 \mathrm{a}^{*} \\
\mathrm{miR}-500\end{array}$ \\
\hline Linfócitos $\mathrm{T} \mathrm{CD}^{+}$ativados DBA-2/J (induzidos) & $\begin{array}{l}\text { miR-302c } \\
\text { miR-691 } \\
\text { miR-712 } \\
\text { miR-125a-3p } \\
\text { miR-29b* } \\
\text { miR-30b* } \\
\text { miR-10b } \\
\text { miR-149 } \\
\text { miR-141 } \\
\text { miR-1897-5p } \\
\text { miR-690 }\end{array}$ \\
\hline $\begin{array}{l}\text { Linfócitos } \mathrm{T} \mathrm{CD}^{+} \text {ativados (CIA) DBA- } 1 / \mathrm{J} \text { (reprimidos somente na } \\
\text { CIA) }\end{array}$ & $\begin{array}{l}\operatorname{miR}-29 a^{*} \\
\operatorname{miR}-135 a^{*}\end{array}$ \\
\hline
\end{tabular}




\subsection{Redes de interação microRNA-mRNA}

Para o estudo do controle pós-transcricional que os microRNAs de timócitos e linfócitos $\mathrm{T} \mathrm{CD}^{+}$periféricos exercem sobre os RNAs mensageiros dessas células, utilizamos o programa GenMiR ${ }^{++}$, que calcula a probabilidade de interação entre um determinado microRNA e um mRNA baseado nos dados de expressão gênica. Esse programa, aliado ao programa gráfico cytoscape, possibilitou a construção de redes de interações durante as fases que envolvem desde a maturação, o desenvolvimento e ativação dos linfócitos T, sempre comparando a linhagem susceptível à indução de CIA, DBA-1/J, e a linhagem resistente DBA-2/J.

Para determinar as interações microRNA-mRNA foram considerados o conjunto dos 14.230 mRNAs e 91 microRNAs diferencialmente expressos nos timócitos e linfócitos $\mathrm{T} \mathrm{CD}^{+}$periféricos de camundongos, na ausência de imunização, sendo que no conjunto total de mRNAs estão genes pertencentes a processos biológicos de interesse para o estudo em questão, como adesão e diferenciação celular, recombinação, regulação da apoptose e sistema imune.

Posteriormente para o estudo das interações durante a emergência da CIA, 3.155 mRNAs diferencialmente expressos, contendo os genes relacionados a resposta imunológica, resposta inflamatória, morte celular e ativação e proliferação de células $\mathrm{T}$, e 62 microRNAs foram utilizados. Optamos pela construção de redes para cada processo biológico relevante previamente selecionado, em cada uma das duas linhagens de camundongo utilizadas no estudo.

A figura 18 mostra a interação dos microRNAs miR-126-3p, miR-221, e miR-200c induzidos em timócitos da linhagem DBA-1/J com 44 alvos (Figura 18a), e os microRNAs miR-let-7e, miR-100, e miR-19a* induzido na linhagem DBA-2/J com 49 alvos (Figura 18b), diferencialmente expressos relacionados aos processos de apoptose e adesão celular. 


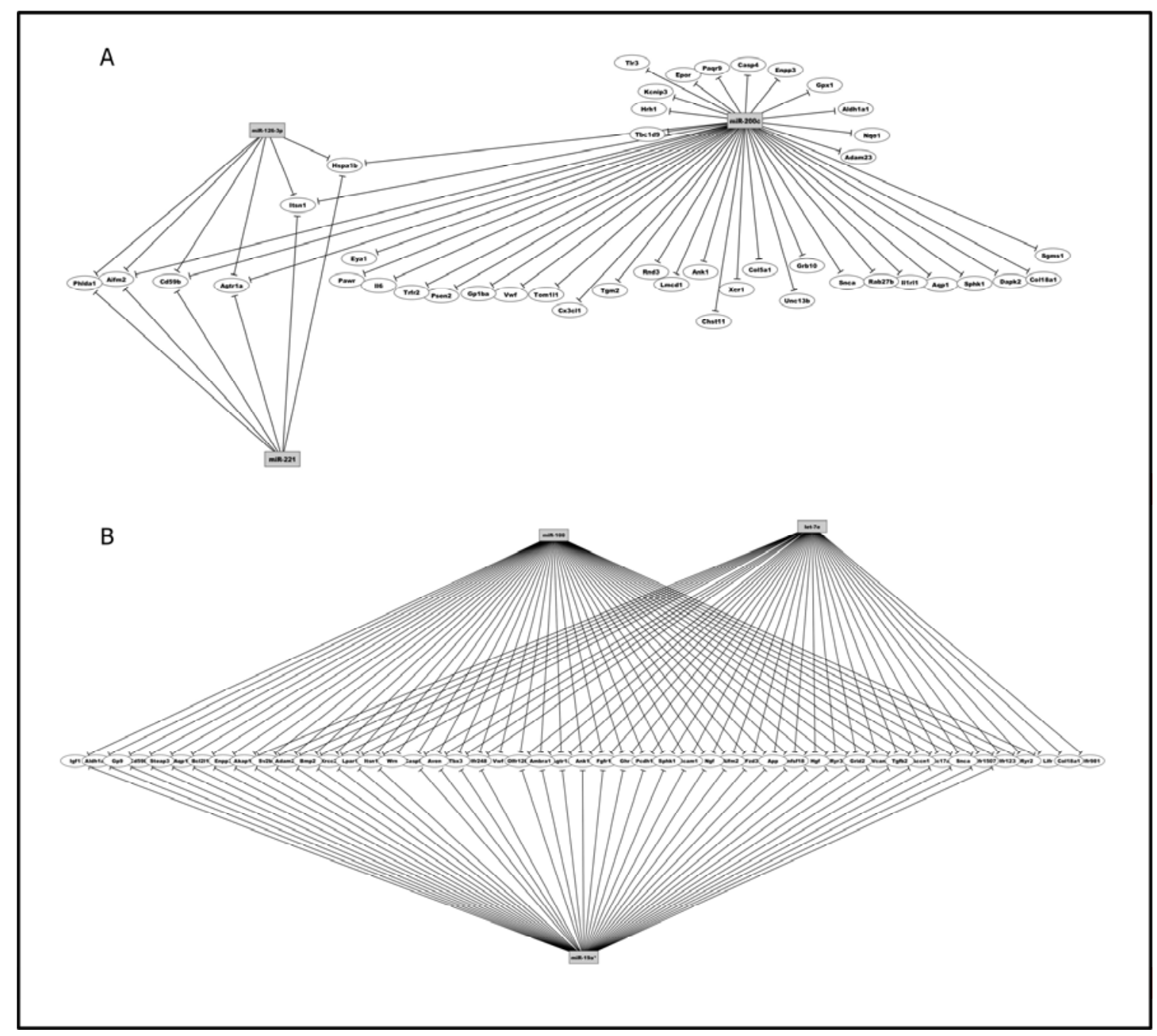

Figura 18. Rede mostrando a interação dos microRNAs induzidos em timócitos da linhagem a) DBA-1/J e b) DBA-2/J com seus respectivos alvos relacionados aos processos biológicos de apoptose e adesão celular.

A figura 19 por sua vez, mostra os mesmos microRNAs interagindo com 51 alvos na linhagem DBA-1/J (Figura 19a), e 43 na linhagem DBA-2/J (Figura 19b) relacionados aos processos de diferenciação celular e recombinação. 


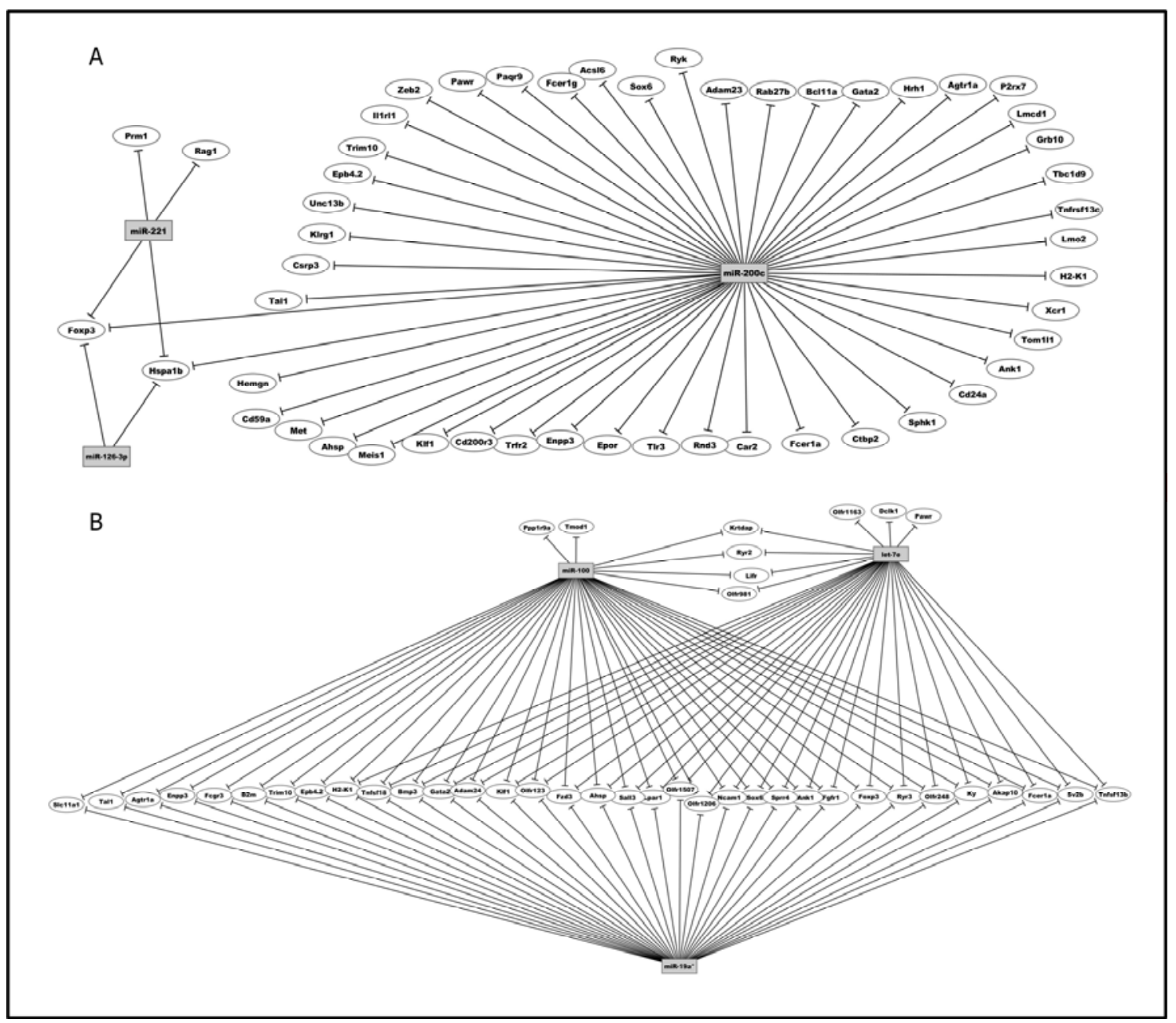

Figura 19. Rede mostrando a interação dos microRNAs induzidos em timócitos da linhagem a) DBA-1/J e b) DBA-2/J com seus respectivos alvos relacionados aos processos biológicos de diferenciação celular e recombinação.

E finalmente a figura 20 mostra a interação destes microRNAs respectivamente com 35 alvos diferencialmente expressos na linhagem DBA-1/J (Figura 20a), e 43 alvos na linhagem DBA-2/J (Figura 20b) relacionados ao sistema imune. 
A

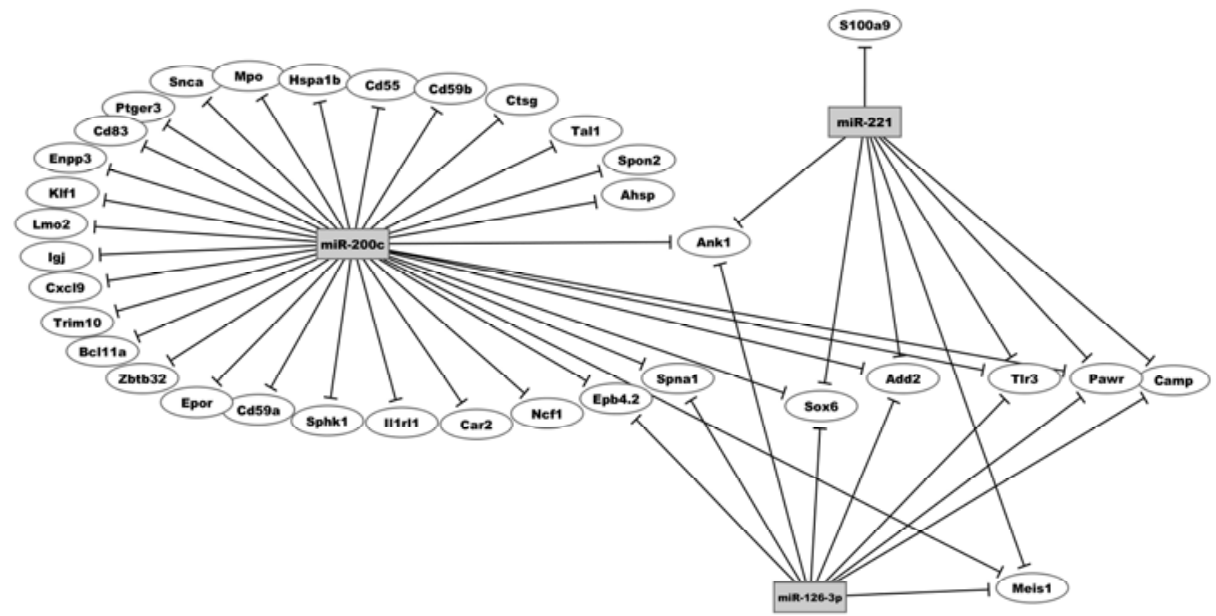

B

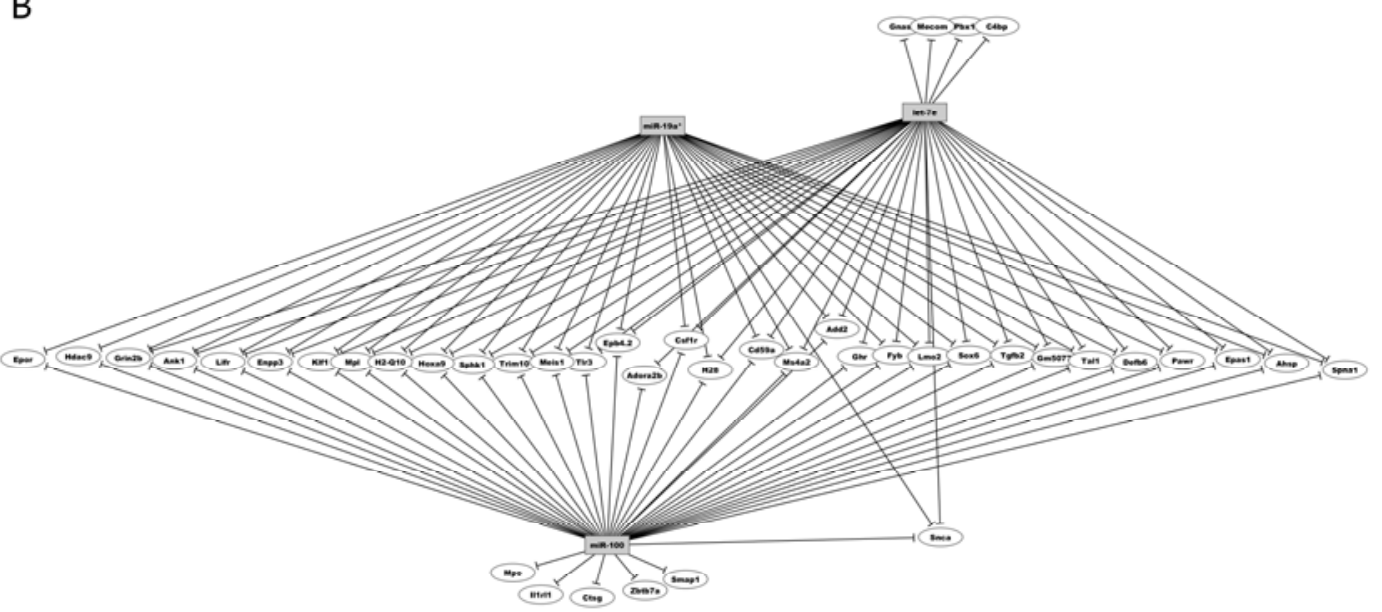

Figura 20. Rede mostrando a interação dos microRNAs induzidos em timócitos da linhagem a) DBA-1/J e b) DBA-2/J com seus respectivos alvos relacionados ao sistema imune.

Com relação aos linfócitos $\mathrm{T}$ periféricos de camundongos não imunizados, a figura 21 mostra as interações dos microRNAs miR-195, miR-689, miR-500, miR-196b, miR-10a e miR-805 induzidos na população de linfócitos T CD3 ${ }^{+}$total nos camundongos DBA-1/J, com 39 alvos (Figura 21a); e os microRNAs miR-467e, miR-101a, miR-125-5p, e miR669a induzidos nos linfócitos da linhagem DBA-2/J interagindo com 30 alvos (Figura 21b), todos eles relacionados aos processos de apoptose e adesão celular. 


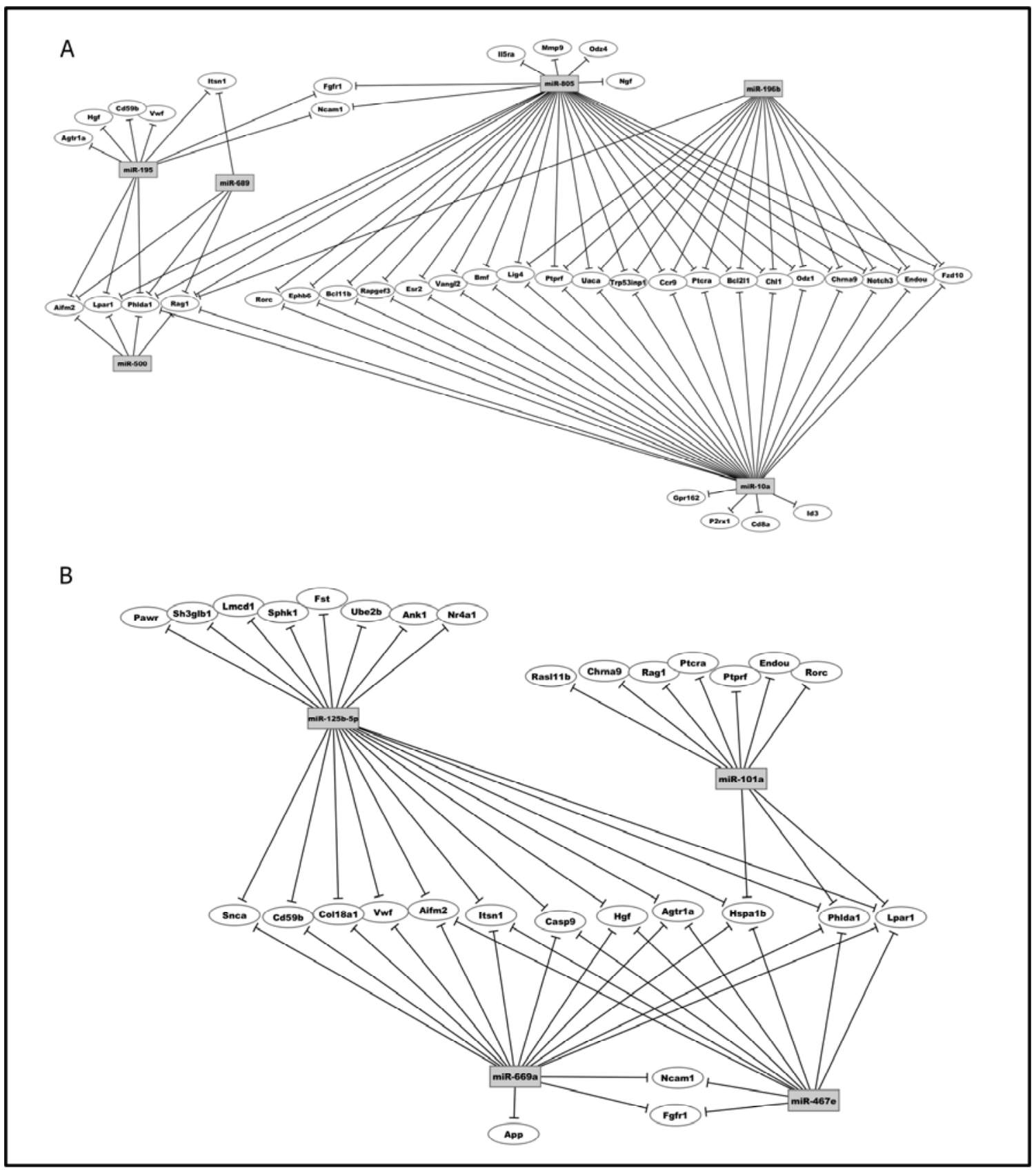

Figura 21. Rede mostrando a interação dos microRNAs induzidos em linfócitos $\mathrm{T}_{\mathrm{CD}}{ }^{+}$provenientes de baço e linfonodos inguinais da linhagem a) DBA-1/J e b) DBA-2/J, não imunizados com seus respectivos alvos relacionados aos processos de apoptose e adesão celular.

A figura 22 mostra os mesmos microRNAs interagindo com 34 alvos na linhagem DBA-1/J (Figura 22a), e 22 alvos na linhagem DBA-2/J (Figura 22b), relacionados aos processos de diferenciação celular e recombinação. 


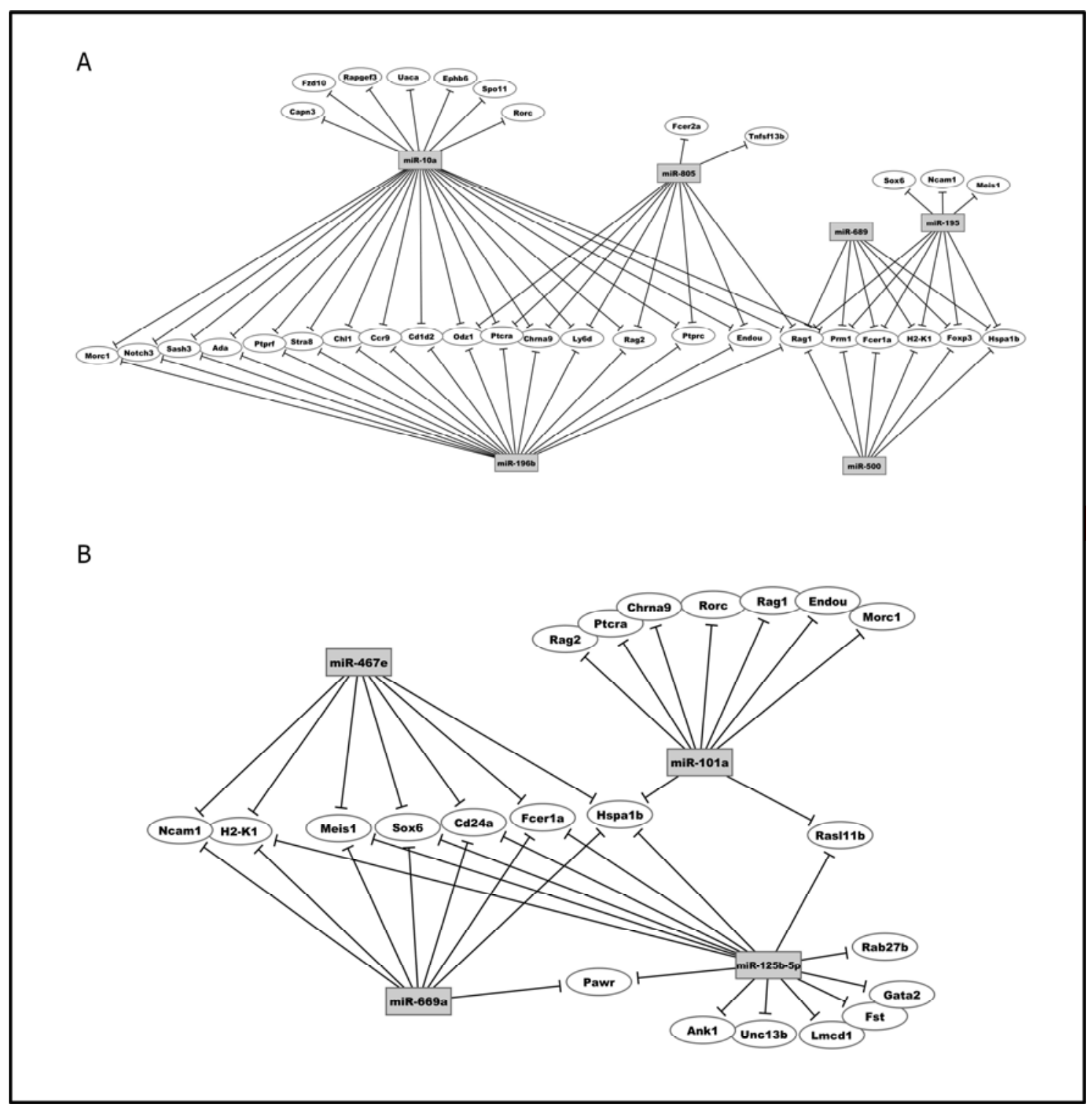

Figura 22. Rede mostrando a interação dos microRNAs induzidos em linfócitos $\mathrm{T}$ CD $3^{+}$provenientes de baço e linfonodos inguinais da linhagem a) DBA-1/J e b) DBA-2/J, não imunizados, com seus respectivos alvos relacionados aos processos de diferenciação celular e recombinação.

Por último a figura 23 mostra as interações dos microRNAs já citados com os mRNAs relacionados ao sistema imune. Um total de 41 alvos foi encontrado na linhagem DBA-1/J (Figura 23a), e 25 na linhagem DBA-2/J (Figura 23b). 


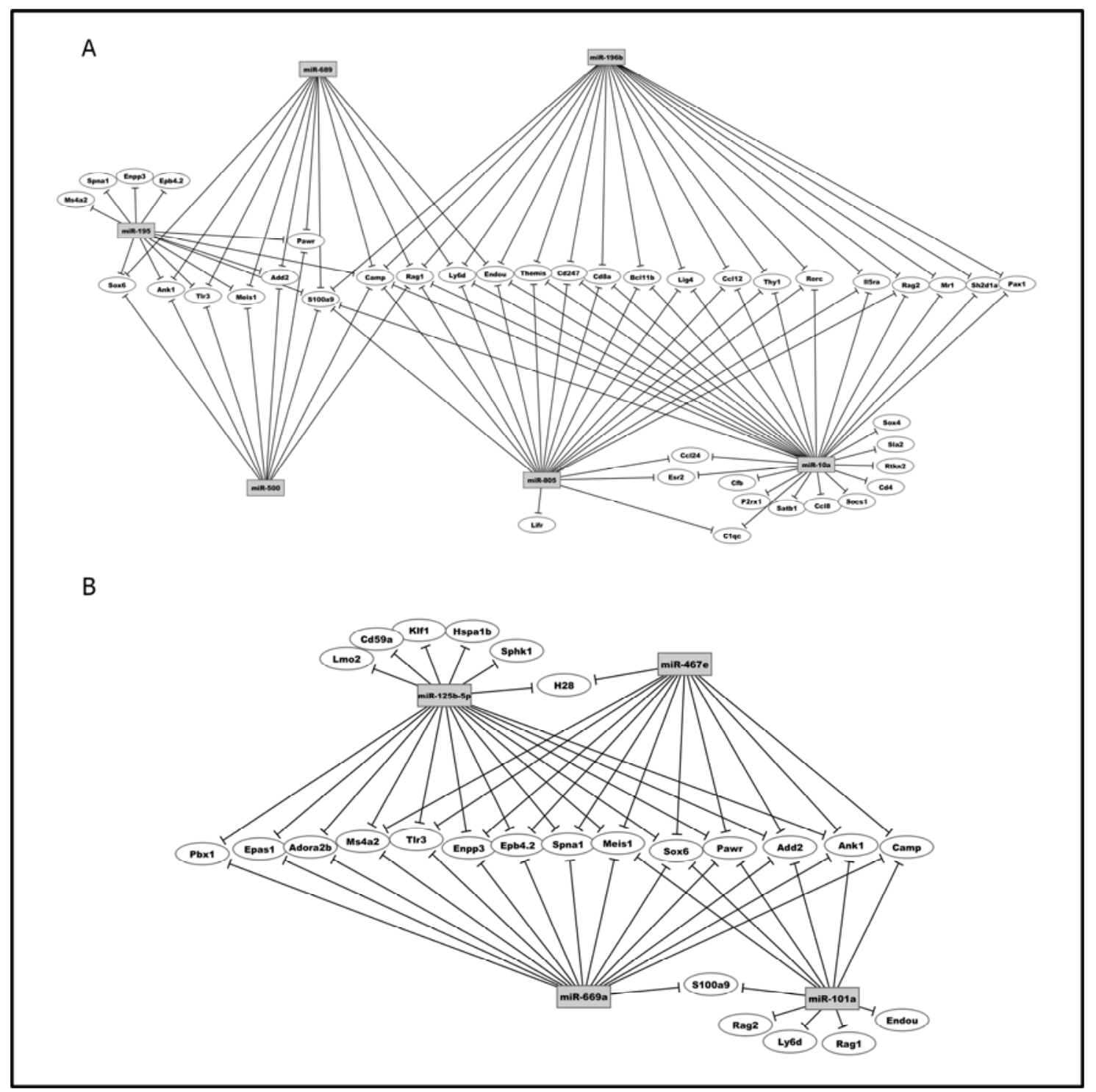

Figura 23. Rede mostrando a interação dos microRNAs induzidos em linfócitos $\mathrm{T}_{\mathrm{CD}}{ }^{+}$ provenientes de baço e linfonodos inguinais da linhagem a) DBA-1/J e b) DBA-2/J, não imunizados, com seus respectivos alvos relacionados ao sistema imune.

Com base dos resultados obtidos observou-se a existência de grupos de genes específicos que diferem em relação às linhagens e às diferentes etapas do desenvolvimento dos linfócitos. Entretanto, é importante ressaltar que apesar da seleção de microRNAs específicos em cada linhagem, foram identificados muitos alvos comuns. A tabela IV mostra os microRNAs e seus respectivos alvos encontrados pelo uso do modelo GenMiR ${ }^{++}$ e apresentados nas figuras 18 a 23. 
Tabela IV. MicroRNAs selecionados com base no perfil de expressão de timócitos e de linfócitos $\mathrm{T} \mathrm{CD}^{+}$de camundongos não imunizados, DBA-1/J e DBA-2/J, e seus alvos definidos pelo uso do algoritmo GenMiR ${ }^{++}$.

\begin{tabular}{|c|c|}
\hline MicroRNAs & RNA mensageiros alvos \\
\hline miR-221 & $\begin{array}{l}\text { Add2, Ank1, Camp, Meis1, Pawr, S100a9, Sox6, Tlr3, Agtr1a, } \\
\text { Aifm2,Cd59b, Foxp3, Hspa1b, Itsn1, Phlda1, Prm1, Rag1 }\end{array}$ \\
\hline $\operatorname{miR}-126-3 p$ & $\begin{array}{l}\text { Add2, Ank1, Camp, Epb4.2, Meis1, Pawr, Sox6, Spna1, Tlr3, Agtr1a, } \\
\text { ifm2, Cd59b, Hspa1b, Itsn1, Phlda1, Foxp3 }\end{array}$ \\
\hline miR-200c & $\begin{array}{l}\text { Add2, Ahsp, Ank1, Bc111a, Car2, Cd55, Cd59a, Cd59b, Cd83, Ctsg, } \\
\text { Cxc19, Epb4.2, Epor, Hspa1b, Igj, K1f1, Lmo2, Meis1, Mpo, Ncf, } \\
\text { Pawr, Ptger3, Snca, Sox6, Sphk1, Spna1, Spon2, Tal1, Tlr3, Trim11, } \\
\text { Zbtb32, Agtr1a, Aifm2, Aldh1a1, Casp4, Cd59b, Chst11, Col18a, } \\
\text { Cx3cl1, Dapk2, Eya1, Gpx1,Hspa1b, I16, Itsn1, Kcnip3, Nqo1, Psen2, } \\
\text { Sgms1, Snca, Sphk1, Tgm2, Adam23, Ank1, Aqp1, Col5a1, Enpp3, } \\
\text { Epor, Gp1ba, Grb10, Hrh1, I11r11, Lmcd1, Paqr9, Rab27b, Rnd, } \\
\text { Tbc1d9, Tlr3, Tom111, Trfr2, Unc13b, Vwf, Xcr1, Acs16, Ahsp, } \\
\text { Bc111a, Car2, Cd200r3, Cd59a, Csrp3, Ctbp2, Epb4.2, Gata2, } \\
\text { Hemgn, Klf1, Klrg1, Lmo2, Meis1, Met, Ryk, Sox6, Tal1, Trim10, } \\
\text { Zeb2, Cd24a, Fcer1a, Fcer1g, Foxp3, H2-K1, P2rx7, Tnfrsf13c }\end{array}$ \\
\hline miR-let-7e & $\begin{array}{l}\text { Add2, Adora2b, Ahsp, Ank1, C4bp, Cd59a, Csf1r,Defb6, Enpp3, } \\
\text { Epas1, Epb4.2, Fyb, Ghr, Gm5077, Gnas, Grin2b, H28, H2-Q10, } \\
\text { Hoxa9, Klf1, Lifr, Lmo2, Mecom, Meis1, Mp1, Ms4a2, Pawr, Pbx1, } \\
\text { Snca, Sox6, Sphk1, Spna1, Ta11, Tgfb2, Tlr3, Trim10, Accn1, } \\
\text { Adam24, Agtr1a, Ahsp, Aifm2, Akap10, Ambra1, Ank1, App, Aven, } \\
\text { Bmp2, Bmp3, Casp9, Col18a1, Dclk1, Fcer1a, Fgfr1, Foxp3, Fzd, } \\
\text { Gata2, Ghr, Grid2, H2-K1, Hgf, Itsn1, Klf1, Krtdap, Ky, Lifr, Lpar1, } \\
\text { Ncam1, Ngf, Olfr1163, Olfr1206, Olfr123, Olfr1507, Olfr24, } \\
\text { Olfr981, Pawr, Pcdh17, Ryr2, Ryr3, Sall3, Slc17a7, Snca, Sphk1, } \\
\text { Sprr4, Sv2b, Tbx3, Tgfb2, Tnfsf13b, Tnfsf18, Vcan, Xrcc2 }\end{array}$ \\
\hline miR-195 & $\begin{array}{l}\text { Add2, Ank1, Camp, Enpp3, Epb4.2, Meis1, Ms4a2, Pawr, S100a9, } \\
\text { Sox6, Spna1, Tlr3, Agtr1a, Aifm2, Cd59b, Fcer1a, Fgfr1, Foxp3, H2- } \\
\text { K1, Hgf, Hspa1b, Itsn1,Lpar1, Meis1, Ncam1, Phlda1, Prm1, Rag1, } \\
\text { Vwf }\end{array}$ \\
\hline miR-689 & $\begin{array}{l}\text { Add2, Ank1, Camp, Endou, Ly6d, Meis1, Pawr, Rag1, S100a9, Sox6, } \\
\text { Tlr3, Aifm2, Fcer1a, Foxp3, H2-K1, Hspa1b, Itsn1, Ph1da1, Prm1 }\end{array}$ \\
\hline
\end{tabular}




\begin{tabular}{|c|c|}
\hline MicroRNAs & RNA mensageiros alvos \\
\hline miR-500 & $\begin{array}{l}\text { Add2, Ank1, Camp, Meis1, Pawr, Rag1, S100a9, Sox6, Tlr3, Aifm2, } \\
\text { Fcer1a, Foxp3, H2-K1, Hspa1b, Lpar1, Phlda1, Prm1 }\end{array}$ \\
\hline miR-196b & $\begin{array}{l}\text { Bcl11b, Camp, Cc112, Cd247, Cd8a, Endou, I15ra, Lig4, Ly6d, Mr1, } \\
\text { Pax1, Rag1, Rag2, Rorc, S100a9, Sh2d1a, Themis, Thy1, Ada, } \\
\text { Bc1211, Ccr9, Cd1d2, Chl1, Chrna9, Endou, Fzd10, Lig4, Ly6d, } \\
\text { Morc1, Notch3, Odz1, Ptcra, Ptpre, Ptprf, Sash3, Stra8, Trp53inp1, } \\
\text { Uaca }\end{array}$ \\
\hline miR-10a & $\begin{array}{l}\text { Bcl11b, C1qc, Camp, Ccl12, Cc124, Cc18, Cd247, Cd4, Cd8a, Cfb, } \\
\text { Endou, Esr2, I15ra, Lig4, Ly6d, Mr1, P2rx1, Pax1, Rag1, Rag2, Rorc, } \\
\text { Rtkn2, S100a9, Satb1, Sh2d1a, Sla2, Socs1, Sox4, Themis, Thy1, } \\
\text { Ada, Bc111b, Bc1211, Bmf, Capn3, Ccr9, Cd1d2, Cd8a, Ch11, Chrna, } \\
\text { Ephb6, Fzd10, Gpr162, Id3, Morc1, Notch3, Odz1, Ph1da1, Prm1, } \\
\text { Ptcra, Ptprc, Ptprf, Rapgef3, Sash3, Spo11, Stra8, Trp53inp1, Uaca, } \\
\text { Vang12 }\end{array}$ \\
\hline miR-805 & $\begin{array}{l}\text { Bcl11b, C1qc, Camp, Cc112, Ccl24, Cd247, Cd8a, Endou, Esr2, I15ra, } \\
\text { Lifr, Lig4, Ly6d, Rag1, Rag2, Rorc, S100a9, Themis, Thy1, Bcl211, } \\
\text { Bmf, Ccr9, Chl1, Chrna9, Ephb6, Fcer2a, Fgfr1, Fzd10, Lpar1, } \\
\text { Mmp9, Ncam1, Ngf, Notch3, Odz1, Odz4, Phlda1, Ptcra, Ptpre, } \\
\text { Ptprf, Rapgef3, Tnfsf13b, Trp53inp1, Uaca, Vangl2 }\end{array}$ \\
\hline miR-125-5p & $\begin{array}{l}\text { Add2, Adora2b, Ank1, Cd59a, Enpp3, Epas1, Epb4.2, H28, Hspa1b, } \\
\text { K1f1, Lmo2, Meis1, Ms4a2, Pawr, Pbx1, Sox6, Sphk1, Spna1, Tlr3, } \\
\text { Agtr1a, Aifm2, Ank1, Casp9, Cd24a, Col18a1, Fcer1a, Fst, Gata, } \\
\text { H2-K1, Hgf, Itsn1, Lmed1, Lpar1, Meis1, Nr4a1, Pawr, Phlda1, } \\
\text { Rab27b, Ras111b, Sh3glb1, Snca, Sphk1, Ube2b, Unc13b }\end{array}$ \\
\hline $\operatorname{miR}-467 \mathrm{e}$ & $\begin{array}{l}\text { Add2, Ank1, Camp, Enpp3, Epb4.2, H28, Meis1, Ms4a2, Pawr, Sox6, } \\
\text { Spna1, Tlr3, Agtr1a, Aifm2, Casp9, Cd24a, Fcer1a, Fgfr1, H2-K1, } \\
\text { Hgf, Hspa1b, Itsn1, Lpar1, Meis1, Ncam1, Phlda1, Vwf }\end{array}$ \\
\hline $\operatorname{miR}-669 a$ & $\begin{array}{l}\text { Add2, Adora2b, Ank1, Camp, Enpp3, Epas1, Epb4.2, Meis1, Ms4a2, } \\
\text { Pawr, Pbx1, S100a9, Spna1, Tlr3, Agtr1a, Aifm2, App, Casp9, } \\
\text { Cd24a, Cd59b, Col18a1, Fcer1a, Fgfr1, H2-K1, Hgf, Hspa1b, Itsn1, } \\
\text { Lpar1, Meis1, Ncam1, Pawr, Phlda1, Snca, Sox6 }\end{array}$ \\
\hline miR-101a & $\begin{array}{l}\text { Add2, Ank1, Camp, Endou, Ly6d, Meis1,Pawr, Rag1, Rag2, S100a9, } \\
\text { Sox6, Chrna9, Hspa1b, Lpar1, Morc1, Phlda1, Ptcra, Ptprf, Ras111b, } \\
\text { Rorc }\end{array}$ \\
\hline
\end{tabular}


As figuras 24, 25 e 26 mostram as redes de interação em linfócitos T ativados em camundongos de 12 semanas de idade, durante a indução de CIA. Genes importantes relacionados à função de morte celular (Figura 24), sistema imune (Figura 25), e processo inflamatório (Figura 26), no qual diversos genes de proliferação e ativação de linfócitos $\mathrm{T}$ são encontrados, foram identificados como alvos dos microRNAs, que diferem entre as linhagens susceptível (DBA-1/J) e resistente (DBA-2/J) a CIA. MRNAs alvos específicos são regulados por cada uma das linhagens, definindo um padrão diferencial de regulação envolvido na susceptibilidade/resistência a CIA.

A figura 24 mostra a interação dos microRNAs: miR-181a, miR-144, miR17*, miR-202-3p, miR467a*, e miR-500, induzidos na linhagem DBA-1/J durante a a CIA interagindo com 111 alvos (Figura 24a); e os microRNAs: miR-302c, miR691, miR-712, miR-125-3p, miR-29b*, miR-30b*, miR-10b, miR-149, miR-141, miR-1897-5p, e miR690 induzidos na linhagem DBA-2/J, interagindo com 52 alvos (Figura 24b), todos relacionados ao processo de morte celular.

Já a figura 25 mostra a interação destes microRNAs com 131 alvos na linhagem DBA-1/J (Figura 25a), e 108 alvos na linhagem DBA-2/J (Figura 25b), relacionados ao sistema imune.

E finalmente a figura 26 mostra a interação dos mesmos microRNAs com 42 alvos na linhagem DBA-1/J (Figura 26a), e 43 na linhagem DBA-2/J (Figura 26b) relacionados aos processos de inflamação, proliferação e diferenciação de linfócitos T. 
A

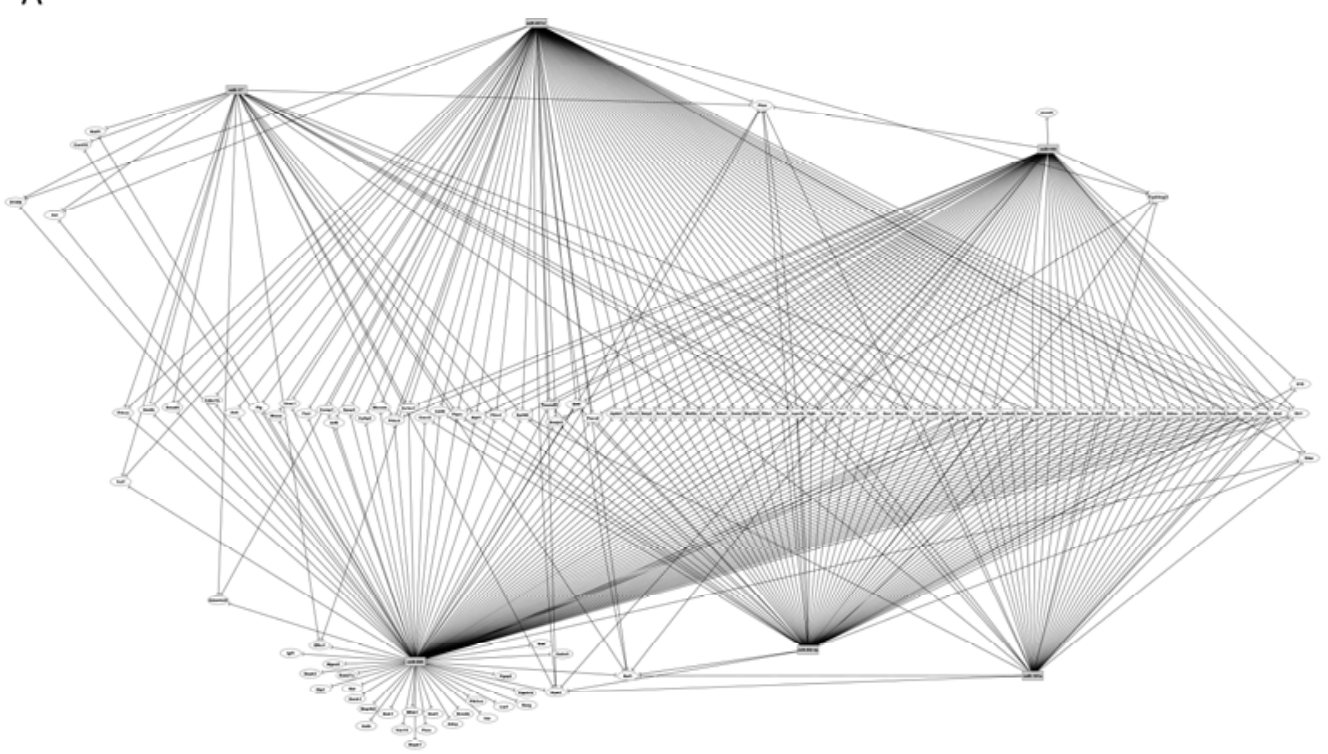

B

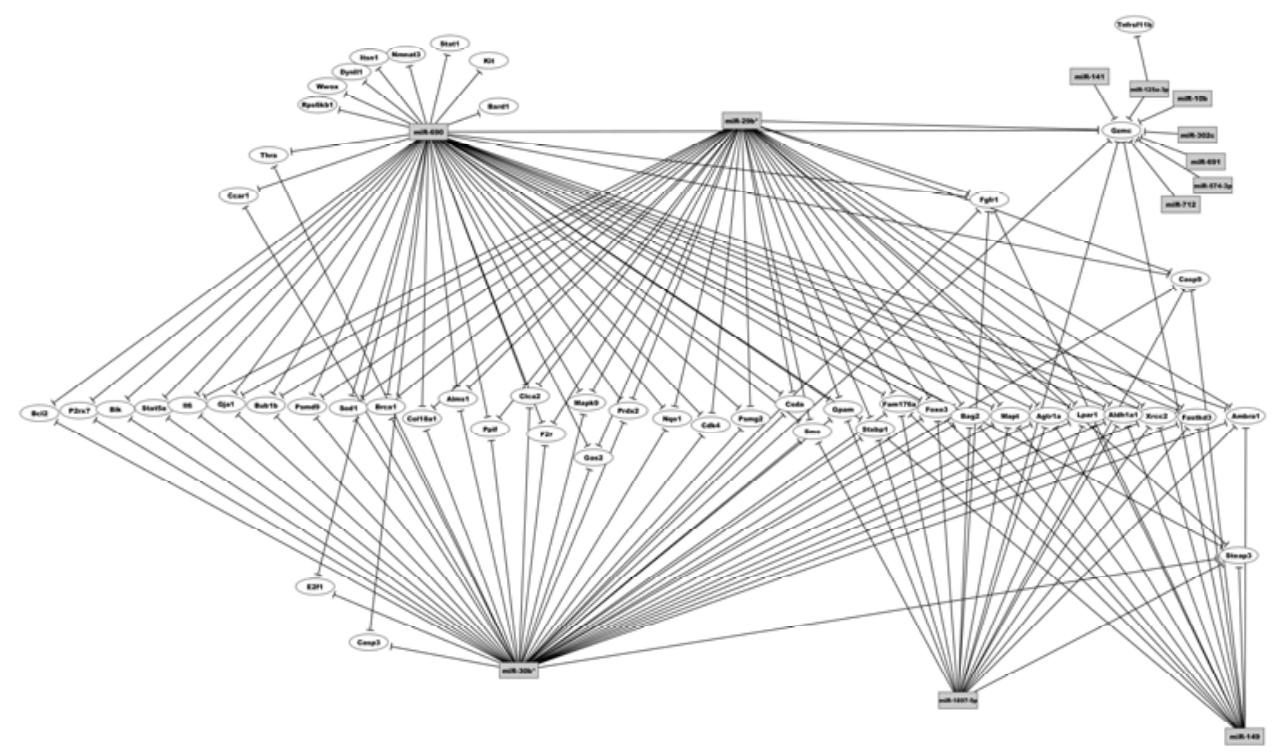

Figura 24. Rede mostrando a interação dos microRNAs induzidos em linfócitos $\mathrm{T}_{\mathrm{CD}}{ }^{+}$provenientes de baço e linfonodos inguinais da linhagem a) DBA-1/J e b) DBA-2/J durante a indução de CIA, com seus respectivos alvos relacionados ao processo de morte celular. 
A

B
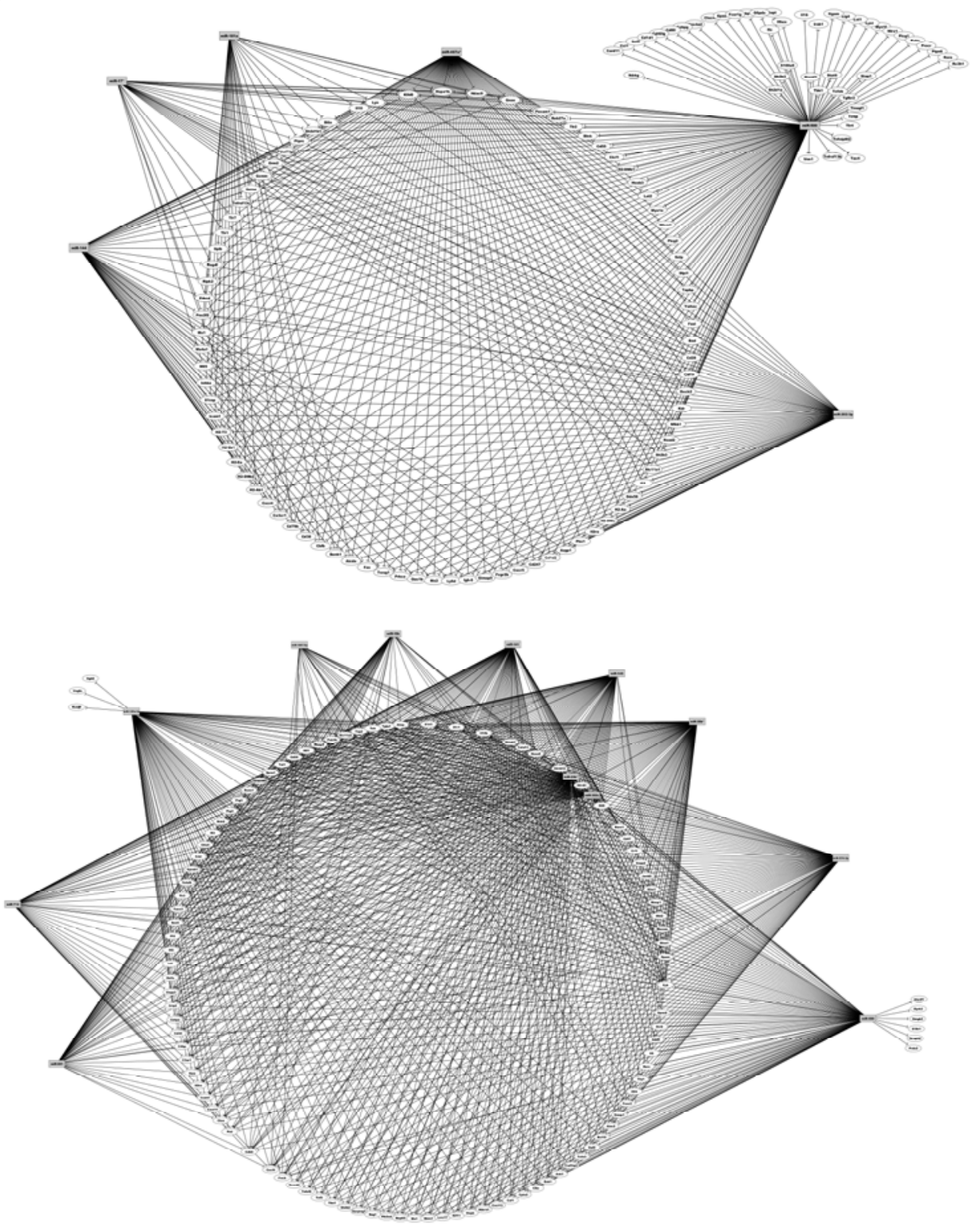

Figura 25. Rede mostrando a interação dos microRNAs induzidos em linfócitos $\mathrm{T} \mathrm{CD}^{+}$provenientes de baço e linfonodos inguinais da linhagem a) DBA-1/J e b) DBA-2/J durante a indução de CIA, com seus respectivos alvos relacionados ao sistema imune. 


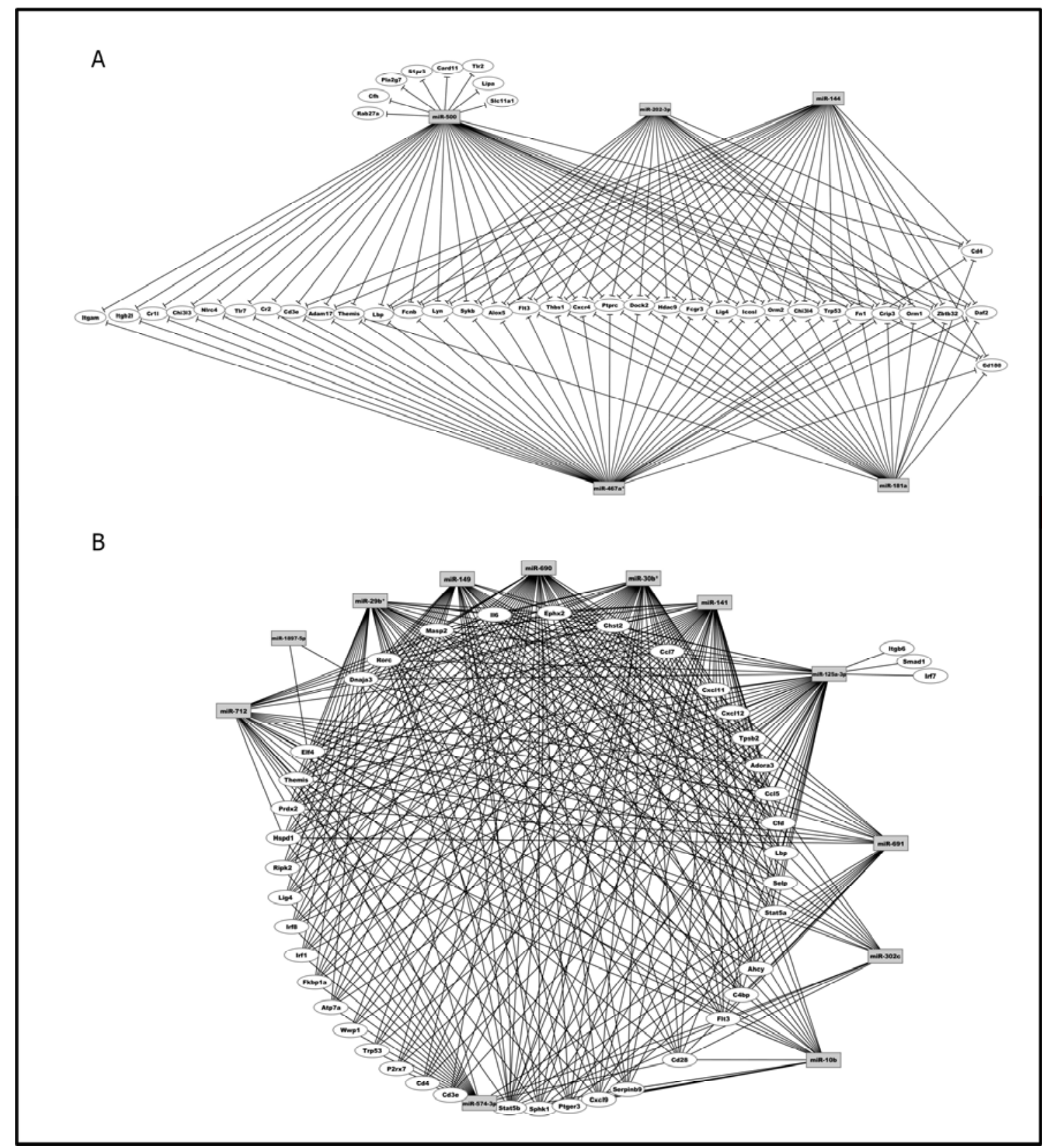

Figura 26. Rede mostrando a interação dos microRNAs induzidos em linfócitos $\mathrm{T} C D 3^{+}$provenientes de baço e linfonodos inguinais da linhagem a) DBA-1/J e b) DBA-2/J durante a indução de CIA, com seus respectivos alvos relacionados aos processos inflamatórios, diferenciação e proliferação de linfócitos $\mathrm{T}$. 
Nas análises de expressão dos microRNAs, dois deles: o miR-29a* e o miR-135a*, estão reprimidos nos linfócitos T somente no camundongo da linhagem susceptível DBA1/J, após a indução de CIA. Sendo um dos nossos principais objetivos identificar a expressão desregulada de microRNAs envolvidos na artrite, fomos averiguar os alvos desses microRNAs. A figura 27 mostra a interação do miR-29a* com 114 alvos, e a figura 28 mostra as interações do miR-135a* com 62 alvos.

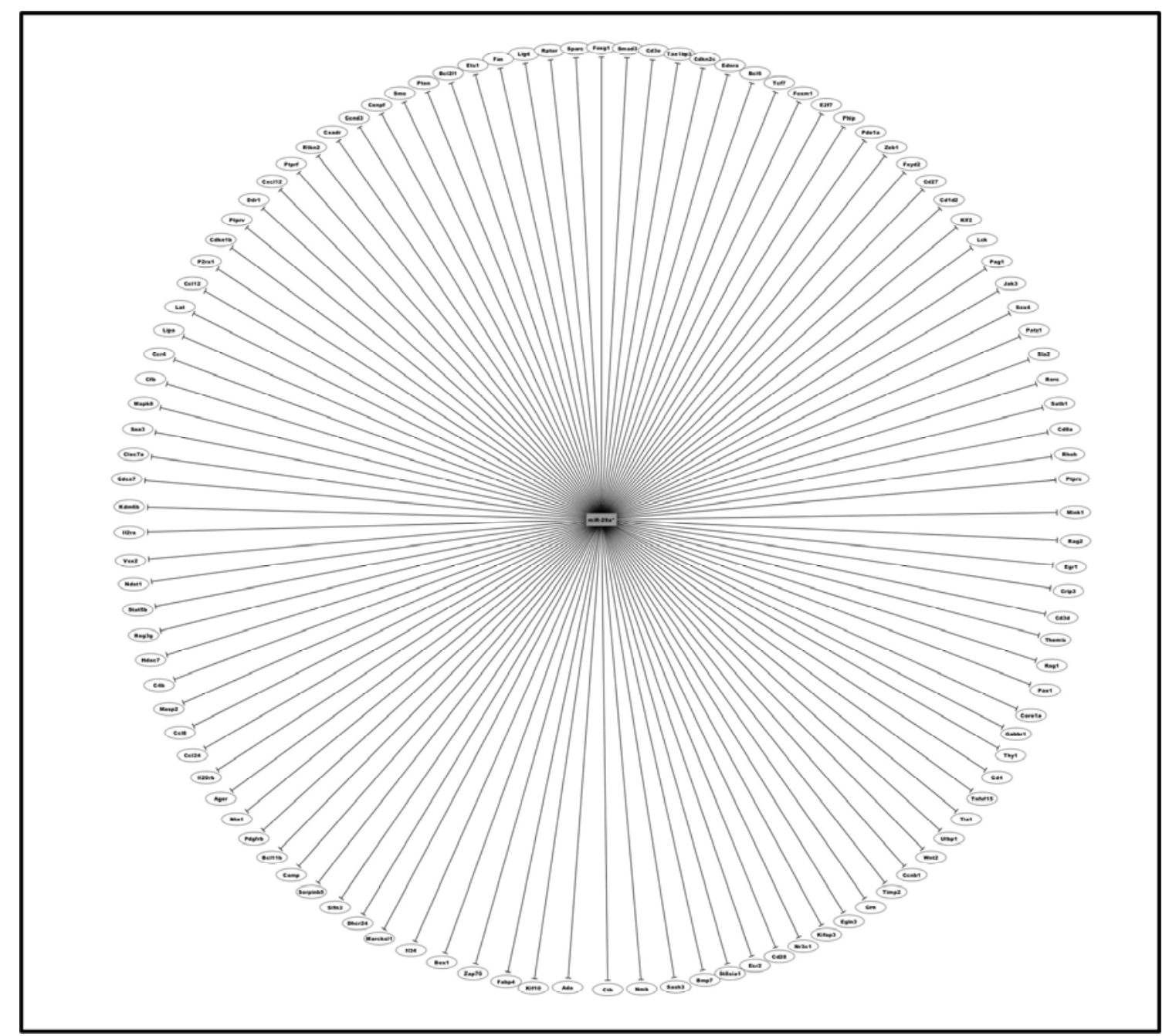

Figura 27. Rede mostrando a interação do microRNA miR-29a* reprimido em linfócitos $\mathrm{T}^{\mathrm{C}} \mathrm{CD}^{+}$ provenientes de baço e linfonodos inguinais da linhagem DBA-1/J durante a indução de CIA e seus respectivos alvos. 


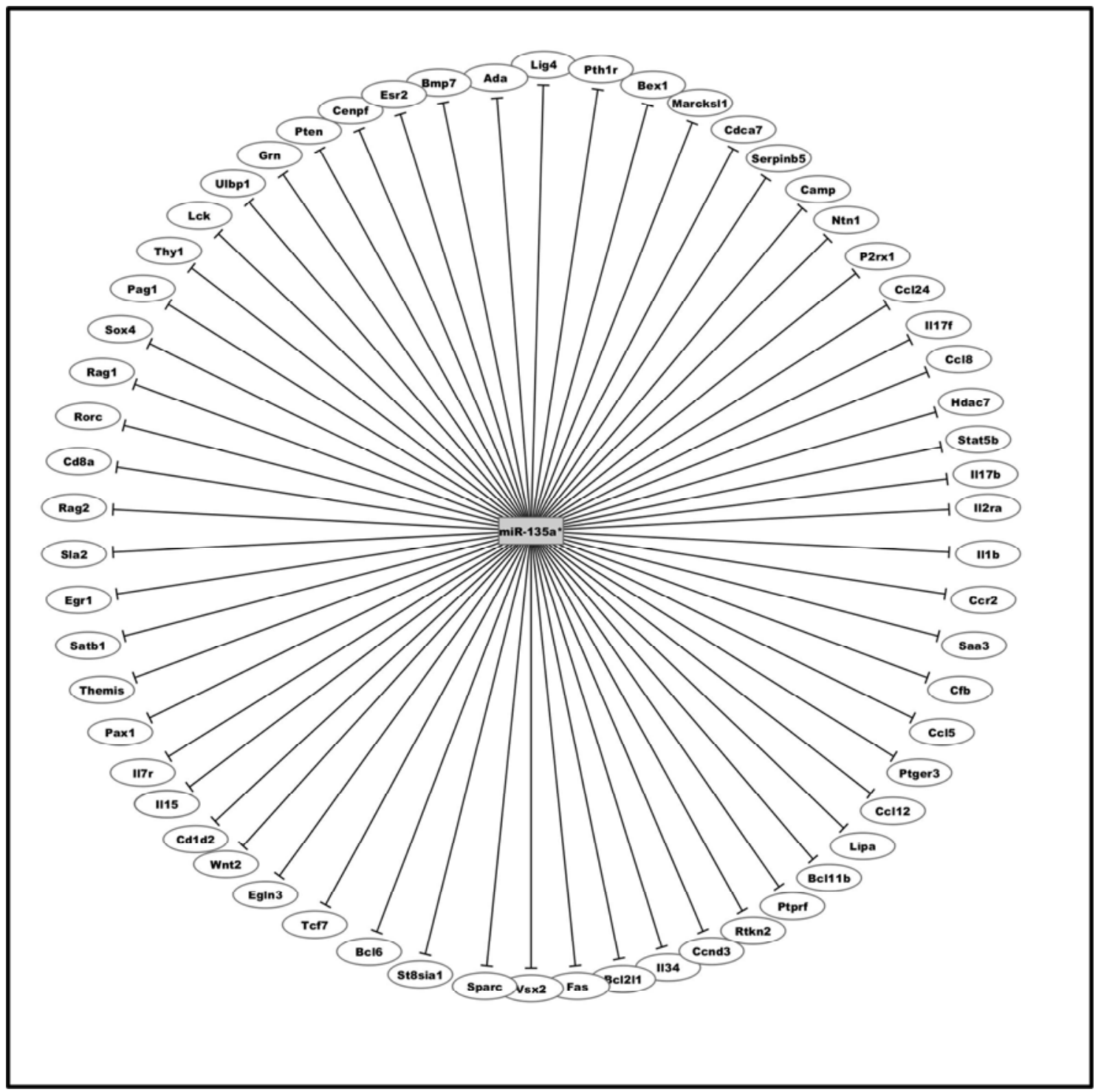

Figura 28. Rede mostrando a interação do microRNA miR-135a* reprimido em linfócitos $\mathrm{T}^{\mathrm{CD}} 3^{+}$ provenientes de baço e linfonodos inguinais da linhagem DBA-1/J durante a indução de CIA e seus respectivos alvos.

De maneira interessante, foi possível observar que os alvos desses microRNAs estão relacionados, como era de se esperar, aos processos biológicos de inflamação, proliferação e ativação de linfócitos T, e produção de citocinas.

A tabela $\mathrm{V}$ mostra os microRNAs e seus $\mathrm{r}$ alvos identificados nas figuras 24 a 28 . 
Tabela V. MicroRNAs selecionados pelo perfil de expressão nos linfócitos $\mathrm{T} \mathrm{CD}^{+}$de camundongos DBA-1/J e DBA-2/J, durante a indução de CIA e seus respectivos alvos definidos pelo uso do modelo GenMiR ${ }^{++}$.

\begin{tabular}{|c|c|}
\hline MicroRNAs & RNA mensageiro alvos \\
\hline miR-144 & $\begin{array}{l}\text { Acin1, Adam17, Aicda, Aifm1, Aip11, Aktip, Aldoc, Alox12, Alox5, } \\
\text { Als2, Apbb1, Asah2, Azgp1, Bank1, Bmf, Btla, Casp7, Cbfb,Cd180, } \\
\text { Cd1d2, Cd247, Cd38, Cd3e, Cd4, Cd79b, Chi314, Chia, Crip3, } \\
\text { Cx3cr1, Cxcr4, Cxcr5, Daf2, Dedd2, Dnaja3, Dnase1, Dock2, Edar, } \\
\text { Egfr, Elmo1, Ep300, Faz, Fcgr2b, Fcgr3, Fcnb, Fig4, Flt3, Fn1, } \\
\text { Gimap5, Gnas, Gsn, Gzma, Gzmm, H2-Ab1, H2-DMb2, H2-Ea, H2- } \\
\text { Eb1, H2-T3, Hc, Hdac9, Hipk3, Hspa1b, Icam1, Icos1, Igh-6, Il10, } \\
\text { Il1rap, Inhba, Irak3, K1h16, Lbp, Lig4, Ly6d, Lyn, Lyz1, Lyz2, } \\
\text { Map3k9, Mef2a, Mef2c, M115, Ms4a1, Mx1, Mx2, Naip2, Ncf1, } \\
\text { Nlrp1a, Oas1b, Olr1, Orm1, Orm2, P2rx1, Pacs2, Pdcd11g2, Pdcd6ip, } \\
\text { Pglyrp1, Pou2f2, Ppp1r13b, Prkca, Prkcb, Prkcd, Pten, Ptprc, Raf1, } \\
\text { Ripk2, Rock1, Rogdi, Sh2d1b1, Shisa5, slamf1, Slc5a11, Spib, Stk4, } \\
\text { Sykb, Thbs1, Tlr1, Tlr7, Tmem85, Tnfrsf13c, Tnfrsf1a, Traf3ip2, } \\
\text { Trim39, Trp53, Trp53inp1,Twsg1, Zbtb32 }\end{array}$ \\
\hline $\operatorname{miR}-17 *$ & $\begin{array}{l}\text { Adamts14, Aip11, Alox12, Axl, Bad, Btla, Card10, Cd28, Cd38, } \\
\text { Csf1r, Cx3cr1, Cxcr4, Dock2, Efhc1, Egfr, Elmo1, Ep300, Fn1, } \\
\text { Gnas, Hdac9, Hspa1b, Itm2b, Kdr, Klh16, Lyn, Lyz1, M115, Naif1, } \\
\text { Nfkb1, Orm2, P2rx1, Pdcd1lg2, Pecam1, Pou2f2, Prkca, Prkcb, } \\
\text { Prkcd, Pten, Ptprc, Rab27a, Raf1, Ripk2, Rogdi, Rsad2, S100b, Sh2b }\end{array}$ \\
\hline $\operatorname{miR}-181^{\mathrm{a}}$ & $\begin{array}{l}\text { Actc1, Aicda, Aktip, Aldoc, Alox12, Als2, Asah2, Bank1, Btla, Cbfb, } \\
\text { Cd180, Cd4, Cd79b, Chi314, Chia, Crip3, Cx3cr1, Cxcr4, Daf,, } \\
\text { Dnase1, Dock2, Edar, Egfr, Elmo1, Ep300, Fastkd2, Fcgr3, Flt3, Fn1, } \\
\text { Gnas, Gzma, Gzmm, H2-Ab1, H2-DMb2, H2-Ea, H2-Eb1, H2-T3, } \\
\text { Hc, Hdac9, Hspa1b, Icam1, Icos1, Il10, I11rap, Inhba, Irak3, Klh16, } \\
\text { Lig4, Lyn, Lyz1, Lyz2, Mef2a, Ms4a1, Mx1, Ncf1, Olr1, Orm1, } \\
\text { Orm2, Pdcd11g2, Pdcd6ip, Pglyrp1, Ppp1r13b, Prkcb, Prkcd, Pten, } \\
\text { Ptprc, Raf1, Ripk2, Sh2d1b1, Shisa5, Spib, Thbs1, Themis, } \\
\text { Tnfrsf13c, Traf3ip2, Trim39, Trp53, Trp53inp1, Zbtb32 }\end{array}$ \\
\hline $\operatorname{miR}-202-3 p$ & $\begin{array}{l}\text { Acin1, Actc1, Aicda, Aifm1, Aip11, Aktip, Aldoc, Alox12, Alox5, } \\
\text { Als2, Apbb1, Asah2, Azgp1, Bank1, Bmf, Btla, C3, Casp7, Cbf,, } \\
\text { Cd180, Cd1d2, Cd247, Cd36, Cd38, Cd4,Cd79b, Chi314, Chia, Crip3, } \\
\text { Cx3cr1, Cxcr2, Cxcr4, Cxcr5, Daf2, Ddx58, Dedd2, Dnaja3, Dnase1, } \\
\text { Dock2, Edar, Egfr, Elmo1, Ep300, Fas, Fastkd2, Fcgr2b, Fcgr3, } \\
\text { Fcnb, Fig4, Flt3, Fn1, Gimap5, Gnas, Gsn, Gzma, Gzmm,H2-Aa, H2- } \\
\text { Ab1, H2-DMa, H2-DMb2, H2-Ea, H2-Eb1, H2-T3, Hc, Hdac9, Hipk3, } \\
\text { Hspa1b, Icam1, Icos1, Igh-6, I110, I11rap, I12ra, Inhba, Irak3, K1h16, } \\
\text { Lbp, Lig4, Ly6d, Lyn, Lyz1, Lyz2, Map3k9, Mef2a, Mef2c, M11, } \\
\text { Ms4a1, Mx1, Mx2, Naip2, Ncf1, Nlrp1a, Oas1b, Olr1, Orm1, Orm2, } \\
\text { P2rx1, Pacs2, Pbx1, Pdcd1lg2, Pdcd6ip, Pglyrp1, Pou2f2, Ppp1r13b, } \\
\text { Prkca, Prkcb, Prkcd, Pten, Ptprc, Raf1, Ripk2, Rock1, Rogdi, } \\
\text { Sh2d1b1, Shisa5, Slc5a11, Spib, Stk4, Sykb, Thbs1, Tlr1, Tlr7, } \\
\text { Tmem85, Tnfrsf13c, Tnfrsf1a, Traf3ip2, Trim39, Trp53, Trp53inp1, } \\
\text { Twsg1, Zbtb32 }\end{array}$ \\
\hline
\end{tabular}




\begin{tabular}{|c|c|}
\hline MicroRNAs & RNA mensageiro alvos \\
\hline miR-467a* & $\begin{array}{l}\text { Acin1, Actc1, Adam17, Adamts14, Aicda, Aifm1, Aip11, Aktip, } \\
\text { Aldoc, Alox12, Alox5, Als2, Apbb1, Arf6, Asah2, Ax1, Azgp1, Bad, } \\
\text { Bank1, Blnk, Bmf, Btla, C3, Casp7, Cbfb, Cd180, Cd1d2, Cd247, } \\
\text { Cd28, Cd36, Cd38, Cd3e, Cd4, Cd55, Cd79b, Cdkn1b, Chac1, Chi31, } \\
\text { Chi314, Chia, Clcf1, Cr11, Cr2, Crip3, Csf1r, Csrnp1, Cx3cr1, Cxcr2, } \\
\text { Cxcr4, Cxcr5, Cyfip2, Daf2, Ddx58, Dedd2, Dnaja3, Dnase1, Dock2, } \\
\text { Edar, Efhc1, Egfr, Elmo1, Ep300, Faz, Fas1, Fastkd2, Fcgr2b, Fcgr3, } \\
\text { Fcnb, Fig4, Flt3, Fn1, Gimap5, Gnas, Gsn, Gzma, Gzmm, H2-Aa, H2- } \\
\text { Ab1, H2-DMa,H2-DMb1, H2-DMb2, H2-Ea, H2-Eb1, H2-T3, Hc, } \\
\text { Hdac9, Hipk3, Hoxb3, Hspa1b,Icam1, Icos1, Igh-6, Il1rap, I12ra, } \\
\text { Inhba, Irak3, Itgam, Itgb21, Itm2b, Kdr, K1h16, Lat2, Lbp, Lig4, } \\
\text { Ly6d, Lyn, Lyz1, Lyz2, Map3k9, Mecom, Mef2a, Mef2c, M1l, } \\
\text { Ms4a1, Mx1, Mx2, Myo1e, Naip2, Ncf1, Nfam1, Nfkb1, Nlrc4, } \\
\text { Nlrp1a, Oas1b, Olr1, Orm1, Orm2, P2rx1, Pacs2, Pbx1, Pdcd1lg, } \\
\text { Pdcd6ip, Pglyrp1, Plcg2, Plg, Pou2f2, Ppp1r13b, Prf1, Prkca, Prkcb, } \\
\text { Prkcd, Pten, Ptprc, Raf1, Ripk2, Rock1, Rogdi, Rsad2, S100b, Selp, } \\
\text { Sfpi1, Sh2b3, Sh2d1b1, Shisa5, Slc11a1, Slc5a11, Smad4, Spib, } \\
\text { Stk4, Sycp2, Sykb, Tapbp, Tcf7, Thbs1, Themis, Tlr1, Tlr7, } \\
\text { Tmem85, Tnfrsf13c, Tnfrsf1a, Traf3ip2, Trim39, Trp53, Trp53inp1, } \\
\text { Twsg1, Wwox, Ywhaz, Zbtb32 }\end{array}$ \\
\hline $\operatorname{miR}-500$ & $\begin{array}{l}\text { Aatk, Acin1, Actc1, Adam17, Adamts14, Adnp, Aicda, Aifm1, Aip11, } \\
\text { Aktip, Aldoc, Alox12, Alox5, Als2, Apbb1, Arf, Asah2, Ax1, } \\
\text { Azgp1, Bad, Bank1, Blnk, Bmf, Btla, Bub1, C3, Cadm1, Card10, } \\
\text { Card11, Casp7, Cbfb, Ccl1, Cc15, Cd180, Cd1d1, Cd1d2, Cd247, } \\
\text { Cd28, Cd36, Cd38, Cd3e, Cd4, Cd401g, Cd55, Cd79b, Cd80, Cdkn1b, } \\
\text { Cebpg, Cfh, Chac1, Chi313, Chi314, Chia, Clcf1, Clec4a2, Clec4n, } \\
\text { Cr11,Cr2, Crip3, Csf1r, Csrnp1, Cx3cr1, Cxcr2, Cxcr4, Cxcr5, } \\
\text { Cyfip2, Daf2, Dapk3, Ddx58, Dedd2, Dnaja3, Dnase1, Dock1, } \\
\text { Dock2, Edar, Efhc1, Egfr, Elmo1, Ep300, Epas1, Faz, Fas1, Fastkd2, } \\
\text { Fcer1g, Fcgr2b, Fcgr3, Fcnb, Fig4, Fkbp1b, Flt3, Fn1, G6pdx, Gapt, } \\
\text { Gimap5, Gnas, Gsn, Gzma, Gzmm, H2-Aa, H2-Ab1, H2-DMa, H2- } \\
\text { DMb1, H2-DMb2, H2-Ea, H2-Eb1, H2-T3, Hc, Hdac9, Hhex, Hip1, } \\
\text { Hipk3, Hoxb3, Hspa1b, Icam1, Icos1, Igf1, Igh-6, Ikbkg, I116, I11rap, } \\
\text { Il2ra, Inhba, Irak1, Irak3, Itgam, Itgb21, Itm2b, Kdr, K1h16, Lat2, } \\
\text { Lbp, Lig4, Lipa, Lrp1, Lst1, Ly6d, Lyn, Lyst, Lyz1, Lyz2, Map3k5, } \\
\text { Map3k9, Mapk7, Mecom, Mef2a, Mef2c, Mgea5, M115, Ms4a1, Mx1, } \\
\text { Mx2, Myo1e, Myo1f, Naif1, Naip2, Ncf1, Nfam1, Nfkb1, Nlrc4, } \\
\text { Nlrp1a, Nlrx1, Nod1, Oas1b, Olr1, Orm1, Orm2, P2rx1, Pacs2, Pbx1, } \\
\text { Pdcd11g2, Pdcd6ip, Pecam1, Pgap2, Pglyrp1, Pik3ca, Pla2g7, Plcg1, } \\
\text { Plcg2, Plg, Polm, Pou2f2, Ppp1r13b, Ppp2cb, Prf1, Prkca, Prkcb, } \\
\text { Prkcd, Procr, Pten, Ptpn6, Ptprc, Pura, Rab27a, Raf1, Rara, Rarg, } \\
\text { Rc3h1, Ripk2, Rock1, Rogdi, Rrm2b, Rsad2, S100a9, S100b, S1pr3, } \\
\text { Selp, Sfpi1, Sh2b2, Sh2b3, Sh2d1a, Sh2d1b1, Shisa5, Slamf1, } \\
\text { Slc11a1, Slc5a11, Smad4, Spib, Stap1, Stat6, Stk4, Sycp2, Sykb, } \\
\text { Tac4, Tapbp, Tbk1, Tcf7, Tcfeb, Tgfbr2, Thbs1, Themis, Tinag11, } \\
\text { Tirap, Tlr1, Tlr2, Tlr4, Tlr7, Tmem85, Tnfaip812, Tnfrsf13b, } \\
\text { Tnfrsf13c, Tnfrsf1a, Traf3ip2, Trim39, Trp53, Trp53inp1, Twsg1, } \\
\text { Vac14, Vdr, Vnn1, Wwox, Ywhaz, Zbtb32 }\end{array}$ \\
\hline miR-10b & $\begin{array}{l}\text { Ahsp, C3ar1, C4bp, Cc17, Cd28, Cd34, Cdk6, Cebpa, Chst2, Crip2, } \\
\text { Crk1, Ctla4, Cxc19, Dnaja3, Elf4, Enpp3, Ephx2, Flt3, Fyb, Gpam, } \\
\text { Gzmc, H28, H2-Q1, H2-Q10, Hells, Hoxa9, Hspd1, Id2, Il12b, I11r1, }\end{array}$ \\
\hline
\end{tabular}




\begin{tabular}{|c|c|}
\hline MicroRNAs & RNA mensageiro alvos \\
\hline & $\begin{array}{l}\text { Il1r11, I16, Ilf2, Kit, K1f1, Masp2, Msh2, Pf4, Polr3h,Prdx2, Prg2, } \\
\text { Prg3, Ptger3, Rorc, Runx1,Serpinb9, Slc11a2, Sox6, Sphk1, Spna1, } \\
\text { Stat5a, Stat5b, Tacc3,Tal1, Tap2, Tek, Tgtp1, Themis, Tlr3, Tnfsf9, } \\
\text { Vpreb1 }\end{array}$ \\
\hline miR-125a-3p & $\begin{array}{l}\text { Adora3, Ahcy, Ahsp, Alas2, Ank1, Atp7a, Bak1, Barx1, Bcl10, } \\
\text { C3ar1, C4bp, C8a, Cc15, Cc17, Cd28, Cd34, Cd3e, Cd4, Cd47, Cdk6, } \\
\text { Cebpa, Cfd, Chst2, Cplx2, Cr11, Crip2, Crk1, Csf1, Ctla4, Ctse, } \\
\text { Cxcl11, Cxc112, Cxc113, Cxc19, Daf2, Dnaja3, Elf4, Enpp2, Enpp3, } \\
\text { Ephx2, Fech, Fkbp1a,F1t3, Fyb, Gpam, Gzmc, H28, H2-Q1, H2-Q10, } \\
\text { Hbb-b1, Hells, Heph, Hmgb1, Hoxa9, Hspd1, Icam1, Id2, I112b, I11r1, } \\
\text { I11r11, I12ra, I16, Ilf2, Irf1, Irf7, Irf8, Itgb6, Jarid2, Kcnj8, Kit, Klf1, } \\
\text { K1f11, K1re1, Lbp, Lig4, Lrrc17, Masp1, Masp2, Mb12, Mecom, } \\
\text { Meis1, Msh2, Mx1, Nup85, Osm, P2rx7, Pf4, Pik3cd,Pm1, Polr3h, } \\
\text { Prdx2, Prg2, Prg3, Ptger3, Rag1, Ripk2, Rorc, Runx1, Selp, } \\
\text { Serpinb9, Serping1, Sfxn1, Sh2b2, Slc11a2, Smad1, Sox6, Sphk1, } \\
\text { Spna1, Stat5a, Stat5b, Tacc3, Tal1, Tap2, Tbx1, Tcf3, Tcfe3, Tek, } \\
\text { Tgtp1, Themis, Tlr3, Tnfrsf11b, Tnfsf11, Tnfsf8, Tnfsf9, Tpsb2, } \\
\text { Traf3ip2, Trp53, Txnrd2, Vegfa, Vpreb1, Wwp1 }\end{array}$ \\
\hline miR-141 & $\begin{array}{l}\text { Adora3, Ahcy, Ahsp, Alas2, Ank1, Atp7a, Bak1, Barx1, Bcl10, } \\
\text { C3ar1, C4bp, C8a, Cc15, Cc17, Cd28, Cd34, Cd3e, Cd4, Cd47, Cdk6, } \\
\text { Cebpa, Cfd, Chst2, Cplx2, Cr11, Crip2, Crk1, Csf1, Ctla4, Ctse, } \\
\text { Cxc111, Cxc112, Cxc113, Cxc19, Daf2, Dnaja3, Elf4, Enpp2, Enpp3, } \\
\text { Ephx2, Fech, Fkbp1a, Flt3, Fyb, Gpam, Gzmc, H28, H2-Q1, H2-Q10, } \\
\text { Hbb-b1, Hells, Heph, Hmgb1, Hoxa9, Hspd1, Icam1, Id2, Il12b, } \\
\text { I11r1, I11r11, I12ra, I16, Ilf2, Irf1, Irf8, Jarid2, Kit, Klf1, Klf11, Klre1, } \\
\text { Lbp, Lig4, Lrrc17, Masp1, Masp2, Mb12, Mecom, Meis1, Msh2, } \\
\text { Mx1, Nup85, Osm, P2rx7, Pf4, Pik3cd, Pm1, Polr3h, Prdx2, Prg2, } \\
\text { Prg3, Ptger3, Rag1, Ripk2, Rorc, Runx1, Selp, Serpinb9, Serping1, } \\
\text { Sfxn1, Sh2b2, Slc11a2, Sox6, Sphk1, Spna1, Stat5a, Stat5b, Tacc3, } \\
\text { Tal1, Tap2, Tbx1, Tcf3, Tcfe3, Tek, Tgtp1, Themis, Tlr3, Tnfsf11, } \\
\text { Tnfsf8, Tnfsf9, Tpsb2, Traf3ip2, Trp53, Txnrd2, Vpreb1, Wwp1 }\end{array}$ \\
\hline $\operatorname{miR}-149$ & $\begin{array}{l}\text { Adora3, Agtr1a, Ahcy, Ahsp, Aldh1a1, Ambra1, Atp7a, Bag2, Bak1, } \\
\text { C3ar1, C4bp, C8a, Casp9, Cc15, Cc17, Cd28, Cd34, Cdk6, Cebpa, } \\
\text { Cfd, Chst2, Cplx2, Crip2, Crk1, Csf1, Ctla4, Ctse, Cxc111, Cxcl13, } \\
\text { Cxc19, Dnaja3, Elf4, Enpp3, Ephx2, Fam176a, Fastkd3, Fech, Fgfr1, } \\
\text { Fkbp1a, Flt3, Foxo3, Fyb, Gpam, Gzmc, H28, H2-Q1, H2-Q10, Hbb- } \\
\text { b1, Hells, Heph, Hoxa9, Hspd1, Icam1, Id2, I112b, I11r1, I11r11, I12ra, } \\
\text { I16, Ilf2, Irf1, Irf8, Kit, Klf1, Klf11, Lbp, Lig4, Lpar1, Lrrc17, Mapt, } \\
\text { Masp2, Meis1, Msh2, Mx1, Nup85, Osm, Pf4, Pik3cd, Pm1, Polr3h, } \\
\text { Prdx2, Prg2, Prg3, Ptger3, Rag1, Ripk2, Rorc, Runx1, Selp, } \\
\text { Serpinb9, Serping1, Sh2b2, Slc111a2, Sox6, Sphk1, Spna1, Stat5a, } \\
\text { Stat5b, Steap3, Stxbp1, Tacc3, Tal1, Tap2, Tbx1, Tcf3, Tek, Tgtp1, } \\
\text { Themis, Tlr3, Tnfsf8, Tnfsf9, Tpsb2, Txnrd2, Vpreb1,Xrcc2 }\end{array}$ \\
\hline miR-1897-5p & $\begin{array}{l}\text { Agtr1a, Ahsp, Aldh1a1, Ambra1, Bag2, Casp9, Cdk6, Cxc19, Dnaja3, } \\
\text { Elf4, Fam176a, Fastkd3, Fech,Fgfr1, Foxo3, Fyb, Gpam, Gzmc, H28, } \\
\text { H2-Q1, H2-Q10, Hoxa9, Il12b, I11r1, Il1r11, Klf1, Lpar1, Mapt, } \\
\text { Masp2, Polr3h, Slc11a2, Smap1, Smo, Steap3, Stxbp1, Tap2, Tek, } \\
\text { Tgtp1, Xrcc2 }\end{array}$ \\
\hline $\operatorname{miR}-29 b^{*}$ & $\begin{array}{l}\text { Add2, Adora3, Agtr1a, Ahcy, Ahsp, Aldh1a1, Alms1, Ambra1, Ank1, } \\
\text { Atp7a, Bag2, Bak1, Brca1, Bub1b, C3ar1, C4bp, C8a, Casp9, Cc15, } \\
\text { Cc17, Cd28, Cd34, Cdk4, Cdk6, Cebpa, Cfd, Chst2, Clca2, Col18a1, }\end{array}$ \\
\hline
\end{tabular}




\begin{tabular}{|c|c|}
\hline MicroRNAs & RNA mensageiro alvos \\
\hline & $\begin{array}{l}\text { Cplx2, Crip2, Crk1, Csda, Csf1, Ctla4, Ctse, Cxcl11, Cxcl13, Cxc19, } \\
\text { Dnaja3, Elf4, Enpp3, Ephx2, F2r, Fam176a, Fastkd3, Fech, Fgfr1, } \\
\text { Fkbp1a, Flt3, Foxo3, Fyb, Gas2, Gja1, Gpam, Gzmc, H28, H2-Q1, } \\
\text { H2-Q10, Hbb-b1, Hells, Heph, Hoxa9, Hspd1, Icam1, Id2, I112b, } \\
\text { I11r1, I11r11, I12ra, Il6, Ilf2, Irf1, Irf8, Kit, K1f1, K1f11, Lbp, Lig4, } \\
\text { Lpar1, Lrrc17, Mapk9, Mapt, Masp2, Meis1, Msh2, Mx1, Nqo1, } \\
\text { Nup85, Osm, Pf4, Pik3cd, Pm1, Polr3h, Ppif, Prdx2, Prg2, Prg3, } \\
\text { Psmd9, Psmg2, Ptger3, Rag1, Ripk2, Rorc, Runx1, Selp, Serpinb9, } \\
\text { Serping1, Sh2b2, Slc11a2, Smap1, Smo, Sod1, Sox6, Sphk1, } \\
\text { Spna1,Spon2, Stat5a, Stat5b, Steap3, Stxbp1, Tacc3, Tal1, Tap2, } \\
\text { Tbx1, Tcf3, Tek, Tgtp1, Themis, Thy1, Tlr3, Tnfsf8, Tnfsf9, Tpsb2, } \\
\text { Txnrd2, Vpreb1, Xrcc2 }\end{array}$ \\
\hline miR-302c & $\begin{array}{l}\text { Add2, Adora3, Agtr1a, Ahcy, Ahsp, Aldh1a1, Alms1, Ambra1, Ank1, } \\
\text { Atp7a, Bag2, Bak1, Brca1, Bub1b, C3ar1, C4bp, C8a, Casp9, Ccl5, } \\
\text { Cc17, Cd28, Cd34, Cdk4, Cdk6, Cebpa, Cfd, Chst2, Clca2, Col18a1, } \\
\text { Cplx2, Crip2, Crk1, Csda, Csf1, Ctla4, Ctse, Cxc111, Cxc113, Cxc19, } \\
\text { Dnaja3, Elf4, Enpp3, Ephx2, F2r, Fam176a, Fastkd3, Fech, Fgfr1, } \\
\text { Fkbp1a, Flt3, Foxo3, Fyb, Gas2, Gja1, Gpam, Gzmc, H28, H2-Q1, } \\
\text { H2-Q10, Hbb-b1, Hells, Heph, Hoxa9, Hspd1, Icam1, Id2, Il12b, } \\
\text { I11r1, I11r11, I12ra, I16, Ilf2, Irf1, Irf8, Kit, K1f1, K1f11, Lbp, Lig4, } \\
\text { Lpar1, Lrrc17, Mapk9, Mapt, Masp2, Meis1, Msh2, Mx1, Nqo1, } \\
\text { Nup85, Osm, Pf4, Pik3cd, Pm1, Polr3h, Ppif, Prdx2, Prg2, Prg3, } \\
\text { Psmd9, Psmg2, Ptger3, Rag1, Ripk2, Rorc,Runx1, Selp, Serpinb9, } \\
\text { Serping1, Sh2b2, Slc11a2, Smap1, Smo, Sod1, Sox6, Sphk1, } \\
\text { Spna1,Spon2, Stat5a, Stat5b, Steap3, Stxbp1, Tacc3, Tal1, Tap2, } \\
\text { Tbx1, Tcf3, Tek, Tgtp1, Themis, Thy1, Tlr3, Tnfsf8, Tnfsf9, Tpsb2, } \\
\text { Txnrd2, Vpreb1, Xrcc2 }\end{array}$ \\
\hline miR-30b* & $\begin{array}{l}\text { Add2, Adora3, Agtr1a, Ahcy, Ahsp, Alas2, Aldh1a1, Alms1, } \\
\text { Ambra1, Ank1, Atp7a, Bag2, Bak1, Barx1, Bcl10, Bc12, Bik, Brca1, } \\
\text { Bub1b, C3ar1, C4bp, C8a, Casp3, Casp9, Ccar1, Cc15, Cc17, Cd28, } \\
\text { Cd34, Cd3e, Cd4, Cd47, Cdk4, Cdk6, Cebpa, Cfd, Chst2, Clca2, } \\
\text { Co118a1, Cplx2, Cr11, Crip2, Crk1, Csda, Csf1, Ctla4, Ctse, Cxc111, } \\
\text { Cxc112, Cxc113, Cxc19, Daf2, Dnaja3, E2f1, Elf4, Enpp2, Enpp3, } \\
\text { Ephx2, F2r, Fam176a, Fastkd3, Fech, Fgfr1, Fkbp1a, Flt3, Foxo3, } \\
\text { Fyb, Gas2, Gja1, Gpam, Gzmc, H28, H2-Q1, H2-Q10, Hbb-b1, Hells, } \\
\text { Heph, Hoxa9, Hspd1, Icam1, Id2, Il12b, Il1r1, Il1r11, I12ra, Il6, Ilf2, } \\
\text { Irf1, Irf8, Jarid2, Kit, Klf1, K1f11, Klre1, Lbp, Lig4, Lpar1, Lrrc17, } \\
\text { Mapk9, Mapt, Masp1, Masp2, Mbl2, Mecom, Meis1, Msh2, Mx1, } \\
\text { Nqo1, Nup85, Osm, P2rx7, Pf4, Pik3cd, Pm1, Polr3h, Ppif, Prdx2, } \\
\text { Prg2, Prg3, Psmd9, Psmg2, Ptger3, Rag1, Ripk2, Rorc, Runx1, Selp, } \\
\text { Serpinb9, Serping1, Sfxn1, Sh2b2, Slc11a2, Smap1, Smo, Sod1, } \\
\text { Sox6, Sphk1, Spna1, Stat5a, Stat5b, Steap3, Stxbp1, Tacc3, Tal1, } \\
\text { Tap2, Tbx1, Tcf3, Tcfe3, Tek, Tgtp1, Themis, Thra, Thy1, Tlr3, } \\
\text { Tnfsf8, Tnfsf9, Tpsb2, Traf3ip2, Trp53, Txnrd2, Vpreb1, Wwp1, } \\
\text { Xrcc2 }\end{array}$ \\
\hline miR-690 & $\begin{array}{l}\text { Add2, Adora3, Agtr1a, Ahctf1, Ahcy, Ahsp, Alas2, Aldh1a1, Alms1, } \\
\text { Ambra1, Ank1, Atp7a, Bag2, Bak1, Bard1, Bcl10, Bc12, Bik, Brca1, } \\
\text { Bub1b, C3ar1, C4bp, C8a, Casp3, Casp9, Ccar1, Cc15, Cc17, Cd28, } \\
\text { Cd34, Cd3e, Cd4, Cdk4, Cdk6, Cebpa, Cfd, Chst2, Clca2, Col18a1, } \\
\text { Cplx2, Crip2, Crk1, Csda, Csf1, Ctla4, Ctse, Cxc111, Cxc113, Cxc19, } \\
\text { Daf2, Dnaja3, Dyn1l1, Dyrk3, E2f1, Elf4, Enpp3, Ephx2, F2r, } \\
\text { Fam176a, Fastkd3, Fech, Fgfr1, Fkbp1a, Flt3, Foxo3, Fyb, Gas2, }\end{array}$ \\
\hline
\end{tabular}




\begin{tabular}{|c|c|}
\hline MicroRNAs & RNA mensageiro alvos \\
\hline & $\begin{array}{l}\text { Gja1, Gpam, Gzmc, H28, H2-Q1, H2-Q10, Hbb-b1, Hells, Heph, } \\
\text { Hmgb3, Hoxa9, Hspd1, Icam1, Id2, Il12b, Il18r1, Il1r1, I11r11, Il2ra, } \\
\text { I16, Ilf2, Irf1, Irf8, Itsn1, Kit, K1f1, K1f11, Lbp, Lig4, Lpar1, Lrrc17, } \\
\text { Mapk9, Mapt, Masp2, Meis1, Msh2, Mx1, Ncaph2, Nmnat3, Nqo1, } \\
\text { Nup85, Osm, P2rx7, Pf4, Pik3cd, Pml, Polr3h, Ppif, Prdx2, Prg2, } \\
\text { Prg3, Psmd9,Psmg2, Ptger3, Rag1, Ripk2, Rorc, Rps6kb1, Runx1, } \\
\text { Selp, Serpinb9, Serping1, Sh2b2, Slc11a2, Smap1, Smo, Sod1, Sox6, } \\
\text { Sphk1, Spna1, Spon2, Stat1, Stat5a, Stat5b, Steap3, Stxbp1, Tacc3, } \\
\text { Ta11, Tap2, Tbx1, Tcf3, Tcfe3, Tek, Tgtp1, Themis, Thra, Thy1, } \\
\text { Tlr3, Tnfsf8, Tnfsf9, Tpsb2, Traf3ip2, Trp53, Txnrd2, Vpreb1, } \\
\text { Wwox, Wwp1, Xrcc2 }\end{array}$ \\
\hline miR-691 & $\begin{array}{l}\text { Ahcy, Ahsp, C3ar1, C4bp, Ccl7, Cd28, Cd34, Cdk6, Cebpa, Chst2, } \\
\text { Crip2, Crk1, Ctla4, Ctse, Cxc111, Cxc19, Dnaja3, Elf4, Enpp3, Ephx2, } \\
\text { Flt3, Fyb, Gpam, Gzmc, H28, H2-Q1, H2-Q10, Hells, Hoxa9, Hspd1, } \\
\text { Icam1,Id2, Il12b, I11r1, I11r11, Il2ra, I16, Ilf2, Kit, K1f1, Masp2, } \\
\text { Msh2, Osm, Pf4, Polr3h, Prdx2, Prg2, Prg3, Ptger3, Rorc, Runx1, } \\
\text { Serpinb9, Slc11a2, Sox6, Sphk1, Spna1, Stat5a, Stat5b, Tacc3, Ta1, } \\
\text { Tap2, Tek, Tgtp1, Themis, Tlr3, Tnfsf9, Vpreb1 }\end{array}$ \\
\hline $\operatorname{miR}-712$ & $\begin{array}{l}\text { Adora3, Ahcy, Ahsp, C3ar1, C4bp, Cc15, Cc17, Cd28, Cd34, Cdk6, } \\
\text { Cebpa, Cfd, Chst2, Crip2, Crk1, Ctla4, Ctse, Cxcl11, Cxc19, Dnaja3, } \\
\text { Elf4, Enpp3, Ephx2, Flt3, Fyb, Gpam, Gzmc, H28, H2-Q1, H2-Q10, } \\
\text { Hells, Hoxa9, Hspd1, Icam1, Id2, I112b, I11r1, I11r11, I12ra, I16, Ilf2, } \\
\text { Kit, K1f1, Lbp, Masp2, Msh2, Osm, Pf4, Pml, Polr3h, Prdx2, Prg2, } \\
\text { Prg3, Ptger3, Rorc, Runx1, Selp, Serpinb9, Slc11a2, Sox6, Sphk1, } \\
\text { Spna1, Stat5a, Stat5b, Tacc3, Tal1, Tap2, Tek, Tgtp1, Themis, Tlr3, } \\
\text { Tnfsf9, Vpreb1 }\end{array}$ \\
\hline miR-29a* & $\begin{array}{l}\text { Ada, Ager, Bcl11b, Bcl211, Bc16, Bex1, Bmp7, C4b, Camp, Cc112, } \\
\text { Cc124, Cc18, Ccnb1, Ccnd3, Ccr4, Cd1d2, Cd27, Cd28, Cd3d, Cd3e, } \\
\text { Cd4, Cd8a, Cdca7, Cdkn1b, Cdkn2c, Cenpf, Cfb, Clec7a, Coro1, } \\
\text { Crip3, Cth, Cxadr, Cxc112, Ddr1, Dhcr24, E2f7, Ednra, Egln3, Egr1, } \\
\text { Esr2, Ets1, Fabp4, Fas, Foxg1, Foxm1, Fxyd2, Gabbr1, Grn, Hdac7, } \\
\text { I120rb, I12ra, I134, Jak3, Kdm6b, Kifap3, K1f10, Klf2, Lat, Lck, Lig4, } \\
\text { Lipa, Mapk8, Marcks11, Masp2, Mink1, Ndst1, Nmb, Nr3c1, Ntn1, } \\
\text { P2rx1, Pag1, Patz1, Pax1, Pde1a, Pdgfrb, Phip, Pten, Ptprc, Ptpr, } \\
\text { Ptprv, Rag1, Rag2, Reg3g, Rhoh, Rorc, Rptor, Rtkn2, Saa3, Sash3, } \\
\text { Satb1, Serpinb5, Sla2, Slfn3, Smad3, Smo, Sox4, Sparc, St8sia1, } \\
\text { Stat5b, Tax1bp3, Tcf7, Themis, Thy1, Tia1, Timp2, Tnfsf15, Ulbp1, } \\
\text { Vsx2, Wnt2, Zap70, Zeb1 }\end{array}$ \\
\hline miR-135a* & $\begin{array}{l}\text { Ada, Bc111b, Bc1211, Bc16, Bex1, Bmp7, Camp, Ccl12, Cc124, Ccl5, } \\
\text { Cc18, Ccnd3, Ccr2, Cd1d2, Cd4, Cd8a, Cdca7, Cenpf, Cfb, Egln3, } \\
\text { Egr1, Esr2, Fas, Grn, Hdac7, I117b, I117f, I11b, Il2ra, Il34, I17r, Lck, } \\
\text { Lig4, Lipa, Marcks11, Ntn1, P2rx1, Pag1, Pax1, Pten, Ptger3, Pth1r, } \\
\text { Ptprf, Rag1, Rag2, Rorc, Rtkn2, Saa3, Satb1, Serpinb5, Sla2, Sox4, } \\
\text { Sparc, St8sia1, Stat5b, Tcf7, Themis, Thy1, Ulbp1, Vsx2, Wnt2 }\end{array}$ \\
\hline
\end{tabular}

Para validar os dados obtidos nas redes de interações, fizemos uso do programa RNAhybrid (http://bibiserv.techfak.uni-bielefeld.de/rnahybrid/submission.html), que analisa a estrutura secundária, e determina o sítio de hibridação mais favorável entre um determinado microRNA e seu mRNA alvo. A metodologia é baseada no princípio de termodinâmica de 
interação, e a interação é determinada pela mínima energia livre, ou mfe (do inglês minimum free energy). A tabela VI mostra algumas das interações encontradas pelo modelo GenMiR ${ }^{++}$, com seus respectivos valores de mfe, e interação molecular obtidas pelo RNAhybrid.

Tabela VI. Estrutura molecular de interações microRNA-mRNA selecionadas, e suas respectivas energias livres de interação obtidas pelo programa RNAhybrid.

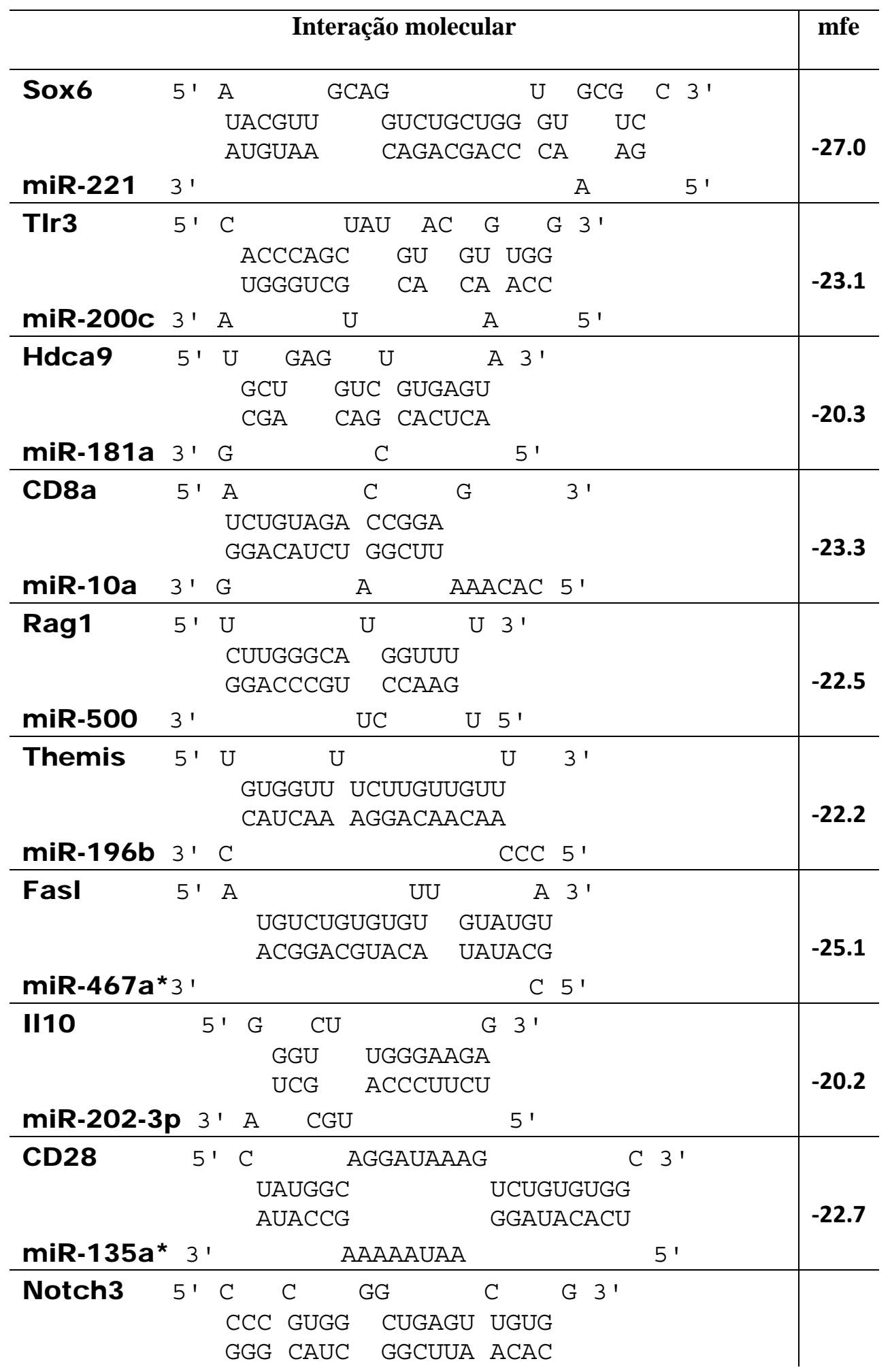




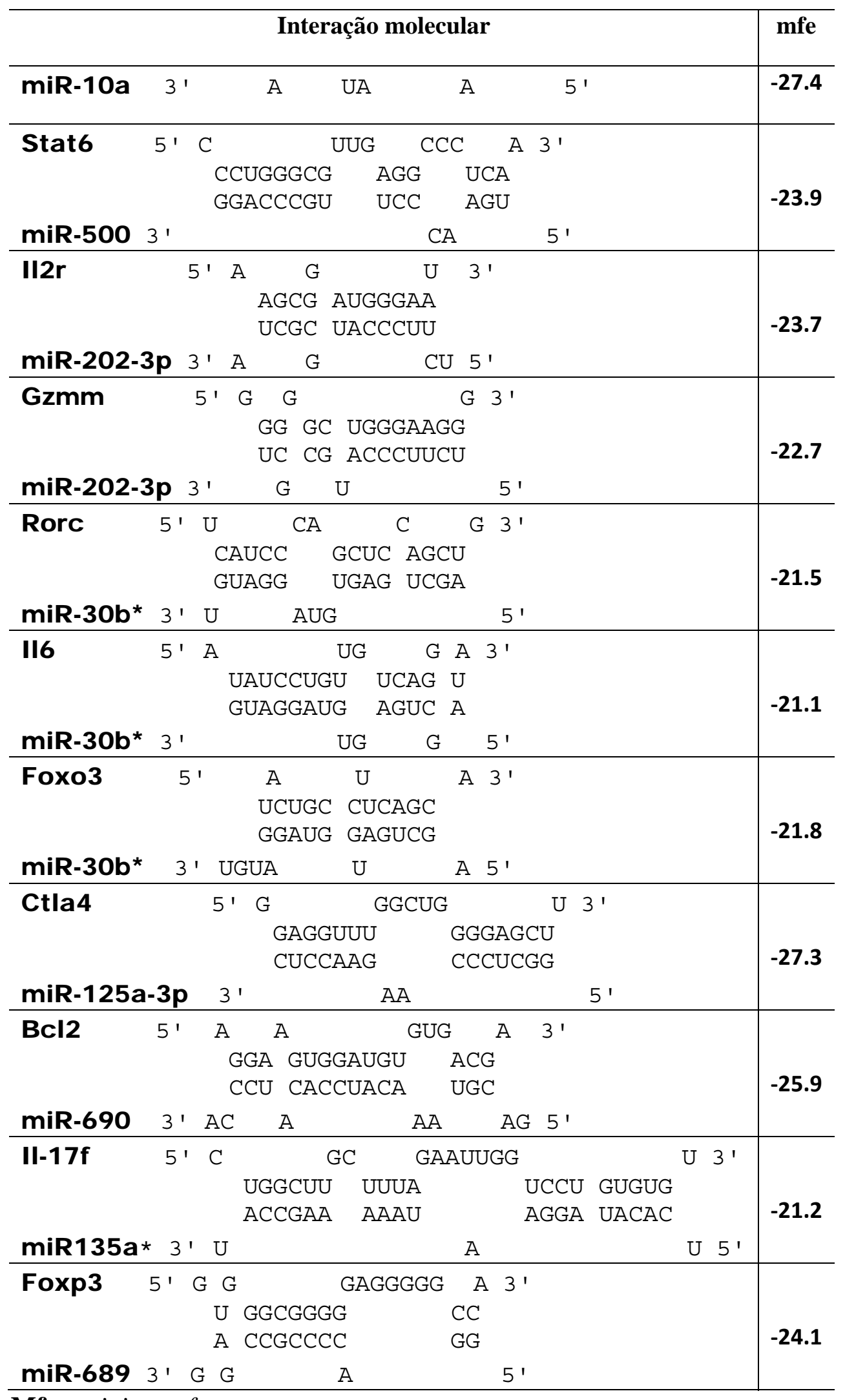

Mfe : minimum free energy 


\subsection{Identificação de novos microRNAs em pacientes com artrite reumatóide}

Os resultados apresentados nessa seção são referentes ao estágio de seis meses na Divisão de Imunologia, Infecção e Inflamação da Universidade de Glasgow (Escócia, Reino Unido). O nosso objetivo foi selecionar e investigar o papel de novos microRNAs em linfócitos $\mathrm{T}$ de pacientes com artrite reumatóide (AR), tendo como base resultados obtidos no nosso estudo, somente dos camundongos susceptível DBA-1/J.

\subsubsection{Análise dos microRNAs diferencialmente expressos}

Os dados de microRNAs foram normalizados utilizando o quantil, e a distribuição dos valores de intensidade dos dados normalizados para cada amostra foram plotados em um gráfico Box-whisker. Após a análise estatística por meio de One-way ANOVA com pvalue $\leq 0,05$, e fold-change $\geq 2.0$, o perfil de microRNAs identificou 75 microRNAs diferencialmente expressos em linfócitos $\mathrm{T}_{\mathrm{CD}}{ }^{+}$durante a indução de CIA quando comparado ao controle (Figura 29). A tabela VI mostra o perfil de cada microRNA baseado no fold-change. 


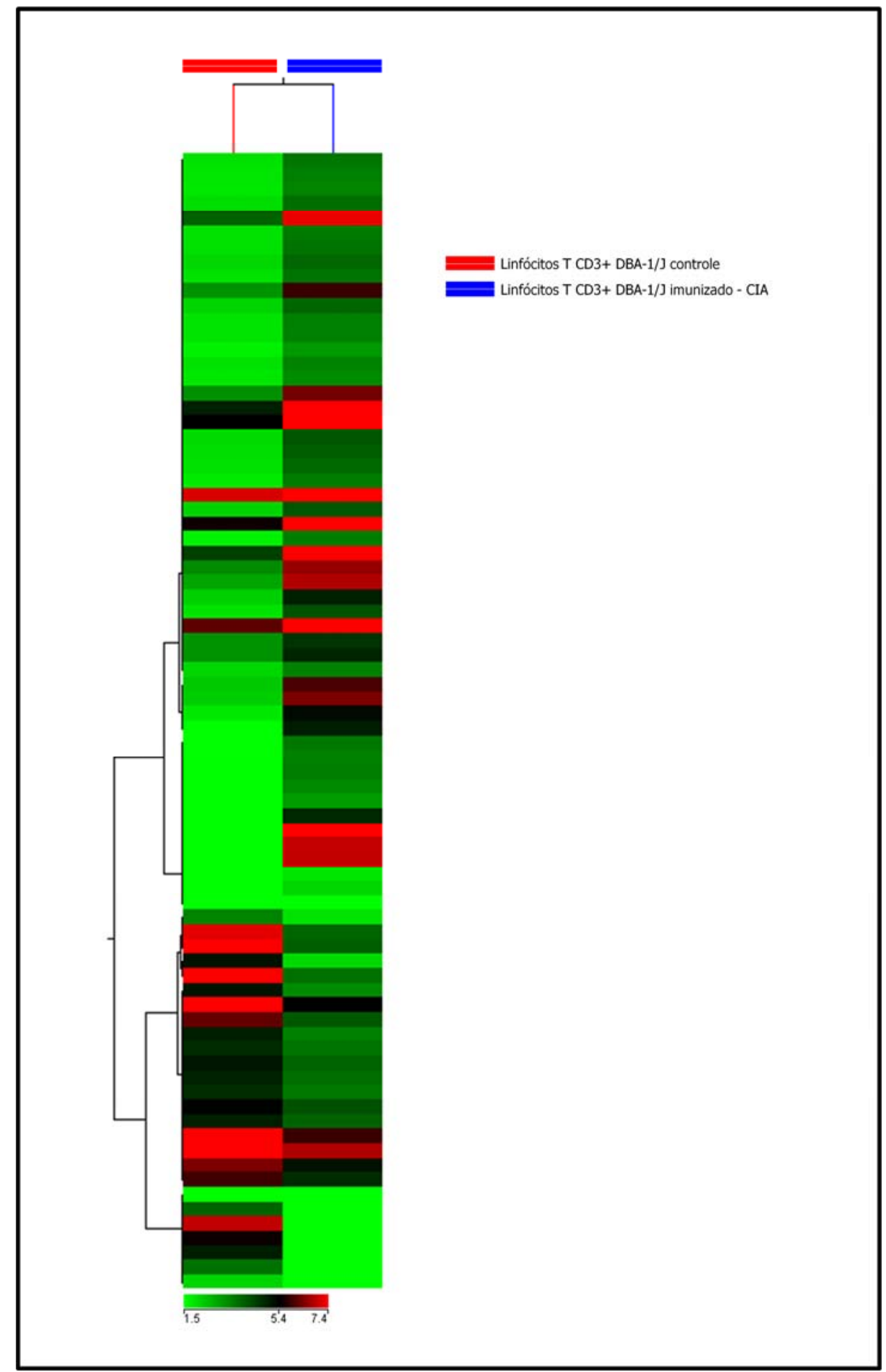

Figura 29. Comparação dos perfis de expressão dos 75 microRNAs diferencialmente expressos nos camundongos da linhagem DBA-1/J imunizado com colágeno tipo II, e seu respectivo controle. Matriz de expressão de microRNAs de linfócitos $\mathrm{T} \mathrm{CD}^{+}$periféricos do baço e linfonodo inguinal de camundongos 12 semanas de idade. $\mathrm{O}$ grupo controle foi imunizado somente com adjuvante completo de Freund (sem colágeno). A correlação de Pearson foi utilizada como medida de similaridade. O vermelho representa microRNA com expressão induzida, o verde representa microRNA com expressão reprimida e o preto representa que a expressão do microRNA não variou entre as amostras . 
Tabela VII. MicroRNAs diferencialmente expressos nos linfócitos $\mathrm{T} \mathrm{CD}^{+}$durante a indução de CIA comparado ao controle.

\begin{tabular}{|c|c|c|}
\hline microRNA & Fold-change (CIA vs Controle) & Expressão \\
\hline miR-32 & 3.1172369 & reprimido \\
\hline miR-297a* & 10.504313 & reprimido \\
\hline miR-1198 & 2.786261 & induzido \\
\hline miR-130b* & 9.463529 & reprimido \\
\hline $\operatorname{miR}-669 b$ & 8.813779 & reprimido \\
\hline $\operatorname{miR}-486$ & 3.6046288 & induzido \\
\hline $\operatorname{miR}-126-3 p$ & 3.2796102 & reprimido \\
\hline $\operatorname{miR}-188-5 p$ & 3.4592383 & reprimido \\
\hline $\operatorname{miR}-467 f$ & 3.5926702 & reprimido \\
\hline miR-294 & 2.0927107 & reprimido \\
\hline $\operatorname{miR}-468$ & 4.094006 & reprimido \\
\hline miR-151-5p & 2.240051 & induzido \\
\hline miR-671-5p & 10.3343 & reprimido \\
\hline $\operatorname{miR}-125 b-5 p$ & 27.89622 & reprimido \\
\hline $\operatorname{miR}-378$ & 2.2966325 & induzido \\
\hline miR-let-7e & 2.852218 & induzido \\
\hline miR-let-7b* & 2.9828968 & reprimido \\
\hline miR-466i & 12.906437 & reprimido \\
\hline $\operatorname{miR}-324-3 p$ & 7.031794 & reprimido \\
\hline $\operatorname{miR}-466 a-3 p$ & 3.9836123 & reprimido \\
\hline miR-1894-3p & 3.3440251 & reprimido \\
\hline miR-207 & 24.91743 & reprimido \\
\hline $\operatorname{miR}-15 b^{*}$ & 38.030598 & reprimido \\
\hline $\operatorname{miR}-350$ & 2.326111 & induzido \\
\hline miR-345-5p & 5.670853 & reprimido \\
\hline $\operatorname{miR}-328$ & 3.3161476 & reprimido \\
\hline miR-144 & 2.4599586 & induzido \\
\hline miR-202-3p & 4.4337683 & induzido \\
\hline miR-296-5p & 2.7494256 & reprimido \\
\hline miR-290-3p & 2.5812304 & reprimido \\
\hline miR-128 & 3.2135763 & reprimido \\
\hline $\operatorname{miR}-196 b$ & 15.559422 & reprimido \\
\hline $\operatorname{miR}-10 b$ & 8.644523 & reprimido \\
\hline $\operatorname{miR}-378^{*}$ & 2.4850345 & induzido \\
\hline miR-340-3p & 17.9041 & reprimido \\
\hline miR-702 & 2.7649026 & reprimido \\
\hline $\operatorname{miR}-29 a^{*}$ & 1762.5299 & reprimido \\
\hline let-7d* & 27.75012 & reprimido \\
\hline $\operatorname{miR}-467 a$ & 3.2460563 & reprimido \\
\hline $\operatorname{miR}-362-3 p$ & 6.6967955 & reprimido \\
\hline miR-805 & 14.729438 & induzido \\
\hline
\end{tabular}




\begin{tabular}{lcc}
\hline microRNA & Fold-change (CIA vs Controle) & Expressão \\
\hline miR-872 & & \\
miR-340-5p & 10.216842 & reprimido \\
miR-320 & 2.263621 & induzido \\
miR-467a* & 4.316168 & induzido \\
miR-211 & 8.713233 & induzido \\
miR-222 & 108.47097 & reprimido \\
miR-29b* & 2.117261 & induzido \\
miR-99a & 45.511078 & induzido \\
miR-324-5p & 3.2235005 & reprimido \\
miR-532-5p & 2.8643975 & reprimido \\
miR-505 & 8.678 & induzido \\
miR-149 & 31.612041 & induzido \\
miR-466h & 2.909299 & reprimido \\
miR-185 & 6.65911 & reprimido \\
miR-181b & 2.255733 & induzido \\
miR-146b & 3.1065238 & reprimido \\
miR-135a* & 3.0503242 & induzido \\
miR-219 & 111.00356 & reprimido \\
miR-706 & 108.89398 & reprimido \\
miR-186* & 2.3069701 & induzido \\
miR-17* & 3.8167481 & reprimido \\
miR-297c & 2.2222357 & induzido \\
miR-18a* & 2.4515488 & reprimido \\
miR-500 & 9.727325 & reprimido \\
miR-721 & 72.74448 & induzido \\
miR-466c-5p & 15.948348 & induzido \\
miR-30b* & 10.477839 & induzido \\
miR-466f-3p & 12.786841 & induzido \\
miR-191* & 3.8806348 & reprimido \\
miR-192 & 11.650104 & reprimido \\
miR-669d & 10.770756 & reprimido \\
miR-365 & 3.2469206 & reprimido \\
miR-714 & 2.7036536 & reprimido \\
miR-181d & 35.168987 & \\
\hline & 4.845017 & \\
\hline
\end{tabular}

Baseado no fold-change e na conservação dos microRNAs entre as duas espécies (humano e camundongo), foram selecionados 8 microRNAs: 4 deles induzidos na CIA (miR-500, miR-505, miR-30b* e miR-29b*) e 4 reprimidos (miR-29a*, miR-let-7d, miR15b* e miR-135a*) quando comparados ao controle, para investigação nos linfócitos $\mathrm{T}$ $\mathrm{CD}^{+}$de pacientes e indivíduos saudáveis. 


\subsubsection{Análise da expressão dos microRNAs por PCR quantitativa em tempo real (qPCR)}

Os microRNAs: miR-500, miR-505, miR-30b*, miR-29b*, miR-29a*, miR-let-7d, miR-15b*, e miR-135a* foram avaliados por qPCR. As figuras 30 e 31 mostram as expressões relativas dos microRNAs selecionados, nos linfócitos $\mathrm{T} \mathrm{CD}^{+}$de indivíduos saudáveis, e pacientes com artrite reumatóide (AR) resistentes aos tratamentos DMARDs ou anti-TNF $\alpha$.

A figura 30 mostra a expressão em linfócitos T $\mathrm{CD}^{+}$humanos, dos microRNAs selecionados que são expressos durante a CIA.

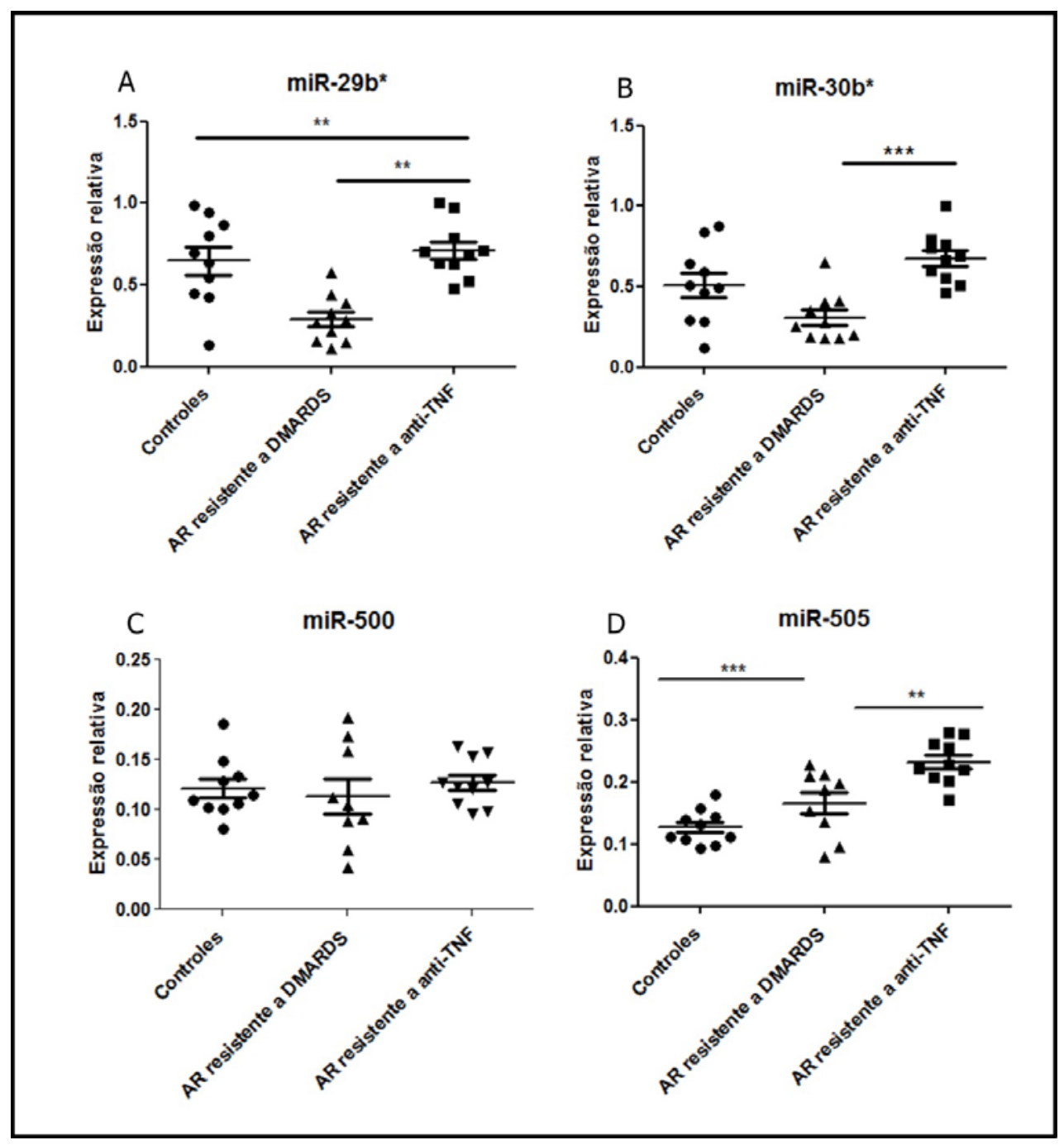

Figura 30. PCR quantitativa dos microRNAs a) miR-29b*, b) miR-30b*, c) miR-500 e d) miR-505 em linfócitos $\mathrm{T} \mathrm{CD}^{+}$isolados de PBMCs de indivíduos saudáveis (controles) e pacientes resistentes aos tratamentos DMARDs e anti-TNF. Os níveis de expressão foram normalizados utilizando o RNA RUN6B. A diferença entre os grupos foi avaliada utilizando o teste de Mann-Whitney. ${ }^{* *} P<0.01$ e $* * * P<0.001$ foram considerados significantes. 
O microRNA miR-29b* é mais expresso nos indivíduos saudáveis (controles) quando comparado aos pacientes resistentes ao tratamento com DMARDs. Este microRNA também apresentou expressão significativa nos pacientes resistentes ao tratamento com anti-TNF quando comparados aos pacientes resistentes ao tratamento com DMARDs (Figura 30a).

Já o miR-30b* é mais expresso nos pacientes resistentes ao tratamento com antiTNF quando comparados aos pacientes resistentes ao tratamento com DMARDs, e não houve diferença em relação aos controles (Figura 30b), enquanto que o miR-500 não apresentou diferença entre os grupos analisados (Figura 30c).

O miR-505 por sua vez, é mais expresso nos pacientes resistentes ao tratamento com anti-TNF quando comparado ao grupo resistente ao tratamento com DMARDs e aos indivíduos saudáveis (controles). É importante ressaltar que também houve diferença entre o grupo resistente ao tratamento com DMARDs e o grupo controle (Figura 30d).

A figura 31 mostra a expressão em linfócitos $\mathrm{T} \mathrm{CD}^{+}$humanos, dos microRNAs selecionados que estão reprimidos durante a CIA quando comparados ao controle. Os microRNAs miR-29a* e miR-135a* não apresentaram nenhuma diferença entre os grupos analisados (Figura 31a e d). Por outro lado, os microRNAs miR-let-7d e miR15b* são mais expressos nos pacientes resistentes ao tratamento com anti-TNF quando comprados aos pacientes resistentes ao tratamento com DMARDs, entretanto não apresentaram nenhuma diferença em relação aos controles (Figura $31 \mathrm{~b}$ e c).

Dos microRNAs selecionados apenas os dados de expressão do miR-505 foi similar ao encontrado nos experimentos de microarray em camundongo (induzido na doença quando comparado ao controle). Além disso, este microRNA mostrou-se de grande interesse devido a sua alta expressão nos pacientes resistentes ao tratamento com anti-TNF. Por esse motivo, fomos avaliar o papel do miR-505 em linfócitos $\mathrm{T}$, com o objetivo de identificar sua importância na AR. 

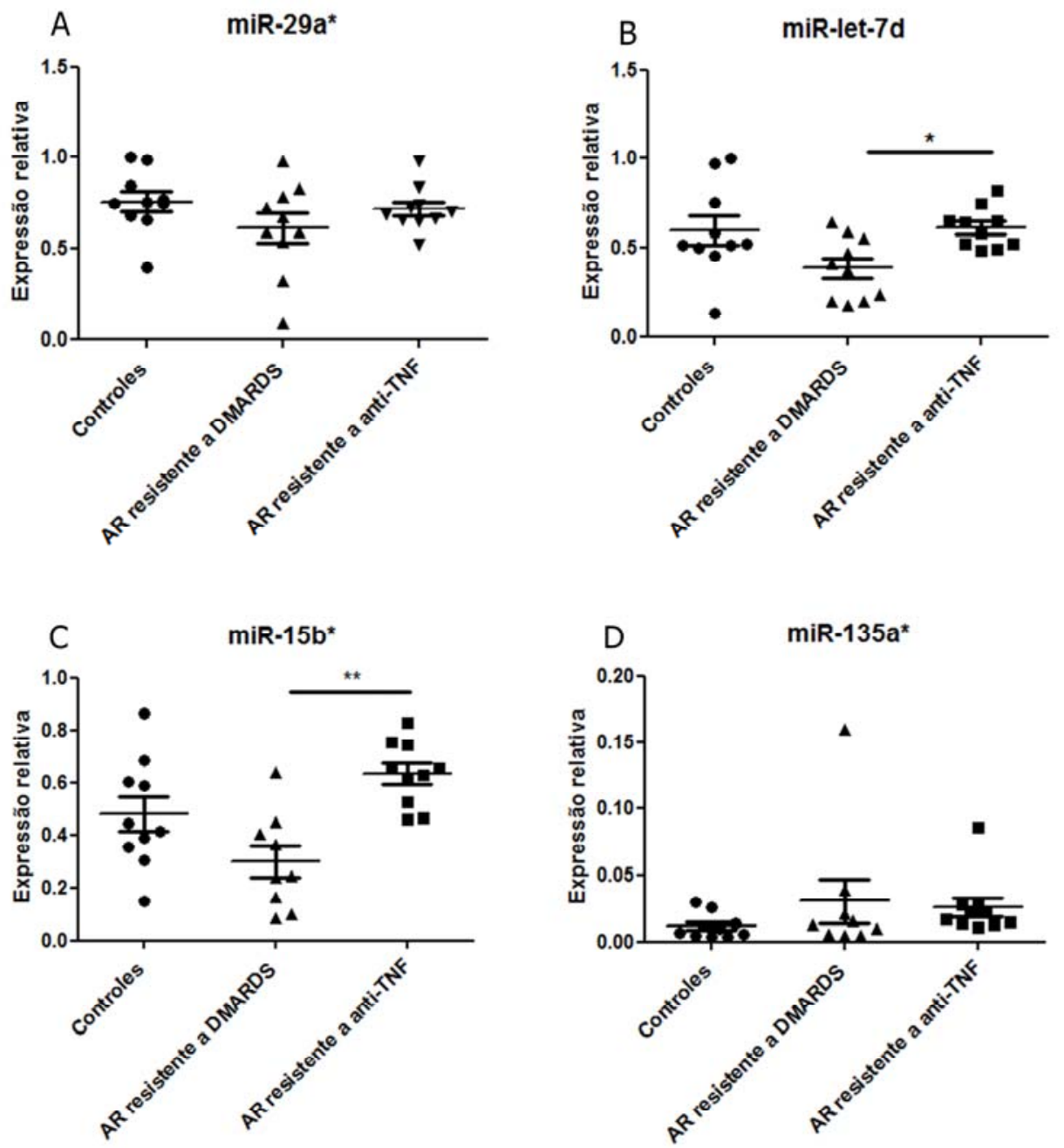

Figura 31. PCR quantitativa dos microRNAs a) miR-29a*, b) miR-let-7d, c) miR-15b* e d) miR-135a* em linfócitos $\mathrm{T} \mathrm{CD}^{+}$isolados de PBMCs de indivíduos saudáveis (controles) e pacientes resistentes aos tratamentos DMARDs e anti-TNF. Os níveis de expressão foram normalizados utilizando o RNA RUN6B. A diferença entre os grupos foi avaliada utilizando o teste de Mann-Whitney. ${ }^{*} P<0.05$ e $* * P<0.01$ foram considerados significantes.

\subsubsection{Avaliação dos alvos do miR-505 em humanos}

Pouco se sabe a respeito do miR-505, e nunca antes foi sugerido a sua participação na autoimunidade ou seu envolvimento com linfócitos T. Com base nestas informações fomos averiguar a lista de alvos preditos deste microRNA pelo banco de dados Targetscan (www.targetscan.org/) em humanos. A figura 32 mostra uma rede de interação entre o miR-505 e seus alvos, utilizando o programa de desenho gráfico Cytoscape. 


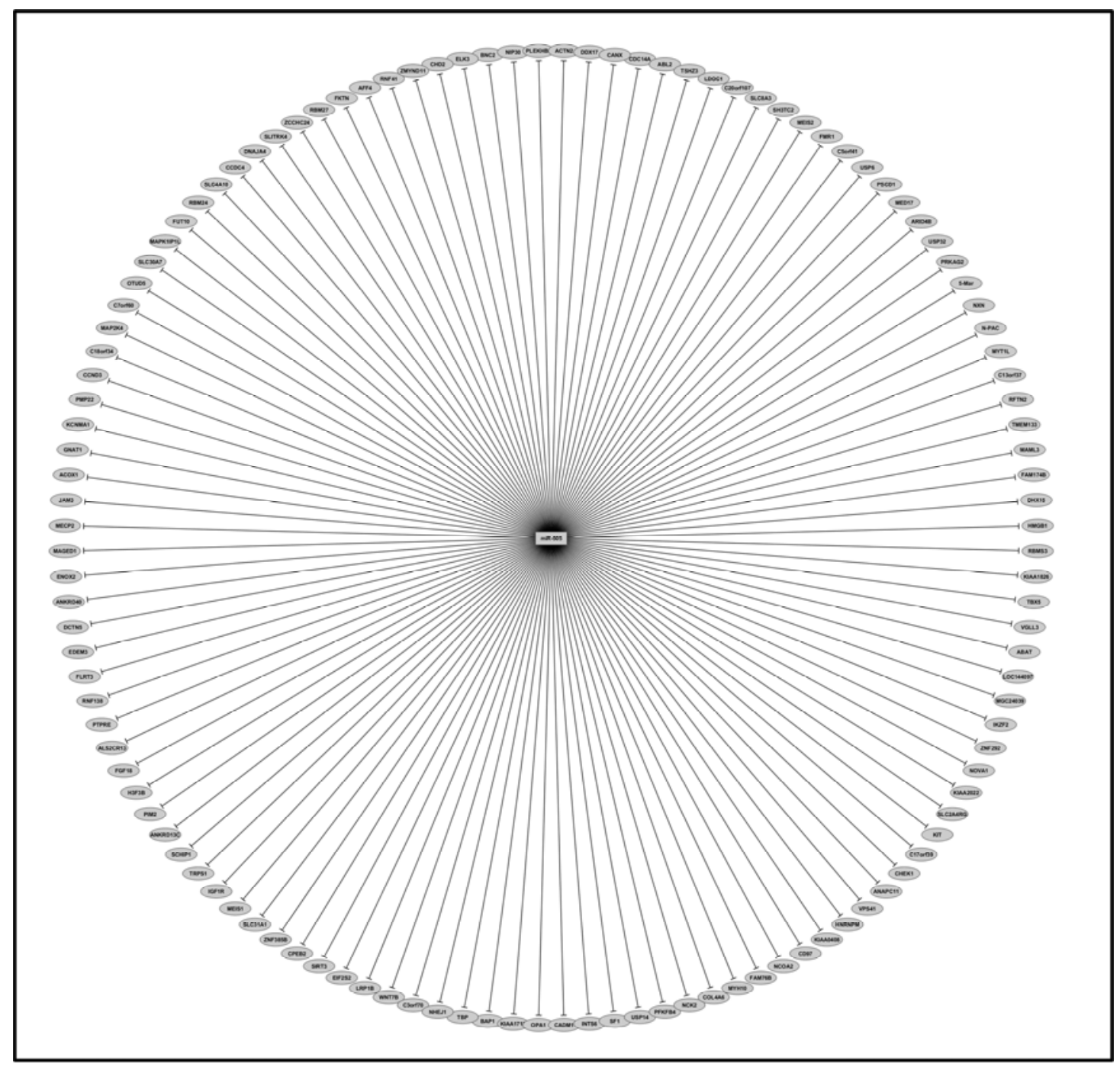

Figura 32: Rede de interação entre o miR-505 e seus alvos preditos pelo banco de dados targetscan. A rede foi gerada utilizando o programa gráfico cytoscape.

$\mathrm{Na}$ lista de alvos encontrarmos alguns relacionados a ciclo celular (ANAPC11, CDC14A, CHEK1, CCND3) e a via de sinalização do receptor de células T (NCK2, CBL). Entretanto, nenhum deles apontava diretamente para o potencial papel deste microRNA nos linfócitos $\mathrm{T}$ no contexto de autoimunidade relacionado a AR.

A tabela VI mostra os alvos preditos do miR-505 em humanos. 
Tabela VIII. Alvos preditos do microRNA miR-505 pelo banco de dados targetscan em humanos.

\begin{tabular}{|c|c|}
\hline MicroRNA & Alvos preditos \\
\hline miR-505 & $\begin{array}{l}\text { HMGB1, RBMS3, DHX15, KIAA1826, FAM174B, TBX5, MAML3, } \\
\text { VGLL3, TMEM133, ABAT, RFTN2, LOC144097, C13orf37, } \\
\text { MGC24039, MYT1L, IKZF2, N-PAC, ZNF292, NXN, NOVA1, 5- } \\
\text { Mar, KIAA2022, PRKAG2, SLC2A4RG, USP32, KIT, ARID4B, } \\
\text { C17orf39, MED17, CHEK1, PSCD1, ANAPC11, USP6, VPS41, } \\
\text { C5orf41, HNRNPM, FMR1, KIAA0408, MEIS2, CD97, SH3TC2, } \\
\text { NCOA2, SLC8A3, FAM76B, C20orf107, MYH10, LDOC1, } \\
\text { COL4A6, TSHZ3, NCK2, ABL2, PFKFB4, CDC14A, USP14, } \\
\text { CANX, SF1, DDX17, INTS6, ACTN2, CADM1, PLEKHB2, OPA1, } \\
\text { NIP30, KIAA1712, BNC2, BAP1, ELK3, TBP, CHD2, NHEJ1, } \\
\text { ZMYND11, C3orf70, RNF41, WNT7B, AFF4, LRP1B, FKTN, } \\
\text { EIF2S2, RBM27, SIRT3, ZCCHC24, CPEB2, SLITRK4, ZNF385B, } \\
\text { DNAJA4, SLC31A1, CCDC4, MEIS1, SLC4A10, IGF1R, RBM24, } \\
\text { TRPS1, FUT10, SCHIP1, MAPK1IP1L, ANKRD13C, SLC30A7, } \\
\text { PIM2, OTUD5, H3F3B, C7orf60, FGF18, MAP2K4, ALS2CR13, } \\
\text { C18orf34, PTPRE, CCND3, RNF138, PMP22, FLRT3, KCNMA1, } \\
\text { EDEM3, GNAT1, DCTN5, ACOX1, ANKRD40, JAM3, ENOX2, } \\
\text { MECP2, MAGED1 }\end{array}$ \\
\hline
\end{tabular}

\subsubsection{Ensaios de proliferação e diferenciação celular in vitro e avaliação da expressão} do miR-505

Para os ensaios in vitro foram utilizados linfócitos $\mathrm{T} \mathrm{CD}^{+}$isolados de PBMCs de doadores saudáveis. A figura 33 mostra a pureza das células obtidas, de um dos experimentos de citometria de fluxo, após separação por esferas magnéticas. Devemos ressaltar que em todos os experimentos realizados a pureza relativa aos linfócitos TCD $4^{+}$foi em torno de $90 \%$.

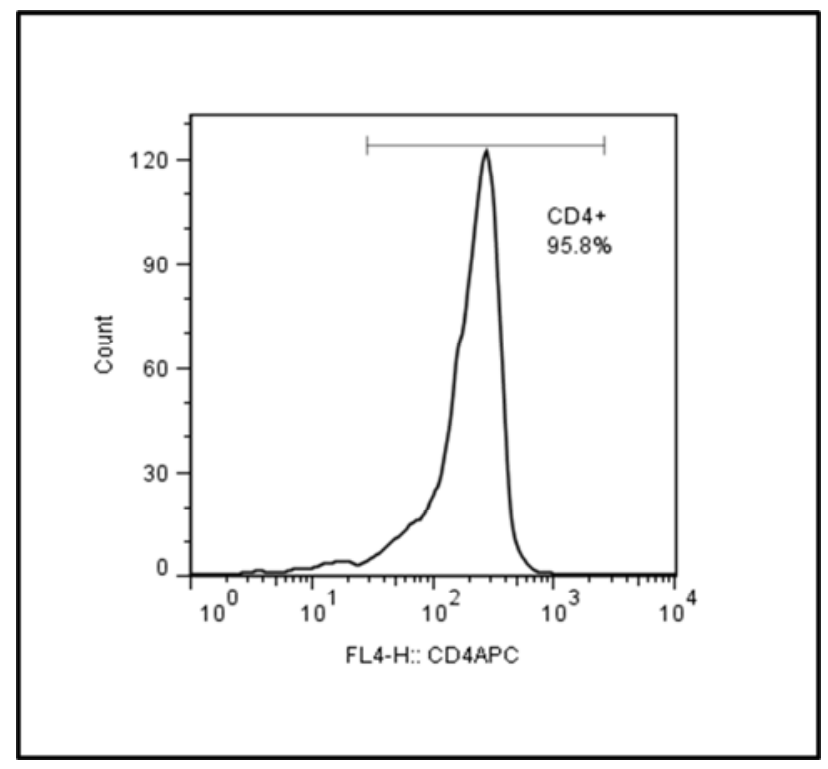

Figura 33. Análise da pureza de células $\mathrm{T} \mathrm{CD}^{+}$provenientes de doadores saudáveis por citometria de fluxo. 
Para verificar se o miR-505 estava relacionado ao processo de proliferação dos linfócitos T, as células isoladas de doadores saudáveis, foram estimulados com anti-CD3 ou anti-CD3/anti-CD28, pelo período de 4, 8, 12, 24, 48, e 72 horas (Figura 34a e b).

Como podemos observar não houve diferença significativa em relação aos períodos analisados.

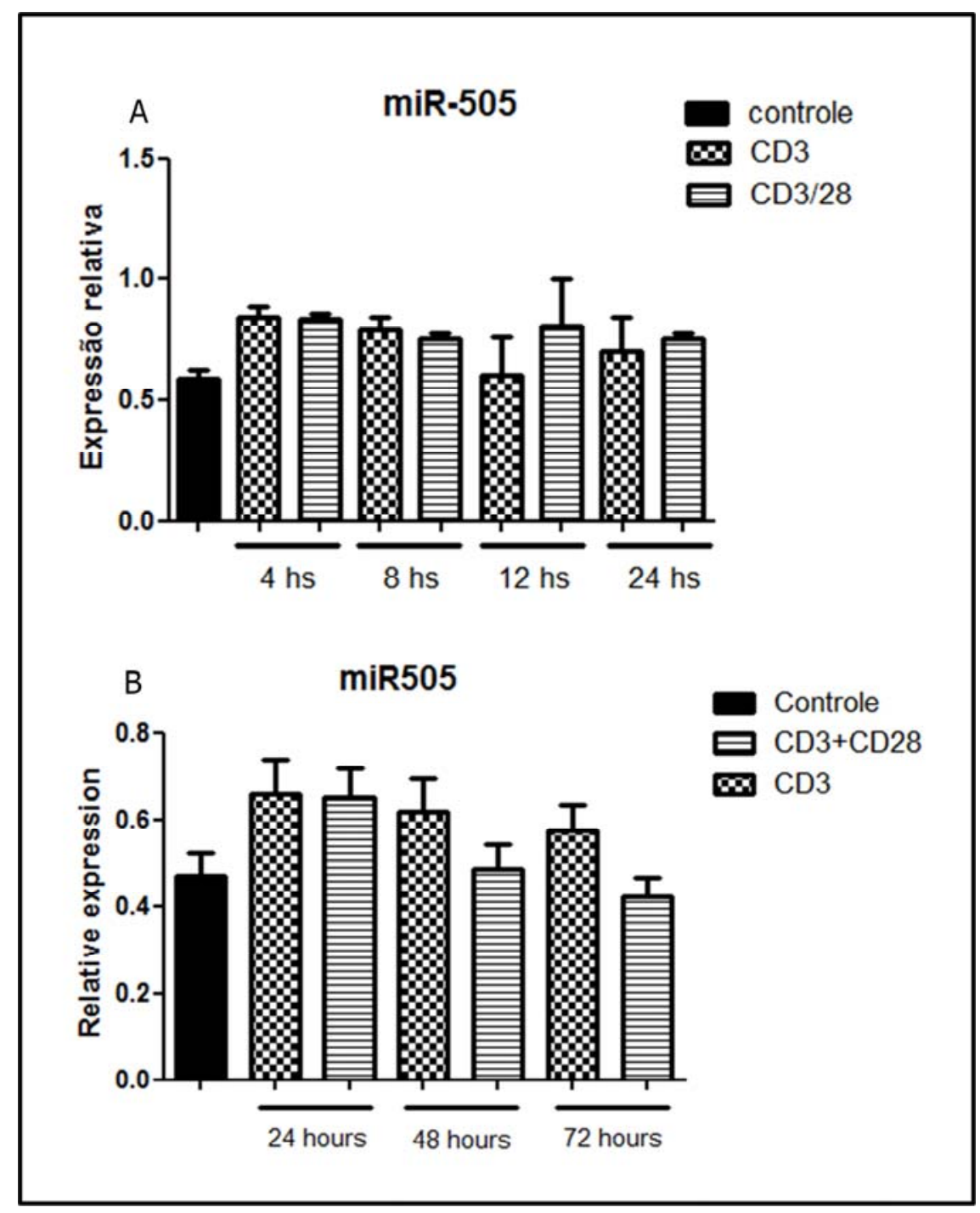

Figura 34. PCR quantitativa do microRNA miR-505 em linfócitos TCD4 ${ }^{+}$estimulados com anti-CD 3 e antiCD3/anti-CD28 a) nos períodos de 4, 8, 12, e 24 horas e b) nos períodos de 24, 48, e 72 horas. Os linfócitos $\mathrm{T}$ foram isolados de PBMCs de indivíduos saudáveis por esferas magnéticas. Como controle foi utilizado linfócitos T recém isolados e não estimulados. Os níveis de expressão foram normalizados utilizando o RNA RUN6B. A diferença entre os grupos foi avaliada utilizando o teste ANOVA seguido de teste de Tukey's comparados ao grupo controle. 
Em seguida fomos verificar se a estimulação por citocinas influenciava a expressão deste microRNA nos linfócitos T. A figura 35 mostra a estimulação de células provenientes de doadores saudáveis, com as citocinas TNF, IL-2 e IL-6, nas concentrações de $25 \mathrm{ng} / \mathrm{ml}$ para o TNF e IL-2, e 100ng/ml para IL-6, nos períodos de 3, 5, e 7 dias.

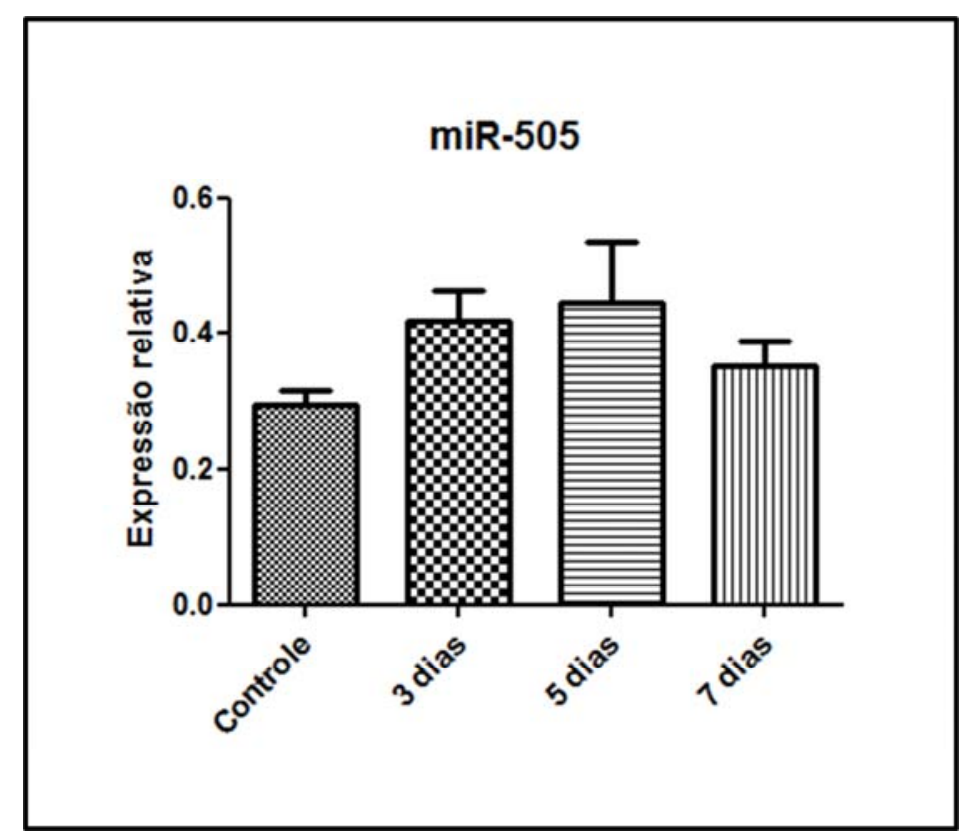

Figura 35. PCR quantitativa do microRNA miR-505, em linfócitos TCD4 ${ }^{+}$estimulados com TNF, Il-2, e IL6 recombinantes na concentração final de $25 \mathrm{ng} / \mathrm{ml}$ (TNF e IL-2), e 100ng/ml (IL-6), nos períodos de 3, 5, e 7 dias. Os linfócitos $\mathrm{T}$ foram isolados de PBMCs de indivíduos saudáveis por esferas magnéticas. Como controle foi utilizado linfócitos $\mathrm{T}$ recém isolados não estimulados. Os níveis de expressão foram normalizados utilizando o RNA RUN6B. A diferença entre os grupos foi avaliada utilizando o teste ANOVA seguido de teste de Tukey's comparados ao grupo controle.

Novamente, não foi possível observar nenhuma diferença significativa entre os grupos analisados. Com base nos resultados obtidos, o miR-505 parece não estar envolvido com o processo de proliferação dos linfócitos T.

O próximo passo foi verificar o nível de expressão deste microRNA nos subtipos específicos de linfócitos T $\mathrm{CD}^{+}$. Para isso, os linfócitos isolados de células do sangue periférico de doadores saudáveis foram diferenciados em Th1, Th2 ou Th17, utilizando como controle células não estimuladas e células não diferenciadas. Para a análise de expressão de miR-505 nos linfócitos $\mathrm{T}$ reguladores (Tregs), as células T CD4 ${ }^{+} \mathrm{CD} 25^{+}$ foram isoladas utilizando-se esferas magnéticas, e as células $\mathrm{TCD} 4^{+} \mathrm{CD} 25^{-}$foram utilizadas como controle. A pureza das Tregs isoladas em todos os experimentos foi sempre maior que $86 \%$ (Figura 36 ). 


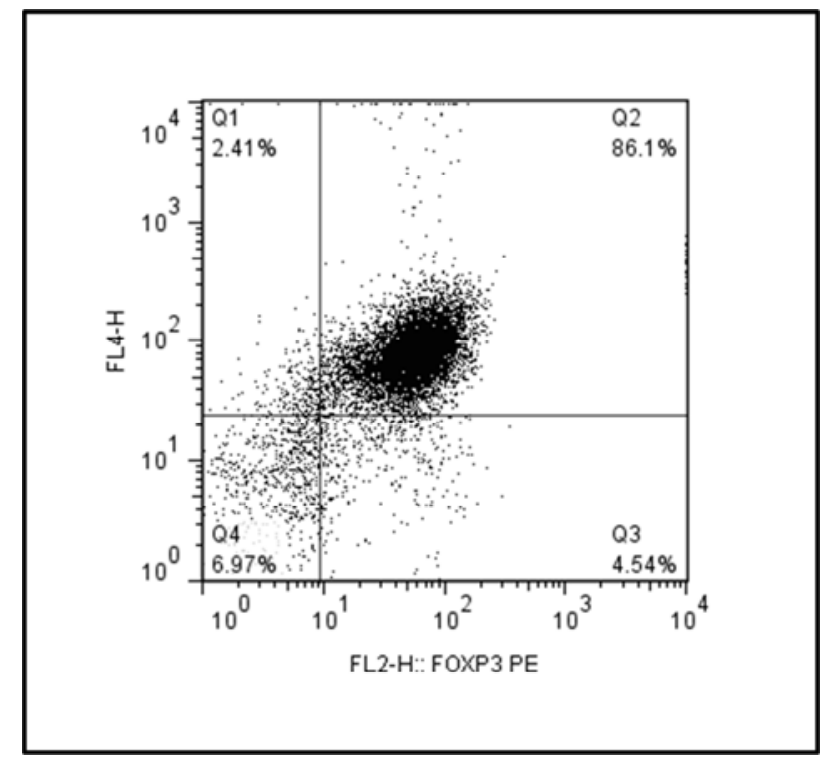

Figura 36. Análise da pureza de células $\mathrm{T} \mathrm{CD} 4^{+} \mathrm{CD} 25^{+} \mathrm{Foxp}^{+}$(Tregs) provenientes de doadores saudáveis por citometria de fluxo.

A figura 37 mostra os níveis de expressão do miR-505 nos diversos subtipos celulares. Como podemos observar, a expressão deste microRNA é reduzida nas células com perfil Th2 (Figura 37a), e nas Tregs (Figura 37b) quando comparado aos demais grupos analisados, e aos respectivos controles.

Ambos os subtipos celulares são de extrema importância para o balanço e o controle da resposta imunológica, o que sugere que nos pacientes esse microRNA pode estar envolvido na supressão de moléculas importantes associadas ao processo de regulação, favorecendo a exacerbação do processo inflamatório característico da AR. 


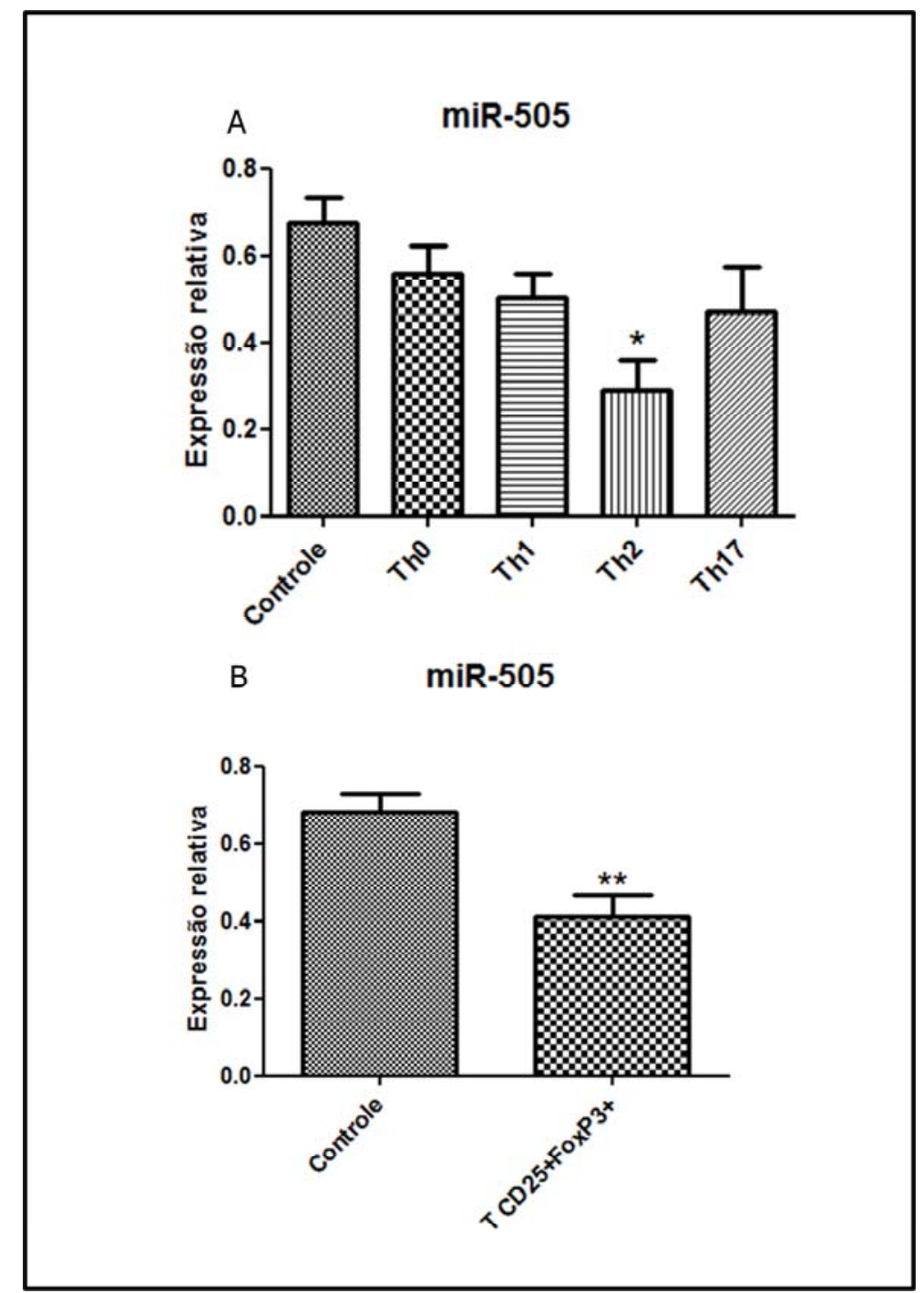

Figura 37. PCR quantitativa do microRNA miR-505, em linfócitos TCD4 ${ }^{+}$a) estimulados com antiCD3/anti-CD28, e Il-12 (10ng/ml) para diferenciação em Th1, IL-4 (10ng/ml) para diferenciação de Th2, e IL-6 $(25 \mathrm{ng} / \mathrm{ml})$, IL-23 $(10 \mathrm{ng} / \mathrm{ml})$ e IL-1 $\beta(10 \mathrm{ng} / \mathrm{ml})$ para diferenciação em Th17 durante 3 dias. Os linfócitos $\mathrm{T} \mathrm{CD}^{+}$foram isolados de PBMCs de indivíduos saudáveis por esferas magnéticas. Como controle foi utilizado os linfócitos $\mathrm{T}$ recém isolados não estimulados e linfócitos $\mathrm{T}$ não diferenciados. As Tregs b) $\mathrm{T}$ $\mathrm{CD}_{25}{ }^{+} \mathrm{FoxP}^{+}$foram isoladas por esferas magnéticas de PBMCs de doadores saudáveis, e as células $\mathrm{T}$ CD25- utilizadas como controle. Os níveis de expressão foram normalizados utilizando o RNA RUN6B. A diferença entre os grupos foi avaliada utilizando o teste ANOVA ou teste t, seguido de teste de Tukey's comparados ao grupo controle. ${ }^{*} P<0.05$ e $* * P<0.01$ foram considerados significantes. 


\subsubsection{Análise dos mRNAs diferencialmente expressos}

Os dados de RNA mensageiros (mRNA) foram normalizados utilizando o 75 percentil e a distribuição dos valores de intensidade dos dados normalizados para cada amostra foram plotados num gráfico Box-whisker. Após a análise estatística por meio de Test-t com $p$-value $\leq 0,05$, e fold-change $\geq 2.0$, no qual as amostras de DBA- $1 / \mathrm{J}$ imunizados com colágeno foram comparadas ao seu respectivo controle, foram evidenciados 13.332 mRNAs diferencialmente expressos (Figura 38). Utilizando-se o banco de dados do Gene Ontology (GO) como ferramenta, e após a escolha de um p-value cut-off $<0,1$ foram selecionados somente os processos biológicos de interesse. Entre eles estão os grupos de genes pertencentes aos processos biológicos de ciclo celular, ativação de linfócitos, sistema imune, processo metabólico e regulação do processo metabólico. 


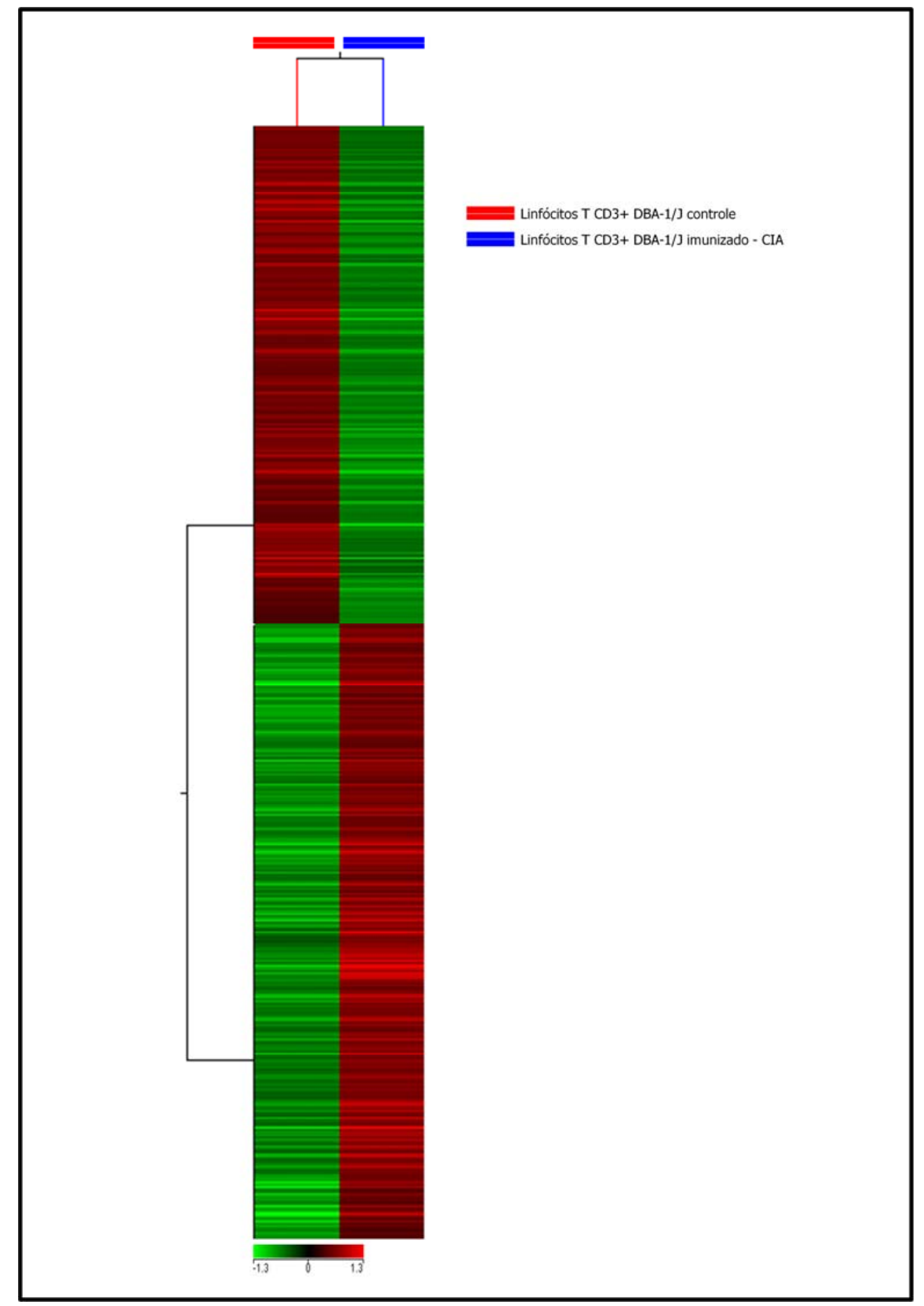

Figura 38. Comparação dos perfis de expressão gênica no camundongo da linhagem DBA-1/J, imunizado com colágeno do tipo II (CIA), e seu respectivo controle. Matriz de expressão de 13.332 MRNA de linfócitos $\mathrm{T} \mathrm{CD}^{+}$periféricos do baço e linfonodo inguinal de camundongos com 12 semanas de idade. O grupo controle recebeu imunização, porém sem a administração de colágeno. A correlação de Pearson foi utilizada como medida de similaridade. $\mathrm{O}$ vermelho representa mRNA com expressão induzida, o verde representa mRNA com expressão reprimida e o preto representa que a expressão do mRNA não variou entre as amostras. 


\subsubsection{Redes de interação miR-505-mRNAs}

Para determinar as interações do miR-505 e seus alvos em camundongo, utilizamos o programa GenMiR ${ }^{++}$, que calcula a probabilidade de interação entre um determinado microRNA e um mRNA baseado nos dados de expressão gênica. Para as análises foi considerado o conjunto dos 13.332 mRNAs diferencialmente expressos nos linfócitos $\mathrm{T}$ $\mathrm{CD}^{+}$periféricos de camundongos DBA-1/J durante a indução da CIA, comparado ao seu respectivo controle.

A figura 39 mostra a interação do microRNAs miR-505 e 39 alvos relacionados aos processos de ciclo celular, ativação de linfócitos, sistema imune, processo metabólico e regulação do processo metabólico.

A tabela VII mostra os potenciais alvos deste microRNA obtidos pelo uso do modelo GenMiR ${ }^{++}$.

Tabela IX. Alvos preditos do microRNA miR-505 utilizando o modelo $\mathrm{GenMiR}^{++}$em camundongos.

\begin{tabular}{|c|c|}
\hline MicroRNA & Alvos preditos \\
\hline miR-505 & $\begin{array}{l}\text { Abcb1a, Als2, Apo19a, Cbfb, Cd28, Cdk15, Daf2, Dennd5b, Dst, } \\
\text { Ecscr, Fcamr, Flt3, H1f0, Ikzf2, I12ra, Irf1, Kctd20, Mecom, Myh9, } \\
\text { Nampt, Nup153, Pafah1b1, Pcnt, Pkd2, Ppp2ca, Prkcd, Ptpre, } \\
\text { Rabgap1, Rag1, Rala, Rbbp4, Rps6ka2, Sec1414, Sesn1, Slc4a7, } \\
\text { Stat5b, Trim16, Uhrf2, Zfp474 }\end{array}$ \\
\hline
\end{tabular}




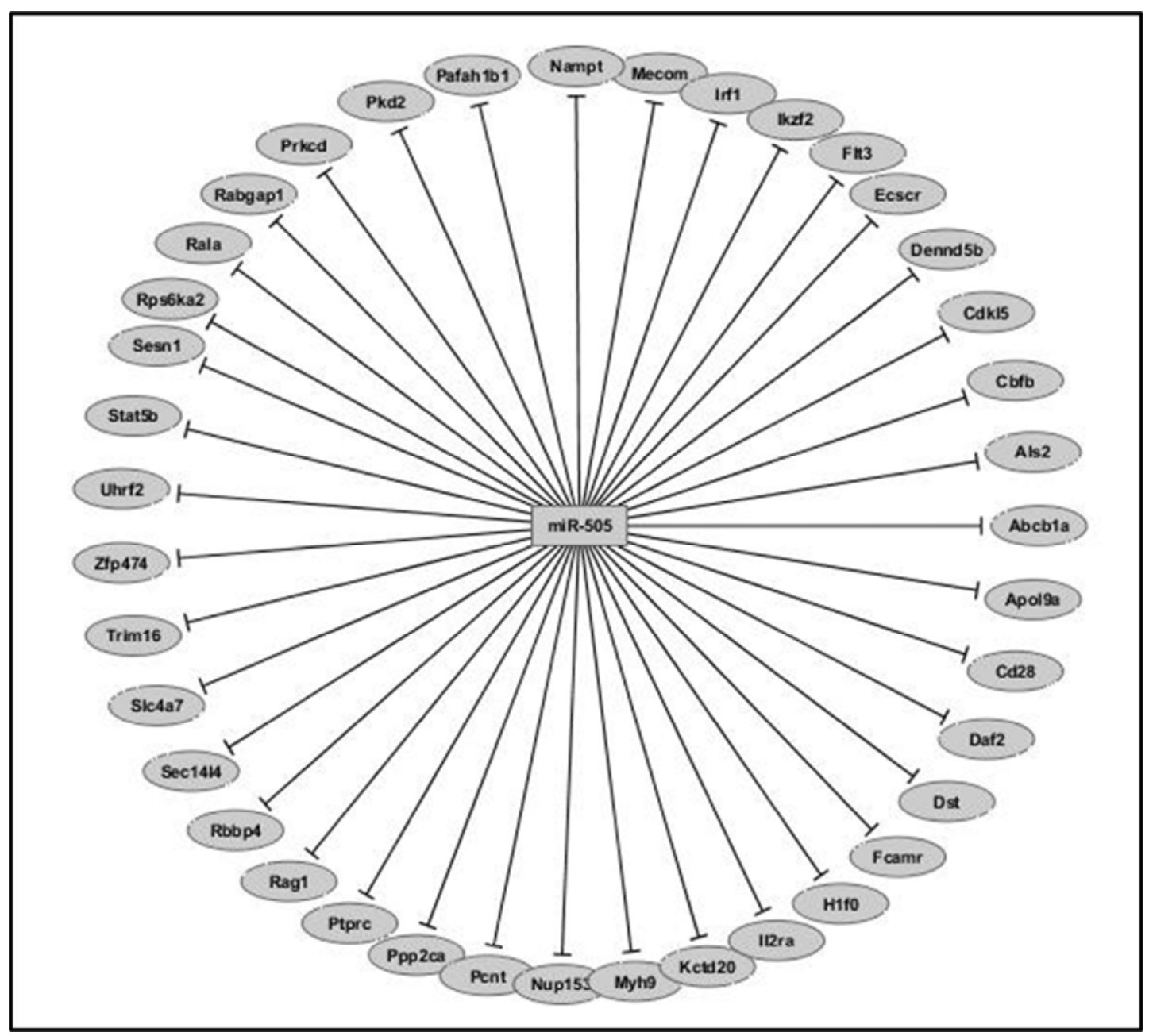

Figura 39. Rede mostrando a interação do microRNA miR-505 e seus respectivos alvos preditos pelo GenMiR ${ }^{++}$.

Comparando os alvos do miR-505 encontrados pelo programa GenMiR ${ }^{++}$em camundongo, e os alvos preditos deste microRNA em humanos baseado no banco de dados targetscan, nós encontramos um gene alvo comum e altamente conservado entre as duas espécies. Esse gene é o IKZF2 (Ikaros family zinc finger 2) que codifica o fator de transcrição Helios. Estudos demonstraram que esse fator é seletivamente expresso em Tregs quando comparado aos linfócitos T convencionais (SUGIMOTO et al., 2006; HILL et al., 2007), e representa um marcador específico das chamadas Tregs naturais, os linfócitos reguladores que se originam no timo (Thornton et al 2011).

Devido a expressão reduzida do miR-505 nas Tregs de doadores saudáveis, e a importância do gene IKZF2 nesse subtipo celular, fomos verificar se o IKZF2 era de fato alvo deste microRNA. 


\subsubsection{Ensaio de luciferase para verificação do gene IKZF2 como alvo do miR-505}

Para determinar se o gene que codifica o fator de transcrição Helios é alvo do microRNA miR-505, utilizamos um ensaio de luciferase. Para o ensaio, a região de ligação do miR-505 no gene IKZF2 foi amplificada por PCR e o produto clonado em vetor contendo o gene da luciferase. Células da linhagem HEK292 foram transfectadas com o vetor contendo o inserto. Posteriormente foi adicionado o mimic miR-505 ou o mimic controle 547. Após 24 horas foi feita a leitura da atividade da luciferase (Figura 40).

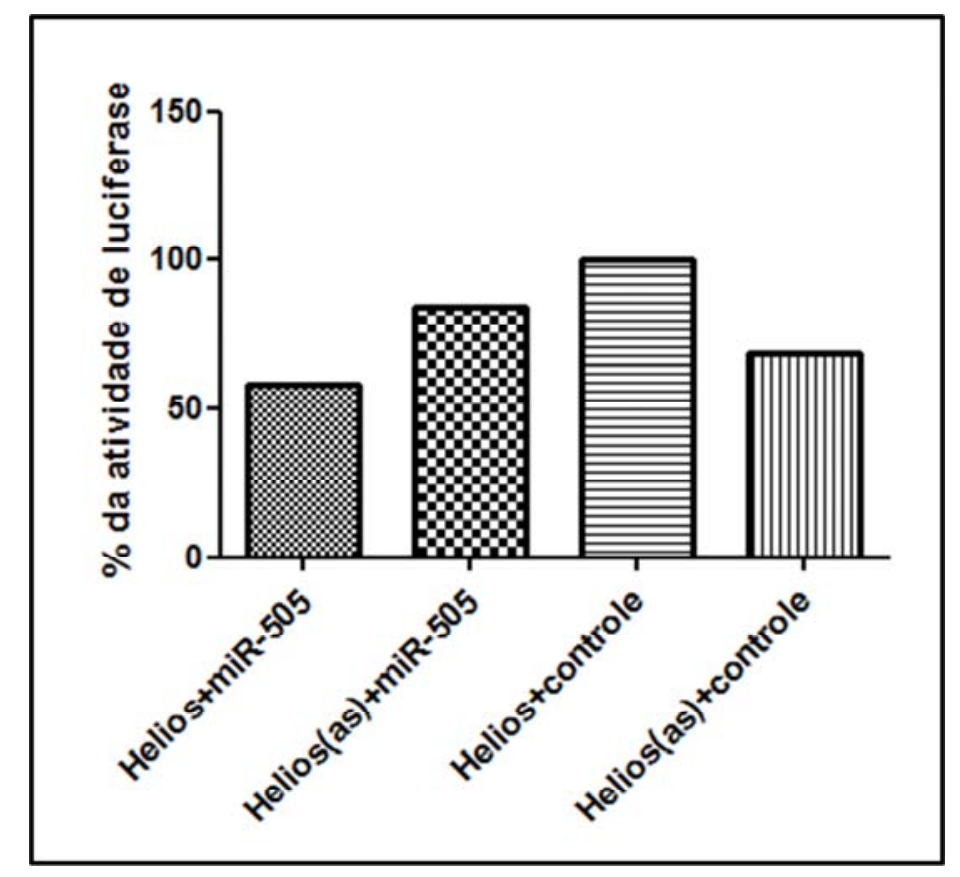

Figura 40. Ensaio de luciferase em células da linhagem HEK292 transfectadas com vetores contendo a região de ligação do miR-505 no gene IKZF2. O inserto foi clonado na direção sense e anti-sense (as). Após a transfecção foram adicionados o mimic miR-505 ou o mimic controle 547 $(40 \mathrm{nM})$. As células permaneceram em cultura em estufa $5 \% \mathrm{CO}_{2}$ a $37^{\circ} \mathrm{C}$ por um período de 24 horas antes da leitura da atividade da luciferase.

Como podemos observar, houve uma redução de quase $50 \%$ da atividade da luciferase, mostrando grande probabilidade do gene IKZF2, que codifica a proteína Helios ser realmente alvo do miR-505. Entretanto, vale ressaltar que um novo experimento deve ser realizado para confirmação dos resultados obtidos. 
DISCUSSÃO 


\section{DISCUSSÃO}

Uma das propriedades mais notáveis do sistema imunológico é a capacidade de distinguir antígenos próprios de antígenos estranhos (não-próprios) estabelecendo a tolerância imunológica. Muitas das doenças auto-imunes parecem ser resultadas de falha na tolerância central, que envolve o processo de seleção tímica dos linfócitos, onde diferenças quantitativas de expressão de antígenos e/ou a resposta dos linfócitos a eles podem afetar esse mecanismo, culminando com reações autoimunes agressivas na periferia. A tolerância do repertório de células $\mathrm{T}$ ao próprio é adquirida pela interação de seus receptores de antígenos (TCR) aos peptídeos ligados ao complexo maior de histocompatibilidade (MHC) e, por isso, a diversidade de antígenos expressos no timo é de grande importância. A expressão de antígenos ectópicos no timo é chamada de expressão gênica promíscua (PGE). A PGE é uma propriedade fisiológica característica das células tímicas epiteliais medulares (mTECs) e é a base da indução do processo de tolerância central (KYEWSKI et al., 2002).

A presente Tese de Doutorado faz parte da linha de pesquisa do Grupo de Imunogenética Molecular, coordenado pelo Professor Geraldo A. Passos, sobre a genética molecular da tolerância central, focando a PGE. Nessa linha de pesquisa, utilizamos modelos murinos (M. musculus) que reproduzem doenças autoimunes, como por exemplo, o camundongo non-obese diabetic (NOD) que desenvolve o diabetes mellitus do tipo 1 (DM-1) e os camundongos DBA-1/J e DBA-2/J que são respectivamente susceptíveis e resistentes ao desenvolvimento de artrite reumatóide induzida pela imunização com colágeno, (collagen-induced arthritis, CIA).

Durante nosso trabalho de mestrado (Donate, 2008), realizamos o estudo da PGE no modelo de susceptibilidade/resistência a artrite experimental. Nossos resultados demonstraram que no estroma tímico da linhagem DBA-1/J (susceptível a indução de CIA) há expressão de um menor número de antígenos relacionados ao sistema locomotor (osso e cartilagem), quando comparado com a linhagem resistente DBA- 2/J. A menor diversidade desses autoantígenos no timo poderia atenuar a seleção negativa de linfócitos $\mathrm{T}$ autorreativos, contribuindo assim com o processo de auto-imunidade. Além disso, a observação de que o MRNA de pró-colágeno II teve sua transcrição diminuída no estroma tímico de animais DBA-1/J submetidos ao esquema de imunização, reforçou ainda mais a sugestão apresentada. Além disso, no mestrado, realizamos um estudo sobre a interação entre os genes de auto-antígenos no timo, o que foi 
evidenciada por meio de redes de interação transcricional. Demonstramos que o gene do MHC-H2 interage de maneira diferente com genes down-stream de auto-antígenos nessas duas linhagens de camundongo. Esses resultados do trabalho de mestrado foram publicados em revista internacional (DONATE et al., 2011).

No presente trabalho de doutorado, continuamos com a linha de controle da expressão gênica na autoimunidade em artrite experimental (CIA), mas desta vez focamos os timócitos e linfócitos periféricos. Além de investigarmos os perfis da expressão gênica em grande escala (perfis do transcriptoma de mRNAs), investigamos a expressão de microRNAs (miRNAs), pois esta classe de RNAs desempenham papel importante no controle póstranscricional. Perguntamos se as interações miRNA-mRNA são diferentes nas linhagens DBA-1/J e DBA-2/J. Nossa principal metodologia é a dos microarrays para a determinação da variação da expressão gênica seguida de análise bioinformática dos dados, o que inclui a reconstrução de redes de interação miRNA-mRNA. Mas para respondermos a essas questões, precisamos conhecer melhor nosso modelo experimental de CIA.

A artrite reumatóide (AR) é caracterizada por um influxo descontrolado de células inflamatórias na articulação, que podem causar eventual destruição articular. O papel dos diferentes subtipos de linfócitos T efetores na manutenção, local ou sistêmica, e na indução do processo inflamatório da doença, têm sido mais bem compreendido pela utilização de modelos animais.

Motivados pela importância dessas células em uma doença complexa como a AR, decidimos que os linfócitos $\mathrm{T}$ deveriam corresponder um dos principais focos do presente estudo. Para o desenvolvimento do trabalho, foram utilizados os timócitos, e os linfócitos T $\mathrm{CD}^{+}$totais provenientes de baço e linfonodos inguinais dos camundongos das linhagens DBA-1/J e DBA-2/J, não imunizados e durante a indução de CIA.

Além dos estudos com camundongos e modelo experimental de artrite, estendemos nossa investigação com linfócitos de pacientes com AR. Isso representa um esforço de transportar o conhecimento fundamental dito "de laboratório" para a doença humana.

\subsection{Caracterização da população de linfócitos T $\mathrm{CD}^{+}$total}

Com o objetivo de interpretar melhor os dados obtidos com microarrays, realizamos uma caracterização da população de linfócitos $\mathrm{T} \mathrm{CD}^{+}$total, quanto à sua expressão dos marcadores CD4, CD8, CD25, Foxp3 e Roryt. 
No modelo de artrite induzida por colágeno (CIA), os linfócitos T $\mathrm{CD}^{+}$ apresentam um papel importante na indução da doença nos camundongos imunizados (MAURI et al., 1997; DONCARLI et al., 1997), e são essenciais para a transferência adotiva da doença para camundongos SCID (KADOWAKI et al., 1994).

Nossos resultados de citometria de fluxo mostraram não haver diferença significativa entre as duas linhagens (DBA-1/J e DBA-2/J), nos grupos analisados (Figura 13a). A porcentagem de linfócitos $\mathrm{T} \mathrm{CD}^{+}$aumenta após o processo de imunização, mesmo na ausência do colágeno. Esses resultados eram de certa forma esperados, já que o adjuvante utilizado no processo de imunização é capaz de promover a expansão de células do sistema imune.

A capacidade de alguns adjuvantes, que não apresentam propriedades imunogênicas, por si só causarem artrite em ratos de linhagens susceptíveis já havia sido observada (HOLMDAHL et al., 1992). O papel dos adjuvantes em modelos animais de AR, principalmente a CIA, foi recentemente revisado (BILLIAU \& MATTHYS, 2011). Postulou-se que a causa primária da artrite no modelo de CIA seria a estimulação exacerbada do sistema imune inato, resultando em um processo inflamatório sistêmico. A presença de bactérias no adjuvante daria início a uma resposta imune específica, com participação de linfócitos do subtipo Th1 e Th17. Os linfócitos específicos para o colágeno apareceriam em um estágio posterior, após a destruição da cartilagem por um grande influxo de células provenientes do baço e exposição do antígeno aos linfócitos específicos, caracterizando um processo autoimune.

A importância dos linfócitos $\mathrm{T} \mathrm{CD}^{+}$na $\mathrm{AR}$ ainda é controverso, já que os estudos em modelos animais revelam papeis contraditórios dessas células na indução ou proteção da doença. Estudos no modelo de CIA sugerem que a habilidade dos camundongos DBA1/J desenvolverem artrite na ausência de linfócitos T $\mathrm{CD}^{+}$, se deve a presença de células T $\mathrm{CD}^{+}$(TADA et al., 1996). No mesmo estudo a ausência de linfócitos T CD8 $8^{+}$foi capaz de reduzir a incidência da doença, mas não apresentou nenhum efeito na sua severidade.

Foi possível observar resultados bem interessantes em relação à porcentagem dos linfócitos $\mathrm{T} \mathrm{CD}^{+}$em nossas amostras (Figura 13b). Houve diferença significativa entre as duas linhagens em todos os grupos analisados. Além disso, nós observamos que apenas no timo há um aumento dessas células nos camundongos da linhagem susceptível DBA-1/J, enquanto que na periferia os camundongos da linhagem DBA-2/J, resistentes a indução de CIA, apresentaram um aumento significante dessas células independente do processo de 
imunização, e da presença do colágeno. Esses dados sugerem que esses linfócitos poderiam apresentar um papel protetor na artrite.

Já é bem conhecido, o papel importante dos linfócitos reguladores (Tregs) $\mathrm{CD}^{+}$ $\mathrm{CD}_{2} 5^{+}$Foxp $^{+}$na prevenção de autoimunidade. No modelo de CIA, essas células podem ser encontradas na articulação, líquido sinovial e linfonodos drenantes do camundongo artrítico (MORGAN et al., 2005; GONZALES-REY et al., 2007), entretanto não são efetivas em suprimir a resposta de linfócitos $\mathrm{T}$ efetores. Recentemente, a função supressora defeituosa das Tregs na AR foi confirmada, e estaria correlacionada a expressão reduzida do fator de transcrição Foxp3 (VALENCIA et al., 2006). Nossos resultados mostraram não haver diferença entre as linhagens, em relação à porcentagem dessas células no timo. Entretanto, na periferia, a porcentagem de linfócitos $\mathrm{CD}_{2} 5^{+}$Foxp $3^{+}$nos camundongos resistentes DBA-2/J é maior na ausência de imunização, bem como na presença de colágeno. Os resultados sugerem que essas células poderiam contribuir para a resistência ao desenvolvimento do processo inflamatório articular crônico, e corroboram com os achados de que a função defeituosa das Tregs estaria relacionada à expressão reduzida de Foxp3 (Figura 13c).

O papel dos linfócitos do subtipo Th17, produtores da citocina IL-17, na patogênese da artrite já é bem estabelecido, e foi confirmado no modelo de CIA (LUBBERTS et al., 2001). Nossos resultados de citometria mostraram uma alta porcentagem desses linfócitos após a indução de CIA nos camundongos susceptíveis da linhagem DBA-1/J, como já era esperado (Figura 13d).

\subsection{Análise dos microRNAs diferencialmente expressos}

A descoberta dos microRNAs representou um passo importante para as pesquisas científicas, e tem revolucionado a biologia e a ciência médica. Esses pequenos RNAs não codificantes são potentes reguladores pós-transcricionais e estão envolvidos nos mais diversos processos fisiológicos.

A primeira indicação de que os microRNAs poderiam regular as resposta imunes surgiu em 2004, com a identificação da expressão dos microRNAs miR-142a, miR-181a e miR-223 em linfócitos B e células mielóides (CHEN et al., 2004). Deste ponto em diante, o papel dos microRNAs na regulação dos processos de maturação, proliferação, diferenciação e ativação passou a ser melhor estudado. Não demorou muito e ficou 
evidente que a expressão dos microRNA deveria ser regulada apropriadamente para manter a homeostase imunológica. Assim, a expressão desregulada de microRNAs foi logo relacionada a uma diversidade de doenças, e sua associação com a indução de autoimunidade vem sendo descrita.

A relação crescente entre os microRNAs e o sistema imune estimulou nosso interesse pelo estudo de novos microRNAs envolvidos nos processos de maturação, desenvolvimento e ativação dos linfócitos T no contexto de autoimunidade.

O papel fundamental dos microRNAs nos desenvolvimento de células $\mathrm{T}$ ficou claro quando a interrupção de sua biogênese, ou ainda a deleção condicional da enzima Dicer, nos progenitores linfóides, prejudicou o desenvolvimento e a quantidade dessas células no timo e em órgãos linfóides periféricos. Além disso, a ausência dos microRNAs resultou em diferenciação e produção de citocinas aberrantes nesses linfócitos (COOB et al., 2005; MULJO et al., 2005).

Utilizando a tecnologia dos microarrays, nos traçamos o perfil transcricional dos

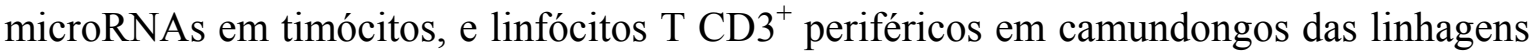
DBA-1/J e DBA-2/J, modelo este, que nos permite o estudo das bases moleculares que podem estar envolvidas a susceptibilidade/resistência a artrite experimental.

Nossos resultados evidenciaram 91 microRNAs diferencialmente expressos em timócitos e linfócitos $\mathrm{T} \mathrm{CD}^{+}$periféricos de camundongos não imunizados, com 4 semanas de idade (Figura 16), e 62 microRNAs em linfócitos $\mathrm{T} \mathrm{CD}^{+}$periféricos durante a indução de CIA (Figura 17) nos camundongos de ambas as linhagens DBA-1/J e DBA-2/J. Para os estudos de interação microRNA-mRNA foram selecionados apenas os microRNAs induzidos em cada uma das etapas do desenvolvimento dos linfócitos $\mathrm{T}$, e exclusivos das linhagens utilizadas nesse estudo (tabela III). Além dos microRNAs induzidos nos diferentes grupos, foram acrescentados dois microRNAs que se encontravam reprimidos apenas no camundongo susceptível da linhagem DBA-1/J durante o desenvolvimento de CIA, tendo como base o envolvimento entre a expressão desregulada de microRNAs e o processo autoimune.

Dos microRNAs selecionados, somente os microRNAs miR-100, miR221 e miR181a já foram previamente identificado em linfócitos T. Em um estudo de como os microRNAs estariam afetando a expressão de genes codificadores de moléculas envolvidas na diferenciação de subtipos de linfócitos $\mathrm{T}$, o perfil específico de diversos microRNAs foi determinado. Entre eles, o miR-100 estava induzido em linfócitos T CD4 ${ }^{+}$naives. 
O miR-221 foi encontrado recentemente expresso em linfócitos $\mathrm{T}$ humano durante o processo de ativação com CD3/CD28 (GRIGORVYEV et al., 2011). Por outro lado, a função do miR-181a nos linfócitos T já é bem conhecida. Esse microRNA apresenta papel fundamental na maturação dessas células regulando a intensidade de sinalização do receptor de células T (TCR), durante a seleção positiva e negativa no timo (LI et al., 2007).

Nos nossos resultados o miR-100 foi encontrado em timócitos da linhagem resistente a indução de CIA DBA-2/J, o miR-221 em timócitos da linhagem susceptível DBA-1/J, e o miR-181a expresso nos linfócitos $\mathrm{T}$ ativados durante a indução de CIA, também da linhagem DBA-1/J.

Outros microRNAs já bem conhecidos e com funções documentadas no desenvolvimento de linfócitos T, são o miR-155, o miR-150, e o miR-146a. O miR-155 é expresso durante a ativação dos linfócitos $\mathrm{T}$ e é importante para manutenção da homeostase dessas células e sua diferenciação no subtipo Th1. Além disso, esse microRNA é importante para o desenvolvimento das Tregs, mas não é essencial pra sua função supressora (THAI et al., 2007; KOHLHAAS et al., 2009). O miR-150, por sua vez, é expresso em células maduras, mas não nos progenitores (MONTICELLI et al .,2005). Com relação ao miR-146a, ele é expresso durante a diferenciação dos linfócitos $\mathrm{T}$ e favorece o subtipo Th1, sendo a sua expressão não detectada no subtipo Th2. Estudo recente revelou ainda, que esse microRNA é expresso nas Tregs e controla a supressão de respostas inflamatórias atuando no fator de transcrição STAT1 (LU et al., 2010; MONTICELLI et al $., 2005)$.

Esses microRNAs já bem descritos foram encontrados nas nossas análises, em linfócitos T periféricos de camundongos não imunizados. Entretanto, não houve diferença nos níveis de expressão quando as duas linhagens utilizadas foram comparadas. Esses achados sugerem que esses microRNAs são importantes para homeostase e diferenciação dos linfócitos, mas não estão relacionados com a susceptibilidade/resistência a CIA.

Recentes estudos estão identificando o papel de microRNAs específicos na AR, e uma desregulação na sua expressão parece contribuir para os mecanismos moleculares da doença. Li e colaboradores investigaram a expressão e a função dos microRNAs em linfócitos $\mathrm{T} \mathrm{CD}^{+}$do líquido sinovial e sangue periférico em pacientes com AR. Eles encontraram uma expressão aumentada do miR-146a, enquanto os microRNAs miR-363 e miR-498 estavam reprimidos (LI et al., 2010). Um segundo trabalho, desenvolvido por Fulci e colaboradores, realizou a análise da expressão dos microRNAs em linfócitos $\mathrm{T}$ de 
sangue periférico comparando pacientes e indivíduos saudáveis, e encontraram a expressão do miR-223 em linfócitos $\mathrm{T} \mathrm{CD}^{+}$naives de pacientes (FULCI et al.,2010). Dos microRNAs associados a artrite, nenhum deles foi evidenciado nas nossas análises.

Os microRNAs encontrados em nosso estudo, estão relacionados a funções diversas como o desenvolvimento e a lactação de glândulas mamárias no camundongo (CUI et al., 2011); na diferenciação de células tronco embrionárias (REN et al., 2009; KIM et al., 2011); isquemia renal (GODWIN et al., 2010); associados a modelos de retinite pigmentosa (LOSCHER et al., 2011), sepsis (SWEENEY et al., 2010), e lúpus (DAÍ et al., 2010); ou ainda encontrados no sistema nervoso central e em gânglios periféricos (WHEELER et al., 2006; YU et al., 2011). Entretanto, a grande maioria desses microRNAs está relacionada aos mais diversos tipos de câncer, já que é a doença no qual os microRNAs foram melhor estudados. Dois dos microRNAs encontrados em nossas análises, o miR196b e miR-1897-5p não apresentam ainda nenhum relato na literatura.

Assim, nosso estudo encontrou novos microRNAs associados ao desenvolvimento de linfócitos $\mathrm{T}$, e a expressão diferencial desses microRNAs específicos nas linhagens resistente e susceptível a indução de CIA corrobora com a nossa hipótese, de que a expressão alterada de microRNAs nas células $\mathrm{T}$ poderia contribuir para o processo de autoimunidade.

\subsection{Análise das redes de interação microRNA-mRNA}

Os experimentos realizados em escala genômica objetivam avaliar os processos biológicos como um todo, mas com precisão molecular. O uso da bioinformática na análise da expressão gênica revela uma profunda lógica molecular e biológica no entendimento da ativação e diferenciação celulares (STAUDT \& BROWN, 2000).

O estudo das redes de interação microRNA-MRNA foi realizado com o intuito de identificar RNA mensageiros (mRNA) alvos na susceptibilidade/resistência a artrite experimental. Para isso, além do perfil de expressão de microRNAs, realizamos em paralelo o perfil transcricional dos mRNAs, e com o objetivo de entender as etapas que envolvem o desenvolvimento, maturação e ativação das células $T$, nossa análise foi dividida em duas etapas. Na comparação de timócitos e linfócitos $\mathrm{T} \mathrm{CD}^{+}$periféricos de camundongos não imunizados, de ambas as linhagens (DBA-1/J e DBA-2/J), foram evidenciados 14.230 mRNAs diferencialmente expressos (Figura 14). Utilizando-se o 
banco de dados do Gene Ontology (GO) como ferramenta, foram selecionados somente os processos biológicos de interesse para o estudo. Entre eles estão os grupos de genes pertencentes aos processos biológicos de adesão e diferenciação celular, recombinação, regulação da apoptose e genes associados ao sistema imune.

$\mathrm{Na}$ segunda etapa foram analisados os genes diferencialmente expressos em linfócitos $\mathrm{T}$ periféricos de camundongos imunizados com colágeno, ou seja, durante a emergência da CIA, e seus respectivos controles, de ambas as linhagens DBA-1/J e DBA2/J. Foram evidenciados 3.155 mRNAs diferencialmente expressos (Figura 15), e os genes relacionados aos processos de resposta imunológica, resposta inflamatória, morte celular e ativação e proliferação de células $T$, foram selecionados. Somente os mRNAs dos processos biológicos de interesse, e os microRNAs específicos de cada linhagem em cada uma das etapas do desenvolvimento das células $\mathrm{T}$ foram utilizados para confecção das redes de interação.

Os microRNAs são capazes de induzir repressão transducional ou degradação do MRNA alvo, regulando assim os níveis da proteína codificadas por eles. O processo de degradação, por muito tempo foi considerado um modo de repressão dominante em plantas (JONES-RHOADES et al., 2006), devido ao pareamento perfeito entre microRNA e seu respectivo alvo. Entretanto, experimentos utilizando a tecnologia dos microarrays revelaram uma redução nos níveis de mRNAs (LIM et al., 2005; REHWINKEL et al., 2006), e trabalho recente demonstrou que a regulação exercida tanto por microRNAs endógenos quanto ectópicos, era responsável pela redução dos níveis de mais de $84 \%$ dos mRNAs codificadores das proteínas que se apresentavam com baixa expressão (GUO et al., 2010). Essa redução é causa de um processo denominado "desestabilização do MRNA alvo", e é caracterizado por deadenilação, remoção do revestimento 5', ocasionando a rápida degradação do mRNA.

A identificação dos alvos de microRNA é em grande parte ainda realizada por predição, baseado principalmente na sequência e na conservação dos mRNA ao longo das espécies. Vale ressaltar que, apesar de ser uma ferramenta muito importante para os estudo de microRNAs, o índice de falso-positivos ainda é alto, o que estimula o desenvolvimento de programas computacionais que tentam sanar essas falhas.

O programa GenMiR ${ }^{++}$é um modelo baesiano que identifica as interações microRNA-mRNA baseado não na sequência, mas nos dados de expressão obtidos por microarrays (HUANG et al., 2007), e leva em consideração o fato de que grande parte dos 
mRNAs alvos são degradados com a expressão dos microRNAs. No nosso estudo o algoritmo GenMiR ${ }^{++}$aliado ao programa gráfico citoscape, foram utilizados para confecção das redes de interação microRNA-mRNA (Figuras 18-28).

Alguns mRNAs interessantes e importantes para o desenvolvimento das células $T$, e relacionados ao seu processo de diferenciação durante uma resposta imune, foram encontrados como alvos dos microRNAs selecionados e serão discutidos (Tabelas IV e V).

Os genes Rag1 e Rag2 atuam no processo de recombinação V(D)J, que gera a diversidade dos receptores de antígeno (TCR) e é o processo central em torno do qual a maturação do linfócito está organizado (SCHATZ \& JI, 2011). Seus respectivos mRNAs foram identificados como alvos de microRNAs expressos em timócitos do camundongo da linhagem DBA-1/J, em linfócitos $\mathrm{T} \mathrm{CD}^{+}$de camundongos não imunizados de ambas as linhagens (DBA-1/J e DBA-2/J), e por uma grande quantidade dos microRNAs expressos na linhagem DBA-2/J após a imunização com colágeno. Esses resultados estão de acordo com o fato de que as populações de linfócitos $\mathrm{T}$ utilizados para marcação dos microarrays em nosso estudo, já possuem seu TCR formado expresso na superfície celular, e não necessitam mais do processo de recombinação. Por isso a expressão desses genes poderia estar sendo regulada por microRNAs.

O gene Notch3 codifica uma proteína, membro da família dos receptores Notch, que controla a progressão do ciclo celular e apoptose em diferentes tipos celulares, além de ser essencial para a diferenciação dos progenitores de células T. A sua expressão é aumentada nos timócitos duplo negativos $\left(\mathrm{CD}^{-} \mathrm{CD}^{-}\right)$e duplo positivos $\left(\mathrm{CD} 4^{+} \mathrm{CD}^{+}\right)$, quando comparado aos timócitos simples positivos $\left(\mathrm{CD}^{+}\right.$ou $\mathrm{CD}^{+}$) (BELLAVIA et al., 2003; CAMPESE et al., 2003). Recentemente foi demonstrado que a sua regulação é controlada pelo microRNA miR-150, e que a expressão forçada desse microRNA interfere na transição do estágio duplo negativo 3 para o 4 (GHISI et al., 2011). O mRNA de Notch3 foi encontrado como alvo de microRNAs expressos em linfócitos $\mathrm{T} \mathrm{CD}^{+}$ periféricos de camundongos da linhagem $\mathrm{DBA}-1 / \mathrm{J}$ que não passaram pelo processo de imunização, corroborando com os achados da literatura. Como esse mRNA não aparece como alvo de microRNAs expressos na linhagem DBA-2/J, outros mecanismos de regulação devem estar atuando para garantir sua baixa expressão, baseado na informação de que camundongos que expressam constitutivamente a forma ativa de Notch3 desenvolve linfomas agressivos mediado por células T (XIAO et al., 2007). 
O gene Foxp3 codifica um fator de transcrição essencial para o desenvolvimento e a função das Tregs (ZIEGLER, 2006; HUEHN, 2009; HA, 2009). O seu mRNA foi identificado como alvo de microRNAs expressos pelos timócitos de ambas as linhagens. Como é no timo que surgem as chamadas Tregs naturais (SAKAGUCHI, 2004; WATANABE et al., 2005), nossos resultados sugerem que os microRNAs podem estar controlando a geração dessas células. Na periferia esse mRNA foi encontrado como alvo de microRNAs induzidos em linfócitos $\mathrm{T}_{\mathrm{CD}}{ }^{+}$na linhagem susceptível a indução de CIA, na ausência de imunização. Esses achados, somados aos resultados de citometria de fluxo que mostram uma menor porcentagem de Tregs na periferia, sugere que os microRNAs estariam controlando a expressão de Foxp3, influenciando negativamente o controle da resposta exacerbada dos linfócitos $\mathrm{T}$ durante o estabelecimento da artrite.

Nas análises das interações microRNA-mRNA envolvendo os linfócitos T CD3 ${ }^{+}$ periféricos durante os processos de imunização e indução de CIA, foram encontrados dados interessantes. Como alvos de microRNAs expressos na linhagem susceptível DBA1/J, encontramos mRNAs associados a mecanismos de controle e/ou balanço da resposta inflamatória que acomete a artrite, como por exemplo, o Stat6, Fas e FasL. O mRNA do gene Stat6 é alvo de muitos microRNAs na linhagem susceptível, durante o desenvolvimento da CIA. Esse gene codifica um fator de transcrição da família STAT (Signal transducer and activator of transcription) ativado por IL-4 e IL-13, e importante mediador da resposta de linfócitos T do subtipo Th2 (revisado por GOENKA et al., 2011). Apesar do papel dos linfócitos Th2 na artrite ser ainda controverso, muitos estudos utilizando o modelo de CIA descreveram o papel protetor de IL-4 (CHU et al., 1996, JOOSTEN et al., 1999; LUBBERTS et al., 2000; SARKAR et al., 2009). Com base nessas informações, nossos dados sugerem que o controle de um fator de transcrição associado com a resposta do tipo Th2 durante a CIA, pode favorecer o padrão pró-inflamatório característico da doença.

Já os genes Fas e FasL codificam moléculas envolvidas no processo de morte celular envolvida por ativação (AICD - activation-induced cell death) importantes para indução de apoptose nos linfócitos $\mathrm{T}$ ativados, e controle da resposta celular in vivo (HUGHES et al., 2008; WEANT et al., 2008). Na AR esses mecanismos parecem estar inibidos e contribuem para a exacerbação do processo inflamatório. Nossos resultados sugerem a participação dos microRNAs no controle dessas moléculas durante a CIA. 
Em contrapartida, na linhagem DBA-2/J, resistente a indução de CIA, nossas redes evidenciaram mRNAs alvos envolvidos no ciclo celular e inflamação, como exemplo, o Foxo3 e o Rorc. O gene Foxo3 codifica um fator de transcrição associado a regulação do ciclo e a sobrevivência celular. Experimentos de microarrays identificaram níveis elevados desse mRNA em PBMCs de pacientes com AR. Esse mesmo resultado foi encontrado em agregados de linfócitos T no tecido sinovial, sugerindo que a expressão desse gene estaria prolongando a sobrevivência dessas células e contribuindo para a inflamação crônica (TURREL-DAVIN et al., 2010).

Já o gene Rorc está implicado com o surgimento dos receptores retinóicos, que correspondem a uma família de receptores nucleares regulados por metabólitos da vitamina A. Entre eles está a variante Roryt, que é importante para a diferenciação do linfócito $\mathrm{T}$ $\mathrm{CD}^{+}$no subtipo Th17 (JETTEN, 2009), implicado em diversas doenças autoimunes, incluindo a AR. O controle desses mRNAs sugere uma contribuição dos microRNAs para o fenótipo resistente dos camundongos DBA-2/J, enquanto que a ausência desse controle na linhagem DBA-1/J, poderia favorecer a diferenciação desse subtipo celular, sua participação na artrite e exacerbação do processo inflamatório.

Além dos genes citados acima, baseado no trabalho de Wang e colaboradores, que comparou o perfil de expressão gênica de linfócitos $\mathrm{T} \mathrm{CD} 3^{+}, \mathrm{CD}^{+}$, e $\mathrm{CD} 8^{+}$ativados (WANG et al., 2008); nós encontramos que muitos dos genes reprimidos após a ativação dessas células foram encontrados como alvos nas nossas redes de interação microRNAmRNA. Como exemplo, nós podemos citar os mRNAs dos genes que codificam para moléculas do MHC, expressos nos linfócitos T em repouso, mas não após sua ativação. Em nossos resultados, esses mRNAs são alvos de muitos microRNAs expressos durante a indução de CIA em ambas as linhagens, e novamente sugere o envolvimento dos microRNAs no controle dessa expressão.

Nós ainda tivemos o interesse de identificar os alvos dos dois microRNAs (miR29a* e miR-135a*) reprimidos durante a indução de CIA, nos camundongos DBA-1/J. MRNAs importantes, que codificam proteínas associadas à ativação e função de células $T$ como o CD28, Zap70 e as citocinas IL-17b e IL-17f foram encontrados com alvos desses microRNAs.

A coestimulação de linfócitos $T$ naives através da ligação CD28/CD80 é provavelmente o sinal secundário mais importante que promove a proliferação e a diferenciação dessas células (KOTANI et al., 2006). 
A molécula Zap-70 por sua vez, é importante para a via de sinalização do TCR, recrutando moléculas downstreams. Mutações nessa molécula prejudicam o desenvolvimento dos linfócitos T e a estimulação do TCR, interrompem os processos de seleção positiva e negativa no timo, além de reduzir o número de Tregs (HSU et al., 2009).

A família da citocina IL-17 é constituída por 6 membros: IL-17A-F. A expressão de cada membro e a sua contribuição para a patogênese da artrite foi recentemente descrita no modelo de CIA (YAMAGUCHI et al., 2007). A expressão da citocinas IL-17A, IL-17B, IL17C, IL-17F, e seus respectivos receptores são expressos nas articulações dos camundongos artríticos quando comparados aos controles. As citocinas IL-17A e IL-17F são expressas exclusivamente na população $\mathrm{CD}^{+}$de linfócitos $\mathrm{T}$, enquanto a expressão de Il-17B é encontrada na cartilagem, e a Il-17C expressa em linfócitos T CD4 ${ }^{+}$e células mielóides.

$\mathrm{O}$ fato de esses mRNAs terem sido encontrados como alvos dão suporte a nossa hipótese de que uma desregulação de microRNAs na patogênese da artrite experimental estariam contribuindo para a exacerbação do processo de autoimunidade. Além disso, muitas das interações encontradas neste trabalho não foram previamente descritas ou preditas nos bancos de dados. Para validar algumas de nossas interações (tabela IV) fizemos uso da ferramenta de bioinformática RNAhybrid (REHMSMEIER et al., 2004; KRÜGER \& REHMSMEIER, 2006). O programa apresenta como metodologia um algoritmo de programação dinâmica que calcula o local para a hibridação, entre RNAs, mais favorável em termos de energia. Essa metodologia é baseada no princípio da propriedade termodinâmica de interação microRNA-mRNA, na qual uma fita dupla de RNA é mais estável, ou seja, a ligação entre o microRNA e mRNA é mais forte, quando a energia livre é menor (LEWIS et al., 2005). A interação é determinada pelo cálculo da mínima energia livre, ou mfe (do inglês minimum free energy), normalizada pelo comprimento do mRNA alvo. Para um microRNA de $\sim 22$ nt de comprimento e um mRNA de $\sim 1000 \mathrm{pb}$, a mfe ideal é $\sim 20 \mathrm{kcal} / \mathrm{mol}$. Como grande parte dos microRNAs e seus alvos se enquadram nessa característica, adotamos uma mfe mínima de $\sim 20 \mathrm{kcal} / \mathrm{mol}$ para confirmar as interações.

\subsection{Papel do miR-505 nos linfócitos T na artrite reumatóide}

Para a identificação de novos microRNAs associados a AR, selecionamos alguns dos microRNAs obtidos em nosso estudo com camundongos. Utilizando a tecnologia dos microarrays, nós analisamos o perfil transcricional dos microRNAs em linfócitos T CD3 ${ }^{+}$ 
periféricos de camundongos DBA-1/J durante o desenvolvimento de CIA. Nossos resultados evidenciaram 75 microRNAs diferencialmente expressos (Figura 29). Baseado nos valores de fold-change e na conservação dos microRNAs entre as duas espécies (humano e camundongo), foram selecionados 8 microRNAs: 4 deles induzidos na CIA quando comparados ao controle (miR-500, miR-505, miR-30b* e miR-29b*) e 4 reprimidos (miR-29a*, miR-let-7d, miR-15b* e miR-135a*), para investigação nos linfócitos $\mathrm{T} \mathrm{CD}^{+}$de pacientes e indivíduos saudáveis (Tabela VI). A expressão relativa desses microRNAs foi quantificada por PCR quantitativa em tempo real (Figura 30 e 31).

Apesar de identificarmos algumas diferenças na expressão dos microRNAs entre os grupos analisados, o miR-505 foi o que mais chamou nossa atenção por sua alta expressão nos pacientes resistentes ao tratamento com anti-TNF, comparados aos demais grupos, e por ser o único a apresentar o mesmo perfil visto em camundongo. Poucas são as informações na literatura a respeito deste microRNA. Sua expressão foi identificada em tumor de glândulas mamárias (ZHU et al., 2011), e ele parece estar envolvido no processo de senescência em fibroblastos embrionários de camundongo (VERDUCI et al., 2010). Além disso, nunca antes foi sugerido a participação do miR-505 no processo de autoimunidade, ou seu envolvimento com linfócitos T.

Após analisar a lista de alvos preditos do miR-505 pelo banco de dados Targetscan (www.targetscan.org/), encontrarmos alguns alvos relacionados a ciclo celular (ANAPC11, CDC14A, CHEK1, CCND3) e com a via de sinalização do receptor de células T (NCK2, CBL). Notamos que esse microRNA parece não estar envolvido com a proliferação dos linfócitos $\mathrm{T}$, já que após estímulo in vitro, com anti $\mathrm{CD} 3 / \mathrm{CD} 28$ ou com citocinas não houve diferença significante na expressão do miR-505 nos diferentes tempos analisados (Figura 34 e 35).

Quando a expressão deste microRNA foi analisada nos diferentes subtipos de linfócitos $\mathrm{T} \mathrm{CD}^{+}$, foi possível verificar níveis reduzidos no subtipo Th2, e nas Tregs (Figura 37). Ambos os subtipos celulares são de extrema importância para o balanço e o controle da resposta imunológica, o que sugere que nos pacientes esse microRNA pode estar envolvido na supressão de moléculas importantes associadas ao processo de regulação, favorecendo a exacerbação do processo inflamatório característico da AR.

Utilizando o algoritmo GenMiR ${ }^{++}$para confecção das interações microRNAmRNA com o intuito de identificar os potenciais alvos em camundongo e compará-los com os já descritos em humanos, nós encontramos um gene alvo comum e altamente 
conservado entre ambas as espécies, o IKZF2. Esse gene codifica o fator de transcrição Helios, que faz parte da família de fatores de transcrição Ikaros. Essa família é composta de cinco membros de proteínas que se ligam ao DNA, e apresentam 6 domínios altamente conservados de $\mathrm{C} 2 \mathrm{H} 2$ zinc fingers. Quatro desses domínios N-terminais estão envolvidos com a ligação ao DNA, e os outros dois são responsáveis pela formação de dímeros de proteína (COBB \& SMALE, 2005). Dois dos seus membros, Eos e Pegasus, são amplamente expressos em uma variedade de tecidos, enquanto que os outros 3, Ikaros, Helios e Aiolos, são expressos em células hematopoiéticas (KELLEY et al., 1998; MORGAN et al., 1997). O fator de transcrição Helios, foi originalmente clonado de uma linhagem de tumor tímico, e sua expressão determinada em uma subpopulação não definida de linfócitos T (HAHM et al., 1998). Estudos posteriores de microarrays mostraram que esse fator era seletivamente expresso em linfócitos Foxp $^{+}$quando comparado aos linfócitos T convencionais (SUGIMOTO et al., 2006; HILL et al., 2007).

Recentemente, foi demonstrado que o Helios representa um marcador específico das chamadas Tregs naturais, linfócitos reguladores que se originam no timo, já que os linfócitos $\mathrm{T}$ induzidos a expressar o fator Foxp3 na periferia, não expressam esse fator de transcrição (THORNTON et al., 2011). Dada a expressão reduzida de miR-505 nas Tregs de doadores saudáveis, e a importância do gene IKZF2 nesse subtipo celular, fomos verificar se o Helios era de fato alvo deste microRNA. Para isso, utilizamos um ensaio de luciferase (Figura 40), no qual foi observado uma redução de quase 50\% na atividade da enzima, demonstrando grande probabilidade do gene IKZF2, que codifica a proteína Helios, ser alvo do miR-505.

Esses achados são promissores, baseado no fato de que a deficiência das Tregs em pacientes com AR é bem conhecida. Essas células estão presentes nos pacientes, entretanto, apresentam baixa atividade supressora (EHRENSTEIN et al., 2004) e alto índice de apoptose espontânea (TOUBI et al., 2005). Essas deficiências na maioria dos casos são revertidas após tratamento com anti-TNF. Isso torna nosso estudo ainda mais interessante, já que identificamos altos níveis de expressão do miR-505 em pacientes não responsivos ao tratamento com anti-TNF. Além disso, apesar de estudo recente ter demonstrado que a inativação de Helios não prejudica a diferenciação e a função efetora de vários subtipos de células $\mathrm{T}$, entre elas as Tregs (CAI et al., 2011), esse tipo de estudo não foi realizado no contexto de autoimunidade. 
Nossa hipótese é a de que os altos níveis de miR-505 nos pacientes estão controlando a expressão do fator de transcrição Helios, que por um mecanismo ainda não conhecido estaria contribuindo para o fenótipo deficiente característico das Tregs na doença. A expressão desregulada deste microRNA nessas células impediria a reversão deste fenótipo deficiente mesmo após o tratamento com anti-TNF. Por isso, temos grande interesse em continuar os estudos com o objetivo de compreender melhor o papel do miR505 nos linfócitos T, no contexto da AR.

Como um todo, nossos achados contribuem para a melhor compreensão dos mecanismos moleculares que podem estar envolvidos na susceptibilidade/resistência a artrite experimental. Dessa forma, se considerarmos desde nosso trabalho de mestrado e agora o do doutorado, realizamos um estudo bem abrangente do controle da expressão gênica no timo na autoimunidade, inicialmente focando o estroma tímico e agora os timócitos e os linfócitos periféricos. 
CONCLUSÕES 


\section{CONCLUSÕES}

$>$ Os camundongos das linhagens DBA-1/J e DBA-2/J apresentam expressão diferenciada de mRNAs e de microRNAs em timócitos e linfócitos T CD3 ${ }^{+}$.

Além disso, os linfócitos $\mathrm{T} \mathrm{CD}^{+}$periféricos de ambas as linhagens de camundongo durante a indução de CIA, também apresentam expressão diferenciada de RNAm e de microRNAs.

Dvidenciamos "novos" microRNAs que podem ser associados ao desenvolvimento de células T nos camundongos das linhagens utilizadas no estudo, e relacionados ao processo de auto-imunidade característica da artrite.

> As redes de interação microRNA-RNAm evidenciaram alvos envolvidos a processos de importância relacionados com CIA como: sistema imune, apoptose, diferenciação e adesão celular, recombinação, resposta inflamatória e ativação e proliferação de linfócitos T.

$>$ Em pacientes com AR, o miR-505 foi identificado em linfócitos T CD4 ${ }^{+}$, o qual pode estar implicado no controle dos mecanismos regulatórios importantes para promover o balanço e/ou o controle da resposta inflamatória característica da doença.

> Nossos achados contribuem para a melhor compreensão dos mecanismos moleculares que podem estar envolvidos na susceptibilidade/resistência a artrite experimental. 
REFERÊNCIAS BIBLIOGRÁFICAS 


\section{REFERÊNCIAS BIBLIOGRÁFICAS}

ABDEL-NOUR, A. N.; ELSON, C. J.; DIEPPE, P. A. Proliferative responses of T-cell lines grown from joint fluids of patients with rheumatoid arthritis and other. Arthritides Immunology Letters. v.12, p.329-333, 1986.

ACR Clinical Guidelines Committee Guidelines for the management of rheumatoid arthritis. Arthritis Rheumathism. v.39, p.713-722, 1996.

ADAMSON, K. A.; PEARCE, S. H.; LAMB, J. R.; SECKL, J. R.; HOWIE, S. E. A comparative study of mRNA and protein expression of the autoimmune regulator gene (Aire) in embryonic and adult murine tissues. The Journal of Pathology. v.202, n.2, p.180-187, 2004.

AHO, K.; HELIOVAARA, M. Alcohol, androgens and arthritis. Annals of the Rheumatic Diseases. v.52, n.12, p.897, 1993.

ALEVIZOS, I.; ILLEI, G. G. MicroRNAs as biomarkers in rheumatic diseases. Nature Reviews Rheumatology. v.6, n.7, p. 391-398, 2010.

ALLAN, S. E.; PASSERINI, L.; BACCHETTA, R.; CRELLIN, N.; DAI, M.; ORBAN, P. C.; ZIEGLER, S. F.; RONCAROLO, M. G.; LEVINGS, M. K. The role of 2 FOXP3 isoforms in the generation of human CD4+ Tregs. The Journal of Clinical Investigation. v.115, n.11, p.3276-3284, 2005.

AMBROS, V. The functions of animal microRNAs. Nature. v.431, n.7006,p.350-355, 2004.

AMBROS, V.; BARTEL, B.; BARTEL, D. P.; BURGE, C. B.; CARRINGTON, J. C.; CHEN, X.; DREYFUSS, G.; EDDY, S. R.; GRIFFITHS-JONES, S.; MARSHALL, M.; MATZKE, M.; RUVKUN, G.; TUSCHL, T. A uniform system for microRNA annotation. RNA. v.9, n.3, p. 277-279, 2003.

ANDERSON, G.; JENKINSON, E. J. Lymphostromal interactions in thymic development and function. Nature Reviews Immunology. v.1, n.1, p.31-40, 2011.

ANDERSON, G.; JENKINSON, W. E.; JONES, T.; PARNELL, S. M.; KINSELLA, F. A. M.; WHITE, A. J.; PONGRAC'Z, J. E.; ROSSI, S. W.; JENKINSON, E. J. Establishment and functioning of intrathymic microenvironments. Immunological Reviews. v.209, p.1027, 2006. 
ANDERSON, G.; LANE, P. J.; JENKINSON, E. J. Generating intrathymic microenvironments to establish T-cell tolerance. Nature Reviews Immunology. v.7, n.12, p.954-963, 2007.

AREND, W. P. Physiology of cytokine pathways in rheumatoid arthritis. Arthritis \& Rheumatism. v.45, n.1, p.101-106, 2001.

ARNETT, F. C.; EDWORTHY, S. M.; BLOCH, D. A.; MCSHANE, D. J.; FRIES, J. F.; COOPER, N. S.; HEALEY, L. A.; KAPLAN, S. R.; LIANG, M. H.; LUTHRA, H. S. The American Rheumatism Association 1987 revised criteria for the classification of rheumatoid arthritis. Arthritis \& Rheumatism. v.31, n.3, p.315-324, 1988.

AZUMA, T.; ZHU, G.; XU, H.; RIETZ, A. C.; DRAKE, C. G.; MATTESON, E. L.; CHEN, L. Potential role of decoy B7-H4 in the pathogenesis of rheumatoid arthritis: a mouse model informed by clinical data. PLoS Medicine. v.6, n.10, e1000166, 2009.

BALTIMORE, D.; BOLDIN, M. P.; O'CONNELL, R. M.; RAO, D. S.; TAGANOV, K. D. MicroRNAs: new regulators of immune cell development and function. Nature Immunology. v.9, n.8,p.839-845, 2008.

BARTEL, D.P.; CHEN, C. Z. Micromanagers of gene expression: the potentially widespread influence of metazoan microRNAs. Nature Reviews Genetics. v.5, n.5, p.396-400, 2004.

BARTEL, D.P. MicroRNAs: target recognition and regulatory functions. Cell. v.136, n.2, p. 215-233, 2009.

BEGOVICH, A. B.; CARLTON, V. E.; HONIGBERG, L. A. A missense singlenucleotide polymorphism in a gene encoding a protein tyrosine phosphatase (PTPN22) is associated with rheumatoid arthritis. The American Journal of Human Genetics. v.75, n.2, p.330 $337,2004$.

BELLAVIA, D.; CAMPESE, A. F.; VACCA, A.; GULINO, A.; SCREPANTI, I. Notch3, another Notch in T cell development. Seminars in Immunology. v.15, n.2, p.107-112, 2003.

BEREZIKOV, E.; CHUNG, W. J.; WILLIS, J. CUPPEN, E.; LAI, E. C. Mammalian mirtron genes. Molecular Cell. v.28, n.2, p. 328-336, 2007.

BETEL, D.; WILSON, M.; GABOW, A.; MARKS, D. S.; SANDER, C. The microRNA.org resource: targets and expression. Nucleic Acids Research. v.36, p.149$153,2008$. 
BHAN, A. K.; REINHERZ, E. L.; POPPEMA, S.; MCCLUSKEY, R. T.; SCHLOSSMAN, S. F. Location of $\mathrm{T}$ cell and major histocompatibility complex antigens in the human thymus. The Journal Experimental Medicine. v.152, n.4, p. 771-782, 1980.

BHANJI, R.A.; EYSTATHIOY, T.; CHAN, E. K. L.; BLOCH, D. B.; FRITZLER, M. J. Clinical and serological features of patients with autoantibodies to GW/P bodies. Clinical Immunology. v.125, n.3, p. 247-256, 2007.

BILLIAU, A.; AND MATTHYS, P. Collagen-induced arthritis and related animal models: How much of their pathogenesis is auto-immune, how much is auto-inflammatory. Cytokine \& Growth Factor Reviews. v.22, n.5-6, p.339-344, 2011.

BLEUL, C. C.; BOEHM, T. Chemokines define distinct microenvironments in the developing thymus. European Journal of Immunology. v.30, n.12, p. 3371-3379, 2000.

BLEUL, C. C.; CORBEAUX, T.; REUTER, A.; FISCH, P.; MÖNTING, J. S.; BOEHM, T. Formation of a functional thymus initiated by a postnatal epithelial progenitor cell. Nature. v.441, n.7096, p.992-996, 2006.

BOCKMAN, D. E.; KIRBY, M. L. Dependence of thymus development on derivatives of the neural crest. Science. v.223, n.4635, p.498-500, 1984.

BOEHM T, BLEUL CC, SCHORPP M. Genetic dissection of thymus development in mouse and zebrafish. Immunological Reviews. v.195, p.15-27, 2003.

BOEHM, T.; BLEUL, C. C. Thymus-homing precursors and the thymic microenvironment. Trends in Immunology. v.27, n.10, p.477-484, 2006.

BOERS, M.; VERHOEVEN, A. C.; MARKUSSE, H. M.; VAN DE LAAR, M. A.; WESTHOVENS, R.; VAN DENDEREN, J. C.; VAN ZEBEN, D.; DIJKMANS, B. A.; PEETERS, A. J.; JACOBS, P.; VAN DEN BRINK, H. R.; SCHOUTEN, H. J.; VAN DER HEIJDE, D. M.; BOONEN, A.; VAN DER LINDEN, S. Randomised comparison of combined step-down prednisolone, methotrexate and sulphasalazine with sulphasalazine alone in early rheumatoid arthritis. The Lancet. v.350, n.9074, p.309-318, 1997.

BOILARD, E.; NIGROVIC, P. A.; LARABEE, K.; WATTS, G. F.; COBLYN, J. S.; WEINBLATT, M. E.; MASSAROTTI, E. M.; REMOLD-O'DONNELL, E.; FARNDALE, R. W.; WARE, J.; LEE, D. M. Platelets amplify inflammation in arthritis via collagendependent microparticle production. Science. v.327, n.5965, p.580-583, 2010.

BRENNAN, F. M.; CHANTRY, D.; JACKSON, A. M.; MAINI, R. N.; FELDMANN, M. Cytokine production in culture by cells isolated from the synovial membrane. Journal of Autoimmunity. v.2, p.177-186, 1989. 
BRESNIHAN, B.; ALVARO-GRACIA, J. M.; COBBY, M.; DOHERTY, M.; DOMLJAN, Z.; EMERY, P.; NUKI, G.; PAVELKA, K.; RAU, R.; ROZMAN, B.; WATT, I.; WILLIAMS, B.; AITCHISON, R.; MCCABE, D.; MUSIKIC, P. Treatment of rheumatoid arthritis with recombinant human interleukin-1 receptor antagonist. Arthritis \& Rheummatism. v.41, n.12, p. 2196-2204, 1998.

BRUNSBERG， U.; GUSTAFSSON， K.; JANSSON， L.; MICHAËLSSON， E.; ÄHRLUND-RICHTER, L.; PETTERSSON, S.; MATTSSON, R.; HOLMDAHL, R. Expression of a transgenic class II Ab gene confers susceptibility to collagen-induced arthritis. European Journal of Immunology. v.24, n.7, p.1698-1702, 1994.

BUCKNER, J. H. Mechanisms of impaired regulation by CD4(+)CD25(+)FOXP3(+) regulatory $\mathrm{T}$ cells in human autoimmune diseases. Nature Review Immunology. v.10, n.12, p. 849-859, 2010.

BUKHARI, M.; LUNT, M.; HARRISON, B. J.; SCOTT, D. G.; SYMMONS, D. P.; AND SILMAN, A. J. Rheumatoid factor is the major predictor of increasing severity of radiographic erosions in rheumatoid arthritis: results from the Norfolk Arthritis Register Study, a large inception cohort. Arthritis \& Rheumatism. v.46, n.4, p.906912, 2002.

BURKHARDT, H.; HOLMDAHL, R.; DEUTZMANN, R.; WIEDEMANN, H.; VON DER MARK, H.; GOODMAN, S.; VON DER MARK, K. Identification of a major antigenic epitope on $\mathrm{CNBr}$-fragment 11 of type II collagen recognized by murine autoreactive B cells. European Journal of Immunology. v.21, n.1, p. 49-54, 1991.

CAI, Q.; DIERICH, A.; OULAD-ABDELGHANI, M.; CHAN, S.; KASTNER, P. Helios deficiency has minimal impact on $\mathrm{T}$ cell development and function. The Journal of Immunology. v.183, n.4, p.2303-2311, 2009.

CAMPESE, A. F.; BELLAVIA, D.; GULINO, A.; SCREPANTI, I. Notch signalling at the crossroads of $\mathrm{T}$ cell development and leukemogenesis. Seminars in Cell and Development Biology. v.14, n.2, p.151-157, 2003.

CANTOR, H.; WEISSMAN, I. Development and function of subpopulations of thymocytes and T lymphocytes. Progress in Allergy. v.20, p.1-64 1976.

CAO, D.; MALMSTRÖM, V.; BAECHER-ALLAN, C.; HAFLER, D.; KLARESKOG, L.; TROLLMO, C. Isolation and functional characterization of regulatory CD2 bright CD4+ T cells from the target organ of patients with rheumatoid arthritis. European Journal of Immunology. v.33, n.1, p. 215-223, 2003. 
CARDOSO, R. S.; JUNTA, C. M.; MACEDO, C.; MAGALHÃES, D. A.; SILVEIRA, E. L.; PAULA, M. O.; MARQUES, M. M.; MELLO, S. S.; ZÁRATE-BLADÉS, C. R.; NGUYEN, C.; HOUlGATTE, R.; DONADI, E. A.; SAKAMOTO-HOJO, E. T.; PASSOS, G. A. Hybridization signatures of gamma-irradiated murine fetal thymus organ culture (FTOC) reveal modulation of genes associated with T-cell receptor V(D)J recombination and DNA repair. Molecular Immunology. v.43, n.5, p.464- 472, 2006.

CATALÁN, D.; ARAVENA, O.; SABUGO, F.; WURMANN, P.; SOTO, L.; KALERGIS, A.M.; CUCHACOVICH, M.; AGUILLÓN, J.C. B cells from rheumatoid arthritis patients show important alterations in the expression of CD86 and FcgammaRIIb, which are modulated by antitumor necrosis factor therapy. Arthritis Research \& Therapy. v.12, n.2, R68, 2010.

CHABAUD, M.; DURAND, J. M.; BUCHS, N.; FOSSIEZ, F.; PAGE, G.; FRAPPART, L.; MIOSSEC, P. Human interleukin-17: a T cell-derived proinflammatory cytokine produced by the rheumatoid synovium. Arthritis \& Rheumatism. v.42, n.5, p. 963-970, 1999.

CHATZIKYRIAKIDOU, A.; VOULGARI, P. V.; GEORGIOU, I.; DROSOS, A. A. A polymorphism in the 30-UTR of interleukin-1 receptor-associated kinase (IRAK1), a target gene of miR-146a, is associated with rheumatoid arthritis susceptibility. Joint Bone Spine. v.77, n.5, p. 411-413, 2010.

CHEN, C. Z.; LI, L.; LODISH, H. F.; BARTEL, D. P. MicroRNAs modulate hematopoietic lineage differentiation. Science. v.303, n.5654, p.83-86, 2004.

CHEN, X. M.; SPLINTER, P. L.; O'HARA, S. P.; LARUSSO, N. F. A cellular microRNA, let-7i, regulates toll-like receptor 4 expression and contributes to cholangiocyte immune responses against Cryptosporidium parvum infection. The Journal of Biological Chemistry. v.282, n.39, p.28929-28938, 2007.

CHO, Y.; CHO, M.; MIN, S. Y.; KIM, H. Y. Type II collagen autoimmunity in mouse model of human rheumatoid arthritis. Autoimmunity reviews. v.7, n.1, p.65-70, 2007.

CHOY, E. H.; PANAYI, G. S. Cytokine pathways and joint inflammation in rheumatoid arthritis. The New England Journal of Medicine. v.344, n.12, p.907-916, 2001.

CHU, C.Q.; LONDEI, M. Induction of Th2 cytokines and control of collagen-induced arthritis by nondepleting anti-CD4 Abs. The Journal of Immunology. v.157, n. 6, p. 2685-2689, 1996.

CIFUENTES, D.; XUE, H.; TAYLOR, D. W.; PATNODE, H.; MISHIMA, Y.; CHELOUFI, S.; MA, E.; MANE, S.; HANNON, G. J.; LAWSON, N. D.; WOLFE, S. A,; GIRALDEZ, A. J. A novel miRNA processing pathway independent of Dicer requires Argonaute2 catalytic activity. Science. v.328, n. 5986, p. 1694-1698, 2010. 
CIOFANI, M. \& ZÚÑIGA-PFLÜCKER, J. C. The thymus as an inductive site for T lymphopoiesis. Annual Review of Cell and Developmental Biology. v.23, p.463-493, 2007.

COBB, B. S.; NESTEROVA, T. B.; THOMPSON, E.; HERTWECK, A.; O'CONNOR, E.; GODWIN, J.; WILSON, C. B.; BROCKDORFF, N.; FISHER, A. G.; SMALE, S. T.; MERKENSCHLAGER, M. T cell lineage choice and differentiation in the absence of the RNase III enzyme Dicer. The Journal of Experimental Medicine. v.201, n.9, p.13671373, 2005.

COBB, B. S.; SMALE, S. T. Ikaros-family proteins: in search of molecular functions during lymphocyte development. Current Topics in Microbiology and Immunology. v.290, p. 29-47, 2005.

CORDIER, A. C.; HAUMONT, S. M. Development of thymus, parathyroids, and ultimobranchial bodies in NMRI and nude mice. American Journal of Anatomy. v.157, n.3, p.227-263, 1980.

CUI, W.; LI, Q.; FENG, L.; DING, W. MiR-126-3p regulates progesterone receptors and involves development and lactation of mouse mammary gland. Molecular and Cell Biochemistry. v.355, n.1-2, p.17-25, 2011.

CRIADO, G.; SIMELYTE, E.; INGLIS, J. J.; ESSEX, D.; WILLIAMS, R. O. Indoleamine 2,3-dioxygenase-mediated tryptophan catabolism regulates accumulation of Th1/Th17 cells in the joint in collagen-induced arthritis. Arthritis \& Rheumatism. v.60, n.5 p. 1342-1351, 2009.

DAI, R.; ZHANG, Y.; KHAN, D.; HEID, B.; CAUDELL, D.; CRASTA, O.; AHMED, S. A. Identification of a common lupus disease-associated microRNA expression pattern in three different murine models of lupus. PLoS One. v.5, n.12, e14302, 2010.

DERBINSKI， J.; GÄBLER，J.; BRORS， B.; TIERLING， S.; JONNAKUTY， S.; HERGENHAHN, M.; PELTONEN, L.; WALTER, J.; KYEWSKI, B. Promiscuous gene expression in thymic epithelial cells is regulated at multiple levels. The Journal of Experimental Medicine. v.202, n.1, p.33-45, 2005.

DERBINSKI, J.; SCHULTE, A.; KYEWSKI, B.; KLEIN, L. Promiscuous gene expression in medullary thymic epithelial cells mirrors the peripheral self. Nature Immunology. v.2, n.11, p.1032-1039, 2001.

DEVOSS, J.; HOU, Y.; JOHANNES, K.; LU, W.; LIOU, GI.; RINN, J.; CHANG, H.; CASPI, R. R.; FONG, L.; ANDERSON, M. S. Spontaneous autoimmunity prevented by thymic expression of a single self-antigen. The Journal of Experimental Medicine. v.203, n.12, p.2727-2735, 2006. 
DONATE, P. B. Análise da Expressão Gênica Promíscua no Timo de Camundongos DBA1 e DBA-2 Durante a Imunização com Colágeno: Modelo de Susceptibilidade/Resistência a Artrite Reumatóide. Dissertação de mestrado, 2008.

DONATE, P. B.; FORNARI, T. A.; JUNTA, C. M.; MAGALHÃES, D. A.; MACEDO, C.; CUNHA, T. M.; NGUYEN, C.; CUNHA, F. Q.; PASSOS, G. A. Collagen induced arthritis (CIA) in mice features regulatory transcriptional network connecting major histocompatibility complex (MHC H2) with autoantigen genes in the thymus. Immunobiology. v.216, n.5, p.591-603, 2011.

DONCARLI, A.; STASIUK, L. M.; FOURNIER, C.; ABEHSIRA-AMAR, O. Conversion in vivo from an early dominant Th0/Th1 response to a Th2 phenotype during the development of collagen-induced arthritis. European Journal of Immunology. v.27, n.6, p. 1451-1458, 1997.

DORIA, A.; IACCARINO, L.; SARZI-PUTTINI, P.; GHIRARDELLO, A.; ZAMPIERI, S.; ARIENTI, S.; CUTOLO, M.; TODESCO, S. Estrogens in pregnancy and systemic lupus erythematosus. Annals of the New York Academy of Sciences. v.1069, p. 247-256, 2006.

DU, C.; LIU, C.; KANG, J.; ZHAO, G.; YE, Z.; HUANG, S.; LI, Z.; WU, Z.; PEI, G. MicroRNA miR-326 regulates TH-17 differentiation and is associated with the pathogenesis of multiple sclerosis. Nature Immunology. v.10, n.12, p.1252-1259, 2009.

DUGGAN, D. J.; BITTNER, M.; CHEN, Y.; MELTZER, P.; TRENT, J. M. Expression profiling using cDNA microarrays. Nature Genetics. v.21, n.1, p.10-14, 1999.

EDWARDS, J. C.; SZCZEPANSKI, L.; SZECHINSKI, J.; FILIPOWICZ-SOSNOWSKA, A.; EMERY, P.; CLOSE, D. R.; STEVENS, R. M.; SHAW, T. Efficacy of B-celltargeted therapy with rituximab in patients with rheumatoid arthritis. The New England Journal of Medicine. v.350, n.25, p. 2572-2581, 2004.

EGERTON, M.; SCOLLAY, R.; SHORTMAN, K. Kinetics of mature T-cell development in the thymus. Proceedings of the National Academy of Sciences of the USA. v.87, n.7, p. 2579-2582, 1990.

EHRENSTEIN, M. R.; EVANS, J. G.; SINGH, A.; MOORE, S.; WARNES, G.; ISENBERG, D.A.; MAURI, C. Compromised function of regulatory T cells in rheumatoid arthritis and reversal by anti-TNFalpha therapy. The Journal of Experimental Medicine. v.200, n.3, p. 277-285, 2004.

ELLIOTT, M. J.; MAINI, R. N.; FELDMANN, M.; KALDEN, J. R.; ANTONI, C.; SMOLEN, J. S.; LEEB, B.; BREEDVELD, F. C.; MACFARLANE, J. D.; BIJL, H. Randomised double-blind comparison of chimeric monoclonal antibody to tumour necrosis factor alpha (cA2) versus placebo in rheumatoid arthritis. The Lancet. v.344, n.8930, p.1105-1110, 1994. 
ELLIOTT, M. J.; MAINI, R. N.; FELDMANN, M.; LONG-FOX, A.; CHARLES, P.; KATSIKIS, P.; BRENNAN, F. M.; WALKER, J.; BIJL, H.; GHRAYEB, J. Treatment of rheumatoid arthritis with chimeric monoclonal antibodies to tumor necrosis factor alpha. Arthritis \& Rheummatism. v.36, n.12, p.1681-1690, 1993.

EYSTATHIOY, T.; CHAN, E. K. L.; TENENBAUM, S. A.; KEENE, J. D.; GRIFFITH, K.; FRITZLER, M. J. A phosphorylated cytoplasmic autoantigen, GW182, associates with a unique population of human mRNAs within novel cytoplasmic speckles. Molecular Biology of the Cell. v.13, n.4, p. 1338-1351, 2002.

FABIAN, M. R.; SONENBERG, N.; FILIPOWICZ, W. Regulation of mRNA translation and stability by microRNAs. Annual Review of Biochemistry. v.79, p. 351-379, 2010.

FATHMAN, C. G.; SOARES, L.; CHAN, S. M.; UTZ, P. J. An array of possibilities for the study of autoimmunity. Nature. v.435, n.7042, p.605-611, 2005.

FELDMANN, M.; BRENNAN, F. M.; MAINI, R. N. Rheumatoid arthritis. Cell. v.5, p. 307-310, 1996a.

FELDMANN, M.; BRENNAN, F. M.; MAINI, R.N. Role of cytokines in rheumatoid arthritis. Annual Review of Immunology. v.14, p.397-440, 1996 b.

FILIPOWICZ, W.; BHATTACHARYYA, S. N.; SONENBERG, N. Mechanisms of posttranscriptional regulation by microRNAs: are the answers in sight? Nature Reviews Genetics. v.9, n.2, p. 102-114, 2008.

FONTENOT, J. D.; GAVIN, M. A.; RUDENSKY, A. Y. Foxp3 programs the development and function of CD4+CD25+ regulatory T cells. Nature Immunology. v.4, n.4, p. 330-336, 2003.

FONTENOT, J. D.; RASMUSSEN, J. P.; WILLIAMS, L. M.; DOOLEY, J. L.; FARR, A. G.; RUDENSKY, A. Y. Regulatory $\mathrm{T}$ cell lineage specification by the forkhead transcription factor Foxp3. Immunity. v.22, n.3, p. 329-341, 2005.

FORNARI, T.A.; DONATE, P. B.; MACEDO, C.; MARQUES, M. M.; MAGALHÃES, D. A.; PASSOS, G. A. Age-related deregulation of Aire and peripheral tissue antigen genes in the thymic stroma of non-obese diabetic (NOD) mice is associated with autoimmune type 1 diabetes mellitus (DM-1). Molecular and Cellular Biochemistry. v.342, n.1-2, p.21-28, 2010. 
FULCI, V.; SCAPPUCCI, G.; SEBASTIANI, G. D.; GIANNITTI, C.; FRANCESCHINI, D.; MELONI, F.; COLOMBO, T.; CITARELlA, F.; BARNABA, V.; MINISOLA, G.; GALEAZZI, M.; MACINO, G. miR-223 is overexpressed in T-lymphocytes of patients affected by rheumatoid arthritis. Human Immunology. v.71, n.2, p. 206 - 211, 2008.

GANTIER, M. P.; SADLER, A. J.; WILLIAMS, B. R. Fine-tuning of the innate immune response by microRNAs. Immunology \& Cell Biology. v.85, n.6, p.458-462, 2007.

GAVANESCU, I.; KESSLER, B.; PLOEGH, H.; BENOIST, C.; MATHIS, D. Loss of Aire-dependent thymic expression of a peripheral tissue antigen renders it a target of autoimmunity. Proceedings of the National Academy of Science of the USA. v.104, n.11, p.4583-4587, 2007.

GERMERAAD, W. T.; KAWAMOTO, H.; ITOI, M.; JIANG, Y.; AMAGAI, T.; KATSURA, Y.; VAN EWIJK, W. Development of thymic microenvironments in vitro is oxygendependent and requires permanent presence of T-cell progenitors. Journal of Histochemistry and Cytochemistry. v.51, n.9, p.1225-1235, 2003.

GHISI M, CORRADIN A, BASSO K, FRASSON C, SERAFIN V, MUKHERJEE S, MUSSOLIN L, RUGGERO K, BONANNO L, GUFFANTI A, DE BELLIS G, GEROSA G, STELLIN G, D'AGOSTINO DM, BASSO G, BRONTE V, INDRACCOLO S, AMADORI A, ZANOVELLO P. Modulation of microRNA expression in human T-cell development: targeting of NOTCH3 by miR-150. Blood. 2011 Jun 30;117(26):7053-62.

GODWIN, J. G.; GE, X.; STEPHAN, K.; JURISCH, A.; TULLIUS, S. G.; IACOMINI, J. Identification of a microRNA signature of renal ischemia reperfusion injury. Proceedings of the National Academy of Science of the USA. v.107, n.32, p.14339-14344, 2010.

GONZALEZ-REY, E.; CHORNY, A.; VARELA, N.; O’VALlE, F.; DELGADO, M. Therapeutic effect of urocortin on collagen-induced arthritis by downregulation of inflammatory and Th1 responses and induction of regulatory $\mathrm{T}$ cells. Arthritis \& Rheumatism. v.56, n.2, p. 531-543, 2007.

GORDON, J.; WILSON, V. A.; BLAIR, N. F.; SHERIDAN, J.; FARLEY, A.; WILSON, L.; MANLEY, N. R.; BLACKBURN, C. C. Functional evidence for a single endodermal origin for the thymic epithelium. Nature Immunology. v.5, n.5, p.546-553, 2004.

GORONZY, J. J.; WEYAND, C. M. T and B cell-dependent pathways in rheumatoid arthritis. Current Opinion in Rheumatology. v.7, n.3, p.214-221, 1995.

GOTTER, J.; BRORS, B.; HERGENHAHN, M.; KYEWSKI, B. Medullary epithelial cells of the human thymus express a highly diverse selection of tissue-specific genes colocalized in chromosomal clusters. The Journal of Experimental Medicine. v.199, n.2, p.155-166, 2004. 
GRAY, D. H.; CHIDGEY, A. P.; BOYD, R. L. Analysis of thymic stromal cell populations using flow cytometry. Journal of Immunological Methods. v.260, n.1-2, p.15-28, 2002.

GRAY, D. H.; SEACH, N.; UENO, T.; MILTON, M. K.; LISTON, A.; LEW, A. M.; GOODNOW, C. C.; BOYD, R. L. Developmental Kinetics, turnover, and stimulatory capacity of thymic epithelial cells. Blood. v.108, n.12, p.3777-3785, 2006.

GRAY, D. H.; UENO, T.; CHIDGEY, A. P.; MALIN, M.; GOLDBERG, G. L.; TAKAHAMA, Y.; BOYD, R. L.; GRAY, D. H. D. Controlling the thymic microenvironment. Current Opinion in Immunology. v.17, n.2, p. 137-143, 2005.

GREGERSEN, P. K.; SILVER, J.; WINCHESTER, R. J. The shared epitope hypothesis an approach to understanding the molecular genetics of rheumatoid arthritis susceptibility. Arthritis \& Rheumatism. v.30, n.11, p.1205- 1213, 1987.

GRIGORYEV, Y. A.; KURIAN, S. M.; HART, T.; NAKORCHEVSKY, A. A.; CHEN, C.; CAMPBELL, D.; HEAD, S. R.; YATES JR, R. D.; SALOMON, D. R. MicroRNA regulation of molecular networks mapped by global microRNA, mRNA, and protein expression in activated T lymphocytes. The Journal of Immunology. v.187, n.5, p. 22332243, 2011.

GUO, H.; INGOLIA, N. T.; WEISSMAN, J. S.; BARTEL, D. P. Mammalian microRNAs predominantly act to decrease target mRNA levels. Nature. v.466, n.7308, p. 835-840, 2010.

HAHM, K.; COBB, B. S.; MCCARTY, A. S.; BROWN, K. E.; KLUG, C. A.; LEE, R.; AKASHI, K.; WEISSMAN, I. L.; FISHER, A. G.; SMALE, S. T. Helios, a T cellrestricted Ikaros family member that quantitatively associates with Ikaros at centromeric heterochromatin. Genes Dev. v.12, p. 782-796, 1998.

HAKS, M. C.; KRIMPENFORT, P.; BORST, J.; KRUISBEEK, A. M. The CD3 gamma chain is essential for development of both the TCR alpha beta and TCR gamma delta lineages. The EMBO Journal. v.17, n.7, p.1871-1882, 1998.

HALONEN, M.; PELTO-HUIKKO, M.; ESKELIN, P.; PELTONEN, L.; ULMANEN, I.; KOLMER, M. Subcellular location and expression pattern of autoimmune regulator (Aire), the mouse orthologue for human gene defective in autoimmune polyendocrinopathy candidiasis ectodermal dystrophy (APECED). Journal of Histochemistry and Cytochemistry. v.49, n.2, p.197-208, 2001. 
HAN, J.; LEE, Y.; YEOM, K. H.; KIM, Y. K.; JIN, H.; KIM, V. N. The Drosha-DGCR8 complex in primary microRNA processing. Genes \& Development. v.18, n.24, p. 30163027, 2004.

HARMAN, B. C.; JENKINSON, W. E.; PARNELL, S. M.; ROSSI, S. W.; JENKINSON, E. J.; ANDERSON, G. T/B lineage choice occurs prior to intrathymic Notch signaling. Blood. v.106, n.3, p.886-892, 2005.

HAYNES, B. F.; HEINLY, C. S. Early human T cell development: analysis of the human thymus at the time of initial entry of hematopoietic stem cells into the fetal thymic microenvironment. The Journal of Experimental Medicine. v.181, n.4, p. 1445-1458, 1995.

HILL, J. A.; FEUERER, M.; TASH, K.; HAXHINASTO, S.; PEREZ, J.; MELAMED, R.; MATHIS, D.; BENOIST, C. Foxp3 transcription-factor-dependent and -independent regulation of the regulatory $\mathrm{T}$ cell transcriptional signature. Immunity. v.27, p. 786-800, 2007.

HOLLÄNDER, G. A. Normal thymic architecture and negative selection are associated with Aire expression, the gene defective in the autoimmunepolyendocrinopathycandidiasis-ectodermal dystrophy (APECED). The Journal of Immunology. v.165, n.4, p.1976-1983, 2000.

HOLMDAHL，R.; BAILEY，C.; ENANDER，I.; MAYER，R.; KLARESKOG，L.; MORAN, T.; BONA, C. Origin of the autoreactive anti-type II collagen response. II. Specificities, Ab isotypes and usage of $\mathrm{V}$ gene families of anti- type II collagen B cells. The Journal of Immunology. v.142, n.6, p. 1881-1886, 1989.

HOLMDAHL, R.; GOLDSCHMIDT, T. J.; KLEINAU, S.; KVICK, C.; JONSSON, R. Arthritis induced in rats with adjuvant oil is a genetically restricted, alpha beta T-cell dependent autoimmune disease. Immunology. v.76, n.2, p. 197-202, 1992.

HORI, S.; NOMURA, T.; SAKAGUCHI, S. Control of regulatory T cell development by the transcription factor Foxp3. Science. v.299, n. 5609, p. 1057-1061, 2003.

HOVDENES, J.; GAUDERNACK, G.; KVIEN, T. K.; EGELAND, T.; MELLBYE, O. J. A functional study of purified $\mathrm{CD} 4+$ and $\mathrm{CD} 8+$ cells isolated from synovial fluid of patients with rheumatoid arthritis and other arthritides. Scandinavian Journal of Immunology. v.29, n.6, p. 641-649, 1989.

HUANG, J. C.; MORRIS, Q. D.; FREY, B. J. Bayesian inference of MicroRNA targets from sequence and expression data. Journal of Computational Biology. v.14, n.5, p.550563, 2007. 
HUANG, Y.; ZOU, Q.; SONG, H.; SONG, F.; WANG, L.; ZHANG, G.; SHEN, X. A study of miRNAs targets prediction and experimental validation. Protein Cell. v.1, n.11, p.979-986, 2010.

HUEHN, J.; POLANSKY, J. K.; HAMANN, A. Epigenetic control of FOXP3 expression: the key to a stable regulatory T-cell lineage? Nature Review Immunology. v.9, n.2, p.83$89,2009$.

HUGHES, P.D.; BELZ, G.T.; FORTNER, K. A.; BUDD, R. C.; STRASSER, A.;, AND BOUILLET, P. Apoptosis regulators Fas and Bim cooperate in shutdown of chronic immune responses and prevention of autoimmunity. Immunity. v.28, n.2 , p. 197205,2008 .

INFANTE-DUARTE, C.; HORTON, H. F.; BYRNE, M. C.; KAMRADT, T. Microbial lipopeptides induce the production of IL-17 in Th cells. The Journal of Immunology. v.165, n.11, p. 6107-6115, 2000.

JAKYMIW, A.; IKEDA, K.; FRITZLER, M. J.; REEVES, W. H.; SATOH, M.; CHAN, E. K. L. Autoimmune targeting of key components of RNA interference. Arthritis Research \& Therapy. v.8, n.4, R87, 2006.

JAKYMIW, A.; PAULEY, K. M.; LI, S.; IKEDA, K.; LIAN, S.; EYSTATHIOY, T.; SATOH, M.; FRITZLER, M. J.; CHAN, E. K. The role of GW/P-bodies in RNA processing and silencing. Journal of Cell Science. v.120, n.8, p. 1317-1323, 2007.

JAMES EA, MOUSTAKAS AK, BUI J, ET AL. HLA-DR1001 presents 'alteredself'peptides derived from joint-associated proteins by accepting citrulline in three of its binding pockets. Arthritis \& Rheumatism. v.62, n.10, p.2909-2918, 2010.

JAMESON, S. C.; BEVAN, M. J. T-cell selection. Current Opinion in Immunology. v.10, n.2, p.214-219, 1998.

JETTEN, A. M. Retinoid-related orphan receptors (RORs): critical roles in development, immunity, circadian rhythm, and cellular metabolism. Nuclear Receptor Signal. v.7, e003, 2009.

JIANG, W.; ANDERSON, M. S.; BRONSON, R.; MATHIS, D.; BENOIST, C. Modifier loci condition autoimmunity provoked by Aire deficiency. The Journal of Experimental Medicine. v.202, n.6, p. 805-815, 2005. 
JOLICOEUR, C.; HANAHAN, D.; SMITH, K. M. T-cell tolerance toward a transgenic beta-cell antigen and transcription of endogenous pancreatic genes in thymus. Proceedings of the National Academy of Science of the USA. v.91, n.14, p.6707-6711, 1994.

JONSSON, I. M.; VERDRENGH, M.; BRISSLERT, M.; LINDBLAD, S.; BOKAREWA, M.; ISLANDER, U.; CARLSTEN, H.; OHLSSON, C.; NANDAKUMAR, K. S.; HOLMDAHL, R.; TARKOWSKI, A. Ethanol prevents development of destructive arthritis. Proceedings of the National Academy of Science USA. v.104, n.1, p.258-263, 2007.

JONES-RHOADES, M. W.; BARTEL, D. P.; BARTEL, B. MicroRNAs and their regulatory roles in plants. Annual Review of Plant Biology. v.57, p.19-53, 2006.

JOOSTEN, L. A.; LUBBERTS, E.; HELSEN, M. M.; SAXNE, T.; COENEN-DE ROO, C. J.; HEINEGARD, D.; VAN DEN BERG, W. B. Protection against cartilage and bone destruction by systemic interleukin-4 treatment in established murine type II collageninduced arthritis. Arthritis Research. v.1, n.1, p. 81-91, 1999.

JORDAN, B. R. Large-scale expression measurement by hybridization methods: from high-density membranes to "DNA chips". The Journal of Biochemistry. v.124, n.2, p.251-258, 1998.

KADOWAKI, K. M.; MATSUNO, H.; TSUJI, H.; TUNRU, I. CD4+ T cells from collageninduced arthritic mice are essential to transfer arthritis into severe combined immunodeficient mice. Clinical \& Experimental Immunology. v.97, n.2, p. 212-218, 1994.

KALLBERG, H.; JACOBSEN, S.; BENGTSSON, C.; PEDERSEN, M.; PADYUKOV, L.; GARRED, P.; FRISCH, M.; KARLSON, E. W.; KLARESKOG, L.; ALFREDSSON, L. Alcohol consumption is associated with decreased risk of rheumatoid arthritis: results from two Scandinavian case-control studies. Annals of the Rheumatic Diseases. v.68, n.2, p.222$227,2008$.

KAMRADT, T. \& MITCHISON, N. A. Tolerance and autoimmunity. The New England Journal of Medicine. v.344, n.9, p.655-664, 2001.

KARLSON, E. W.; LEE, I. ; COOK, N. R.; MANSON, J. E.; BURING, J. E.; HENNEKENS, C. H. A retrospective cohort study of cigarette smoking and risk of rheumatoid arthritis in female health professionals. Arthritis \& Rheumatism. v.42, n.5, p.910-917, 1999.

KELCHTERMANS, H.; DE KLERCK, B.; MITERA, T.; VAN BALEN, M.; BULLENS, D.; BILLIAU, A.; LECLERCQ, G.; MATTHYS, P. Defective CD4+CD25+ regulatory T cell functioning in collagen-induced arthritis: an important factor in pathogenesis, counter-regulated by endogenous IFN-gamma. Arthritis Research \& Therapy. v.7, n.2, R402-415, 2005. 
KELlEY, C. M.; IKEDA, T.; KOIPALly, J.; AVITAHL, N.; WU, L.; GEORGOPOULOS, K.; MORGAN, B. A. Helios, a novel dimerization partner of Ikaros expressed in the earliest hematopoietic progenitors. Current Biology. v.8, p. 508-515, 1998.

KIM, N.; KIM, H.; JUNG, I.; KIM, Y.; KIM, D.; HAN, Y. M. Expression profiles of miRNAs in human embryonic stem cells during hepatocyte differentiation. Hepatology Research. v.41, n.2, p.170-183, 2011.

KIMURA, Y.; ZHOU, L.; MIWA, T.; SONG, W. C. Genetic and therapeutic targeting of properdin in mice prevents complement-mediated tissue injury. The Journal of Clinical Investigation. v.120, n.10, p.3545-3554, 2010.

KISHIMOTO, H.; SPRENT, J. Several different cell surface molecules control negative selection of medullary thymocytes. The Journal Experimental Medicine. v.190, n.1, p.65-73, 1999.

KLARESKOG, L.; CATRINA, A. I.; PAGET, S. Rheumatoid arthritis. Lancet. v.373, p. 659-672, 2009.

KLEIN, L. \& KYEWSKI, B. Self-antigen presentation by thymic stromal cells: a subtle division of labor. Current Opinion in Immunology. v.12, n.2, p.179-186, 2000a.

KLEIN, L.; KYEWSKI, B. "Promiscuous" expression of tissue antigens in the thymus: a key to T-cell tolerance and autoimmunity? Journal of Molecular Medicine. v.78, n.9, p.483-494, 2000 b.

KLEIN, L.; HINTERBERGER, M.; WIRNSBERGER, G.; KYEWSKI, B. Antigen presentation in the thymus for positive selection and central tolerance induction. Nature Reviews Immunology. v.9, n.12, p.833-844, 2009.

KLOCKARS, M.; KOSKELA, R. S.; JARVINEN, E.; KOLARI, P. J.; ROSSI, A. Silica exposure and rheumatoid arthritis: a follow up study of granite workers 1940-81. BMJ. v.294, n.6578, p.997-1000, 1987.

KOHLHAAS, S.; GARDEN, O. A.; SCUDAMORE, C.; TURNER, M.; OKKENHAUG, K.; VIGORITO, E. Cutting edge: the Foxp3 target miR-155 contributes to the development of regulatory T cells. The Journal of Immunology. v. 182, n.5, p.2578-2582, 2009.

KOOPMAN, W. J. Prospects for autoimmune disease: research advances in rheumatoid arthritis. Journal of the American Medical Association. v.285, n. 5, p.648-650, 2001. 
KOTAKE, S.; UDAGAWA, N.; TAKAHASHI, N.; MATSUZAKI，K.; ITOH，K.; ISHIYAMA, S.; SAITO, S.; INOUE, K.; KAMATANI, N.; GILLESPIE, M. T.; MARTIN, T. J.; SUDA, T. IL-17 in synovial fluids from patients with rheumatoid arthritis is a potent stimulator of osteoclastogenesis. Journal of Clinical Investigation. v.103, n.9, p.1345$1352,1999$.

KOTZIN, B. L.; AND J, KAPPLER. Targeting the T cell receptor in rheumatoid arthritis. Arthritis \& Rheumatism. v.41, n.11, p1906-1910, 1998.

KREK, A.; GRÜN, D.; POY, M. N.; WOLF, R.; ROSENBERG, L.; EPSTEIN, E. J.; MACMENAMIN, P.; DA PIEDADE, I.; GUNSALUS, K. C.; STOFFEL, M.; RAJEWSKY, N. Combinatorial microRNA target predictions. Nature Genetics. v.37, n.5, p.495-500, 2005.

KREMER, J. M.; WESTHOVENS, R.; LEON, M.; DI GIORGIO, E.; ALTEN, R.; STEINFELD, S.; RUSSELL, A.; DOUGADOS, M.; EMERY, P.; NUAMAH, I. F.; WILLIAMS, G. R.; BECKER, J. C.; HAGERTY, D. T.; MORELAND, L. W. Treatment of rheumatoid arthritis by selective inhibition of T-cell activation with fusion protein CTLA4Ig. The New England Journal of Medicine. v.349, n.20, p. 1907-1915, 2003.

KROL, J.; LOEDIGE, I.; FILIPOWICZ, W. The widespread regulation of microRNA biogenesis, function and decay. Nature Reviews Genetics. v.11, n.9, p.597-610, 2010.

KRUGER, J.; AND REHMSMEIER, M. RNAhybrid: microRNA target prediction easy, fast and flexible. Nucleic Acids Research. v.34, W451-W454, 2006.

KUMAR, P. G.; LALORAYA, M.; WANG, C. Y.; RUAN, Q. G.; DAVOODISEMIROMI, A.; KAO, K. J.; SHE, J. X. The autoimmune regulator (Aire) is a DNA binding protein. The Journal of Biological Chemistry. v.276, n.44, p.4135741364, 2001.

KURELLA, M.; HSIAO, L. L.; YOSHIDA, T.; RANDALL, J. D.; CHOW, G.; SARANG, S. S.; JENSEN, R. V.; GULLANS, S. R. DNA microarray analysis of complex biologic processes. Journal of the American Society of Nephrology. v.12, n.5, p.1072-1078, 2001.

KURODA, N.; MITANI, T.; TAKEDA, N.; ISHIMARU, N.; ARAKAKI, R.; HAYASHI, Y.; BANDO, Y.; IZUMI, K.; TAKAHASHI, T.; NOMURA, T.; SAKAGUCHI, S.; UENO, T.; TAKAHAMA, Y.; UCHIDA, D.; SUN, S.; KAJIURA, F.; MOURI, Y.; HAN, H.; MATSUSHIMA, A.; YAMADA, G.; MATSUMOTO, M. Development of autoimmunity against transcriptionally unrepressed target antigen in the thymus of Airedeficient mice. The Journal of Immunology. v.174, n.4, p.1862-1870, 2005. 
KURREEMAN, F. A.; PADYUKOV, L.; MARQUES, R. B.; SCHRODI, S. J.; SEDDIGHZADEH, M.; STOEKEN-RIJSBERGEN, G.; VAN DER HELM-VAN MIL, A. H.; ALLAART, C. F.; VERDUYN, W.; HOUWING-DUISTERMAAT, J.; ALFREDSSON, L.; BEGOVICH, A. B.; KLARESKOG, L.; HUIZINGA, T. W.; TOES, R. E. A candidate gene approach identifies the TRAF1/C5 region as a risk factor for rheumatoid arthritis. PLoS Medicine. v.4, n.9, p.e278, 2007.

KYEWSKI, B. \& DERBINSKI, J. Self-representation in the thymus: an extended view. Nature Reviews Immunology. v.4, n.9, p.688-698, 2004.

LAGOS-QUINTANA, M.; RAUHUT, R.; LENDECKEL, W.; TUSCHL, T. Identification of novel genes coding for small expressed RNAs. Science. v.294,n.5543, p.853-858, 2001.

LAU, N. C.; LIM, L. P.; WEINSTEIN, E. G.; BARTEL, D. P. An abundant class of tiny RNAs with probable regulatory roles in Caenorhabditis elegans. Science. v.294, n. 5543, p.858-862, 2001.

LE DOUARIN, N. M.; JOTEREAU, F. V. Tracing of cells of the avian thymus through embryonic life in interspecific chimeras. The Journal of Experimental Medicine. v.142, n.1, p.17-40, 1975.

LEE, R. C. \& AMBROS, V. An extensive class of small RNAs in Caenorhabditis elegans. Science. v.294, n.5543, p.862-864, 2001.

LEE, R. C.; FEINBAUM, R. L.; AMBROS, V. The C. elegans heterochronic gene lin-4 encodes small RNAs with antisense complementarity to lin-14. Cell. v.75,n.5, p. 843-854, 1993.

LEWIS, B. P.; BURGE, C. B.; BARTEL, D. P. Conserved seed pairing, often flanked by adenosines, indicates that thousands of human genes are microRNA targets. Cell. v.120, n.1, p.15-20, 2005.

LI, J.; WAN, Y.; GUO, Q.; ZOU, L.; ZHANG, J.; FANG, Y.; ZHANG, J.; ZHANG, J.; FU, X.; LIU, H.; LU, L.; WU, Y. Altered microRNA expression profile with miR-146a upregulation in CD4+ T cells from patients with rheumatoid arthritis. Arthritis Research \& Therapy. v.12, n.3, p. R81, 2010.

LIAN, S. L.; LI, S.; ABADAL, G. X.; PAULEY, B. A.; FRITZLER, M. J.; CHAN, E. K. L. The C-terminal half of human Ago2 binds to multiple GW-rich regions of GW182 and requires GW182 to mediate silencing. RNA. v.15, n.5, p. 804-813, 2009. 
LIM, L. P.; LAU, N. C.; GARRETT-ENGELE, P.; GRIMSON, A.; SCHELTER, J. M.; CASTLE, J.; BARTEL, D. P.; LINSLEY, P. S.; JOHNSON, J. M. Microarray analysis shows that some microRNAs downregulate large numbers of target mRNAs. Nature. v.433, n.7027, p.769-773, 2005.

LIPSHUTZ, R. J.; FODOR, S. P.; GINGERAS, T. R.; LOCKHART, D. J. High density co-stimulator messenger RNA. Nature. v.450, n.7167, p. 299 - 303, 2007.

LISTON, A.; GRAY, D. H.; LESAGE, S.; FLETCHER, A. L.; WILSON, J.; WEBSTER, K. E.; SCOTT, H. S.; BOYD, R. L.; PELTONEN, L.; GOODNOW, C. C. Gene dosage-limiting role of Aire in thymic expression, clonal deletion, and organ-specific autoimmunity. The Journal Experimental Medicine. v.200, n.8, p.1015-1026, 2004.

LIU, C.; UENO, T.; KUSE, S.; SAITO, F.; NITTA, T.; PIALI, L.; NAKANO, H.; KAKIUCHI, T.; LIPP, M.; HOLLANDER, G.A.; TAKAHAMA, Y. The role of CCL21 in recruitment of T precursor cells to fetal thymus. Blood. v.105, n.1, p.31-39, 2005.

LIU, J.; CARMELL, M. A.; RIVAS, F. V.; MARSDEN, C. G.; THOMSON, J. M.; SONG, J. J.; HAMMOND, S. M.; JOSHUA-TOR, L.; HANNON, G. J. Argonaute2 is the catalytic engine of mammalian RNAi. Science. v.305, n.5689, p. 1437-1441, 2004.

LIU, M. F.; WANG, C. R.; FUNG, L. L.; LIN, L. H.; TSAI, C. N. The presence of cytokinesuppressive CD4+CD25+ T cells in the peripheral blood and synovial fluid of patients with rheumatoid arthritis. Scandinavian Journal of Immunology. v.62, n.3, p.312-317, 2005.

LOSCHER, C. J.; HOKAMP, K.; KENNA, P. F.; IVENS, A. C.; HUMPHRIES, P.; PALFI, A.; FARRAR, G. J. Altered retinal microRNA expression profile in a mouse model of retinitis pigmentosa. Genome Biology. v.8, n.11, R248, 2007.

LOUZADA-JR, P.; SOUZA, B. D. B.; TOLEDO, R. A.; CICONELLI, R. M. Análise descritiva das características demográficas e clínicas de pacientes com artrite reumatóide no Estado de São Paulo. Revista Brasileira de Reumatologia. v.47, p.84-90, 2007.

LU, L. F.; BOLDIN, M. P.; CHAUDHRY, A.; LIN, L. L.; TAGANOV, K. D.; HANADA, T.; YOSHIMURA, A.; BALTIMORE, D.; RUDENSKY, A. Y. Function of miR-146a in controlling Treg cell-mediated regulation of Th1 responses. Cell. v.142, n.6, p. 914-929, 2010.

LUBBERTS, E.; JOOSTEN, L. A.; OPPERS, B.; VAN DEN BERSSELAAR, L.; COENEN-DE ROO, C. J.; KOLLS, J. K.; SCHWARZENBERGER, P.; VAN DE LOO, F. A.; VAN DEN BERG, W. B. IL-1-independent role of IL-17 in synovial inflammation and joint destruction during collagen-induced arthritis. The Journal of Immunology. v.167, n.2, p. 1004-1013, 2001. 
LUROSS, J. A.; WILLIAMS, N. A. The genetic and immunopathological processes underlying collagen-induced arthritis.Immunology. Immunology. v.103, n.4, p.407-416, 2001 .

MACEDO, C.; EVANGELISTA, A. F.; MAGALHÃES, D. A.; FORNARI, T. A.; LINHARES, L. L.; JUNTA, C. M.; SILVA, G. L.; SAKAMOTO-HOJO, E. T.; DONADI, E. A.; SAVINO, W.; PASSOS, G. A. Evidence for a network transcriptional control of promiscuous gene expression in medullary thymic epithelial cells. Molecular Immunology. v.46, n.16, p.3240-3244, 2009.

MACGREGOR, A. J.; SNIEDER, H.; RIGBY, A. S.; KOSKENVUO, M.; KAPRIO, J.; AHO, K.; SILMAN A. J. Characterizing the quantitative genetic contribution to rheumatoid arthritis using data from twins. Arthritis \& Rheumatism. v.43, n.1, p.30-37, 2000 .

MAGALHÃES, D. A.; SILVEIRA, E. L.; JUNTA, C. M.; SANDRIN-GARCIA, P.; FACHIN, A. L.; DONADI, E. A.; SAKAMOTO-HOJO, E. T.; PASSOS, G. A. Promiscuous gene expression in the thymus: the root of central tolerance. Clinical and Developmental Immunology. v.13, n.2-4, p.81-99, 2006.

MAINI, R. N.; BREEDVELD, F. C.; KALDEN, J. R.; SMOLEN, J. S.; DAVIS, D.; MACFARLANE, J. D.; ANTONI, C.; LEEB, B.; ELLIOTT, M. J.; WOODY, J. N.; SCHAIBLE, T. F.; FELDMANN, M. Therapeutic efficacy of multiple intravenous infusions of anti-tumor necrosis factor alpha monoclonal antibody combined with low-dose weekly methotrexate in rheumatoid arthritis. Arthritis \& Rheummatism. v.41, n.9, p.1552-1563, 1998.

MANLEY, N. R.; BLACKBURN, C. C. A developmental look at thymus organogenesis: where do the non-haematopoietic cells in the thymus come from? Current Opinion in Immunology.v.15, n.2, p.225-232, 2003.

MARQUES-NETO, J. F.; GONCALVES, E. T.; BARROS, E. F. O. Estudo multicêntrico da prevalência da artrite reumatóide do adulto em amostras da população brasileira. Revista Brasileira de Reumatologia. v.33, p.169-173, 1993.

MAURI, C.; CHU, C. Q.; WOODROW, D.; MORI, L.; LONDEI, M. Treatment of a newly established transgenic model of chronic arthritis with nondepleting anti-CD4 monoclonal antibody. The Journal of Immunology. v.159, n.10, p. 5032-5041, 1997.

MCCAUGHTRY, T. M.; WILKEN, M. S.; HOGQUIST, K. A. Thymic emigration revisited. The Journal of Experimental Medicine. v.204, n.11, p.2513-2520, 2007. 
MCINNES, I. B.; SCHETT, G. Cytokines in the pathogenesis of rheumatoid arthritis. Nature Reviews Immunology. v.7, n.6, p.429-442, 2007.

MEDINA, P. P AND SLACK, F. J. MicroRNAs and cancer: An overview. Cell Cycle. V.7, n. 16, p.2485-2492, 2008.

MILLER, J. F. Immunological function of the thymus. The Lancet. v.2, n.7205, p. 748$749,1961$.

MONTICELLI, S.; ANSEL, K. M.; XIAO, C.; SOCCI, N. D.; KRICHEVSKY, A. M.; THAI, T. H.; RAJEWSKY, N.; MARKS, D. S.; SANDER, C.; RAJEWSKY, K.; RAO, A.; KOSIK, K. S. MicroRNA profiling of the murine hematopoietic system. Genome Biology. v.6, n.8, R71, 2005.

MORGAN, B.; SUN, L.; AVITAHL, N.; ANDRIKOPOULOS， K.; IKEDA， T.; GONZALES, E.; WU, P.; NEBEN, S.; GEORGOPOULOS, K. Aiolos, a lymphoid restricted transcription factor that interacts with Ikaros to regulate lymphocyte differentiation. EMBO Journal. v.16, p 2004-2013, 1997.

MORGAN, M. E.; FLIERMAN, R.; VAN DUIVENVOORDE, L. M.; WITTEVEEN, H. J.; VAN EWIJK, W.; VAN LAAR, J. M.; DE VRIES, R.R.; TOES, R. E. Effective treatment of collagen-induced arthritis by adoptive transfer of CD25+ regulatory $\mathrm{T}$ cells. Arthritis \& Rheumatism. v. 52, n.7, p. 2212-2221, 2005.

MÖTTÖNEN, M.; HEIKKINEN, J.; MUSTONEN, L.; ISOMÄKI, P.; LUUKKAINEN, R.; LASSILA, O. CD4+ CD25+ T cells with the phenotypic and functional characteristics of regulatory $\mathrm{T}$ cells are enriched in the synovial fluid of patients with rheumatoid arthritis.

Clinical \& Experimental Immunology. v.140, n.2, p.360-367, 2005.

MÖTTÖNEN, T.; HANNONEN, P.; LEIRISALO-REPO, M.; NISSILÄ, M.; KAUTIAINEN, H.; KORPELA, M.; LAASONEN, L.; JULKUNEN, H.; LUUKKAINEN, R.; VUORI, K.; PAIMELA, L.; BLÅFIELD, H.; HAKALA, M.; ILVA, K.; YLIKERTTULA, U.; PUOLAKKA, K.; JÄRVINEN, P.; HAKOLA, M.; PIIRAINEN, H.; AHONEN, J.; PÄLVIMÄKI, I.; FORSBERG, S.; KOOTA, K.; FRIMAN, C.. Comparison of combination therapy with single-drug therapy in early rheumatoid arthritis: a randomised trial. The Lancet. v.353, n.9164,p. 1568-1573, 1999.

MULJO, S. A.; ANSEL, K. M.; KANELlOPOULOU, C.; LIVINGSTON, D. M.; RAO, A.; RAJEWSKY, K. Aberrant $\mathrm{T}$ cell differentiation in the absence of Dicer. Journal Experimental Medicine. v.202, n.2, p.261-269, 2005.

MUNN, D.H.; MELLOR, A.L. Indoleamine 2,3-dioxygenase and tumorinduced tolerance. The Journal of Clinical Investagion. v.117, n.5, p. 1147-1154, 2007. 
MURATA, K.; YOSHITOMI, H.; TANIDA, S.; ISHIKAWA, M.; NISHITANI, K.; ITO, H.; NAKAMURA, T. Plasma and synovial fl uid microRNAs as potential biomarkers of rheumatoid arthritis and osteoarthritis. Arthritis Research \& Therapy. v.12, n.3, p.R86, 2010 .

MUSTILA, A.; PAIMELA, L.; LEIRISALO-REPO, M.; HUHTALA, H.; AND MIETTINEN, A. Antineutrophil cytoplasmic Abs in patients with early rheumatoid arthritis: an early marker of progressive erosive disease. Arthritis \& Rheumatism. v.43, n.6, p.1371-1376, 2000.

NAGATA, Y.; NAKASA, T.; MOCHIZUKI, Y.; ISHIKAWA, M.; MIYAKI, S.; SHIBUYA, H.; YAMASAKI, K.; ADACHI, N.; ASAHARA, H.; OCHI, M. Induction of apoptosis in the synovium of mice with autoantibody-mediated arthritis by the intraarticular injection of double-stranded MicroRNA-15a. Arthritis \& Rheumatism. v.60, n.9, p.2677-2683, 2009.

NAKAMACHI, Y.; KAWANO, S.; TAKENOKUCHI, M.; NISHIMURA, K.; SAKAI, Y.; CHIN, T.; SAURA, R.; KUROSAKA, M.; KUMAGAI, S. MicroRNA-124a is a key regulator of proliferation and monocyte chemoattractant protein 1 secretion in fibroblastlike synoviocytes from patients with rheumatoid arthritis. Arthritis \& Rheumatism. v.60, n.5, p.1294-1304, 2009.

NAKASA, T.; MIYAKI, S.; OKUBO, A.; HASHIMOTO, M.; NISHIDA, K.; OCHI, M.; ASAHARA, H. Expression of microRNA-146 in rheumatoid arthritis synovial tissue. Arthritis \& Rheumatism. v.58, n.5, p. 1284-1292, 2008.

NAKASA, T.; SHIBUYA, H.; NAGATA, Y.; NIIMOTO, T.; OCHI, M. The inhibitory effect of microRNA-146 expression on bone destruction in arthritis. Arthritis \& Rheumatism. v.63, n.6, p. 1582-1590, 2011.

NANDAKUMAR, K. S.; HOLMDAHL, R. Antibody-induced arthritis: disease mechanisms and genes involved at the effector phase of arthritis. Arthritis Research \& Therapy. v.8, n.6, p.223, 2006.

NEHLS, M.; KYEWSKI, B.; MESSERLE, M.; WALDSCHÜTZ, R.; SCHÜDDEKOPF, K.; SMITH, A. J.; BOEHM, T. Two genetically separable steps in the differentiation of thymic epithelium. Science. v.272, n.5263, p. 886-889, 1996.

NITTA, T.; OHIGASHI, I.; NAKAGAWA, Y.; TAKAHAMA, Y. Cytokine crosstalk for thymic medulla formation. Current Opinion in Immunology. v.23, n.2, p.190-197, 2011. 
O'CONNELL, R. M.; RAO, D. S.; CHAUDHURI, A. A.; BALTIMORE, D. Physiological and pathological roles for microRNAs in the immune system. Nature Reviews Immunology. v.10, n.2, p.111-122, 2010.

O'DELL, J. R.; HAIRE, C. E.; ERIKSON, N.; DRYMALSKI, W.; PALMER, W.; ECKHOFF, P. J.; GARWOOD, V.; MALOLEY, P.; KLASSEN, L. W.; WEES, S.; KLEIN, H.; MOORE, G.F. Treatment of rheumatoid arthritis with methotrexate alone, sulfasalazine and hydroxychloroquine, or a combination of all three medications. The New England Journal of Medicine. v.334, n.20, p.1287-1291.

OKAMOTO, Y.; GOTOH, Y.; TOKUI, H.; MIZUNO, A.; KOBAYASHI, Y.; NISHIDA, M. Characterization of the cytokine network at a single cell level in mice with collageninduced arthritis using a dual color ELISPOT assay. J. Interferon Cytokine Research. v.20, n.1, p. 55-61, 2000.

OLIVER, J. E.; SILMAN, A. J. Risk factors for the development of rheumatoid arthritis. Scandinavian Journal of Rheumatology. v.35, n.3, p.169-174, 2006.

OLSSON, A. R.; SKOGH, T.; AXELSON, O.; WINGREN, G. Occupations and exposures in the work environment as Determinants for rheumatoid arthritis. Occupational and Environmental Medicine. v.61, n.3, p. 233-238, 2004.

OROM, U. A.; NIELSEN, F. C.; LUND, A. H. MicroRNA-10a binds the 50UTR of ribosomal protein mRNAs and enhances their translation. Molecular Cell. v.30, n.4, p. 460-471, 2008.

OWEN, J. J.; RITTER, M. A. Tissue interaction in the development of thymus lymphocytes. The Journal of Experimental Medicine.v.129, n.2, p. 431-442, 1969.

PADYUKOV, L.; SILVA, C.; STOLT, P.; ALFREDSSON, L.; KLARESKOG, L.; A gene-environment interaction between smoking and shared epitope genes in HLA-DR provides a high risk of seropositive rheumatoid arthritis. Arthritis \& Rheumatism. v.50, n.10, p.3085-3092, 2004.

PALMERO, E. I.; DE CAMPOS, S. G.; CAMPOS, M.; DE SOUZA, N. C.; GUERREIRO, I. D.; CARVALHO, A. L.; MARQUES, M. M. Mechanisms and role of microRNA deregulation in câncer onset and progression. Genetics Molecular Biology. v.34, n.3, p.363-370, 2011.

PASSOS, G. A. S.; NGUYEN, C.; JORDAN, B. Projeto Transcriptoma - Análise da expressão gênica em larga escala usando DNA-arrays. Biotecnologia, Ciência \& Desenvolvimento. v.12, p.34-37, 2000. 
PASQUINELLI, A. E.; REINHART, B. J.; SLACK, F.; MARTINDALE, M. Q.; KURODA, M. I.; MALLER, B.; HAYWARD, D. C.; BALL, E. E.; DEGNAN, B.; MÜLLER, P.; SPRING, J.; SRINIVASAN, A.; FISHMAN, M.; FINNERTY, J.; CORBO, J.; LEVINE, M.; LEAHY, P.; DAVIDSON, E.; RUVKUN, G. Conservation of the sequence and temporal expression of let-7 heterochronic regulatory RNA. Nature. v.408, n.6808, p.86-89, 2000.

PAULEY, K. M.; EYSTATHIOY, T.; JAKYMIW, A.; HAMEL, J. C.; FRITZLER, M. J.; CHAN, E. K. L. Formation of GW bodies is a consequence of microRNA genesis. EMBO. v.7, n.9, p. 904-910, 2006.

PAULEY, K. M.; SATOH, M.; CHAN, A. L.; BUBB, M. R.; REEVES, W. H.; CHAN, E. $\mathrm{K}$. Upregulated miR-146a expression in peripheral blood mononuclear cells from rheumatoid arthritis patients. Arthritis Research \& Therapy. v.10, n.4, p.R101, 2008.

PAULEY, K. M.; CHA, S.; CHAN, E. K. L. MicroRNA in autoimmunity and autoimmune diseases. Journal of Autoimmunity. v.32, n. 3-4, p. 189-194, 2009.

PETRIE, H. T. Cell migration and the control of post-natal T-cell lymphopoiesis in the thymus. Nature Reviews Immunology. v.3, n.11, p.859-866, 2003.

PITKÄNEN, J. \& PETERSON, P. Autoimmune regulator: from loss of function to autoimmunity. Genes \& Immunity. v.4, n.1, p.12-21, 2003.

PLENGE, R. M.; SEIELSTAD, M.; PADYUKOV, L.; LEE, A. T.; REMMERS, E. F.; DING, B.; LIEW, A.; KHALILI, H.; CHANDRASEKARAN, A.; DAVIES, L. R.; LI, W.; TAN, A. K.; BONNARD, C.; ONG, R. T.; THALAMUTHU, A.; PETTERSSON, S.; LIU, C.; TIAN, C.; CHEN, W. V.; CARULli, J. P.; BECKMAN, E. M.; ALTSHULER, D.; ALFREDSSON, L.; CRISWELL, L. A.; AMOS, C. I.; SELDIN, M. F.; KASTNER, D. L.; KLARESKOG, L.; GREGERSEN, P. K. TRAF1-C5 as a risk locus for rheumatoid arthritis: a genomewide study. The New England Journal of Medicine. v.357, n.12, p. 1199-1209, 2007.

RAMIALISON, M.; MOHR, E.; NAL, B.; SABOUL, T.; CARRIER, A.; TAGETT, R.; GRANJEAUD, S.; NGUYEN, C.; GAUTHERET, D.; JORDAN, B. R.; FERRIER, P. Expression profiling in mouse fetal thymus reveals clusters of coordinately expressed genes that mark individual stages of T-cell ontogeny. Immunogenetics. v.54, n.7, p.469478, 2002.

RAZA, K.; FALCIANI, F.;CURNOW, S. J.; ROSS, E. J.; LEE, C. Y.; AKBAR, A. N.; LORD, J. M.; GORDON, C.; BUCKLEY, C.D.; SALMON, M. Early rheumatoid arthritis is characterized by a distinct and transient synovial fluid cytokine profile of $\mathrm{T}$ cell and stromal cell origin. Arthritis Research \& Therapy. v.7, n.4, p.784-795, 2005. 
REHWINKEL, J.; NATALIN, P.; STARK, A.; BRENNECKE, J.; COHEN, S. M.; IZAURRALDE, E. Genome-wide analysis of mRNAs regulated by Drosha and Argonaute proteins in Drosophila melanogaster. Molecular Cell Biology. v.26, n.8, p. 2965-2975, 2006.

REHMSMEIER, M.; STEFFEN, P.; HOCHSMANN, M.; GIEGERICH, R. Fast and effective prediction of microRNA/target duplexes. RNA. v.10, n. 10, p.1507-1517, 2004.

REINHART, B. J.; SLACK, F. J.; BASSON, M.; PASQUINELLI, A. E.; BETTINGER, J. C.; ROUGVIE, A. E.; HORVITZ, H. R.; RUVKUN, G. The 21-nucleotide let-7 RNA regulates developmental timing in Caenorhabditis elegans. Nature. v.403, n.6772, p.901906, 2000.

REMMERS EF, PLENGE RM, LEE AT, ET AL. STAT4 and the risk of rheumatoid arthritis and systemic lupus erythematosus. The New England Journal of Medicine. v.357, n.10, p.977-986, 2007.

REN, J.; JIN, P.; WANG, E.; MARINCOLA, F. M.; STRONCEK, D. F. MicroRNA and gene expression patterns in the differentiation of human embryonic stem cells. Journal of Translational Medicine. v.7, p.20, 2009.

RODEWALD, H. R. Thymus organogenesis. Annual Review Immunology. v.26, p.355$388,2008$.

ROSSI, F. M.; CORBEL, S. Y.; MERZABAN, J. S.; CARLOW, D. A.; GOSSENS, K.; DUENAS, J.; SO, L.; YI, L.; ZILTENER, H. J. Recruitment of adult thymic progenitors is regulated by P-selectin and its ligand PSGL-1. Nature Immunology. v.6, n.6, p. 626-634, 2005.

ROSSI, S. W.; JENKINSON, W. E.; ANDERSON, G.; JENKINSON, E. J. Clonal analysis reveals a common progenitor for thymic cortical and medullary epithelium. Nature. v.441, n.7096, p.988-991, 2006.

ROUAS, R.; FAYYAD-KAZAN, H.; EL ZEIN, N.; LEWALLE, P.; ROTHÉ, F.; SIMION, A.; AKL, H.; MOURTADA, M.; EL RIFAI, M.; BURNY, A.; ROMERO, P.; MARTIAT, P.; BADRAN, B. Human natural Treg microRNA signature: role of microRNA-31 and microRNA-21 in FOXP3 expression. European Journal of Immunology. v.39, n.6, p.1608-1618, 2009.

SAINTE-MARIE, G.; LEBLOND, C. P. Cytologic features and cellular migration in the cortex and medulla of thymus in the young adult rat. Blood. v.23, p. 275-299, 1964. 
SAKAGUCHI, S.; SAKAGUCHI, N.; ASANO, M.; ITHOH, M.; TODA, M. Immunologic self-tolerance maintained by activated $\mathrm{T}$ cells expressing IL-2 receptor alpha-chains (CD25). Breakdown of a single mechanism of self-tolerance causes various autoimmune diseases. The Journal of Immunology. v.155, n.3, p. 1151-1164, 1995.

SAKAGUCHI, S. Naturally arising CD4 + regulatory $t$ cells for immunologic selftolerance and negative control of immune responses. Annual Review of Immunology. v. 22, p.531-562, 2004.

SAKAGUCHI, S. Naturally arising Foxp3-expressing CD25+CD4+ regulatory $\mathrm{T}$ cells in immunological tolerance to self and non-self. Nature Immunology. v.6, n.4, p. 345-352, 2005 .

SAKAMOTO-HOJO, E. T.; MELlO, S. S.; CARDOSO, R. S.; PASSOS, G. A. S. Utilização de genômica funcional e proteômica em mutagênese (Cap. 12). Mutagênese Ambiental. Ed. ULBRA, 356p, 2003.

SARKAR, S.; COONEY, L. A.; WHITE, P.; DUNLOP, D. B.; ENDRES, J.; JORNS, J.M.; WASCO, M. J.; FOX, D. A. Regulation of pathogenic IL-17 responses in collageninduced arthritis: roles of endogenous interferon-gamma and IL-4. Arthritis Research \& Therapy. v.11, n.5, R158, 2009.

SATO, K.; SUEMATSU, A.; OKAMOTO, K.; YAMAGUCHI, A.; MORISHITA, Y.; KADONO, Y.; TANAKA, S.; KODAMA, T.; AKIRA, S.; IWAKURA, Y.; CUA, D. J.; TAKAYANAGI, H. Th17 functions as an osteoclastogenic helper T cell subset that links T cell activation and bone destruction. The Journal of Experimental Medicine. v.203, n.12, p. 2673-2682, 2006.

SAVINO, W. The thymus is a common target organ in infectious diseases. PLoS Pathogens. v.2, n.6, p.e62, 2006.

SAVINO, W.; AYRES MARTINS, S.; NEVES-DOS-SANTOS, S.; SMANIOTTO, S.; OCAMPO, J. S.; MENDES-DA-CRUZ, D. A.; TERRA-GRANADO, E.; KUSMENOK, O.; VILLA-VERDE, D. M. Thymocyte migration: an affair of multiple cellular interactions? Brazilian Journal of Medical and Biological Research. v.36, n.8, p.1015$1025,2003$.

SCHATZ, D. G.; JI, Y. Recombination centres and the orchestration of V(D)J recombination. Nature Reviews of Immunology. v.11, n.4, p.251-263, 2011.

STAUDT, L. M.; BROWN, P. O. Genomic views of the immune system. Annual Review of Immunology.v.18, p.829-859, 2000. 
SCHMUTZ, C.; CARTWRIGHT, A.; WILLIAMS, H.; HAWORTH, O.; WILLIAMS, J. H.; FILER, A.; SALMON, M.; BUCKLEY, C.D.; MIDDLETON, J. Monocytes/macrophages express chemokine receptor CCR9 in rheumatoid arthritis and CCL25 stimulates their differentiation. Arthritis Research \& Therapy. v.12, n.4, R161, 2010 .

SCOLLAY, R. G.; BUTCHER, E. C.; WEISSMAN, I. L. Thymus cell migration. Quantitative aspects of cellular traffic from the thymus to the periphery in mice. European Journal of Immunology. v.10, n.3, p. 210-218, 1980.

SHANNON, P.; MARKIEL, A.; OZIER, O.; BALIGA, N.; WANG, J.; RAMAGE, D.; AMIN, N.; SCHWIKOWSKI, B.; IDEKER, T. Cytoscape: a software environment for integrated models of biomolecular interaction networks. Genome Research. v.13, n.11, p.2498-2504, 2003.

SHIN, C.; NAM, J. W.; FARH, K. K.; CHIANG, H. R.; SHKUMATAVA, A.; BARTEL, D. P. Expanding the microRNA targeting code: functional sites with centered pairing. Molecular Cell. v.38, n.6, p. 789-802, 2010.

SMOLEN, J. S.; BEAULIEU, A.; RUBBERT-ROTH, A.; RAMOS-REMUS, C.; ROVENSKY, J.; ALECOCK, E.; WOODWORTH, T.; ALTEN, R. Effect of interleukin-6 receptor inhibition with tocilizumab in patients with rheumatoid arthritis (OPTION study): a double-blind, placebo-controlled, randomised trial. The Lancet. v.371, n.9617, p. 987997, 2008.

SONKOLY, E.; STAHLE, M.; PIVARCSI, A. MicroRNAs and immunity: novel players in the regulation of normal immune function and inflammation. Seminars in Cancer Biology. v.18, n.2, p.131-140, 2008.

SOSPEDRA, M.; FERRER-FRANCESCH， X.; DOMÍNGUEZ， O.; JUAN, M.; FOZSALA, M.; PUJOL-BORRELL, R. Transcription of broad range of self-antigens in human thymus suggests a role for central mechanisms in tolerance toward peripheral antigens. The Journal of Immunology. v.161, n.11, p.5918-5929, 1998.

SPRENT, J. Central tolerance of T cells. International Reviews of Immunology. v.13, n.2, p.95-105, 1995.

STAHL, H. F.; FAUTI, T.; ULLRICH, N.; BOPP, T.; KUBACH, J.; RUST, W.; LABHART, P.; ALEXIADIS, V.; BECKER, C.; HAFNER, M.; WEITH, A.; LENTER, M. C.; JONULEIT, H.; SCHMITT, E.; MENNERICH, D. miR-155 inhibition sensitizes CD41 Th cells for TREG mediated suppression. PLoS ONE. v.4, n.9, p.e7158, 2009. 
STANCZYK, J.; PEDRIOLI, D. M.; BRENTANO, F.; SANCHEZ-PERNAUTE, O.; KOLLING, C.; GAY, R. E.; DETMAR, M.; GAY, S.; KYBURZ, D. Altered expression of MicroRNA in synovial fibroblasts and synovial tissue in rheumatoid arthritis. Arthritis \& Rheumatism. v.58, n.4, p. 1001-1009, 2008.

STUTMAN, O. Intrathymic and extrathymic T cell maturation. Immunological Reviews. v.42, p.138-184, 1978.

SUGIMOTO, N. T.; OIDA, K.; HIROTA, K.; NAKAMURA, T.; NOMURA, T.; SAKAGUCHI, S. Foxp3-dependent and -independent molecules specific for CD25+CD4+ natural regulatory $\mathrm{T}$ cells revealed by DNA microarray analysis. International Immunology. v.18, p. 1197-1209, 2006.

SUN, D.; WHITAKER, J. N.; HUANG, Z.; LIU, D.; COLECLOUGH, C.; WEKERLE, H.; RAINE, C. S. Myelin antigen-specific CD8+ T cells are encephalitogenic and produce severe disease in C57BL/6 mice. The Journal of Immunology. v.166, n.12, p. 7579-7587, 2001.

SUZUKI, E.; KOBAYASHI, Y.; KAWANO, O.; ENDO, K.; HANEDA, H.; YUKIUE, H.; SASAKI, H.; YANO, M.; MAEDA, M.; FUJII, Y. Expression of AIRE in thymocytes and peripheral lymphocytes. Autoimmunity. v.41, n.2, p.133-139, 2008.

SVENSSON, B.; BOONEN, A.; ALBERTSSON, K.; VAN DER HEIJDE, D.; KELLER, C.; HAFSTROM, I. Low-dose prednisolone in addition to the initial disease-modifying antirheumatic drug in patients with early active rheumatoid arthritis reduces joint destruction and increases the remission rate: a two-year randomized trial. Arthritis \& Rheumatism. v.52, n.11, p. 3360-3370, 2005.

SVENSSON, L.; JIRHOLT, J.; HOLMDAHL, R.; JANSSON, L. B cell-deficient mice do not develop type II collagen-induced arthritis (CIA). Clinical \& Experimental Immunology. v.111, n.3, p. 521-526, 1998.

SVERDRUP, B.; KALLBERG, H.; BENGTSSON, C.; LUNDBERG, I.; PADYUKOV, L.; ALFREDSSON, L.; KLARESKOG, L. Association between occupational exposure to mineral oil and rheumatoid arthritis: results from the Swedish EIRA case-control study. Arthritis Research \& Therapy. v.7, n.6, p.1296-1303, 2005.

SYMMONS, D. P. M.; BARRET, E. M.; BANKHEAD, C. R.; SCOTT, D. G. I.; SILMAN, A. J. The incidence of rheumatoid arthritis in the United Kingdom: results from the Norfolk arthritis register. British Journal Rheumatology. v.33, n.8, p.735-739, 1994.

SYMMONS, D. P.; BANKHEAD, C. R.; HARRISON, B. J.; BRENNAN, P.; BARRET, E. M.; SCOTT, D. G.; SILMAN, A. J. Blood transfusion, smoking, and obesity as risk factors for the development of rheumatoid arthritis: results from a primary care-based incident case-control study in Norfolk, England. Arthritis \& Rheumatism. v.40, N.11, P1955-1961, 1997. 
SWEENEY, T. E.; SULIMAN, H. B.; HOLLINGSWORTH, J. W.; PIANTADOSI, C. A. Differential regulation of the PGC family of genes in a mouse model of Staphylococcus aureus sepsis. PLoS One. v.5, n.7, e11606, 2010.

TADA, Y.; HO, A.; KOH, D. R.; MAK, T. W. Collagen-induced arthritis in CD4- or CD8deficient mice: $\mathrm{CD} 8+\mathrm{T}$ cells play a role in initiation and regulate recovery phase of collagen-induced arthritis. The Journal of Immunology. v.156, n.11, p. 4520-4526, 1996.

TAGANOV, K. D.; BOLDIN, M. P.; BALTIMORE, D. MicroRNAs and immunity:tiny players in a big field. Immunity. v.26, n.2, p.133-137, 2007.

TAGANOV, K. D.; BOLDIN, M. P.; CHANG, K. J.; BALTIMORE, D. NFkappaBdependent induction of microRNA miR-146, an inhibitor targeted to signaling proteins of innate immune responses. Proceedings of the National Academy of Sciences of the USA. v.103, n.33, p.12481-12486, 2006.

THAI, T. H.; CALADO, D. P.; CASOLA, S.; ANSEL, K. M.; XIAO, C.; XUE, Y.; MURPHY, A.; FRENDEWEY, D.; VALENZUELA, D.; KUTOK, J. L.; SCHMIDTSUPPRIAN, M.; RAJEWSKY, N.; YANCOPOULOS, G.; RAO, A.; RAJEWSKY, K. Regulation of the germinal center response by microRNA-155. Science. v.316, n.5824, p.604-608, 2007.

TAKAHAMA,Y.Journey through the thymus: stromal guides for T-cell development and selection. Nature Reviews Immunology. v.6, n.2, p.127-135, 2006.

TARNER, I. H. \& FATHMAN, C. G. Gene therapy in autoimmune disease. Current Opinion in Immunology. v.13, n.6, p.676-682, 2001.

TERATO, K.; HASTY, K. A.; REIFE, R. A.; CREMER, M. A.; KANG, A. H.; STUART, J. M. Induction of arthritis with monoclonal antibodies to collagen. The Journal of Immunology. v.148, n.7, p. 2103-2108, 1992.

THORNTON, A. M.; KORTY, P. E.; TRAN, D. Q.; WOHLFERT, E. A.; MURRAY, P. E.; BELKAID, Y.; SHEVACH, E. M. Expression of Helios, an Ikaros transcription factor family member, differentiates thymic-derived from peripherally induced Foxp3 $+\mathrm{T}$ regulatory cells. The Journal of Immunology. v.184, n.7, p. 3433-3441, 2010.

TILI, E.; MICHAILLE, J. J.; CIMINO, A.; COSTINEAN, S.; DUMITRU, C. D.; ADAIR, B.; FABBRI, M.; ALDER, H.; LIU, C. G.; CALIN, G. A.; CROCE, C. M. Modulation of miR-155 and miR-125b levels following lipopolysaccharide/TNF-alpha stimulation and their possible roles in regulating the response to endotoxin shock. The Journal of Immunology. v.179, n.8, p.5082-5089, 2007. 
TILI, E.; MICHAILlE, J. J.; COSTINEAN, S.; CROCE, C. M. MicroRNAs, the immune system and rheumatic disease. Nature Clinical Practice Rheumatology. v.4, n.10, p.534$541,2008$.

TODD, J. A.; ACHA-ORBEA, H.; BELL, J. I.; CHAO, N.; FRONEK, Z.; JACOB, C. O.; MCDERMOTT, M.; SINHA, A. A.; TIMMERMAN, L.; STEINMAN, L. A molecular basis for MHC class II - associated autoimmunity. Science. v.240, n.4855, p.1003-1009, 1988.

TOUBI, E.; KESSEL, A.; MAHMUDOV, Z.; HALLAS, K.; ROZENBAUM, M.; ROSNER, I. Increased spontaneous apoptosis of CD4+CD25+ T cells in patients with active rheumatoid arthritis is reduced by infliximab. Annals of the New York Academy of Science. v.1051, p. 506-514, 2005.

TRENTHAM, D. E.; TOWNES, A. S.; KANG, A. H. Autoimmunity to type II collagen: an experimental model of arthritis. The Journal of Experimental Medicine. v.146, n.3, p.857-868, 1977.

TURREL-DAVIN, F.; TOURNADRE, A.; PACHOT, A.; ARNAUD, B.; CAZALIS, M. A.; MOUGIN, B.; MIOSSEC, P. FoxO3a involved in neutrophil and T cell survival is overexpressed in rheumatoid blood and synovial tissue. Annals of the Rheumatic Diseases. v.69, n.4, p.755-760, 2010.

VALENCIA, X.; STEPHENS, G.; GOLDBACH-MANSKY, R.; WILSON, M.; SHEVACH, E. M.; LIPSKY, P. E. TNF downmodulates the function of human CD4+CD25hi T-regulatory cells. Blood. v.108, n.1, p.253-261, 2006.

VAN AMELSFORT, J. M.; JACOBS, K. M.; BIJLSMA, J. W.; LAFEBER, F. P.; TAAMS, L. S. CD4(+)CD25(+) regulatory T cells in rheumatoid arthritis: differences in the presence, phenotype, and function between peripheral blood and synovial fluid. Arthritis \& Rheumatism. v.50, n.9, p.2775-2785, 2004.

VAN BOXEL, J. A.; PAGET, S.A. Predominantly T-cell infiltrate in rheumatoid synovial membranes. The New England Journal of Medicine. v.293, n.11, p. 517-520, 1975.

VAN DEN BROEK, M. F.; DE HEER, E.; VAN BRUGGEN, M. C.; DE ROO, G.; KLEIVERDA, K.; EULDERINK, F.; VAN DEN BERG, W. B. Immunomodulation of streptococcal cell wall-induced arthritis. Identification of inflammatory cells and regulatory $\mathrm{T}$ cell subsets by mercuric chloride and in vivo CD8 depletion. European Journal of Immunology. v.22, n.12, p. 3091-3095, 1992.

VAN EWIJK, W. T-cell differentiation is influenced by thymic microenvironments. Annu Rev Immunol. v.9, p.591-615, 1991. 
VAN EWIJK, W.; HOLLANDER, G. A.; TERHORST, C.; WANG, B. Stepwise development of thymic microenvironments in vivo is regulated by thymocyte subsets. Development. v.127, n.8, p.1583-1591, 2000.

VAN EWIJK, W.; SHORES, E. W.; SINGER, A. Crosstalk in the mouse thymus. Immunology Today. v.15, n.5, p.214-217, 1994.

VAN HAL, N. L.; VORST, O.; VAN HOUWELINGEN, A. M.; KOK, E. J.; PEIJNENBURG, A.; AHARONI, A.; VAN TUNEN, A. J.; KEIJER, J. The application of DNA microarrays in gene expression analysis. Journal of Biotechnology. v.78, n.3, p.271-280, 2000.

VAN ROON, J.A.; BIJLSMA, J.W. Th2 mediated regulation in RA and the spondyloarthropathies. Annals of the Rheumatic Diseases. v.61, n.11, p. 951-954, 2002.

VERDUCI, L.; SIMILI, M.; RIZZO, M.; MERCATANTI, A.; EVANGELISTA, M.; MARIANI, L.; RAINALDI, G.; PITTO, L. MicroRNA (miRNA)-mediated interaction between leukemia/lymphoma-related factor (LRF) and alternative splicing factor/splicing factor 2 (ASF/SF2) affects mouse embryonic fibroblast senescence and apoptosis. Journal Biology Chemistry. v.285, n.50, p.39551-39563, 2010.

VERHOEF, C. M.; VAN ROON, J. A.; VIANEN, M. E.; BRUIJNZEEL-KOOMEN, C. A.; LAFEBER, F. P.; BIJLSMA, J. W. Mutual antagonism of rheumatoid arthritis and hay fever; a role for type 1/type $2 \mathrm{~T}$ cell balance. Annals of the Rheumatic Diseases. v.57, n.5, p. 275-280, 1998.

VESSEY, M. P.; VILLARD-MACKINTOSH, L.; YEATES, D. Oral contraceptives, cigarette smoking and other factors in relation to arthritis. Contraception. v.35, n.5, p.457-464, 1987.

VIGNALI, D. A.; COLLISON, L. W.; WORKMAN, C. J. How regulatory T cells work. Nature Reviews Immunology. v.8, n.7, p.523-532, 2008.

WANG, B.; GONZALEZ, A.; BENOIST, C.; MATHIS, D. The role of CD8+ T cells in the initiation of insulin-dependent diabetes mellitus. European Journal of Immunology. v. 26, n.8, p. 1762-1769, 1996.

WANG, Y.; JOSHI, T.; ZHANG, X. S.; XU, D.; CHEN, L. Inferring gene regulatory networks from multiple microarray datasets. Bioinformatics. v.22, n.19, p.2413-2420, 2006. 
WATANABE, N.; WANG, Y. H.; LEE, H.K.; ITO, T.; WANG, Y. H.; CAO, W.; LIU, Y. J. Hassall's corpuscles instruct dendritic cells to induce CD4+CD25+ regulatory T cells in human thymus. Nature. v.436, n.7054, p. 1181-1185, 2005.

WEANT, A. E.; MICHALEK, R. D.; KHAN, I. U.; HOLBROOK, B. C.; WILLINGHAM, M. C.; AND GRAYSON. J. M. Apoptosis regulators Bim and Fas function concurrently to control autoimmunity and CD8+ T cell contraction. Immunity v.28, n.2 ,p. 218-230, 2008 .

WHEELER, G.; NTOUNIA-FOUSARA, S.; GRANDA, B.; RATHJEN, T.; DALMAY, T. Identification of new central nervous system specific mouse microRNAs. FEBS Letter. v.580, n.9, p.2195-200, 2006.

WHITNEY, L. W. \& BECKER, K. G. Radioactive 33-P probes in hybridization to glass cDNA microarrays using neural tissues. Journal of Neuroscience Methods. v.106, n.1, p.9-13, 2001.

WIGHTMAN, B.; HA, I.; RUVKUN, G. Posttranscriptional regulation of the heterochronic gene lin-14 by lin-4 mediates temporal pattern formation in C. elegans. Cell. v.75, n.5, p.855-862, 1993.

WITOWSKI, J.; KSIAZEK, K.; JORRES, A. S. Interleukin-17: a mediator of inflammatory responses. Cellular and Molecular Life Sciences. v.61, n.5,p.567-579, 2004.

WOOLEY, P. H.; LUTHRA, H. S.; SINGH, S. K.; HUSE, A. R.; STUART, J. M.; DAVID, C. S. Passive transfer of arthritis to mice by injection of human anti-type II collagen antibody. Mayo Clinic Proceedings. v.59, n.11, p.737-743, 1984.

WOOLEY, P. H.; LUTHRA, H. S.; STUART, J. M.; DAVID, C. S. Type II collagen induced arthritis in mice. I. Major histocompatibility complex (I-region) linkage and antibody correlates. The Journal of Experimental. Medicine. v.154, n.3, p. 688-700, 1981.

WURBEL, M. A.; MALISSEN, M.; GUY-GRAND, D.; MEFFRE, E.; NUSSENZWEIG, M. C.; RICHELME, M.; CARRIER, A.; MALISSEN, B. Mice lacking the CCR9 CCchemokine receptor show a mild impairment of early $\mathrm{T}$ - and B-cell development and a reduction in T-cell receptor $\gamma \delta+$ gut intraepithelial lymphocytes. Blood. v.98, n.9, p, 26262632, 2001.

XIAO, C.; CALADO, D. P.; GALLER, G.; THAI, T. H.; PATTERSON, H. C.; WANG, J.; RAJEWSKY, N.; BENDER, T. P.; RAJEWSKY, K. MiR-150 controls B cell differentiation by targeting the transcription factor c-Myb. Cell. v.131, n.1, p.146-159, 2007. 
XIAO, C.; RAJEWSKY, K. MicroRNA control in the immune system:basic principles. Cell. v.136, n.1, p.26-36, 2009.

YAMAGUCHI, Y.; FUJIO, K.; SHODA, H.; OKAMOTO, A.; TSUNO, N. H.; TAKAHASHI, K.; YAMAMOTO, K. IL-17B and IL-17C are associated with TNF-alpha production and contribute to the exacerbation of inflammatory arthritis. The Journal of Immunology. v.179, n.10, p. 7128-7136, 2007.

YAMAMURA, Y.; GUPTA, R.; MORITA, Y.; HE, Y.; PAI, R.; ENDRES, J.; FREIBERG, A.; CHUNG, K.; AND FOX, D. A. Effector function of resting T cells: activation of synovial fibroblasts. The Journal of Immunology. v.166, n.4, p.2270-2275, 2001.

YE, S. Q.; USHER, D. C.; ZHANG, L. Q. Gene expression profiling of human diseases by serial analysis of gene expression. Journal of Biomedical Science. v.9, n.5, p.384-394, 2002.

YU, D.; TAN, A. H.; HU, X.; ATHANASOPOULOS, V.; SIMPSON, N.; SILVA, D. G.; HUTLOFF, A.; GILES, K. M.; LEEDMAN, P. J.; LAM, K. P.; GOODNOW, C. C.; VINUESA, C. G. Roquin represses autoimmunity by limiting inducible T-cell costimulator messenger RNA. Nature. v.450, n.7167, p. 299-303, 2007.

ZAMISCH, M.; MOORE-SCOTT, B.; SU, D. M.; LUCAS, P. J.; MANLEY, N.; RICHIE, E. R. Ontogeny and regulation of IL-7-expressing thymic epithelial cells. The Journal of Immunology. v. 174, n.1, p. 60-67, 2005.

ZENDMAN, A. J.; VAN VENROOIJ, W. J.; AND PRUIJN, G. J. Use and significance of anti-CCP autoantibodies in rheumatoid arthritis. Rheumatology. v.45, n.1, p20-25, 2006.

ZHANG, G. X.; XIAO, B. G.; BAKHIET, M.; VAN DER MEIDE, P.; WIGZELL, H.; LINK, H.; OLSSON, T. Both CD4+ and CD8+ T cells are essential to induce experimental autoimmune myasthenia gravis. The Journal of Experimental Medicine. v.184, n.2, p. 349-356, 1996.

ZHAO, T.; LI, G.; MI, S.; LI, S.; HANNON, G. J.; WANG, X. J.; QI, Y. A complex system of small RNAs in the unicellular green alga Chlamydomonas reinhardtii. Genes \& Development. v.21, n.10, p.1190-1203, 2007.

ZHOU, H.; HUANG, X;, CUI, H.; LUO, X.; TANG, Y.; CHEN, S.; WU, L.; SHEN, N. MiR-155 and its star-form partner miR-155/ cooperatively regulate type I interferon production by human plasmacytoid dendritic cells. Blood. v.116, n.26, p. 5885-5894, 2010 . 
ZHU, M.; YI, M.; KIM, C. H.; DENG, C.; LI, Y.; MEDINA, D.; STEPHEN, R.; GREEN, J. E. Integrated miRNA and mRNA expression profiling of mouse mammary tumor models identifies miRNA signatures associated with mammary tumor lineage. Genome Biology. v.12, n.8, R77, 2011.

ZIEGLER, S. F. FOXP3: Of Mice and Men. Annual Review of Immunology. v.24, p. 209-226, 2006.

ZINKERNAGEL, R. M.; CALLAHAN, G. N.; ALTHAGE, A.; COOPER, S.; KLEIN, P. A.; KLEIN, J. On the thymus in the differentiation of "H-2 self-recognition" by T cells: evidence for dual recognition? The Journal of Experimental . Medicine. v.147, n. 3, p.882-896, 1978.

ZUKLYS, S.; BALCIUNAITE, G.; AGARWAL, A.; FASLER-KAN, E.; PALMER, E.; HOLLANDER, G. A. Normal thymic architecture and negative selection are associated with Aire expression, the gene defective in the autoimmune-polyendocrinopathycandidiasis-ectodermal dystrophy (APECED). The Journal of Immunology. v.165, n.4, p. 1976-1983, 2000. 
MANUSCRITO 


\section{T cell post-transcriptional miRNA-mRNAinteractionnetworks identifies targets associated to susceptibility/resistance to collagen-induced arthritis in mice}

Paula B. Donate ${ }^{1}$,Thais A. Fornari ${ }^{1}$,Claudia Macedo ${ }^{1}$,Tiago Cunha ${ }^{2}$, Fernando Q Cunha ${ }^{2}$, Elza T. Sakamoto-Hojo ${ }^{3}$, Eduardo A. Donadi ${ }^{4}$, Geraldo A. Passos ${ }^{1,5^{*}}$

(1) Molecular Immunogenetics Group, Department of Genetics, Faculty of Medicine of Ribeirão Preto, University of São Paulo (USP), 14040-900, Ribeirão Preto, SP, Brazil.

(2) Inflammation and Pain Group, Department of Pharmacology, Faculty of Medicine of Ribeirão Preto, USP, 14040-900, Ribeirão Preto, SP, Brazil.

(3) Department of Biology, Faculty of Philosophy, Sciences and Letters of Ribeirão Preto, USP, 14040-900, Ribeirão Preto, SP, Brazil.

(4) Division of Clinical Immunology, Department of Medicine, Faculty of Medicine of Ribeirão Preto, USP, 14040-900, Ribeirão Preto, SP, Brazil.

(5) Disciplines of Genetics and Molecular Biology, Department of Morphology, Faculty of Dentistry of Ribeirão Preto, USP, 14040-900, Ribeirão Preto, SP, Brazil.

* Send correspondence to Dr. Geraldo A. Passos, Molecular Immunogenetics Group, Department of Genetics, Faculty of Medicine of Ribeirão Preto, University of São Paulo (USP), 3900 Bandeirantes Avenue, ZIP Code 14040-900, Ribeirão Preto, SP, Brazil. TEL: +55 1636023030 FAX: +55 1636020222 E-mail: passos@rge.fmrp.usp.br 


\begin{abstract}
Considering the recentevidence that deregulation of miRNAs (miRNAs) in $T$ cellscontributes to increase the severity of rheumatoid arthritis,we raised the hypothesis that deregulated miRNAs may interact with key mRNA targets controlling the function and/or differentiation of these cells. To test this, we used microarrays to survey, for the first time, the expression of all known mouse miRNAs in parallel with genome-wide mRNAsin thymocytes, naïve and activated peripheral CD3+ T cells of two mouse strains; DBA-1/J (MHC H2q) susceptible and DBA-2/J (MHC-H2d) resistant to collagen induced arthritis (CIA). Hierarchical clustering of data showed that throughout immunization with collagen, severalT cell miRNAs and mRNAswere differentially expressed between the mouse strains.Bayesian statistics using the GenMir++ algorithm allowed reconstruction of post-transcriptional miRNA-mRNA interaction networks for target prediction. We revealed the participation of miR-500, miR-202-3p and miR-690, which established interaction with at least one of the following mRNAs; Rorc, Fas, Fasl, Il-10, and Foxo3, among others.Among the interactions that were validated bycalculating the minimal free-energy of base pairing between the miRNA and the 3'UTR of the mRNA target, we highlight the interaction miRNA 30b*-RORcmRNA since the respective coded a protein implicated in pro-inflammatory Th17 cell differentiation (Roryt). FACS analysis revealed that ROR$\gamma$ tprotein levels, as well as Th17 cell counts were comparatively reduced in DBA- $2 / \mathrm{J}$ strain. This result confirms our starting hypothesis. The miRNAsidentified in this study represent new candidates involved with $\mathrm{T}$ cell function and control of susceptibility/resistance to CIA.
\end{abstract}

Key words: MiRNA, target prediction, $\mathrm{T}$ cells, collagen-induced arthritis, resistance to arthritis. 


\section{Introduction}

Rheumatoid arthritis (RA) is a systemic autoimmune disordermainly characterized by the inflammation of synovial tissue thatcan lead to destruction of bone and cartilage, and eventual disability (Klareskog et al 2009, Firestein et al 2003). The mechanisms involved in disease initiation and progression are still incompletely understood, as RA has a complexcomponent controlled by several genes that interact together with environmental and stochastic factors (Klareskog et al 2009).

A hallmark pathological feature of RA is the infiltration and accumulation of $\mathrm{T}$ cells in the (Panayi et al 1992). The T cells isolated from synovial and joint tissue show an activated and memory phenotype.These cells appear to respond poorly to stimulation with mitogen or antigens in vitro and fail to undergo apoptosis (Ali et al 2001). The possible mechanisms underlying the impaired apoptosis of $\mathrm{T}$ cells in RA remains largely unclear. Anyway, inhibition of apoptosis causes these cells to accumulate in both the synovia and the periphery.

Due to inherent difficulty to study these questions in humans, researchers use collagen-induced arthritis (CIA) in mice as an adequate animal model of autoimmune inflammatory polyarthritis reproducing the clinical and pathological features of human RA (Trentham et al 1977). Similar to RA, susceptibility to CIA has a genetic basis, whichis associated with certain MHC-II alleles (H2-Aq and $\mathrm{H} 2-\mathrm{Ar}$ ), which make certain mouse strains susceptible (Griffiths et al 1994).

The molecular genetics of RA and CIA is an emerging topic with contributions from our group (Silva et al 2007, 2009; Junta et al 2009; Donate et al 2011) and from others (Wu et al 2010; Haeupl et al 2010) which have demonstrated association of transcriptional expression profiles of mRNAs and RA. Recent data suggest that certain miRNAs in T cells might play a role in the onset of this disease (Li et al 2010).

Moreover, groups have focused their attention onthe role played by miRNAs in the pathogenesis of RA, as well as their potential use as biomarkers to monitor the disease (Pauley et al, 2008; Murata et al, 2010).

The miRNAs have emerged as post-transcriptional regulators of gene expression in a variety of biological processes (Plasterk 2006, Chen and Lodish 2005,Ambros 2004, Bartel 2004). The mode of miRNA regulation is protein repression via complementary sequence recognition in the $3^{\prime}$ untranslated region ( $3^{\prime} \mathrm{UTR}$ ) of the target mRNA and/or triggering the degradation of the target transcript (Engels and Hutvagner, 2006; Rajewsky 
2006, Behm-Ansmant et al 2006). A recent paper indicates that the major effect of miRNAs is todecrease mRNA levels (Guo et al 2010). MiRNAs can potentially regulate hundreds of proteins (Grimson et al 2007) and modulate concentration of proteins over a narrow range in a dose dependent manner (Selbach et al 2008).

These molecules are involved in hematopoietic cell function and development and a few miRNAs have been linked to specific $\mathrm{T}$ lymphocyte mechanisms as for example miRNA 181a (Li et al 2007), miRNA 181c (Xue et al 2010), miRNA 155 (Thai et al 2007), miRNA 150 (Wu et al 2007), miRNA 146 (Li et al 2010), and miRNA 142 (Huang et al 2009)via regulation of $T$ cell sensitivity to antigen stimulation, regulating transcription factors, and activation-induced cell death.

Altered miRNA expressionin RA patients compared to healthy controls or patients affected by osteoarthritis (Pauley et al 2008, Stanczyk et al 2008) had been the focus of many studies, and most of them mainly considered miRNA expression in plasma andserum, while others mainly focused on tissue analysis (Murata et al 2010).

Some miRNAs were identified in $\mathrm{T}$ cells of RA patients; miRNA 223 is upregulated in $\mathrm{CD}^{+}$naïve $\mathrm{T}$ lymphocytes (Fulci et al 2010). As $\mathrm{T}$ lymphocytes are considered to play a role in the pathogenesis of RA, these results suggest that this miRNA could target Tcell response and therefore contribute to the onset of the disease. A recent study shows that miRNA 363 and miRNA 498 are downregulated in CD4 ${ }^{+}$T cells of RA patients, while miRNA 146a expression is significantly upregulated(Li et al 2010).

In this study, we used a multidimensional approach to integrate genome-wide miRNA, and mRNA expression. We surveyed, for the first time, the expression of 627 mouse miRNA sequences inthymocytes, naïve and activated $\mathrm{T}$ cells in both mouse strains, DBA-1/J susceptible and DBA-2/J refractory to CIA. In parallel, we profiled global mRNA including the whole mouse genome (transcriptome profiling).

We found 96 significantly differentially expressed miRNAs comparing thymocytes and naïve $T$ cells of both mouse strains, and 62 during CIA induction.Using a Bayesian statistics-based data analysis algorithm, GenMiR++, to reconstruct miRNA-mRNA networks interactions, important mRNAs related to immune system, $\mathrm{T}$ cell function and differentiationwere found as potential targets.

The minimal Gibbs free-energy calculations using the RNA-Hybrid algorithm (Rehmsmeier et al, 2004; Krüger\&Rehmsmeier, 2006) validated the majority of the miRNA-mRNA interaction networks, one of which (miR-30b* interacting with ROR- 
$\gamma$ tmRNA) is highlighted since ROR- $\gamma$ tprotein is a transcription factor involved in Th17 cell differentiation (Jetten, 2009). We observed that both mRNA and ROR- $\gamma$ t protein were down-regulated in DBA-2/J strain, which is refractory to CIA. Moreover, the proportion of Th17 cells in this strain is lower than DBA-1/J.

In this study we identified novel miRNAs involved with $\mathrm{T}$ cell function in the context of autoimmunity, providing evidence for their role acting in post-transcriptional networks with key mRNAs, which down-regulated might control the susceptibility/resistance to CIA in mice.

\section{Material and methods}

\section{Animals}

Male DBA/1J and DBA-2/J mice (4 and 12weeks-old) weighing 18-22 g each were housed in temperature-controlled rooms $\left(22^{\circ} \mathrm{C}\right)$ in the animal facility of the School of Medicine of Ribeirão Preto, University of São Paulo, São Paulo, Brazil, and received water and food ad libitum. The experimental protocols were approved by the local Ethical Committee on Animal Experimentation of the Faculty of Medicine of Ribeirão Preto, University of São Paulo, Ribeirão Preto, Brazil (protocol nº 119/2008).

\section{Induction and assessment of collagen-induced arthritis}

Male DBA/1J and DBA-2/J mice received $200 \mu \mathrm{g}$ of bovine type II collagen(Sigma) emulsioned in complete Freund's adjuvant (CFA) by intradermal injection (day 0). A second injection of collagen (200 $\mu \mathrm{g}$ dissolved in sterile apyrogenic pH 7.2 phosphate buffered saline, PBS) was given on day 21 by intra peritoneal injection (Leung et al 2003). Mice were monitored daily for signs of arthritis for which severity scores were derived as follows: $0=$ normal paw, $1=$ paw with erythema, $2=$ paw with erythema plus swelling, $3=$ paw with extension/loss function and total score $=$ sum of four limbs. Disease onset characterized by erythema and/or paw swelling was seen between days 25 and 35. The control group corresponded to the sham-immunized mice, which received the only injection CFA. 


\section{Thymocytes and $\mathrm{CD}^{+} \mathrm{T}$ cell isolation}

The thymi from 4 weeks-old male DBA-1/J and DBA-2/J mice were dissected and trimmed of fat and connective tissue in DMEM/F10medium, and thymocytes were obtained by 2-3 passagesof the thymic fragments throughout a $10-\mu \mathrm{m}$ mesh nylon membrane (Sefar Inc. Depew, NY, USA). Pelletedthymocytes were suspended in pH 7.2 phosphate-buffered saline(PBS). Fluorescent-activated cell sorting (FACS) analysis in a BD-FACScalibur flow cytometer with phycoerythrin (PE)-labeled anti-CD3 antibody indicated that thisprocedure yielded approximately $93 \%$ purity of the thymocyte population. These cells werethen used for total RNA preparation. The peripheral T CD3 ${ }^{+}$ lymphocytes from 4-weeks-old non-immunized mice (here considered as naïve), and 12weeks-old control and collagen immunized male mice of both strains were isolated from inguinal lymph nodes and spleens using magneticbeads for negative selection (Pan T-cell isolation kit, mouse,MiltenyiBiotec) according to the manufacturer's instructions.FACS analysis with PE-labeled anti-CD3 antibody indicated that this procedure yielded approximately $88 \%$ purity of the $\mathrm{CD}^{+} \mathrm{T}$ lymphocyte population. These cells were then used for total RNA preparation. For the microarray hybridizations, we used a pool of cells (thymocytes, peripheral naïve and activated $\mathrm{T}$ cells) from five animals (DBA-1/J and DBA-2/J strains). Each hybridization of RNA pools was performed in triplicate for mRNA or in duplicate for miRNA microarrays.

\section{Total RNA extraction}

The total RNA was extractedfrom approximately $1 \times 10^{7}$ thymocytes or peripheral T CD3+ lymphocytes using the mirVana total RNA isolation kit (Ambion, NY, USA) accordingto the manufacturer's instructions. RNA preparations were confirmed to be free of proteins and phenol by UVspectrophotometry. The state of degradation was assessed bymicrofluidic electrophoresis using Agilent RNA Nano chips6000 and an Agilent 2100 Bioanalyzer (Agilent Technologies,Santa Clara, CA, USA). Only RNA samples that were free ofproteins and phenol and featured an RNA Integrity Number(RIN) $\geq 9.0$ were used. 


\section{Microarrays}

\section{mRNA expression profiling using Agilent $4 \times 44 \mathrm{~K}$ mouse arrays}

Individual 500ng of total RNA samples pooled from five mice per group (thymocytes, naïve or peripheral T cells from CIA or control groupsof DBA-1/J or DBA2/J mice) were used to synthesize double-stranded cDNA and cyanine 3-CTP cyaninelabelled complementary amplified RNA (cRNA) using theAgilent Linear Amplification Kit (Agilent Technologies, Santa Clara, CA, USA)according to the manufacturer's instructions.Cyanine-labelled complementary RNA was hybridized to microarrays in SureHyb chambers (Agilent)in a rotator oven to Agilentmouse $4 \times 44 \mathrm{~K}$ oligonucleotide microarrays (Agilent Technologies) for 18 hat $60^{\circ} \mathrm{C}$. Each array contained 44,000 oligonucleotide probes covering the whole mouse functional genome plus internal control probes. Arrays were washed according to the manufacturer's instructions and scanned.

\section{MiRNA expression profiling using Agilent 15 x 15 K mouse arrays}

The total RNA samples pooled from five mice per group (thymocytes, naïve or peripheral $\mathrm{T}$ cells from CIA or control groups of DBA-1/J or DBA-2/J mice) were Cy-3labeled using the Agilent miRNA Complete Labelling and Hybridisation Kit (Agilent Tech, Mississauga, ON, Canada). Briefly, 100 ng total RNAwas dephosphorylated by incubation with calf intestinal phosphatase at $37^{\circ} \mathrm{C}$ during 30 minutes, denatured in $100 \%$ DMSOat $100{ }^{\circ} \mathrm{C}$ for 5 minutes and then labeled with pCp-Cy3 using T4 ligase at $16{ }^{\circ} \mathrm{C}$ for $1 \mathrm{~h}$. Each labeled RNA sample was hybridized to an individual array on $8 \times 15 \mathrm{~K}$ format Agilent mouse miRNA array slides and each array containing probesfor 567mousemiRNAand 10mousegammaherpes virus miRNAs. Hybridizations were performed in SureHyb chambers (Agilent)for $20 \mathrm{~h}$ at $55{ }^{\circ} \mathrm{C}$ and washed according to manufacturer's instructions and scanned.

\section{Microarray data analysis}

The oligo-mRNA and oligo-miRNA array slideswere scanned using a DNA microarray scanner (AgilentTechnologies), and the hybridization signals were extractedusing the Agilent Feature Extraction software version 10.5.Gene expression profiles from independent preparationsof thymocytes (from 4 weeks-old DBA-1/J and DBA-2/J mice) or $\mathrm{CD}^{+}$peripheral lymphocytes (from 4 and 12-weeks-old DBA-1/J and DBA-2/J mice) were analyzed through comparisons of the microarrayhybridizations of the respective samples. Figure 1 depicts the experimental design for further comparison of the 
gene profiling. The microarray numerical quantitative data were normalizedto the 75 th percentile and were analyzed using the GeneSpring GX bioinformatics platform (http://www.agilent.com/chem/genespring) according todefault instructions allowing hierarchical clustering ofsamples ofmice or genes based on ANOVA statistical analysis $(P$ $<0.05$ ) and fold change $\geq 2.0$ and an uncentered Pearson correlation metrics (Eisen et al 1998).

The similarities and dissimilaritiesin gene expression (mRNA and miRNA) are presented as dendrograms, in which the pattern and length of the branches reflect the relatedness of the samples or genes and heat maps. Gene ontology annotations were retrieved from GeneSpring platform and used to access the biological functions of mRNAs. Information about miRNAs was retrieved from miRBase data bank (www.mirbase.org).

A complete file that provides all of the mRNAs and miRNAs present in the arrays used in this study, as well as the experimental conditions, is available online at theMIAME public database (http://www.ebi.ac.uk/miamexpress), ArrayExpress accession E-MEXP 3369 (for mRNA hybridizations) and E-MEXP-3370 (for miRNA hybridizations).

\section{Reconstruction of miRNA-mRNA post-transcriptional interaction networks}

To reconstruct the miRNA-mRNA interaction networks we used the GenMiR++ algorithm, which take as a basis the respective miRNA and mRNA expression profiles from the same sets of tissues or cell types to identify candidate miRNA-mRNA target pairs that are best supportedby the expression data (Huang et al 2007).

For each mRNA differentially expressed, the candidatemiRNA regulators were scored according to how much themiRNA expression profile contributed to explaining down-regulationof the mRNA expression, given all other miRNA candidates.

GenMiR $^{++}$calculates the scores by attempting to reproduce an mRNA's profile by a weighted combination of the genome-wide average normalized expression profile and the negatively weighted profiles of a subset of the miRNA regulators. MiRNAs that often appear in subsets whose reproductions are good fits to the mRNA profile are assigned the highest scores. The graphical program Cytoscape v 2.1 was used for the network reconstruction (www.cytoscape.org). 


\section{Hybridization minimum free energy for validation of miRNA-mRNA interactions}

Observing the miRNA-mRNA interaction networks generated by the GenMiR++ algorithm, we selected certain pairs according to the function of the mRNA target. The RNA-hybrid algorithm (Rehmsmeier et al, 2004; Krüger\&Rehmsmeier, 2006), which is available at (http://bibiserv.techfak.uni-bielefeld.de/rnahybrid) was then used in order to validate the annealing. This method involves a dynamic programming algorithm that calculates the most favorable hybridization between a given miRNA and its mRNA target calculating the minimum free energy (MFE), based in a thermodynamic state, which postulates that an RNA duplex is more stable and thermodynamicallystronger, when the free energy is low (Lewis et al, 2005).

\section{Flow cytometry}

Spleen and lymph nodes were prepared as single-cell suspensions, according to standard protocols, and the following monoclonal antibodies (from BD Biosciense, New Jersey, USA) were used for staining; CD4 Percep, and CD8 FITC. For intracellular detection of ROR $\gamma$ PE, cells were first treated with anti-CD4 and then fixed, permeabilized, and then stained. Flow cytometry was performed on a FACSCalibur instrument (Becton Dickinson, New Jersey, USA) and analyzed with FlowJo software (TreeStar, Ashland, USA).

\section{Statistical analysis}

Results are presented as means \pm SEM. The differences were evaluated by one-way ANOVA followed by Bonferroni's ttest (three or more groups) or Student's t-test (two groups). $P<0.05, P<0.01, P<0.001$ was considered statistically significant.

\section{Results}

\section{Collagen-induced arthritis (CIA)}

The immunization schedule with type II collagen induced the development of arthritis (CIA) in male DBA-1/J mice, whose CIA scores reached a peak on day 35. Male DBA-2/J mice injected in the same schedule and didn't feature any signal of arthritis development. Male mice from both strainsimmunized only with CFA were considered as controls. 


\section{MiRNA expression profile in thymocytes and peripheral $\mathrm{T}$ cells}

Firstly, we compared miRNA expression of thymocytes and peripheral naïve $\mathrm{CD}^{+}$ total $\mathrm{T}$ cells of4 weeks-old DBA-1/J and DBA-2/J strains, without any immunization (Figure 2). After, we compared miRNA expression of activated $\mathrm{CD}^{+} \mathrm{T}$ cells from spleen and lymph nodes of 12-weeks-old mice, whichwere immunized with collagen (CIA modelsystem) (Figure 3).

We identified 91 differentially expressed miRNAs $(\mathrm{p}<0.05$, fold-change $\geq 2.0$ ) comparing thymocytes to naïve peripheral $\mathrm{CD}^{+} \mathrm{T}$ cells ofDBA-1/J and DBA-2/J mice strains (Figure 2), and 62 miRNAs ( $<<0.05$, and fold-change $\geq 2.0$ ) comparing activated $\mathrm{CD}^{+} \mathrm{T}$ cells, during CIA development (Figure 3). We selected just the specific upregulated miRNAs in each group for subsequent miRNA-mRNA interaction analysis. Three miRNAs (miR-126-3p, miR-221 and miR-200c) wereexclusively up-regulated in thymocytes of DBA-1/J strain; and three other (miR-let-7e, miR-100 and miR-19a*)were exclusively up-regulated in DBA-2/J strain.

In naïve peripheral $\mathrm{CD}^{+} \mathrm{T}$ cells we found six exclusively up-regulated miRNAs (miR195, miR-689, miR-500, miR-196b, miR-10a and miR-805) in DBA-1/J mice, and four exclusively up-regulated (miR-467e, miR-101a, miR-125-5p, miR-669a) in DBA-2/J. In the course of CIA six miRNAs (miR-181a, miR-144, miR-17*, miR-202-3p, miR-467a*, miR-500) were up-regulated in peripheral T $\mathrm{CD}^{+}$lymphocytes of the susceptible DBA-1/J strain. In peripheral $\mathrm{T} \mathrm{CD}^{+}$lymphocytes of the resistant DBA-2/J strain we found 11 miRNAs (miR-302c, miR-691, miR-712, miR-125a-3p, miR-29b*, miR-30b*, miR-10b, miR-149, miR-141, miR-1897-5p, miR-690).

\section{Messenger RNAs differentially expressed in thymocytes and peripheral $\mathbf{T}$ cells}

Although the expression pattern remained unchanged for the majority of the 44,000 sequences tested during CIA development, 14,230 were found to be differentially expressed in thymocytes compared to naïve $\mathrm{T}$ cells and 3,155 compared t oactivated $\mathrm{CD} 3^{+} \mathrm{T}$ cells.

Functional analysis of the differentially expressed mRNAs, by means of Gene Ontology (GO), identified 1,813 immune system-related mRNAs among the 14,230 significantly expressed in thymocytes compared to naïveT cells (Figure 4), and 486 immune system-related mRNAsin $\mathrm{CD}^{+} \mathrm{T}$ cells in CIA(Figure 5). The hierarchical clustering revealed that these sequences featured distinct expression patterns. Then, these 
sequences were used to reconstruct miRNA-mRNA interaction network, to identify potential targets.

\section{MiRNA-mRNAinteraction networks}

The miRNA-mRNA interaction networks predicting immune system mRNA targets in thymocytes, peripheral naïve and activated $\mathrm{CD}^{+} \mathrm{T}$ cells from the DBA-1/J and DBA-2/J mice strains, are depicted inFigures 3 to 5. The selected miRNAs and their targets are showed in the table 1.

During the initial stage of the $\mathrm{T}$ cell maturation in the thymus, and their migration to periphery, we found few potential targets related to immune process function, compared to the activated $\mathrm{T}$ cells during immunization (table 1). In general, the up-regulated miRNAs found in DBA-2/J strain regulate higher number of targets (884 mRNA targets) compared toDBA-1/J strain (521mRNA targets).

Interestingly, in thymocytes of both mouse strains, two different setsof miRNAs regulated a common set of targets, i.e., Sox6, Tlr3 and Add2mRNAs (Figure 6).

As expected, the peripheral mature T lymphocytes in these strains regulated Rag1, Rag2, and ThemismRNAs, which are associated to $\mathrm{T}$ cell differentiation and maturation (Figure 7).

Figure 7a shows that miRNAsmiR-196b, miR-805 and miR-10 are gulated CD8 mRNA in peripheral $\mathrm{T}$ cells of DBA-1/J strain. As an extension and validation of the participation of these miRNAs as negative regulatory controllers, we showed by flow cytometry analysis that percentage of peripheral $\mathrm{CD}^{+} \mathrm{T}$ cells is lower in DBA-1/J compared to DBA-2/J strain (Figure 8).

During the development of CIA in DBA-1/J strain, the numbermRNA targets increases which does include important tmRNAs, which wer ehighlighted, as for example, Fas and FasL that encode apoptosis proteins, IL-10, Stat6, and granzymes Gzmm and Gzma (Figure 9a).

However, during collagen immunizationof DBA-2/J strain, the following mRNA targets Rorc, IL-6, Foxo3 and Bcl2 were found (Figure 9b). Since Th17 cells are strongly correlated to arthritis development, we point the Rorc mRNA, which encodes the transcription factor Roryt implicated in differentiation of these cells. Rorc mRNA was regulated by miR-30b*, miR-690, and miR-29b* (table 1). 
As an extension and validation of the participation of these miRNAs as negative regulatory controllers, we showed by flow cytometry analysis that the percentage of $\mathrm{CD}^{+}{ }^{+}$Ror $^{+} \mathrm{t}^{+} \mathrm{T}$ cells is lower in DBA-2/J strain (Figure 10).

We also validate some of the interactions obtained by the $\mathrm{GenMiR}^{++}$model using a bioinformatic tool, the RNAhybrid, that that shows the most favorable hybridization between a given miRNA and its mRNA target calculating the minimum free energy (MFE). The molecular interaction and the MFE can be visualized in the figure 11.

\section{Discussion}

Rheumatoid arthritis (RA) is an autoimmune disease that engages an uncontrolled influx of inflammatory $\mathrm{T}$ cells to the joints, eventually leading to damage. Pro- and antiinflammatory cytokines and chemokines and/or their receptors, key mediators of the effector function of $\mathrm{T}$ cells, appear to be centrally involved in the pathogenesis of RA (Firestein et al 2003).

The role that $\mathrm{T}$ cells play in maintenance against inflammation and joint damage was better understood through the use of animal models, mainly mice (review Alzabin et al, 2011). The DBA-1/J and DBA-2/J strains of mouse, which are respectively susceptible andresistant to CIA (Wooley et al,1981) represent a unique opportunity for studies on the mechanisms involved in susceptibility to arthritis.

Although the main effector cellsand proteins have already been identified in human RA and experimental CIA, efforts for a better understanding of its molecular-genetic control is just in its beginning.In this regard, our group recently demonstrated that thymic stroma of DBA-1/J and DBA-2/J strains differ in their transcriptional expression of peripheral tissue antigens (PTAs). Interestingly, in DBA-1/J (strain susceptible to CIA) the MHC-H2 gene represents a key regulator of downstream genes that code joint and bone PTAs(Donate et al, 2011) controlling at least part the expression of autoantigens in the thymus, a phenomenon known as promiscuous gene expression (Derbinski and Kyewski, 2010; Irla et al 2010; Magalhães et al 2006).In this previous study, we provided evidence that CIA susceptibility in mice may be due to a cascade-like transcriptional control connecting MHC-H2 to PTA genes in the thymic stroma.

In the present study, we asked whether T cells in their different phases of development and activation i.e., thymocytes, naïve and activated peripheral $\mathrm{CD}^{+} \mathrm{T}$ lymphocytes in the 
context of CIA also feature differences in their transcriptional expression involving mRNAs and miRNAs.

Considering the role played by miRNAs in the post-transcriptional control of gene expression in immune cells (review Dai et al, 2011) we also asked whether these molecules could differentially interact with mRNA targets.

To test this, we used the microarray method and bioinformatics programs (Figure 1). Initially we constructed genome-wide transcriptional profiling of miRNAs and mRNAs as depicted respectively in Figures 2 to 4.

When thymocytes where compared to naïve $\mathrm{T}$ cells we noticed that some miRNAs as for example miR-30e, miR-363 and miR-130b do not alter their expression from thymus to the periphery. On the other hand we found T cell developmental stagespecific miRNAs, with no difference between mouse strains. This suggests that these miRNAs arerelated to commonprocessesbetween strains.

As our aim was to identify those miRNAs associated to susceptibility/resistance to CIA, wefocused our study incell-type/strain-specific miRNAs (Figure 2).

Figure 3 shows the clustering of peripheral $\mathrm{T} \mathrm{CD}^{+}$lymphocyte miRNA profile of DBA-1/J and DBA-2/J strains after immunization process. Interestingly, most of the miRNAs differ in their expression between the mouse strains, with some exception, as for example the miR-223, which was induced in both strains (Figure 3).

Figures 4 and 5 shows the mRNA expression profile of thymocytes and peripheralT $\mathrm{CD}^{+}$lymphocytes comparingDBA-1/J and DBA-2/Jstrains.Using the Gene Ontology (GO) we identified the mRNAs related to immune system due to their importance in arthritis.

Gene ontology (GO) allowed identifying 1,813 immune system-related mRNAs in thymocytes and naïve T cells (Figure 4), and 486 immune system-related mRNAs in $\mathrm{CD} 3^{+} \mathrm{T}$ cells in CIA (Figure 5) of both mouse strains.

These results were important to demonstrate that transcriptional programming of $\mathrm{T}$ cells is somewhat different between these two mouse strains and therefore respond our first question.Then, these sequences were used to reconstruct miRNA-mRNA interaction network, to identify potential targets.

Regarding grouping of biological samples, the hierarchical clustering of microarray data is very useful and represents the choice method. Nevertheless, this does not easily respond if the differentially expressed RNAs are somehow interacting with each other. As 
our second question was about the possible miRNA-mRNA interaction, now we had used a more appropriate method to estimate this. We choose the $\mathrm{GenMir}^{++}$program (Huang et al, 2007) as an adequate analysis algorithm, which establishes network interactions based on Bayesian statistics of opposite expression levels of miRNAs and mRNAs from actual microarray data.

In general, miRNA-mRNA target pairs are penalized if both the miRNA and mRNA were highly expressed in the same sample andare rewarded if a given miRNA was highly expressed in a sample that a givenmRNA had low expression in, especially if few of its other predictedmiRNA regulators were highly expressed therein.

Eachdata set of differentially expressed RNAs (miRNAs and mRNAs) from the same sample was analyzed together in order to reconstruct interaction networks. The networks depicted in Figures6, 7, and 9show that one given miRNA can establish interaction with several mRNA targets and that one mRNA can interact with several miRNAs at once. The interactions showed in the figures can be clearly identifies in Table 1.

During $T$ cell maturation in the thymus of DBA-1/J and DBA-2/J strains, potential mRNA targets related to immune system could be found as for example; Sox6 Tlr3, Add2 (Figure 6). Regardless the differential miRNA profile in thymocytes between the two mouse strains studied, in addition to the exclusive, they have common mRNA targets. So we asked if any deregulation in the peripherycould be associated to the disease.

In naïve $\mathrm{T}$ cells,although the number of mRNA targets is low, interesting differences could be seen. For example, the Rag1, Rag2 and Themis mRNAs, which are involved withdifferentiation and maturation of thymocytes, were regulated in of both strains (Figure 7). Themis is expressed in a tightly regulated manner during $T$ celldevelopment, in late double-negative (DN) and especially in double-positive (DP) thymocytes (Fu et al 2009). It is down-regulated after positive selection and is expressed at low levels in mature $\mathrm{T}$ cells. As expected, we found that genes involved with early $\mathrm{T}$ cell differentiation processes as Rag-1, Rag-2 and Themis were regulated by miRNAs and consequently down-regulated in the periphery.

Another interesting mRNA target found to be regulated in DBA-1/J strain is the Cluster of differentiation 8 (CD8). $\mathrm{CD}^{+} \mathrm{T}$ cells seem to be important in the effector phase of arthritis disease but are dispensable for its initiation (Ehinger et al 2001). However, the importance of the $\mathrm{CD} 8^{+} \mathrm{T}$ cells in arthritis and their role in induction or protection are still 
controversial. Interestingly, we found that the DBA-1/J strain shows lowernumbers of $\mathrm{CD}^{+} \mathrm{T}$ cells in the peripherycompared to DBA-2/J (Figure 8).

Figure 9 shows the miRNA-mRNA interaction in DBA-1/J and DBA-2/J strains during CIA development. Among the mRNAs differentially expressed, anddownregulated in peripheral $\mathrm{T} \mathrm{CD}^{+}$cells during collagen immunization and CIA development in DBA-1/J mice, we found those related with the positive regulation of the inflammation process, as for example Fas and FasL involved with apoptosis, and IL-10 involved in Tregs suppression function.

Fas and FasL are part of the activation-induced cell death (AICD) involved in the removal of activated $\mathrm{T}$ cells in vivo (Hughes et al, 2008; Weant et al, 2008). The IL-10 production by Tregs is one of their mechanisms involved in inhibit the production of inflammatory mediators and lymphocyte proliferation (Bluestone and Abbas, 2003; Roncarolo et al, 2006). In this way, our results suggest that the strong regulation of the genes, in the susceptible strain DBA-1/J, might be contributing for the exacerbate response of $\mathrm{T}$ cells observed in CIA.

On the other hand, among the down-regulatedtargets during collagen immunization of DBA-2/J strain, we found Rorc involved in Th17 differentiation, and Foxo3 involved in cell cycle and survival, both directly related to arthritis pathogenesis. In fact, Foxo3 had already been associated with RA. Foxo3 mRNA is increased in patients, and it has been suggested that its overexpression may lead to the prolonged survival of $T$ cells in RA, thereby contributing to chronic inflammation (Turrel-Davin et al 2010).

Rorc mRNA encodes the transcription factor Ror $\gamma$ t that is involved in the differentiation of $\mathrm{CD}^{+} \mathrm{T}$ cells into Th17 pro-inflammatory cells. The role of IL-17 in the pathogenesis of arthritis is well known, and was first confirmed in CIA model (Yamaguchi et al 2007).

In line with the FACS results involving $\mathrm{CD}^{+}$naïve $\mathrm{T}$ cells, we also found that the CIA resistant DBA-2/J strain has diminished numbers of Roryt ${ }^{+} \mathrm{T}$ cells in the periphery (Figure $10)$.

An intriguing result obtained in this study is that Rorc mRNA was found to be regulated by miR-500 in naïve $\mathrm{T}$ cells of DBA-1/J strain. However, during collagen immunization and CIA development in this strain, any miRNA regulation upon this mRNA was observed. Contrarily, in DBA-2/J, Rorc mRNA was regulated by miR-29b*, miR30b* and miR-690 (Figure 10). 
To best of our knowledge, just miR-181a and miR-221, which were included in such interaction networks have been previously identified and associated to play a role in $\mathrm{T}$ lymphocytes (Li et al 2007; Grigoryev et al 2011). In this study, we found new miRNAs that were up-regulated during the development and activation of $\mathrm{T}$ lymphocytes in the context of susceptibility/resistance to CIA.

Finally, the miRNA-mRNA interactions, which were not previously predicted in data bases as TargetScan (www.targetscan.org/), as for example, miR-30b*-Rorc and miR-202$3 p-I L-10$, were validated by calculations of the minimal free energy of the respective RNA-RNA hybridizations. For this, we used the RNAhybrid program (http://bibiserv. techfak.uni-bielefeld.de/rnahybrid/submission.html), which allowed us to visualize the specific miRNA-mRNA sequence annealing.

For each miRNA-mRNA interaction the minimum free energy (MFE) is calculated, based on the respective thermodynamic state (Figure 11). We used an MFE threshold of $20 \mathrm{kcal} / \mathrm{mole}$, based on the interaction between miRNAs of length 22 nucleotides (nt) in a target of length 1,000nt (Rehmsmeier et al, 2004).

In this study we identified a set of new miRNAs, which regulate mRNA targets in different stages of $\mathrm{T}$ cell differentiation and activation in the context of CIA in mice. The found miRNAdiffer in their expression profiling between DBA- $1 / \mathrm{J}$ and DBA-2/J mice, which are susceptible and resistant to CIA, respectively.

The modulation of miRNA expression allowedmiRNA-mRNA interactions, which were visualized through networks reconstructed based on actualmicroarray transcriptional profile and validated through MFE calculations.

Important mRNA targets related to $\mathrm{T}$ cell differentiation and activation were predicted as for example, those related to inflammation processes (Rorc), which were strongly regulated in the CIA resistant DBA-2/J strain.

ThemRNAsinvolved with the control of the aggressive immune response, as for example Fas and FasL, were found as miRNA targetsin the CIA susceptible DBA-1/J strain.

These findings make perfect sense since all the mRNAs found in this study encode proteins related to the pathogenesis of arthritis. Moreover, our results suggest a deregulation of miRNAs that could be associated at the control of molecules involved in inflammation development, in the susceptible strain DBA-1/J after CIA induction. 
These results contribute to a better understanding of the genetic-molecular mechanism that might be contributing to the susceptibility/resistance to CIA in mice.

\section{References}

Ali M, Ponchel F, Wilson KE, et al,2001.Rheumatoid arthritis synovial $\mathrm{T}$ cells regulatetranscription of several genes associated with antigen-induced anergy. $J$ Clin Invest.107: $519-28$.

Ambros, V, 2004. The functions of animal miRNAs.Nature 431: 350-355.

Alzabin S, and Williams RO, 2011. Effector T cells in rheumatoid arthritis: lessons from animal models. FEBS lett. 585(23): 3649-3659.

Bartel DP, 2004. MiRNAs: genomics, biogenesis, mechanism, and function.Cell116: 281297.

Behm-Ansmant I, Rehwinkel J, and Izaurralde E, 2006. MiRNAs silence gene expression by repressing protein expression and/or by promoting mRNAdecay. Quant. Biol. 71: 523530.

Bluestone, J A, and Abbas, A K, 2003.Natural versus adaptive regulatory T cells.Nat Rev3: 253-257.

Chen CZ, and Lodish HF, 2005.MiRNAs as regulators of mammalian hematopoiesis.Semin.Immunol. 17: 155-165.

Dai R, and Ahmed SA, 2011.MicroRNA, a new paradigm for understanding immunoregulation, inflammation and autoimmune diseases.Translational Research.157(4): 163-179.

Derbinski J, Kyewski B, 2010.How thymic antigen presenting cells sample the body's selfantigens.CurrOpinImmunol.22(5):592-600.

Donate, PB,Fornari, TA, Junta, CM,Magalhães, DA, Macedo, C, Cunha, TM, Nguyen, C, Cunha, FQ, Passos, GA, 2011 Collagen induced arthritis (CIA) in mice features regulatory transcriptional network connecting major histocompatibility complex (MHC H2) with autoantigen genes in the thymus. Immunobiology. 216:5, 591-603.

Ehinger M, Vestberg M, Johansson AC, Johannesson M, Svensson A andHolmdahl $\mathrm{R}, 2001$. Influence of CD4 or CD8 deficiency on collagen-inducedarthritis. Immunology 103: $291-300$.

Eisen, MB, Spellman, PT, Brown PO, Botstein D, 1998. Cluster analysis and display of genome-wide expression patterns. Proceedings of the National Academy of Sciences of the United States of America, vol. 95, no. 25, pp. 14863-14868.

Engels BM, and Hutvagner G, 2006. Principles and effects of miRNAmediated posttranscriptional gene regulation. Oncogene 25: 6163-6169. 
Firestein GS, 2003.Evolving concepts of rheumatoid arthritis.Nature423:356-361.

Fulci V, Scappucci G, Sebastiani GD, Giannitti C, Franceschini D, MeloniF,Colombo T, Citarella F, Barnaba V, Minisola G, Galeazzi M, Macino G, 2010.miR-223 is overexpressed in T-lymphocytes of patients affected by rheumatoidarthritis. Hum Immunol71:206-211.

Fu G, Vallee S, Rybakin V, McGuire MV, Ampudia J, BrockmeyerC,Salek M, Fallen PR, Hoerter JAH, Munshi A et al, 2009. Themis controls thymocyte selection through regulation of T cell antigen receptor-mediated signaling. Nat Immunol10:848-856.

Griffiths, MM, Nabozny, GH, Hanson, J, Harper, DS, McCall, S, Moder, KG,Cannon, GW, Luthra, HS and David, CS, 1994. Collagen-induced arthritisand TCRs in SWR and B10Q mice expressing an Ek alpha transgene J Immunol153: 2758-2768.

Grigoryev YA, Kurian SM, Hart T, Nakorchevsky AA, Chen C, Campbell D, Head SR, Yates JR 3rd, Salomon DR, 2011.MiRNA Regulation of Molecular Networks Mapped by Global MiRNA, mRNA, and Protein Expression in Activated T Lymphocytes.JImmunol 1-11.

Grimson, A, KFarh, K, Johnston, W K, Garrett-Engele, P, Lim, LP and Bartel, DP, 2007. MiRNA targeting specificity in mammals: determinantsbeyond seed pairing Mol Cell27: 91-105.

Guo, H, Ingolia, NT, Weissman, JS and Bartel, DP, 2010. Mammalian miRNAs predominantly act to decrease target mRNA levels. Nature 466:835-840.

Haeupl T, Witt H, Koczan D, Krenn V, Huber H, et al, 2010.Molecular signatures and new candidates to target the pathogenesis of rheumatoid arthritis.Physiol Genomics.29;42A(4):267-82.

Huang, B, Zhao J, Lei Z, Shen S, Li D, Shen GX, Zhang GM, andFeng ZH, 2009.miR142-3p restricts cAMP production in CD4+CD25- T cellsand CD4+CD25+ TREG cells by targeting AC9 mRNA.EMBO Rep10:180v185.

Huang, JC, Morris, Q D \& Frey, BJ, 2007. Bayesian inference of MiRNA targets fromsequence and expression data.J ComputBiol14: 550-563.

Hughes, PD, Belz, GT, Fortner, KA, Budd, RC, Strasser, A, and Bouillet, P, 2008. Apoptosis regulators Fas and Bim cooperate in shutdown of chronic immune responses and prevention of autoimmunity. Immunity 28: 197-205.

Irla M, Hollander G, Reith W, 2010.Control of central self-tolerance induction by autoreactive CD4+ thymocytes. Trends Immunol.31(2):71-9.

Jetten AM, 2009. Retinoid-related orphan receptors (RORs): critical roles in development, immunity, circadian rhythm, and cellular metabolism. Nuclear Receptor Signal.7: e003.

Junta CM, Sandrin-Garcia P, Fachin-Saltoratto AL, Mello SS, Oliveira RD, Rassi DM, Giuliatti S, Sakamoto-Hojo ET, Louzada-Junior P, Donadi EA, Passos GA, 2009. Differential gene expression of peripheral blood mononuclear cells from rheumatoid arthritis patients may discriminate immunogenetic, pathogenic and treatment features. Immunology.127(3):365-72. 
Kruger J and Rehmsmeier M, 2006.RNAhybrid: microRNA target prediction easy, fast and flexible. Nucleic Acids Research.34: W451-W454.

Lewis, BP, Burge, CB,Bartel, DP, 2005. Conserved seed pairing, often flanked by adenosines, indicates that thousands of human genes are microRNA targets. Cell.120:1, $15-20$.

Li, J, Wan, Y, Guo, Q, Zou, L, Zhang, J, Fang, Y, Zhang, J, Zhang, J, Fu, X, Liu, H et al, 2010. Altered miRNA expression profile with miR-146a upregulationin CD4+ T cells from patients with rheumatoid arthritis.Arthritis ResTher.12: R81.

Li, QJ, Chau J, Ebert PJ, Sylvester G, Min H, Liu G, Braich R,Manoharan M, Soutschek J, Skare P, et al, 2007. miR-181a is an intrinsicmodulator of $\mathrm{T}$ cell sensitivity and selection.Cell129: 147-161.

Klareskog, L, Catrina, AI and Paget, S, 2009.Rheumatoid arthritis.Lancet373: 659-672.

Magalhães, DA, Silveira, EL, Junta, CM, Sandrin-Garcia, P, Fachin, AL, Donadi, EA, Sakamoto-Hojo, ET, Passos, GA, 2006. Promiscuous gene expression in the thymus: the root of central tolerance. Clin and Develop.Immunol.13:2-4, 81-99.

Murata K, Yoshitomi H, Tanida S, Ishikawa M, Nishitani K, Ito H, Nakamura T, 2010. Plasma and synovial fluid miRNAs as potential biomarkers of rheumatoid arthritis and osteoarthritis.Arthritis Res Ther.12:R86.

Panayi GS, Lanchbury JS, Kingsley GH, 1992.The importance of the T cell in initiatingand maintaining the chronic synovitis of rheumatoid arthritis. Arthritis Rheum.35: 729 - 35.

Pauley KM, Satoh M, Chan AL, Bubb MR, Reeves WH, Chan EK, 2008. UpregulatedmiR-146a expression in peripheral blood mononuclear cells fromrheumatoid arthritis patientsArthritis Res Ther.10:R101.

Plasterk, RH, 2006. Micro RNAs in animal development.Cell124: 877-881.

Rajewsky N, 2006.miRNA target predictions in animals.Nat Genet.38: S8-S13.

Rehmsmeier M, Steffen P, Hochsmann M, Giegerich R, 2004. Fast and effective prediction of microRNA/target duplexes.RNA.10(10): 1507-1517.

Roncarolo, MG, and Levings, MK, 2000. The role of different subsets of T regulatory cells in controlling autoimmunity.Curr.Opin.Immunol.12:676-683.

Selbach, M, Schwanhausser B, Thierfelder N, Fang Z, Khanin R, andRajewsky N, 2008. Widespread changes in protein synthesis induced bymiRNAs.Nature455: 58-63.

Silva GL, Junta CM, Mello SS, Garcia PS, Rassi DM, Sakamoto-Hojo ET, Donadi EA, Passos GA, 2007.Profiling meta-analysis reveals primarily gene coexpression concordance between systemic lupus erythematosus and rheumatoid arthritis.Ann N Y AcadSci.1110:3346. 
Silva GL, Junta CM, Sakamoto-Hojo ET, Donadi EA, Louzada-Junior P, Passos GA, 2009 Geneticsusceptibility loci in rheumatoidarthritisestablishtranscriptionalregulatory networks withother genes. Ann N Y AcadSci.1173:521-37.

Stanczyk J, Pedrioli DM, Brentano F, Sanchez-Pernaute O, Kolling C, Gay RE, Detmar M, Gay S, Kyburz D, 2008. Altered expressionof MiRNA in synovialfibroblastsandsynovialtissue in rheumatoidarthritis. Arthritis Rheum.58:10011009.

Thai TH, Calado DP, Casola S, Ansel KM, Xiao C, Xue Y, Murphy A, Frendewey D, Valenzuela D, Kutok JL, 2007.Regulation of the germinalcenter response by miRNA155.Science316: 604-608.

Trentham DE, Townes AS and Kang AH, 1977.Autoimmunity to type IIcollagen an experimental model of arthritis.JExp Med. 146: 857-868.

Turrel-Davin F, Tournadre A, Pachot A, et al, 2010. FoxO3a involved in neutrophil andT cell survival is overexpressed in rheumatoid blood and synovial tissue. Ann Rheum Dis.69:755-760.

Weant, AE.,Michalek, RD., Khan, IU.. Holbrook, BC., Willingham, MC., and Grayson. J. M., 2008. Apoptosis regulators Bim and Fas function concurrently to control autoimmunity and CD8+ T cell contraction. Immunity28: 218-230.

Wooley, PH,Luthra, HS, Stuart, JM, David, CS, 1981. Type II collagen induced arthritis in mice. I. Major histocompatibility complex (I-region) linkage and antibody correlates. $J$ Exp Med. 154:3, 688-700.

Wu H, Neilson JR, Kumar P, Manocha M, Shankar P, Sharp PA, and Manjunath N, 2007. MiRNA profiling of naive, effector and memory CD8T cells.PLOS ONE 2: e1020.

Wu G, Zhu L, Dent JE, Nardini C, 2010.A comprehensive molecular interaction map for rheumatoid arthritis.PLoS One.16;5(4):e10137.

Yamaguchi Y, Fujio K, Shoda H, Okamoto A, Tsuno NH, Takahashi K andYamamoto K, 2007. IL-17B and IL-17C are associated with TNF-alphaproduction and contribute to the exacerbation of inflammatory arthritis.JImmunol.179: 7128-7136.

Xue Q, Guo ZY, Li W, Wen WH, Meng YL, Jia LT, Wang J, Yao LB,Jin BQ, Wang T, and Yang AG, 2010. Human activated CD4(+)T lymphocytes increase IL-2 expression by downregulating miRNA-181c.MolImmunol.48: 592-599. 


\section{Figures}

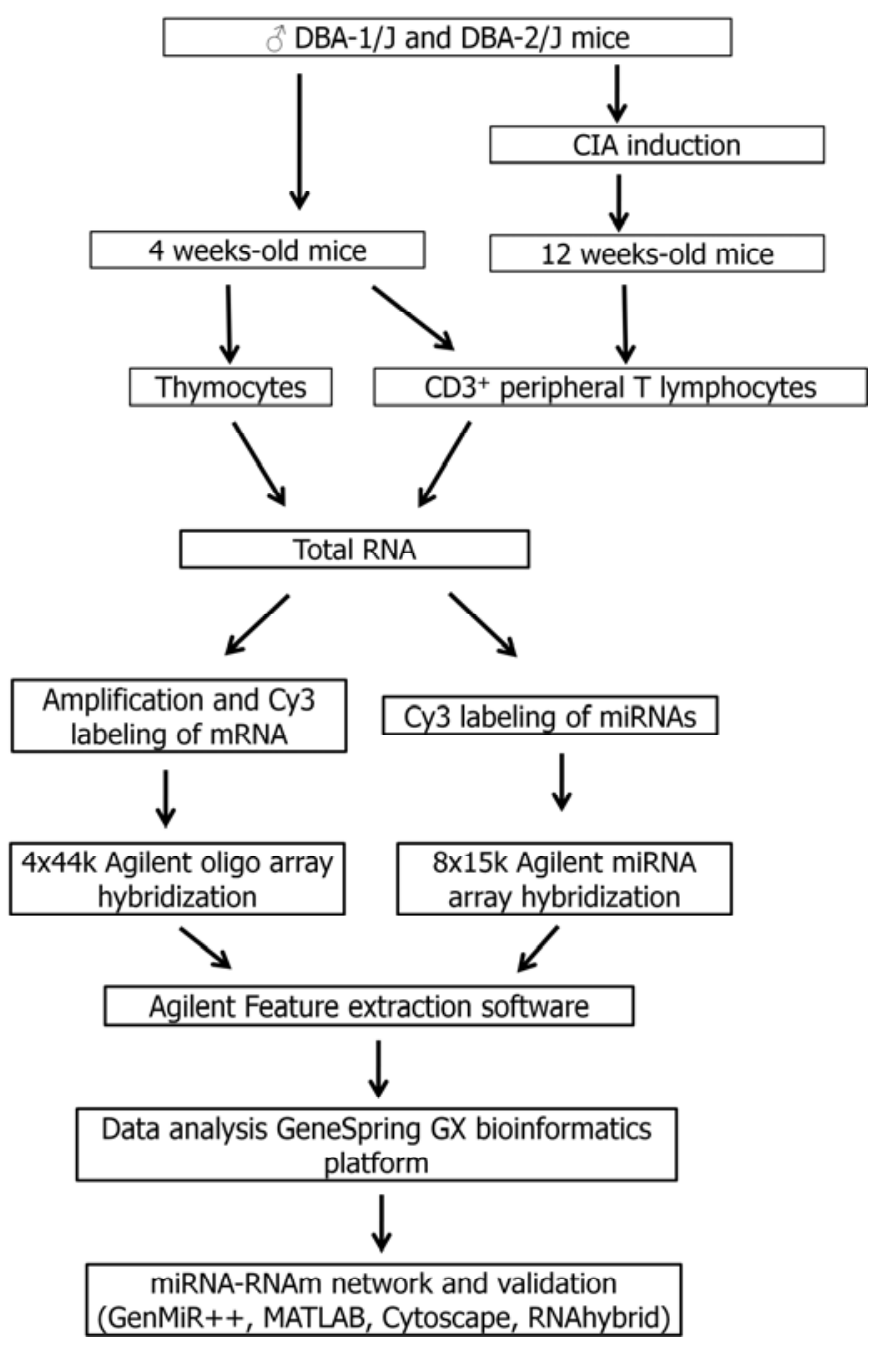

Figure 1. Experimental design of the work discriminating the biological samples used (animal groups and cell types), total RNA extraction, hybridizations, and microarray data analysis. 


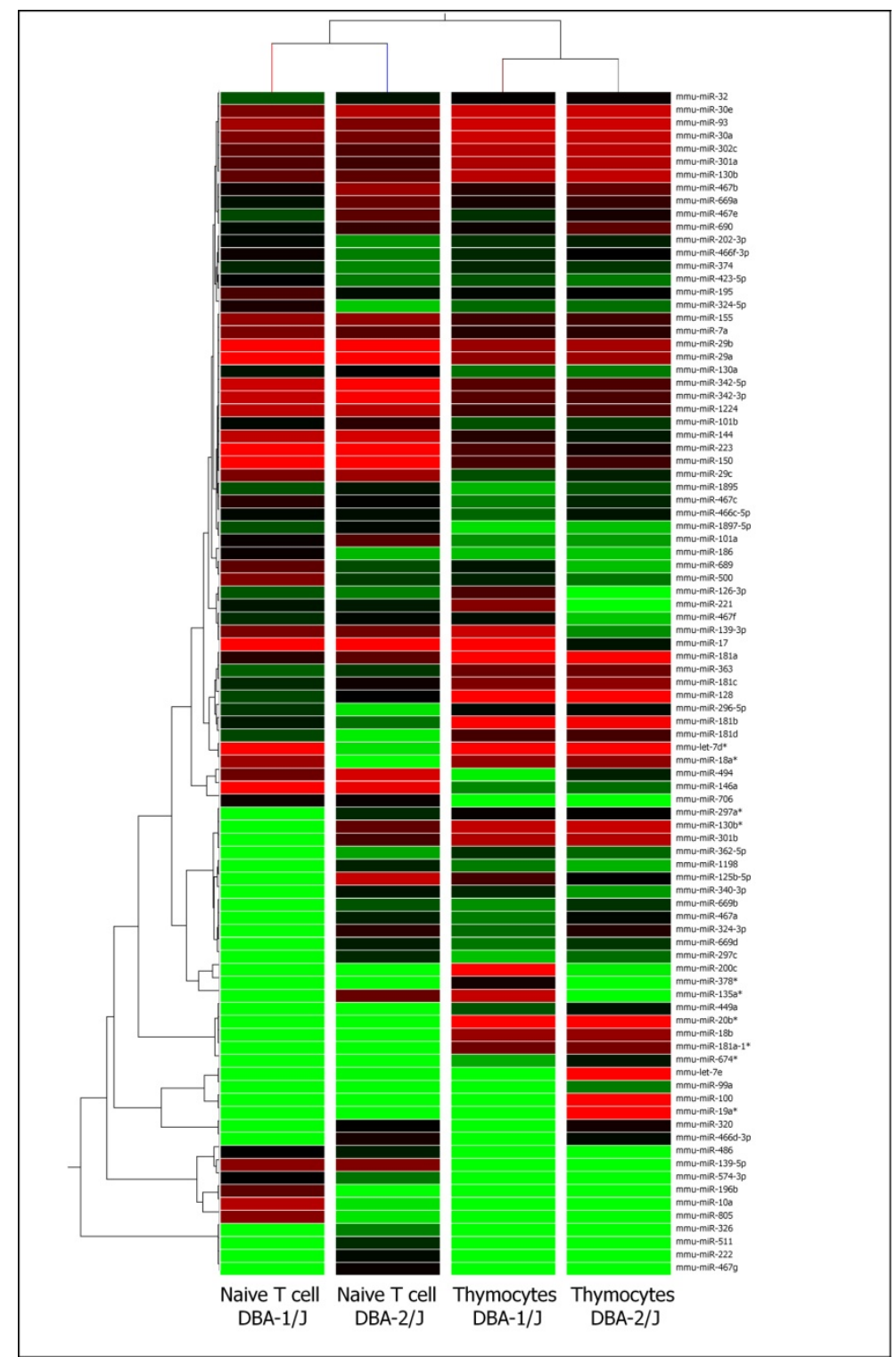

Figure 2.Hierarchical clustering and color heat-map of mirnome (miRNAs) of thymocytes isolated from DBA-1/J and DBA-2/J mice strains of 4-weeks-old, and CD3 ${ }^{+} \mathrm{T}$ cells from spleen and lymph nodes in mice of 4-weeks-old of both strains, based on microarray expression profiling. Dendrogram and heat-map were obtained using cluster and tree-view algorithms through Agilent GeneSpring platform. 


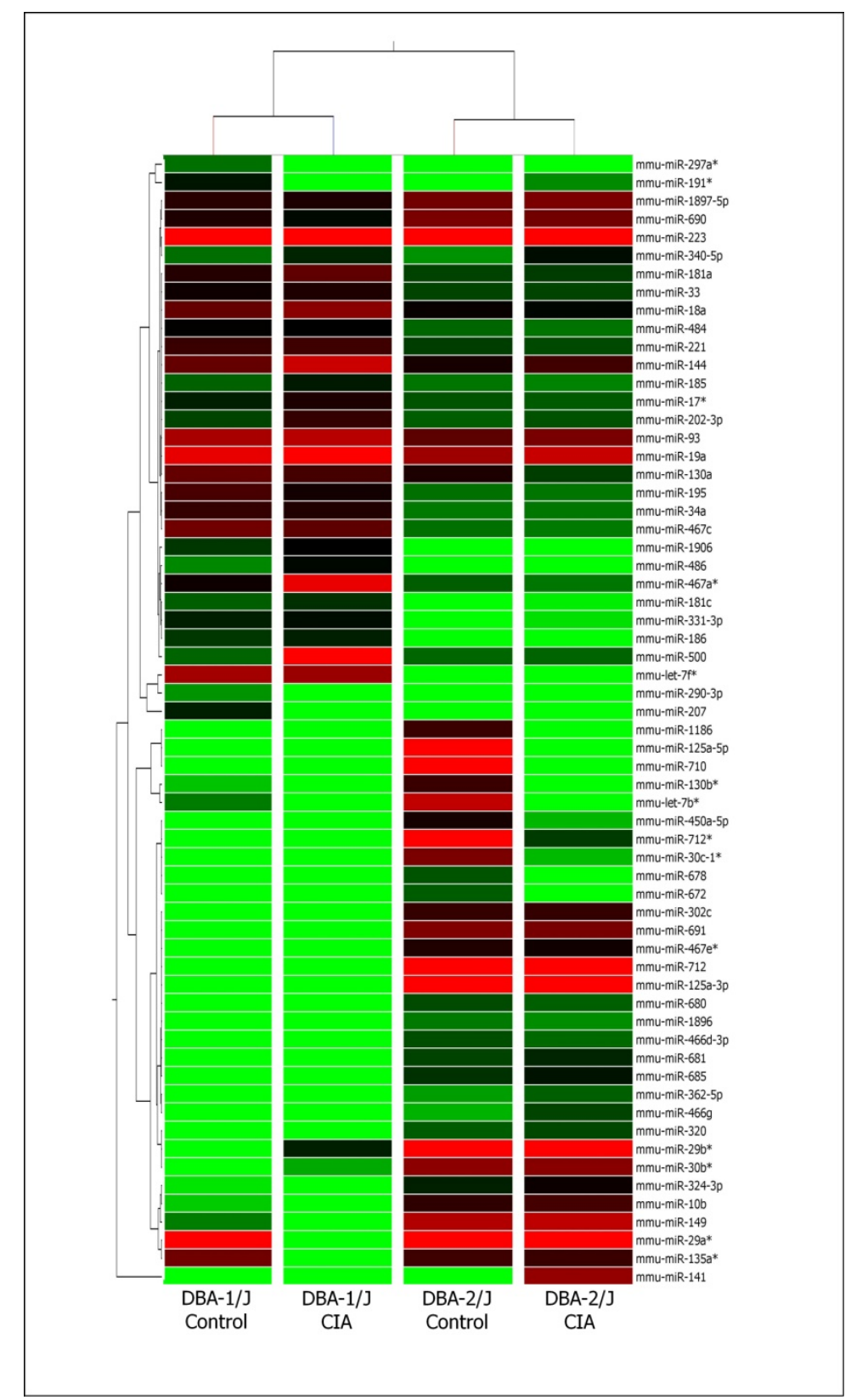

Figure 3. Hierarchical clustering and color heat-map of mirnome (miRNAs) of $\mathrm{CD}^{+} \mathrm{T}$ cells from spleen and lymph nodes in mice of 12-weeks-old immunized with chicken type II collagen in the resistant strain DBA$2 / \mathrm{J}$ and the susceptible DBA-1/J, based on microarray expression profiling. The controls were immunized without the collagen administration. Dendrogram and heat-map were obtained using cluster and tree-view algorithms through Agilent GeneSpring platform. 


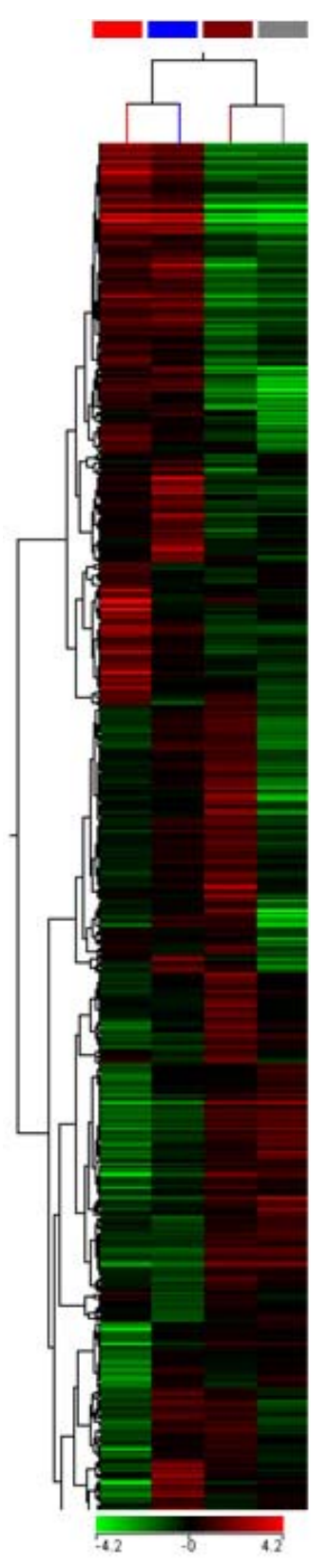

Figure 4. Hierarchical clustering and color heat-map of transcriptome (mRNAs) of thymocytes isolated from DBA-1/J and DBA-2/J mice strains of 28 days-old, and $\mathrm{CD}^{+} \mathrm{T}$ cells from spleen and lymph nodes in mice of 4-weeks-old of both strains, based on microarray expression profiling. Dendrogram and heat-map were obtained using cluster and tree-view algorithms through Agilent GeneSpring platform. This figure shows expression of genes related to immune system function based on Gene Ontology (GO). Legend: red- Naïve T cell DBA-1/J; blue-Naïve T cell DBA-2/J; brown-Thymocytes DBA-1/J; gray-Thymocytes DBA-2/J. 


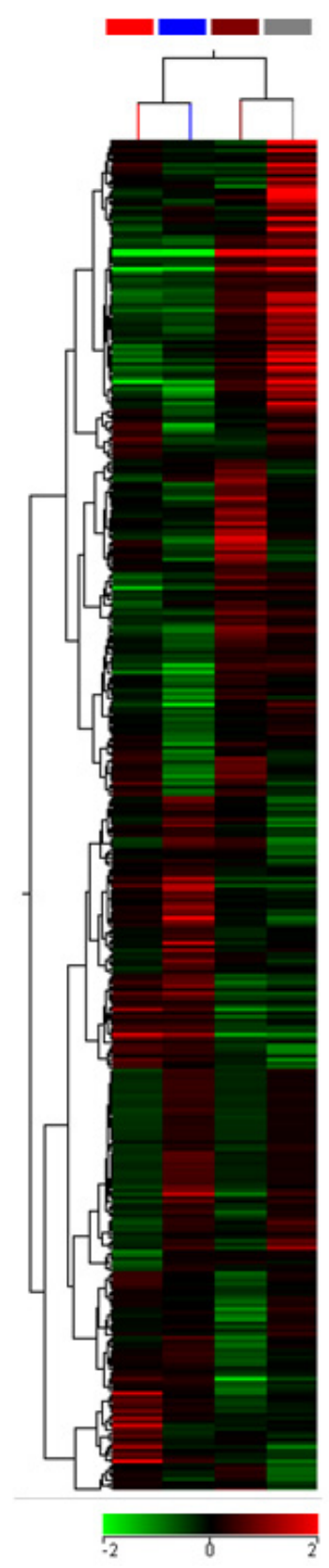

Figure 5. Hierarchical clustering and color heat-map of transcriptome (mRNAs) of CD3+ $\mathrm{T}$ cells from spleen and lymph nodes in mice of 12-weeks-old immunized with chicken type II collagen in the resistant strain DBA-2/J and the susceptible DBA-1/J, based on microarray expression profiling. The controls were immunized without the collagen administration. Dendrogram and heat-map were obtained using cluster and tree-view algorithms through Agilent GeneSpring platform. This figure shows expression of genes related to immune system function based on Gene Ontology (GO). Legend: red- DBA-1/J control; blue-DBA-1/J CIA; brown- DBA-2/J control; gray-DBA-2/J CIA. 


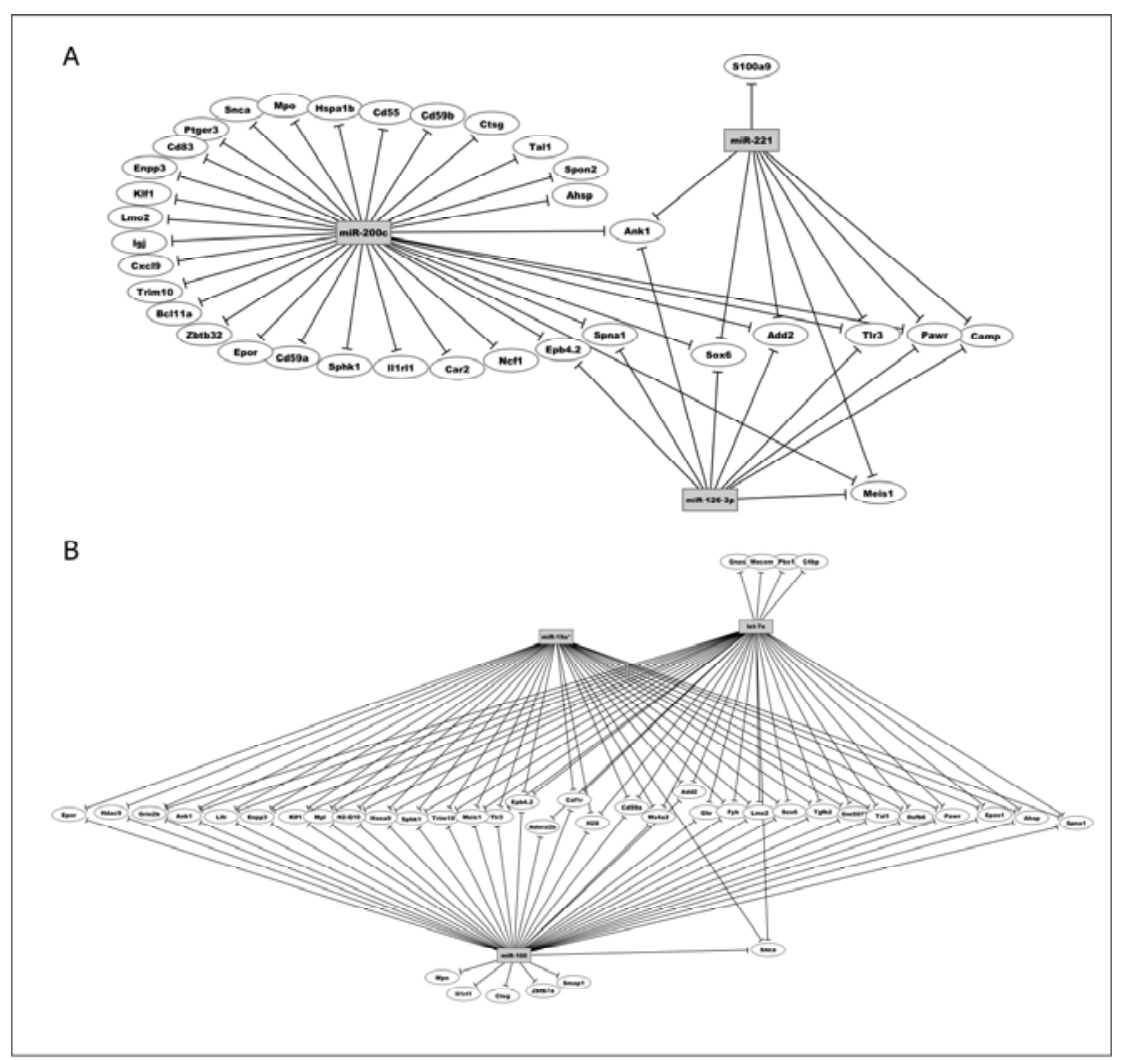

Figure 6. Post-transcriptional miRNA-mRNA interaction network based on microarray expression data in thymocytes. Network was obtained using the $\mathrm{GenMir}^{++}$algorithm. This figure shows the participation of a) 3 miRNAs up-regulated in DBA-1/J strain and b) 3 miRNAs DBA-2/J thymocytes, which interact with mRNAs related to immune system biological function. 


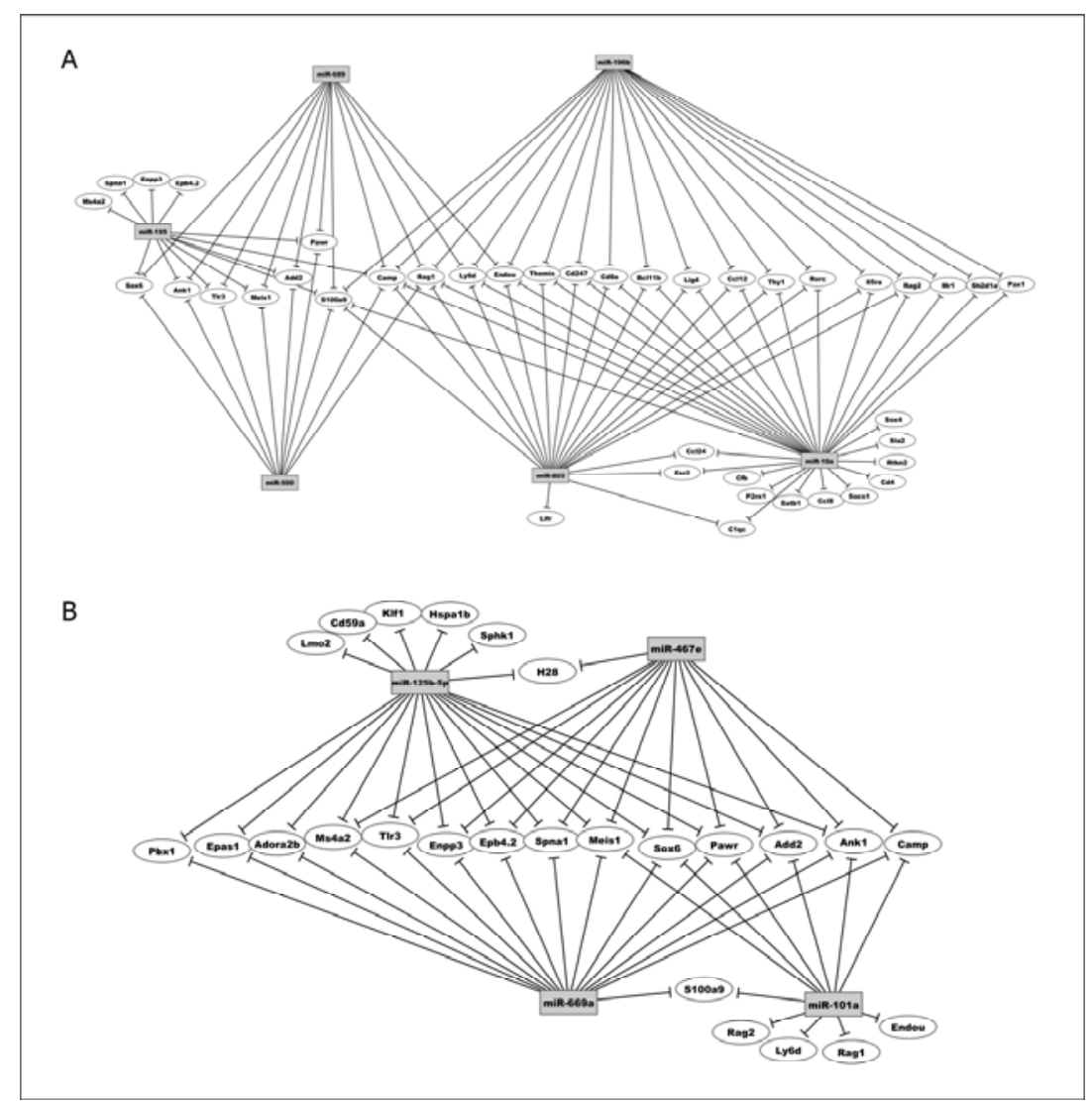

Figure 7. Post-transcriptional miRNA-mRNA interaction network based on microarray expression data in $\mathrm{CD}^{+} \mathrm{T}$ cells from spleen and lymph nodes. Network was obtained using the GenMir ${ }^{++}$algorithm. This figure shows the participation of a) 6 miRNAs up-regulated in DBA-1/J strain, and b) 4 miRNAs up-regulated in DBA-2/J strain, which interact with mRNAs related to immune system biological function.

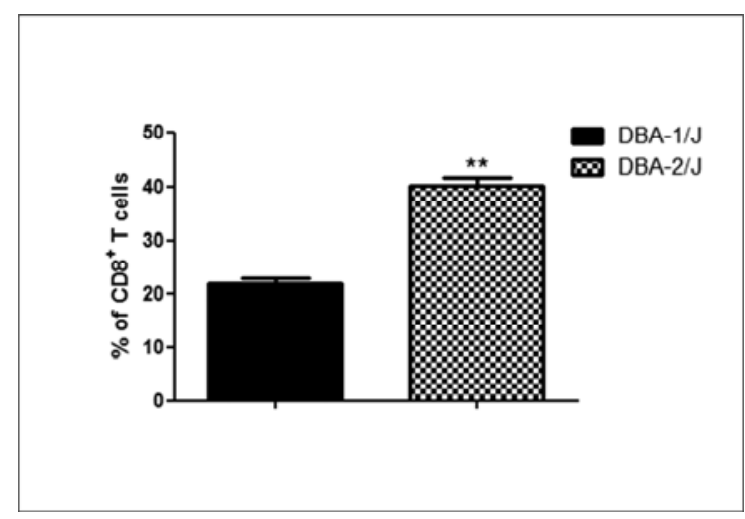

Figure 8. The percentage of $T$ cells from spleen and lymph nodes from DBA-1/J and DBA-2/J mice strain expressing CD8. Data from 3 independent experiments are shown. Results are presented as means $\pm \mathrm{SEM}$. The differences were evaluated by Student's t-test. $P<0.01$ was considered statistically significant. 


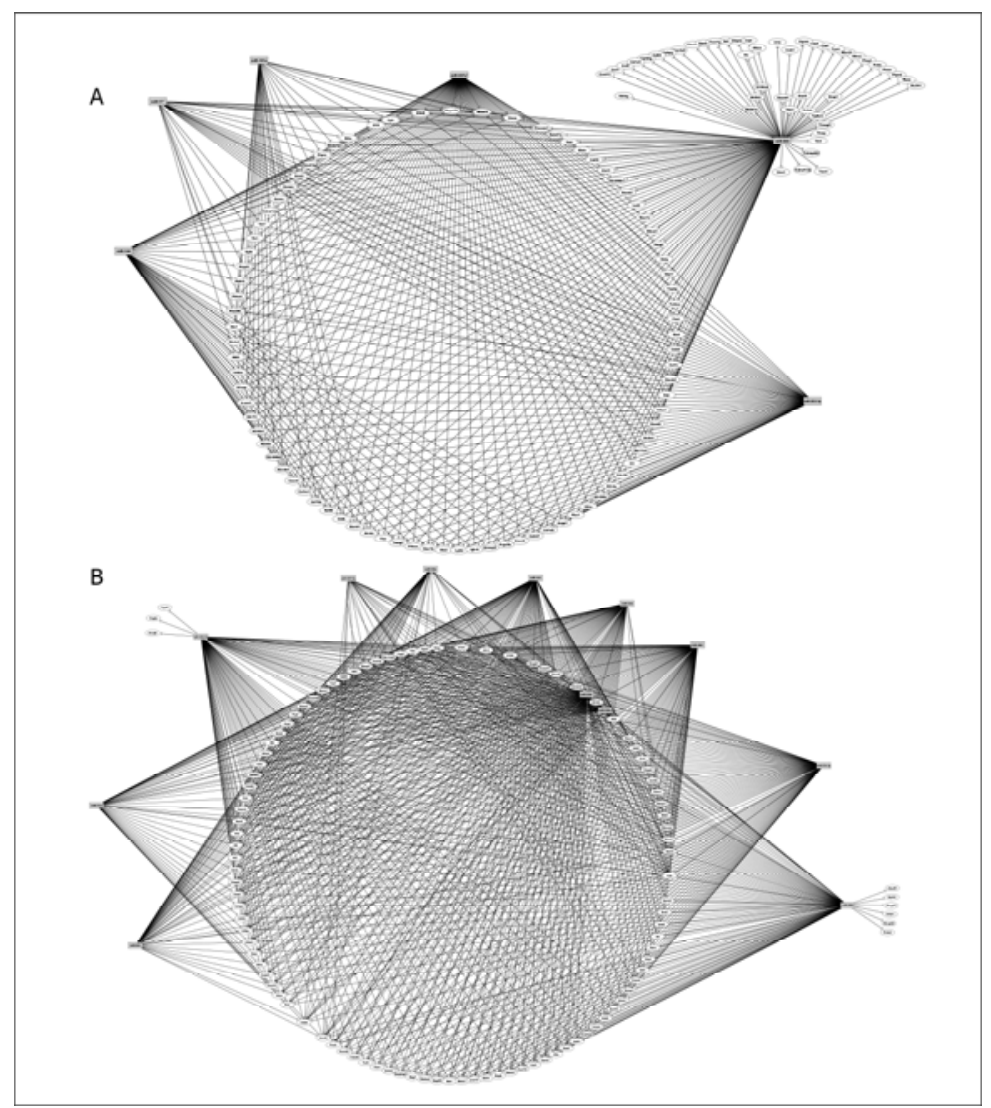

Figure 9. Post-transcriptional miRNA-mRNA interaction network based on microarray expression data in CD3+ T cells from spleen and lymph nodes, after immunization with chicken type II collagen. Network was obtained using the GenMir ${ }^{++}$algorithm. This figure shows the participation of a) 6 miRNAs up-regulated in DBA-1/J and b) 11 miRNAs in DBA-2/J, which interact with mRNAs related to immune system biological function. The controls were immunized without collagen administration.

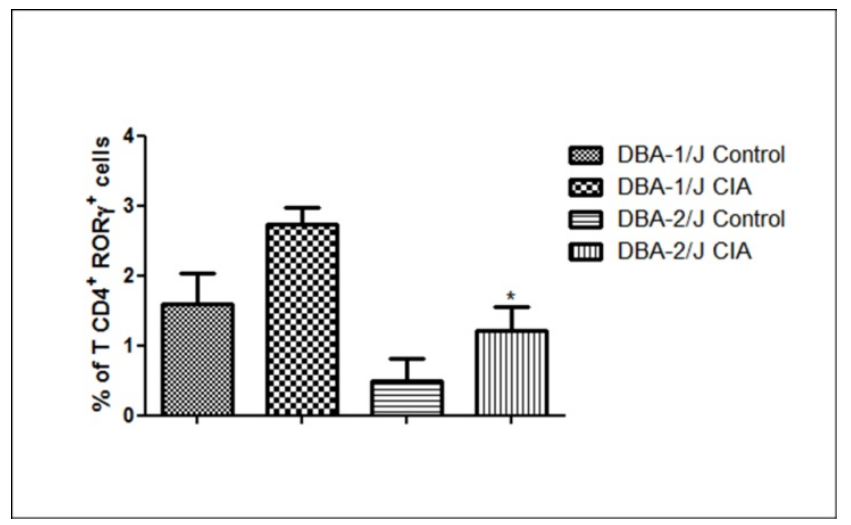

Figure 10. The percentage of $\mathrm{T}$ cells from spleen and lymph nodes from DBA-1/J and DBA-2/J mice strain, during immunization with collagen type II expressing ROR $\gamma \mathrm{t}$. Controls receive the same immunization without collagen administration. Data from 3 independent experiments are shown. Results are presented as means \pm SEM. The differences were evaluated by one-way ANOVA followed by Bonferroni'sttest. $P<0.05$ was considered statistically significant. 


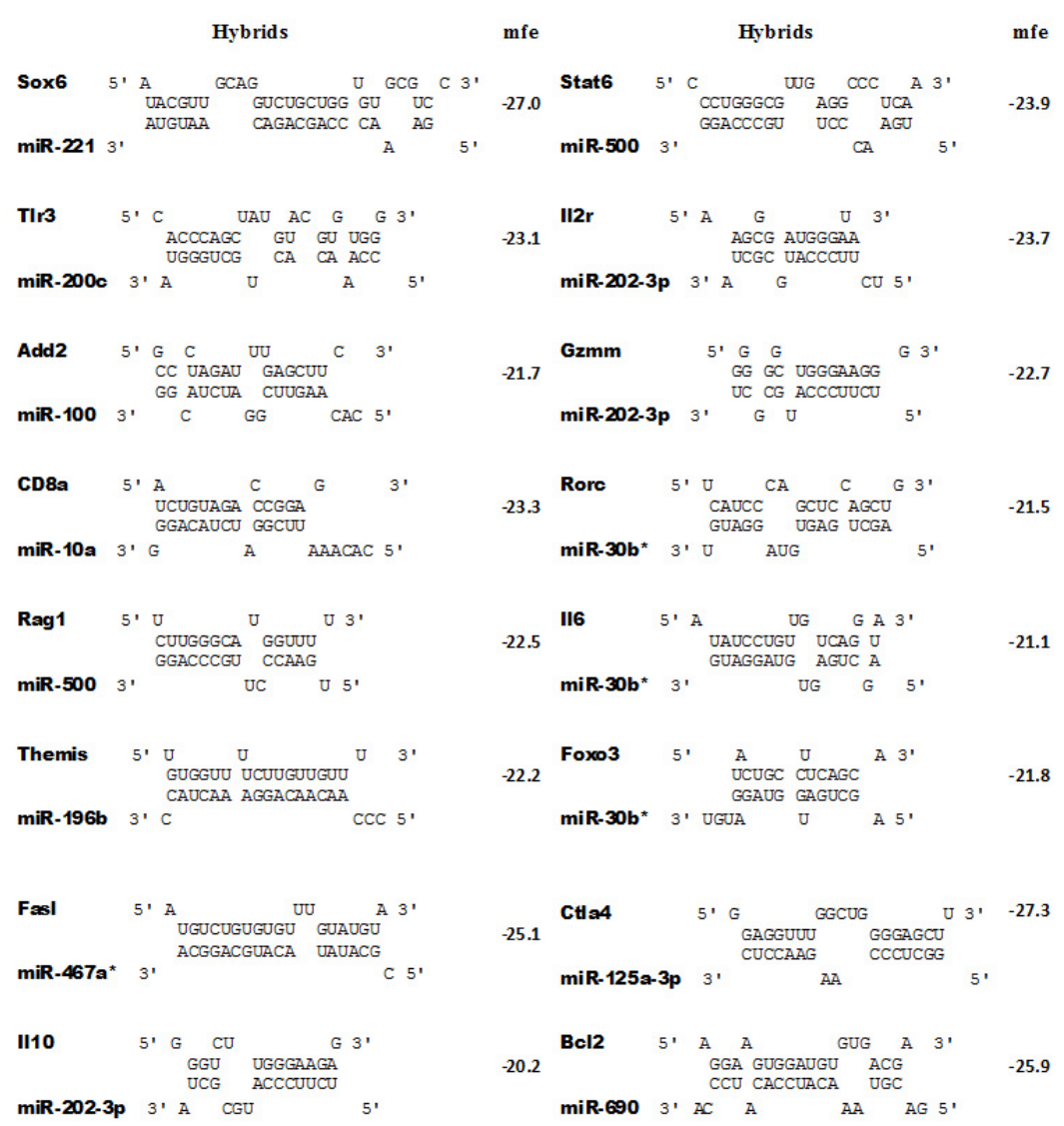

Figure 11. Calculated miRNA:mRNA hybrid structures for selected examples of miRNA-mRNA interaction from our prediction using GenMiR++ model. Sixteen structures of miRNA:mRNA hybrids predicted with RNAhybrid are presented. The miRNA binding site of the target mRNA is shown on top, the complementary miRNA as the bottom strand, calculated mfe (minimum free energy) values are given to the right (kcal/mol). The name of the gene as well as the designation of the miRNA (miRBase) are shown to the left.

Table 1: Up-regulated microRNAs in thymocytes and CD3+T lymphocytes in DBA-1/J and DBA-2/J mice strains and their potential targets related to immune system predicted by GenMiR ${ }^{++}$.

\begin{tabular}{l|l}
\hline \multicolumn{1}{c|}{ MicroRNAs } & \multicolumn{1}{c}{ Potencial targets } \\
\hline miR-221 & Add2, Ank1, Camp, Meis1, Pawr, S100a9, Sox6, Tlr3 \\
\hline miR-126-3p & Add2, Ank1, Camp, Epb4.2, Meis1, Pawr, Sox6, Spna1, Tlr3 \\
\hline miR-200c & $\begin{array}{l}\text { Add2, Ahsp, Ank1, Bc111a, Car2, Cd55, Cd59a, Cd59b, Cd83, Ctsg, Cxc19, } \\
\text { Enpp3, Epb4.2, Epor, Hspa1b, Igj, I11r11, Klf1, Lmo2, Meis1, Mpo, Ncf1, } \\
\text { Pawr, Ptger3, Snca, Sox6, Sphk1, Spna1, Spon2, Tal1, Tlr3, Trim10, Zbtb32 }\end{array}$ \\
\hline
\end{tabular}




\begin{tabular}{|c|c|}
\hline miR-let-7e & $\begin{array}{l}\text { Add2, Adora2b, Ahsp, Ank1, C4bp, Cd59a, Csf1r,Defb6, Enpp3, Epas1, Epb4.2, } \\
\text { Fyb, Ghr, Gm5077, Gnas, Grin2b, H28, H2-Q10, Hoxa9, Klf1, Lifr, Lmo2, } \\
\text { Mecom, Meis1, Mpl, Ms4a2, Pawr, Pbx1, Snca, Sox6, Sphk1, Spna1, Tal1, } \\
\text { Tgfb2, Tlr3, Trim10 }\end{array}$ \\
\hline miR-100 & $\begin{array}{l}\text { Add2, Adora2b, Ahsp, Ank1, Cd59a, Csf1r, Ctsg, Defb6, Enpp3, Epas1, Epb4.2, } \\
\text { Epor, Fyb, Ghr, Gm5077, Grin2b, H28, H2-Q10, Hdac9, Hoxa9, I11r11, Klf1, } \\
\text { Lifr, Lmo2, Meis1, Mpl, Mpo, Ms4a2, Pawr, Smap1, Snca, Sox6, } \\
\text { Sphk1,Spna1,Tal1, Tgfb2, Tlr3, Trim10, Zbtb7a }\end{array}$ \\
\hline $\operatorname{miR}-19 a^{*}$ & $\begin{array}{l}\text { Add2, Ahsp, Ank1, Cd59a, Csf1r, Defb6, Enpp3, Epas1, Epb4.2, Epor, Fyb, } \\
\text { Gm5077, Grin2b, H28, H2-Q10, Hdac9, Hoxa9, Klf1, Lifr, Lmo2, Meis1,Mpl, } \\
\text { Ms4a2,Pawr, Snca, Sox6, Sphk1, Spna1, Tal1, Tgfb2, Tlr3, Trim10 }\end{array}$ \\
\hline miR-195 & $\begin{array}{l}\text { Add2, Ank1, Camp, Enpp3, Epb4.2, Meis1, Ms4a2, Pawr, S100a9, Sox6, Spna1, } \\
\text { Tlr3 }\end{array}$ \\
\hline miR-689 & Add2, Ank1, Camp, Endou, Ly6d, Meis1, Pawr, Rag1, S100a9, Sox6, Tlr3 \\
\hline miR-500 & Add2, Ank1, Camp, Meis1, Pawr, Rag1, S100a9, Sox6, Tlr3 \\
\hline miR-196b & $\begin{array}{l}\text { Bcl11b, Camp, Ccl12, Cd247, Cd8a, Endou, I15ra, Lig4, Ly6d, Mr1, Pax1, Rag1, } \\
\text { Rag2, Rorc, S100a9, Sh2d1a, Themis, Thy1 }\end{array}$ \\
\hline miR-10a & $\begin{array}{l}\text { Bcl11b, C1qc, Camp, Ccl12, Ccl24, Ccl8, Cd247, Cd4, Cd8a, Cfb,Endou, Esr2, } \\
\text { Il5ra, Lig4, Ly6d, Mr1, P2rx1, Pax1, Rag1, Rag2, Rorc, Rtkn2, S100a9, Satb1, } \\
\text { Sh2d1a, Sla2, Socs1, Sox4, Themis, Thy1 }\end{array}$ \\
\hline miR-805 & $\begin{array}{l}\text { Bcl11b, C1qc, Camp, Ccl12, Ccl24, Cd247, Cd8a, Endou, Esr2, Il5ra, Lifr, } \\
\text { Lig4,Ly6d, Rag1, Rag2, Rorc, S100a9, Themis, Thy1 }\end{array}$ \\
\hline miR-125-5p & $\begin{array}{l}\text { Add2, Adora2b, Ank1, Cd59a, Enpp3, Epas1, Epb4.2, H28, Hspa1b, Klf1, } \\
\text { Lmo2, Meis1, Ms4a2, Pawr, Pbx1, Sox6, Sphk1, Spna1, Tlr3 }\end{array}$ \\
\hline $\operatorname{miR}-467 \mathrm{e}$ & $\begin{array}{l}\text { Add2, Ank1, Camp, Enpp3, Epb4.2, H28, Meis1, Ms4a2, Pawr, Sox6, Spna1, } \\
\text { Tlr3 }\end{array}$ \\
\hline miR-669a & $\begin{array}{l}\text { Add2, Adora2b, Ank1, Camp, Enpp3, Epas1, Epb4.2, Meis1, Ms4a2, Pawr, } \\
\text { Pbx1, S100a9, Sox6, Spna1, Tlr3 }\end{array}$ \\
\hline miR-101a & Add2, Ank1, Camp, Endou, Ly6d, Meis1,Pawr, Rag1, Rag2, S100a9, Sox6 \\
\hline miR-144 & $\begin{array}{l}\text { Aicda, Azgp1, Bank1, Btla, Cbfb, Cd1d2, Cd247, Cd38, Cd79b, Cx3cr1, Cxcr4, } \\
\text { Cxcr5, Fcgr2b, Gimap5, Gnas, H2-Ab1, H2-DMb2, H2-Ea, H2-Eb1, H2-T3, }\end{array}$ \\
\hline
\end{tabular}




\begin{tabular}{|c|c|}
\hline & $\begin{array}{l}\text { Hdac9, Hspa1b, Icam1, Igh-6, Il1rap, Inhba, Klh16, Ly6d, Lyn, Ml15, Ms4a1, } \\
\text { Mx1, Mx2, Oas1b, Orm2, Pdcd1lg2, Pou2f2, Prkca, Prkcd, Ptprc, Ripk2, Rogdi, } \\
\text { Sh2d1b1, Spib, Tlr1, Tlr7, Tnfrsf13c, Twsg1, Fas, Gzma, Gzmm, Il10 }\end{array}$ \\
\hline miR-17* & $\begin{array}{l}\text { Bad, Btla, Cd28, Cd38, Csf1r, Cxcr4, Dock2, Gnas, Hdac9, Hspa1b, Kdr, Klh16, } \\
\text { Lyn, Ml15, Nfkb1, Orm2, Pdcd1lg2, Pecam1, Pou2f2, Ptprc, Rab27a, Rogdi, } \\
\text { Rsad2, Sh2b3, Sh2d1b1, Slc11a1, Tlr1, Tlr2, Tlr7 }\end{array}$ \\
\hline miR-181a & $\begin{array}{l}\text { Aicda, Bank1, Btla, Cbfb, Cd79b, Cx3cr1, Gnas, H2-Ab1, H2-DMb2, H2-Ea, } \\
\text { H2-Eb1, H2-T3, Hdac9, Hspa1b, Icam1, Il1rap, Inhba, Klh16, Lyn, Ms4a1, } \\
\text { Mx1, Orm2, Pdcd1lg2, Prkcd, Ptprc, Ripk2, Sh2d1b1, Spib, Tnfrsf13c, Gzma, } \\
\text { Gzmm, Il10 }\end{array}$ \\
\hline miR-202-3p & $\begin{array}{l}\text { Aicda, Azgp1, Bank1, Btla, C3, Cbfb, Cd1d2, Cd247, Cd38, Cd79b, Cx3cr1, } \\
\text { Cxcr4, Cxcr5, Ddx58, Fcgr2b, Gimap5, Gnas, H2-Aa, H2-Ab1, H2-DMa, H2- } \\
\text { DMb2, H2-Ea, H2-Eb1, H2-T3, Hdac9, Hspa1b, Hspa1b, Icam1, Igh-6, Il1rap, } \\
\text { Il2ra, Inhba, Klh16, Ly6d, Lyn, Mll5, Ms4a1, Mx1, Mx2, Oas1b, Orm2, Pbx1, } \\
\text { Pdcd1lg2, Pou2f2, Prkca, Prkcd, Ptprc, Ripk2, Rogdi, Sh2d1b1, Spib, Tlr1, Tlr7, } \\
\text { Tnfrsf13c, Twsg1, Fas, Gzma, Gzmm, Il10 }\end{array}$ \\
\hline miR-467a* & $\begin{array}{l}\text { Aicda, Azgp1, Bad, Bank1, Blnk, Btla, C3, Cbfb, Cd1d2, Cd247, Cd28, Cd38, } \\
\text { Cd55, Cd79b, Clcf1, Csf1r, Cx3cr1, Cxcr4, Cxcr5, Ddx58, Dock2, Fcgr2b, } \\
\text { Gimap5, Gnas, H2-Aa, H2-Ab1, H2-DMa, H2-DMb1, H2-DMb2, H2-Ea, H2- } \\
\text { Eb1, H2-T3, Hdac9, Hoxb3, Hspa1b, Icam1, Igh-6, Il1rap, Il2ra, Inhba, Kdr, } \\
\text { Klh16, Lat2, Ly6d, Lyn, Ml15, Ms4a1, Mx1, Mx2, Myo1e, Nfam1, Nfkb1, } \\
\text { Oas1b, Orm2, Pbx1, Pdcd1lg2, Plcg2, Pou2f2, Prkca, Prkcd, Ptprc, Ripk2, } \\
\text { Rogdi, Rsad2, Selp, Sfpi1, Sh2b3, Sh2d1b1, Slc11a1, Spib, Tapbp, Tlr1, Tlr7, } \\
\text { Tnfrsf13c, Twsg1, Ywhaz, Fas, Fasl, Gzma, Gzmm }\end{array}$ \\
\hline miR-500 & $\begin{array}{l}\text { Aicda, Azgp1, Bad, Bank1, Blnk, Btla, C3, Card11, Cbfb, Ccl1, Cc15, Cd1d1, } \\
\text { Cd1d2, Cd247, Cd28, Cd38, Cd401g, Cd55, Cd79b, Cd80, Cebpg, Clcf1, } \\
\text { Clec4a2, Clec4n, Csf1r, Csf1r, Cx3cr1, Cxcr4, Cxcr5, Ddx58, Dock2, Epas1, } \\
\text { Fcer1g, Fcgr2b, Fkbp1b, G6pdx, Gapt, Gimap5, Gnas, H2-Aa, H2-Ab1, H2- } \\
\text { DMa, H2-DMb1, H2-DMb2, H2-Ea, H2-Eb1, H2-T3, Hc, Hdac9, Hhex, Hoxb3, } \\
\text { Hspa1b, Icam1, Igh-6, Ikbkg, I116, Il1rap, Il2ra, Inhba, Irak1, Itgam, Kdr, Klh16, } \\
\text { Lat2, Lig4, Lst1, Ly6d, Lyn, Lyst, Mll5, Ms4a1, Mx1, Mx2, Myo1e, Myo1f, } \\
\text { Nfam1, Nfkb1, Nlrx1, Oas1b, Orm2, Pbx1, Pdcd1lg2, Pecam1, Plcg1, Plcg2, } \\
\text { Polm, Pou2f2, Prkca, Prkcd, Procr, Ptpn6, Ptprc, Rab27a, Rara, Rc3h1, Ripk2, } \\
\text { Rogdi, Rsad2, S100a9, Selp, Sfpi1, Sh2b2, Sh2b3, Sh2d1a, Sh2d1b1, Slamf1, } \\
\text { Slc11a1, Spib, Stap1, Stat6, Tac4, Tapbp, Tbk1, Tcfeb, Tgfbr2, Tinagl1, Tirap, } \\
\text { Tlr1, Tlr2, Tlr4, Tlr7, Tnfaip812, Tnfrsf13b, Tnfrsf13c, Twsg1, Vnn1, Ywhaz, } \\
\text { Fas, Fasl, Gzma, Gzmm }\end{array}$ \\
\hline miR-10b & $\begin{array}{l}\text { Ahsp, C3ar1, C4bp, Cd34, Cdk6, Cebpa, Crip2, Crk1, Ctla4, Cxc19, Enpp3, Fyb, } \\
\text { Gpam, H28, H2-Q1, H2-Q10,Hells, Hoxa9, Id2, Il12b, Il1r1, Il1r11, Ilf2, Kit, } \\
\text { Klf1, Masp2, Msh2, Pf4, Polr3h, Prg2, Prg3, Runx1, Serpinb9, Slc11a2, Sox6, } \\
\text { Spna1, Tacc3, Tal1, Tap2, Tek, Tgtp1, Tlr3, Tnfsf9, Vpreb1, Cd28 }\end{array}$ \\
\hline
\end{tabular}




\begin{tabular}{|c|c|}
\hline miR-125a-3p & $\begin{array}{l}\text { Ahsp, Alas2, Ank1, Bak1, Barx1,Bcl10, C3ar1, C4bp, C8a, Cd34, Cd47, Cdk6, } \\
\text { Cebpa, Cplx2, Cr11, Crip2, Crk1, Csf1, Ctla4, Ctse, Cxcl11, Cxcl13, Cxc19, } \\
\text { Daf2, Enpp2, Enpp3, Fech, Fyb, Gpam, H28, H2-Q1, H2-Q10, Hbb-b1, Hells, } \\
\text { Heph, Hmgb1, Hoxa9, Icam1, Id2, Il12b, Il1r1, Il1r11, Il2ra, Ilf2, Jarid2, Kcnj, } \\
\text { Kit, Klf1, Klf11, Klre1, Lrrc17, Masp1, Masp2, Mbl2, Mecom, Meis1, Msh2, } \\
\text { Mx1, Nup85, Osm, Pf4, Pik3cd, Pml, Polr3h, Prg2, Prg3, Rag1, Runx1, } \\
\text { Serpinb9, Serping1, Sfxn1, Sh2b2, Slc11a2, Sox6, Spna1, Tacc3, Tal1, Tap2, } \\
\text { Tbx1, Tcf3, Tcfe3, Tek, Tgtp1, Tlr3, Tnfsf11, Tnfsf8, Tnfsf9, Traf3ip2, } \\
\text { Txnrd2, Vegfa, Vpreb1, Cd28, Itgb6 }\end{array}$ \\
\hline miR-141 & $\begin{array}{l}\text { Ahsp, Alas2, Ank1, Bak1, Barx1, Bcl10, C3ar1, C4bp, C8a, Cd34, Cd47, Cdk6, } \\
\text { Cebpa, Cplx2, Cr11, Crip2, Crk1, Csf1, Ctla4, Ctse, Cxcl11, Cxcl13, Cxc1, } \\
\text { Daf2, Enpp2, Enpp3, Fech, Fyb, Gpam, H28, H2-Q1, H2-Q10, Hbb-b1, Hells, } \\
\text { Heph, Hmgb1, Hoxa9, Icam1, Id2, I112b, Il1r1, Il1rl1, Il2ra, Ilf2, Jarid2, Kit, } \\
\text { Klf1, Klf11, Klre1, Lrrc17, Masp1, Masp2, Mbl2, Mecom, Meis1, Msh2, Mx1, } \\
\text { Nup85, Osm, Pf4, Pik3cd, Pml, Polr3h, Prg2, Prg3, Rag1, Runx1, Serpinb9, } \\
\text { Serping1, Sfxn1, Sh2b2, Slc11a2, Sox6, Spna1, Tacc3, Tal1, Tap2, Tbx1, Tcf, } \\
\text { Tcfe3, Tek, Tgtp1, Tlr3, Tnfsf11, Tnfsf8, Tnfsf9, Traf3ip2, Txnrd2, Vpreb1, } \\
\text { Cd28 }\end{array}$ \\
\hline miR-149 & $\begin{array}{l}\text { Ahsp, Bak1, C3ar1, C4bp, C8a, Cd34, Cdk6, Cebp, Cplx2, Crip2, Crk1,Csf1, } \\
\text { Ctla4, Ctse, Cxcl11, Cxcl13, Cxc19, Enpp3, Fech, Fyb, Gpam, H28, H2-Q1, H2- } \\
\text { Q10, Hbb-b1, Hells, Heph, Hoxa9, Icam1, Id2, Il12b, Il12b, Il1r1, I11r11, Il2ra, } \\
\text { Ilf2, Kit, Klf1, Klf11, Lrrc17, Masp2, Meis1, Msh2, Mx1, Nup85, Osm, Pf4, } \\
\text { Pik3cd, Pml,Polr3h, Prg2, Prg3, Rag1, Runx1, Serpinb9, Serping1, Sh2b2, } \\
\text { Slc11a2, Sox6, Spna1, Tacc3, Tal1, Tap2, Tbx1, Tcf3, Tek, Tgtp1, Tlr3, Tnfsf,, } \\
\text { Tnfsf9, Txnrd2, Vpreb1, Cd28 }\end{array}$ \\
\hline miR-1897-5p & $\begin{array}{l}\text { Cdk6, Cxc19, Elf4, Fech, Foxo3, Fyb, Fyb, Gpam, H28, H2-Q1, H2-Q10, } \\
\text { Hoxa9, Il12b, Il12b, Il1r1, Il1r11, Klf1, Masp2, Masp2, Polr3h, Slc11a2, } \\
\text { Slc11a2, Smap1, Tap2, Tek, Tgtp1 }\end{array}$ \\
\hline miR-29b* & $\begin{array}{l}\text { Add2, Ahsp, Ank1, Bak1, C3ar1, C4bp, C8a, Cd34, Cdk6, Cebpa, Cplx2, Crip2, } \\
\text { Crk1, Csf1, Ctla4, Ctse, Cxcl11, Cxcl13, Cxc19, Elf4, Enpp3, Fech, Fech, Fech, } \\
\text { Foxo3, Fyb, Gpam, H28, H2-Q1, H2-Q10, Hbb-b1, Hells, Heph, Hoxa9, Icam1, } \\
\text { Id2, Il12b, Il1r1, Il1rl1, Il2ra, I16, Ilf2, Kit, Klf1, Klf11, Lrrc17, Masp2,Meis1, } \\
\text { Msh2, Mx1, Nup85, Osm, Pf4, Pik3cd, Pml, Polr3h, Prg2, Prg3, Rag1, Rorc, } \\
\text { Runx1, Serpinb9, Serping1, Sh2b2, Slc11a2, Smap1, Sox6, Spna1, Spon2, } \\
\text { Tacc3, Tal1, Tap2, Tbx1, Tcf3, Tek, Tgtp1, Thy1, Tlr3, Tnfsf8, Tnfsf9, Txnrd, } \\
\text { Vpreb1, Cd28 }\end{array}$ \\
\hline $\mathrm{miR}-302 \mathrm{c}$ & $\begin{array}{l}\text { Ahsp, Cdk6, Crk1, Ctla4, Cxc19, Fyb, Gpam, H28, H2-Q1, H2-Q10, Hoxa9, } \\
\text { Il12b, Il1r1, Il1r11, Kit, Klf1, Masp2, Msh2, Polr3h, Prg2, Prg3, Runx1, } \\
\text { Serpinb9, Slc11a2, Spna1, Tal1, Tap2, Tek, Tgtp1, Cd28 }\end{array}$ \\
\hline miR-30b* & $\begin{array}{l}\text { Add2, Ahsp, Alas2, Ank1, Bak1, Barx1, Bcl10, C3ar1, C4bp, C8a, Cd34, Cd47, } \\
\text { Cdk6, Cebpa, Cplx2, Cr11, Crip2, Crk1, Csf1, Ctla4, Ctse, Cxcl11, Cxcl13, } \\
\text { Cxc19, Daf2, Elf4, Enpp2, Enpp3, Fech, Foxo3, Fyb, Gpam, H28, H2-Q1, H2- }\end{array}$ \\
\hline
\end{tabular}




\begin{tabular}{|c|c|}
\hline & $\begin{array}{l}\text { Q10, Hbb-b1, Hells, Heph, Hoxa9, Icam1, Id2, Il12b, Il1r1, Il1rl1, Il2ra, Il6, Ilf2, } \\
\text { Jarid2, Kit, Klf1, Klf11, Klre1, Lrrc17, Masp1, Masp2, Mb12, Mecom, Meis1, } \\
\text { Msh2, Mx1, Nup85, Osm, Pf4, Pik3cd, Pml, Polr3h, Prg2, Prg3, Rag1, Rorc, } \\
\text { Runx1, Serpinb9, Serping1, Sfxn1, Sh2b2, Slc11a2, Smap1, Sox6, Spna1, } \\
\text { Tacc3, Tal1, Tap2, Tbx1, Tcf3, Tcfe3, Tek, Tgtp1, Thy1, Tlr3, Tnfsf8, Tnfsf,, } \\
\text { Traf3ip2, Txnrd2, Vpreb1, Bc12, Cd28 }\end{array}$ \\
\hline miR-690 & $\begin{array}{l}\text { Add2, Ahctf1, Ahsp, Alas2, Ank1, Bak1, Bcl10, C3ar1, C4bp, C8a, Cd34, Cdk6, } \\
\text { Cebpa, Cplx2, Crip2, Crk1, Csf1, Ctla4, Ctse, Cxcl11, Cxcl13, Cxc19, Daf2, } \\
\text { Dyrk3, Elf4, Enpp3, Fech, Foxo3, Fyb, Gpam, H28, H2-Q1, H2-Q10, Hbb-b1, } \\
\text { Hells, Heph, Hmgb3, Hoxa9, Icam1, Id2, Il12b, Il12b, Il18r1, Il1r1, Il1rl1, Il2ra, } \\
\text { Il6, Ilf2, Kit, Klf1, Klf11, Lrrc17, Masp2, Meis1, Msh2, Mx1, Ncaph2, Nup8,, } \\
\text { Osm, Pf4, Pik3cd, Pml, Polr3h, Prdx2, Prg2, Prg3, Rag1, Rorc, Runx1, } \\
\text { Serpinb9, Serping1, Sh2b2, Slc11a2, Slc11a2, Smap1, Sox6, Spna1, Spon2, } \\
\text { Tacc3, Tal1, Tap2, Tbx1, Tcf3, Tcfe3, Tek, Tgtp1, Thy1, Tlr3, Tnfsf8, Tnfsf9, } \\
\text { Traf3ip2, Txnrd2, Vpreb1, Bc12, Cd28 }\end{array}$ \\
\hline miR-691 & $\begin{array}{l}\text { Ahsp, C3ar1, C4bp, Cd34, Cdk6, Cebpa, Crip2, Crk1,Ctla4, Ctse, Cxcl11, Cxc19, } \\
\text { Enpp3, Fyb, Gpam, H28, H2-Q1, H2-Q10, Hells, Hoxa9, Icam1, Id2, Il12b, } \\
\text { Il1r1, Il1r11, Il2ra, Ilf2, Kit, Klf1, Masp2, Msh2, Osm, Pf4, Polr3h, Prg2, Prg3, } \\
\text { Runx1, Serpinb9, Slc11a2, Sox6, Spna1, Tacc3, Tal1, Tap2, Tek, Tgtp1, Tlr3, } \\
\text { Tnfsf9, Vpreb1, Cd28 }\end{array}$ \\
\hline miR-712 & $\begin{array}{l}\text { Ahsp, C3ar1, C4bp, Cd34, Cdk6, Cebpa, Crip2, Crk1, Ctla4, Ctse, Cxcl11, } \\
\text { Cxc19, Enpp3, Fyb, Gpam, H28, H2-Q1, H2-Q10, Hells, Hoxa9, Icam1, Id, } \\
\text { Il12b, Il1r1, Il1r11, Il2ra, Ilf2, Kit, Klf1, Masp2, Msh2, Osm, Pf4, Pml, Polr3h, } \\
\text { Prg2, Prg3, Runx1, Serpinb9, Slc11a2, Sox6, Spna1, Tacc3, Tal1, Tap2, Tek, } \\
\text { Tgtp1, Tlr3, Tnfsf9, Vpreb1, Cd28 }\end{array}$ \\
\hline
\end{tabular}


SÚMULA CURRICULAR 


\section{CURRICULUM VITAE (Fevereiro 2012)}

Paula Barbim Donate Yabuta

Bióloga

E-mail: paulabarbim@.usp.br

\section{DADOS PESSOAIS:}

Nome: Paula Barbim Donate Yabuta

Endereço: Rua Afonso Arinos, 1763 - Jd. Piratininga.

Ribeirão Preto - SP CEP: 14030-530

Fone: (16) 8185-3306

Filiação: Paulo Marcos Donate e Waldemarina Barbim

Nacionalidade: Brasileira

Data de Nascimento: 11/12/1982 Ribeirão Preto - SP, Brasil.

Estado Civil: casada

\section{DADOS DE IDENTIFICAÇÃO:}

Carteira de identidade: 20.906.999-5, SSP/SP - 15/01/1998

Cadastramento de pessoa física: 220.990.978-36

Título de eleitor: 290927170108

\section{FUNÇÃO ATUAL}

Doutorado: Departamento de Imunologia Básica e Aplicada, Faculdade de Medicina de Ribeirão Preto-USP, Campus de Ribeirão Preto, com bolsa de pesquisa CAPES/PROEX. Área de concentração: Imunologia.

\section{ESCOLARIDADE}

Doutor em Ciências (em andamento) pela Faculdade de Medicina de Ribeirão Preto. Área de concentração: Imunologia. Sub-área: Imunogenética Molecular - Projeto de Doutorado: O Papel dos microRNAs de Células T na Susceptibilidade/Resistência a Artrite Reumatóide Experimental. 
Mestre em Ciências pela Faculdade de Medicina de Ribeirão Preto. Área de concentração: Imunologia. Sub-área: Imunogenética Molecular - Dissertação: Análise da Expressão Gênica Promíscua no Timo de Camundongos DBA-1 e DBA-2 Durante a Imunização com Colágeno: Modelo de Susceptibilidade/Resistência a Artrite Reumatóide. Período de 2006 a 2008.

Licenciada em Ciências Biológicas pela Faculdade Barão de Mauá, no período de 2002.

\section{CURSOS DE EXTENSÃO UNIVERSITÁRIA}

$\checkmark$ “Aplicações e Fundamentos da PCR quantitativa em tempo real”, realizado pela Applied Biosystem, no período de 12 a 15 de janeiro, com carga horária de 30 horas.

$\checkmark$ “Difusão: Radioproteção para uso, preparo e manuseio de fontes radioativas”, realizado na Faculdade de Medicina de Ribeirão Preto - USP, no período de 27 de novembro a 08 de dezembro de 2006, com carga horária de 50 horas.

$\checkmark$ “From Statistical Tools to Different Analisys Methods Apllied to Transcriptome Studies”, INSERM Research Beatrice Loriod e Geneviève Victorero - Marseille, França, realizado pelo Departamento de Genética da Faculdade de Medicina de Ribeirão Preto USP, no período de 05 a 09 de junho de 2006, com carga horária total de 20 horas.

\section{ESTÁGIOS}

$\checkmark$ Laboratório de Inflamação e Dor do Departamento de Farmacologia da Faculdade de Medicina de Ribeirão Preto - USP - sob orientação do Prof. Dr.Fernando Q. Cunha, no período de outubro de 2002 a fevereiro de 2004. Iniciação científica. Projeto: "Análise da expressão gênica diferencial das articulações de camundongos susceptíveis (DBA-1/J) e resistentes (DBA-2/J) à indução de artrite reumatóide pelo colágeno", com bolsa FAPESP.

\section{ESTÁGIO NO EXTERIOR}

$\checkmark$ Center for Rheumatic Diseases in the Institute of Infection, Immunity and Inflammation, University of Glasgow - UK localizado na cidade de Glasgow, Escócia e dirigido pela Dra. Mariola Kurowska-Stolarska com linha de pesquisa voltada para estudos de microRNAs na Artrite Reumatóide. Fevereiro a agosto de 2011. 


\section{MONITORIAS E AULAS PRÁTICAS}

1) Instituição: FMRP-USP

III Curso de Inverno de Imunologia: Departamento de Imunologia Básica e Aplicada

Data: 26 a 30 de julho de 2010.

Monitoria de Estágio no Laboratório de Imunogenética Molecular.

2) Instituição: FMRP-USP

II Curso de Inverno de Imunologia: Departamento de Imunologia Básica e Aplicada

Data: 13 a 17 de julho de 2009.

Monitoria de Estágio no Laboratório de Imunogenética Molecular.

3) Instituição: FMRP-USP

XIV Curso de Verão em Genética: Departamento de Genética (graduação)

Data: 19 a 30 de janeiro de 2009.

Monitoria de Estágio no Laboratório de Imunogenética Molecular.

4) Instituição: FMRP-USP

Análise da Expressão Gênica por Microarrays realizado pela Sociedade Brasileira de Mutagênese, Carcinogênese e Teratogênese Ambiental (SBMCTA): Departamento de Genética.

Data: 08 a 11 de dezembro de 2008.

Aula prática: “A metodologia de microarrays" no Laboratório de Imunogenética Molecular.

5) Instituição: FMRP-USP

XIII Curso de Verão em Genética: Departamento de Genética (graduação)

Data: 14 a 25 de janeiro de 2008.

Aula teórico-prática e monitoria no Laboratório de Imunogenética Molecular.

6) Instituição: FMRP-USP

XII Curso de Verão em Genética: Departamento de Genética (graduação)

Data: 22 de janeiro a 02 de fevereiro de 2007.

Aula teórico-prática no Laboratório de Imunogenética Molecular.

\section{PALESTRAS E MINI-CURSOS PROFERIDOS}

- Palestra intitulada "Técnicas Aplicadas no Estudo de Imunologia: microarrays" apresentada durante o I Curso de Inverno de Imunologiano Departamento de Imunologia 
Básica e Aplicada da Faculdade de Medicina de Ribeirão Preto - USP realizada no período de 07 a 18 de julho de 2008.

\section{EXPERIÊNCIA DIDÁTICA}

Estágio no Programa de Aperfeiçoamento de Ensino - PAE.

Desenvolvimento de atividades didáticas junto à disciplina de genética, Faculdade de Odontologia de Ribeirão Preto, com carga horária de 6 horas semanais, no primeiro semestre de 2010.

\section{PRODUÇÃO CIENTÍFICA}

\section{A) APRESENTAÇÃO DE TRABALHOS}

1) Fornari TA; Donate PB; Macedo C; Donadi EA; Sakamoto-Hojo ET; Passos GAS. Development of type 1 Diabetes mellitus (T1D) in NOD mice is characterized by distinct transcriptional profiling of T lymphocytes. I Workshop de Imunologia nos dias 26 e 27 de novembro de 2010, Ribeirão Preto.

2) Donate PB; Fornari TA; Magalhães DA; Marques MMC; Cunha T; Cunha FQ; Passos GAS. Post-transcriptional regulation in autoimmunity: expression of microRNAs by $\mathrm{T}$ cells during immunization of DBA mice with collagen: a model system of susceptibility/resistance to rheumatoid arthritis. VII Workshop de Imunologia no período de 09 a 11 de julho de 2008, Ribeirão Preto.

3) Donate PB; Fornari TA; Cunha T; Cunha FQ; Passos GAS. Analysis of promiscuous gene expression in the thymus of DBA-1 and DBA-2 mice during immunization with collagen: a model-system to study susceptibility/resistance to rheumatoid arthritis. VI Workshop de Imunologia no período de 02 a 04 de agosto de 2006, Ribeirão Preto.

\section{B) TRABALHOS PUBLICADOS EM PERIÓDICOS (COMPLETO)}

1) Paula B. Donate, Thiago M. Cunha, Waldiceu A. Verri Jr, Cristina M. Junta, Flavia O. Lima, Silvio M. Vieira, Rafael S. Peres, Karina F. Bombonato-Prado, Paulo Louzada Jr, Sergio H. Ferreira, Eduardo A. Donadi, Geraldo A. S. Passos. Bosentan, an endothelin receptor antagonist, ameliorates collagen-induced arthritis: the role of TNF-a in the induction of endothelin system genes. Inflammation Research. Epub ahead of print. 2011 
2) Fornari TA, Donate PB, Macedo C, Sakamoto-Hojo ET, Donadi EA, Passos GA. Development of type 1 diabetes mellitus in nonobese diabetic mice follows changes in thymocyte and peripheral T lymphocyte transcriptional activity. Clinical \& Developmental Immunology 2011:158735.

3) Donate PB, Fornari TA, Junta CM, Magalhães DA, Macedo C, Cunha TM, Nguyen C, Cunha FQ, Passos GA. Collagen induced arthritis (CIA) in mice features regulatory transcriptional network connecting major histocompatibility complex (MHC H2) with autoantigen genes in the thymus. Immunobiology (Jena. 1979), v.216(5), p.591 $603,011$.

4) Fornari TA, Donate PB, Macedo C, Marques MMC, Magalhães DA, Passos GA. Age-related deregulation of Aire and peripheral tissue antigen genes in the thymic stroma of non-obese diabetic (NOD) mice is associated with autoimmune type 1 diabetes mellitus (DM-1). Molecular and Cellular Biochemistry, v.342(1-2), p.21 - 28, 2010.

\section{C) TRABALHOS PUBLICADOS EM ANAIS (RESUMOS) EM CONGRESSOS NO BRASIL}

1) Donate PB; Fornari TA; Macedo C; Cunha T; Cunha FQ; Passos GAS. Differentially expressed microRNAs in $\mathrm{T}$ cells might contribute to the resistance/susceptibility in collagen induced arthritis (CIA) in mice. In: XXXVI Congress of the Brazilian Society for Immunology, IV ESCI - Extra Section of Clinical Immunology, Effector Immune Responses and viral Immunity, no period de 15 a 19 de outubro de 2011, Foz do Iguaçu - PR.

2) Macedo C; Oliveira EH; Almeida RS; Donate PB; Fornari TA; Sakamoto-Hojo ET; Donadi EA; Passos GAS. Participation of micro-rnas in the post-transcriptional control of tissue specific antigens in medullary thymic epithelial cells of nod mice. In: XXXVI Congress of the Brazilian Society for Immunology, IV ESCI - Extra Section of Clinical Immunology, Effector Immune Responses and viral Immunity, no período de 15 a 19 de outubro de 2011, Foz do Iguaçu - PR.

3) Fornari TA; Donate PB; Macedo C; Donadi EA; Sakamoto-Hojo ET; Passos GAS. Distinct transcription profiling of $\mathrm{T}$ lymphocytes characterize the development of type 1 Diabetes mellitus (T1D) in NOD mice. XXXV Congress of the Brazilian Society for Immunology / III Extra Section of Clinical Immunology, no período de 03 a 06 de novembro de 2010, Porto Alegre - RS. 
4) Donate PB; Fornari TA; Macedo C; Cunha T; Cunha FQ; Passos GAS.Thymocyte signaling cascade mRNAs are differentially expressed between DBA-1/J and DBA-2/J mouse strains as a result from post-transcriptional regulation by microRNAs. XXXV Congress of the Brazilian Society for Immunology / III Extra Section of Clinical Immunology, no período de 03 a 06 de novembro de 2010, Porto Alegre - RS.

5) Macedo C; Evangelista AF; Fornari TA; Donate PB; Dernowsek JA; SakamotoHojo ET; Donadi EA; Savino W; Passos GAS. Promiscuous Gene Expression in medullary thymic epithelial cells is synergistically controlled by Aire and microRNAs. XXXV Congress of the Brazilian Society for Immunology / III Extra Section of Clinical Immunology, no período de 03 a 06 de novembro de 2010, Porto Alegre - RS.

6) Macedo C; Adorni F; Fornari TA; Donate PB; Silva S; Felipe MS; Calich V; Savino $\mathrm{W}$; Passos GAS. The mouse thymic stroma expresses autoantigen mRNAs that crosshybridize with Paracoccidioides brasiliensis cDNAs. XXXV Congress of the Brazilian Society for Immunology / III Extra Section of Clinical Immunology, no período de 03 a 06 de novembro de 2010, Porto Alegre - RS.

7) Rostock ACM; Macedo C; Fornari TA; Donate PB; Evangelista AF; Passos GAS. Aire transcription factor may control the expression of tumor antigen genes in medullary thymic epithelial cells (mTECs). XXXV Congress of the Brazilian Society for Immunology / III Extra Section of Clinical Immunology, no período de 03 a 06 de novembro de 2010, Porto Alegre - RS.

8) Fornari TA; Donate PB; Macedo C; Marques MMC; Magalhães DAR; Passos GAS. Deregulation of promiscuous gene expression in the thymus of NOD (non obese diabetic) mice is associated to the development of type 1 Diabetes mellitus. XXXIII Congress of the Brazilian Society for Immunology / II Extra Section of Clinical Immunology, no período de 18 a 22 de outubro de 2008, Ribeirão Preto - SP.

9) Donate PB; Fornari TA; Marques MMC; Magalhães DAR; Macedo C; Cunha T; Cunha FQ; Passos GAS. Altered promiscuous gene expression in the thymus during collagen induced arthritis in DBA-1/J and DBA-2/J strains correlates with evolution of autoimmunity. XXXIII Congress of the Brazilian Society for Immunology / II Extra Section of Clinical Immunology, no período de 18 a 22 de outubro de 2008, Ribeirão Preto - SP.

10) Rassi DM; Junta CM; Magalhães DA; Silva GL; Evangelista AF; Donate PB; Fornari TA; Wastowski IJ; Crispim JO; Martelli-Palomino G; Fernandes APM; Foss- 
Freitas MC; Deghaide NNHS; Foss MC; Soares CP; Sakamoto-Hojo ET; Passos GAS; Donadi EA. Modulated immune system genes in lymphomononuclears cells of recently diagnosed type 1 Diabetes mellitus patients. XXXIII Congress of the Brazilian Society for Immunology / II Extra Section of Clinical Immunology, no período de 18 a 22 de outubro de 2008, Ribeirão Preto - SP.

11) Fornari TA; Donate PB; Marques MMC; Macedo C; Magalhães DAR; Passos GAS. Promiscuous gene expression in the thymus of NOD (non obese diabetic) mice during onset of type 1 diabetes mellitus (DM-1). $54^{\circ}$ Congresso Brasileiro de Genética no período de 16 a 19 de setembro de 2008, Salvador - BA.

12) Fornari TA; Donate PB; Marques MMC; Junta CM; Passos GAS. Failure of the promiscuous gene expression in the thymus of NOD (non obese diabetic) mice is followed by onset of type 1 diabetes mellitus (DM-1). 53 $3^{\circ}$ Congresso Brasileiro de Genética no período de 02 a 05 de setembro de 2007, Águas de Lindóia - SP.

13) Donate PB; Fornari TA; Marques MMC; Junta CM; Cunha T; Cunha FQ; Passos GAS. Repression of genes coding for extracellular matrix specific antigens in the thymus may be a cause of the rheumatoid arthritis. $53^{\circ}$ Congresso Brasileiro de Genética no período de 02 a 05 de setembro de 2007, Águas de Lindóia - SP.

14) Donate PB; Fornari TA; Marques MMC; Junta CM; Cunha T; Cunha FQ; Passos GAS. Modulation of genes characterizing locomotory system in the thymus may be associated to rheumatoid arthritis susceptibility/resistance in mice. 13th International Congress of Immunology no período de 21 a 25 de agosto de 2007, Rio de Janeiro - RJ.

\section{D) TRABALHOS PUBLICADOS EM CONGRESSOS E/OU REUNIÕES CIENTÍFICAS NO EXTERIOR}

1) Fornari TA; Donate PB; Macedo C; Sakamoto-Hojo ET; Donadi EA; Passos GAS. The transcriptional modulation involving mRNAS and microRNAs during development of $\mathrm{T}$ cells is associated with the emergence of type 1 Diabetes mellitus in NOD mice. In: 47 th Annual Meeting of the European Association for the Study of Diabetes (EASD), no período de 12 a 16 de setembro de 2011, Lisboa, Portugal.

2) TM Cunha, PB Donate, WA Verri Jr, CM Junta, SM Vieira, P Louzada Jr, EA Donadi, GA Passos, FQ Cunha. Endothelin receptor antagonist Bosentan ameliorates collagen-induced arthrits in mice and modulates gene expression in lynph nodes. In $10^{\text {th }}$ World Congress in Inflammation, de 25 a 29 de junho de 2011, Paris,França. 
3) Macedo C, Evangelista A, Fonari T, Donate P,Dernowsek J, Sakamoto-Hojo E, Donadi E, Savino W. Promiscuous Gene Expression in Medullary Thymic Epithelial Cells is Synergistically Controlled by Aire and microRNAs. In MicroRNA in Human Disease \& Development, no período de 28 a 30 de março, Cambridge, MA.

\section{MENÇÃO HONROSA}

Menção Honrosa concedido pela participação no Prêmio Pós-Graduação com o trabalho intitulado: Repression of genes coding for extracellular matrix specific antigens in the thymus may be a cause of the rheumatoid arthritis autoria de Donate PB; Fornari TA; Marques MMC; Junta CM; Cunha T; Cunha FQ; Passos GAS apresentado durante o 53 Congresso Brasileiro de Genética no período de 02 a 05 de setembro de 2007, Águas de Lindóia - SP.

\section{RELATOR DE TRABALHOS}

$\checkmark$ Atuação como avaliadora na área de Imunologia, no $18^{\circ}$ SIICUSP- Simpósio Internacional de Iniciação Científica da Universidade de São Paulo- Áreas Ciências Biológicas, realizado no Centro de Convenções de Ribeirão Preto no dia 23 de novembro de 2011.

$\checkmark$ Atuação como avaliadora na área de Imunologia, no $18^{\circ}$ SIICUSP- Simpósio Internacional de Iniciação Científica da Universidade de São Paulo- Áreas Ciências Biológicas, realizado no Centro de Convenções de Ribeirão Preto nos dias 17 e 18 de novembro de 2010.

$\checkmark$ Atuação como debatedora na área de Genética, no $17^{\circ}$ SIICUSP- Simpósio Internacional de Iniciação Científica da Universidade de São Paulo- Áreas Ciências Biológicas, realizado no Centro de Convenções de Ribeirão Preto nos dias 10 e 11 de novembro de 2009.

\section{PARTICIPAÇÃO EM CONGRESSOS E REUNIÕES CIENTÍFICAS NO BRASIL}

$\checkmark$ VIII Workshop de Imunologia, realizado pelo Programa de Pós-graduação em Imunologia Básica e Aplicada da Faculdade de Medicina de Ribeirão Preto - USP, no período de 21 a 23 de julho de 2010. 
$\checkmark$ VII Workshop de Imunologia, realizado pelo Programa de Pós-graduação em Imunologia Básica e Aplicada da Faculdade de Medicina de Ribeirão Preto - USP, no período de 09 a 11 de julho de 2008.

$\checkmark$ VII Workshop de Imunologia, realizado pelo Programa de Pós-graduação em Imunologia Básica e Aplicada da Faculdade de Medicina de Ribeirão Preto - USP, no período de 09 a 11 de julho de 2008.

$\checkmark$ XXXIII Congress of the Brazilian Society for Immunology / II Extra Section of Clinical Immunology, realizado pelo Departamento de Imunologia Básica e Aplicada da Faculdade de Medicina de Ribeirão Preto - USP, no período de 18 a 22 de outubro de 2008.

$\checkmark$ II Fórum Regional de Ética em Pesquisa e Experimentação Animal,realizado no Centro Universitário Barão de Mauá em Ribeirão Preto - SP nos dias 12 e 13 de maio de 2008.

$\checkmark$ VI Workshop de Imunologia, realizado pelo Programa de Pós-graduação em Imunologia Básica e Aplicada da Faculdade de Medicina de Ribeirão Preto - USP, no período de 02 a 04 de agosto de 2006.

$\checkmark \quad 4^{\circ}$ Simpósio sobre Ética no Uso de Animais, realizado em Ribeirão Preto-SP, no Espaço Cultural do Campus nos dias 27 e 28 de abril de 2006.

$\checkmark$ I Simpósio Satélite da Regional de São Paulo, realizado em Ribeirão Preto- SP, no Anfiteatro do COC no dia 07 de abril de 2006.

$\checkmark$ XXXI Meeting of the Brazilian Society forImmunology, realizado em Búzios - SP nos dias 22 a 25 de outubro de 2006. 


\title{
Bosentan, an endothelin receptor antagonist, ameliorates collagen-induced arthritis: the role of TNF- $\alpha$ in the induction of endothelin system genes
}

\author{
Paula B. Donate - Thiago M. Cunha - Waldiceu A. Verri Jr • Cristina M. Junta • \\ Flavia O. Lima - Silvio M. Vieira - Rafael S. Peres - Karina F. Bombonato-Prado • \\ Paulo Louzada Jr • Sergio H. Ferreira • Eduardo A. Donadi • Geraldo A. S. Passos • \\ Fernando Q. Cunha
}

Received: 5 September 2011/Revised: 23 October 2011/Accepted: 5 December 2011

(C) Springer Basel AG 2012

\begin{abstract}
Objective Endothelins (ETs) are involved in several inflammatory events. The present study investigated the efficacy of bosentan, a dual ETA/ETB receptor antagonist, in collagen-induced arthritis (CIA) in mice.

Treatment CIA was induced in DBA/1J mice. Arthritic mice were treated with bosentan $(100 \mathrm{mg} / \mathrm{kg})$ once a day, starting from the day when arthritis was clinically detectable. Methods CIA progression was assessed by measurements of visual clinical score, paw swelling and hypernociception. Histological changes, neutrophil infiltration and proinflammatory cytokines were evaluated in the joints. Gene expression in the lymph nodes of arthritic mice was evaluated by microarray technology. PreproET-1 mRNA
\end{abstract}

P. B. Donate and T. M. Cunha contributed equally to this study.

Responsible Editor: John Di Battista.

Electronic supplementary material The online version of this article (doi:10.1007/s00011-011-0415-5) contains supplementary material, which is available to authorized users.

P. B. Donate - T. M. Cunha - E. A. Donadi .

G. A. S. Passos - F. Q. Cunha

Post Graduation Program in Basic and Applied Immunology,

School of Medicine of Ribeirão Preto, University of São Paulo,

Avenue Bandeirantes, 3900, Ribeirão Preto,

São Paulo 14049-900, Brazil

T. M. Cunha · W. A. Verri Jr · F. O. Lima

S. M. Vieira · R. S. Peres · S. H. Ferreira · F. Q. Cunha $(\square)$

Department of Pharmacology, School of Medicine of Ribeirão

Preto, University of São Paulo, Avenue Bandeirantes, 3900,

Ribeirão Preto, São Paulo 14049-900, Brazil

e-mail: fdqcunha@fmrp.usp.br

W. A. Verri Jr

Department of Pathology, University of Londrina, Londrina,

Paraná 86051-990, Brazil expression in the lymph nodes of mice and in peripheral blood mononuclear cells (PBMCs) was evaluated by realtime PCR. The differences were evaluated by one-way ANOVA or Student's $t$ test.

Results Oral treatment with bosentan markedly ameliorated the clinical aspects of CIA (visual clinical score, paw swelling and hyperalgesia). Bosentan treatment also reduced joint damage, leukocyte infiltration and proinflammatory cytokine levels (IL-1 $\beta$, TNF $\alpha$ and IL-17) in the joint tissues. Changes in gene expression in the lymph nodes of arthritic mice returned to the levels of the control mice after bosentan treatment. PreproET mRNA expression increased in PBMCs from rheumatoid arthritis (RA) patients but returned to basal level in PBMCs from patients under anti-TNF therapy. In-vitro treatment of PBMCs with $\mathrm{TNF} \alpha$ upregulated ET system genes.

Conclusion These findings indicate that ET receptor antagonists, such as bosentan, might be useful in controlling RA. Moreover, it seems that ET mediation of arthritis is triggered by $\mathrm{TNF} \alpha$.

\section{M. Junta}

Department of Genetics, School of Medicine of Ribeirão Preto, University of São Paulo, Avenue Bandeirantes, 3900,

Ribeirão Preto, São Paulo 14049-900, Brazil

K. F. Bombonato-Prado · G. A. S. Passos

Department of Morphology, School of Dentistry,

University of São Paulo, Avenue Bandeirantes, 3900,

Ribeirão Preto, São Paulo 14049-900, Brazil

P. Louzada Jr · E. A. Donadi

Division of Clinical Immunology, School of Medicine

of Ribeirão Preto, University of São Paulo,

Avenue Bandeirantes, 3900, Ribeirão Preto,

São Paulo 14049-900, Brazil 
Keywords Rheumatoid arthritis .

Collagen-induced arthritis · Bosentan · Inflammation .

Microarray · Endothelins

$\begin{array}{ll}\text { Abbreviations } \\ \text { ET } & \text { Endothelin } \\ \text { RA } & \text { Rheumatoid arthritis } \\ \text { CIA } & \text { Collagen-induced arthritis } \\ \text { TNF } & \text { Tumor necrosis factor } \\ \text { IL } & \text { Interleukin } \\ \text { LT } & \text { Lymphotoxin } \\ \text { MTX } & \text { Methotrexate } \\ \text { CII } & \text { Collagen type 2 } \\ \text { CFA } & \text { Complete Freund's adjuvant } \\ \text { PBS } & \text { Phosphate-buffered saline } \\ \text { SAM } & \text { Significance analysis of microarrays } \\ \text { PBMCs } & \text { Peripheral blood mononuclear cells }\end{array}$

\section{Introduction}

Rheumatoid arthritis (RA) is a chronic inflammatory disorder of unknown cause. It is characterized by synovial leukocyte infiltration, pannus formation, degradation of cartilage and bone, and disabling pain [1,2]. Increased levels of tumor necrosis factor $\alpha$ (TNF- $\alpha$ ) and the interleukins IL- $1 \beta$ and IL-17 have been associated with variable degrees of bone and cartilage erosion, which causes a loss of function, disability, shortened life expectancy and considerable health care costs $[3,4]$.

Although no effective treatment is available, there have been major advances in the treatment of RA, including more aggressive use of disease-modifying antirheumatic drugs (DMARDs) and the development of immune therapies such as the anti-TNF agents [5, 6]. Despite these enormous advances, the large differences in patients' responses, incidences of remission, and costs of treatments promotes a continuous search for the development of new drugs.

Endothelins (ETs) are a family of naturally occurring peptides [7] with growth-promoting, vasoactive, and nociceptive properties, and they affect the function of a number of tissues and systems [8]. There are 3 known, 21-aminoacid-long ETs in humans (ET-1, ET-2, and ET-3) that are produced as preproET and then cleaved by ET-converting enzymes to form big-ET and the active peptide [9].

These peptides have overlapping tissue distributions and are synthesized by vascular endothelial and smooth muscle cells and neural, renal, pulmonary and immune cells, such as macrophages and leukocytes [10]. Additionally, these peptides seem to exert an important influence by autocrine and paracrine actions mediated through G-protein-coupled specific ETA and ETB receptors [11].
ETs have pathophysiological roles in pulmonary hypertension, arterial hypertension, atherosclerosis, cerebral vasospasm and inflammatory processes [9, 12], in which they stimulate the formation of cytokines, such as interleukins and TNF [13]. In this context, high levels of ET-1 are detected in the synovial fluid of RA, osteoarthritis (OA), and gout patients. Plasma levels of ET-1 in active RA exceed the values in nonactive RA. Moreover, ET-1-like immunoreactivity in synovial fluid was found to be at levels several times higher than those in plasma and was found to be secreted from macrophage-like synoviocytes [14-16]. ETs may also act locally; ET-1-binding sites are localized in the synovial blood vessels, modulating synovial perfusion and exacerbating hypoxia in chronic arthritis [17]. Moreover, ET-1 has been shown to increase the net metalloproteases/ tissue inhibitor of metalloproteases- 1 balance and increase collagen degradation [18]. Recently, the participation of ETs in the development of arthritis and arthritic pain was demonstrated using the antigen-induced monoarthritis (AIA) model, with methylated bovine serum albumin as the antigen [19]. Taking into account the evidence mentioned above, we addressed the efficacy of the dual ET receptor antagonist bosentan in the collagen-induced arthritis (CIA) model, which is the animal model that best resembles human RA. Bosentan is the prototype of the sentan-class drugs and was first approved by the US Food and Drug Administration (FDA) for human use in pulmonary arterial hypertension. We also evaluated the impact of this treatment on differential gene expression profiles of draining inguinal lymph nodes. The modulation of ET system gene (preproET, ETA and ETB) expression was evaluated in peripheral blood mononuclear cells (PBMCs) from healthy donors and RA patients, and the impact of anti-TNF- $\alpha$ therapy in this process was evaluated.

\section{Materials and methods}

Animals

Male DBA/1J mice (12 weeks old; $18-22 \mathrm{~g}$ ) were housed in temperature-controlled rooms $\left(22-25^{\circ} \mathrm{C}\right)$ in the animal facility of the School of Medicine of Ribeirão Preto, University of São Paulo, São Paulo, Brazil, and received water and food ad libitum. The experimental protocols were approved by the local Ethical Committee on Animal Experimentation of the School of Medicine of Ribeirão Preto, University of São Paulo, São Paulo, Brazil (n244/2005).

Induction and assessment of CIA

Male DBA/1J mice received $200 \mu \mathrm{g}$ bovine type II collagen (CII; Sigma) in complete Freund's adjuvant (CFA) by 
intradermal injection into the tail (day 0). CII [200 $\mu \mathrm{g}$ in phosphate-buffered saline (PBS)] was given again on day 21 by intraperitoneal injection [20]. Mice were monitored daily for signs of arthritis, for which severity scores were derived as follows: $0=$ normal, $1=$ erythema, $2=$ erythema plus swelling, $3=$ extension/loss function, and total score $=$ sum of four limbs. Disease onset characterized by erythema and/or paw swelling was observed between days 25 and 35. The experimental control group corresponds to the sham-immunized mice that received the same amount of CFA injection but without the administration of type II collagen. For the therapeutic approach, DBA/1J mice were treated with bosentan (Actelion Pharmaceuticals, Allschwil, Switzerland) (100 $\left.\mathrm{mg} \mathrm{kg}^{-1}\right)$ p.o. [21-23] once a day for a total of 11 days. The treatment began on the day that CIA was clinically detectable; thus, only mice that developed CIA were treated.

Measurement of mechanical hyperalgesia: electronic von Frey

The term hyperalgesia was used to define the decrease of nociceptive withdrawal threshold [24]. Mechanical hyperalgesia was tested in mice as previously reported [25]. The test consisted of evoking the hindpaw flexion reflex with a hand-held force transducer (electronic anesthesiometer; IITC Life Science, Woodland Hills, CA, USA) adapted with a $0.5-\mathrm{mm}^{2}$ polypropylene tip. The investigator was trained to apply the tip perpendicular to the central area of the hindpaw with a gradual increase in pressure. The endpoint was characterized by removal of the paw followed by clear flinching movements. After paw withdrawal, the intensity of pressure was automatically recorded. The value for the response was obtained by averaging three measurements. The results are expressed by delta $(\Delta)$ withdrawal threshold (in g) calculated by subtracting zero-time mean measurements from time interval mean measurements.

\section{Histological examination}

For histological assessment, CIA mice treated with vehicle or bosentan were killed at the end of the experiments (11 days after CIA was clinically detected), and the paw joints were removed, fixed in 4\% PFA buffer, and decalcified in EDTA. Sections (4 mm) were stained with H\&E. The joint pathology was examined and scored. Scores are based on exudates, granulocyte infiltration, hyperplasia, mononuclear cell infiltration, periarticular mononuclear and granulocyte cell infiltration (each scoring 0-3), bone and cartilage destruction (scoring 0-4) and an additional score of 1 for fibrin deposition, resulting in a maximum possible score of 20 . The sections were scanned with a Leica DM 4000B microscope, and the pictures were analyzed at a magnification of $500 \mu \mathrm{m}$ with Leica LAS (Leica Application Suite) software.

\section{Cytokine measurements}

Eleven days after CIA was clinically detected, animals were killed by $\mathrm{CO}_{2}$ inhalation, and the surrounding joint tissue was removed and homogenized in $300 \mu \mathrm{L}$ buffer containing protease inhibitors. IL-17, TNF- $\alpha$ and IL- $1 \beta$ levels were determined as described previously [26] by ELISA using paired antibodies (R\&D Systems). The results are expressed as pg/joint for each cytokine. As a control, the concentration of each cytokine was determined in sham-immunized mice.

\section{Myeloperoxidase activity assay}

Neutrophil accumulation in the surrounding joint tissue of mice was evaluated by assaying myeloperoxidase (MPO) activity. Eleven days after CIA was clinically detected, animals were killed by $\mathrm{CO}_{2}$ inhalation, and the surrounding joint tissue was removed and homogenized with a tissue homogenizer (Power Gen 125, Fischer Scientific) in $0.2 \mathrm{~mL}$ pH 4.7 buffer $\left(0.1 \mathrm{M} \mathrm{NaCl}, 0.02 \mathrm{M} \mathrm{NaPO}_{4}\right.$, $0.015 \mathrm{M}$ Na-EDTA). The suspensions were centrifuged at $3,000 \mathrm{~g}$ for $15 \mathrm{~min}$, the pellet was resuspended in lysis buffer $(0.2 \% \mathrm{NaCl})$ and was further centrifuged for $15 \mathrm{~min}$. The pellet cells were resuspended and homogenized in $0.5 \mathrm{~mL} \mathrm{H}$-TAB buffer $\left(0.05 \mathrm{M} \mathrm{NaPO}_{4}\right.$ buffer ( $\mathrm{pH} 5.4$ ) containing $0.5 \%$ dexadecyltrimethylammonium bromide) and centrifuged at $10,000 \mathrm{~g}$ for $15 \mathrm{~min}$, and the supernatants were used for determination of MPO activity. MPO activity in the resuspended pellet was assayed by measuring the change in absorbance at $450 \mathrm{~nm}$ using $o$-dianisidine dihydrochloride and $1 \%$ hydrogen peroxide. The results are reported as MPO units/mg of tissue. A unit of MPO activity was defined as that required to convert $1 \mu \mathrm{mol}$ hydrogen peroxide to water in $1 \mathrm{~min}$ at $22^{\circ} \mathrm{C}$.

\section{Total RNA preparation}

The DBA/1J mice were killed by $\mathrm{CO}_{2}$ inhalation, and the lymph nodes were surgically removed. To obtain sufficient mRNA for hybridization to the glass slides and the realtime PCR experiments, total inguinal lymph node RNA was pooled at each time point $(n=3$ mice). Total RNA samples were prepared using Trizol ${ }^{\circledR}$ reagent according to the manufacturer's instructions (Invitrogen, Carlsbad, CA, USA). For microarray and real-time PCR experiments, we used only undegraded and DNA-, protein- and phenol-free RNA preparations as evaluated by conventional agarose gel electrophoresis stained with ethidium bromide and ultraviolet spectrophotometry, respectively. 
Human samples

Healthy donors and RA patients, from the Clinical Hospital of Ribeirão Preto-USP-SP, with active disease under treatment with methotrexate (MTX) or MTX plus anti-TNF (infliximab) were recruited, and they provided written informed consent. Peripheral blood samples from seven healthy volunteers and 14 RA patients were collected. All 14 RA patients recruited fulfilled the 1987 revised criteria of the American College of Rheumatology for the diagnosis of RA [27]. Seven of the patients were under treatment with methotrexate (MTX) alone, and seven of the patients were under treatment with MTX plus anti-TNF (infliximab) (clinical information is presented in Table 1). According to the Disease Activity Score 28 (DAS28, [28]), patients treated with MTX plus anti-TNF therapy exhibited lower levels of DAS28 (mean = 3.5) than those treated with MTX alone (DAS28: mean =5.6). RA patients that received anti-TNF therapy presented a reduction of at least 1.6 in their DAS28 score, indicating the beneficial effect of anti-TNF therapy. The healthy donors did not present any clinical signs of disease upon anamnesis or clinical investigation.

For cell culture and RNA extraction, the PBMCs were separated on a Ficoll-Paque PLUS density gradient (GE Healthcare Life Sciences). For in-vitro experiments, $1 \times 10^{6}$ PBMCs from six healthy donors and RA patients were cultured in $10 \%$ fetal bovine serum-supplemented RPMI 1640 medium at $37^{\circ} \mathrm{C}$ in a $5 \% \mathrm{CO}_{2}$ atmosphere in 96-well plates. PBMCs were incubated with $100 \mathrm{ng} / \mathrm{mL}$ TNF- $\alpha$ for $2 \mathrm{~h}$. After stimulation, total mRNA was extracted from PBMCs using Trizol ${ }^{\circledR}$ reagent following the manufacturer's instructions. The integrity of the total RNA samples was evaluated by denaturing agarose gel electrophoresis under standard conditions. The study was approved by the Human Ethics Committee of the Faculty of Medicine of Ribeirao Preto.
Gene expression analysis using microarrays

Gene expression in the lymph nodes was assessed using glass slide microarrays prepared on silane-coated UltraGAPS slides (\#40015, Corning, New York, NY, USA). The arrays contained a total of 4,500 cDNA sequences that represented most murine tissues and organs. Sequences were obtained from the Soares thymus 2NbMT normalized library, which represents expressed sequence tag (EST) cDNA clones prepared from the thymus of a C57BL/6J 4-week-old male mouse, and is available at the IMAGE Consortium (http://image.hudsonalpha.org/).

The microarrays were prepared based on published protocols with PCR products from the cDNA clones [29] using a Generation III Array Spotter (Amersham Molecular Dynamics, Sunnyvale, CA, USA). A complete file that provides all of the genes and ESTs present on the microarrays used in this study is available on the MIAME database under accession code E-MEXP-2404 (http://www. ebi.ac.uk/microarray-as/ae/).

\section{Complex cDNA probe preparation and hybridization}

The cDNA complex probes derived from the total RNA obtained from the lymph nodes were prepared by reverse transcription using $10 \mu \mathrm{g}$ of total RNA. The cDNA samples were monocolor labeled with $\mathrm{Cy} 3$ fluorochrome using the CyScribe post-labeling kit (GE Healthcare Life Sciences). Samples were hybridized for $15 \mathrm{~h}$ and then washed with an automatic slide processor system (ASP, Amersham Biosciences). Microarrays were scanned using a Generation III laser scanner (Amersham Biosciences).

As a reference for the hybridization procedure, we used equimolar quantities of cDNAs obtained from unrelated total RNA (mouse thymus total RNA). This approach allowed us to estimate the amount of target cDNA on each microarray spot.
Table 1 Clinical and demographic features of healthy donors and RA patients treated with MTX or MTX + anti-TNF (infliximab)

$R F$ rheumatoid factor, Anti$C C P$ anti-cyclic citrullinated peptide antibodies, MTX methotrexate, DAS Disease Activity Score

\begin{tabular}{llll}
\hline Clinical features & $\begin{array}{l}\text { MTX only } \\
(n=7)\end{array}$ & $\begin{array}{l}\text { MTX + infliximab } \\
(n=7)\end{array}$ & $\begin{array}{l}\text { Healthy donors } \\
(n=7)\end{array}$ \\
\hline Mean age (years) & $53.8 \pm 4.6$ & $47.2 \pm 4.9$ & $31.9 \pm 2.7$ \\
Women $n,(\%)$ & $5(71.4 \%)$ & $6(85.7 \%)$ & $4(57.1 \%)$ \\
Caucasian $n,(\%)$ & $7(100 \%)$ & $7(100 \%)$ & $7(100 \%)$ \\
RF-positive $n,(\%)$ & $6(85.7 \%)$ & $6(85.7 \%)$ & $0(100 \%)$ \\
Anti-CCP positive $n,(\%)$ & $4(57.1 \%)$ & $5(71.4 \%)$ & $0(100 \%)$ \\
Mean disease duration (years) & $3.5 \pm 1.4$ & $8.2 \pm 2.4$ & None \\
MTX dose (mg/week) & 11.2 & 15 & None \\
MTX (months use, mean) & $13 \pm 1.9$ & $22.6 \pm 1.3$ & None \\
Infliximab dose (mg/kg/dose) & None & 4 & None \\
Infliximab use $(>6$ months) $n,(\%)$ & None & $7(100 \%)$ & None \\
DAS28 (mean \pm SEM) & $5.6 \pm 0.3$ & $3.5 \pm 0.5$ & None \\
\hline
\end{tabular}




\section{Microarray data analysis}

Microarray images were quantified using Spotfinder software (http://www.tm4.org/spotfinder.html) and normalized using the R platform (http://www.r-project.org). Statistical analyses were performed using $\mathrm{MeV}$ software, version 3.1 (http://www.tm4.org/mev.html). Differentially expressed genes were identified using the significance analysis of microarrays (SAM) program [30], considering only those genes with an FDR (false discovery rate) $\leq 0.05$.

To analyze the gene expression profiles from the SAM program data set, we used a hierarchical clustering method that grouped genes on the vertical axis and samples on the horizontal axis using similarity in their expression patterns. The similarities and dissimilarities in gene expression were presented as dendrograms, in which the pattern and length of the branches reflected the relatedness of the samples or genes, and as heat maps (http://rana.lbl.gov/Eisen Software.htm) [31].

\section{Real-time PCR}

Real-time PCR was performed using a 7500 Real Time PCR system (Applied Biosystems). The cDNA was synthesized by oligo(dT) priming starting from $2.0 \mu \mathrm{g}$ of lymph node total RNA as previously described, amplified using specific primers, and normalized to the amount of the housekeeping gene glyceraldehyde-3-phosphate dehydrogenase (Gapdh, ID: 008084). Reactions were performed in a final volume of $20 \mu \mathrm{L}$ containing 10 pmol of each primer, $1 \times$ SYBR Green (Applied Biosystems) and $1 \mu \mathrm{L}$ of first-strand cDNA. The specificity of the PCR products was assessed by melting curve analysis for all samples, and the products were also verified for correct size by agarose gel electrophoresis. Each sample was assayed in triplicate, and the mean $C_{\mathrm{t}}$ values were transformed into relative Amjhelike transcript quantities using the comparative $C_{\mathrm{t}}$ method (Applied Biosystems, user bulletin \#2). The primers were identified using PRIMER3 software (http://frodo.wi.mit. edu/cgibin/primer3/primer3_www.cgi) and the cDNA sequences retrieved from GenBank (http://www.ncbi. nlm.nih.gov) for each gene. The following primers were used for mice: Gapdh, ID: 008084.2, sense 5'-GGGTGTG AACCACGAGAAAT- $3^{\prime}$, antisense 5'-CCTTCCACA ATGCCAAAGTT-3'; preproET-1, ID: 010104.2, sense 5'TGTGTCTACTTCTGCCACCT-3', antisense 5'-CACCA GCTGCTGATAGATAC-3'; Mapk1, ID: 011949.3, sense 5'-CTTCCAACCTCCTGCTGAAC-3', antisense 5'-TGG AGCTCTGTACCAACGTG-3'; Ccr5, ID: 009917.3, sense $5^{\prime}$-TTCCGAAAACACATGGTCAA- ${ }^{\prime}$, antisense $5^{\prime}$-GTT CTCCTGTGGATCGGGTA-3'; Ccr2, ID: 009915.1, sense $5^{\prime}$-ACTGGATGAAGCAGGGACAG- $3^{\prime}$, antisense $5^{\prime}$-CCA AAAATAAGGCGTTGGAA-3'; and Ltb, ID: 008518.1, sense $5^{\prime}$-TATCACTGTCCTGGCTGTGC- ${ }^{\prime}$, antisense $5^{\prime}$ TAGAGGGTGAGGGCAAGATG- $3^{\prime}$. Human primers were as follows: GAPDH, ID: 002046.3, sense 5'-CTGCACC ACCAACTGCTTA- ${ }^{\prime}$, antisense $5^{\prime}$-CATGACGGCAGG TCAGGTC-3'; PREPRO ET, ID: 001955.3, sense 5'-TCG TTTTCCTTTGGGTTCAG-3', antisense $5^{\prime}$-CTGTTTCT GGAGCTCCTTGG-3'; PRO-IL-1 $\beta$, ID: 000002.11 sense $5^{\prime}$-GCAATGAGGATGACTTGTTTTG- $3^{\prime}$, antisense $5^{\prime}$-CA GAGGTCCAGGTCCTGGAA-3'; ETA，ID: 000004.11 sense $5^{\prime}$-CTGTGCTGGAGCAAAAGTCA-3', antisense 5'-AGCAATCTGTCTGGCGAAGT-3'; and ETB, ID: 000013.10 sense 5'-TCATCGGGAACTCCACACTT-3', antisense $5^{\prime}$-GGATGTCAATGACGATGTGC-3'.

\section{Statistical analysis for real-time PCR and hyperalgesia}

The results are presented as means \pm SEM. The differences were evaluated by one-way ANOVA followed by Bonferroni's $t$ test (three or more groups) or Student's $t$ test (two groups). $P<0.05, P<0.01$, and $P<0.001$ were considered statistically significant.

\section{Results}

Effects of bosentan treatment on collagen-induced arthritis

The increasing evidence of the role of ETs in the inflammatory process prompted us to evaluate the impact of bosentan treatment in a well-established model of arthritis, CIA. DBA/1J mice were immunized with type II collagen and therapeutically treated with bosentan for 11 days starting on the day that arthritis was clinically detectable. Oral treatment with bosentan ameliorated arthritis as determined by a reduction in the clinical score, the number of affected paws, and mechanical hyperalgesia observed during the course of the disease (Fig. 1a-c). A representative image of paws of vehicle- and bosentan-treated mice is shown in Fig. 1d. Infiltration of granulocytes and mononuclear cells into the inflamed joint and bone and cartilage destruction were lower in mice treated with bosentan than in the CIA vehicle-treated group (Fig. 2a). Bosentan-treated mice also presented significantly lower histological scores for inflammation and tissue destruction than the CIA vehicle-treated group (Fig. 2b; Table 2).

The reduction in the disease scores in bosentan-treated mice was also associated with a reduction in joint tissue levels of the pro-inflammatory cytokines IL- $1 \beta$, TNF- $\alpha$, and IL-17 (Fig. 3a-c). Bosentan-treated mice also presented a reduction in neutrophil accumulation in joint tissues compared with the CIA vehicle-treated group (Fig. 3d). 

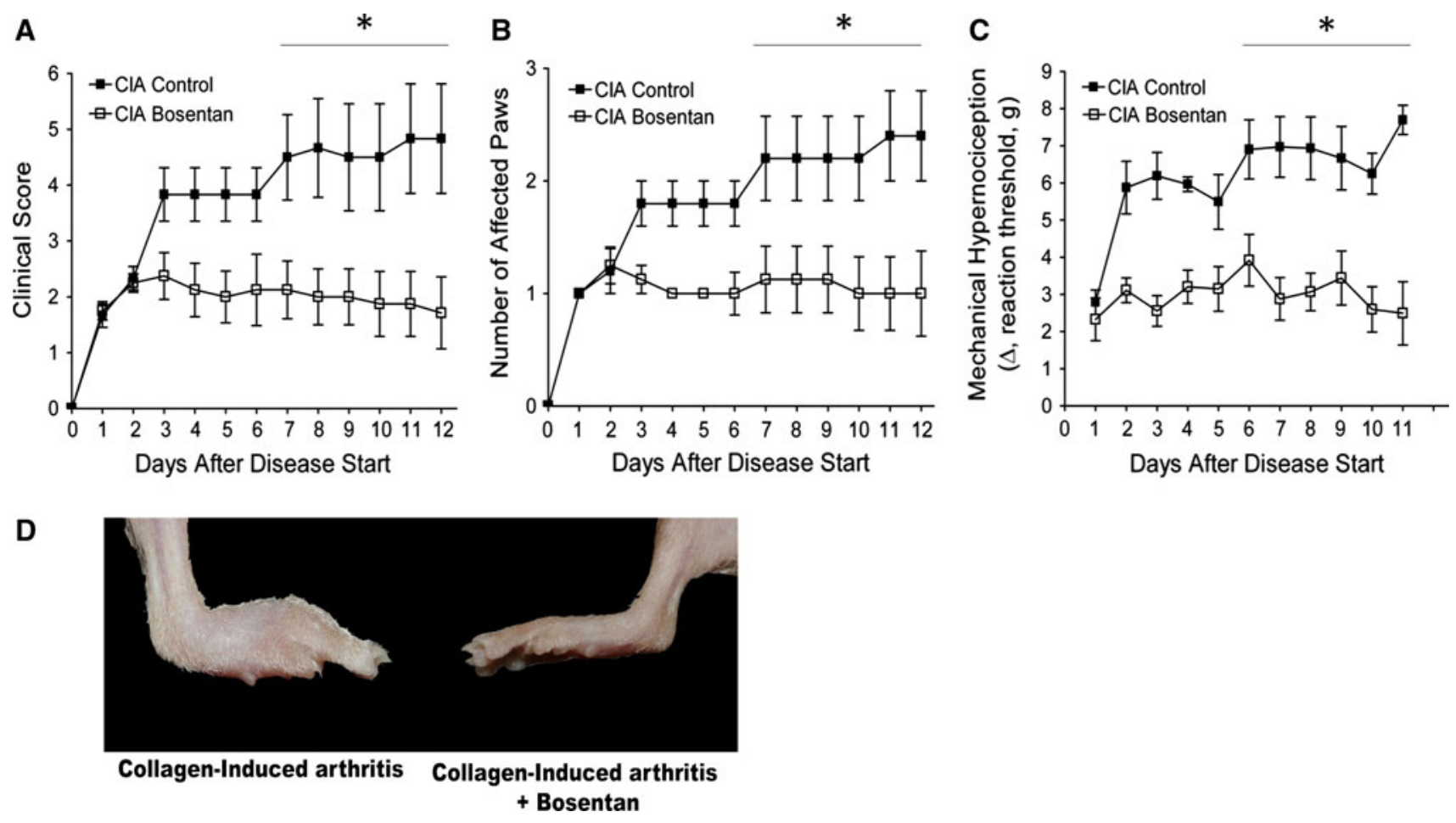

Fig. 1 Bosentan (dual antagonist of ETA/ETB receptors) treatment ameliorates collagen-induced arthritis (CIA) in mice. DBA/1J mice were immunized with collagen, and the appearance of arthritis was monitored daily. Treatment with bosentan $\left(100 \mathrm{mg} \mathrm{kg}^{-1}\right.$ once a day) was started 1 day after CIA was clinically significant and lasted for a total of 11 days. The clinical score (a), number of affected paws

PreproET mRNA expression increase in lymph nodes of arthritic mice

ETs are produced as preproET, which is cleaved by ETconverting enzymes to form big-ET and the active peptide [9]. Therefore, we next analyzed the levels of the ET precursor preproET-1 by quantitative PCR in the inguinal lymph nodes of sham and immunized mice. As shown in Fig. 4, the levels of preproET-1 were higher in the lymph nodes of arthritic mice than in those of sham mice.

Bosentan treatment modulates gene expression in the lymph nodes

To elucidate the possible molecular mechanism associated with bosentan's action and consequently the role of ETs in the CIA model, microarray technology was used to identify significant changes in gene expression during the treatment. The inguinal lymph node mRNA expression of sham and immunized mice was initially compared, and then we compared immunized mice before and after treatment with bosentan.

Although the expression pattern remained unchanged among the groups for a majority of the 4,500 sequences

(b) and hyperalgesia (c) were evaluated daily. (d) Representative pictures of mice paws showing the visual aspect of CIA development in vehicle- or bosentan-treated groups. The data are from one experiment with eight mice per group (error bars, SEM). ${ }^{*} P<0.05$ compared with the CIA control group (Student's $t$ test)

tested [presented $d(i) \approx d_{E}(i)$ ], 508 genes were differentially expressed between sham and immunized mice, whereas 127 genes were found to be significantly modulated between immunized and bosentan-treated mice. With these data, clusters of repressed and induced genes were identified.

The Cluster-Tree View program was used to acquire hierarchical cluster analysis of results from the SAM program, and a comparison of the hybridization signatures showed variability among the three experimental groups. Based on heat map analysis, it was possible to distinguish the expression signature of the disease state and the treatment (Online Resource 1,2). Genes that were differentially expressed in both heat maps were selected for further analysis according to their major biological processes. The genes were related to cell communication, cell cycle, cell death, response to stress and catabolic processes, among others. The genes involved with immune response are of particular importance, and a more careful analysis allowed a selection of those genes related to inflammatory processes, aside from being strictly related to CIA/RA. Among the genes analyzed, we found a group of important genes that exhibited an expression profile of particular interest. The Mapk1 (Mitogen-activated protein kinase 1), Ccr2 
Fig. 2 Effect of bosentan treatment on the histopathological manifestation of CIA in mice. CIA mice were treated with vehicle or bosentan (100 $\mathrm{mg} \mathrm{kg}^{-1}$ once a day) for 11 days, and treatment started 1 day after CIA was clinically detectable. After treatment, tibio-tarsal joints were removed and processed followed by (a) hematoxylin and eosin staining of joint sections. (b) Histological scores are based on HE section analyses. Each symbol represents one paw. The data are from one experiment with six mice per group (error bars, SEM). $* * P<0.01$ compared with the CIA group treated with vehicle (Student's $t$ test)
A
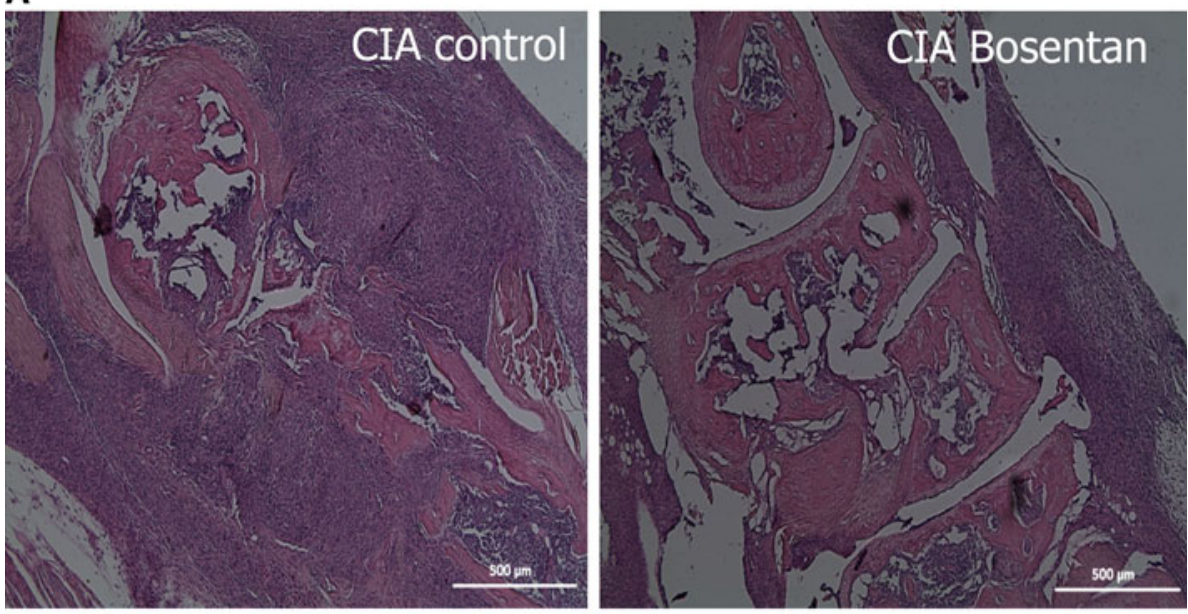

B

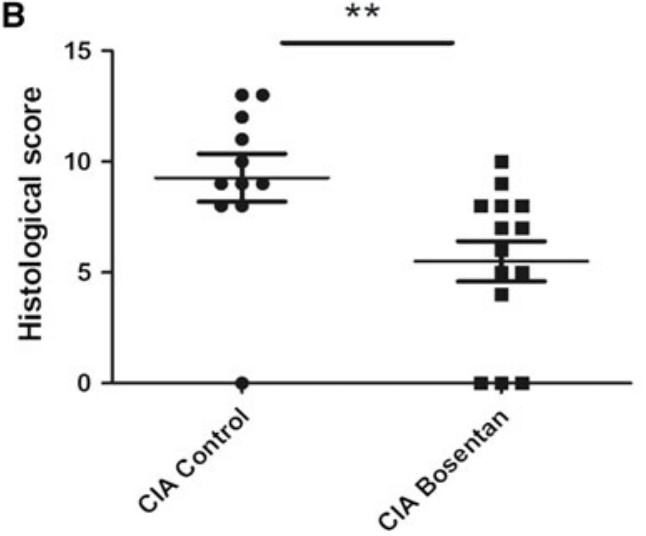

(Chemokine (C-C motif) receptor 2), Ccr5 (Chemokine $(C-C$ motif) receptor 5$)$ and Ltb (Lymphotoxin B) genes are involved in the arthritis process and are highly expressed during CIA development. On the other hand, during treatment with bosentan, their expressions were similar to control levels.

Real-time PCR confirmed the microarray data, showing increased transcription levels during disease in immunized mice and lower expression during bosentan treatment, with levels similar to control values (Fig. 5a-d).

\section{PreproET mRNA is increased in RA-patient-derived PBMCs}

The level of the ET precursor preproET was elevated in PBMCs from patients under treatment with MTX compared to healthy donors (Fig. 6a). On the other hand, PBMCs from patients receiving infliximab showed similar levels of preproET-1 compared with healthy donors (Fig. 6a). These results suggest that TNF- $\alpha$ could be involved in the upregulation of the ET system during RA. In an attempt to investigate this hypothesis, we performed in-vitro experiments using PBMCs from healthy donors and RA patients. PBMCs were cultured with TNF- $\alpha$ $(100 \mathrm{ng} / \mathrm{ml})$ for $2 \mathrm{~h}$, followed by mRNA extraction. mRNA expression of preproET and ETA and ETB receptors increased in PBMCs from healthy donors and RA patients after TNF- $\alpha$ (Fig. 6b). However, this effect was more prominent in cells isolated from the RA patients (Fig. 6b). Interestingly, TNF- $\alpha$ also upregulated IL- $1 \beta$ mRNA expression in PBMCs from RA patients, but its expression was no different from cells from healthy donors.

\section{Discussion}

The pro-inflammatory properties of ETs were described immediately after their discovery, and they explain why these peptides contribute to the progression of a wide range of diseases that present inflammatory components, such as lupus erythematosus, systemic sclerosis and scleroderma $[32,33]$. Our group and others have shown that ETs might participate in the pathophysiology of RA [14-17, 19]. Here, we extended these studies showing that bosentan, which is a dual ET receptor antagonist and was recently approved by the FDA for human use, ameliorated the 
Table 2 Histological scores for collagen-induced arthritis (CIA)

\begin{tabular}{|c|c|c|c|c|c|c|c|c|}
\hline \# & Exudate & $\begin{array}{l}\text { Granulocyte } \\
\text { infiltration }\end{array}$ & Hyperplasia & $\begin{array}{l}\text { Mononuclear } \\
\text { infiltration }\end{array}$ & $\begin{array}{l}\text { Periarticular } \\
\text { mononuclear and } \\
\text { granulocyte } \\
\text { infiltration }\end{array}$ & $\begin{array}{l}\text { Bone and cartilage } \\
\text { destruction }\end{array}$ & $\begin{array}{l}\text { Visible fibrin } \\
\text { deposition }\end{array}$ & $\begin{array}{l}\text { Total } \\
\text { score }\end{array}$ \\
\hline CIA \#1 & 2 & 2 & 0 & 1 & 1 & 1 & 1 & 8 \\
\hline CIA \#2 & 1 & 2 & 0 & 1 & 2 & 2 & 1 & 9 \\
\hline CIA \#3 & 1 & 2 & 1 & 2 & 2 & 3 & 1 & 13 \\
\hline CIA \#4 & 3 & 2 & 0 & 2 & 1 & 3 & 1 & 12 \\
\hline CIA \#5 & 1 & 2 & 0 & 2 & 1 & 1 & 1 & 8 \\
\hline CIA \#6 & 1 & 3 & 0 & 2 & 2 & 1 & 1 & 10 \\
\hline CIA \#7 & 0 & 2 & 0 & 2 & 2 & 2 & 1 & 9 \\
\hline CIA \#8 & 2 & 3 & 0 & 3 & 2 & 2 & 1 & 13 \\
\hline CIA \#9 & 1 & 3 & 0 & 3 & 2 & 1 & 1 & 11 \\
\hline CIA \#10 & 1 & 2 & 0 & 2 & 2 & 1 & 1 & 9 \\
\hline CIA \#11 & 0 & 0 & 0 & 0 & 0 & 0 & 0 & 0 \\
\hline CIA \#12 & 0 & 0 & 0 & 0 & 0 & 0 & 0 & 0 \\
\hline Mean \pm SD & $1.08 \pm 0.90$ & $1.9 \pm 0.99$ & $0.08 \pm 0.28$ & $1.66 \pm 0.98$ & $1.41 \pm 0.79$ & $1.41 \pm 0.99$ & $0.83 \pm 0.38$ & $8.5 \pm 4.3$ \\
\hline Bosentan \#1 & 1 & 2 & 0 & 2 & 2 & 1 & 0 & 8 \\
\hline Bosentan \#2 & 0 & 0 & 0 & 0 & 0 & 0 & 0 & 0 \\
\hline Bosentan \#3 & 0 & 0 & 0 & 0 & 0 & 0 & 0 & 0 \\
\hline Bosentan \#4 & 1 & 2 & 0 & 2 & 0 & 1 & 1 & 7 \\
\hline Bosentan \#5 & 1 & 1 & 0 & 1 & 1 & 0 & 0 & 4 \\
\hline Bosentan \#6 & 1 & 2 & 0 & 2 & 2 & 1 & 0 & 8 \\
\hline Bosentan \#7 & 1 & 2 & 0 & 2 & 2 & 2 & 1 & 10 \\
\hline Bosentan \#8 & 0 & 0 & 0 & 0 & 0 & 0 & 0 & 0 \\
\hline Bosentan \#9 & 1 & 1 & 0 & 1 & 1 & 1 & 1 & 6 \\
\hline Bosentan \#10 & 1 & 1 & 0 & 1 & 1 & 1 & 0 & 5 \\
\hline Bosentan \#11 & 1 & 1 & 0 & 1 & 1 & 1 & 0 & 5 \\
\hline Bosentan \#12 & 1 & 1 & 0 & 1 & 2 & 1 & 1 & 7 \\
\hline Mean \pm SD & $0.75 \pm 0.45$ & $1.08 \pm 0.79$ & 0 & $1.08 \pm 0.79$ & $1.0 \pm 0.85$ & $0.75 \pm 0.62$ & $0.33 \pm 0.49$ & $5.0 \pm 3.4$ \\
\hline
\end{tabular}

clinical and pathological inflammatory signals of CIA. Moreover, the bosentan treatment also prevented CIAinduced changes in the expression of important genes that encode key inflammatory mediators in the lymph nodes. In addition, the expression of ET precursor, preproET-1, was enhanced in the lymph nodes of CIA mice. From a clinical perspective, we also observed that the levels of ET precursors were elevated in PBMCs from RA patients who had undergone conventional treatment and were reduced by treatment with anti-TNF therapy. In vitro, TNF- $\alpha$ was able to enhance gene expression of the ET system (preproET-1, ETA and ETB) in PBMCs from RA patients compared with healthy donors.

Since their discovery, it has been clear that ETs are not merely vasoconstrictors but multifunctional peptides with cytokine-like activity, and they interfere with almost all aspects of cell function. Clinical studies have found elevated levels of ET-1 in synovial fluid and plasma of RA patients [14-16]. The strong association between these peptides and inflammation led us to investigate the efficacy of bosentan in CIA, which is a well-established experimental model for RA. CIA is characterized by acute and chronic inflammation of the joints and resembles most features of human RA, such as swelling, cartilage degradation, pain and loss of joint function [34]. Bosentan-treated mice presented a reduction in the following inflammatory parameters: edema, pain, joint movement, granulocyte and mononuclear cell infiltration into the joint tissue, bone and cartilage destruction, the production of pro-inflammatory cytokines and neutrophil migration. These results are in accordance with previous results that demonstrated that ET-1 mediates inflammatory events of zymosan-induced articular inflammation, including edema and neutrophil infiltration [35]. Moreover, ETs seem to be involved in pain in antigen-induced arthritis in mice [22, 36].

RA is a complex disease that results from an uncontrolled attack of the adaptive and innate immune system on joint structures. Although tissue and cells obtained from the 
Fig. 3 Effect of bosentan treatment on the levels of proinflammatory cytokines in joint tissues of arthritic mice. CIA mice were treated with vehicle or bosentan $\left(100 \mathrm{mg} \mathrm{kg}^{-1}\right.$ once a day) for 11 days. After the treatment period, the mice were killed, the surrounding tissue of the tibio-tarsal joint was removed and the concentrations of IL- $1 \beta(\mathbf{a})$, TNF- $\alpha(\mathbf{b})$, and IL-17 (c) and MPO activity (d) were determined. The levels of these cytokines and MPO activity in samples from shamimmunized mice were used as a control. The results are presented as mean \pm SEM from one experiment with six mice per group. ${ }^{*} P<0.05$ compared with CIA group treated with vehicle (Student's $t$ test)
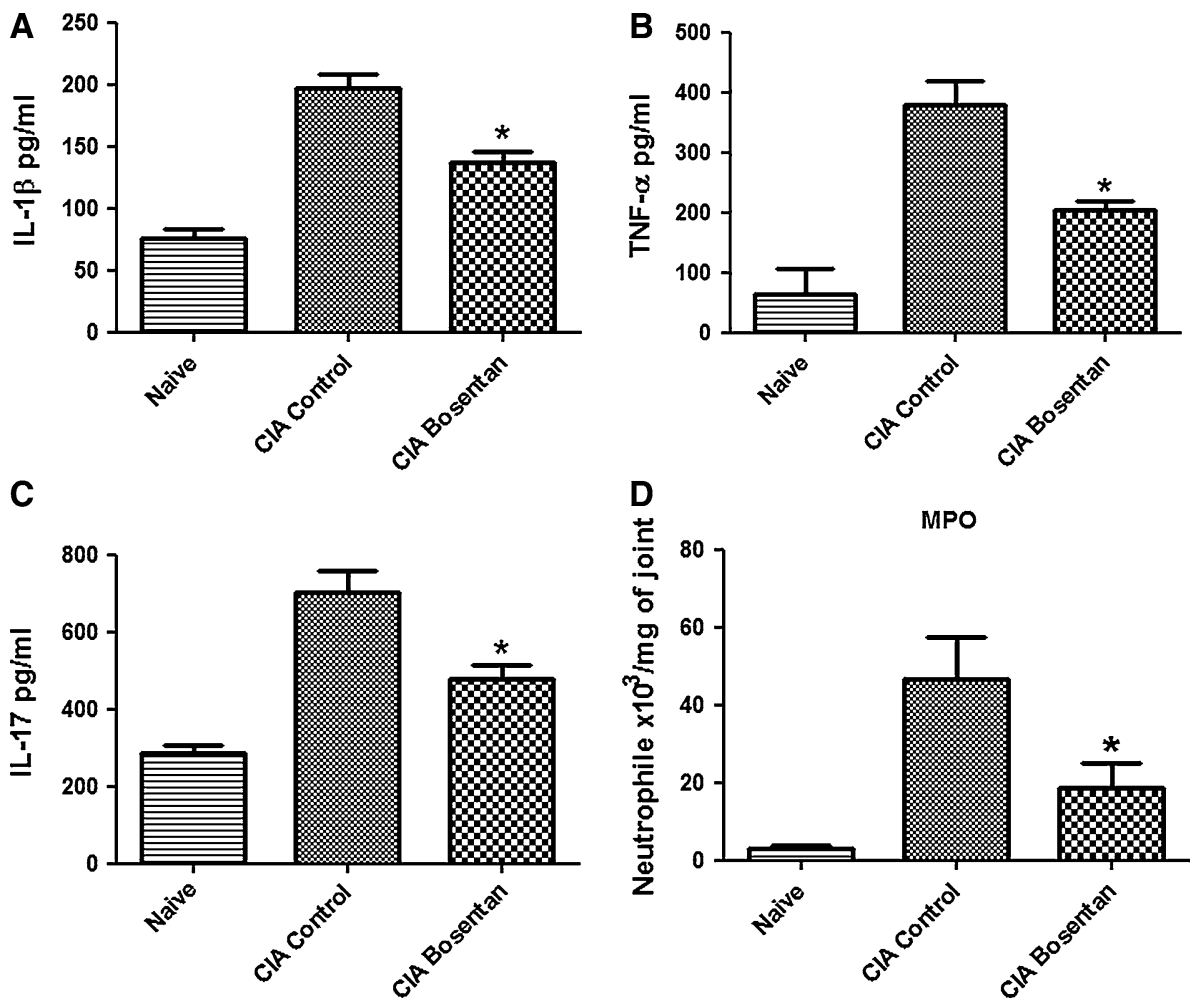

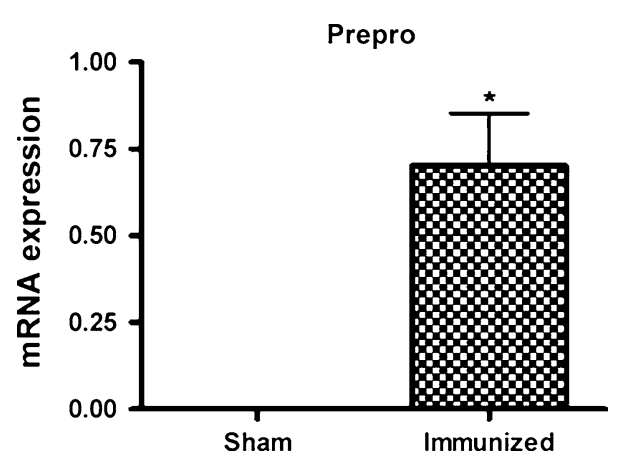

Fig. 4 PreproET mRNA expression in lymph nodes during CIA. Real-time PCR was used to compare the mRNA levels of preproET genes in inguinal lymph nodes of sham and immunized mice during CIA. Lymph nodes were removed 11 days after CIA was clinically detected. The expression levels were normalized to Gapdh expression. The results are presented as mean \pm SEM from one experiment with eight mice per group. ${ }^{*} P<0.05$ compared with sham-immunized mice

inflamed joint might more accurately reflect the ongoing pathogenetic features of chronic diseases, lymph nodes and circulating immune cells are used to identify novel disease mediators, treatment responses and genetic disease variants $[37,38]$. The use of large-scale analyses of gene expression patterns is increasing in many fields, including rheumatology. Array-based approaches allow the analysis of thousands of genes in a single experiment [39] and have been of special interest in the genetic study of heterogeneous autoimmune diseases such as RA. Therefore, in an attempt to elucidate the possible molecular mechanisms behind the role of ETs in CIA, the microarray technique was used to discover differences in lymph node gene profiles during CIA and bosentan treatment. Gene expression in the lymph nodes of arthritic mice was analyzed 11 days after bosentan treatment started because it was the time point when the effect of bosentan was most prominent. In our study, 4,500 sequences were analyzed by the SAM algorithm. A statistically significant set of 508 genes was found between sham and immunized mice, and a set of 127 genes was found between immunized mice treated with vehicle and those treated with bosentan. Moreover, a hierarchical cluster analysis of the results from SAM using the Cluster-Tree View program showed that the three experimental groups analyzed (sham, CIA vehicle- or bosentan-treated) had distinct profiles.

There were four main genes involved in the immune response whose expressions were increased during CIA and repressed by bosentan treatment. One gene was Mitogen-activated protein kinase 1 (Mapk1), a signaling molecule that regulates the production of cytokines and cytotoxic enzymes that have been implicated in RA pathogenesis. In agreement with our results, Mapk1 is induced through ETA and ETB receptors, and it mediates important peripheral functions of ETs, including DNA synthesis, mitogenesis, and the activation of vascular smooth muscle [40, 41]. Chemokine (C-C motif) receptor 2 (Ccr2) and chemokine $(\mathrm{C}-\mathrm{C}$ motif) receptor 5 (Ccr5), which along 

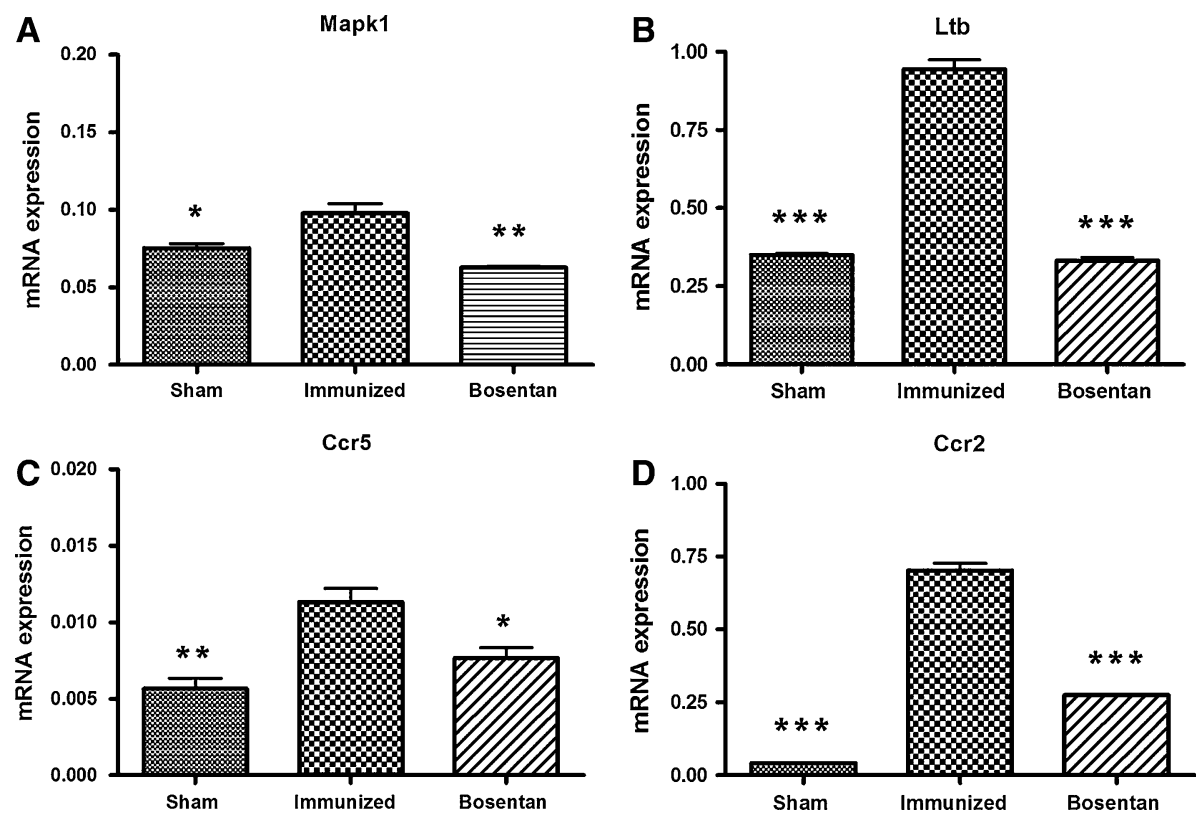

Fig. 5 Confirmation of repressed gene expression in lymph nodes during bosentan treatment in CIA. Real-time PCR was used to confirm the mRNA levels of Mapk1 (a), Ltb (b), Ccr5 (c) and Ccr2 (d) in inguinal lymph nodes from sham, immunized and bosentantreated DBA/1J mice. Lymph nodes were removed 11 days after CIA was clinically detected. Expression levels were normalized to Gapdh

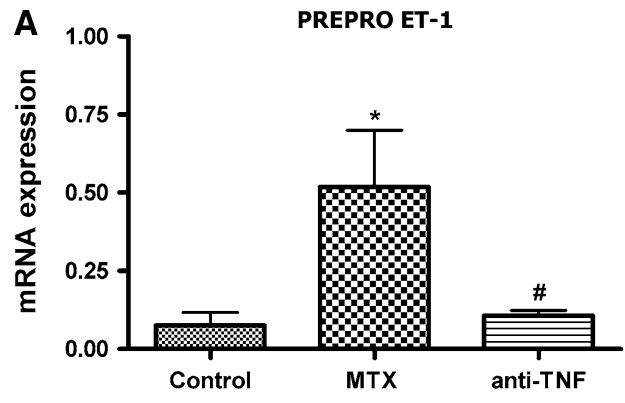

Fig. 6 TNF- $\alpha$ induces the expression of ET system genes in PBMCs of healthy individuals and RA patients. Real-time PCR was used to detect the mRNA levels of (a) preproET in PBMCs from healthy individuals and RA patients and (b) IL- $1 \beta$, preproET, and ETA and ETB receptors in PBMCs cultured with $100 \mathrm{ng} / \mathrm{ml} \mathrm{TNF}-\alpha$ or medium for $2 \mathrm{~h}$. The expression levels were normalized to GAPDH

with their cognate ligands have been detected in the synovial fluid of patients with RA and in inflamed joints in CIA, were also affected by CIA and bosentan treatment [42-44]. Another affected gene was Lymphotoxin (LT) Beta, which is predominantly expressed in a variety of immune cells $[45,46]$ and is highly expressed in the RA synovial lymphoid follicles. In addition, treatment with LT-BetaR-Ig prevents the induction of murine CIA [47, 48]. It is important to mention that the expression of these genes described above was also evaluated by real-time PCR (Fig. 3), which confirmed the participation and

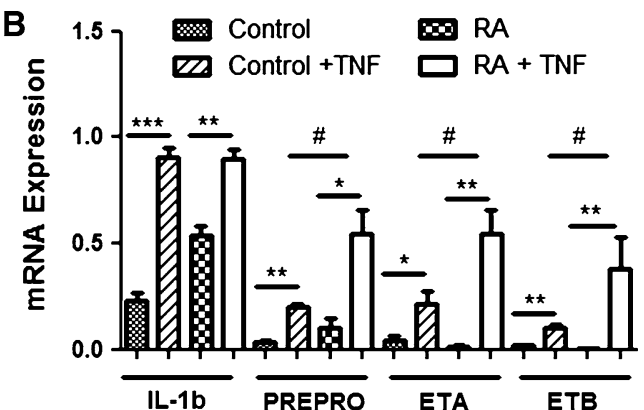

expression. The results are expressed as mean \pm SEM. The differences between responses were evaluated by one-way ANOVA followed by Bonferroni's $t$ test (three or more groups). $* P<0.05$ and ${ }^{\#} P<0.05$ compared with healthy individuals and the MTXtreated patients group, respectively $(\mathbf{a}) ; * P<0.05$ and $* * P<0.01$ compared with control group (b)

modulation of these transcripts in the studied model, suggesting that they might have importance in the cascade of ET effects. Corroborating the participation of endogenous ETs in the modulation of these transcripts in peripheral lymph nodes, we detected an increased expression of preproET during CIA (Fig. 4). Therefore, it seems that ETs may have an immunomodulatory role by acting in the lymph nodes during experimental arthritis. This effect might contribute to the exacerbation of the immune response in RA. In agreement with this hypothesis, there is evidence that dendritic cells produce large amounts of 
ET-1 and significantly increase the expression of ET receptors upon activation. Furthermore, selective blockade of the ETA receptor significantly reduced expression of the mature dendritic cell marker CD83, decreased the production of IL-12, downregulated the ability of dendritic cells to stimulate $\mathrm{T}$ cells, and promoted dendritic cell apoptosis [49].

Once the effectiveness of bosentan was demonstrated in the CIA model, suggesting the participation of the ET system in the pathophysiology of CIA, we then evaluated the expression of the ET precursor in immune cells from RA patients. Our results showed increased levels of preproET-1 in PBMCs from RA patients who were under MTX treatment compared with levels in cells from healthy donors. With a combination of MTX and anti-TNF (infliximab) therapy, preproET-1 gene expression level did not differ from the expression in healthy donors. These results suggest that upregulation of ET gene expression in PBMCs from RA patients seems to be controlled by pro-inflammatory cytokines, specifically TNF- $\alpha$. There is a large body of evidence showing that TNF and other cytokines promote ET gene expression in a variety of cell types [50-52]. On the other hand, ETs can also contribute to the production of pro-inflammatory mediators such TNF, IL-1, IL-6, IL-8, monocyte chemotactic protein-1 and granulocyte/macrophage colony-stimulating factor $[13,52]$. Aside from the possible immunomodulatory role of ETs in RA, we could not discount their local involvement in several inflammatory events in the joints. Indeed, as mentioned above, the levels of ET-1 were higher in RA patients than in osteoarthritic patients $[15,16]$. Furthermore, an increased expression of preproET in zymosan- and antigen-induced articular inflammation was found in mice [22, 35]. Additionally, ETA and ETB receptors are functionally expressed in synovial tissue [23, 34]. Further supporting the involvement of TNF- $\alpha$ in the upregulation of ET system genes, we showed that TNF- $\alpha$ increased the expression of preproET-1, ETA and ETB in PBMCs from healthy donors and RA patients. TNF- $\alpha$ also increased the expression of IL- $1 \beta$ mRNA in PBMCs. Interestingly, the effect of TNF- $\alpha$ on the ET system genes was more prominent in cells from RA patients than in cells from healthy donors; however, this effect was not observed for IL-1 $\beta$ expression, suggesting a specific effect of TNF- $\alpha$ on the ET system. The intracellular mechanism by which TNF- $\alpha$ upregulates the gene expression of ETs in cells from RA patients was not addressed. Further studies are required to clarify the regulation of the TNF- $\alpha /$ ET axis, and a higher number of patients is necessary to achieve a definitive conclusion. Nevertheless, these results might provide an important novel mechanism by which anti-TNF- $\alpha$ therapy ameliorates inflammation via downregulation of ET system gene expression in leukocytes in RA.

\section{Conclusions}

The results from this investigation contribute to a better understanding of the mechanisms involved in CIA and the participation of ETs in CIA. These results could lead to future associated therapies for RA, including the use of ET receptor antagonists.

Acknowledgments This work was supported by grants from Fundação de Amparo à Pesquisa do Estado de São Paulo (FAPESP) and Conselho Nacional de Desenvolvimento Científico e Tecnológico (CNPq) (São Paulo, Brazil). qRT-PCRs were carried out in Dr. Zilá L. P. Simões's Laboratory, University of São Paulo at Ribeirão Preto. We thank Dr. Catherine Nguyen, from the Institut National de la Santé et de la Recherche Médicale (INSERM, Marseille, France) for the cDNA clones used in the preparation of the microarrays and acknowledge the excellent technical assistance of Ieda Regina dos Santos Schivo, Sérgio Roberto Rosa, Fabiola Mestriner, Giuliana Bertozi Francisco and Vani Maria Alves.

\section{References}

1. Arend WP. Physiology of cytokine pathways in rheumatoid arthritis. Arthritis Rheum. 2001;45:101-6.

2. Yamamura YR, Gupta Y, Morita X, He R, Pai J, Endres A, et al. Effector function of resting T cells: activation of synovial fibroblasts. J Immunol. 2001;166:2270-5.

3. Feldmann M, Brennan FM, Maini RN. Role of cytokines in rheumatoid arthritis. Annu Rev Immunol. 1996;14:397-440.

4. Lajas C, Abasolo L, Bellajdel B. Costs and predictors of costs in rheumatoid arthritis: a prevalence-based study. Arthritis Rheum. 2003;49:64-70.

5. Christopher JE. Immunological therapies for rheumatoid arthritis. Br Med Bull. 2005;73 and 74:71-82.

6. Feldmann M, Maini RN. Lasker clinical medical research award: TNF defined as a therapeutic target for rheumatoid arthritis and other autoimmune diseases. Nat Med. 2003;9:1245-50.

7. Yanagisawa M, Kurihara H, Kimura S, Goto K, Masaki T. A novel peptide vasoconstrictor, endothelin, is produced by vascular endothelium and modulates smooth muscle $\mathrm{Ca}_{2}$ channels. J Hypertens. 1988;6:188-91.

8. Rubanyi GM, Polokoff MA. Endothelins: molecular biology, biochemistry, pharmacology, physiology, and pathophysiology. Pharmacol Rev. 1988:46:325-415.

9. Dhaun N, Pollock DM, Goddard J, Webb DJ. Selective and mixed endothelin receptor antagonism in cardiovascular disease. Trends Pharmacol Sci. 2007;28:573-9.

10. Inoue A, Yanagisawa M, Kimura S. The human endothelin family: three structurally and pharmacologically distinct isopeptides predicted by three separate genes. Proc Natl Acad Sci USA. 1989;86:2863-7.

11. Webb DJ, Monge JC, Rabelink TJ, Yanagisawa M. Endothelin: new discoveries and rapid progress in the clinic. Trends Pharmacol Sci. 1998;19:5-8.

12. Ferreira SH, Romitelli M, de Nucci G. Endothelin -1 participation in overt and inflammatory pain. J Cardiovasc Pharmocol. 1989; $5: 220-2$.

13. Rae GA, Henriques MG. Endothelins in inflammation: proinflammatory and anti-inflammatory peptides. Marcel Dekker: New York; 1998. p. 163-202.

14. Haq A, El-Ramahi K, Al-Dalaan A, Al-Sedairy ST. Serum and synovial fluid concentrations of endothelin-1 in patients with rheumatoid arthritis. J Med. 1999;30(1-2):51-60. 
15. Miyasaka N, Hirata Y, Ando K, Sato K, Morita H, Shichiri M, et al. Increased production of endothelin-1 in patients with inflammatory arthritis. Arthritis Rheum. 1992;35:397-400.

16. Yoshida H, Imafuku Y, Ohhara M, Miyata M, Kasukawa R, Ohsumi K, et al. Endothelin-1 production by human synoviocytes. Ann Clin Biochem. 1998;35(2):290-4.

17. Wharton J, Rutherford RA, Walsh DA, Mapp PI, Knock GA, Blake DR, et al. Autoradiographic localization and analysis of endothelin-1 binding sites in human synovial tissue. Arthritis Rheum. 1992;35(8):894-9.

18. Marjolaine RB, Johanne MP, Jean-Pierre P, Khatija NM, Stephan C, Fazool S, et al. Endothelin 1 promotes osteoarthritic cartilage degradation via matrix metalloprotease 1 and matrix metalloprotease 13 induction. Arthritis Rheum. 2003;48(10):2855-64.

19. Imhof AK, Gluck L, Gajda M, Brauer R, Schaible H, Schulz S. Potent antiinflammatory and antinociceptive activity of the endothelin receptor antagonist bosentan in monoarthritic mice. Arthritis Res Ther. 2001;13(3):R97.

20. Leung BP, Sattar N, Crilly A, Prach M, McCarey DW, Payne H, et al. A novel anti-inflammatory role for simvastatin in inflammatory arthritis. J Immunol. 2003;170:1524-30.

21. Lagares D, García-Fernández RA, Jiménez CL, Magán-Marchal $\mathrm{N}$, Busnadiego O, Lamas S, et al. Endothelin 1 contributes to the effect of transforming growth factor $\beta 1$ on wound repair and skin fibrosis. Arthritis Rheum. 2010;62(3):878-89.

22. Verri WA Jr, Cunha T, Magro DA, Guerrero ATG, Vieira SM, Carregaro V, et al. Targeting endothelin ETA and ETB receptors inhibits antigen-induced neutrophil migration and mechanical hypernociception in mice. Naunyn-Schmiedeberg's Arch Pharmacol. 2008;379:271-9.

23. Verri WA Jr, Guerrero AT, Fukada SY, Valerio DA, Cunha TM, $\mathrm{Xu} \mathrm{D}$, et al. IL-33 mediates antigen-induced cutaneous and articular hypernociception in mice. Proc Natl Acad Sci USA. 2008;105(7):2723-8.

24. Cunha TM, Verri WA Jr, Poole S, Parada CA, Cunha FQ, Ferreira SH. Pain facilitation by proinflammatory cytokine actions at peripheral nerve terminals. In: DeLeo J, Sorkin L, Watkins L, editors. Immune and glial regulation of pain. Seattle: IASP; 2007. p. 67-83.

25. Cunha TM, Verri WA Jr, Vivancos GG, Moreira IF, Reis S, Parada CA. An electronic pressure-meter nociception paw test for mice. Braz J Med Biol Res. 2004;37:401-7.

26. Cunha TM, Verri WA Jr, Silva JS, Poole S, Cunha FQ, Ferreira $\mathrm{SH}$. A cascade ofcytokines mediates mechanical inflammatory hypernociception in mice. Proc Natl Acad Sci USA. 2005; 102(5): 1755-60.

27. Arnett FC, Edworthy SM, Bloch DA, McShane DJ, Fries JF, Cooper NS, et al. The American Rheumatism Association 1987 revised criteria for the classification of rheumatoid arthritis. Arthritis Rheum. 1988;31:315-24.

28. Prevoo ML, Van't Hof MA, Kuper HH, Van Leeuwen MA, Van de Putte LB, Van Riel PL. Modified disease activity scores that include twenty-eight-joint counts. Development and validation in a prospective longitudinal study of patients with rheumatoid arthritis. Arthritis Rheum. 1995;38:44-8.

29. Hegde P, Qi R, Abernathy K, Gay C, Dharap S, Gaspard R, et al. A concise guide to cDNA microarray analysis. Biotechniques. 2000;29(3):548-56.

30. Tusher VG, Tibshirani R, Chu G. Significance analysis of microarrays applied to the ionizing radiation response. Proc Natl Acad Sci USA. 2001;98(9):5116-21.

31. Eisen MB, Spellmam PT, Brown PO, Botstein D. Cluster analysis and display of genome-wide expression patterns. Proc Natl Acad Sci USA. 1998;95:14863-8.

32. Denton CP. Therapeutic targets in systemic sclerosis. Arthritis Res Ther. 2007;9(2):S6.
33. Mayes MD. Endothelin and endothelin receptors antagonists in systemic rheumatic disease. Arthritis Rheum. 2003;48:1190-9.

34. Bendele A. Animal models of rheumatoid arthritis. J Musculoskelet Neuronal Interact. 2001;1:377-85.

35. Conte FP, Barja-Fidalgo C, Verri WA Jr, Cunha FQ, Rae GA, Penido $\mathrm{C}$, et al. Endothelins modulate inflammatory reaction in Zymosan induced arthritis: participation of LTB4, TNF $\alpha$, and CXCL-1. J Leukocyte Biol. 2008;84:652-60.

36. Pinto LG, Cunha TM, Vieira SM, Lemos HP, WA VerriJ, Cunha FQ, et al. IL-17 mediates articular hypernociception in antigeninduced arthritis in mice. Pain. 2010;148(2):247-56.

37. Shaffer AL, Wright G, Yang L, Powell J, Ngo V, Lamy L, Lam LT, et al. A library of gene expression signatures to illuminate normal and pathological lymphoid biology. Immunol Rev. 2006;210:7-85.

38. Yamagata T, Benoist C, Mathis DA. Shared gene-expression signature in innate-like lymphocytes. Immunol Rev. 2006;210: 52-66.

39. Lequerre T, Coulouarn C, Derambure C, Lefebvre G, Vittecoq O, Daveau M. A new tool for rheumatology: large-scale analysis of gene expression. Joint Bone Spine. 2003;70:248-56.

40. Barman SA, Marrero MB. Mechanism of endothelin-1 activation of map kinases in neonatal pulmonary vascular smooth muscle. Lung. 2005;183:425-39.

41. Khodorova A, Montmayeur JP, Strichartz G. Endothelin receptors and pain. J Pain. 2009;10:4-28.

42. Patel DD, Zachariah JP, Whichard LP. CXCR3 and CCR5 ligands in rheumatoid arthritis synovium. Clin Immunol. 2001; 98:39-45.

43. Robinson E, Keystone EC, Schall TJ, Gillett N, Fish EN. Chemokine expression in rheumatoid arthritis (RA): evidence of RANTES and macrophage inflammatory protein (MIP)-1 beta production by synovial T cells. Clin Exp Immunol. 1995;101: 398-407.

44. Thornton S, Duwel LE, Boivin GP, Ma Y, Hirsch R. Association of the course of collagen-induced arthritis with distinct patterns of cytokine and chemokine messenger RNA expression. Arthritis Rheum. 1999;42:1109-18.

45. Agyekum S, Church A, Sohail M, Krausz T, Van Noorden S, Polak J. Expression of lymphotoxin-beta (LT-Beta) in chronic inflammatory conditions. J Pathol. 2002;199:115-21.

46. Lu G, Janjic BM, Janjic J, Whiteside TL, Storkus WJ, Vujanovic NL. Innate direct anticancer effector function of human immature dendritic cells. II. Role of TNF, lymphotoxin-alpha(1)beta(2), Fas ligand, and TNF-related apoptosis-inducing ligand. J Immunol. 2002;168:1831-9.

47. Rennert PD, James D, Mackay F, Browning JL, Hochman PS. Lymph node genesis is induced by signaling through the lymphotoxin beta receptor. Immunity. 1998;9:71-9.

48. Takemura S, Braun A, Crowson C, Kurtin PJ, CoWeld RH, O'Fallon WM. Lymphoid neogenesis in rheumatoid synovitis. J Immunol. 2001;167:1072-80.

49. Guruli G, Pflug BR, Pecher S, Makarenkova V, Shurin MR, Nelson JB. Function and survival of dendritic cells depend on endothelin-1 and endothelin receptor autocrine loops. Blood. 2004;104(7):2107-15.

50. Kurihara H, Yoshizumi M, Sugiyama T, Takaku F, Yanagisawa M. Transforming growth factor-beta stimulates the expression of endothelin mRNA by vascular endothelial cells. Biochem Biophys Res Commun. 1989;159:1435-40.

51. Lattmann T, Hein M, Horber S, Ortmann J. Activation of proinflammatory and anti-inflammatory cytokines in host organs during chronic allograft rejection: role of endothelin receptor signaling. Am J Transplant. 2005;5:1042-9.

52. Marsden PA, Brenner BM. Regulation of ET-1 gene by TNF- $\alpha$. Am J Physiol. 1992;262:C854-61. 


\title{
Development of Type 1 Diabetes Mellitus in Nonobese Diabetic Mice Follows Changes in Thymocyte and Peripheral T Lymphocyte Transcriptional Activity
}

\author{
Thais A. Fornari, ${ }^{1}$ Paula B. Donate, ${ }^{1}$ Claudia Macedo, ${ }^{1}$ Elza T. Sakamoto-Hojo,, 2 \\ Eduardo A. Donadi, ${ }^{1,3}$ and Geraldo A. Passos ${ }^{1,4}$ \\ ${ }^{1}$ Molecular Immunogenetics Group, Department of Genetics, Faculty of Medicine of Ribeirão Preto, University of São Paulo (USP), \\ 14040-900, School Ribeirão Preto, SP, Brazil \\ ${ }^{2}$ Department of Biology, School of Philosophy, Science and Letters of Ribeirão Preto, USP, 14040-900 Ribeirão Preto, SP, Brazil \\ ${ }^{3}$ Department of Clinical Medicine, Faculty of Medicine of Ribeirão Preto, USP, 14040-900, Ribeirão Preto, SP, Brazil \\ ${ }^{4}$ Disciplines of Genetics and Molecular Biology, Department of Morphology (DMEF), School of Dentistry of Ribeirão Preto, USP, \\ 14040-900 Ribeirão Preto, SP, Brazil
}

Correspondence should be addressed to Geraldo A. Passos, passos@rge.fmrp.usp.br

Received 13 January 2011; Revised 21 March 2011; Accepted 22 March 2011

Academic Editor: Vincent Geenen

Copyright () 2011 Thais A. Fornari et al. This is an open access article distributed under the Creative Commons Attribution License, which permits unrestricted use, distribution, and reproduction in any medium, provided the original work is properly cited.

\begin{abstract}
As early as one month of age, nonobese diabetic (NOD) mice feature pancreatic infiltration of autoreactive T lymphocytes, which destruct insulin-producing beta cells, producing autoimmune diabetes mellitus (T1D) within eight months. Thus, we hypothesized that during the development of T1D, the transcriptional modulation of immune reactivity genes may occur as thymocytes mature into peripheral T lymphocytes. The transcriptome of thymocytes and peripheral $\mathrm{CD}^{+} \mathrm{T}$ lymphocytes from prediabetic or diabetic mice analyzed through microarray hybridizations identified 2,771 differentially expressed genes. Hierarchical clustering grouped mice according to age/T1D onset and genes according to their transcription profiling. The transcriptional activity of thymocytes developing into peripheral T lymphocytes revealed sequential participation of genes involved with $\mathrm{CD} 4^{+} / \mathrm{CD} 8^{+} \mathrm{T}$-cell differentiation (Themis), tolerance induction by Tregs (Foxp3), and apoptosis (Fasl) soon after T-cell activation (IL4), while the emergence of T1D coincided with the expression of cytotoxicity (Crtam) and inflammatory response genes (Tlr) by peripheral T lymphocytes.
\end{abstract}

\section{Introduction}

Type 1 diabetes (T1D) is an autoimmune disease that results in the destruction of pancreatic insulin-producing beta cells $[1,2]$. This destruction is a progressive process that occurs over five to eight months in the nonobese diabetic (NOD) mouse or several years in human patients [3]. The early stages of T1D pathogenesis are characterized by insulitis, an inflammation of the beta cells of the pancreas caused by lymphocyte infiltration. Nevertheless, the molecular genetics regulating the progress of beta cell failure and factors determining time of presentation of clinical diabetes are still poorly understood.
The NOD mouse is an autoimmune mouse strain and is a primary animal model used to dissect the mechanisms of lack of immune tolerance and autoimmune T1D, which reflects at least a part of human T1D [4-6]. The most important genetic determinants in susceptibility to diabetes lie in the major histocompatibility complex (MHC). Within the MHC locus, the class II molecules DQ8 and DQ2 in humans and the mouse homologue I- $\mathrm{Ag}^{7}$ in the NOD mouse are thought to be particularly crucial [7]. In addition, many other genes have been identified that contribute to the development of diabetes in the NOD mouse [8].

In this murine strain, it is now clear that both the $\mathrm{CD} 4^{+}$ and $\mathrm{CD}^{+}$subsets of T-cells play a role in the development of 


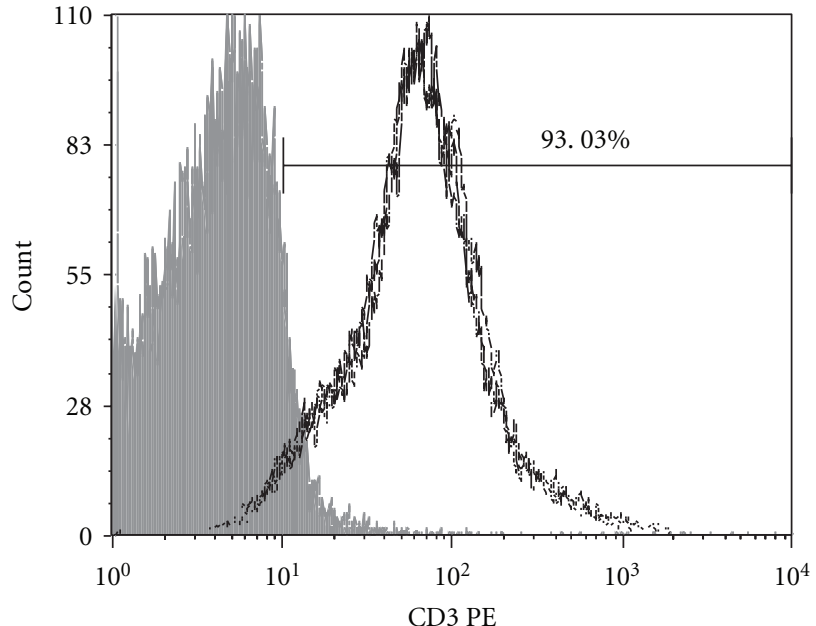

(a)

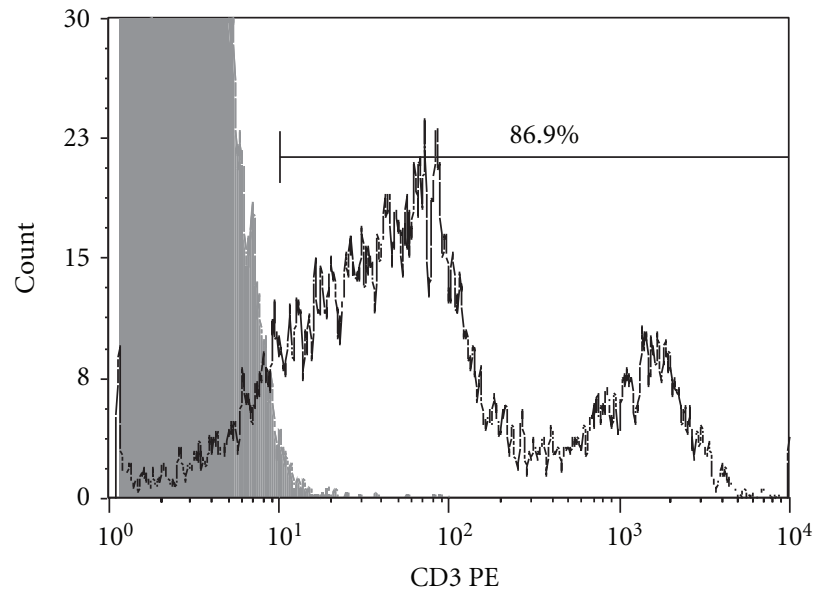

(b)

FIGURE 1: Fluorescent-activated cell sorting (FACS) analysis of thymocytes (approx. 93\% purity) (a) and of peripheral CD3 ${ }^{+} \mathrm{T}$ lymphocytes (approx. 87\% purity).

disease. Diabetes does not occur in the absence of $\mathrm{CD} 4^{+}$cells, as shown by studies using anti-CD4 antibodies [9] as well as in mice that lack $\mathrm{CD} 4^{+}$T-cells [10], mice that are deficient in $\mathrm{CD}^{+}$cells, either by anti-CD8 antibody injection into young mice [11], or mice in which few $\mathrm{CD} 8^{+} \mathrm{T}$-cells develop because of a genetic lack of Beta-2 microglobulin [12-14]. These findings support the idea that T1D is a function of the action of autoreactive $\mathrm{CD}^{+}$T-cells that feature either a $\mathrm{CD} 4^{+}$or $\mathrm{CD} 8^{+}$phenotype.

The BDC2.5 line, which derives from a $\mathrm{CD}^{+}{ }^{+} \mathrm{T}$-cell clone that is restricted by the NOD MHC class II $\mathrm{A}^{\mathrm{g} 7}$ molecule and specific for an unknown beta cell protein $[15,16]$, has been instrumental in the elucidation of several features of the immunoregulatory genes or cells that control the aggressively autoreactive T-cells in the periphery [17-20].

The differentiation into cytotoxic effector cells is the major function of $\mathrm{CD} 8^{+} \mathrm{T}$-cells, which are able to recognize antigenic peptides in the context of MHC class I molecules. These peptides are produced through the endogenous antigen presenting pathways, though evidence suggests that exogenous antigens are also presented by MHC class I molecules $[21,22]$.

The thymus exerts an important role in controlling autoreactive T-cells. An extremely diverse repertoire of Tcells is generated through the random rearrangement of Tcell receptor (TCR) gene segments. This random process generates autoreactive T-cells that are eventually eliminated through negative selection, which occurs in the medullar compartment of the thymic stroma in close association with the medullary thymic epithelial cells (mTECs). The negative selection plays an essential role in preventing pathogenic autoimmune reactions and/or autoimmune diseases.

The mTECs are essentially self-antigen-presenting cells. These cells express most of the parenchymal organs' selfantigens, a phenomenon that has been termed promiscuous gene expression (PGE) [23, 24]. Thymocytes are in close interaction with mTECs, establishing the thymic cross-talk.
In fact, the self-antigens are coded from peripheral tissue antigen (PTA) genes. The translated PTAs are trimmed into peptides that are presented to thymocytes by means of the MHC. Dendritic cells also participate in the negative selection process after they have acquired PTA peptides from mTECs [23, 25-31].

Thymocyte clones that recognize self-peptide antigens during the cross-talk phase trigger a death gene expression cascade and die by apoptosis. Accordingly, the escaping autoreactive thymocytes from negative selection may cause severe aggressive reactions in the peripheral tissues and/or organs, provoking aggressive autoimmunity/autoimmune diseases. Thus, an imbalance in the central tolerance may have important consequences in the pathogenesis of autoimmune diseases, including T1D.

The central tolerance imbalance may explain, at least in part, the results of early studies using anti-CD3 antibodies; the results indicated that T1D in the NOD mouse is a T-cellmediated disease [32].

We considered the following factors in our experiment: (1) peripheral T-cells represent the primary effectors in T1D autoreactivity in NOD mice; (2) the role played by autoreactive T-cells in the periphery may be a consequence of failure of the negative selection in the thymus; (3) the autoreactive phenotype of these cells may be a direct consequence of their transcriptional activity. Thus, our interest in this study was to analyze the transcriptome profile of thymocytes and peripheral $\mathrm{CD}^{+}$lymphocytes in the course of T1D in NOD mice to elucidate the sequential participation of genes associated with autoreactivity.

\section{Materials and Methods}

2.1. Animals, Thymocytes and Peripheral TCD $3^{+}$Lymphocyte Isolation. Female NOD mice were born in specific pathogenfree (SPF) conditions at the CEMIB-UNICAMP animal facility of the University of Campinas, SP, Brazil and maintained 


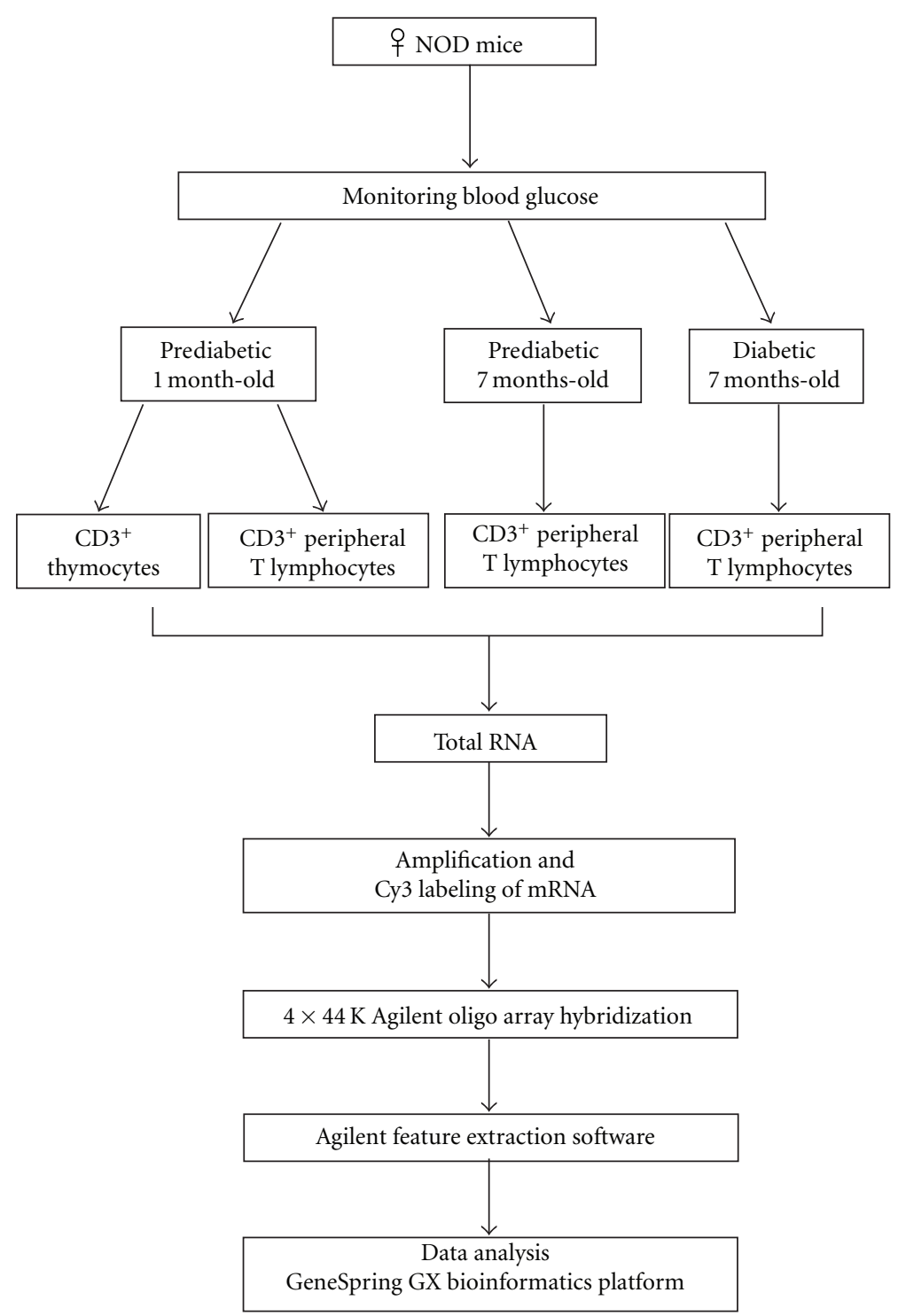

FIGURE 2: Experimental design of the work discriminating the biological samples used (animal groups and cell types), total RNA extraction, hybridizations, and microarray data analysis.

in SPF mini-isolators in our laboratory at the University of São Paulo, Campus of Ribeirão Preto, SP, Brazil during the experiment. We studied prediabetic 1-month-old and diabetic 7-month-old animals. Diabetes was confirmed by blood glucose levels ( $\geq 250 \mathrm{mg}$ glucose/dL) using the AccuChek Active kit (Roche Diagnostics Brazil, São Paulo, Brazil).

The thymi from 1-month-old animals were dissected and trimmed of fat and connective tissue in DMEM/F10 medium, and thymocytes were obtained by $2-3$ passages of the thymic fragments throughout a $10-\mu \mathrm{m}$ mesh nylon membrane (Sefar Inc. Depew, NY, USA). Pelleted thymocytes were resuspended in phosphate-buffered saline (PBS). Fluorescent-activated cell sorting (FACS) analysis in a BD-FACScalibur flow cytometer with phycoerythrin(PE-) labeled anti-CD3 antibody indicated that this procedure yielded approximately $93 \%$ purity of the thymocyte population (Figure 1(a)). These cells were then used for total RNA preparation.

The peripheral $\mathrm{T} \mathrm{CD}^{+}$lymphocytes from 1-monthold prediabetic, 7-month-old prediabetic, or 7-month-old diabetic animals were isolated from spleens using magnetic beads for negative selection (Pan T-cell isolation kit, mouse, Miltenyi Biotec) according to the manufacturer's instructions. FACS analysis with PE-labeled anti-CD3 antibody indicated that this procedure yielded approximately $87 \%$ purity of the $\mathrm{CD}^{+} \mathrm{T}$ lymphocyte population (Figure 1(b)). These cells were then used for total RNA preparation. The animal experimental protocol was previously approved by the Commission for Ethics in Animal Research, Faculty of Medicine of Ribeirão Preto, USP, Brazil (Protocol no. 120/2008). 
TABLE 1: Clusters of the differentially expressed genes and their ontology.

\begin{tabular}{|c|c|c|}
\hline Cluster & Biological process & Genes \\
\hline \multirow{20}{*}{1} & Activation of immune system & $\begin{array}{l}\text { Cd55 Daf2 Fcer1g Klre1 Klrk1 Lax1 Lyn Malt1 Masp2 Plcg2 Tlr3 Tlr4 } \\
\text { Tlr6 Unc93b1 }\end{array}$ \\
\hline & Adaptive immune response & $\begin{array}{l}\text { Bcl3 Cd55 Cd74 Daf2 Fcer1g Fcgr3 Icam1 Icosl Lilrb3 Masp2 Pou2f2 } \\
\text { Slc11a1 Tlr6 }\end{array}$ \\
\hline & Cell activation & $\begin{array}{l}\text { Bank1 Bcl11a Bcl3 Btk Casp1 Cd74 Clcf1 Cplx2 Cxcr5 Elf4 Entpd1 } \\
\text { Fcer1g Fcgr3 Fyb Gapt Gpr183 H2-M3 Hdac9 Hhex Icosl Il4 Irf1 Irf4 } \\
\text { Itgax Klre1 Klrk1 Lax1 Lbp Lilrb3 Lyn Malt1 Plcg2 Pou2f2 Slc11a1 } \\
\text { Tlr3 Tlr4 Tlr6 Vwf }\end{array}$ \\
\hline & Defense response & $\begin{array}{l}\text { Alox5 Bcl3 Btk Ccl19 Ccl5 Ccr2 Ccr5 Cd163 Cd180 Cd36 Cd55 Cd74 } \\
\text { Chst2 Ciita Clec4a2 Clec4d Cnr2 Daf2 Ddx58 Fcer1g Fcgr3 H2-K1 } \\
\text { H2-M3 Hdac9 Il18rap Il1b Irf8 Lbp Lta Ly86 Lyn Malt1 Masp2 Mefv } \\
\text { Ncf1 Neurod2 Pglyrp1 Prg2 Samhd1 Slc11a1 Tirap Tlr3 Tlr4 Tlr6 }\end{array}$ \\
\hline & $\begin{array}{l}\text { I-kappa8 kinase/NF-kappa8 } \\
\text { cascade }\end{array}$ & Btk Irak2 Malt1 Rel Tirap Tlr4 \\
\hline & Immune effector process & $\begin{array}{l}\text { Bcl3 Btk Cd55 Cd74 Cplx2 Daf2 Fcer1g Fcgr3 Icam1 Icosl Lax1 Lbp } \\
\text { Lilrb3 Lyn Masp2 Ncf1 Pou2f2 Slc1la1 }\end{array}$ \\
\hline & Immune response & $\begin{array}{l}\text { Bcl3 Btk Ccl19 Ccl5 Cc19 Ccr2 Cd180 Cd55 Cd74 Ciita Clec4a2 } \\
\text { Clec4d Cplx2 Daf2 Ddx58 Enpp1 Fasl Fcer1g Fcgr3 Fcgrt Gpr183 } \\
\text { H2-D1 H2-K1 H2-M3 H2-Q10 H2-Q2 H2-Q7 H2-Q8 H2-T23 Hfe } \\
\text { Icam1 Icosl Igj Il18rap Il1b Il4 Irf8 Irf8 Lax1 Lbp Lilrb3 Lta Ltb Ly86 } \\
\text { Lyn Malt1 Masp2 Ncf1 Oas1b Pglyrp1 Plcg2 Pou2f2 Prg2 Samhd1 } \\
\text { Slc11a1 Tirap Tlr3 Tlr4 Tlr6 }\end{array}$ \\
\hline & $\begin{array}{l}\text { Immune response-activating } \\
\text { signal transduction }\end{array}$ & Fcer1g Klre1 Klrk1 Lax1 Lyn Malt1 Plcg2 Tlr3 Tlr4 Tlr6 Unc93b1 \\
\hline & Immune system process & $\begin{array}{l}\text { Bank1 Bcl11a Bcl3 Btk Casp1 Ccl19 Ccl5 Ccl9 Ccr2 Cd180 Cd300lf } \\
\text { Cd55 Cd74 Ciita Clcf1 Clec4a2 Clec4d Cplx2 Crkl Csf1 Csf3r Cxcr5 } \\
\text { Daf2 Ddx58 Dnase2a Elf4 Enpp1 Fasl Fcer1g Fcgr3 Fcgrt Fyb Gapt } \\
\text { Gpr183 H2-D1 H2-K1 H2-M3 H2-Q10 H2-Q2 H2-Q7 H2-Q8 } \\
\text { H2-T23 Hdac9 Hfe Hhex Icam1 Icos1 Igj Il18rap Il1b Il4 Irf1 Irf4 Irf8 } \\
\text { Itgax Klre1 Klrk1 Lax1 Lbp Lilrb3 Lta Ltb Ly86 Lyn Malt1 Masp2 } \\
\text { Myo1e Ncf1 Oas1b Pglyrp1 Plcg2 Pou2f2 Prg2 Samhd1 Slc11a1 Terc } \\
\text { Tirap Tlr3 Tlr4 Tlr6 Tnfrsf13c Unc93b1 }\end{array}$ \\
\hline & Inflammatory response & $\begin{array}{l}\text { Alox5 Btk Ccl19 Ccl5 Ccr2 Cd163 Cd180 Cd55 Chst2 Cnr2 Daf2 } \\
\text { Fcgr3 Hdac9 Il1b Lbp Lta Ly86 Lyn Masp2 Mefv Ncf1 Slc1la1 Tirap } \\
\text { Tlr3 Tlr4 Tlr6 }\end{array}$ \\
\hline & Lymphocyte activation & $\begin{array}{l}\text { Bank1 Bcl11a Bcl3 Cd74 Clcf1 Cxcr5 Elf4 Gapt Gpr183 H2-M3 } \\
\text { Hdac9 Hhex Icosl Il4 Irf1 Itgax Klre1 Klrk1 Lax1 Malt1 Plcg2 Pou2f2 } \\
\text { Slc11a1 }\end{array}$ \\
\hline & $\begin{array}{l}\text { Lymphocyte activation during } \\
\text { immune response }\end{array}$ & Bcl3 Gpr183 H2-M3 Plcg2 Slc11a1 \\
\hline & Lymphocyte mediated immunity & $\begin{array}{l}\text { Bcl3 Cd55 Cd74 Daf2 Fcer1g Fcgr3 Icam1 Icosl Lilrb3 Masp2 Pou2f2 } \\
\text { Slc11a1 }\end{array}$ \\
\hline & $\begin{array}{l}\text { Positive regulation of } \\
\text { interferon-gamma production }\end{array}$ & Bcl3 H2-M3 Irf8 Klre1 Klrk1 Lta Slc11a1 Tlr4 \\
\hline & Regulation of defense response & $\begin{array}{l}\text { Adrb2 Anxa1 Cadm1 Ccl5 Ccr5 Cnr2 Crtam Fcer1g Fcgr3 H2-Bl } \\
\text { H2-M3 Klrb1b Klre1 Klrk1 Lta Nt5e Tgm2 Tlr3 Tlr4 Tlr6 Unc93b1 }\end{array}$ \\
\hline & $\begin{array}{l}\text { Regulation of immune effector } \\
\text { process }\end{array}$ & $\begin{array}{l}\text { Cadm1 Crtam Fcer1g Fcgr3 H2-Bl H2-K1 H2-M3 Hmox1 Klrb1b } \\
\text { Klre1 Klrk1 Lta }\end{array}$ \\
\hline & Regulation of immune response & $\begin{array}{l}\text { Btla Cadm1 Cd55 Crtam Daf2 Fcer1g Fcgr3 H2-Bl H2-K1 H2-M3 Il4 } \\
\text { Klrb1b Klre1 Klrk1 Lax1 Lta Lyn Malt1 Masp2 Plcg2 Slc11a1 Tlr3 } \\
\text { Tlr4 Tlr6 Tnfrsf13c Unc93b1 }\end{array}$ \\
\hline & $\begin{array}{l}\text { Regulation of inflammatory } \\
\text { response }\end{array}$ & Adrb2 Anxa1 Ccl5 Cnr2 Fcer1g Fcgr3 Lta Nt5e Tgm2 Tlr4 \\
\hline & $\begin{array}{l}\text { Regulation of leucocyte mediated } \\
\text { cytotoxicity }\end{array}$ & Cadm1 Crtam H2-Bl H2-K1 H2-M3 Klrb1b Klre1 Klrk1 \\
\hline & Apoptosis & $\begin{array}{l}\text { Actc1 Bag3 Dapl1 Dedd2 Fasl Gramd4 Hipk2 Nfkb1 Nod1 Pea15a } \\
\text { Pim2 Pmaip1 Psen2 Ripk1 Sgk1 Sgms1 Shisa5 Tmem173 Traf1 } \\
\text { Traf3ip2 Traf5 }\end{array}$ \\
\hline
\end{tabular}


TABle 1: Continued.

\begin{tabular}{|c|c|c|}
\hline Cluster & Biological process & Genes \\
\hline \multirow{4}{*}{2} & Immune response & $\begin{array}{l}\text { B2m Ccl3 Ccl5 Cxcl9 Eomes Fasl Foxp3 H2-Q10 Il18r1 Il1r11 Il7r } \\
\text { Irgm1 Myo1f Pf4 Psen2 Tgtp1 Tlr1 Tmem173 Tnfaip812 Tnfsf8 } \\
\text { Traf3ip2 }\end{array}$ \\
\hline & Immune system process & $\begin{array}{l}\text { B2m Ccl3 Ccl5 Cxcl9 Eomes Fasl Flt31 Foxp3 Gimap5 H2-Q10 Il18r1 } \\
\text { Il1rl1 Il2rb Il7r Irf1 Irgm1 Jak3 Myo1f Nfkb1 P2rx7 Pf4 Pik3cd Psen2 } \\
\text { Slamf1 Tgfbr2 Tgtp1 Tlr1 Tmem173 Tnfaip812 Tnfsf8 Traf3ip2 }\end{array}$ \\
\hline & $\begin{array}{l}\text { Regulation of I-kappaB } \\
\text { kinase/NF-kappaB cascade }\end{array}$ & Card6 Il1rl1 Nod1 Pim2 Tgm2 \\
\hline & Regulation of signal transduction & $\begin{array}{l}\text { Arhgef12 Arhgef3 Arrb1 Arrb2 Axin2 Card6 Cd44 Fasl Furin Il1rl1 } \\
\text { Nod1 P2rx7 Pim2 Psen2 Rasa3 Rasgrp2 Rgs11 Runx2 S1pr1 Smad7 } \\
\text { Socs3 Spry2 Tgm2 Zeb2 }\end{array}$ \\
\hline 3 & Immune system process & $\begin{array}{l}\text { Add2 Ahsp Ank1 Ccl4 Ccr2 Cd48 Cebpa Ctla4 Ctse Elane Epas1 } \\
\text { Epb4.2 Gimap5 Gm5077 Id2 Ifng Il1r1 Il1rl1 Il1r12 Itgam Junb Klf1 } \\
\text { Klf11 Mpo Plscr1 Polr3c Samhd1 Spna1 Tal1 Tgtp1 Trim10 Txnrd2 } \\
\text { Zbtb32 }\end{array}$ \\
\hline \multirow[t]{5}{*}{4} & Cell communication & $\begin{array}{l}\text { Atg1611 Bmp8a Cacna1c Cblc Chat Cldn5 Cxcr7 Drd5 Erbb3 Gad1 } \\
\text { Gad2 Gast Gja5 Gnal Gpr12 Gpr173 Gpr82 Grp Grpr Hnf1b Itgax } \\
\text { Kcnk2 Lin7a Mrgprb2 Ngfr Olfr1010 Olfr1022 Olfr1048 Olfr107 } \\
\text { Olfr1090 Olfr1115 Olfr1161 Olfr128 Olfr1377 Olfr1384 Olfr1388 } \\
\text { Olfr1459 Olfr1462 Olfr1469 Olfr1495 Olfr304 Olfr33 Olfr350 Olfr365 } \\
\text { Olfr516 Olfr523 Olfr556 Olfr606 Olfr62 Olfr651 Olfr68 Olfr684 } \\
\text { Olfr724 Olfr768 Olfr770 Olfr784 Olfr790 Olfr796 Olfr845 Olfr889 } \\
\text { Olfr904 Olfr924 Olfr974 Park2 Pdx1 Pik3c2g Plat Pth Rab3b Rab3c } \\
\text { Slc1a2 Slc6a4 Syn2 Taar4 Tacr1 Upk1a Vmn2r26 Vmn2r81 Xcr1 }\end{array}$ \\
\hline & $\begin{array}{l}\text { G-protein coupled receptor } \\
\text { protein signaling pathway }\end{array}$ & $\begin{array}{l}\text { Cxcr7 Drd5 Gast Gnal Gpr12 Gpr173 Gpr82 Grp Grpr Kcnk2 } \\
\text { Mrgprb2 Olfr1010 Olfr1022 Olfr1048 Olfr107 Olfr1090 Olfr1115 } \\
\text { Olfr1161 Olfr128 Olfr1377 Olfr1384 Olfr1388 Olfr1459 Olfr1462 } \\
\text { Olfr1469 Olfr1495 Olfr304 Olfr33 Olfr350 Olfr365 Olfr516 Olfr523 } \\
\text { Olfr556 Olfr606 Olfr62 Olfr651 Olfr68 Olfr684 Olfr724 Olfr768 } \\
\text { Olfr770 Olfr784 Olfr790 Olfr796 Olfr845 Olfr889 Olfr904 Olfr924 } \\
\text { Olfr974 Pth Taar4 Tacr1 Vmn2r26 Vmn2r81 Xcr1 }\end{array}$ \\
\hline & Signal transduction & $\begin{array}{l}\text { Bmp8a Cblc Cxcr7 Drd5 Erbb3 Gast Gnal Gpr12 Gpr173 Gpr82 Grp } \\
\text { Grpr Itgax Kcnk2 Mrgprb2 Ngfr Olfr1010 Olfr1022 Olfr1048 Olfr107 } \\
\text { Olfr1090 Olfr1115 Olfr1161 Olfr128 Olfr1377 Olfr1384 Olfr1388 } \\
\text { Olfr1459 Olfr1462 Olfr1469 Olfr1495 Olfr304 Olfr33 Olfr350 } \\
\text { Olfr365 Olfr516 Olfr523 Olfr556 Olfr606 Olfr62 Olfr651 Olfr68 } \\
\text { Olfr684 Olfr724 Olfr768 Olfr770 Olfr784 Olfr790 Olfr796 Olfr845 } \\
\text { Olfr889 Olfr904 Olfr924 Olfr974 Pdx1 Pik3c2g Plat Pth Rab3b Rab3c } \\
\text { Taar4 Tacr1 Upk1a Vmn2r26 Vmn2r81 Xcr1 }\end{array}$ \\
\hline & Apoptosis, apoptosis regulation & $\begin{array}{l}\text { Alms1 Bcl211 Birc5 Bub1 Bub1b Casp6 Ckap2 Cul7 E2f1 E2f2 Egln3 } \\
\text { Epha2 Fas Ift57 Krt18 Krt8 Lig4 Phlda1 Rad21 Rtn3 Stk3 Tfdp1 Tia1 } \\
\text { Tpx2 Traf4 Trp53inp1 Vdac1 }\end{array}$ \\
\hline & Cell activation & $\begin{array}{l}\text { Ada Bcl11b Ccnd3 Cd4 Cd8a Cxcl12 Fas Hdac7 Hells Lig4 Ly6d Msh6 } \\
\text { Patz1 Rag1 Rorc Satb1 Sox4 Themis }\end{array}$ \\
\hline 5 & Cell cycle & $\begin{array}{l}\text { 1190002H23Rik Anapc5 Anln Aspm Aurka B230120H23Rik Birc5 } \\
\text { Bub1 Bub1b C79407 Casc5 Ccdc99 Ccna2 Ccnb1 Ccnb2 Ccnd3 } \\
\text { Ccne2 Ccnf Ccng2 Cdc20 Cdc25a Cdc25c Cdc45 Cdca2 Cdca3 Cdca5 } \\
\text { Cdk1 Cdkn1a Cdkn2c Cdkn3 Cenpe Cenpj Cep55 Chek1 Ckap2 } \\
\text { Ckap5 Cul7 E2f1 E2f2 E2f3 E2f7 Ercc61 Esco2 Espl1 F630043A04Rik } \\
\text { Fam33a Fbxo5 Gas213 Gsg2 H2afx Haus2 Hells Kif11 Kif2c Kifc1 Lig4 } \\
\text { Mad111 Mki67 Myb Ncapd2 Ncaph Ndc80 Nde1 Nek2 Nsl1 Nuf2 } \\
\text { Nusap1 Pard6g Phgdh Prc1 Psrc1 Pttg1 Rad21 Rad51c Rbbp4 Rcc1 } \\
\text { Sgol1 Sgol2 Skp2 Spag5 Spc25 Stmn1 Tacc2 Tacc3 Tfdp1 Tpx2 } \\
\text { Trp53inp1 Tubb5 Tubg1 Ube2c Uhrf1 Wee1 }\end{array}$ \\
\hline
\end{tabular}


Table 1: Continued.

\begin{tabular}{|c|c|c|}
\hline Cluster & Biological process & Genes \\
\hline & Cell proliferation & $\begin{array}{l}\text { Alms1 Aspm Bcl211 Ccnd3 Cxcl12 Gins1 Hells Hmgb1 Lig4 Lipa } \\
\text { Mki67 Ncapg2 Nde1 Satb1 Tacc2 Tacc3 Uhrf1 Vegfa }\end{array}$ \\
\hline & Lymphocyte activation & $\begin{array}{l}\text { Ada Bcl11b Ccnd3 Cd4 Cd8a Cxcl12 Faz Hdac7 Hells Lig4 Ly6d } \\
\text { Msh6 Patz1 Rag1 Rorc Satb1 Sox4 Themis }\end{array}$ \\
\hline & Lymphocyte differentiation & $\begin{array}{l}\text { Ada Bcl11b Cd4 Cd8a Fas Hdac7 Hells Lig4 Ly6d Patz1 Rag1 Rorc } \\
\text { Satb1 Sox4 Themis }\end{array}$ \\
\hline & T-cell activation & $\begin{array}{l}\text { Bcl11b Ccnd3 Cd4 Cd8a Cxcl12 Fas Lig4 Patz1 Rag1 Rorc Satb1 Sox } 4 \\
\text { Themis }\end{array}$ \\
\hline & T-cell differentiation & Bcl11b Cd4 Cd8a Fas Lig4 Patz1 Rag1 Rorc Satb1 Sox4 Themis \\
\hline & $\mathrm{V}(\mathrm{D}) \mathrm{J}$ recombination & Bcl11b Lig4 Rag1 Xrcc6 \\
\hline & $\begin{array}{l}\text { CD8-positive, alpha-beta T-cell } \\
\text { differentiation }\end{array}$ & Pax1 Satb1 \\
\hline & Cell differentiation & $\begin{array}{l}\text { Acan Bcl11b Bcl211 Bcl6 Bmp7 Cby1 Cdkn1c Cux1 Cxcl12 Dyrk1b } \\
\text { Ephb2 Gjc1 Gpc2 Hdac2 Id3 Ift81 Igfbp3 Lhx2 Lig4 Morc1 Msi2 } \\
\text { Myh10 Notch1 Notch3 Ntn1 Paqr5 Pax1 Pias2 Pitx2 Ptprf Rag1 Rag2 } \\
\text { Runx1 Satb1 Sox11 Spata6 Spo11 Stra8 Tbata Thy1 Whrn }\end{array}$ \\
\hline \multirow[t]{7}{*}{6} & Cell-cell adhesion & Acan Arvcf Jup Lmo4 Mcam Ncam1 Ntn1 Ptprf Pvrl3 Vangl2 \\
\hline & Lymphocyte differentiation & Bcl11b Bcl6 Lig4 Pax1 Rag1 Rag2 Satb1 \\
\hline & $\begin{array}{l}\text { Somatic diversification and } \\
\text { recombination of T-cell receptor } \\
\text { genes }\end{array}$ & Bcl11b Lig4 \\
\hline & T-cell activation & Bcl11b Cxcl12 Lig4 Pax1 Rag1 Rag2 Satb1 Sla2 \\
\hline & T-cell differentiation & Bcl11b Lig4 Pax1 Rag1 Rag2 Satb1 \\
\hline & $\begin{array}{l}\mathrm{T} \text {-cell receptor } \mathrm{V}(\mathrm{D}) \mathrm{J} \\
\text { recombination }\end{array}$ & Bcl11b Lig4 \\
\hline & $\mathrm{V}(\mathrm{D}) \mathrm{J}$ recombination & Bcl11b Lig4 Rag1 Rag2 \\
\hline
\end{tabular}

2.2. Total RNA Preparation. The total RNA was extracted from $1 \times 10^{7}$ thymocytes or peripheral T CD3 ${ }^{+}$lymphocytes using a mirVana total RNA isolation kit (Ambion) according to the manufacturer's instructions. RNA preparations were confirmed to be free of proteins and phenol by UV spectrophotometry. The state of degradation was assessed by microfluidic electrophoresis using Agilent RNA Nano 6000 chips and an Agilent 2100 Bioanalyzer (Agilent Technologies, Santa Clara, CA, USA). Only RNA samples that were free of proteins and phenol and featured an RNA Integrity Number $($ RIN $) \geq 9.0$ were used.

2.3. RNA Amplification, Labeling, Microarray Hybridization and, Data Analysis. Changes in gene expression were evaluated using the Agilent one-color (Cy3 fluorochrome) microarray-based gene expression platform according to the manufacturer's instructions. For hybridization onto whole mouse genome $4 \times 44 \mathrm{~K} 60$-mer oligonucleotide arrays (G4122F, Agilent Technologies, Palo Alto, CA, USA), 500 ng total RNA was used in the one-color Quick Amp labeling kit (Agilent Technologies, Santa Clara, CA, USA). Samples of complementary RNA (cRNA) were hybridized for $18 \mathrm{~h}$ at $42^{\circ} \mathrm{C}$ in a rotator oven and were then washed. The array slides were scanned using a DNA microarray scanner (Agilent Technologies), and the hybridization signals were extracted using the Agilent Feature Extraction software version 10.5.

Gene expression profiles from independent preparations of thymocytes (from 1-month-old prediabetic mice) or
$\mathrm{CD}^{+}$peripheral lymphocytes (from 1-month-old prediabetic, 7-month-old prediabetic or 7-month-old diabetic mice) were analyzed through comparisons of the microarray hybridizations of the respective samples. Figure 2 depicts the experimental design for further comparison of the gene profiling.

A complete file that provides all of the genes present in the microarray used in this study, as well as the experimental conditions, is available online at the MIAME public database [33], ArrayExpress accession E-MEXP 3047.

The microarray numerical quantitative data were normalized to the 75th percentile and were analyzed using the GeneSpring GX bioinformatics platform [34] according to the default instructions allowing hierarchical clustering of samples of mice or genes based on ANOVA statistical analysis $(P<.01)$ with a fold change $>2.0$ and an uncentered Pearson correlation metrics [35]. The similarities and dissimilarities in gene expression are presented as dendrograms, in which the pattern and length of the branches reflect the relatedness of the samples or genes, and heat maps.

2.4. Gene Ontology. Microarray data analysis was used to identify gene expression based on combined information from the public databases DAVID [36] and SOURCE [37]. These databases show gene annotation enrichment analysis, functional annotation clustering, BioCarta and KEGG pathway mapping (DAVID), or microarray data and sequencing 


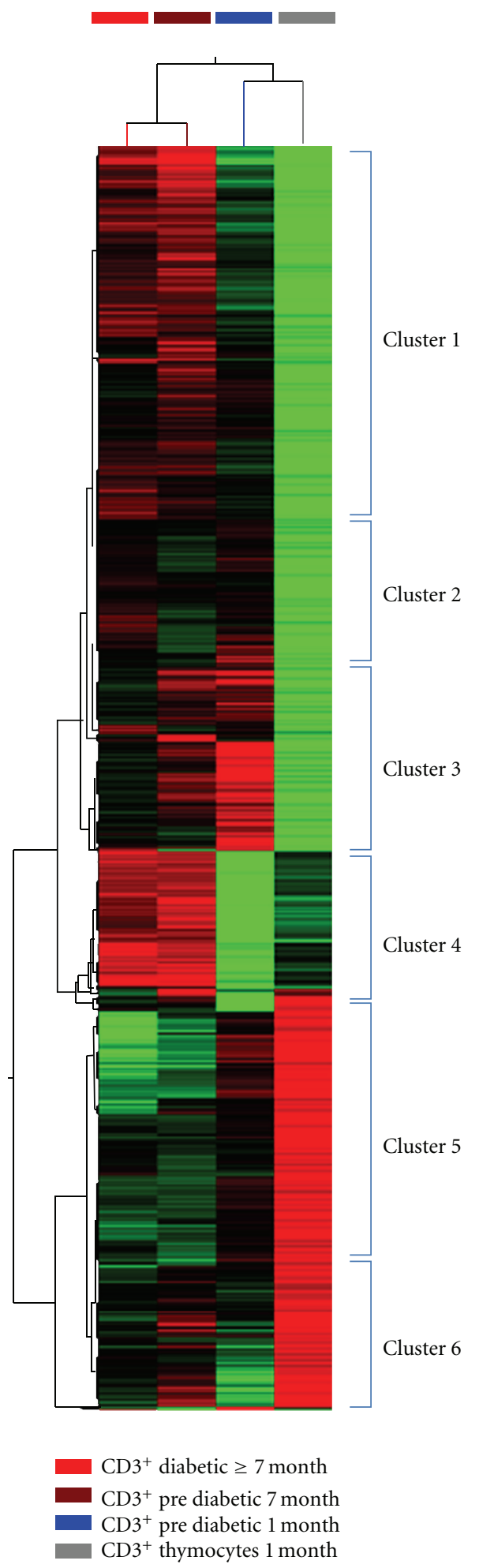

FIgURE 3: Hierarchical clustering of thymocytes and peripheral $\mathrm{CD}^{+}$lymphocytes of nonobese diabetic (NOD) mice based on microarray gene expression profiling. Dendrograms and heat maps were obtained using the Cluster-Tree View program within the GeneSpring GX (Agilent) platform. Red = upregulation, green $=$ downregulation, and black = unmodulated (Pearson correlation metrics, 75 percentile). The 2,771 differentially expressed genes were divided in six clusters (clusters 1 to 6 ) according to their relative expression levels and ontology. of cDNA clones from different organ/tissues (SOURCE), including GenBank accession number, chromosomal location and the molecular/biological function of each gene analyzed.

2.5. Oligonucleotide Primer Design and Quantitative RealTime Polymerase Chain Reaction ( $q R T-P C R$ ). Microarray data were confirmed using qRT-PCR for the genes listed below that were differentially expressed between thymocytes and peripheral $\mathrm{CD}^{+}{ }^{+} \mathrm{T}$ lymphocytes. The cDNA sequences of these genes were retrieved from the NCBI GenBank database (http://www.ncbi.nlm.nih.gov/genbank/ GenbankSearch.html), and the Primer3 web tool (http:// biotools.umassmed.edu/bioapps/primer3_www.cgi) was used to select pairs of oligonucleotide primers spanning an intron/exon junction and with consideration of the alternative transcripts. An optimal melting temperature of $60^{\circ} \mathrm{C}$ was standardized for all genes. The following forward and reverse sequences are given in the $5^{\prime}$ to $3^{\prime}$ orientation: Hypoxanthine phosphoribosyltransferase 1 (HPRT1, accession number NM_000194.2, GACCAGTCAA CAGGGGACAT' ${ }^{\prime}$ and CTGCATTGTTTTGCCAGTGT); Fas ligand (Fasl, accession number NM_000639, ACTCCGTG AGTTCACCAACC and GTGGGGGTTCCCTGTTAAAT); Toll-like receptor 3 (Tlr3, accession number BC068487, TTGTCTTCTGCACGAACCTG and CCCGTTCCCAACTT TGTAGA); Toll-like receptor 4 (Tlr4, accession number NM_138554, TCAGAACTTCAGTGGCTGGA CCTGGGGA AAAACTCTGGAT); Forkhead box P3 (Foxp3, accession number NM_014009, TCTTCGAGGAGCCAGAAGAG and GCTCCAGAGACTGCACCACT); Thymocyte selection associated (Themis, accession number NM_001164685, AAATG AAGCTCACCTTGCTCA and ATCCTGGCCACTTTCATC TG). HPRT1 was used as the constitutively expressed gene. Transcriptional expression levels were determined using a StepOne Real-Time PCR System (Applied Biosystems, USA). The $\triangle \Delta \mathrm{CT}$ relative normalization method was used as described previously. We used the GraphPad Prism 5.00 tool (http://www.graphpad.com/prism/Prism.html) to run one-way or two-way ANOVAs with Bonferroni's correction statistics.

\section{Results}

Although the expression pattern remained unchanged between thymocytes and peripheral $\mathrm{T}$ lymphocytes from prediabetic and diabetic animals for the majority of the 44,000 sequences tested, which presented a control/test ratio $\approx 1.0$ (Pearson correlation), 2,771 genes were found to be differentially expressed. Hierarchical clustering of the data allowed for the identification of clusters of upregulated (induced) and downregulated (repressed) genes. Changes in gene expression profile could be observed when comparing thymocytes from 1-month-old prediabetic mice with peripheral $\mathrm{CD}^{+}$lymphocytes from 1-month-old prediabetic, 7month-old prediabetic, or 7-month-old diabetic mice to observe the modulated genes that coincided with the development of T1D. 
Fasl

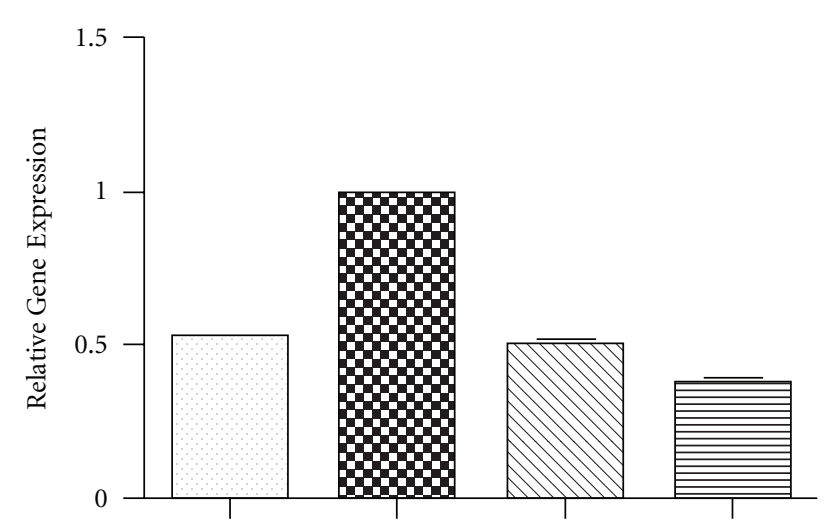

Tlr3

Tlr4
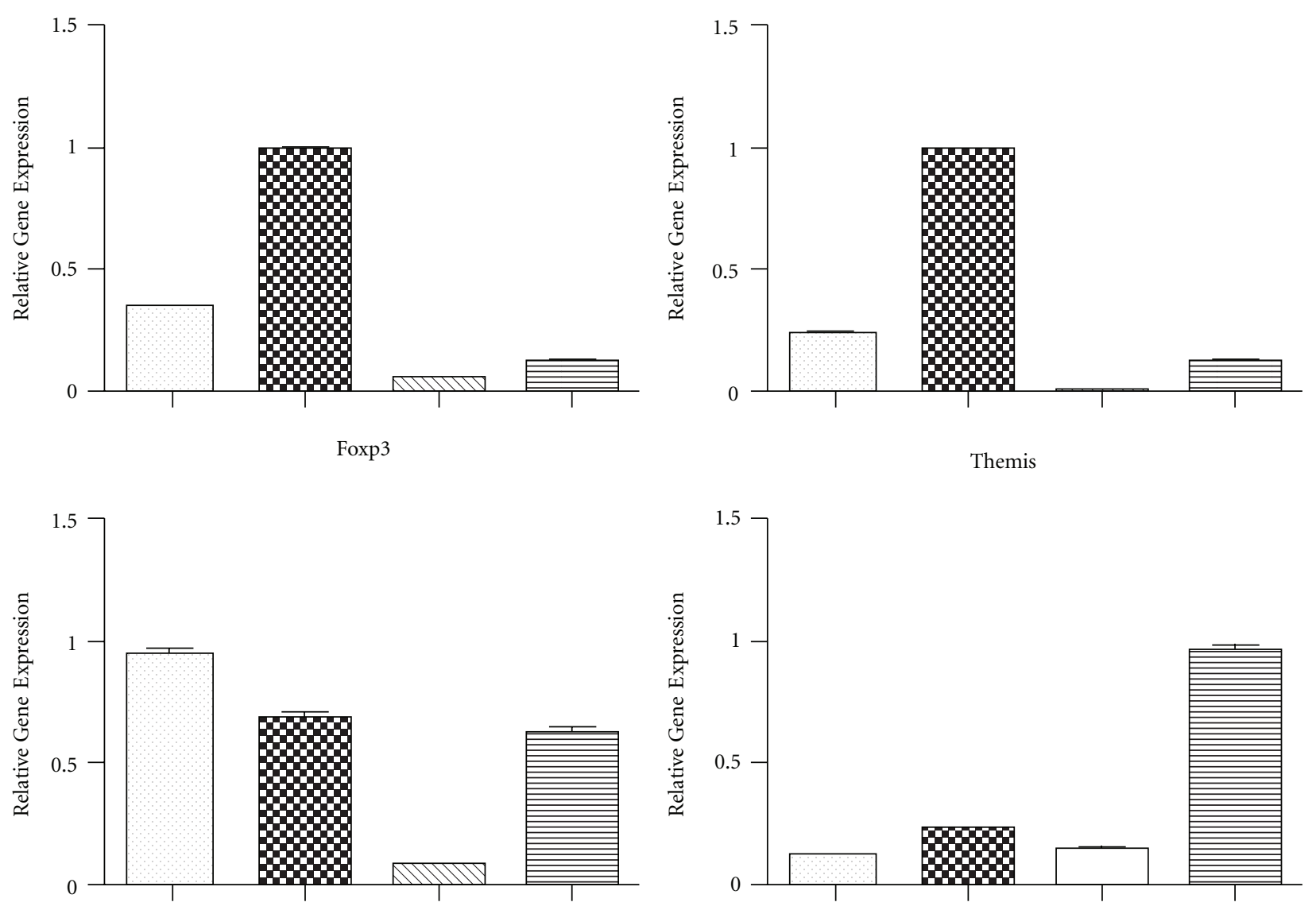

\section{$\square \mathrm{CD}^{+}$diabetic 7 month $\quad \mathrm{MV} \mathrm{CD}^{+}$pre diabetic 1 month \\ W0 $\mathrm{CD}^{+}$pre diabetic 7 month $\equiv \mathrm{CD}^{+}$thymocytes 1 month}

FIgURE 4: Confirmation of microarray data by qRT-PCR. The Fasl, Tlr3, and Tlr4 genes were downregulated in thymocytes from prediabetic animals, Foxp3 was upregulated in peripheral $\mathrm{CD}^{+}$lymphocytes from diabetic animals, and Themis was upregulated in thymocytes from prediabetic animals. 
Hierarchical clustering analysis depicted in Figure 3 shows variability in the hybridization signatures between cell types. The upper horizontal dendrogram (cell samples) demonstrates that this variability could distinguish cells according to their developmental phase, namely, thymocytes (prediabetic animals) from peripheral $\mathrm{CD} 3^{+}$lymphocytes (prediabetic and diabetic animals). The left vertical dendrogram shows the genes that were differentially expressed (up- or downregulated) according to their respective biological function, and the genes were divided into six clusters (Figure 3 and Table 1). Clusters 1 to 4 contain genes downregulated in thymocytes and peripheral $\mathrm{CD}^{+}$ lymphocytes from 1-month-old prediabetic animals and progressively upregulated in peripheral $\mathrm{CD}^{+}$lymphocytes from 7-month-old prediabetic and diabetic animals.

Cluster 1 comprises 767 differentially expressed genes, and the following genes were highlighted because they participate in immune processes potentially implicated in the pathogenesis of T1D: IL4, involved with T-cell activation, Crtam, involved in cytotoxicity and Tlr3, Tlr4, and Tlr6, involved in inflammatory response.

Cluster 2 comprises 340 differentially expressed genes, and the following genes were highlighted: Fasl, involved in the induction of apoptosis by extracellular signals and FoxP3, involved in $\mathrm{CD}_{2} 5^{+}$alpha-beta T-regulatory (Treg) cell differentiation and positive regulation of T-cell tolerance induction.

Cluster 3 comprises 435 differentially expressed genes, and the following genes were highlighted: Chemokine $(\mathrm{C}-$ $\mathrm{C}$ motif) ligand 4 gene ( $\mathrm{Ccl} 4)$ and Chemokine ( $\mathrm{C}-\mathrm{C}$ motif) receptor 2 gene (Ccr2), both involved in inflammatory response; CD48 antigen gene, involved in T-cell activation; Cytotoxic T-lymphocyte-associated protein 4 gene (Ctla4), involved in negative regulation of Treg cell differentiation; Interferon gamma gene (Ifng), involved in positive regulation of T-cell proliferation; Integrin alpha M gene (Itgam), involved in cell-cell adhesion.

Cluster 4 comprises 292 differentially expressed genes, and the following genes were highlighted: Integrin alpha $\mathrm{X}$ (Itgax) and Claudin 5 (Cldn5) gene, involved in cellcell adhesion; Gap junction protein, alpha 5 (Gja5) gene, involved in cell-cell signaling; HNF1 homeobox 1 transcription factor, involved in maturity onset diabetes of the young and circadian regulation of transcription; and Gastrin (Gast) and Guanine nucleotide-binding protein 1 (Gnal) gene, both involved in protein signaling pathway. Interestingly, this cluster comprises various members of the olfactory receptor (Olfr) gene family, which is involved with cell signaling pathways.

Finally, clusters 5 and 6 comprise 610 and 327 genes, respectively, which feature a different expression pattern than those included in the previous clusters, that is, they were mainly upregulated in thymocytes from prediabetic mice and progressively downregulated in peripheral $\mathrm{CD}^{+}$ lymphocytes from prediabetic and diabetic animals. These two clusters contain genes involved in CD4/CD8 cell differentiation (Themis) and $\mathrm{V}(\mathrm{D}) \mathrm{J}$ recombination (Rag1 and Rag2).
Using qRT-PCR, we assayed the expression levels of five differentially expressed genes (Fasl, Tlr3, Tlr4, Foxp3 and Themis) that are associated with thymocyte selection, Tcell differentiation, cell activation, or inflammation. The expression levels obtained with qRT-PCR method were comparable with microarrays, for example; the Fasl, Tlr3 and Tlr4 genes were downregulated in thymocytes from prediabetic animals, Foxp3 was upregulated in peripheral $\mathrm{CD}^{+}$lymphocytes from diabetic animals, and Themis was upregulated in thymocytes from prediabetic animals (Figure 4).

\section{Discussion}

In this study, we assessed the hypothesis that the transcriptional modulation of immune reactivity genes may occur during the development of T1D as thymocytes mature into peripheral T lymphocytes. Consequently, the emergence of T1D might follow a pattern of the transcriptional activity of these cells, sequentially featuring genes associated with a negative selection of thymocytes, T-cell maturation, differentiation, and autoreactivity.

As discussed in a previous study [38], diabetes in NOD mice is similar to T1D patients, and the progress of diabetes in these animals occurs in two stages. In the first stage, autoreactive $\mathrm{CD}^{+} \mathrm{T}$ lymphocytes infiltrate the pancreatic islet by 1 month after the birth. However, most pancreatic islets are preserved at this phase, and the animals are clinically healthy. Stage one can persist for months because the autoimmune attack is under control and is relatively nondestructive. In the second stage, most of pancreatic islets are destructed and animals are often diabetic.

Because these animals spontaneously develop autoimmune diabetes mellitus that is similar to human T1D, including the presence of pancreas-specific autoantibodies and autoreactive $\mathrm{CD}^{+}$or $\mathrm{CD} 8^{+}$T-cells and synteny to human chromosomal linkage groups associated with T1D, they are a classical model system for investigating autoimmune T1D and/or failure in the tolerance mechanisms $[4,6,28]$. Thus, we chose to employ the NOD mouse as a model system given the difficulty of easily testing this theory in humans.

To exclude the influence of genetic backgrounds of nonautoimmune mouse strains, we compared only groups of NOD mice in two distinct phases of autoimmunity, namely, prediabetic (1- or 7-month-old) and diabetic ( $\geq 7$-monthold).

Moreover, by establishing transcriptome comparisons between cells from prediabetic and diabetic animals or between thymocytes and peripheral $\mathrm{T}$ lymphocytes, it was possible to find genes temporally regulated (because T1D emerges according to age) and regulated according to T-cell development.

The procedures for isolation of thymocytes and peripheral $\mathrm{CD}^{+} \mathrm{T}$ lymphocytes used in this work yielded purities (approximately $93 \%$ for thymocytes and $85 \%$ for peripheral $\mathrm{CD}^{+} \mathrm{T}$ lymphocytes) that are comparable to automated cell sorting of T-cells. Moreover, the peripheral $\mathrm{CD}^{+}{ }^{+} \mathrm{T}$ lymphocytes were isolated by negative separation, minimizing eventual cell activation by artifacts. 
Figure 3 (clusters 1 to 4 ) and Table 1 show the gene expression pattern observed in thymocytes and peripheral $\mathrm{CD}^{+}$lymphocytes from prediabetic 1-month-old animals. The gene expression in these cells could be considered to occur in the first stage of T1D, and this expression features the down-regulation of genes involved with the activation of the immune system/adaptive response, cell activation, NF-KappaB cascade, immune effector/immune response processes, inflammatory response, lymphocyte activation, the regulation of interferon-gamma production, the regulation of leukocyte-mediated cytotoxicity, apoptosis, cell communication, and signal transduction. Altogether, these biological processes are necessary for the development of lymphocyte differentiation and autoreactivity.

The thymocytes from prediabetic 1-month-old animals featured down-regulation of genes associated with several biological processes that were gradually upregulated in the peripheral $\mathrm{CD}^{+}$lymphocytes from prediabetic 1-monthold, prediabetic 7-month-old, and diabetic 7-month-old animals (Figure 3 and Table 1). Among these processes and their respective genes, we selected some of the most important to discuss because of their direct or indirect association with aggressive autoimmunity.

The apoptosis process featured genes including Fas ligand (Fasl), TNF receptor-associated factor (Traf1 and Traf5), Traf3 interacting protein 2 (Traf3ip2), and Tumor necrosis factor (ligand) superfamily, member 8 (Tnfsf8 or TRAIL).

Because apoptosis is the final stage of the negative selection of thymocytes in the thymus [29], the downregulation of these genes may favor the survival of autoreactive thymocyte clones, including those that recognize pancreatic beta cell autoantigens.

A role for TRAIL in T1D in NOD mice has been evidenced by its blockade with consequent exacerbation of the disease [39] and by its systemic delivery indicating that T1D can be prevented by TRAIL overexpression through an enhancement of the tissue inhibitor of the metalloproteinase1 (TIMP-1) function [40]. The authors concluded that elevated TIMP-1 production inhibits the activity of matrix metalloproteinases, which may contribute to the suppression of the transmigration of diabetogenic T-cells into the pancreatic islets and protects pancreatic beta cells from cytokineinduced apoptosis.

The tolerance induction process featured Forkhead box P3 (Foxp3) gene, which was also downregulated in thymocytes from 1-month-old prediabetic animals. This gene is involved in tolerance induction via $\mathrm{CD} 4^{+} \mathrm{CD} 25^{+}$ T-regulatory cells (Tregs) [41-43], a process that directly activates any of the steps required for tolerance, a physiologic state in which the immune system does not react destructively against self-components. Thus, their deregulation may impair the Treg-mediated suppression of aggressive autoimmunity, favoring the survival of autoreactive thymocytes in the thymus.

The T-cell activation process featured several downregulated genes in thymocytes from 1-month-old prediabetic animals, from which we highlight Chemokine (C-C ligand motif) ligand 4 ( $\mathrm{Ccl} 4)$, Chemokine (C-C motif) receptor 2 (Ccr2), Cd48 antigen and Interferon, gamma (Ifng), and
Interleukin 4 (IL4) genes. These genes were gradually upregulated in peripheral CD3+ lymphocytes from prediabetic to diabetic animals and may increase the activation of autoreactive T-cell clones in the periphery.

Interestingly, the G-protein-coupled receptor protein signaling pathway and signal transduction processes shared several members of the olfactory gene family (Olfr), which is involved in sensory perception of smell through receptor and signal transducer activity. The two pathways also shared bone morphogenetic protein $8 \mathrm{a}(\mathrm{Bmp} 8 \mathrm{a})$ gene, which is involved in growth and ossification. These genes were downregulated in thymocytes from 1-month-old prediabetic animals and were gradually upregulated in peripheral $\mathrm{CD} 3^{+}$lymphocytes from prediabetic to diabetic animals. Despite their disparate biological processes in the context of T1D, these genes may play a role in the receptor-mediated signal transduction activity of peripheral T-cells in diabetic animals.

Dissimilar from the pattern of genes related to the processes discussed above, the T-cell receptor $\mathrm{V}(\mathrm{D}) \mathrm{J}$ recombination and $\mathrm{CD}^{+} / \mathrm{CD}^{+}$T-cell differentiation featured genes were upregulated in thymocytes and $\mathrm{CD}^{+}$peripheral $\mathrm{T}$ lymphocytes from prediabetic 1-month-old animals and were gradually downregulated in peripheral CD3+ lymphocytes from prediabetic and diabetic 7-month-old animals.

Among these genes, we highlight the recombination activating genes (Rag-1 and Rag-2) that code the recombinase catalytic complex involved in the recognition of recombination signal sequences (RSS) within the T-cell receptor loci (TCR alpha, beta, gamma or delta), cutting and recombining DNA during aleatory generation of TCR diversity. The generation of TCR diversity implies the production of T-cell clones directed to foreign antigens and also autoreactive clones. Autoreactive clones are normally eliminated by apoptosis throughout the negative selection process.

Also, Adenosine deaminase (Ada) gene, which is involved in a process that increases the frequency of T-cell differentiation in the thymus, and Cytotoxic T-lymphocyte-associated protein 4 (Ctla4) gene, which in contrast to Ada gene, is involved in the negative regulation of T-cell proliferation, were both identified.

Finally, we found the Thymocyte selection associated (Themis) gene, which is expressed in the thymus and to a lesser extent in the spleen but is not detectable in nonlymphoid tissues. This gene is highly expressed in thymocytes between the pre-T-cell antigen receptor (preTCR) and positive-selection checkpoints and is expressed at a low level in mature T-cells (at the protein level). Themis is also implicated in the control of T-helper CD4+/cytotoxic CD8+ cell fate. Moreover, the CD4 as well as CD8a antigen genes, which define the respective $\mathrm{T}$-helper $\mathrm{CD}^{+}$or $\mathrm{T}$ cytotoxic CD8+ phenotypes, were also found.

During their permanence within the thymus, thymocytes activate a developmentally complex mechanism because of close contact with thymic stroma. The medullary thymic epithelial cells (mTECs), which form the stromal medullar compartment, present peripheral tissue antigens (PTAs) to thymocytes to eliminate autoreactive clones by inducing 
apoptosis (negative selection), leading to tolerance induction $[23,24]$.

Failure in the expression of specific PTA genes in the thymic stroma is strongly associated with aggressive autoimmunity as recently observed during the development of T1D in NOD mice [38] or collagen-induced arthritis in DBA-1/J mice [44]. This indeed led to survival of autoreactive thymocyte clones that once in the periphery, mediate autoimmune attack of target structures such as pancreatic beta cells.

To better understand the control of transcriptional activity of thymocytes specifically associated with the induction of tolerance and negative selection within the thymus or cytotoxicity and inflammatory response in peripheral $\mathrm{T}$ lymphocytes, we propose further experiments to evaluate the participation of microRNAs (miRNAs) that once dysregulated might be associated with aggressive autoimmunity of T1D.

\section{Conclusion}

In this study, we were able to construct a transcriptional profile of T-cell development comparing thymocytes with peripheral CD3+ lymphocytes in the context of the emergence of T1D. The sequential participation of genes involved with the main steps of T-cell development such as the generation of TCR diversity, $\mathrm{CD} 4^{+} / \mathrm{CD}^{+}$cell fate, apoptosis, and negative selection demonstrated that the T1D autoimmune phenotype in NOD mice runs in parallel with transcriptome changes of T-cells. The results obtained confirm our initial hypothesis.

\section{Acknowledgments}

This study was funded by the following agencies: Fundação de Amparo à Pesquisa do Estado de São Paulo (FAPESP) and Conselho Nacional de Desenvolvimento Científico e Tecnológico (CNPq). T. A. Fornari and Paula B. Donate are equally contributed to this work.

\section{References}

[1] A. L. Notkins and A. Lernmark, "Autoimmune type 1 diabetes: resolved and unresolved issues," Journal of Clinical Investigation, vol. 108, no. 9, pp. 1247-1252, 2001.

[2] B. Regnault, J. Osorio Y Fortea, D. Miao, G. Eisenbarth, and E. Melanitou, "Early over expression of messenger RNA for multiple genes, including insulin, in the Pancreatic Lymph Nodes of NOD mice is associated with Islet Autoimmunity," BMC Medical Genomics, vol. 2, article no. 63, 2009.

[3] E. H. Leiter, M. Prochazka, and D. L. Coleman, "The nonobese diabetic (NOD) mouse," American Journal of Pathology, vol. 128, no. 2, pp. 380-383, 1987.

[4] M. A. Atkinson and E. H. Leiter, "The NOD mouse model of type 1 diabetes: as good as it gets?" Nature Medicine, vol. 5, no. 6, pp. 601-604, 1999.

[5] M. S. Anderson and J. A. Bluestone, "The NOD mouse: a model of immune dysregulation," Annual Review of Immunology, vol. 23, pp. 447-485, 2005.
[6] J. P. Driver, D. V. Serreze, and Y. -G. Chen, "Mouse models for the study of autoimmune type 1 diabetes: a NOD to similarities and differences to human disease," Seminars in Immunopathology, vol. 33, no. 1, pp. 67-87, 2011.

[7] H. Ikegami, S. Makino, E. Yamato et al., "Identification of a new susceptibility locus for insulin-dependent diabetes mellitus by ancestral haplotype congenic mapping," Journal of Clinical Investigation, vol. 96, no. 4, pp. 1936-1942, 1995.

[8] L. S. Wicker, J. A. Todd, and L. B. Peterson, "Genetic control of autoimmune diabetes in the NOD mouse," Annual Review of Immunology, vol. 13, pp. 179-200, 1995.

[9] J. A. Shizuru, C. Taylor-Edwards, B. A. Banks, A. K. Gregory, and C. G. Fathman, "Immunotherapy of the nonobese diabetic mouse: treatment with an antibody to T-helper lymphocytes," Science, vol. 240, no. 4852, pp. 659-662, 1988.

[10] F. S. Wong, I. Visintin, LI. Wen, J. Granata, R. Flavell, and C. A. Janeway, "The role of lymphocyte subsets in accelerated diabetes in nonobese diabetic-rat insulin promoter-B7-1 (NOD-RIP-B7-1) mice," Journal of Experimental Medicine, vol. 187, no. 12, pp. 1985-1993, 1998.

[11] BO. Wang, A. Gonzalez, C. Benoist, and D. Mathis, "The role of CD8 T cells in the initiation of insulin-dependent diabetes mellitus," European Journal of Immunology, vol. 26, no. 8, pp. 1762-1769, 1996.

[12] J. Katz, C. Benoist, and D. Mathis, "Major histocompatibility complex class I molecules are required for the development of insulitis in non-obese diabetic mice," European Journal of Immunology, vol. 23, no. 12, pp. 3358-3360, 1993.

[13] D. V. Serreze, E. H. Leiter, G. J. Christianson, D. Greiner, and D. C. Roopenian, "Major histocompatibility complex class I-deficient NOD-B2m(null) mice are diabetes and insulitis resistant," Diabetes, vol. 43, no. 3, pp. 505-509, 1994.

[14] T. Sumida, M. Furukawa, A. Sakamoto et al., "Prevention of insulitis and diabetes in $\beta$-microglobulin-deficient non-obese diabetic mice," International Immunology, vol. 6, no. 9, pp. 1445-1449, 1994.

[15] J. D. Katz, B. Wang, K. Haskins, C. Benoist, and D. Mathis, "Following a diabetogenic T cell from genesis through pathogenesis," Cell, vol. 74, no. 6, pp. 1089-1100, 1993.

[16] B. Bergman and K. Haskins, "Islet-specific T-cell clones from the NOD mouse respond to $\beta$-granule antigen," Diabetes, vol. 43, no. 2, pp. 197-203, 1994.

[17] A. Gonzalez, J. D. Katz, M. G. Mattei, H. Kikutani, C. Benoist, and D. Mathis, "Genetic control of diabetes progression," Immunity, vol. 7, no. 6, pp. 873-883, 1997.

[18] O. Kanagawa, A. Militech, and B. A. Vaupel, "Regulation of diabetes development by regulatory $\mathrm{T}$ cells in pancreatic islet antigen-specific TCR transgenic nonobese diabetic mice," Journal of Immunology, vol. 168, no. 12, pp. 6159-6164, 2002.

[19] L. Poirot, C. Benoist, and D. Mathis, "Natural killer cells distinguish innocuous and destructive forms of pancreatic islet autoimmunity," Proceedings of the National Academy of Sciences of the United States of America, vol. 101, no. 21, pp. 8102-8107, 2004.

[20] S. Zucchelli, P. Holler, T. Yamagata, M. Roy, C. Benoist, and D. Mathis, "Defective central tolerance induction in NOD mice: genomics and genetics," Immunity, vol. 22, no. 3, pp. 385-396, 2005.

[21] K. L. Rock, S. Gamble, and L. Rothstein, "Presentation of exogenous antigen with class I major histocompatibility complex molecules," Science, vol. 249, no. 4971, pp. 918-921, 1990.

[22] M. Kovacsovics-Bankowski and K. L. Rock, "Presentation of exogenous antigens by macrophages: analysis of major 
histocompatibility complex class I and II presentation and regulation by cytokines," European Journal of Immunology, vol. 24, no. 10, pp. 2421-2428, 1994.

[23] B. Kyewski and J. Derbinski, "Self-representation in the thymus: an extended view," Nature Reviews Immunology, vol. 4, no. 9, pp. 688-698, 2004.

[24] D. A. R. Magalhães, E. L. V. Silveira, C. M. Junta et al., "Promiscuous gene expression in the thymus: the root of central tolerance," Clinical and Developmental Immunology, vol. 13, no. 2-4, pp. 81-99, 2006.

[25] L. Klein and B. Kyewski, "Self-antigen presentation by thymic stromal cells: a subtle division of labor," Current Opinion in Immunology, vol. 12, no. 2, pp. 179-186, 2000.

[26] J. Derbinski, A. Schulte, B. Kyewski, and L. Klein, "Promiscuous gene expression in medullary thymic epithelial cells mirrors the peripheral self," Nature Immunology, vol. 2, no. 11, pp. 1032-1039, 2001.

[27] B. Kyewski and L. Klein, "A central role for central tolerance," Annual Review of Immunology, vol. 24, pp. 571-606, 2006.

[28] Y. Takahama, "Journey through the thymus: stromal guides for T-cell development and selection," Nature Reviews Immunology, vol. 6, no. 2, pp. 127-135, 2006.

[29] G. A. Hollönder, "Claudins provide a breath of fresh Aire," Nature Immunology, vol. 8, no. 3, pp. 234-236, 2007.

[30] M. Irla, S. Hugues, J. Gill et al., "Autoantigen-specific interactions with $\mathrm{CD}^{+}$thymocytes control mature medullary thymic epithelial cell cellularity," Immunity, vol. 29, no. 3, pp. 451463,2008 .

[31] J. Villaseñor, W. Besse, C. Benoist, and D. Mathis, "Ectopic expression of peripheral-tissue antigens in the thymic epithelium: probabilistic, monoallelic, misinitiated," Proceedings of the National Academy of Sciences of the United States of America, vol. 105, no. 41, pp. 15854-15859, 2008.

[32] A. R. Hayward and M. Shreiber, "Neonatal injection of CD3 antibody into nonobese diabetic mice reduces the incidence of insulitis and diabetes," Journal of Immunology, vol. 143, no. 5, pp. 1555-1559, 1989.

[33] http://www.ebi.ac.uk/miamexpress.

[34] http://www.agilent.com/chem/genespring.

[35] M. B. Eisen, P. T. Spellman, P. O. Brown, and D. Botstein, "Cluster analysis and display of genome-wide expression patterns," Proceedings of the National Academy of Sciences of the United States of America, vol. 95, no. 25, pp. 14863-14868, 1998.

[36] http://david.abcc.ncifcrf.gov.

[37] http://smd.stanford.edu/cgi-bin/source/sourceSearch.

[38] T. A. Fornari, P. B. Donate, C. Macedo, M. M. C. Marques, D. A. Magalhães, and G. A. S. Passos, "Age-related deregulation of Aire and peripheral tissue antigen genes in the thymic stroma of non-obese diabetic (NOD) mice is associated with autoimmune type 1 diabetes mellitus (DM-1)," Molecular and Cellular Biochemistry, vol. 342, no. 1-2, pp. 21-28, 2010.

[39] Q. S. Mi, D. Ly, S. E. Lamhamedi-Cherradi et al., "Blockade of tumor necrosis factor-related apoptosis-inducing ligand exacerbates type 1 diabetes in NOD mice," Diabetes, vol. 52, no. 8, pp. 1967-1975, 2003.

[40] S. Kang, E.-J. Park, Y. Joe et al., "Systemic delivery of TNFRelated Apoptosis-Inducing Ligand (TRAIL) elevates levels of tissue inhibitor of metalloproteinase-1 (TIMP-1) and prevents type 1 diabetes in nonobese diabetic mice," Endocrinology, vol. 151, no. 12, pp. 5638-5646, 2010.

[41] J. D. Fontenot, M. A. Gavin, and A. Y. Rudensky, "Foxp3 programs the development and function of $\mathrm{CD} 4{ }^{+} \mathrm{CD} 25^{+}$ regulatory T cells," Nature Immunology, vol. 4, no. 4, pp. 330336, 2003.

[42] S. Hori, T. Nomura, and S. Sakaguchi, "Control of regulatory T cell development by the transcription factor Foxp3," Science, vol. 299, no. 5609, pp. 1057-1061, 2003.

[43] J. H. Buckner, "Mechanisms of impaired regulation by $\mathrm{CD} 4^{+}$ $\mathrm{CD}_{2} 5^{+} \mathrm{FOXP}^{+}$regulatory $\mathrm{T}$ cells in human autoimmune diseases," Nature Reviews Immunology, vol. 10, no. 12, pp. 849 859, 2010.

[44] P. B. Donate, T. A. Fornari, C. M. Junta et al., "Collagen induced arthritis (CIA) in mice features regulatory transcriptional network connecting major histocompatibility complex (MHC H2) with autoantigen genes in the thymus," Immunobiology, vol. 216, no. 5, pp. 591-603, 2011. 


\title{
Collagen induced arthritis (CIA) in mice features regulatory transcriptional network connecting major histocompatibility complex (MHC H2) with autoantigen genes in the thymus
}

\author{
Paula B. Donate ${ }^{\mathrm{a}, 1}$, Thaís A. Fornari ${ }^{\mathrm{a}, 1}$, Cristina M. Junta ${ }^{\mathrm{a}}$, Danielle A. Magalhães ${ }^{\mathrm{a}}$, Cláudia Macedo ${ }^{\mathrm{a}}$, \\ Thiago M. Cunha ${ }^{b}$, Catherine Nguyen ${ }^{c}$, Fernando Q. Cunha ${ }^{b}$, Geraldo A. Passos ${ }^{a, d, *}$ \\ a Molecular Immunogenetics Group, Department of Genetics, Faculty of Medicine of Ribeirão Preto, University of São Paulo (USP), $14040-900$ Ribeirão Preto, SP, Brazil \\ b Department of Pharmacology, Faculty of Medicine of Ribeirão Preto, USP, 14040-900 Ribeirão Preto, SP, Brazil \\ ${ }^{\mathrm{c}}$ National Institute of Health and Medical Research (INSERM U928) 13100 Marseille, France \\ d Disciplines of Genetics and Molecular Biology, Department of Morphology, Faculty of Dentistry of Ribeirão Preto, USP, 14040-904 Ribeirão Preto, SP, Brazil
}

\section{A R T I C L E I N F O}

\section{Article history:}

Received 29 April 2010

Received in revised form

20 September 2010

Accepted 21 September 2010

\section{Keywords:}

Thymus

Promiscuous gene expression

Aire

MHC

Transcriptional network

Collagen induced arthritis

\begin{abstract}
A B S T R A C T
Considering that imbalance of central tolerance in the thymus contributes to aggressive autoimmunity, we compared the expression of peripheral tissue autoantigens (PTA) genes, which are involved in selfrepresentation in the thymic stroma, of two mouse strains; DBA-1/J (MHC-H2q ) susceptible and DBA-2/J $\left(\mathrm{MHC}-\mathrm{H}^{d}\right)$ resistant to collagen induced arthritis (CIA). We evaluate whether these strains differ in their thymic gene expression, allowing identification of genes that might play a role in susceptibility/resistance to CIA. Microarray profiling showed that 1093 PTA genes were differentially modulated between collagen immunized DBA-1/J and DBA-2/J mice. These genes were assigned to 17 different tissues/organs, including joints/bone, characterizing the promiscuous gene expression (PGE), which is implicated in self-representation. Hierarchical clustering of microarray data and quantitative RT-PCR analysis showed that Aire (autoimmune regulator), an important regulator of the PGE process, Aire-dependent (insulin), Aire-independent (Col2A1 and Gad67), and other 22 joint/bone autoantigen genes were down-regulated in DBA-1/J compared with DBA-2/J in the thymus. Considering the importance of MHC-H2 in peptide-self presentation and autoimmunity susceptibility, we reconstructed transcriptional networks of both strains based on actual microarray data. The networks clearly demonstrated different MHC-H2 transcriptional interactions with PTAs genes. DBA-1/J strain featured MHC-H2 as a node influencing downstream genes. Differently, in DBA-2/J strain network MHC-H2 was exclusively self-regulated and does not control other genes. These findings provide evidence that CIA susceptibility in mice may be a reflex of a cascade-like transcriptional control connecting different genes to MHC-H2 in the thymus.
\end{abstract}

(c) 2010 Elsevier GmbH. All rights reserved.

\section{Introduction}

The unique structural and functional thymic microenvironment, which allows for a quality control of the nascent $\mathrm{T}$ cell repertoire,

Abbreviations: CII, type II collagen; CIA, collagen induced arthritis; CFA, complete Freud's adjuvant; HLA, human leukocyte antigen; MHC, major histocompatibility complex; PBS, phosphate-buffered saline; PGE, promiscuous gene expression; PTA, peripheral tissue autoantigens; TEC, thymic epithelial cell; cTEC, cortical thymic epithelial cell; mTEC, medullary thymic epithelial cell; RA, rheumatoid arthritis; SAM, significance analysis of microarrays.

* Corresponding author at: Molecular Immunogenetics Group, Department of Genetics, Faculty of Medicine of Ribeirão Preto, University of São Paulo (USP), 3900 Via Bandeirantes, 14040-900 Ribeirão Preto, SP, Brazil. Tel.: +55 163602 3030; fax: +551636330069.

E-mail address: passos@rge.fmrp.usp.br (G.A. Passos).

1 These authors contributed equally to this study. is provided by stromal cells, which besides macrophages and dendritic cells, is mainly formed by the two major subsets of thymic epithelial cells (TEC), cortical (CTEC) and medullary (mTEC). These two last, also define the two major compartments of the thymus, the cortex and the medulla, respectively (Van Ewijk 1991; Bleul et al. 2006).

T cells pass through both compartments in a spatially and temporally ordered process. During the cortical phase, a highly diverse $\mathrm{T}$ cell repertoire is generated and subjected to positive selection for self-MHC restriction. The subsequent medullary phase imposes $\mathrm{T}$ cell tolerance on the nascent repertoire via negative selection of auto-reactive effectors cells (Anderson et al. 2006). Although much is known about the biology of thymocytes, our understanding of the thymic stroma, and all its implication during the development of the autoimmune process, is still poor.

A better understanding of the central tolerance mechanism emerged from evidence that peripheral tissue antigens (PTAs) are 
expressed in the thymus and contribute to the selection of the T cell repertoire (Kyewski et al. 2002). Expression of PTAs is a physiological property of TECs, in particular mTECs, a phenomenon known as promiscuous gene expression (PGE) due to the extensive selfrepresentation of autoantigens, which mobilizes up to $5-10 \%$ of all known mouse genes (Derbinski et al. 2001; Gotter et al. 2004).

Autoimmune regulator (Aire) considered a master regulator, drives the self presentation in the thymus. Expression profiling of MTECs isolated from Aire-knockout mice allowed the identification of autoantigen-encoding genes, such as insulin (Ins), salivary protein 1 and fatty-acid-binding protein ( $F a b p)$, which are under control of this transcription factor (Anderson et al. 2002). Meanwhile, other PTA genes, such as C-reactive protein (Crp) and glutamic acid decarboxylase of $67 \mathrm{kDa}$ (Gad67), appeared to be independent of Aire, which also regulates the transcription of genes that do not encode PTAs (Derbinski et al. 2005).

Recent evidence showed that Aire also controls PGE either in an indirect manner; initially controlling the transcription of Gucy2d gene, which is connected to downstream PTA genes through transcriptional network (Macedo et al. 2009).

Studies on the control of PGE and PTA expression in the thymus have gained priority among several research groups, including our own, allowing the identification of gene expression and demarcation of PGE emergence during thymus ontogeny (Magalhães et al. 2006; Sousa Cardoso et al. 2006; Fornari et al. 2010).

Immunologists realize that the main implication of the heterogeneous expression of PTAs in the thymic stroma is associated with maintenance of the immunological homeostasis in the body. Deregulation of PGE may be an early warning sign for aggressive autoimmunity, which may lead autoimmune diseases, as it guarantees PTA representation in the thymus.

A manner to establish association between changes in the thymic stroma and aggressive autoimmunity is to make use of an experimental model-system, reproducing an autoimmune disease. Rheumatoid arthritis (RA) is a prototype of autoimmune disease, which in mice should be experimentally induced by immunization with collagen (collagen induced arthritis or CIA) of susceptible DBA$1 / \mathrm{J}$ strain (Wooley et al. 1981). Given that it is still unclear whether imbalance in the central tolerance influences CIA and/or RA, this approach seems adequate to the study.

Moreover, major histocompatibility complex (MHC) is a strong genetic determinant of susceptibility to CIA as determined by Vyacheslav et al. (2002) in a study showing that combining $H 2^{q}$ and $H 2^{d}$ alleles in mice resulted in codominant inheritance with a reduction of disease severity. MHC haplotypes as well as mutations along the Aire gene are associated to autoimmune diseases (Tiwari and Terasaki 1985; Anderson et al. 2002; Ramsey et al. 2002). However, the detailed mechanism(s) that trigger aggressive autoimmunity is still not totally understood despite our knowledge on the role of MHC molecules in autoantigen presentation and/or their role as genetic determinant of autoimune diseases.

For the reasons abovementioned and given the essential contribution of PTAs in the negative selection of autoreactive T cells in the thymus, we decided to compare both their expression and transcriptional interactions in mouse strains featuring CIA susceptibility (DBA-1/J) or resistance (DBA-2/J). MHC-H2 in these strains was highlighted due to its association with CIA development. The microarray method enabled us to explore the large scale expression of PTAs and quantitative RT-PCR to detect the expression of the Aire gene and genes that code for specific PTAs including Col2a1; the most important antigen associated with the RA development.

In view, Aire and genes that code joint/bone PTAs were downregulated in DBA-1/J when comparing with the DBA-2/J mice. Interestingly, the reconstructed transcriptional networks based on the actual microarray data showed that while in DBA-1/J MHC-H2 modulate downstream PTA genes, in DBA-2/J it was solely self- regulated and does not connect to any downstream genes. The differential PTA profiling and transcriptional networks observed between the two mouse strains, which include (or not) MHC-H2, may influence CIA susceptibility in mice.

\section{Materials and methods}

\section{Animals and collagen-induced arthritis (CIA)}

DBA/1J and DBA-2/J mice (12-14 weeks old) weighing 18-22 g each were housed in temperature-controlled rooms $\left(22-25^{\circ} \mathrm{C}\right)$ in the animal facility of the Faculty of Medicine of Ribeirão Preto, University of São Paulo, Brazil, and received water and food ad libitum. DBA-1/J and DBA-2/J male mice were used in type II collagen immunizations.

For CIA, at day 0, DBA/1J and DBA-2/J males were intradermally injected at the base of the tail with $200 \mu \mathrm{g}$ of bovine type II collagen (CII) (Sigma) in $100 \mu$ l of $0.05 \mathrm{M}$ acetic acid emulsified with equal volume of complete Freund's adjuvant (Chondrex, Redmond, WA). On day 21 , a second injection of CII ( $200 \mu \mathrm{g}$ in acetic acid) was given intraperitoneally (i.p). A caliper was used to determine the paw diameter and swelling was determined as the increase in diameter compared to day 0 of immunization.

The severity of CIA was graded according to a score (CIA score) attributing the 0 (zero) value to normal paw with no swelling, erythema and no increase in joint diameter, 1 to slight swelling, erythema and $0.1-0.3 \mathrm{~mm}$ increase in joint diameter, 2 to swelling, erythema and $0.3-0.6 \mathrm{~mm}$ increase in joint diameter, 3 to extensive swelling, erythema and $0.6-0.9 \mathrm{~mm}$ increase in joint diameter and 4 to pronounced swelling and erythema with joint thickness of $0.9-1.2 \mathrm{~mm}$ increase or obvious joint destruction associated with visible joint deformity or ankylosis. Each limb was graded, resulting in a maximum clinical score of 16 per animal and expressed as the mean score on a given day. Disease onset was typically seen between days 25 and 35 after CII injection and was characterized by erythema and/or paw swelling. Only those animals presenting score 16 at day 35 were used for thymic stromal cell preparation and RNA extraction. For all experiments, we used six animals per group.

The experimental protocols were approved by the Commission for Ethics in Animal Research, Faculty of Medicine of Ribeirão Preto, USP, Brazil (Protocol \# 244/2005).

\section{Thymic stroma separation, mTEC 3.10 cell strain culture and total RNA preparation}

The thymic stroma was separated from the whole thymus, as previously described (Gray et al. 2002). In brief, thymi were dissected and trimmed of fat and connective tissue. Tissue fragments were then gently agitated in $50 \mathrm{ml}$ of RPMI 1640 medium at $4{ }^{\circ} \mathrm{C}$ with a magnetic stirrer for $30 \mathrm{~min}$ to remove the majority of thymocytes. The resulting thymic fragments were then transferred to $10 \mathrm{ml}$ of fresh RPMI 1640 medium and remaining thymocytes were dispersed by successive pipetting. Medium was changed 2-3 times after agitations, with fragments recovered by settling each time. The thymic fragments were then incubated in $5 \mathrm{ml}$ of $0.125 \%(\mathrm{w} / \mathrm{v})$ collagenase type II with $0.1 \%$ DNAse I (both from Invitrogen, Carlsbad, CA, USA) in RPMI 1640 at $37^{\circ} \mathrm{C}$ for $15 \mathrm{~min}$, with gentle agitation every 5 min using a $1 \mathrm{ml}$ pipettor. After 3-4 digestions, stromal cells were pooled and centrifuged at $450 \times g$ for 5 min and finally resuspended in $200 \mu \mathrm{l}$ PBS. These cells were then used for total RNA preparation.

The MTEC 3.10 medullary thymic epithelial cell line was established from C57BL/6 mice, and the original medullary phenotype was confirmed by immunostaining with Th-3 and Th-4 antibody, recognizing cortical and medullary phenotypes, respectively 
(Hirokawa et al. 1986). They were further evaluated using a panel of anti-cytokeratin monoclonal antibodies, which confirmed the original distinct medullary phenotype (Werneck et al. 2000). Cells were cultured in $10 \%$ fetal bovine serum (Cultilab, Campinas, SP, Brazil) - supplemented RPMI 1640 medium (Sigma-Aldrich ${ }^{\mathrm{TM}}$, St. Louis, MO, USA) at $37{ }^{\circ} \mathrm{C}$ and $5 \% \mathrm{CO}_{2}$. To reach the ideal concentration of total RNA for all the experiments, 6 thymi (from higher arthritic score DBA-1/J or DBA-2/J mice) were used initially to separate the stromal cells and further to prepare RNA, as a pool, or $1 \times 10^{7}$ mTEC 3.10 cells. Total RNA extraction was performed using Trizol $^{\circledR}$ reagent according to manufacturer's instructions (Invitrogen, Carlsbad, CA). RNA preparations were confirmed to be free of proteins or phenol using UV spectrophotometry. The state of degradation was assessed by microfluidic electrophoresis on RNA 6000 nano chips in an Agilent 2100 Bioanalyzer. Only no degraded RNA samples featuring RNA integrity number $(\mathrm{RIN} \geq 8.5)$ that were free of proteins, phenol, were used.

\section{Gene expression analysis using microarrays}

Gene expression in the thymic stroma and in the MTEC 3.10 cells was assessed using glass slide cDNA microarrays prepared on silane-coated UltraGAPS slides (\# 40015, Corning ${ }^{\circledR}$, New York, NY, USA). The arrays contained a total of 4500 target tissue-restricted antigen cDNA sequences that represented most murine tissues and organs. Sequences were obtained from the Soares thymus 2NbMT normalized library that represented expressed sequence tag (ESTs) cDNA clones prepared from the thymus of a C57BL/6J 4-week-old male mouse, and available at the IMAGE Consortium (http://image.hudsonalpha.org).

The microarrays were prepared based on published protocols using PCR products from the cDNA clones (Hegde et al. 2000) using a Generation III Array Spotter (Amersham Molecular Dynamics, Sunnyvale, CA, USA). A complete file providing all genes and ESTs present in the microarray used in this study, as well as the quantitative data and experimental conditions is available on line at MIAME public database (http://www.mged.org/Workgroups/MIAME/miame.html) Array Express accession E-MEXP-2338.

\section{Labeled-cDNA preparation and microarray hybridization}

The cDNAs derived from the thymic stroma or mTEC 3.10 cell line were prepared by reverse transcription using $10 \mu \mathrm{g}$ of total RNA. The cDNA samples were monocolor labeled with Cy3 fluorochrome using the CyScribe post-labeling kit (GE Healthcare Biosciences). Samples were hybridized for $15 \mathrm{~h}$ and then washed using an automatic slide processor system (ASP, Amersham Biosciences). Microarrays were scanned in a Generation III laser scanner (Amersham Biosciences).

As a reference for the hybridization procedure, we used equimolar quantities of cDNAs obtained from irrelevant total RNA(C57BL/6 whole thymus total RNA). This approach allowed us to estimate the relative amount of target cDNA in each microarray spot.

\section{Microarray data analysis and transcriptional gene networks reconstruction}

Microarray images were quantified using the Spotfinder software (http://www.tm4.org/spotfinder.html) and normalized using the $\mathrm{R}$ platform (http://www.r-project.org). Statistical analyses were performed using Multiexperiment Viewer (MeV) software (version 3.1) (http://www.tm4.org/mev.html). Differentially expressed genes were identified using the significance analysis of microarrays (SAM) program (Tusher et al. 2001), considering only those genes with a false discovery rate $(F D R) \leq 0.01$.
To analyze the gene expression profiles from the SAM program data set, we used a hierarchical clustering method that grouped genes on the horizontal axis. The samples were supervised on the vertical axis. The similarities and dissimilarities in gene expression are presented as both heat maps and dendrograms, in which the pattern and length of the branches reflect the relatedness of the samples or genes (Eisen et al. 1998) (Cluster version 3.0 and Java Tree View) (http://rana.lbl.gov/EisenSoftware.html).

The GeneNetwork 1.2 algorithm (Wu et al. 2004) was applied to compare means of different gene expression values whose standard deviation did not overlap, whose objective was to compute a network that established relationships between all genes. Bayesian statistics and linear interpolation for the network organization was used. The software for this algorithm can be obtained from the authors (http://idv.sinica.edu.tw/hchuang/GeneNetwork1.2Setup.exe).

In order to organize networks only with genes whose expression values were significant, we used values for the induced and repressed genes selected by the SAM statistics. In this case, of the 4500 sequences present on the microarray, a total of 23 differentially expressed genes were included in the calculations of the GeneNetwork software due to their statistical significance.

\section{Determination of promiscuous gene expression}

The microarray analysis data was used to identify PGE based on combined information from the public databases BioGPS (http://biogps.gnf.org/?referer=symatlas\#goto=welcome) and/or SOURCE (http://smd.stanford.edu/cgi-bin/source/sourceSearch). These databases show gene expression in more than 60 mouse tissue/organs, as assessed by sequencing of cDNA clones from different organ/tissues (SOURCE) or gene array analysis using Affymetrix microarrays (BioGPS). Data information from these databases includes GenBank accession number, chromosomal location, tissue/organ representation and the molecular/biological function of each gene analyzed.

In this study, we considered the promiscuous genes of which the expression was detected in different organs or tissues and of which the expression levels that were greater than the median in relation to the different organs.

Oligonucleotide primer design and quantitative real-time polymerase chain reaction ( $q R T-P C R$ )

Microarray data were confirmed using qRT-PCR of three PTA genes (Bcap31, Fcgr1 and Prkrir) that differed between DBA1/J and DBA2/J animals; the genes were selected based on their expression pattern and hierarchical clustering. The Aire and three autoantigen genes (Gad1, Ins2 and Col2a1) were selected because their sequences were not included in the microarray used in this study. The Primer3 web tool (http://biotools.umassmed.edu/bioapps/primer3_www.cgi) was used to select pairs of oligonucleotide primers spanning an intron/exon junction with an optimal melting temperature of $60^{\circ} \mathrm{C}$. The cDNA sequences of these genes were retrieved from the NCBI GenBank database (http://www.ncbi.nlm. nih.gov/sites/entrez?db=nuccore\&itool=toolbar) for each gene. The forward and reverse sequences are given in the $5^{\prime}$ to $3^{\prime}$ orientation; Aire (GenBank acc NM_009646.1) (5' GCAACTCTGGCCTCAAAGAG 3' and 5' GGTCTGAATTCCGTTTCCAA 3'), Gad67 (Gad1) (GenBank acc NM_008077.3) (5' TCACCCTCGATTTTTCAACC $3^{\prime}$ and 5' AACAAACACGGGTGCAATTT $3^{\prime}$ ), Ins2 (GenBank acc NM_008387.3) (5' ACCTTCAGACCTTGGCACTG $3^{\prime}$ and 5' GCTGGGTAGTGGTGGGTCTA 3'), Bcap31 (GenBank acc NM_012060) (5' ATGACCGCCTGCTAGAAGAA $3^{\prime}$ and $5^{\prime}$ GCAGTAAGCATGGGTCAGGT $3^{\prime}$ ), Fcgr1 (GenBank acc NM_010186) (5' GGGAAGACACCGCTACACAT 3' 
and 5' GTTCAGGGTGACCAGACTCC $3^{\prime}$ ), Prkrir (GenBank acc NM_028410) (5' CCGCATAGCAGACACAGAAA 3' and 5' GGGTTCTGAGCATTGGTGTT 3') and Col2a1 (GenBank acc NM_031163.2) (5' AACACTTTCCAACCGCAGTC $3^{\prime}$ and $5^{\prime}$ TCTGCCCAGTTCAGGTCTCT $\left.3^{\prime}\right)$. The cDNA samples were prepared using Superscript II reverse transcriptase (Invitrogen Corporation, Carlsbad, CA, USA) enzyme, as recommended. Expression of the abovementioned genes was quantified using a 7500 Real Time PCR System (Applied Biosystems) and normalized to the expression of the housekeeping gene Gapdh (GenBank acc NM_008084.2) (5' GGGTGTGAACCACGAGAAAT 3' and $5^{\prime}$ CCTTCCACAATGCCAAAGTT 3').

\section{Results}

Development of CIA in DBA-1/J mice

The immunization schedule with type CII induced the development of arthritis (CIA) in male DBA- $1 / \mathrm{J}$ mice, whose CIA scores reached a peak on day 35 . Male DBA-2/J mice injected in the same schedule were considered as controls. These animals did not feature any signal of arthritis development.

\section{Genes differentially expressed during CIA}

Although the expression pattern remained unchanged between CIA susceptible DBA-1/J and resistant DBA-2/J strain thymic stroma for the majority of the 4500 sequences tested $\left.\left[d(i) \approx d_{E}(i)\right)\right], 1093$ genes were found as significantly modulated. Thus, it was possible to identify clusters of repressed and induced genes.

To try to identify changes in the gene expression profiles associated to susceptibility or resistance to CIA we compared CII immunized DBA-1/J and DBA-2/J mice respectively. Expression profiling showed differences from the thymic stroma of DBA- $1 / \mathrm{J}$ and DBA-2/J mice. Parallel profiling of mTEC 3.10 cell line, served as a parameter to help identify genes involved in PGE.

The hierarchical gene cluster analysis of the results obtained with the SAM program and comparison of the hybridization signatures showed variability between these three sample types.

Genes that were differentially expressed (repressed or induced) in the stroma of mice were selected for further analysis as these characterize PGE (Fig. 1 and Table 1 ).

\section{Parenchymal organ representation in the thymus}

The 25 induced and the 33 repressed sequences in the thymic stromal cells of DBA-1/J and DBA-2/J stains were then assigned to 57 parenchymal and 7 lymphoid organs, according to their predominant expression (Table 1 ). These were then sub-grouped into 17 anatomic-functional body systems (Fig. 2).

The following 22 gene transcripts: Psap (acc NM_ 011179), Rab1 (acc NM_008996), Rab3d (acc NM_031874), Prkd2 (acc NM_178900), Elf1 (acc NM_007920), Tieg3/Klf11 (acc NM_178357), St5 (acc NM_01001326), Zwint (acc NM_025635), Pias1 (acc AK162584), Tspan3 (acc NM_019793), Fau (acc NM_007990), Ccnd3 (acc NM_001081636), Glb1 (acc AK082033), Serpinb2 (acc NM_011111), Csnk1d (acc NM_139059), Nkx6-2 (acc NM_183248), Mapk3 (acc NM_011952), Trim24 (acc NM_145076), Dusp1 (acc NM_013642), Atf4 (acc NM_009716), Fcgr1 (NM_010186), and Galnt10 (NM_134189) that code for respective PTAs expressed in the bone and/or joint and, therefore, related to locomotory system, were repressed in DBA-1/J strain and induced in DBA-2/J strain.

\section{Gene networking}

Fig. 3 shows the transcriptional network analysis of the 22 bone and/or joint PTA genes, which were repressed in DBA-1/J and

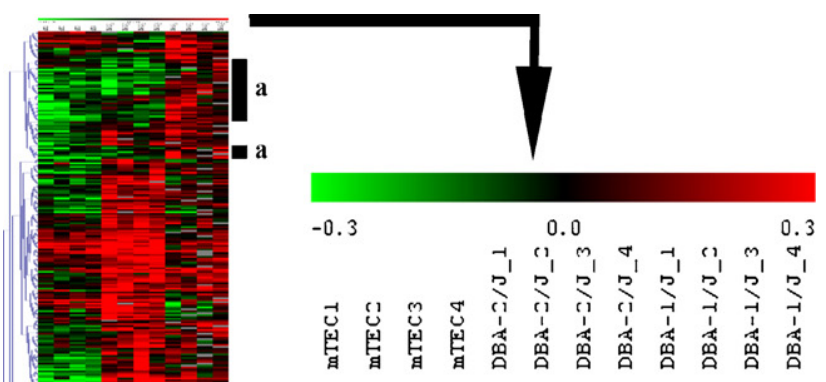

(1)


Table 1

Genes differentially and significantly expressed (repressed or induced) in the thymic stroma of DBA-1/J mice and mTEC 3.10 cell line as detected by SAM program.

\begin{tabular}{|c|c|c|c|c|}
\hline \multicolumn{5}{|c|}{ Induced genes } \\
\hline Gene name & $\begin{array}{l}\text { GenBank Acc } \\
\text { (mRNA) }\end{array}$ & $\begin{array}{l}\text { Chromosomal } \\
\text { location }\end{array}$ & Predominant expression (mRNA) & $\begin{array}{l}\text { Function of the } \\
\text { coded protein }\end{array}$ \\
\hline Sdccag8 & NM_029756 & $1 \mathrm{H} 3$ & $\begin{array}{l}\text { Spinal cordupper, liver, spleen, brown fat, adipose tissue, adrenal } \\
\text { gland, salivary gland, pancreas, pituitary, thyroid, bone, skeletal } \\
\text { muscle, bone marrow, B cells, CD } 4+\text { T cells, trigeminal, dorsal root } \\
\text { ganglia, muscle, ovary, lung, blastocysts, oocyte }\end{array}$ & Unknown function \\
\hline
\end{tabular}

cancer

Il11ra1

NM_010549

4A5

Interleukin 11 receptor, alpha chain 1

Hdac1

NM_008228

4D2

Histone deacetylase 1

Nol6

NM_139236

4A5

Nucleolar protein family 6

(RNA-associated)

2310035C23Rik

NM_173187

1D

NM_001099917 10C1

GenBank

accession

Chromosome

Gene name

Gga1

NM_145929

$15 \mathrm{E} 2$

Golgi associated, gamma adaptin ear containing, ARF binding protein 1 Frag1

NM_145583

$7 \mathrm{E} 3$

FGF receptor activating protein 1 Bcap31

NM_012060

XA6

B-cell receptor-associated protein 31 Tulp3

NM_011657

$6 \mathrm{~F} 3$

Tubby-like protein 3

Sfrs5

NM_009159
Heart, cerebellum substantia nigra, stomach, epidermis, retina, adipose tissue, Adrenal gland, salivary gland, pancreas, pituitary, bone, lymphnode, thymus, ovary, placenta, prostate, umbilical cord, uterus, lung, trachea, vomeronasal organ, main olfactory epithelium, tongue, digits, bladder, kidney

Spleen, epidermis, snout epidermis, adipose tissue, adrenal gland, large intestine, bone, bone marrow, B-cells, CD4+ T-cells, CD8+ T-cells, lymphnode, thymus, ovary, testis, umbilical cord, uterus, lung, trachea, main olfactory epithelium, vomeronasal organ, digits, bladder, blastocysts, embryo

Amygdala, frontal cortex, preoptic, cerebellum, cerebral cortex, dorsal striatum, hippocampus, hypothalamus, olfactory bulb, spinal cordlower, spinal cordupper, substantia nigra, snout epidermis, adipose tissue, adrenal gland, B-cells, CD4+ T-cells, CD8+ T-cells, lymphnode, dorsal root ganglia, ovary, placenta, prostate, bladder, blastocysts, embryo, kidney

Amygdala, frontal cortex, preoptic, cerebellum, cerebral cortex, dorsal striatum, hippocampus, hypothalamus, olfactory bulb, spinal cordlower, spinal cordupper, substantia nigra, stomach, snout epidermis, retina, mammary gland, pituitary, large intestine, B-cells, thymus, dorsal root ganglia, trigeminal, trachea, main olfactory epithelium, tongue, digitis, blastocysts, oocyte

Stomach, pancreas, large intestine, small, intestine, testis, kidney

Molecular/biological

dorsal striatum, hippocampus, stomach, epidermis, adipose tissue, salivary gland, pancreas, thyroid, brown fat, bone, trigeminal, small intestine, bone, B-cells, CD4+ T-cells, lymphnode, ovary, prostate, testis, umbilical cord, uterus, lung, vomeronasal organ, blastocystis, tongue

Heart, stomach, snout epidermis, epidermis, adipose tissue, brown fat, adrenal gland, mammary gland, large intestine, ovary, prostate, uterus, lung, trachea, vomeronasal organ, main olfactory epithelium, tongue, digitis, blastocysts, embryo, fertilized egg, oocyte

Preoptic, liver, epidermis, snout epidermis, brown fat, adipose tissue, adrenal gland, large intestine, small intestine, B220+ B-cells, CD4+ T cells, thymus, trigeminal, dorsal root ganglia, ovary, placenta, prostate, uterus, lung, trachea, vomeronasal organ, main olfactory epithelium, tongue, digitis, bladder, kidney, blastocysts, fertilized egg, oocyte

Preoptic, cerebellum, snout epidermis, retina, adrenal gland, pancreas, pituitary, thymus, trigeminal, dorsal root ganglia, ovary, prostate, umbilical cord, uterus, lung, trachea, main olfactory epithelium, vomeronasal organ, tongue, kidney, embryo, fertilized egg, oocyte

Amygdala, cerebellum, hypothalamus, olfactory bulb, spinal cordlower, epidermis, snout epidermis, retina, adipose tissue, adrenal gland, mammary gland, salivary gland, bone, bone marrow, CD4+ and CD8+ T cells, B cells, lymphnode, thymus, ovary, prostate, umbilical cord, uterus, lung, trachea, main olfactory epithelium, vomeronasal organ, tongue, digits, bladder
Unknown function function

Intracellular protein transport

Immune response ( $\mathrm{T}$ cell activation)

Transcription

Transcription

Binding

Signal transduction

Intracellular protein transport

Unknown function

Transcription 
Table 1 (Continued)

\begin{tabular}{|c|c|c|c|}
\hline Gene name & $\begin{array}{l}\text { GenBank } \\
\text { accession }\end{array}$ & Chromosome & Predominant expression \\
\hline \multicolumn{4}{|c|}{$\begin{array}{l}\text { Splicing factor, arginine/serine-rich } 5 \\
\text { (SRp40, HRS) }\end{array}$} \\
\hline Nup50 & NM_016714 & $15 \mathrm{E} 2$ & $\begin{array}{l}\text { Amygdala, frontal cortex, pancreas, thyroid, small intestine, } \\
\text { bonemarrow, B cells, CD } 4+\text {, CD } 8+\text { T cells, lymphnode, thymus, } \\
\text { placenta, testis, embryo, day } 10.5 \text {, embryo day } 6.5 \text {, embryo, } \\
\text { oocyte, blastocysts }\end{array}$ \\
\hline \multicolumn{4}{|r|}{ 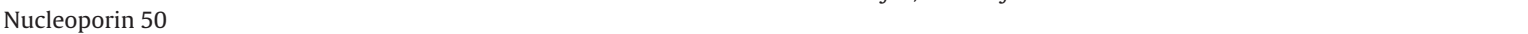 } \\
\hline Gprk6 & NM_011938 & 13B1-3 & $\begin{array}{l}\text { Amygdala, preoptic, cerebral cortex, hippocampus, substantia } \\
\text { nigra, spleen, stomach, snout epidermis, adipose tissue, adrenal } \\
\text { gland, large intestine, bone, bonemarrow, B cells, CD4+, CD8+ T } \\
\text { cells, lymph node, thymus, trigeminal, dorsal root ganglia, ovary, } \\
\text { umbilical cord, uterus, trachea, digitis, embryo }\end{array}$ \\
\hline \multicolumn{4}{|c|}{ G protein-coupled receptor kinase 6} \\
\hline 9930021J03Rik & NM_172826 & $19 C 1$ & $\begin{array}{l}\text { Amygdala, frontal cortex, preoptic, cerebellum, cerebral cortex, } \\
\text { hippocampus, hypothalamus, olfactory bulb, spinal cordlower, } \\
\text { substantia nigra, epidermis, snout epidermis, retina, adipose } \\
\text { tissue, large, small intestine, B cells, CD8+ T cells, thymus, } \\
\text { trigeminal, dorsal root ganglia, ovary, testis, lung, trachea, main } \\
\text { olfactory epithelium, vomeronasal organ, digitis, bladder }\end{array}$ \\
\hline \multicolumn{4}{|c|}{ RIKEN cDNA 9930021J03 gene } \\
\hline Tusc4 & NM_018878 & 9F1 & $\begin{array}{l}\text { Amygdala, frontal cortex, preoptic, cerebellum, cerebral cortex, } \\
\text { hippocampus, hypothalamus, olfactory bulb, spinal cordlower, } \\
\text { substantia nigra, liver, snout epidermis, adipose tissue, adrenal } \\
\text { gland, pituitary, B cells, CD4+, CD }+ \text { T cells, thymus, trigeminal, } \\
\text { dorsal root ganglia, ovary, testis, trachea, main olfactory } \\
\text { epithelium, kidney, blastocysts, embryo, fertilized egg, oocyte }\end{array}$ \\
\hline \multicolumn{4}{|c|}{ Tumor suppressor candidate 4} \\
\hline Prkrir & NM_028410 & 7F1 & $\begin{array}{l}\text { Heart, frontal cortex, cerebellum, hypothalamus, olfactory bulb, } \\
\text { epidermis, retina, adipose tissue, adrenal gland, skeletal muscle, } \\
\text { B cells, CD4+, CD8+ T cells, thymus, ovary, prostate, umbilical } \\
\text { cord, uterus, lung, main olfactory epithelium, trachea, } \\
\text { vomeronasal organ, tongue, digits, bladder, embryo, fertilized } \\
\text { egg, oocyte }\end{array}$ \\
\hline
\end{tabular}

Protein-kinase, interferon-inducible double stranded RNA dependent inhibitor, repressor of (P58 repressor)

Stambpl1 NM_029682

Preoptic, dorsal striatum, hypothalamus, liver, spleen, stomach, salivary gland, pituitary, pancreas, large, small intestine, bone, skeletal muscle, bonemarrow, B cells, CD4+, CD8+ T cells, thymus, trigeminal, dorsal root ganglia, placenta, prostate, testis, trachea, vomeronasal organ, embryo, fertilized egg, oocyte

Stam binding protein like 1

Sh3yl1

NM_013709

Cerebral cortex, stomach, epidermis, snout epidermis, retina, mammary gland, salivary gland, pancreas, pituitary, thyroid, large, small intestine, dorsal root ganglia, ovary, prostate, testis, uterus, trachea, main olfactory epithelium, vomeronasal organ, tongue, digitis, bladder, kidney, fertilized egg, oocyte

Sh3 domain YSC-like 1

Sumo2

NM_133354

$11 \mathrm{E} 2$

Frontal cortex, preoptic, cerebellum, cerebral cortex, hippocampus, olfactory bulb, snout epidermis, retina, bone, $\mathrm{B}$ cells, CD4+, CD8+ T cells, lymphnode, thymus, ovary, uterus, lung, trachea, main olfactory epithelium, vomeronasal organ, digitis, bladder, embryo, fertilized egg, oocyte

SMT3 suppressor of mif two 3 homolog 2 (yeast) Wdr43

XM001005092

WD repeat domain 43

Taf3

NM_027748

Epidermis, snout epidermis, retina, adipose tissue, adrenal gland, large intestine, B cells, CD4+, CD8+ T cells, lymphnode, thymus, ovary, prostate, umbilical cord, uterus, trachea, main olfactory epithelium, vomeronasal organ, tongue, digitis, blastocysts, embryo, fertilized egg, oocyte

Heart, dorsal striatum, hippocampus, liver, spleen, stomach, brown fat, mammary, salivary gland, pancreas, pituitary, thyroid, small intestine, skeletal muscle, bonemarrow, placenta, prostate, bladder, kidney, blastocysts, embryo, fertilized egg

TAF3 RNA polymerase II, TATA box binding protein (TBP)-associated factor

Gtf2i

Amygdala, frontal cortex, preoptic, cerebellum, cerebral cortex, dorsal striatum, hippocampus, hypothalamus, olfactory bulb, substantia nigra, snout epidermis, retina, adrenal gland, pituitary, CD4+, CD8+ T cells, lymphnode, thymus, dorsal root ganglia, ovary, testis, umbilical cord, uterus, main olfactory epithelium, bladder, kidney, embryo

Molecular/biological

function

Protein binding

Signal transduction

Unknown function

Cell cycle

DNA binding

Ubiquitin activity

Unknown function

Protein

modification

process

Unknown function

Transcription

Transcription 
Table 1 (Continued)

\begin{tabular}{|c|c|c|c|c|}
\hline Gene name & $\begin{array}{l}\text { GenBank } \\
\text { accession }\end{array}$ & Chromosome & Predominant expression & $\begin{array}{l}\text { Molecular/biological } \\
\text { function }\end{array}$ \\
\hline \multicolumn{5}{|c|}{ General transcription factor II } \\
\hline Zfp131 & NM_028245 & 13 & $\begin{array}{l}\text { Heart, amygdala, frontal cortex, snout epidermis, adipose } \\
\text { tissue, adrenal gland, large intestine, bone, skeletal muscle, } \\
\text { bonemarrow, B cells, CD4+, CD8+ T cells, lymphnode, thymus, } \\
\text { ovary, uterus, lung, trachea, digitis, embryo, fertilized egg, } \\
\text { oocyte }\end{array}$ & Transcription \\
\hline \multicolumn{5}{|c|}{ Zinc finger protein 131} \\
\hline Calcoco1 & NM_026192 & $15 \mathrm{~F} 3$ & $\begin{array}{l}\text { Dorsal striatum, olfactory bulb, spinal cordupper, liver, spleen, } \\
\text { brown fat, mammary gland, pancreas, thyroid, large, small } \\
\text { intestine, skeletal muscle, B cells, CD4+, CD } 8+\text { T cells, ovary, } \\
\text { placenta, prostate, testis, umbilical cord, lung, tongue, digitis, } \\
\text { bladder, blastocysts, embryo }\end{array}$ & Transcription \\
\hline
\end{tabular}

domain 1

$\mathrm{Cxcl} 4$

NM_019932

$5 \mathrm{E} 1$

Chemokine (C-X-C motif) ligand 4

Rab3d

NM_031874

9A2

RAB3D, member RAS oncogene family

Il1b

NM_008361

$2 \mathrm{~F}$

Interleukin 1 beta

Nkx6-2

NM_183248

NK6 transcription factor related, locus 2 (Drosophila)

Prkd2

NM_178900

Protein kinase D2

Elf1

NM_007920

14D3

E74-like factor 1

Galnt10

NM_134189

$11 \mathrm{~B} 1$

UDP-N-acetyl-alpha-D-

galactosamine:polypeptide

$\mathrm{N}$-acetylgalactosaminyltransferase

10

Pias1

AK162584

9

Protein inhibitor of activated STAT 1

Tieg3

NM_178357
Heart, spleen, epidermis, snout epidermis, brown fat, adipose tissue, adrenal, mammary glands, bone, skeletal muscle, bonemarrow, trigeminal, ovary, umbilical cord, uterus, lung, trachea, vomeronasal organ, tongue, digitis, bladder

Spleen, stomach, epidermis, snout epidermis, retina, adipose tissue, adrenal, mammary, salivary glands, pancreas, pituitary, thyroid, large, small intestines, bone, trigeminal, dorsal root ganglia, ovary, umbilical cord, uterus, lung, trachea, main olfactory epithelium, vomeronasal organ, digitis, bladder, fertilized egg, oocyte

Heart, liver, spleen, brown fat, mammary, salivary glands, pancreas, thyroid, bone, skeletal muscle, bonemarrow, B cells, lymphnode, lung, vomeronasal organ

Heart, hippocampus, hypothalamus, liver, spleen, stomach, brown fat, mammary, salivary glands, pancreas, thyroid, small intestines, skeletal muscle, bonemarrow, B cells, CD4+, CD8+ T cells, placenta, prostate, testis, tongue, bladder, kidney, blastocysts, embryo, fertilized egg

Heart, spleen, stomach, epidermis, Snout epidermis, brown fat adipose tissue, adrenal gland, pituitary, large, small intestines, bone, bonemarrow, B cells, CD4+, CD8+ T cells, lymphnode, thymus, ovary, uterus, lung, trachea, vomeronasal organ, digitis, embryo, fertilized egg, oocyte

Heart, spleen, stomach, epidermis, adipose tissue, adrenal, mammary, salivary glands, thyroid, small, large intestines, bone, bonemarrow, B cells, CD4+, CD8+ T cells, lymphnode, thymus, ovary, placenta, prostate, umbilical cord, uterus, lung, trachea, main olfactory epithelium, vomeronasal organ, tongue, digitis, bladder, kidney

Preoptic, hypothalamus, olfactory bulb, spinal cordlower, liver epidermis, snout epidermis, retina, adipose tissue, salivary gland, pancreas, pituitary, thyroid, large, small intestines, bone, skeletal muscle, B cells, CD4+, CD8+ cells, lymphnode, thymus, dorsal root ganglia, ovary, placenta, prostate, testis, umbilical cord, uterus, main olfactory epithelium, tongue, embryo

Heart, amygdala, cerebellum, spinal cordlower, substancia nigra, retina, brow fat, adipose tissue, adrenal, mammary, salivary glands, bone, skeletal muscle, B cells, CD4+, CCD8+ T cells, lymphnode, thymus, prostate, lung, trachea, main olfactory epithelium, vomeronasal organ, embryo, fertilized egg

Heart, epidermis, snout epidermis, Adipose tissue, adrenal, mammary glands, bone, dorsal root ganglia, ovary, placenta, prostate, umbilical cord, uterus, lung, trachea, digits, bladder, kidney, blastocysts, embryo, fertilized egg, oocyte
Immune response

Transduction

Immune response

Transcription

Intracellular signaling

Transcription

Protein glycolsylation

Unknown function

Transcription 
Table 1 (Continued)

\begin{tabular}{|c|c|c|c|c|}
\hline Gene name & $\begin{array}{l}\text { GenBank } \\
\text { accession }\end{array}$ & Chromosome & Predominant expression & $\begin{array}{l}\text { Molecular/biological } \\
\text { function }\end{array}$ \\
\hline St5 & NM_029811 & 7E3 & $\begin{array}{l}\text { Heart, cerebellum, olfactory bulb, stomach, epidermis, snout } \\
\text { epidermis, adrenal, salivary gland, pituitary, thyroid, large } \\
\text { intestine, bone, thymus, ovary, placenta, prostate, testis, } \\
\text { umbilical cord, uterus, lung, trachea, main olfactory } \\
\text { epithelium, vomeronasal organ, tongue, digits, bladder, kidney, } \\
\text { embryo }\end{array}$ & Unknown function \\
\hline \multicolumn{5}{|c|}{ Suppression of tumorigenicity 5} \\
\hline Zwint & NM_025635 & 10B5 & $\begin{array}{l}\text { Amygdala, frontal cortex, preoptic, cerebellum, cerebral } \\
\text { cortex, dorsal striatum, hippocampus, hypothalamus olfactory } \\
\text { bulb, spinal cordlower, cordupper, substancia nigra, liver, } \\
\text { retina, adipose tissue, adrenal gland, pituitary, trigeminal, } \\
\text { dorsal root ganglia, placenta, umbilical cord, main olfactory } \\
\text { epithelium, vomeronasal organ, blastocysts, embryo }\end{array}$ & Cell cycle \\
\hline
\end{tabular}

ZW10 interacto

Il18

NM_008360

9A5

Interleukin 18

Tspan3

Tetraspanin 3

$\mathrm{Ccl} 3$

Chemokine ( $\mathrm{C}-\mathrm{C}$ motif) ligand 3

Fau

NM_007990

$19 A$

Finkel-Biskis-Reilly murine sarcoma virus (FBR-MuSV) ubiquitously expressed (fox derived) Cond3

NM_007632

Cyclin D3

Rab1

NM_008996

RAB1, member RAS oncogene family Fcgr1

NM_010186

Fc receptor, IgG, high affinity I Glb1

NM_009752

Galactosidase, beta 1

Rgs1

NM_015811

$1 \mathrm{~F}$

Regulator of G-protein signaling 1

Il16

NM_010551

7D2-D3

Interleukin 16

Serpinb2
NM_011111
Amygdala, frontal cortex, preoptic, cerebellum, cerebral cortex, hippocampus, hypothalamus olfactory bulb, spinal cordlower, cordupper, substancia nigra, liver, spleen, stomach, epidermis, snout epidermis, retina, adipose tissue, pituitary, large, small intestines, bone, bonemarrow, lymphnode, umbilical cord, lung, trachea, tongue digits

Heart, dorsal striatum, hippocampus liver, spleen, stomach, brown fat, mammary, salivary glands, pancreas thyroid, small intestine, skeletal muscle, bonemarrow, placenta, prostate, testis, umbilical cord, uterus, tongue, blastocysts, embryo fertilized egg, oocyte

Heart, dorsal striatum, hippocampus spinal cordupper, liver spleen, epidermis, brown fat, mammary, salivary glands, pancreas, pituitary, thyroid, large, small intestine, skeleta muscle, bonemarrow, CD4+ T cells, dorsal root ganglia, placenta prostate, umbilical cord, bladder, embryo

Spleen, epidermis, snout epidermis, adipose tissue, mammary gland, pituitary, large, small intestines, bone, bonemarrow, B cells, CD4+, CD8+ T cells, thymus, ovary, prostate, umbilical cord, uterus, trachea, vomeronasal organ, tongue digitis, bladder, blastocysts, embryo

Heart, stomach, snout epidermis, adipose tissue, adrenal gland, pituitary, large intestine, bone, bonemarrow, B cells, CD4+, CD8+ T cells, lymphnode, thymus, ovary, prostate, testis, umbilical cord, uterus, lung, bladder, kidney, embryo fertilized egg, oocyte

Amygdala, frontal cortex, hypothalamus, spinal cordlower, cordupper, substancia nigra, stomach, adrenal, mammary, salivary glands, pituitary, large, small intestines, skeletal muscle, trigeminal, ovary, placenta, prostate umbilical cord, uterus, lung, trachea main olfactory epithelium, vomeronasal organ, tongue, digitis, kidney, blastocysts

Heart, cerebral cortex, dorsal striatum, liver, spleen, stomach, snout epidermis, brown fat, salivary gland pancreas, thyroid, skeletal muscle bonemarrow, CD8+ T cells, lymphnode, trigeminal, ovary, placenta, testis, uterus, vomeronasal organ, bladder, embryo, fertilized egg, oocyte

Preoptic, hypothalamus, stomach, adrenal, mammary, salivary glands, pancreas, pituitary, large intestine, bone, B cells, CD4+, CD8+ T cells, lymphnode, thymus, trigeminal, ovary, placenta, prostate, umbilical cord, trachea, uterus, vomeronasal organ, bladder, kidney, blastocysts, embryo

Spleen, stomach, adipose tissue, large intestine, B cells, CD4+, CD8+ T cells, lymphnode, thymus, umbilical cord, uterus, trachea, embryo

Cerebellum, spleen, adipose tissue, bone, B cells, CD4+, CD8+ T cells, lymphnode, thymus, trachea

Epidermis, snout epidermis, bone, thymus, umbilical cord, trachea, tongue, digitis
Immune response

Unknown function

Immune response

Translation

Cell cycle

Intracellular protein transport

Immune response

Metabolic process

Signal transduction

Immune response

Endopeptidase inhibitor activity 
Table 1 (Continued)

\begin{tabular}{|c|c|c|c|c|}
\hline Gene name & $\begin{array}{l}\text { GenBank } \\
\text { accession }\end{array}$ & Chromosome & Predominant expression & $\begin{array}{l}\text { Molecular/biological } \\
\text { function }\end{array}$ \\
\hline
\end{tabular}

Serine (or cysteine) peptidase

inhibitor, clade $\mathrm{B}$, member 2

Csnk1d

NM_139059

$11 \mathrm{E} 2$

Casein kinase 1, delta

Mapk3

NM_011952

7F3

Mitogen activated protein kinase 3

1700120K04Rik

BB475700

7F3

RIKEN cDNA 1700120K04 gene

Trim24

NM_145076

Tripartite motif protein 24

CD209

NM 469815

19

CD209 molecule

C1CL10

NM_021274

Chemokine ( $\mathrm{C}-\mathrm{X}-\mathrm{C}$ motif) ligand 10

Dusp1

NM_013642

Dual specificity phosphatase 1

Hivep2

NM_010437

10

Human immunodeficiency virus type

I enhancer binding protein 2

Cx3cl1

NM_009142

$8 C 5$

Chemokine (C-X3-C motif) ligand 1

Zzz3

NM_198416

3H3

Zinc finger, ZZ domain containing 3 Atf4

NM_009716

$15 \mathrm{E} 1$

Activating transcription factor 4

Psap

NM_011179
Amygdala, frontal cortex, preoptic, cerebellum, cerebral cortex, hippocampus, hypothalamus, spinal cordlower, olfactory bulb, substantia nigra, snout epidermis, adrenal gland, adipose tissue, B cells, CD4+, CD8+ T cells, lymphnode, thymus, trigeminal, ovary, placenta, prostate, uterus, dorsal root ganglia, lung, trachea, main olfactory epithelium, digitis, blastocysts, embryo, oocyte

Amygdala, frontal cortex, preoptic, cerebral cortex, hippocampus, spinal cordlower, olfactory bulb, substantia nigra, spinal cordupper, stomach, epidermis, snout epidermis, adrenal gland, large, small intestine, bone, trigeminal, dorsal root ganglia, ovary, prostate, testis, uterus, lung, vomeronasal organ, tongue, digitis, bladder, oocyte

Testis

Heart, liver, spleen, stomach, epidermis, brown fat, mammary, salivary glands, pancreas, pituitary, small intestine, bone, bonemarrow, CD4+, CD8+ T cells, lymphnode, thymus, trigeminal, dorsal root ganglia, prostate, testis, umbilical cord, kidney, embryo, fertilized egg, oocyte

Liver, spleen, epidermis, snout epidermis, retina, adipose tissue salivary gland, pancreas, thyroid, large, small intestines, bone, skeletal muscle, bonemarrow, B cells, lymphnode, thymus, ovary, uterus, lung, trachea, vomeronasal organ, digitis, bladder, embryo, fertilized egg, oocyte

Heart, dorsal striatum, liver, spleen, brown fat, adrenal mammary, salivary glands, pancreas, thyroid, small intestine, skeletal muscle, bonemarrow, CD4+ T, trigeminal, prostate, tongue, bladder, kidney, embryo

Heart, frontal cortex, cerebellum, cerebral cortex, olfactory, bulb, liver, epidermis, snout epidermis, retina, brown fat, adipose tissue, adrenal gland, pituitary, bone, skeletal muscle, B cells, CD4+ T cell, placenta, umbilical cord, lung, trachea, main olfactory epithelium, vomeronasal organ, tongue, digitis, kidney, fertilized egg, oocyte

Amygdala, frontal cortex, preoptic, cerebral cortex, hippocampus, spinal cordlower, olfactory bulb, substantia nigra, cerebellum, dorsal striatum, hypothalamus, spinal cordupper, epidermis, retina, adipose tissue, adrenal gland, skeletal muscle, B cells, CD4+, CD8+ T cells, lymphnode, thymus, skeletal muscle, dorsal root ganglia, umbilical cord, uterus, lung, trachea, main olfactory epithelium, tongue, digitis

Amygdala, frontal cortex, preoptic, cerebral cortex, hippocampus, spinal cordlower, olfactory bulb, substantia nigra, dorsal striatum, hypothalamus, spinal cordupper, retina, adipose tissue, adrenal gland pituitary, large, small intestines, prostate, lung, main olfactory epithelium, kidney

Heart, amygdala, frontal cortex, cerebral cortex, spinal cordlower, olfactory bulb, dorsal striatum, hypothalamus, spinal cordupper, spleen, epidermis, retina, brown fat adrenal, mammary glands, pancreas, pituitary, thyroid, bonemarrow, ovary, umbilical cord, lung, main olfactory epithelium, vomeronasal organ, bladder, embryo, fertilized egg, oocyte

Cerebellum, snout epidermis, retina, adrenal, salivary glands pituitary, large intestine, bone, skeletal muscle, B cells, CD4+ T cells, thymus, umbilical cord, uterus, lung, trachea, main olfactory epithelium, vomeronasal organ, tongue, digitis, blastocysts, embryo, oocyte

Amygdala, frontal cortex, preoptic, cerebral cortex, hippocampus, spinal cordlower, olfactory bulb, substantia nigra, dorsal striatum, hypothalamus, spinal cordupper, retina, adipose tissue, adrenal gland, B cells, lymphnode, trigeminal, dorsal root ganglia, ovary, placenta, prostate, umbilical cord, trachea, main olfactory epithelium, vomeronasal organ, kidney, blastocysts
Unknown function

Signal transduction

Transcription

Unknown function

Immune response

Cell cycle

Transcription

Immune response

Transcription

Transcription

Lipid metabolic process 


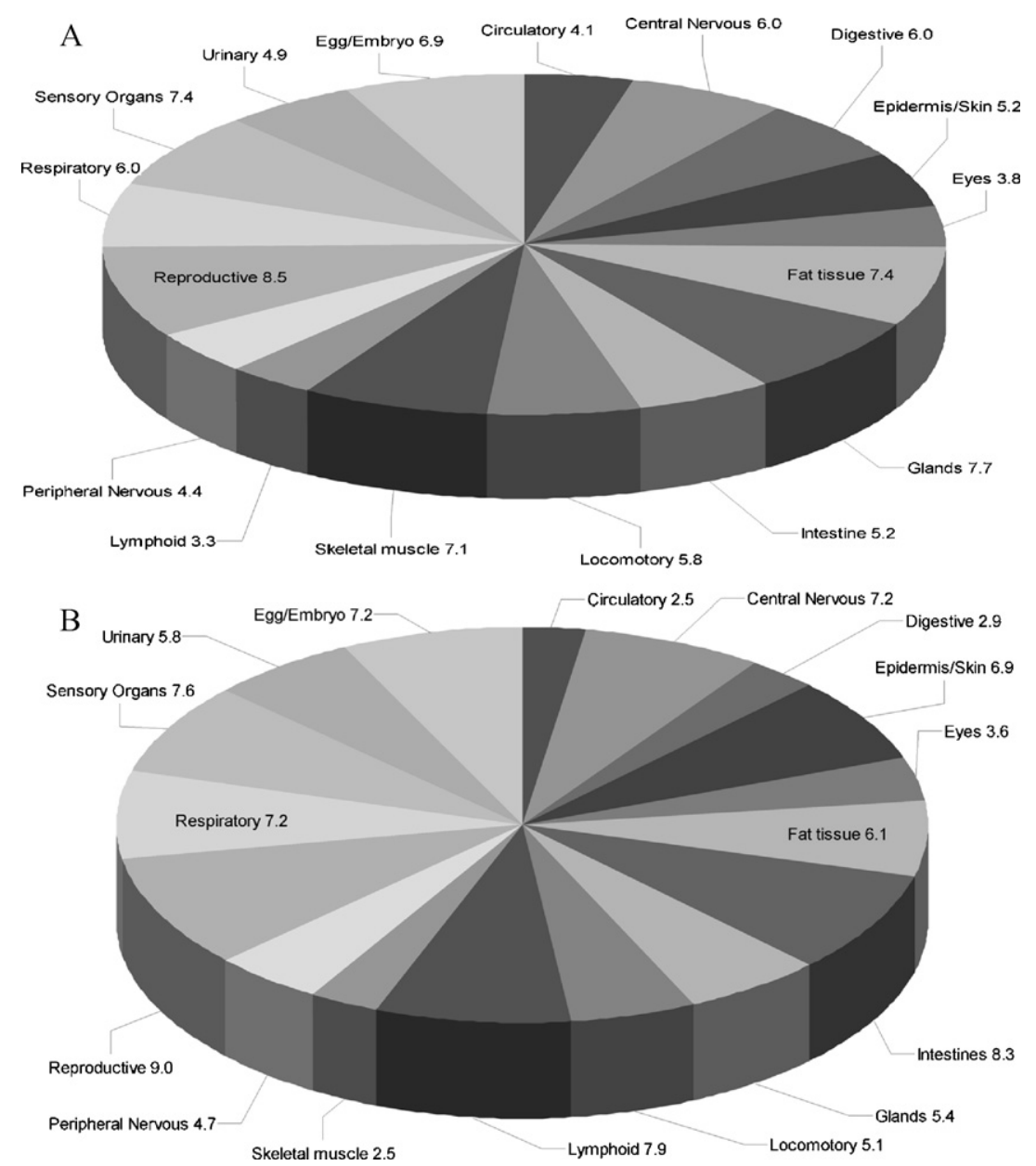

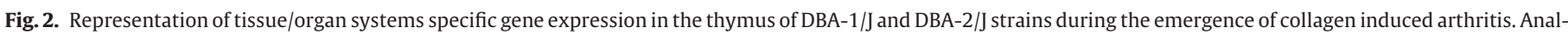

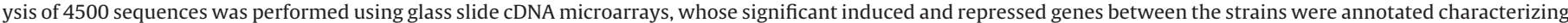
the promiscuous gene expression, which allow self-representation of tissue specific antigens in the thymic stoma of DBA- $1 / \mathrm{J}$ (a) and DBA-2/J (b).

induced in DBA-2/J. The network for both mouse strains was reconstructed putting together the MHC-H2 gene transcript data and shows that PTA genes are actually connected.

DBA-1/J network (Fig. 3a) features the MHC-H2 as a highly modulated gene node, i.e. besides self-modulation, this gene establish connection with 13 downstream PTA genes i.e. Prkd2, Rab1, Dusp1, Glb1, Fau, Nkx6-2, Ccnd3, Csnk1d, Serpinb2, Mapk3, Atf4, Trim24 and Pias1.

Nevertheless, DBA-2/J network (Fig. 3b) features different interactions, in which Ccnd3, Rab1, Fcgr1, Glb1 and Mapk3 are highly controlled PTA genes but MHC-H2 does not participate in such network i.e. it is not controlled by other genes than its own self-modulation, neither exert control over genes. Of note, in the absence of MHC-H2 participation, the Rab1, Glb1 and Mapk3 genes establish interactions among them, which are not observed in DBA-1/J.

\section{Gene expression assessed by quantitative PCR}

Using qRT-PCR, the expression levels of some autoantigen genes whose sequences were not included in the microarray used in this study, such as Gad67 (acc NM_008077), Ins 2 (acc NM_008387), type II collagen (acc NM_031163 and of the Aire gene (acc NM_009646) were compared in thymic stroma of DBA-1/J and DBA-2/J strains. The data show differences between the two mouse strains in which DBA- $1 / \mathrm{J}$ featured down-regulation in all these genes (Fig. 4).

Moreover, the microarray expression levels of the genes Bcap31 (NM_012060), Prkrir (acc NM_028410) (both induced in DBA-1/J), and Fcgr1 (acc NM_010186) (both repressed in DBA-1/J), were also confirmed by qRT-PCR (Fig. 5).

\section{Discussion}

Promiscuous gene expression, characterized by the expression of PTAs in the thymus is an important factor involved in the control of self-tolerance (Derbinski et al. 2001; Gotter et al. 2004; Kyewski and Derbinski 2004). Exposure of differentiating thymocytes to a large variety of PTAs ensures the negative selection of self-reactive nascent $T$ cells and prevents aggressive autoimmune reactions that lead to autoimmune diseases (Derbinski et al. 2001; Gotter et al. 2004). Thus, imbalance in PGE may favors migration of risky autoaggressive $T$ cells to the periphery.

We subsume that the molecular genetic control of autoimmunity may involve a larger number of genes. Thus, we used the microarray method to evaluate the large scale gene expression profile of the thymic stroma in CIA model-system in which DBA$1 / \mathrm{J}$ mouse strain is susceptible and DBA-2/J is resistant to arthritis induction. Divergence in terms of gene expression between strains, as for example the 22 bone/joints genes that were repressed in DBA$1 / \mathrm{J}$ and induced in DBA-2/J (Fig. 2), were interpreted as an effect of the different genetic backgrounds since both strains received the same immunization schedule.

The relevance of the results on differential gene expression between the two strains of mice is that it allows a better view of the influence of different transcription levels of genes encoding PTAs in the thymus on the aggressive autoimmunity phenotype. 


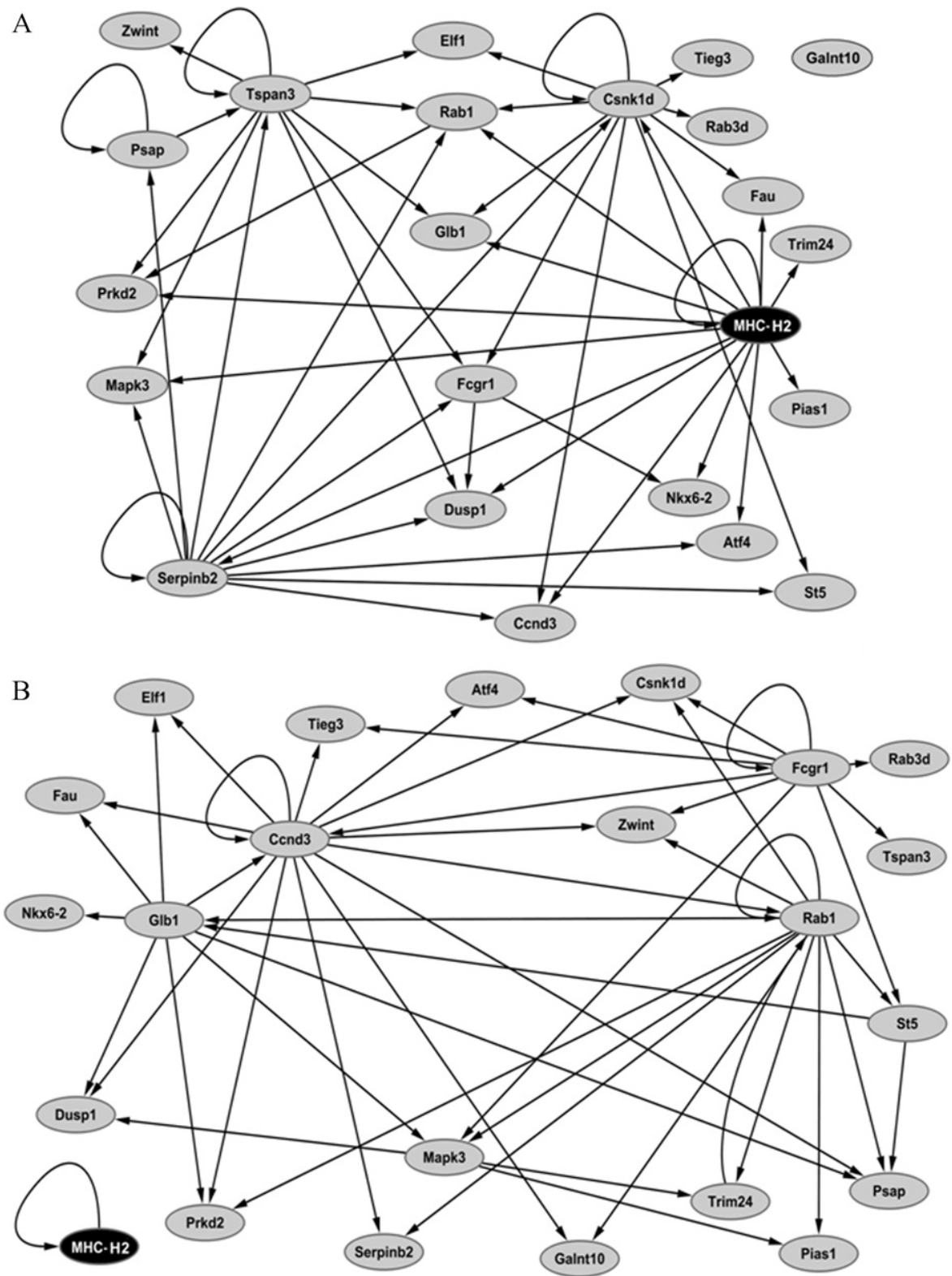

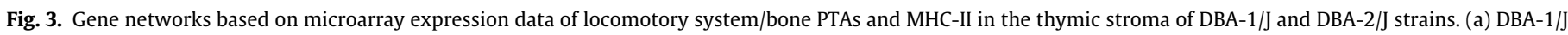
strain, (b) DBA-2/J strain. The arrows represent interactions between genes.

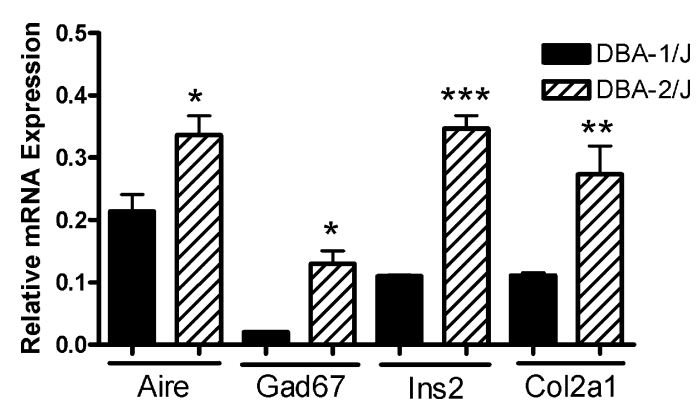

Fig. 4. Autoantigen gene expression in the thymic stroma of DBA- $1 / \mathrm{J}$ and DBA-2/J strains. Quantitative real time PCR of the autoantigen genes Ins2, Gad67, Col2a1 and Aire gene was used to compare the mRNA levels of type II collagen immunized DBA-1/J and DBA-2/J mice. Expression levels were normalized to Gapdh, $n=3$; mean \pm SEM. The differences between responses were evaluated by oneway ANOVA followed by Bonferroni's correction. ${ }^{*} p<0.05$; $^{* *} p<0.01$ and ${ }^{* * *} p<0.001$ were considered significant when compared to DBA-1/J mice group.

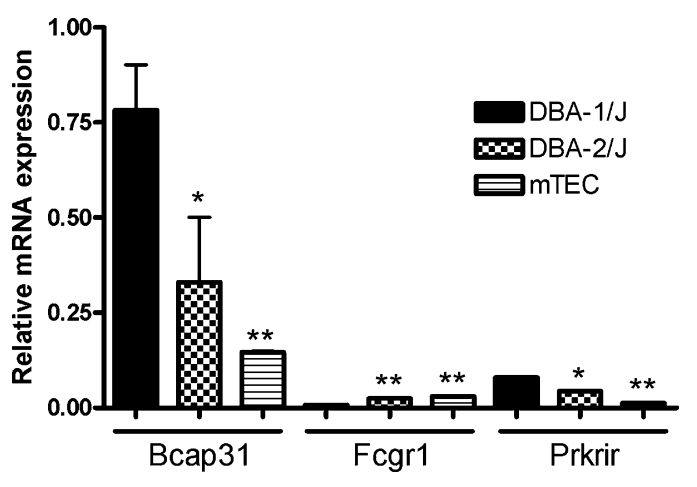

Fig. 5. Confirmation of microarray data by qRT-PCR. Real time PCR of the repressed genes Bcap31 and Prkrir, and Fcgr1 (induced) was used to confirm the mRNA levels in thymic stroma of DBA-1/J and DBA-2/J mice, and in mTEC 3.10 cell line. Expression levels were normalized to Gapd $h, n=3$; mean \pm SEM. The differences between responses were evaluated by one-way ANOVA followed by Bonferroni's correction. ${ }^{*} p<0.05$ and ${ }^{* *} p<0.01$ were considered significant when compared to medullary 3.10 TEC lineage. 
Moreover, the promiscuous PTA genes were identified based on comparison with the expression profile of the cultured mTEC 3.10 cell line. This defined cell line allowed us to select PTA genes that are expressed by mTEC cells. Expression profiling of these genes were then investigated in the thymic stroma of DBA-1/J and DBA-2/J during collagen immunization.

The mTEC 3.10 cell line arose from a mouse with C57BL/6 background, which like DBA-2/J is resistant to CIA. Note that expression profiling of mTEC 3.10 cell line is more comparable to DBA-2/J than DBA-1/J (Fig. 1). This observation agrees with the idea that differential transcription of PTAs in the thymic stromal cells can be associated to manifestation of aggressive autoimmunity.

The set of differentially expressed PTA genes were then assigned to more than 60 murine tissues/organs, including bone/joints. This approach allowed comparison of PGE between the two mouse strains.

In the context of PGE, the transcription level of the autoimmune regulator (Aire) gene is also an additional and important factor that should be considered. Mutations along the human AIRE gene sequence are associated to an autoimmune disease called polyendocrinopathy-candidiasis-ectodermal dystrophy (APECED), which suggests a role for this gene in the control of autoimmunity (Nagamine et al. 1997). Aire knock-out (KO) mouse model-system was of pivotal importance to demonstrate the functional role of this gene that encodes a transcription factor that positively controls the expression of a large number of PTAs, but can also act as negative regulator of other genes (Anderson et al. 2002; Derbinski et al. 2005).

The expression of Aire and the manifestation of autoimmune diseases are also affected by the different murine genetic backgrounds; Aire-deficient NOD mice develop severe exocrine pancreatitis, which is not observed in C57BL/6 or BALB/c mice (Jiang et al. 2005). Also, Aire-deficient mice on the $\mathrm{B} 6$ background had a much greater incidence and severity of CIA than did wild type (Campbell et al. 2009).

Recent evidence were important in the design of the present study: (1) Aire in cultured mTECs plays a role in concert establishing a cascade-like transcriptional network with Gucy2d gene in regulation of downstream PTA genes (Macedo et al. 2009) and (2) HLA-DRB1 and other non-HLA RA-susceptibility genes have a functional role and act in concert also establishing transcriptional networks in peripheral blood mononuclear cells (PBMC) of RA patients (Silva et al. 2009). Moreover, to the best of our knowledge, PGE and expression of Aire in the thymus of DBA- $1 / \mathrm{J}$ background mice were not still described.

Our results show that the expression of Aire and joint/bone PTA genes decreased in the thymic stroma of DBA-1/J. In the context of CIA, down-regulation of joint/bone PTA genes may signal a reduction in the negative selection of respective autoreactive thymocyte clones, which could contribute to a subsequent autoimmune reaction against these antigens in the periphery. Down regulation of Aire-dependent insulin autoantigen, although not directly related to CIA, may illustrate that the general tolerance mechanism is imbalanced in the DBA-1/J strain. This is in contrast to normal non-autoimmune mouse strains, in which the thymic expression of this gene does not alter over time (Kyewski and Derbinski 2004).

However, Aire does not control the expression of all antigens in the thymic stroma. For example, Aire does not regulate betaor kappa-casein, C-reactive protein or glutamic acid decarboxylase (Gad67) (Derbinski et al. 2005). In fact Aire has a limited role in modulating the transcription of terminally differentiating mTECs. The expression of transcription factors associated with developmental plasticity of progenitor mTEC cells as for example Nanog, Oct4, and Sox2, was Aire dependent (Gillard et al. 2007). Moreover, Aire employs a histone-binding module to mediate immunolog- ical tolerance, linking chromatin regulation with organ-specific autoimmunity (Koh et al. 2008).

Recent observation showed that Aire besides acting as a transcription factor also cooperate with other genes in cascade transcriptional networks, thus indirectly controlling downstream PTA genes (Macedo et al. 2009).

Because Aire does not directly control the expression of all antigens in the thymic stroma, we assayed Gad67, an autoantigen gene that is not influenced by Aire expression. Our results show that this autoantigen gene was also down-regulated in DBA-1/J.

Although there are controversies about the Aire-dependency of this antigen in the thymus, CII was expressed in murine and human mTECs (Gotter et al. 2004; Chin et al. 2006), and its role in central tolerance and the consequent evolvement in autoimmunity process have been demonstrated (Campbell et al. 2009). In particular, the higher prevalence of CII-specific antibodies and T cells noted during the early phase of RA indicate that CII-specific immunity plays an important role in the initiation of inflammation in the articular joints (Kim et al. 2004). Due to its importance in the arthritis development we assessed the mRNA levels of Col2A1 in the thymic stroma of both strains, which was also down-regulated in DBA-1/J.

In addition to imbalance in the thymic gene expression, we realize that the emergence of an autoimmune disease is depending on more complex mechanisms in which participate environmental factors as food, drugs or exposure to foreign antigens (microbes?) in association to genetic background of MHC alleles. In RA, complex environmental and genetic factors are believed to contribute to their development (Oliveira et al. 2008). Human leukocyte antigen genes class II region on chromosome 6 (HLA-DRB1 alleles *0401, ${ }^{*} 0404,{ }^{*} 0405,{ }^{*} 0408,{ }^{*} 0101,{ }^{*} 0102,{ }^{*} 1001$ and ${ }^{*} 1402$ ) have been strongly associated with susceptibility to the disease, according to the population studied (du Montcel et al. 2005).

The imbalance in the gene expression evaluated by microarrays data provides evidence for PGE deregulation, which might be under the control of a regulatory transcriptional network. In this study we assessed the hypothesis that PTA gene expression is controlled in cascade-like transcriptional network in which participate the MHC locus. Thus, comparing DBA-1/J $\left(H 2^{q}\right)$ with DBA-2/J $\left(H 2^{d}\right)$ mice, it was possible to observe the influence of different MHC backgrounds on thymic gene expression.

Reconstruction of transcriptional networks enables us to observe that in DBA-1/J PTA genes are connected to MHC H2, which has a controller role (Fig. 3a). It corroborates with previous results firstly showing that PGE in murine mTEC cells is under transcriptional control (Macedo et al. 2009) and secondly that in man the HLA-DRB1 rheumatoid arthritis susceptibility allele is connected to FNDC3A (fibronectin type III domain containing $3 \mathrm{~A}$ ) throughout transcriptional interaction. Given that fibronectin fragments can stimulate mediators of matrix and cartilage destruction in RA, this interaction involving $H L A-D R B 1-F N D C 3 A$ is of special interest (Silva et al. 2009).

These findings strongly suggest that the different MHC haplotypes, $\mathrm{H} 2^{\mathrm{q}}$ in DBA- $1 / \mathrm{J}$ or $\mathrm{H} 2^{\mathrm{d}}$ in DBA-2/J, can establish different transcriptional interactions with PTA genes or even establish no any interaction, as observed in DBA-2/J strain considering the genes studied. The differential transcriptional interaction involving MHC and PTAs may have consequences in the self-representation and consequently in the RA susceptibility/resistance phenotypes.

\section{Acknowledgements}

This work was supported by grants from FAPESP and CNPq (Brazil) and CNPq-INSERM (France) international scientific agreement. qRT-PCRs were carried out at Dr.Zilá L.P. Simões's Laboratory, University of São Paulo at Ribeirão Preto. We thank Dr. Elza Tiemi 
Sakamoto-Hojo and Dr. Eduardo A. Donadi by the laboratory facilities and Mrs. Ieda Regina dos Santos by their technical assistance.

\section{References}

Anderson, G., Jenkinson, W.E., Jones, T., Parnell, S.M., Kinsella, F.A., White, A.J., Pongrac'z, J.E., Rossi, S.W., Jenkinson, E.J., 2006. Establishment and functioning of intrathymic microenvironments. Immunol. Res. 209, 10-27.

Anderson, M.S., Venanzi, E.S., Klein, L., Chen, Z., Berzins, S.P., Turley, S.J., von Boehmer, H., Bronson, R., Dierich, A., Benoist, C., Mathis, D., 2002. Projection of an immunological self-shadow within the thymus by aire protein. Science 298, 1395-1401.

Bleul, C.C., Corbeaux, T., Reuter, A., Fisch, P., Monting, J.S., Boehm, T., 2006. Formation of a functional thymus initiated by a postnatal epithelial progenitor cell. Nature 441, 992-996.

Campbell, I.K., Kinkel, S.A., Drake, S.F., van Nieuwenhuijze, A., Hubert, F.X., Tarlinton, D.M., Heath, W.R., Scott, H.S., Wicks, I.P., 2009. Autoimmune regulator controls $\mathrm{T}$ cell help for pathogenetic autoantibody production in collagen-induced arthritis. Arthritis Rheum. 60, 1683-1693.

Chin, R.K., Zhu, M., Christiansen, P.A., Liu, W., Ware, C., Peltonen, L., Zhang, X., Guo, L., Han, S., Zheng, B., Fu, Y.X., 2006. Lymphotoxin pathway-directed, autoimmune regulator-independent central tolerance to arthritogenic collagen. J. Immunol. $177,290-297$.

Derbinski, J., Gäbler, J., Brors, B., Tierling, S., Jonnakuty, S., Hergenhahn, M., Peltonen, L., Walter, J., Kyewski, B., 2005. Promiscuous gene expression in thymic epithelial cells is regulated at multiple levels. J. Exp. Med. 202, 33-45.

Derbinski, J., Schulte, A., Kyewski, B., Klein, L., 2001. Promiscuous gene expression in medullary thymic epithelial cells mirrors the peripheral self. Nat. Immunol. 2, 1032-1039.

Eisen, M.B., Spellmam, P.T., Brown, P.O., Botstein, D., 1998. Cluster analysis and display of genome-wide expression patterns. Proc. Natl. Acad. Sci. U.S.A. 95, 14863-14868.

Fornari, T.A., Donate, P.B., Macedo, C., Marques, M.M.C., Magalhães, D.A., Passos, G.A., 2010. Age-related deregulation of Aire and peripheral tissue antigen genes in the thymic stroma of non-obese diabetic (NOD) mice is associated with autoimmune type 1 diabetes mellitus (DM-1). Mol. Cell. Biochem. 342, 21-28.

Gillard, G.O., Dooley, J., Erickson, M., Peltonen, L., Farr, A.G., 2007. Aire-dependent alterations in medullary thymic epithelium indicate a role of Aire in thymic epithelial differentiation. J. Immunol. 178, 3007-3015.

Gotter, J., Brors, B., Hergenhahn, M., Kyewski, B., 2004. Medullary epithelial cells of the human thymus express a highly diverse selection of tissue-specific genes colocalized in chromosomal clusters. J. Exp. Med. 199, 155-166.

Gray, D.H., Chidgey, A.P., Boyd, R.L., 2002. Analysis of thymic stromal cell populations using flow cytometry. J. Immunol. Methods 260, 15-28.

Hegde, P., Qi, R., Abernathy, K., Gay, C., Dharap, S., Gaspard, R., Hughes, J.E., Snesrud, E., Lee, N., Quackenbush, J., 2000. A concise guide to cDNA microarray analysis. Biotechniques 29, 548-556.

Hirokawa, K., Utsuyama, M., Moriizumi, E., Handa, S., 1986. Analysis of the thymic microenvironment by monoclonal antibodies with special reference to thymic nurse cells. Thymus 8, 349-360.

Jiang, W., Anderson, M.S., Bronson, R., Mathis, D., Benoist, C., 2005. Modifier loci condition autoimmunity provoked by Aire deficiency. J. Exp. Med. 202, 805-815.

Kim, W.U., Cho, M.L., Jung, Y.O., Min, S.Y., Park, S.W., Min, D.J., Yoon, J.H., Kim, H.Y., 2004. Type II collagen autoimmunity in rheumatoid arthritis. Am. J. Med. Sci. $327,202-211$.
Koh, A.S., Kuo, A.J., Park, S.Y., Cheung, P., Abramson, J., Bua, D., Carney, D., Shoelson, S.E., Gozani, O., Kingston, R.E., Benoist, C., Mathis, D., 2008. Proc. Natl. Acad. Sci. U.S.A. 105, 15878-15883.

Kyewski, B., Derbinski, J., Gotter, J., Klein, L., 2002. Promiscuous gene expression and central T-cell tolerance: more than meets the eye. Trends Immunol. 23, 364-371.

Kyewski, B., Derbinski, J., 2004. Self-representation in the thymus: an extended view. Nat. Rev. Immunol. 4, 688-698.

Macedo, C., Evangelista, A.F., Magalhães, D.A., Fornari, T.A., Linhares, L.L., Junta, C.M., Silva, G.L., Sakamoto-Hojo, E.T., Donadi, E.A., Savino, W., Passos, G.A., 2009. Evidence for a network transcriptional control of promiscuous gene expression in medullary thymic epithelial cells. Mol. Immunol. 16, 3240-3244.

Magalhães, D.A., Silveira, E.L., Junta, C.M., Sandrin-Garcia, P., Fachin, A.L., Donadi, E.A., Sakamoto-Hojo, E.T., Passos, G.A., 2006. Promiscuous gene expression in the thymus: the root of central tolerance. Clin. Dev. Immunol. 13, 81-99.

du Montcel, S.T., Michou, L., Petit-Teixeira, E., Osorio, J., Lemaire, I., Lasbleiz, S., Pierlot, C., Quillet, P., Bardin, T., Prum, B., Cornelis, F., Clerget-Darpoux, F., 2005. New classification of HLA-DRB1 alleles supports the shared epitope hypothesis of rheumatoid arthritis susceptibility. Arthritis Rheum. 52, 1063-1068.

Nagamine, K., Peterson, P., Scott, H.S., Kudoh, J., Minoshima, S., Heino, M., Krohn, K.J., Lalioti, M.D., Mullis, P.E., Antonarakis, S.E., Kawasaki, K., Asakawa, S., Ito, F., Shimizu, N., 1997. Positional cloning of the APECED gene. Nat. Genet. 17, 393-398.

Oliveira, R.D., Junta, C.M., Oliveira, F.R., Silva, L.M., Donadi, E.A., Louzada-Junior, P., 2008. Share epitope, citrullinated cyclic peptide antibodies and smoking in Brazilian rheumatoid arthritis patients. Clin. Rev. Allergy Immunol. 34, 32-35.

Ramsey, C., Winqvist, O., Puhakka, L., Halonen, M., Moro, A., Kämpe, O., Eskelin, P., Pelto-Huikko, M., Peltonen, L., 2002. Aire deficient mice develop multiple features of APECED phenotype and show altered immune response. Hum. Mol. Genet. 11, 397-409.

Silva, G.L., Junta, C.M., Sakamoto-Hojo, E.T., Donadi, E.A., Louzada-Junior, P., Passos, G.A.S., 2009. Genetic Susceptibility Loci in Rheumatoid Arthritis Establish Transcriptional Regulatory Networks with Other Genes. Contemp. Challenges Autoimmun. 1173, 521-537.

Sousa Cardoso, R., Magalhães, D.A., Baião, A.M., Junta, C.M., Macedo, C., Marques, M.M., Sakamoto-Hojo, E.T., Donadi, E.A., Passos, G.A., 2006. Onset of promiscuous gene expression in murine fetal thymus organ culture. Immunology 119, 369-375.

Tiwari, T.L., Terasaki, P.I., 1985. HLA and Disease Associations. Springer, p. 19.

Tusher, V.G., Tibshirani, R., Chu, G., 2001. Significance analysis of microarrays applied to the ionizing radiation response. Proc. Natl. Acad. Sci. U.S.A. 98, 5116-5121.

Van Ewijk, W., 1991. T-cell differentiation is influenced by thymic microenvironments. Annu. Rev. Immunol. 9, 591-615.

Vyacheslav, A.A., Tamás, B.S.C., Mathew, T.P.K.M., Tibor, T.G., 2002. Major histocompatibility complex controls susceptibility and dominant inheritance, but not the severity of the disease in mouse models of rheumatoid arthritis. Immunogenetics 54, 184-192.

Werneck, C.C., Cruz, M.S., Silva, L.C., Villa-Verde, D.M.S., Savino, W., Mourão, P.A.S., 2000. Is there a glycosaminoglycan-related heterogeneity of the thymic epithelium. J. Cell. Physiol. 185, 68-79.

Wooley, P.H., Luthra, H.S., Stuart, J.M., David, C.S., 1981. Type II collagen-induced arthritis in mice. I. Major histocompatibility complex (I Region) linkage and antibody correlates. J. Exp. Med. 154, 688-700.

Wu, C.C., Huang, H.C., Juan, H.F., Chen, S.T., 2004. GeneNetwork: an interactive tool for reconstruction of genetic networks using microarray data. Bioinformatics 20, 3691-3693. 


\title{
Age-related deregulation of Aire and peripheral tissue antigen genes in the thymic stroma of non-obese diabetic (NOD) mice is associated with autoimmune type 1 diabetes mellitus (DM-1)
}

\author{
Thaís A. Fornari · Paula B. Donate • \\ Claudia Macedo • Márcia M. C. Marques • \\ Danielle A. Magalhães • Geraldo A. S. Passos
}

Received: 19 November 2009/Accepted: 12 April 2010/Published online: 23 April 2010

(C) Springer Science+Business Media, LLC. 2010

\begin{abstract}
Gene expression of peripheral tissue antigens (PTAs) in stromal medullary thymic epithelial cells (mTECs) is a key process to the negative selection of autoreactive thymocytes. This phenomenon was termed "promiscuous gene expression" (PGE), which is partially controlled by the Aire gene. Nevertheless, reasons for the correlation of Aire and PTAs with the emergence of autoimmune diseases are largely unknown, though it may be a result of a chronological effect. Although the effect of Aire mutations in pathogenic autoimmunity is well know, it could not be a unique cause for autoimmunity. Independently of mutations, temporal deregulation of Aire expression may imbalance Aire-dependent PTAs and/or wide PGE. This deregulation may be an early warning sign for autoimmune diseases as it guarantees autoantigen representation in the thymus. To assess this hypothesis, we studied the expression levels of Aire, Aire-dependent (Ins2) and Aire-independent (Gad67 and Col2a1) PTAs
\end{abstract}

Thaís A. Fornari and Paula B. Donate contributed equally to this study.

Electronic supplementary material The online version of this article (doi:10.1007/s11010-010-0464-z) contains supplementary material, which is available to authorized users.

T. A. Fornari - P. B. Donate - C. Macedo - M. M. C. Marques ·

D. A. Magalhães · G. A. S. Passos (ه)

Molecular Immunogenetics Group, Department of Genetics, Faculty of Medicine of Ribeirão Preto, University of São Paulo (USP), 3900 Via Bandeirantes, Ribeirão Preto, SP 14040-900, Brazil

e-mail: passos@rge.fmrp.usp.br

\section{G. A. S. Passos}

Disciplines of Genetics and Molecular Biology, Department of Morphology (MEF), Faculty of Dentistry of Ribeirão Preto, USP, Ribeirão Preto, SP 14040-904, Brazil using real-time-PCR of the thymic stromal cells of NOD mice during the development of autoimmune type 1 diabetes mellitus (DM-1). Wide PGE was studied by microarrays in which the PTA genes were identified through parallel $\mathrm{CD} 80^{+}$mTEC 3.10 cell line expression profiling. The results show that Aire gene was down-regulated in young pre-autoimmune (pre-diabetic) NOD mice. PGE and specific PTA genes were down-regulated in adult autoimmune diabetic animals. These findings represent evidence indicating that chronological deregulation of genes important to negative selection may be associated with the development of an autoimmune disease (DM-1) in mice.

Keywords Aire gene - Chronological gene expression Non-obese diabetic (NOD) · Thymic stromal cells .

Type 1 diabetes mellitus

\section{Introduction}

An extremely diverse repertoire of $\mathrm{T}$ cells is generated through the random rearrangement of $\mathrm{T}$ cell receptors (TCR) gene segments. Nevertheless, this random process generates autoreactive $\mathrm{T}$ cells that must be eliminated through negative selection. This process occurs in medullary thymic epithelial cells (mTECs), located in the thymic stroma, which plays an essential role in preventing pathogenic autoimmune reactions and/or autoimmune diseases. The mTECs are essentially self-antigen-presenting cells. Thymocytes are presented by the major histocompatibility complex (MHC) with peptides coded from peripheral tissue antigen (PTA) genes that represent self antigens of most parenchymal organs. Dendritic cells (DCs) also participate in the negative selection process after they have acquired PTA peptides from mTECs [1-8]. 
The signals delivered to the TCR by peptide/MHC initiate a signal transduction cascade in the autoreactive thymocytes that induces apoptosis (death by neglect) [5].

Understanding of the negative selection process of nascent thymocytes and central tolerance mechanisms has been furthered by evidence that PTA genes are normally expressed in the thymic stroma by murine and human mTECs [2, 3, 9-11]. This phenomenon was termed promiscuous gene expression (PGE) [2, 3, 10, 12-16]. Our understanding of central tolerance has recently been reversed with evidence of PGE in the thymus; a more unorthodox conception of the possible mechanism of self-non-self discrimination is taking shape [17-19]. Evidence for PGE was initially biased towards antigens involved in autoimmune reactions, such as insulin, myelin basic protein, or the acetylcholine receptor. It is currently understood that PGE is not as selective as once thought, but instead encompasses a very large set of genes that may include up to $5-10 \%$ of the known mouse genes [3]. Therefore, heterogeneous gene expression in the thymus is most likely associated with maintaining immunological homeostasis in the body and controlling pathogenic autoimmune reactions.

PGE is partly controlled by the autoimmune regulator (Aire) gene, which acts as a transcriptional activator for several PTA genes [20]. In fact, mutations in Aire lead to severe, multi-organ, tissue-specific autoimmunity in both mice and humans [20, 21].

Current evidence suggests that the basis of self-tolerance control in the thymus is dependent on mTEC expression of promiscuously genes that code for PTAs [1-3, 6, 8-10, 12]. Exposure of differentiating thymocytes to a large variety of PTAs ensures the negative selection of self-reactive clones of nascent $\mathrm{T}$ cells and prevents aggressive autoimmune reactions that lead to autoimmune diseases [2, 20].

Patients with autoimmune-polyendocrinopathy-candidiasis-ectodermal-dystrophy (APECED) feature mutations along the Aire gene sequence, which evidentiate its role in the control of autoimmunity, i.e., this gene when mutated triggers aggressive autoimmunity [21, 22].

The functional role of Aire was elegantly demonstrated using a KO mouse model system. Aire (in mice and humans) codes for a transcription factor that positively controls the expression of some PTAs, but it can also act as negative regulator of other genes [15, 20, 23, 24]. This gene is preferentially expressed in mTECs [2, 20, 25, 26], and mTEC association with PTA control has been demonstrated in Aire-KO mice. Aire-deficient mTECs had reduced expression of PTA-encoding mRNAs, such as insulin, salivary gland proteins and caseins [15, 20].
The discovery of Aire's role as a transcriptional controller of PTA genes has generated interest in the intrinsic genetic factors controlling Aire. In fact the different genetic backgrounds of inbred mouse strains influence temporal thymocyte maturation and the kinetics of gene expression for several interleukins in the thymus, including IL-7 [27]. Different murine models have genetically regulated expression levels of autoantigens as insulin in the thymus [28]. In man, susceptibility to DM-1 correlates with a polymorphism in the promoter region of the insulin gene and its transcription level in the thymus [29, 30]. Moreover, the individual variations in Aire and PTA expression levels in mTECs are high in humans [31].

The expression of Aire and the manifestation of autoimmune diseases are also affected by the different murine genetic backgrounds; NOD mice deficient for Aire develop severe exocrine pancreatitis, which is not observed in C57BL/6 or BALB/c mice. Moreover, epigenetic or stochastic mechanisms may be implicated in such variability [32].

Using an artificial vector-based model system, it was possible to demonstrate that Aire expression in NOD mouse thymus is important during perinatal period to prevent autoimmunity [33].

Nevertheless, reasons for the correlation of Aire and PTAs with the emergence of autoimmune diseases are largely unknown, though it may be a result of a chronological effect. As the majority of autoimmune diseases in man emerge between puberty and adulthood, it is possible that the expression levels of these genes in the thymus differ between the healthy and diseased individuals.

In this study, we consider that beside gene mutations, as previously described in the literature, transcriptional deregulation of Aire, PTA, and/or genes featuring PGE might alter the negative selection of autoreactive thymocytes by mTECs and contribute to the onset of autoimmune diseases in genetically susceptible animals.

Considering that expression of Aire in the perinatal period of non-obese diabetic (NOD) mice is both necessary and sufficient to induce self-tolerance, as recently demonstrated using a transcriptionally "on-off” manipulated model-system [33], in this study, we hypothesize that onset of autoimmune type 1 diabetes mellitus (DM-1) in nonmanipulated NOD mice might be associated to early transcriptional deregulation of Aire and/or genes featuring PGE in the thymus.

To assess this hypothesis, we studied Aire, PTA and PGE expression of the thymic stroma in groups of pre-autoimmune (pre-diabetic) and autoimmune (diabetic) of NOD mice; a well-established autoimmune mouse model in which older animals ( $\sim 20$ weeks of age) develop DM-1. 


\section{Materials and methods}

Animals, thymic stroma separation, mTEC 3.10 cell strain and total RNA preparation

The female NOD mice were born in SPF (specific pathogen free) conditions at the CEMIB-UNICAMP animal facility (University of Campinas, SP, Brazil) and maintained in SPF mini-isolators in our laboratory at the University of São Paulo, Campus of Ribeirão Preto, Brazil, during the experiment. We studied pre-diabetic $(8 \pm 2$-week-old $)$ and diabetic animals $(20 \pm 2$-week-old). Diabetes was confirmed by blood glucose levels ( $\geq 250 \mathrm{mg}$ glucose/dl) using Accu Check-Active Kit (Roche Diagnóstica Brasil, São Paulo, Brazil). The thymic stroma was separated from the whole thymus, as previously described [34]. In brief, two or three thymi were dissected and trimmed of fat and connective tissue. Tissue fragments were then gently agitated in $50 \mathrm{ml}$ of RPMI 1640 medium at $4^{\circ} \mathrm{C}$ with a magnetic stirrer for $30 \mathrm{~min}$ to remove the majority of thymocytes. The resulting thymic fragments were then transferred to $10 \mathrm{ml}$ of fresh RPMI 1640 medium and remaining thymocytes were dispersed by successive pipetting. Medium was changed two to three times after agitations, with fragments recovered by settling each time. The thymic fragments were then incubated in $5 \mathrm{ml}$ of $0.125 \%(\mathrm{w} / \mathrm{v})$ collagenase type II with $0.1 \%$ DNAse I (both from Invitrogen, Carlsbad, CA, USA) in RPMI 1640 at $37^{\circ} \mathrm{C}$ for $15 \mathrm{~min}$, with gentle agitation every 5 min using a $1 \mathrm{ml}$ pipettor. After three to four digestions, stromal cells were pooled and centrifuged at $450 \mathrm{~g}$ for $5 \mathrm{~min}$ and finally resuspended in $200 \mu \mathrm{lBS}$. These cells were then used for total RNA preparation.

The mTEC 3.10 medullary thymic epithelial cell line was established from C57BL/6 mice, and the medullary phenotype was determined by immunostaining with anticytokeratin monoclonal antibodies, which confirmed the original distinct medullary phenotype [35]. In addition this cell line constitutively expresses Aire [36]. The CD80 phenotype was confirmed using fluorescent activated cell sorting (FACS) analysis (data not shown). Cells were cultured in 10\% fetal bovine serum-supplemented (Cultilab, Campinas, SP, Brazil) RPMI 1640 medium (Sigma-Aldrich ${ }^{\mathrm{TM}}$, St Louis, MO, USA) at $37^{\circ} \mathrm{C}$ in a $5 \% \mathrm{CO}_{2}$ atmosphere. Total RNA was extracted from $1 \times 10^{7}$ stromal cells (from pre- or diabetic animals) and $1 \times 10^{7}$ mTEC 3.10 cells using Trizol ${ }^{\circledR}$ reagent following the manufacturer's instructions (Invitrogen). RNA preparations were confirmed to be free of proteins and phenol using UV spectrophotometry. The state of degradation was assessed using agarose gel electrophoresis (ethidium bromide staining) (data not shown). Only RNA samples that were free of proteins, phenol, and degradation were used. The animal experimental protocol was previously approved by the Ethical Commission of Ethics in Animal Research, Faculty of Medicine of Ribeirão Preto, USP, Brazil (Protocol \# 021/ 2006).

\section{Gene expression analysis using microarrays}

Gene expression in the thymic stroma and the MTEC 3.10 cell line was assessed using glass slide cDNA microarrays prepared on silane-coated UltraGAPS slides (\# 40015, Corning ${ }^{\circledR}$, New York, NY, USA). The arrays contained a total of 4,500 target tissue-restricted antigen cDNA sequences that represented most murine tissues and organs. Sequences were obtained from the Soares thymus 2NbMT normalized library that represented expressed sequence tag (ESTs) clones prepared from the thymus of a C57BL/6J 4-week-old male mouse, and available at the IMAGE Consortium (http://image.hudsonalpha.org).

The microarrays were prepared based on published protocols using PCR products from the cDNA clones [37] and a Generation III Array Spotter (Amersham Molecular Dynamics, Sunnyvale, CA, USA). A complete file that provides all of the genes and ESTs present in the microarrays used in this study, as well as the experimental conditions, is available on line at MIAME public database (http://www.mged.org/Workgroups/MIAME/miame.html) Array Express accession E-MEXP 2339.

The cDNA complex probes derived from the total RNA obtained from thymic stroma or mTEC 3.10 cells were prepared by reverse transcription using $10 \mu \mathrm{g}$ of total RNA. The cDNA samples were monocolor labeled with $\mathrm{Cy} 3$ fluorochrome using the CyScribe post-labeling kit (GE Healthcare Biosciences). Samples were hybridized for $15 \mathrm{~h}$ and then washed with an automatic slide processor system (ASP, Amersham Biosciences). Microarrays were scanned using a Generation III laser scanner (Amersham Biosciences).

As a reference for the hybridization procedure, we used equimolar quantities of cDNAs obtained from unrelated total RNA (mouse thymus total RNA). This approach allowed us to estimate the amount of target cDNA in each microarray spot.

\section{Microarray data analysis}

Microarray images were quantified using the Spotfinder software (http://www.tm4.org/Spotfinder.html) and normalized using the R platform (http://www.r-project.org). The statistical analyses were performed by the Multiexperiment Viewer (MeV) software (version 3.1) (http:// www.tm4.org/mev.html).

The differentially expressed genes (induced or repressed) were identified by using the significance analysis of 
microarrays program (SAM) (http://www-stat.stanford.edu/ $\sim$ tibs/SAM/) [38] considering only those genes presenting FDR (false discovery rate) $\leq 0.03$.

To analyze the gene expression profiles of the SAM data set, we used a hierarchical clustering method that grouped genes on the vertical axis and samples on the horizontal axis, using similarity in their expression patterns. The similarities and dissimilarities in gene expression are presented as dendrograms, in which the pattern and length of the branches reflect the relatedness of the samples or genes and as heat maps [39] cluster version 3.0 and Java Tree View (http://rana.lbl.gov/EisenSoftware.html).

Determination of promiscuous gene expression

The microarray analysis data was used to identify PGE based on combined information from the public database BioGPS (formerly GNF SymAtlas) (http://biogps.gnf.org/ ?referer=symatlas\#goto=welcome) [40]. This data bank shows gene expression in more than 60 mouse tissue/ organs, as assessed by gene array analysis using Affymetrix microarrays. Data information includes GenBank accession number, chromosomal location, tissue/organ representation and the molecular/biological function of each gene analyzed.

In this study, promiscuous genes were selected on the basis of their expression levels in different organs/tissues, which were upper than the median in relation to all other organs. The transcription level modulations (repression or induction) of these genes were evaluated by comparing thymic stroma of pre-diabetic and diabetic animals with mTEC 3.10 cells.

Oligonucleotide primer design and quantitative real-time polymerase chain reaction (qRT-PCR)

Microarray data were confirmed using qRT-PCR of two PTA genes (Hnrpl and Nsd1) that differed between prediabetic and diabetic animals; the genes were selected based on their expression pattern and hierarchical clustering. The Aire and three autoantigen genes (Gad67, Ins2 and Col2a1) were selected because their sequences were not included in the microarray used in this study. The cDNA sequences of these genes were retrieved from the NCBI GenBank database (http://www.ncbi.nlm.nih.gov/Genbank) using the following accession numbers: Hnrpl (Heterogeneous nuclear ribonucleoprotein L-NM_177301.4), Nsd1 (nuclear receptor-binding SET-domain protein 1-NM_008739.3), Aire (Autoimmune regulator-NM_009646.1), Gad67 (Gad1) (Glutamic acid decarboxylase 1-NM_008077.3), Ins2 (Insulin II-NM_008387.3) and Col2a1 (Collagen, type II, alpha 1-NM_031163.2). The Primer3 web tool (http:// biotools.umassmed.edu/bioapps/primer3_www.cgi) was used to select pairs of oligonucleotide primers spanning an intron/exon junction with an optimal melting temperature of $60^{\circ} \mathrm{C}$ (Table 1). The cDNA samples were prepared using Superscript II reverse transcriptase (Invitrogen Corporation, Carlsbad, CA, USA) enzyme, as recommended. Expression of the abovementioned genes was quantified using a 7500 Real Time PCR System (Applied Biosystems) and normalized to the expression of the housekeeping gene Gapdh (NM_008084.2).

\section{Results}

Genes differentially expressed in the thymic stroma of pre-diabetic, diabetic and mTEC 3.10 cells

Although the expression pattern remained unchanged between pre-diabetic and diabetic thymic stroma for the majority of the 4,500 sequences tested (presented $\left.d(i) \approx d_{E}(i)\right), 1,540$ were found as significantly modulated. It was possible to identify clusters of repressed and induced genes. The detailed color heat-map with gene symbols is available online in our laboratory website (http://www.rge. fmrp.usp.br/passos/NOD_PGE).

To identify changes in the gene expression profiles of pre-diabetic and diabetic NOD mice, we compared young (8-week-old mice) thymic stroma with older (20-week-old mice) thymic stroma, respectively. Parallel expression profiling of mTEC 3.10 cells served as a parameter to better identify the genes characterizing PGE. Expression profiling of thymic stromal cells (3.10 mTEC) from a
Table 1 Oligonucleotide primers used in qRT-PCR

\begin{tabular}{llll} 
& Hnrpl & $5^{\prime}$ CTGGAGTGGGACTCGAAGAG 3' & $5^{\prime}$ TGCAGTGGAGAAGCACAACT 3' \\
Nsd1 & $5^{\prime}$ GCCGTTAGCTCCTCAAACTG 3' & $5^{\prime}$ ACGGTAACGTTCGTGTCTCC 3' \\
& Aire & $5^{\prime}$ GCAACTCTGGCCTCAAAGAG 3' & $5^{\prime}$ GGTCTGAATTCCGTTTCCAA 3' \\
& Gad67 & $5^{\prime}$ TCACCCTCGATTTTCAACC 3' & $5^{\prime}$ AACAAACACGGGTGCAATTT 3' \\
& Ins2 & $5^{\prime}$ ACCTTCAGACCTTGGCACTG 3' & $5^{\prime}$ GCTGGGTAGTGGTGGGTCTA 3' \\
& Col2a1 & $5^{\prime}$ AACACTTTCCAACCGCAGTC 3' & $5^{\prime}$ TCTGCCCAGTTCAGGTCTCT 3' \\
Melting temperature $=60^{\circ} \mathrm{C}$ & Gapdh & $5^{\prime}$ GGGTGTGAACCACGAGAAAT 3' & $5^{\prime}$ CCTTCCACAATGCCAAAGTT 3' \\
\hline
\end{tabular}




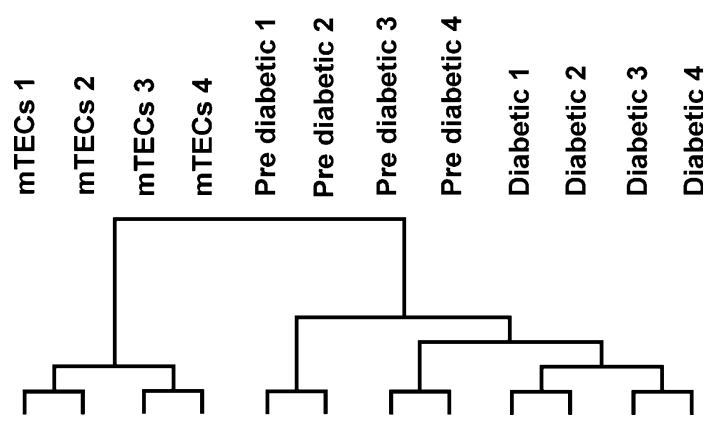

Fig. 1 Hierarchical clustering of mTEC 3.10 cell line, pre-diabetic and diabetic stroma of NOD mice based on cDNA microarray gene expression profiling. Dendrogram and heat-map were obtained using the Cluster-Tree View program. This figure shows that expression profiling of thymic stromal cells (3.10 mTEC) from a non-autoimmune mouse strain (C57BL/6), which was a parameter for PGE, is different from the thymic stromal cells of autoimmune NOD strain. Moreover, the PGE expression profiling differs from pre- to autoimmune state of NOD mice. Complete heat-map available online at (http://www.rge.fmrp.usp.br/passos/NOD_PGE)

non-autoimmune mouse strain (C57BL/6), which was a parameter for PGE, is different from the thymic stromal cells of autoimmune NOD strain.

The hierarchical cluster analysis of the results obtained with the SAM program and comparison of the hybridization signatures showed variability between these three sample types. The dendrogram demonstrated that this variability could distinguish pre-diabetic and diabetic animals and consequently the age of the mice (Fig. 1). Genes that were differentially expressed (repressed or induced) in both the mice and in MTEC 3.10 cells were selected for further analysis as these characterize PGE (Fig. 2; SuppelmentayTable S1). These genes highlighted code for PTAs of glands including pancreas and thus closely associated to DM-1.

\section{Parenchymal organ representation in the thymus}

The 47 sequences that were significantly repressed in the thymic stroma of pre-diabetic animals and in MTEC 3.10 cell strain were assigned to 54 parenchymal and 7 lymphoid organs, according to their predominant expression. These were then sub-grouped into 17 anatomic-functional body systems. The significantly repressed sequences were sub-grouped primarily into gland tissues (including pancreas), reproductive system and lymphoid system, followed by the egg/embryo and central nervous system (Fig. 2a). The 26 significantly induced sequences were found predominantly in the reproductive system, glands and sensory organs, followed by the lymphoid organs, the egg/embryo and fat tissue in the thymus of pre-diabetic animals (Fig. 2b).

\section{Gene expression assessed by qRT-PCR}

The microarray results were confirmed using qRT-PCR of the promiscuously expressed genes Hnrpl and Nsd1. These genes were repressed in MTEC 3.10 cells and pre-diabetic mice and induced in diabetic NOD thymic stroma (Fig. 3). In addition, the Aire gene was induced, and the DM- 1 autoantigens Gad67 and Ins-2 and the DM- 1 unrelated autoantigen Col2a1 were repressed in diabetic animals (Fig. 4). Since these encode promiscuous autoantigens and due to their expression profiling distinguishing the biological samples, they were selected to be confirmed by qRT-PCR.

\section{Discussion}

In this study, we assessed the hypothesis that beside mutations in Aire gene sequence, as previously described in the literature, their transcriptional deregulation, as well as of autoantigen genes, may precede aggressive autoimmunity.

Given the practical impossibility of easily testing this theory in humans, we chose to employ the NOD mouse as a model system.

This inbred strain is an excellent model for investigating autoimmune diabetes and is useful for dissecting tolerance mechanisms, as the animals spontaneously develop autoimmune diabetes that is similar to human DM-1, including the presence of pancreas-specific auto-antibodies and autoreactive $\mathrm{CD}^{+}$or $\mathrm{CD}^{+}{ }^{+} \mathrm{T}$ cells and synteny to human chromosomal linkage groups associated with DM-1 [41,42].

Moreover, comparing only groups of NOD mice in two distinct phases of autoimmunity (pre- and diabetic animals), it was possible to exclude the influence of genetic backgrounds of non-autoimmune mouse strains.
Fig. 2 Representation of tissues-organs by gene expression (PGE) in the thymic stroma comparing pre-diabetic and diabetic NOD mice. a Repressed genes, b induced genes
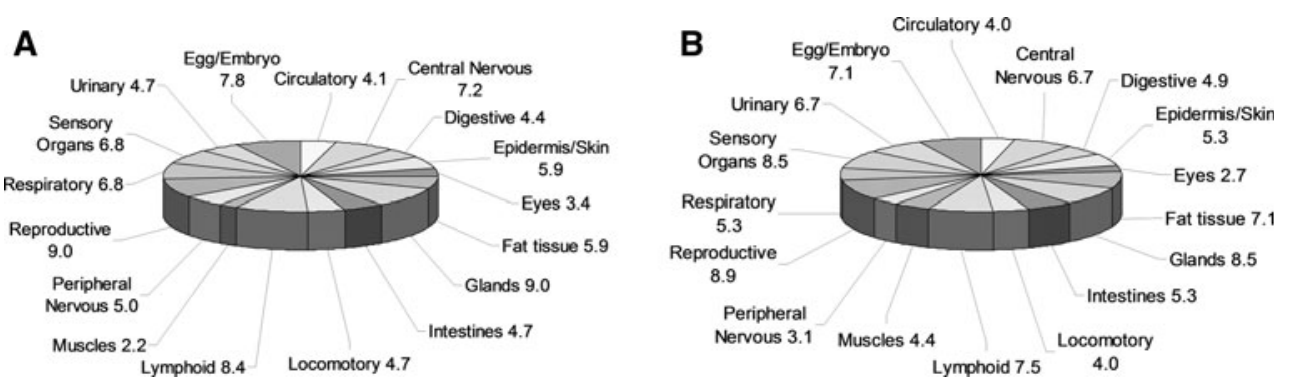


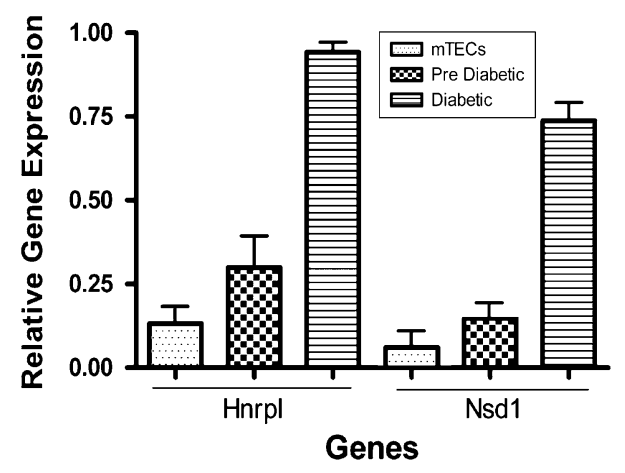

Fig. 3 Quantitative real-time PCR was used to confirm the repression of Hnrpl and Nsd1 genes in both mTEC 3.10 cell line and thymic stroma of pre-diabetic NOD mice. The expression levels were normalized to Gapdh expression. $n=10$; mean \pm standard error of the mean. One-way ANOVA $P<0.001$

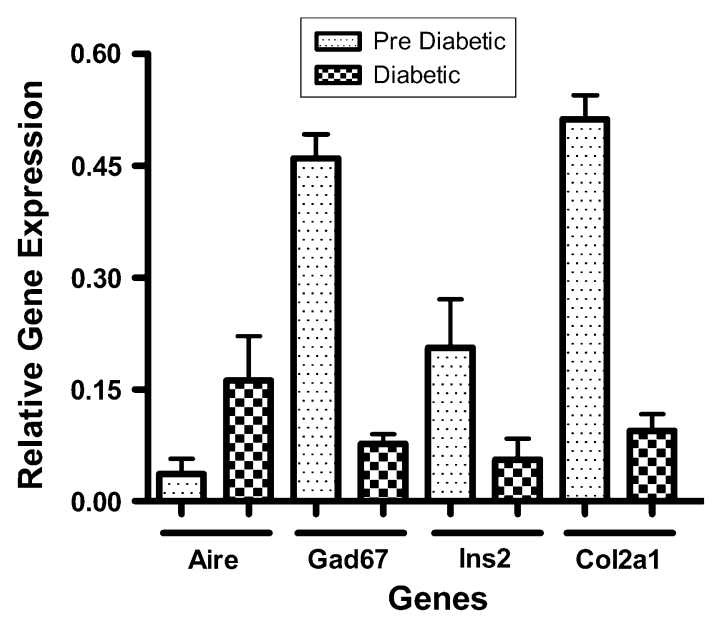

Fig. 4 Quantitative real-time PCR was used to compare the expression levels of the Aire gene and Ins2, Gad67 and Col2a1 autoantigens genes in thymic stroma of pre-diabetic NOD mice. The expression levels were normalized to Gapdh expression. $n=10$; mean \pm standard error of the mean. One-way ANOVA $P<0.05$

Similar to DM-1 patients, the disease progress in the NOD strain occurs in two stages. In the first stage, autoreactive $\mathrm{CD}^{+} \mathrm{T}$ cells infiltrate the pancreatic islet 4-5 weeks after birth. However, most pancreatic islets are preserved at this phase and the animals are clinically healthy. Stage one can persist for months, as the autoimmune attack is under control and relatively non-destructive. Between 15 and 25 weeks of age, the second stage is initiated by an unknown event that provokes severe insulitis. The insulitis progresses to pancreatic islet destruction and the animals become diabetic [43, 44].

Following the start of the second stage, immune tolerance to pancreatic islet antigens breaks down over time in NOD mice. As this tolerance is under molecular control, we believe that the early temporal deregulation of Aire and PTA-encoding genes (PGE) may be associated with the DM-1 emergence in NOD mice.
The gene expression levels of Aire, Aire-dependent autoantigen Ins2, and Aire-independent Gad67 and Col2a1 have been examined with quantitative real-time PCR.

The Aire gene has been shown to positively control the expression of a large set of PTA genes in MTECs [45], which preferentially characterizes differentiated cells $[15,20,45]$.

During the intra-thymic tolerance induction, mTECs present PTAs to thymocytes to eliminate autoreactive clones by inducing apoptosis (negative selection). Our results showed that while the expression of Aire increased in the thymic stroma during the onset of diabetes, Gad67, Ins2, and Col2a1 were down-regulated. This demonstrates that the transcription profile of these genes was inversely proportional to Aire over time. In the context of diabetes, Gad67 e Ins2 down-regulation may signal a reduction in the negative selection of respective autoreactive clones, which could lead to a subsequent autoimmune reaction against these antigens in the periphery.

Down regulation of Col2a1, although not directly related to diabetes might illustrate that tolerance mechanism, in general, is imbalanced in the NOD strain, dissimilar to normal non-autoimmune mouse strains in which the expression of these genes in the thymus does not alter over time [3]. Previous results have demonstrated that lowexpression of insulin in the thymus of Ins2 deficient C57B1/ 6 or BALB-c mice resulted in pro-insulin autoreactive T cells [28].

However, Aire does not control the expression of all antigens in the thymic stroma. For instance, Aire does not regulate beta- or kappa-casein, C-reactive protein or glutamic acid decarboxylase (Gad67) [15]. For this reason, we assayed the Gad67 autoantigen gene and determined that it was down-regulated during diabetes progression.

Moreover, we realize that the control of autoimmunity may involve a large amount of genes more than a unique gene. Thus, we also evaluated the gene expression profile of the thymic stroma using the cDNA microarray method. Since the mTEC 3.10 cell line used in this study constitutively expresses the Aire gene [36], the promiscuous PTA genes were identified on the basis of its expression profile. This approach allowed us to identify changes in gene expression during diabetes progression for genes that represent more than 60 murine tissues/organs (PGE).

Considering that the scope of promiscuously expressed genes at cell population level is highly reproducible and persists as long as $\mathrm{T}$ cells are exported from the thymus, even after thymic involution [3], the imbalance in the expression of these genes we observed in NOD mice, from young to older animals, represents evidence that temporal PGE deregulation is associated to autoimmunity. Deregulation of these genes in young pre-diabetic NOD mice may drive autoimmune DM-1 in elder animals. 
Given the recent evidence for a network transcriptional control of PGE in mTEC cells cultured in vitro [36], our findings open perspective for evaluate whether alterations of PTA gene interactions may occur in vivo in the thymus during emergence of autoimmune diseases including type 1 diabetes mellitus. In this context, we propose further experiments evaluating the participation of microRNAs (miRNAs) that once dysregulated (overexpressed?) in the thymic stroma of NOD mice, might negatively affect the expression of autoantigens.

Acknowledgements This study was funded by Fun dação de Amparo à Pesquisa do Estado de São Paulo (FAPESP), Brazil, Coordenação de Aperfeiçoamento de Pessoal de Nível Superior (CAPES), Ministry of Education of Brazil (MEC) and Conselho Nacional de Desenvolvimento Científico e Tecnológico (CNPq, Brazil). We thank Dr. Eduardo A. Donadi and Dr. Elza T. SakamotoHojo and Dr. Zilá L. P. Simões from the University of São Paulo, Campus of Ribeirão Preto, Brazil by the laboratory facilities. The cDNA clones used to prepare microarrays were kindly ceded by Dr. Catherine Nguyen from the National Institute of Health and Medical Research (INSERM) Unit 928, Marseille, France.

\section{References}

1. Klein L, Kyewski B (2000) Self-antigen presentation by thymic stromal cells: a subtle division of labor. Curr Opin Immunol 12(2):179-186. doi:10.1016/S0952-7915(99)00069-2

2. Derbinski J, Schulte A, Kyewski B, Klein L (2001) Promiscuous gene expression in medullary thymic epithelial cells mirrors the peripheral self. Nature Immunol 2(11):1032-1039. doi:10.1038/ ni723

3. Kyewski B, Derbinski J (2004) Self-representation in the thymus: an extended view. Nat Rev Immunol 4(9):688-698. doi:10.1038/ nri1436

4. Kyewski B, Klein L (2006) A central role for central tolerance. Annu Rev Immunol 24:571-606. doi:10.1146/annurev.immunol. 23.021704.115601

5. Takahama Y (2006) Journey through the thymus: stromal guides for T-cell development and selection. Nat Rev Immunol 6(2):127-135. doi:10.1038/nri1781

6. Holländer GA (2007) Claudins provide a breath of fresh Aire. Nat Immunol 8(3):234-236. doi:10.1038/ni0307-234

7. Irla M, Hugues S, Gill J, Nitta T, Hikosaka Y, Williams IR, Hubert FX, Scott HS, Takahama Y, Holländer GA, Reith W (2008) Autoantigen-specific interactions with CD4+ thymocytes control mature medullary thymic epithelial cell cellularity. Immunity 29(3):451-463. doi:10.1016/j.immuni.2008.08.007

8. Villaseñor J, Besse W, Benoist C, Mathis D (2008) Ectopic expression of peripheral-tissue antigens in the thymic epithelium: probabilistic, monoallelic, misinitiated. Proc Natl Acad Sci USA 105(41):15854-15859. doi:10.1073/pnas.0808069105

9. Jolicoeur C, Hanahan D, Smith KM (1994) T-cell tolerance toward a transgenic beta-cell antigen and transcription of endogenous pancreatic genes in thymus. Proc Natl Acad Sci USA 91(14):6707-6711

10. Gotter J, Brors B, Hergenhahn M, Kyewski B (2004) Medullary epithelial cells of the human thymus express a highly diverse selection of tissue-specific genes colocalized in chromosomal clusters. J Exp Med 199(2):155-166. doi:10.1084/jem.20031677
11. Sousa-Cardoso R, Magalhães DA, Baião AM, Junta CM, Macedo C, Marques MM, Sakamoto-Hojo ET, Donadi EA, Passos GA (2006) Onset of promiscuous gene expression in murine fetal thymus organ culture. Immunology 119(3):369-375. doi:10.1111/ j.1365-2567.2006.02441

12. Sospedra M, Ferrer-Francesch X, Domínguez O, Juan M, Foz-Sala M, Pujol-Borrell R (1998) Transcription of broad range of self-antigens in human thymus suggests a role for central mechanisms in tolerance toward peripheral antigens. J Immunol 161(11):5918-5929

13. Bruno R, Sabater L, Sospedra M, Ferrer-Francesch X, Escudero D, Martínez-Cáceres E, Pujol-Borrell R (2002) Multiple sclerosis candidate autoantigens except myelin oligodendrocyte glycoprotein are transcribed in the human thymus. Eur J Immunol 32(10):2737-2747. doi:10.1002/1521-4141(2002010)32:10<2737: AID-IMMU2737>3.0.CO;2-0

14. Bruno R, Sabater L, Tolosa E, Sospedra M, Ferrer-Francesch X, Coll J, Foz M, Melms A, Pujol-Borrell R (2004) Different patterns of nicotinic acetylcholine receptor subunit transcription in human thymus. J Neuroimmunol 149(1-2):147-159. doi:10.1016/j.jneuroim.2003.11.022

15. Derbinski J, Gäbler J, Brors B, Tierling S, Jonnakuty S, Hergenhahn M, Peltonen L, Walter J, Kyewski B (2005) Promiscuous gene expression in thymic epithelial cells is regulated at multiple levels. J Exp Med 202(1):33-45. doi:10.1084/jem. 20050471

16. Gallegos A, Bevan MJ (2006) Central tolerance: good but imperfect. Immunol Rev 209:290-296. doi:10.1111/j.0105-2896. 2006.00348.x

17. Kyewski B, Derbinski J, Gotter J, Klein L (2002) Promiscuous gene expression and central T-cell tolerance: more than meets the eye. Trends Immunol 23(7):364-371. doi:10.1016/S1471-4906 (02)02248-2

18. Mathis D, Benoist C (2004) Back to central tolerance. Immunity 20(5):509-516. doi:10.1016/S1074-7613(04)00111-6

19. Magalhães DA, Silveira EL, Junta CM, Sandrin-Garcia P, Fachin AL, Donadi EA, Sakamoto-Hojo ET, Passos GA (2006) Promiscuous gene expression in the thymus: the root of central tolerance. Clin Dev Immunol 13(2-4):81-99. doi:10.1080/17402 520600877091

20. Ramsey C, Winqvist O, Puhakka L, Halonen M, Moro A, Kämpe O, Eskelin P, Pelto-Huikko M, Peltonen L (2002) Aire deficient mice develop multiple features of APECED phenotype and show altered immune response. Hum Mol Genet 11(4):397-409

21. Nagamine K, Peterson P, Scott HS, Kudoh J, Minoshima S, Heino M, Krohn KJ, Lalioti MD, Mullis PE, Antonarakis SE, Kawasaki K, Asakawa S, Ito F, Shimizu N (1997) Positional cloning of the APECED gene. Nat Genet 17(4):393-398. doi: $10.1038 / n g 1297-393$

22. Aaltonen J, Björses P, Perheentupa J, Horelli-Kuitunen N, Palotie A, Peltonen L, Lee YS, Francis F, Henning S, Thiel C, Leharach H, Yaspo M (1997) An autoimmune disease, APECED, caused by mutations in a novel gene featuring two PHD-type zinc-finger domains. Nat Genet 17:399-403. doi:10.1038/ng1297-399

23. Su MA, Anderson MS (2004) Aire: an update. Curr Opin Immunol 16(6):746-752. doi:10.1016/j.coi.2004.09.009

24. Kont V, Laan M, Kisand K, Merits A, Scott HS, Peterson P (2008) Modulation of Aire regulates the expression of tissuerestricted antigens. Mol Immunol 45(1):25-33. doi:10.1016/ j.molimm.2007.05.014

25. Heino M, Peterson P, Kudoh J, Nagamine K, Lagerstedt A, Ovod V, Ranki A, Rantala I, Nieminen M, Tuukkanen J, Scott HS, Antonarakis SE, Shimizu N, Krohn K (1999) Autoimmune regulator is expressed in the cells regulating immune tolerance in thymus medulla. Biochem Biophys Res Commun 257(3):821825. doi:10.1006/bbrc. 1999.0308 
26. Heino M, Peterson P, Sillanpää N, Guérin S, Wu L, Anderson G, Scott HS, Antonarakis SE, Kudoh J, Shimizu N, Jenkinson EJ, Naquet P, Krohn KJ (2000) RNA and protein expression of the murine autoimmune regulator gene (Aire) in normal, RelBdeficient and in NOD mouse. Eur J Immunol 30(7):1884-1893. doi:10.1002/1521-4141(200007)30:7<1884:AID-IMMU1884> 3.0.CO;2-P

27. Espanhol AR, Macedo C, Junta CM, Cardoso RS, Victorero G, Loriod B, Nguyen C, Jordan B, Passos GA (2003) Gene expression profiling during thymus ontogeny and its association with TCRVbeta8.1-Dbeta2.1 rearrangements of inbred mouse strains. Mol Cell Biochem 252(1-2):223-228. doi:10.1023/ A: 1025556510001

28. Chentoufi AA, Polychronakos C (2002) Insulin expression levels in the thymus modulate insulin-specific autoreactive T-cell tolerance: the mechanism by which the IDDM2 locus may predispose to diabetes. Diabetes 51(5):1383-1390

29. Pugliese A, Zeller M, Fernandez A Jr, Zalcberg LJ, Bartlett RJ, Ricordi C, Pietropaolo M, Eisenbarth GS, Bennett ST, Patel DD (1997) The insulin gene is transcribed in the human thymus and transcription levels correlated with allelic variation at the INS VNTR-IDDM2 susceptibility locus for type 1 diabetes. Nat Genet 15(3):293-297. doi:10.1038/ng0397-293

30. Vafiadis P, Bennett ST, Todd JA, Nadeau J, Grabs R, Goodyer CG, Wickramasinghe S, Colle E, Polychronakos C (1997) Insulin expression in human thymus is modulated by INS VNTR alleles at the IDDM2 locus. Nat Genet 15(3):289-992. doi:10.1038/ ng0397-289

31. Taubert R, Schwendemann J, Kyewski B (2007) Highly variable expression of tissue-restricted self-antigens in human thymus: implications for self-tolerance and autoimmunity. Eur J Immunol 37(3):838-848. doi:10.1002/eji.200636962

32. Jiang W, Anderson MS, Bronson R, Mathis D, Benoist C (2005) Modifier loci condition autoimmunity provoked by Aire deficiency. J Exp Med 202(6):805-815. doi:10.1084/jem.20050693

33. Guerau-de-Arellano M, Martinic M, Benoist C, Mathis (2009) Neonatal tolerance revisited: a perinatal window for Aire control of autoimmunity. J Exp Med 206(6):1245-1252. doi:10.1084/ jem. 20090300

34. Gray DH, Chidgey AP, Boyd RL (2002) Analysis of thymic stromal cell populations using flow cytometry. J Immunol Methods 260(1-2):15-28. doi:10.1016/S0022-1759(01)00493-8
35. Nihei OK, Campos de Carvalho AC, Spray DC, Savino W, Alves LA (2003) A novel form of cellular communication among thymic epithelial cells: intercellular calcium wave propagation. Am J Physiol Cell Physiol 285(5):C1304-C1313. doi:10.1152/ajpcell. 00568.2002

36. Macedo C, Evangelista AF, Magalhaes DA, Fornari TA, Linhares LL, Junta CM, Silva GL, Sakamoto-Hojo ET, Donadi EA, Savino W, Passos GA (2009) Evidence for a network transcriptional control of promiscuous gene expression in medullary thymic epithelial cells. Mol Immunol 46:3240-3244. doi:10.1016/ j.molimm.2009.08.002

37. Hegde P, Qi R, Abernathy K, Gay C, Dharap S, Gaspard R, Hughes JE, Snesrud E, Lee N, Quackenbush J (2000) A concise guide to cDNA microarray analysis. Biotechniques 29(3): $548-556$

38. Tusher VG, Tibshirani R, Chu G (2001) Significance analysis of microarrays applied to the ionizing radiation response. Proc Natl Acad Sci USA 98(9):5116-5121. doi:10.1073/pnas.091062498

39. Eisen MB, Spellmam PT, Brown PO, Botstein D (1998) Cluster analysis and display of genome-wide expression patterns. Proc Natl Acad Sci USA 95:14863-14868

40. Su AI, Cooke MP, Ching KA, Hakak Y, Walker JR, Wiltshire T, Orth AP, Vega RG, Sapinoso LM, Moqrich A, Patapoutian A, Hampton GM, Schultz PG, Hogenesch JB (2002) Large-scale analysis of the human and mouse transcriptomes. Proc Natl Acad Sci USA 99(7):4465-4470. doi:10.1073/pnas.012025199

41. Atkinson MA, Leiter EH (1999) The NOD mouse model of type 1 diabetes: as good as it gets? Nat Med 5(6):601-604. doi: $10.1038 / 9442$

42. Anderson MS, Bluestone JA (2005) The NOD mouse: a model of immune dysregulation. Annu Rev Immunol 23:447-485. doi: 10.1146/annurev.immunol.23.021704.115643

43. Castaño L, Eisenbarth GS (1990) Type-I diabetes: a chronic autoimmune disease of human, mouse, and rat. Annu Rev Immunol 8:647-679. doi:10.1146/annurev.iy.08.040190.003243

44. Serreze DV, Leiter EH (1994) Genetic and pathogenic basis of autoimmune diabetes in NOD mice. Curr Opin Immunol 6(6): 900-906

45. Pitkänen J, Peterson P (2003) Autoimmune regulator: from loss of function to autoimmunity. Genes Immun 4(1):12-21. doi: 10.1038/sj.gene.6363929 